Essex Field Club Special Memoirs, Vol, II.

THE

BIRDS OF ESSEX.

(ILLUSTRATED.)

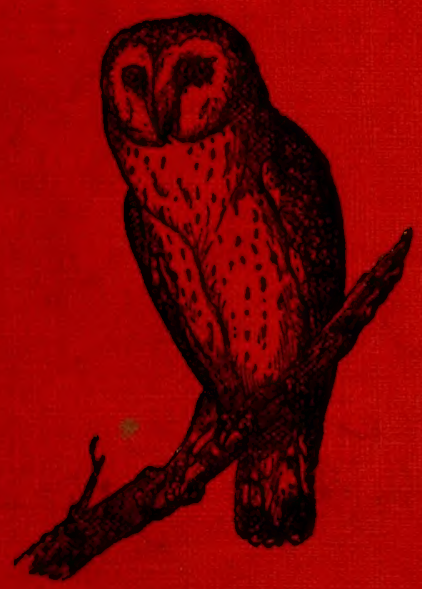

BY MILLER CHRISTY. 

Du 




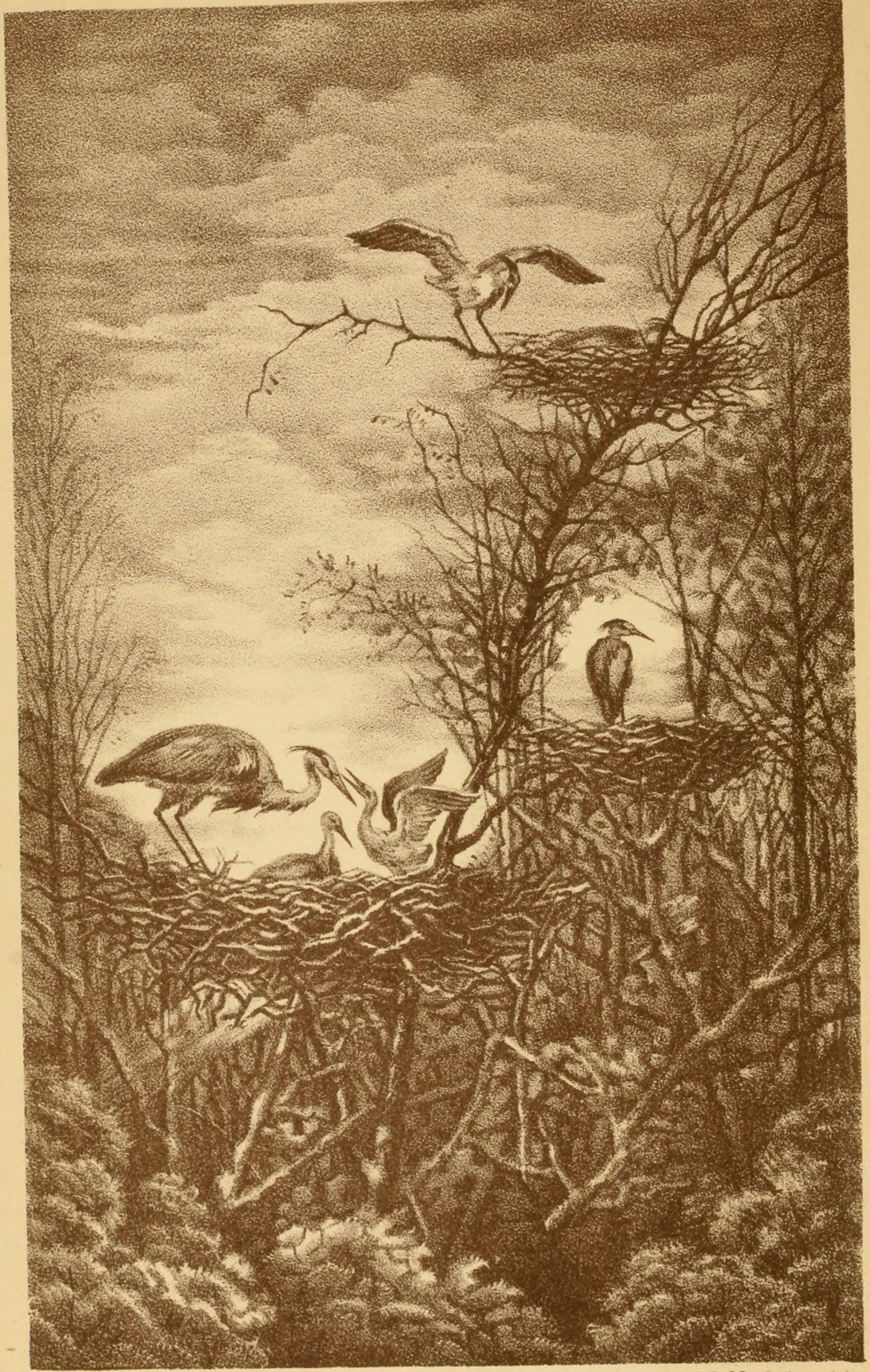


ESSEX FIELD CLUB SPECIAL MEMOIRS.VOL. II.

T H E

\section{BIRDS OF ESSEX:}

\section{(2) Contribution}

TO THE

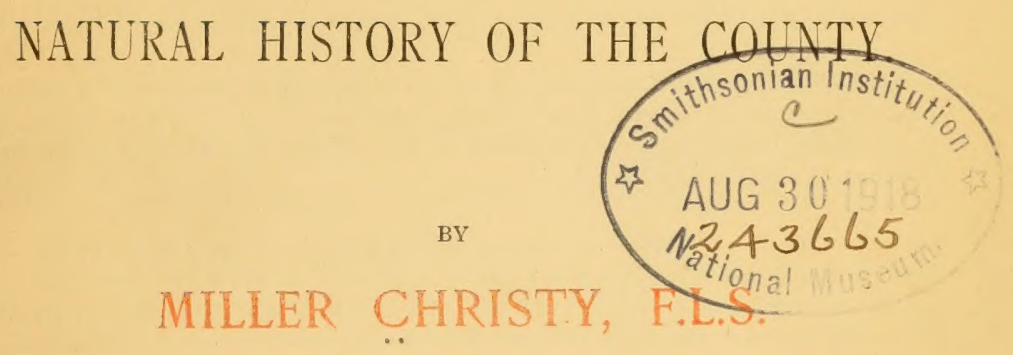

WITH I62 WOODCUT ILLUSTRATIONS, TWO PLANS, AND A FRONTISPIECE.

EBe?msford:

EDMUND DURRANT \& CO., 90, HIGH STREET.

Buckburst 政il?:

THE ESSEX FIELD CLUB.

Q 0 in $\partial 0 \pi$ :

SIMPKIN, MARSHALL. HAMILTON, KENT, \& CO., LTD.

I 890. 
"Men that undertake only one district are much more likely to advance natural knowledge than those that grasp at more than they can possibly be acquainted with. Every kingdom, every province, should have its own monographer."-GiLbert White.

"The utility of provincial histories of all kinds is now generally acknowledged to be great, as these are certainly the materials from which a general structure, either of civil, military, or natural history, is to be raised. In no branch of history is this more apparent than in that of Nature."-Rev. George Low.

"It may be doubted whether the study of animals of particular tracts of country has not contributed, more than any other means, to the advancement of zoological knowledge, especially as regards those important branches of it-the geographical distribution of animals, and the influence of climate, of soil, and of other local circumstances, in determining the range of species the changes of varieties, and the extent and periods of migration."-Prof. THOMAS BELl. 


\section{ONTENTS.}

INTRODUCTION • . . . . . . . . .

Biographical Notices of the Principal Essex OrniTHOLOGISTS . . . . . . . $\delta$

Notices of the Chief Essex Bird Collections - 35

Migration Tables by Hy. Doubleday and the Rev. R.

SHEPPARD . . . . . . . . . 39

Of Hawks and Hawking in Essex in the Olden Time. 43 Wild Fowl Decoys and Wild-Fowling in Essex • 47

A Catalogue of the Birds of Essex . . . . 72 ADDENDA . . . . . . . . 280

A P P E N D I C ES.

A.-List of Subscribers . . . . . . . 285

B.-Chronological List of Works Quoted . . . 293

INDEX . . . . . . . . . 297 
II $A$ YMY, CHRISIY AYD LILLY, LTD., PRIXTERS,

HAITON WORKS, 113, FAREINGDON ROAD, AXD 20, 22, ST. BRIDE ST., E.C. 


\section{PREFACE.}

THE publication of this work is an attempt to meet what 1 has, I believe, been a long-felt want, similar works having met with acceptance in most other counties.

Students of Nature have ever been fully alive to the importance of works describing the Fauna of Counties or other local areas. From such works, the larger general historics of particular countries and regions are built up. Ornithologists, especially, have been very active in publishing local works of this kind. There are now very few of the larger and more important English counties in which some attempt has not been made by a local observer to describe in the form of a book the species of birds which have been observed from time to time to frequent his own particular district. Sterenson's Birds of Norfolk, Mitchell's Birds of Lancashive, Clarke and Roebuck's Vertebrata of Yorkshire, Babington's Birds of Suffolk, Harting's Birds of Middlesex, Macpherson and Duckworth's Birds of Cumberland, Smith's Birds of Somersetslive, and Mansell-Pleydell's Birds of Dorsetshire, are a few good instances of the kind of work referred to, while there are many more, equally worthy of mention, and others are known to be in preparation. Hitherto, however, the birds of Essex have not found a chronicler. It is to supply this omission that I have laboured.

My present work, for which I have been collecting information and materials for over fifteen years, will, I trust, interest all lovers of Nature, and, in particular, all birdstudents, not only within our own county but also throughout Great Britain. 
By arrangement, the work forms one of the Special Memoirs of the Essex Field Club, that body having made a grant towards the expenses of printing.

I have endeavoured to make my book as complete as possible by adding to it, among other matters, some remarks on the chief Physical Features of the County of Essex, brief biographical notices of the principal Essex Ornithologists, descriptions of the most important collections of birds within the County, an account of Decoys and Decoying in Essex, and a Chronological List of published works, \&rc., referred to and quoted from.

No one can be more fully aware than I am myself of the incompleteness of my book. A complete work of the kind is, indeed, impossible. Fresh observations are continually being made and many records of old ones, which have escaped my notice, will doubtless be discovered. The chief use of such a work as mine is to collect all the information available up to a certain date, and, by showing the incompleteness of our local knowledge, to stimulate others to fill the gaps and extend general observation on the habits and distribution of birds. Thus my work will fail in its object if it does not quickly show its own incompleteness.

I have introduced the illustrations because I believe that they will largely add to the popularity of my book. Though not so good or so uniform a series as might have been wished, I believe they will be found useful by many of my readers who are not skilled ornithologists. In some, a resemblance may be traced to the well-known cuts in Yarrell's standard Britis/2 Birds. These originally appeared, many years ago, in a now-almost-forgotten work which at the time of its publication figured in the law courts, the publishers being condemned to pay damages for infringement of copyright. I now use the cuts with the concurrence of Messrs. Gurney and Jackson, the present owners of the copyright in Yarrell's work. Some others will be seen to be merely reduced 
reproductions of some of the best wood-cuts in Bewick's famous series. For the following exquisite little engravings, I am indebted to the kindness of Mr. E. N. Buxton, in whose work on Epping Forest they first appcared :-Grcat Tit (p. 93), Long-tailed Tit (p. 92), Hawfinch (p. I 14), Jay (p. I 32), Green Woodpecker (p. I48), Heron (2 cuts, pp. I 80 and I 83), Ring Dove (p. 2r4), Pewits (p. 237) and Sparrowhawk (p. I69). For the cut of the Little Ringed Plover (p. 236), I am indebted to Mr. Harting. A few have been specially drawn and engraved by Mr. G. E. Lodge, and these I think will not be severely criticised.

I have to acknowledge my great indebtedness to many friends who have most obligingly supplied me with much useful and valuable information. Among these may be mentioned Messrs. G. P. Hope, of Upminster Hall ; F. Kerry, of Harwich; Dr. Henry Laver, F.L.S, of Colchester; and Mr. Walter R. Sackett, of Orsett. Each of these has supplied me with a valuable list of the birds frequenting his particular district, of which I have made extensive use, as will be seen in the following pages. I am also under great obligations for information to many other friends, including the Rev. J. C. Atkinson, LL.D., Mrs. Bree, Major Ed. Taylor, Miss C. Fell Smith, the Rev. H. A. Macpherson, the late Rev. Dr. Babington, the Rev. M. C. H. Bird, Messrs. G. H. Baxter, G. W. Brewis, Joseph Clarke, F.S.A., Walter Crouch, Stanley Edwards, Jonathan Grubb, J. H. Gurney, jun., F.L.S., \&c., J. F. Hills, Robert Page, James Round, M.P., Champion B. Russell, Charles Smoothy, F. Spalding, Hy. Stephenson, Jas. F. T. IViseman, and many others. More especially am I indebted to Mr. E. A. Fitch, of Maldon, President of the Essex Field Club (who has rendered me constant and very valuable assistance whilst passing the sheets through the press), to Mr. Wm. Cole (to whom I am indebted for the notice of the late Mr. English), to Mr. W. H. Dalton (who has kindly assisted me with the index), to Mr. A. P. Wire 
(who has carried out most of the publication arrangements on behalf of the Club), and to Mr. J. E. Harting (who, beside other help, has kindly supplied the chapter on "Hawks and Hawking in Essex"). I have also to thank many of the professional naturalists throughout the county, especially Mr. Travis of Saffron Walden, Mr. Crick of Chelmsford, Mr. Ambrose of Colchester, his successor in business, Mr. John Pettitt, the late Mr. Scruby of Ongar, and Mr. Stacey of Dunmow. In short, there is scarcely any one in the county, having any pretensions to a knowledge of birds, who has not rendered me cordial assistance.

I have also to thank those subscribers (whose names, following a somewhat antiquated custom, I have printed at the end of the book) who by kindly ordering copies in advance have relieved me of much of the loss which usually attends the publication of works of this class.

The system of references I have used so copiously through the work will, I believe, be found convenient. The numbers enclosed within parentheses refer to the works named in Appendix B, and to the volume (where more than one) and page of the particular work referred to. Where the Field, the Essex County Chronicle, or other newspaper is referred to without the year being given, it is to be understood that the year of the occurrence in question is implied.

The word " here," must be understood to mean the district around my home at Chignal St. James, Chelmsford.

I shall always be pleased to hear of the occurrence of rare birds, or of anything notable connected with bird-life, in the county, and until the issue of a second edition (if such be called for) it is my intention to record such occurrences in the pages of the Essex Naturalist.

MILLER CHRISTY.

Chignal St. JAMES,

CHELMSFORD, March, I890. 


\section{B I R DS OF ESSEX.}

\section{INTRODUCTION.}

\section{(a.) The Physical Features of Essex.}

$7 \mathrm{SSEX}$ is a maritime county on the East coast of England. 1 In shape it is, roughly speaking, square, though its eastern coast has been rendered very irregular by the action of the sea. Its area is 1,533 square miles, or 987,032 statute acres. In point of size, it stands tenth among the English counties, being rather smaller than Kent and rather larger than Suffolk, between which two counties it is also geographically situated. On the S., Essex is bounded by Kient, from which it is separated by the River Thames; on the E., by the North Sea or German Ocean ; on the N., partly by Suffolk, from which it is separated by the River Stour, and partly by Cambridgeshire, from which (as Norden says) it "hath no riuer to deuyde it ;" and on the IV., both by Herts and Middlesex, from which it is separated by the Rivers Stort and Lea. If, therefore, separation by rivers makes a peninsula, Essex is one. Its greatest length (Stratford to Harwich) is 72 miles; but, roughly speaking, the county measures about 46 miles from E. to $\mathrm{WV}$., and 42 from N. to S.*

The chief physical features of the county have been briefly and well summed up by a recent writer as follows:- "Essex is a fertile plain, undulating considerably towards the centre and north-west, richly wooded towards the south-west, and sloping away to low humid marshes on the east and south-east, where it is bordered by the sea and the estuary of the Thames, and relieved by rich pasturage on the banks of its principal rivers which mainly have their course from N.W. to N.E. and S.E."

* The above remarks are taken from my Handbook for Essc. (pp. 3 and 4), recently published by Messrs. Edmund Durrant \& Co., of Chelmsford. 
The physical features of every county and district have such a direct and powerful bearing upon the kinds of birds frequenting them that some detailed attempt to describe those features should be an essential part of all avi-faunas.

In More's Distribution of Birds in Great Britain during the Nesting-season (33), Essex is made to form part of Province III (Thames), in which it constitutes the eastern half of Sub-province 8 , comprising Essex, Herts, and Middlesex.

As an ornithological hunting-ground, Essex has been especially favoured by Nature in several different ways. 'The fact of its being situated upon the sea-coast is, in the first place, a very great advantage from the ornithological, as from so many other, points of view; but the additional facts that it is situated on the East coast of England, in close proximity to the continent, and in the direct line of the constant stream of migration which is ever flowing backwards and forwards across the North Sea, and that its coast-line is specialiy suited to attract all kinds of shore-loving birds, still further show how highly the county has been favoured in these matters. The advantage of its maritime situation which, under other circumstances, might have been largely lost, is thus greatly intensified by two other concurrent and auxiliary advantages.

In all probability the ornithological riches of Essex are in no respect inferior to those of the neighbouring county of Norfolk, which, for wealth of bird-life, has, by common consent, been allowed to take a place at the head of all the other English counties. It is very likely that, had the birds of Essex been as attentively studied as have those of Norfolk, we should have been able to show as long and as interesting a list as the ornithologists of that county.

The progress of ornithological study in Norfolk affords an cxcellent proof of the value of these local bird-lists, as a means of encouraging the study of birds. The first list of the birds of Norfolk was written by Sir Thomas Browne, of Norwich, about 1650 . Since then at least ten other lists of Norfolk birds have appeared, as each writer in turn wished to add his observations to those of his last predecessor, until now it may be truly said that (perhaps excepting Yorkshire) Norfolk has produced more county lists and more working ornithologists, who have between them added more to our knowledge of British ornithology as a whole, than any other three English counties combined. If only our illustrious Ray had made some attempt to produce a list of local birds, similar to that of his contemporary, Sir Thomas Browne, there is no saying how many practical Essex ornithologists it might indirectly have brought out, 
or to what a pitch of ornithological eminence the county might by this time have been raised.

Essex has been favoured, too, in its great extent and in the variety presented by its surface, which in different spots presents several widely different kinds of country. It entirely lacks those mountainous tracts, wide open moors, and rocky precipitous cliffs, which afford some of the most interesting birds met with in many other counties; but still, taken as a whole, Essex probably presents as great a variety of surface as any other English county, except, perhaps, Yorkshire. These varied districts next deserve a few words of special mention. They may be roughly classed as :-
(I) The Chalky Uplands,
(2) The Lowlands,
(3) The Forests and Woodlands,
(4) The Marshes and Saltings,
(5) The Open Sea.

(I.) The Chalky Uplands. 'This, though a well-defined area, with striking natural features, is of small extent, being confined to the district around and to the N., N.IV., and W. of Saffron WValden, in the extreme north-western corner of the county, abutting upon Cambridgeshire and Hertfordshire, in which counties this kind of country covers a considerable area. Around Heydon, the appearance of the country a good deal resembles that of the South Downs, though much less undulating, and nearly all enclosed and under cultivation of some sort. Still, the boldly-undulating, well-rounded hills, separated by more or less deep valleys, so characteristic of all chalk-districts, are unmistakably there. Here, naturally, we meet with birds of the open downs. The Stone Plover, which nests nowhere else in the county, breeds in some numbers, while the Dotterel halts awhile, on its spring and autumn migrations. The hills, though for the most part bare, are in places covered with woods, chiefly plantations.

(2.) The Lowlands. This extensive region, though varying a good deal in its chief characteristics and appearance in different spots, may be said to form at least seven-tenths of the entire county. It occupies the whole of the centre, extending almost unbroken from the chalky uplands in the extreme north-west to the marshes and saltings on the coast. Broadly speaking, it is a region of stiff clay, mainly the London Clay, but overlaid by the Chalky Boulder Clays in places, and the whole may be said to be (and to have been 
for centuries) under a high state of cultivation, and not more thickly populated than purely agricultural regions usually are. A comparatively small proportion is under grass, the larger area being arable land, chiefly used in the production of cereals. Throughout the area there is an abundance of old hedgerows, wide overgrown ditches, quiet lanes, and small copses and woods, which afford a home for innumerable small warblers and finches, to say nothing of larger species. Inland sheets of water are conspicuously lacking throughout the county, there being none, I believe, of any consequence, except the artificial, ornamental lakes in private grounds, of which the principal are probably those in Wanstead, Gosfield and Debden Parks.

(3.) Forests and Woodlands. These, although they do not cover a very large aggregate area, are tolerably extensive in certain places, especially where the higher grounds and hill-tops are capped with the Bagshot Gravel, rendering them of little value for agricultural purposes, as in Epping Forest, around Brentwood and Thorndon, in the Writtle High Woods, on Danbury Hill, Tiptree Heath, and elsewhere. In these districts the more purely woodland species especially abound. Hawks, except the Sparrow-hawk, the Kestrel, and rarely the Hobby, are now exterminated, alsn the Raven, so far as the inland parts of our county are concerned; but the Carrion Crow is not uncommon in places, and the Jay abounds. In Epping Forest, the Hawfinch is perhaps commoner than anywhere else in England. Strictly speaking, this region cannot be separated from the last, of which it forms a part.

(4.) Marshes and Saltings. This region is naturally confined to the coast. Though of considerable extent, when contrasted with similar districts in other counties, it is small when compared with the area of the whole county. "Marshes," in Essex, are tracts of land which have at some past time been reclaimed from the sea, and are now protected against its inroads by an artificial sea-wall. They are chiefly under grass, being of considerable value as grazing lands, and are not particularly moist, though lowlying. They are intersected with numerous wide ditches known as "fleets," and interspersed with reedy pools of open water. "Saltings" are those pieces of land which have not been enclosed from the sea, yet are not, strictly speaking, sea-shore, inasmuch as they are completely uncovered at low-tide. Their surface, indeed, though lying entirely outside the sea-wall, is seldom even covered with water, except for a short time twice a day during high tide, and 
supports a considerable flora of saline-loving plants; but the "saltings" are everywhere intersected by innumerable dykes or ditches, which are filled by every tide, and which slowly empty again as the tide falls, leaving a wide expanse of soft mud. Our Essex marshes and saltings are chiefly found around the mouths and estuaries of our larger rivers. They are most extensive at the mouths of the Crouch, Blackwater and Colne. Here, during August and September, and again in May, when the thousands of wading birds which breed further to the north are on migration, the marshes, saltings and the extensive mud-flats outside them, literally swarm with many different species, as the receding tide leaves uncovered their favourite feeding-grounds. Here also many rare waders have from time to time been met with.

(5.) The Open Sea round our coast can perhaps not strictly be claimed as part of Essex, but to all intents and purposes it is so. During the summer-time, our seas are singularly devoid of bird-life, inasmuch as we have none of those rocky and precipitous eminences which form the breeding-places of those birds which chiefly frequent the open sea, such as gulls, guillemots, razorbills, cormorants, gannets, \&c.; but, from autumn to early spring, these birds are usually to be found in greater or less numbers, while ducks, wild geese, and sometimes wild swans, often appear in great numbers, especially during severe weather.

\section{(b.) Previous Essex Bird-Lists.}

The number of local lists of birds relating to Essex which have already appeared is remarkably small, considering the large number of notes and scattered observations which may be met with in general works on Natural History. Those which deserve special mention are Edward Doubleday's List of Epping Birds ( I 5), W. D. King's List of Sudbury Birds (20), and Mr. George Day's articles on The Birds of Essex (4r). Almost all other items of information that have been published are more of the nature of "notes" than systematic lists.

\section{(c.) Light-houses and Light Vessels.}

A large amount of work still remains to be done in recording the movements of the birds appearing at the various light-ships and lighthouses along our coast. From the position occupied by our coast-line, right in the main stream of migration, very valuable results might be expected from a systematic record of occurrences. 
This work has been partially done by the British Association Migration Committee. Our principal lights are the following :-

Cork, L.V., 5 miles off mouth of Harwich River.

Landguard Point, L.H., entrance to Harwich River.

Galloper, $L . V$., 40 miles S.E. of Orfordness ; 2 white, horizontal, fixed.

Kentish Knock, L.V., 33 miles N.E. North Foreland; white, revolving each minute. Swin Middle, $L . V$., off 'Thames; white, revolving every minute.

Tongue, L.V., off Thames; 2 lights, fixed; higher white, lower red.

Nore, $L . V$., entrance to Thames ; white, revolving 30 seconds.

\section{(d.) Number of Species met with in Essex.}

Although it is certain that further observation will bring to light other Essex birds, not recorded in the following pages, it will be found that the list contains no less than 272 species, a number which has, I believe, been exceeded in very few other counties, namely, in Norfolk, Yorkshire, Suffolk, and perhaps one or two others. It would have been easy to increase this total by the addition of at least a score of other species, which have been admitted by some writers, such as the Purple Martin, Great Black Woodpecker, Black Swan, Canada Goose, Virginian Colin and Spotted Sandpiper (which have no claim whatever to a place on the British list), the Great Reed Warbler, Marsh Warbler, Red Grouse, Macqueen's Bustard, Rock Dove and American Wigeon (which have been recorded in Essex, either under doubtful circumstances or on insufficient evidence), the Black-bellied Dipper, Parrot Crossbill, and Intermediate Ringed Dotterel (which I regard as sub-species or geographical races merely). All these, however, I have unhesitatingly rejected.

(e.) British Species first met with in Essex.

The following British Birds, five in number, are notable as having first been met with in Essex :-
Alpine Accentor
Adriatic Gull
Blue.headed Wagtail
Scopoli's Sooty Tern.
Pheasant

\section{(f.) Nomenclature.}

The system of nomenclature and classification I have adopted is that employed in the "Ibis" List of British Birds, compiled by a Committee of the British Ornithologists' Union, and published in I883. This list should, in my opinion, be now regarded as the standard and only duly authorised one; for, although not altogether free from objectionable points, it is the joint work of several of our best working ornithologists, by whom it was most carefully and deliberately compiled, and it has been officially adopted by the 
Union. It is obviously, therefore, of greater weight than any list compiled by a single person only. I am of opinion that the present unsettled and unsatisfactory state of scientific nomenclature has been long enough a disgrace to men of science. It is in reality quite immaterial by what name a species is known, so long as it is by common consent known by that name. But the height of absurdity has been reached, and the utility of any nomenclature at all has 'been almost destroyed, when it is necessary, after mentioning a particular name, to add by whom it was (and often by whom it was not) bestowed!

\section{(g.) SCOPE AND Ains of the Work.}

In compiling the present volume, I have endeavoured to carry out my own ideas as to what the scope and nature of such a work should be. In my opinion, such works should be essentially, and in the first place, local works. General information as to the habits and natural history of the species described, though not actually out of place, if space permits its insertion, is, nevertheless, by no means a prime requisite. A county or other local ornithology should, according to my ideas, deal primarily with the distribution and the frequency or otherwise of the species found within the area treated of, and of their habits and migrations within that area. More general information should, I consider, be reserved for more comprehensive and general works, treating of the entire natural history of the species. Hence, I have inserted in these pages, very little upon the general habits of birds.

NoTE.-Mr. Joseph Clarke is of opinion that many birds are scarcer now than formerly. He writes me as follows: "A goldfinch is now never seen here, though many years ago there were several nests upon the trees in my garden at The Roos. This may be owing in some measure to better farming, which eradicates the thistles, the seeds, of which constitute their chief food. The bullfinch has also disappeared, and the mischievous sparrows now take its place. We have but few swallows, and scarcely a martin, whilst the nightingale has quite deserted us, as also the glow.worm, which may be appropriately associated with it. Years ago a hundred of the latter might be picked up during a walk between here and Saffron Walden, a distance of two miles. The lapwing, too, which used to be plentiful on our hills, is not now to be seen, and many other species now absent might be mentioned." 


\title{
BIOGRAPHICAL NOTICES
}

\author{
OF THE
}

\section{PRINCIPAL ESSEX ORNITHOLOGISTS.}

\begin{abstract}
A BDY, Sir Robert, third baronet, of Albins, in Stapleford A Abbots, Essex, seems to have been interested in birds, and to have been a patron of Eleazar Albin, to whom he sent a number of specimens from time to time. Albin accordingly dedicated to him the first and second volumes of his Natural History of Birds (3.-I73I--38). According to Morant, he was "a man of deep knowledge in antiquity and natural history, a great connoisseur in medals, of which he had a fine collection, and, what is more valuable, a true patriot and a person of unshaken integrity and remarkable humanity."
\end{abstract}

ATKINSON, Rev. J. C., was born in $18 \mathrm{I}_{4}$ at Goldhanger, of which place his father, the Rev. John Atkinson (q.v.), was curate. $\mathrm{He}$ is an excellent ornithologist, as might have been expected from the fact that both his father and grandfather were fond of the study. The days of his boyhood were spent in the district around Goldhanger, Great Wigborough, Little Wigborough, Peldon, Tollesbury, Mersea, \&c., and he thus had unrivalled facllities for becoming intimately acquainted with the birds frequenting that part of the Essex coast, opportunities of which he made excellent use. He also resided in, or by means of visits became familiar with, Bardfield, Finchingfield, Gosfield, Colchester, Maldon, and other parts of Essex. Many notes of his on the ornithology of our coast may be found in the early volumes of the Zoologist. In short, the first twenty-four years of Mr. Atkinson's life, allowing for university residence, were spent in Essex. He afterwards resided in Suffolk, Herefordshire, and Berkshire. In or about 1846 , he became Vicar of Danby, near Grosmont, Yorkshire, where he still resides. He has 
written and edited many books, including a Glossary of the Cleveland Dialect, and a History of Cleveland. He has also written The IValks, Talks, Travels, and Exploits of Tzwo Schoolboy's (1859), and other popular works on Natural History, including the Nests and Eggs of British Birds (36), a charming little book, which has gone through several editions, and is still one of the most popular works on ornithology in the English language; few, if any, books have in their day done more to popularise that science. A threepenny edition of it appeared in $\mathbf{1} 885$. It contains numerous reminiscences of his early days, spent among the birds on the Essex saltings. The town of Elmdon, described in Walks and Talks (pp. I--I8), possesses considerable local interest for Essex people, although it has no connection with the Essex village of that name. In writing the book, Mr. Atkinson says in a letter to me: "I drew largely on my recollections of Kelvedon and of my school life and exploits there, and some of the scenery and places described, such as Docwra's Mill, Watery Lane, and the Stream, certainly had a Kelvedon origin, as also had the twelve daily coaches up to London, the flocks of geese along the roads, the school ghost, the coaches full, inside and out, a little before Christmas, with game, turkeys, \&c., and many other scenes and incidents all through the book; but the moorland, and all that pertains thereto - water-ouzels, trout-fishing, golden plover's nests, and the like-have no connection whatever with Kelvedon." Chapter xix., too, contains a graphic account of a walk on the Essex Marshes, and of a day's wild-fowl shooting on the Main, round the Wigboroughs and Mersea.

In 1887 Mr. Atkinson received the honorary degree of D.C.L. from the University of Durham, "in recognition of his services in many branches of literature." He has filled several important local offices, and is now engaged upon a volume of his Recollections.

ATKINSON, Rev. John (I7S6?-IS70?), was a son of the Rev. Christopher Atkinson, fellow and tutor of Trinity Hall, Cambridge, who was an excellent ornithologist. Some water colour paintings of British Birds, done by him, and now in the possession of the Rev. J. C. Atkinson, are described by the latter as being, he imagines, "quite unequalled for beauty, delicacy of finish, and lifelikeness." He married a sister of Sir John Leycester, afterwards Lord de Tabley. The Rev. John Atkinson became curate of Goldhanger about i 8 ro, and was afterwards curate of Great Wigborough, Iittle Wigborough, Peldon, and elsewhere in Essex. He was, in the 
words of his son, the Rev. J. C. Atkinson, "a good, practical ornithologist, a keen observer, though without any scientific knowledge, and very much interested in anything connected with sport or birds." Not a few notes contributed by him, are to be found in the early numbers of the Zoologist.

BAXTER, G. H., of Hutton Park, Brentwood, takes much interest in birds, and has an interesting collection (p. 34), the principal specimens in which are mentioned hereafter.

BREE, Charles Robert, M.D. (I8II-I886), was the eldest son of the late Mr. John Bree, of Keswick, Cumberland, by Elizabeth, daughter of Mr. John Bearcroft, and was born at Ambleside, on the $4^{\text {th }}$ of February, I8II. He spent his early life mostly in the Lake Country. He was educated for the medical profession in York, during which time he lived in the Minster Yard, and was present at the fire of the Cathedral in 1829 . From York he went to London, and was a pupil at the University College in 1829-30. At the end of his second year, he joined a party of fellow-students and entered into the Polish service, where he remained till Warsaw was taken by the Russians in $183 \mathrm{I}$. After spending a few months in Berlin, he returned to England, and commenced to follow his profession as a general practitioner at Bildeston, in Suffolk. In I 834 , he removed to the neighbouring town of Stowmarket, where he remained until 1858 , in which year he gave up practice and went to Edinburgh, where he studied for one year, and then became M.D. of its University. He married, in I 845, Frances Elizabeth, eldest daughter of the late Sir Augustus Henniker, Bart., who survives him. In the autumn of 1859 , he was clected physician to the Essex and Colchester Hospital, and con. tinued for twenty-two years senior physician to that institution. During this period, he published-rst, The History of the Birds of Europe, not observed in the British Isles (Groombridge \& Co.), which remained for more than ten years the only English general work of reference on the subject, and of which a second edition, containing important additions, published by Bell and Sons, in five vols., has been called for; 2nd. Species not Transmutable, nor the Result of Secondary Causes; 3rd, Popular Illustrations of the Lower Forms of

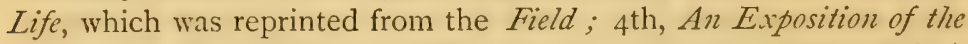
Fallacies in the Hypothesis of $M r$. Darwin (Longmans, Green \& Co.) Dr. Bree was a contributor from time to time to the Field and the Zoologist, as well as also part editor, with the Rev. Mr. Morris, of the 
Naturalist. He was for many years a Fellow of the Linnean and Zoological Societies, and was a J.P. for Essex and Suffolk.

Whilst at Colchester Dr. Bree made a large number of friends, by whom he was very highly esteemed. He always took the greatest interest in the town and its institutions, and delivered many able lectures at the Literary Institute. Early in life - when the Reform Bill of 1832 was passed-Dr. Bree was a Whig, but a few years later, he changed his views, and up to the time of his death he was a staunch Conservative, and a knight of the Primrose League. $\mathrm{He}$ left Colchester in $\mathbf{r} 88 \mathbf{r}$, and afterwards resided at Long Melford, where he died on Sunday, the 17 th of October, 1886 , aged 75. Dr. Bree was seized with paralysis in June, I88I, and deprived of the entire use of his right side, and he then resigned his connection with the hospital. He bore his long illness with the greatest patience and resignation. His remains were interred in the Colchester Cemetery, having been brought from Long Melford for that purpose. The bulk of his collection of skins is now in the possession of Mr. IV. H. Harwood, of Colchester, who purchased it from his representatives shortly after his death. Although consisting mainly of foreign and other specimens, a large number are from Essex, including several of great interest (See p. 34).

CLARKE, Joseph, F.S.A., of The Roos, Saffron Walden, is our veteran Essex naturalist and archæologist, and has supplied much valuable information for use in this work. To his efforts we are largely, if not chiefly, indebted for the magnificent collection of birds in the Walden Museum, a large number of the specimens in which were either acquired through his efforts or collected by him personally in his younger days at Yarmouth and elsewhere. A considerable number of specimens of the commoner inland birds were presented by him to the British Museum Collection before 1836 . Besides supplying many valuable verbal and written communications as to his reminiscences of Essex birds, he has kindly allowed me to make many very interesting extracts from a book of memoranda (24) in which he entered miscellaneous observations and notes of rare birds occurring round Saffron Walden between the years 1820 and 1845 , or thereabouts.

DALE, Samuel (1659?-I739) is, perhaps, chiefly known as the neighbour, disciple, and literary executor of Ray; but Professor Boulger (Journal of Botany, xxi, 193 and 225), claims for him as a botanist much original talent and a high pitch of accuracy in 
detail. He was son of North Dale, of St. Mary, Whitechapel, silkthrower. He was apprenticed for eight years to an apothecary, and in I686, commenced practising at Braintree as a physician. His chief work, Pharmacologia, the first important systematic work on the subject, appeared in 1693 , a supplement following in 1705 . His second great work, The History and Antiquities of Harwich and Dovercourt, written by Silas Taylor, but furnished with an appendix by Dale which exceeds the main work in bulk, was published in 1730 . Dale died on June 6, I739, and was buried in the Dissenters' burial-ground at Bocking. His herbarium, bequeathed to the Apothecaries' Company, is now in the British Museum, and the neat and elaborate tickets to plants obtained from numerous correspondents bear witness to his botanical worth. I am not aware that he made any observations on the birds of this county, except those given in his History of Harzich, many of which are not clear as to whether they are general or local.

DANIEL, Rev. W. B. (about I753?-r833), author of Rural Sports, was educated at Christ's College, Cambridge, taking the degree of B.A. in I 787 and that of M.A. in I 790. He does not appear to have been ever beneficed, although he took orders. $\mathrm{He}$ seems to have indulged in sporting tastes to a degree which shocked even his tolerant age. A writer in the Gentleman's Magasine (ISo2, lxxii, 62I) says, with regard to his unwillingness to own his title as a clergyman, "perhaps there is propriety in such renunciation, for where is the consistency between a fisher of men and a hunter of beasts." He died, at the reputed age of eighty, in Garden Row, within the Rules of the King's Bench, where he had resided for twenty years. Rural Sports, which appeared in I80I, was the delight of sportsmen at the beginning of this century, and has been, says a writer in the Quarterly Revieze, "the basis of many a later book on field sports." It contains a fair number of references to sport and natural history in Essex, due, it may be imagined, to the probable fact of his having resided at Great Waltham, of which parish, it is said, he was once rector.

DIX, Thomas (I $8_{30}-\mathrm{I} 8_{73}$ ?), was born at Dickleburgh, Norfolk, but in early life his parents remored to Essex, and he afterwards became the tenant of Stanford Rivers Hall, near Romford, which he farmed for many years. Whilst residing there, he became intimate with Henry Doubleday; but I have not been able to ascertain that he has left any observations of interest, although he is known to have 
been a very good observer and a skilled taxidermist. In later life he returned to Norfolk, where he died. The late Mr. Henry Stevenson has published a brief, but enthusiastic, obituary notice of him (34. 3775).

DOUBLEDAY, Edward (ISII-I849), was the younger and only brother of Henry Doubleday (q.v.), and was born at Epping. Like his brother Henry, he seems early to have taken up the study of Natural History, for in 1832 , when only just of age, he published a paper on "Stygia" in the Magazine of Natural History', and in the following year, in conjunction with his friend, Edward Newman, he contributed an account of an "Entomological Excursion in North Wales" to the Entomological Magazine. In 1835 he visited the United States, where he remained two years, returning with large and valuable entomological collections, which were presented to the British and other Museums. He laboured hard to obtain the appointment of naturalist to the ill-fated Niger Expedition, but was, fortunately, unsuccessful. He afterwards accepted a post at the British Museum, where he had charge of the Entomological Collections, which he brought to a state of great perfection. This appointment he held until his death, which took place at his house in Harrington Square, on December I 4 , I849, at which time he was secretary to the Entomological Society. His contributions to science were almost wholly entomological. Of the 29 papers enumerated as by him in the Royal Society's Catalogue of Scientific Papers, all, with one exception, have entomological titles, though one, on the "Entomology of the Epping District" ( ${ }_{5}$ ), treats also of its ornithology.

DOUBLEDAY, Henry * ( $1808-1875$ ), was born on July I, I 808 (not I 809 , as has been stated) at Epping, where his father, Benjamin Doubleday, one of the principal tradesmen in the town, had long carried on a general grocery, hardware, and provision business. He was elder and only brother to Edward Doubleday (q.v.). Both the brothers in after life became distinguished as naturalists, though their tastes in this direction do not seem to have been inherited from their parents. Their keen interest in natural science was probably aroused by their surroundings during boyhood, the ancient forests of Epping and Hainault being then in close proximity to the little town.

* The following information is partly copied from a biographical notice which I contributed to the Imperial Dictionary of National Biography. 
From first to last, Henry Doubleday led an exceedingly quiet and retired life. Before $\mathrm{i} 848$, when his father died and the entire management of the business at Epping devolved upon him, he made many collecting expeditions, which were, however, chiefly confined to the Eastern Counties. After that time, he became treasurer, both to the Local Turnpike Trust and to the Epping Poor Law Union, and both duty and inclination kept him constantly at home. Between 1846 and 1873 , he only twice slept away from his own house. A brief visit to Paris in 1843 was the only occasion on which he ever left England. A "Note on the Habits of the Hawfinch" in Jardine's Magazine of Zoology in 1837 (i., p. 448) was probably his first published contribution to science. His first entomological note appeared in r841 (Entomologist, i., p. I02). It described his success in capturing moths at Sallow-blossom, then an entirely novel proceeding. In 1842 (Entomologist, i., 407 and Zoologist, i., p. 20r) he introduced the now very familiar plan of "sugaring" for moths. The credit of having introduced "sugaring" to the notice of entomologists was claimed (43. ii., 32) by the late Mr. J. L. English, who for many years acted as Doubleday's assistant; but there is, to say the least, good reason to think that it rightly belongs to Doubleday (5०. ii. 69). During the whole of his life he frequently contributed observations on the habits of mammals, birds, and insects to the scientific magazines of the day. The Entomlologist and the Zoologist, both conducted by his intimate friend, the late Edward Newman, received most of these notes, but others are to be found in the Proceedings of the Entomological Society of London, of which he was an original (1833) and life-long member. Many notes, too, supplied by him were made use of by Yarrell in his standard History of British Birds ( $1837-\mathrm{I} 843$ ).

Through the kindness of the Rev. H. A. Macpherson, of Carlisle, I have been favoured with the opportunity of perusing at leisure no less than one hundred and one most interesting letters (Io) upon natural history subjects written by Henry Doubleday to Dr. Heysham, of Carlisle, between August 30, I $\delta_{3} \mathrm{I}$, and February 9, I 846 , after which the correspondence seems to have dropped. These letters, which are the property of Mr. J. G. Mounsey, naturally throw considerable light upon his private opinions and upon the passing events of his life at this period. The correspondence seems to have been arranged by Edward Doubleday when, for some reason, he had paid a visit to Heysham at Carlisle. The first few letters are written in strict Quaker phraseology, "thee" and "thou " being always used in place of "you," but this peculiarity soon afterwards disappears 
The first letter of the series, written in a rather irregular, though legible, handwriting, is here given as a fair sample of those which follow :-

\section{"MY DEAR SIR,}

"EPPING, 8th mo., 30th, I831.

"In the first place I must return thee my sincere thanks for the polite attention paid to my brother during his short stop at Carlisle, and also for thy kind offer to assist me in my ornithological pursuits.

"For the last three years I have devoted nearly all my leisure time to ornithology and entomology, and considering that my time is often closely occupied with other affairs, I have made considerable progress, particularly in birds, as thee will see by the annexed list of those I possess,* nearly all of which I have preserved myself. I have added the arrival of the summer birds at Epping [see p. $\left.3^{8}\right]$, as I thought it would be interesting to thee to compare it with their arrival in your neighbourhood, as you have most of them in the north. In the account of them [i.e., the summer birds of passage at Carlisle] published in the Philosophical Magazme [vol. viii., 1830, p. 44t] (which has greatly pleased me) I do not see the Chiff-Chaff mentioned. Do you not have it? It is very common here. $* * *$ I find more difficulty in procuring the Hawks than anything else, as the forest-keepers have almost exterminated them here and we see nothing but a solitary Kestrel and Sparrow-hawk-and even these but rarely. *** The Water Ouzel, Dotterel, and, indeed, any others not in the list, I should be very glad of ; and as I have been thus free in stating my wants, I hope thee will be equally free in stating thine, as nothing would give me greater pleasure than supplying thee with either birds or insects. At present I do not know what to offer, but if a male Garganey would be of any use to thee it is quite at thy service. I procured and stuffed it about three months since and it is in very fine plumage.

"I have succeeded well in my attempts to keep the summer warblers alive in confinement and have now four beautiful male Nighting $\iota$ les, three Blackcaps, two Greater Pettychaps, one Common Whitethroat and one Lesser Whitethroat. They have now just done moulting and are coming into song. They are in beautiful plumage and in the most perfect health, and will sing all through the winter if kept sufficiently warm. $* * *$

"I do not think Selby's arrangements of the birds good; nor do I think he has genera enough. In many instances I prefer the genera as given in Dr. Fleming's work, though some of his are not natural. Genera, to be good, ought to be distinguishable at first sight, and artificial ones are good for nothing. *** I am a strong advocate for the foundation of genera, founded on the consideration of every habit and character, instead of having a heterogeneous mass lumped together with a generic name.

"The change of plumage in birds is another subject in which I feel a great interest. *** [After some remarks upon this and other subjects, containing allusions to Mr. Yarrell which show that he was then in correspondence with him, the letter closes.]

"Believe me to be,

"Very respectfully thine,

"Henry Doubleday."

- One hundred and fifty-three species. 
From this letter, written when Doubleday was only twenty-three years of age, we may gather that he had taken up the study of natural history some three years earlier, namely, in $I \$ 29$, when only about twenty; that he had worked with such energy that he had actually no less than I 53 species of stuffed birds in his collection; and that he was already in correspondence with Yarrell. In the following January, he speaks of "my friend Hewitson," and about the same time he mentions Newman.

On November 2 nd, $18_{3}$, he writes :-

"I have paid considerable attention to the eggs and nests of birds, and have the eggs of most of those which breed in this neighbourhood. ***

"In a neighbourhood like this, covered for miles with forest, the summer warblers are likely to be numerous, and the Nightingale comes over in great numbers, but are much thinned by the London birdcatchers. The three WillowWrens, the two Whitethroats, the Blackcap and Pettychaps are very common. ** * "With regard to the arrival of the birds, I am very particular, never trusting to any one who has not a thorough knowledge of the bird."

On January I 9 th, 1832 , he says :-

"My Nightingales and Blackcaps now sing most delightfully all day long and the Greater Pettychaps also sings occasionally."

On February 13 th, 1836 , he again says :-

"My Nightingales are now singing delightfully."

In February, 1832 , he gives expression to this dictum :-

"Every person has clearly a right to his own opinion and I think that nothing does more injury to science than one person assuming a kind of dictatorship and expecting everybody to bow to his decision."

On June $x$ th, I 833 , he writes :-

"I possess about 216 skins of British birds."

Not long after, when Heysham had evidently paid him a well deserved compliment upon his skill as a taxidermist, he writes. (August 3rd, 1834) :-

"I am sure you praise my efforts at setting up birds far too highly. *** I lave done the best I could, but it often happens that business interrupts me when I am about a bird and I have to leave it for an hour or two.*** You must recollect I am perfectly self-taught."

The spring of ${ }^{8} 3^{6}$ seems to have been unusually cold and late. On July 14 th, Doubleday writes :-

"I think on the whole the summer birds are very thin this year. Some species, I am sure, have not appeared in half their usual numbers here, particularly the Whinchat, Nightingale and Common Whitethroat."

The following paragraph occurs in a letter dated January $24^{\text {th, }}$ I $837:-$ 
"During a visit I have recently been paying to my friend $\mathrm{Wm}$. Yarrell, we had a thorough look through the London collections of birds and insects. There are a few points respecting some of our British birds that we are very anxious to clear up, especially as Mr. Yarrell is about to commence a work on 'British Birds' to correspond with his 'Fishes.'"

The points were the distinctness of the common Pied Wagtail and the continental White IVagtail and the number of species of Ptarmigan.

This series of letters, many extracts from which will be found in the following pages, also contains numerous interesting allusions to and observations upon the current scientific topics of the day. It is, however, to be regretted that rare birds are frequently referred to without any reference to localities. This is unfortunate, but until the last few years many even of the best ornithologists seem to have paid very little attention to the localities whence came their specimens.

Doubleday's brief risit to Paris in $\mathrm{r} 8+3$, proved to him an erent of great consequence. It led him to undertake the chief work of his life. Whilst there, he observed that the system of nomenclature in use among Continental entomologists was wholly different from that employed by those in this country. His attention had, it seems, in the previous year, been directed to the subject of nomenclature, as a "List of the British Nocture" by him appears in the Entomologist (i. p. 377 ) in $\mathbf{I} 842$. On his return, therefore, he set himself diligently to work to compare the two, with a view of ultimately producing uniformity. The execution of this task necessitated a vast amount of patient study and research, and it was not finally completed until some thirty years later. The earliest result of his labour was the publication of the first edition of his Synonomic List of British Lepidoptera, which appeared at intervals between $x 847$ and 1850 . A second, and much more complete edition, was brought out in 1859 . This, with supplements which appeared in $\mathrm{x} 865$ and $\mathrm{I} 873$ respectively, brought up the number of recognised British species to nearly 2, 100. The completion of this list, commonly known as "Doubleday's List," almost marks an epoch in British Entomology. Though little more than a label-list it has proved of the greatest possible service. In i $\delta_{3} 6$, 1) oubleday had attempted to render a somewhat similar service to British ornithologists, by publishing $A$ Nomenclature of British Birds (Wesley and Davis), which quickly ran through several editions.**

* In the Imperial Dictionary of National Biography this is erroneously ascribel to Fidruard Doubleday. It was somewhat severely reviewed in the Naturalist (Neville Wood's: I 37 ; ii., p. 6o). 
As a writer, however, he was not prolific, and he never published any other separate works. His correspondence with brother entomologists, both at home and abroad, was very extensive, and his liberality in supplying them with specimens and information was almost unbounded. His collections both of birds and insects were, in their day, almost unrivalled. During his later life, ornithology, to which he had formerly given much attention, was largely neglected in favour of entomology. He was an excellent shot, and was very skilful as a stuffer. A considerable number of birds from Epping Forest were presented by him to the British Museum. To him we are indebted for first detecting in England the Little Ringed Plover, (.Evialitis curonica), as well as the Blue-headed Wagtail (Motacilla Hava).

In 1866, he sustained a heavy pecuniary loss. For a time he struggled on, but a crisis came in $\mathbf{1} 870$. The thought of being in debt, and of having to part with his collections, so troubled him that for three months early in I87 I he had to be placed in "T'he Retreat" at York, where the balance of his mind, upset by his anxieties, was soon restored. Through the kindness of friends, his books and his collections of lepidoptera were preserved to him, and he was enabled to end his days in the old home, where he busied himself, as before, with his garden and his favourite pursuits. His ornithological collections were sold by auction, by Mr. George Hine, at the Cock Hotel, Epping, directly opposite his house, on August $23 \mathrm{rd}$, I $87 \mathrm{I}$, when $\mathbf{I} 73$ lots, comprising 540 specimens in 288 cases, realized $£ 275$. Among the birds disposed of were the first British Blue-headed Wagtail, the White-winged and Parrot Crossbills shot at Epping, two Forked-tailed Petrels from Epping and a Bittern from Coopersale, as mentioned hereafter. Among the chief purchasers were Messrs. Ashmead, F. Bond, IV. Borrer, David Christy, J. H. Gurney, jun., J. E. Harting, Arthur Lister, A. H. Smee and Septimus Warner.

Henry Doubleday was never married; for nearly thirty years a distant cousin, Ann Main by name, directed his household affairs. He was throughout life a member of the Society of Friends. Among scientific men at large, he cannot hold a high place; but as a lepidopterist simply, he was, in the words of his friend, Edward Newman, "without exception the foremost this country has produced." To this it may be added that, as a naturalist, he was probably, with the exception of the illustrious Ray, the most eminent this county has ever produced. One of his latest scientific articles consisted of some observations on "The Eggs of the Cuckoo" (34. 3472), published in 1873: his last appeared in the Zoologist for May, 1875 
(34. 4429), the month before his death, and consisted of some lengthy and valuable "Critical Notices" on Mr. Hancock's Catalusue of the Birds of Northumberland and Durham. His diary, containing his observations on birds, insects, Ec., is stated (Entomologist, x., p. 53) to be still in existence; but I have not been able to ascertain its present whereabouts.

He died on June 29,1875 , aged sixty-seven years all but two days. I was present at his funeral, which took place in the small, secluded burial-ground adjoining the Friends' Meeting-house at Epping. His almost unrivalled entomological collections, which, during his lifetime, had attracted many a well-known entomologist to the quiet town of Epping, were deposited after his death, in February, i 876 , on loan by his executors in the Bethnal Green branch of the South Kensington Museum, where they have ever since been preserved intact and known as the "Doubleday Collections." In 1877 , a catalogue of them (South Kensington Museum Science Handhooks) was published by the Lords of the Committee of Council on Education. It is to be regretted that the scientific value of the collections is lessened by the absence of any indication of localities attached to the specimens-a fault of nearly all old collections. Obituary notices of Doubleday appeared in the $E n$ tomologist (x. 1). 53-with photograph), the Entonologists' Monthly Magamine (xii. p. 69), the Proceedings of the Entomolosical Society' (1875, p. xxxi.) and the Field (July r 7, r875).

ENGLISH, James Lake (1S20_-r888), "was principally known as a practical field-student of cryptogamic botany, and as a lepidopterist; but his knowledge of birds and skill as a taxidermist entitle him to a place among Essex ornithologists. His father had been a soldier in the Dragoon Guards, who settled in Epping as a gardener, and in that quiet country-town English was born on August 2 Ist, I 820 , in the cottage in which he lived nearly all his life. He received some education at Palmer's School at Epping, but did not shine as a scholar, his talents being of a mechanical and observational character. He aided his father until the latter's death in 1835 , and then being thrown upon his own resources he collected insects for the boys in the Friends' School at Epping. His skill attracted the notice of Henry Doubleday, who engaged English as an assistant and collector, in which he was highly successful, and great numbers of Doubleday's specimens were the result of English's acuteness and perseverance. He was also well skilled in the culture of plants and his mechanical genius was undoubtedly great. He constructed a lathe 
with which he turned out excellent work in wood and metal, and he made a compound microscope, using it constantly in his botanical observations for many years. After Doubleday's death he maintained himself by working as a general mechanic and taxidermist, and any tool required was at once contrived and made by him. His skill as a preserver of birds and animals soon brought in much business; he greatly improved many processes, and hundreds of English's specimens are now to be found in country-houses in Essex and elsewhere. About I 865 his attention was attracted to the study of Fungi, and so skilful did he become in collecting them, that he always took the first prizes at the 'Fungus Shows' of the Royal Horticultural Society. He made a vast number of experiments in quest of a method of pre serving these plants, and in 1882 published a Mamual for the Preservation of the Larger Fungi. For specimens so preserved he received a Diploma of Honour at the National Fisheries Exhibition in IS8 I. His powers of observation were most remarkable, and in spite of want of books and erudition in his subjects, he acquired an extraordinarily good knowledge of the larger fungi, and was full of facts, gained in the fields and woods, of their habitats, peculiarities, \&c.information not to be found in books. Latterly he turned his attention to Mosses, and in 1885 commenced the publication of 'Fasciculi of Epping Forest Mosses,' of which five parts appeared. He was an original member of the Essex Field Club, and while his health lasted was constant as an attendant and exhibitor at the meetings, and as a 'Conductor' at the Annual Fungus Forays. It is much to be regretted that English left so few records of his observations. Until the establishment of the Field Club we are not aware of any publications by him. In the journals of the club, besides short notes, are printed:- 'Two Notes on the Preservation of Plants with their natural colours and forms' (43. i. 7 r.) ; 'The First Night's "Sugaring " in England : a Reminiscence of Epping Forest in I 843' (43. ii. $32)$; 'Entomological Notes from an old Pocket-book' (50. i. 109); and he largely assisted Dr. Cooke in compiling the 'Preliminary List of the Hymenomycetal Fungi of Epping Forest' (43. ii. I SI), which was published in their joint names. He also contributed the lists, \&c., of lepidoptera, fungi and mosses to Mr. E. N. Buxton's Epping Forest (1 884). English was a man of great truthfulness and honesty of mind, pleasant and communicative, of immense industry and perseverance. Under favourable conditions of education and environment he would have doubtless attained a high position as a naturalist. He died on January I 2 th, 1888 , in the cottage in which he first saw light, retaining his interest in and love for natural objects until the 
very last, and was buried in the churchyard of Epping Old Church. His cabinet of lepidoptera was purchased by Mr. T. J. Mann, and is now at Hyde Hall, Sawbridgeworth. The Essex Field Club owns specimens of his skill in preserving flowering plants and fungi, and a list of Epping Forest Mosses left in MS. will shortly be published in the Essex Naturalist." *

FITCH, Edward Arthur, F.L.S., F.E.S., \&c., of Brick House, Maldon, was born at Chelsea. His father, the late Edward Fitch, of Bayswater, was born at Sible Hedingham, and his mother (née Matilda Pannell) at Stoke-by-Clare, in Suffolk, close on the Essex border. Mr. Fitch was educated at Great Ealing School, and at King's College School, London, leaving the latter establishment in July, I87 I. He was then third out of over 700 scholars, and the last speech-day he attended he took five prizes, and might have held a scholarship. In 1870 he passed the Senior Oxford Local (A. A. degree) with honours. He has resided in Essex since I87r, and in his present home since 1874 . He married Fannie, sixth daughter of the late Mr. W. J. Belcham, of Rayleigh, at one time the largest farmer in Essex. On the 16 th of June, I 887 , his eighth child, a boy, was born, and Mr. Fitch then being mayor of Maldon, the child was named Thomas Maldon. The burgesses of the borough noted the event by presenting to their mayor a silver cradle. Mr. Fitch is now deputy-mayor of Maldon, a town councillor, vice-chairman of the Maldon Union, chairman of the Assessment Committee, president of the Essex Field Club, a fellow of the Linnean and Entomological Societies, (of which latter society he was secretary from I88 I to i 886) and of several local natural history and archrological societies. He is a churchwarden of St. Mary's, Maldon. He farms over 2,000 acres of land in Maldon, Hazeleigh, Purleigh, and Woodham Mortimer ; and last year was elected without a poll as County Councillor for the Heybridge Division. He has rendered exceeclingly valuable assistance during the preparation of this work.

GIBSON, Jabez (I794-1838), of Saffron Walden, though not eminent as a working ornithologist, deserves mention as having been the chief of those who were instrumental in organizing the noble Nuseum at Saffron Walden. He contributed very liberally towards the expenses of its establishment and maintenance. In an account of the Museum which appeared in the Essex Literary

* For the foregoing notice of English, I am indebted to the kindness of Mr, William Cole. 
Journal (19. 3.-June, I838), it is stated that it was erected for the purpose through the liberality of Lord Braybrooke, "assisted, amongst others, by the late Jabez Gibson, Esq., the fruit of whose zeal is still visible in many a valuable specimen. The huge elephant in the centre, whose bulky form strikes the attention on first entering, was presented by him in 1837 , and on almost every table we find some traces of his busy hand." Jabez Gibson was born on December I I, I 794, and died on February 23, I838. In an obituary notice which appeared in Wood's Naturalist (vol. iii., p. 283) we read that :-

"In connection with this [Walden Natural History] Society, by the exertions of five or six individuals, a museum has been formed that would do credit to any town in the kingdom. By the industry of the curators and the liberality of Mr. Gibson, some of the rarest objects in zoology have been placed there, and the collection, especially of British birds and British and Foreign insects, is very excellent."

GRUBB, Jonathan, of Sudbury, was born at Clonmel, Ireland, on the $\mathbf{I} 2$ th of January, $\mathbf{1} 808$. He was educated at a private school at Rochester, connected with the Society of Friends, of which body he has been throughout life a prominent member. In early life he carried on the business of corn-miller at Lexden, near Colchester, but in $18_{42}$ he retired to Sudbury, where he still resides. He has long been very widely known as a Temperance advocate. Almost from boyhood he has taken a very warm interest in natural history, especially ornithology, and sereral contributions from him are to be found in Loudon's Magasine of Natural History. In $\mathbf{3} 876$, he contributed an interesting paper on the "Birds of My" Premises" (39) to the Friends' Quarterly" Examiner, from which I have made many extracts.

HILL, Rev. Walter Henry, was curate of Southminster from January, $I_{3} 2$ to 1839 , under Dr. A. J. Scott, the vicar, who was Lord Nelson's chaplain, and whose life has been published. As to who or what he was, I have been able to obtain very little information, but he was evidently a good naturalist, and he contributed a list of birds observed by him round Southminster to Loudon's Magazine (12. vi. 452). Dr. Scott, who died July 24th, I 840 , was succeeded by the Rev. G. C. Berkeley, brother of the late eminent fungologist, who is, I believe, at present, the oldest beneficed clergyman in the county. He writes to Mr. Fitch as follows :-

"Mr. Hill has been dead at least thirty years. He was drowned in some trout stream when on a fishing expedition in either North or South Wales. It was 
supposed he had a fit, as he was found on his face in shallow water. I believe he left a son and daughter, but I know nothing further about him-not even where he livea."

HOPE, G. P., of Upminster Hall, is an ardent sportsman, and takes great interest in birds, of which he has a considerable and interesting collection, consisting chiefly of Essex specimens (pp. 36 and 5o. ii. I 35). He has given much assistance during the preparation of this work.

HOY, J. D. (เ 797-1839), was born in 1797 , and resided at Stoke Priory, Stoke-by-Nayland, on the Stour. He was a first-rate shot, a skilled bird-stuffer, and an ardent naturalist. In some remarks upon his life and his collection of birds by Dr. Bree (29. Sep. 28 th-Dec. I 4 th, I 867 ), it is stated that "as a working naturalist he was almost unequalled in his day in this country." Dr. Bree writes :-

"The Suffolk and Norfolk Consts were the principal fields of his labours, and in the latter part of his life he used to make annual visits to Holland and Germany. It was during one of these visits, whilst living almost in the swamps and marshes of the country, that he laid the foundation of the malady which, at the early age of forty-two, terminated his life on the 15 th of October, $1839 . "$

His premature death prevented him from completing either his notes for publication or his collections. He never published anything except some short communications in the natural history publications of the day, though numerous items of information supplied by him are to be found in the pages of Yarrell and Hewitson. His extensive collection of birds (p. 35) is now in the possession of his nephew; Mr. J. F. Lescher, of Boyles Court, Brentwood, and is contained in 267 cases. The specimens comprise many of considerable interest, and the collection as a whole was very fully described by Dr. Bree. Canon Babington states (46. Io) that a few specimens still remain at Stoke in possession of Mr. Hoy's brother. He adds :-

"Mrs. Lescher has a copy of a MS. catalogue made by Mr. Seaman, of Ipswich, about I8 40 , but the localities named are very few. Most of the specimens, however, were obtained near Stoke."

KERRY, F., of Harwich, is a very good ornithologist, and has devoted much attention to the birds of his district. He furnished the late Canon Babington with much useful information for his Birds of Suffolk (46.5), and has also rendered very valuable aid during the compilation of the present work.

KING, William Doubleday, (I80I-I870), was born at 
Sudbury in r8or. His early education was limited, and he was by trade a draper, but his tastes and pursuits were of a useful and refined character. The elevation of the working classes constituted the chief aim of his life, and was the work to which he devoted most of his leisure time, though he also took a great interest in the welfare of the Mechanics' Institute, the British Schools, the Hospital, the Museum, and other public institutions belonging to his native town, where the whole of his life was spent. For many years, too, he took a very warm interest in the study of natural history, especially ornithology, and to these pursuits much of his attention was directed. He was a very clever bird-stuffer, and was thus able to form a large and valuable collection of British birds, which, at his death, became the property of his nephew, Mr. John Grubb, of Birmingham, and is now preserved in one of the rooms of the Library adjoining the Friends' Meeting-house in that town. It comprises about 250 specimens, preserved in separate cases, and is still in excellent condition. It is much to be regretted that, as the collection was made before the days of modern precise ornithology, the locality, date, and sex have in no case been affixed to the specimens, and the value of the collection is thereby greatly lessened. Still, there is no doubt that the great majority of the specimens were obtained in the immediate vicinity of Sudbury -indeed, with the help of his List of Sudbury Birds it is not difficult to arrive with fair certainty at an idea of the particulars of some few of the specimens, as will be seen hereafter.

This list (20), which is now very scarce, originally appeared in Filcher's Sudbury Magazine for the year 1838 (p. I 26), and was afterwards reprinted separately in the shape of a three-page quarto tract, in double columns. It is simply signed " $\mathrm{K}$," and enumerates I 30 species, some of which were observed, but not obtained. The only separate copy I know of was in the possession of the late Canon Babington, to whom I was indebted for the loan of it and the knowledge of the work in which it originally appeared-knowledge which that gentleman himself does not appear to have possessed when he published his Birds of Suffolk (46.6). Many extracts from the list appear in the following pages. Some of these, of course, relate to occurrences in Suffolk, but as Sudbury is only separated from Essex by a narrow stream it seemed absurd to exclude these.

Another publication of his was a paper On the Study of Natural History, read at the Sudbury Mechanics' Institute, on March I6th, I 849 , and afterwards published by J. Wright, of Sudbury, price $4 \mathrm{~d}$. It is a closely-printed octavo pamphlet of twenty-eight pages. There 
is no copy in the British Museum. Several extracts from it appear in the following pages. IV. I. King also assisted in establishing the Sudbury Museum, and took a lively interest in it until the date of its dispersion in $\mathrm{I}_{72}$. He was throughout life a member of the Society of Friends. He was brother-in-law to Mr. Jonathan Grubb (p. 22) and first cousin to Edward and Henry Doubleday, of Epping (p. I3), all ardent Essex naturalists. He died at Sudbury on the I 5 th of November, 1870 , aged sixty-nine years.

LAVER, Henry, M.R.C.S., L.S.A., F.L.S., F.S.A., \&c., of Colchester, was born at Paglesham, and was educated at Hadleigh, Essex, and St. 'Thomas' Hospital. He came to Colchester to practise in 1857 , and is now senior surgeon to the Essex and Colchester Hospital. In November, I8 $85-86$, he filled the office of Mayor of Colchester. He is the author of the Mammals of Essex (43. ii. I 57) and of a paper on the Land and Fresh-IVater Shells of the Colchester District (43. ii. 88), and has kindly given much valuable help during the preparation of this work.

LEGGE, Capt. W. Vincent, R.A., is an excellent ornithologist. $\mathrm{He}$ is the author of a History of the Birds of Ceylon (Lond. 4to, I 237 pp.), a magnificent work with coloured plates. He is a Fellow of the Linnean and Zoological Societies, a member of the British Ornithologists' Union and other scientific bodies. In I 865 and 1866 he was stationed at Shoebury, where he made many observations on birds, which are described in three most interesting papers contributed by him to the Zoologist, entitled "Notes on the Nesting of Birds in the Flat Lands of Essex" (23. 98 86 ), "Ornithological Notes from South-east Essex" (34.89), and "Oölogical Notes from South-east Essex" (34. 599).

LISTER, Arthur, J.P., F.L.S., \&c., of Leytonstone, takes a considerable interest in Natural History, and has aided to some extent in connection with this work.

MACLEAN, Allan, M.D. (1 796--1869), of Colchester, "was born at Sudbury, where his father, Sir Lachlan Maclean, was in practice as a physician. At an early age he was sent to the Grammar School at Bury St. Edmunds, passing from thence to Cambridge, where he took the degree of Doctor of Medicine. He began practice in Colchester, where he resided for half a century, and he held the appointment of physician to the Essex and Colchester Hospital 
for many years, with satisfaction both to patients and governors of the institution. He died on September 5, 1869, having retired from practice for several years. In many respects he was a most remarkable man. His knowledge of Natural History was very extensive, and if it could be said that he excelled in any branch especially, his life-long habit of observation and fondness for birds would have placed him in the first rank of ornithologists, had he made public the vast store of facts he had accumulated, but unfortunately he never published anything. This may have been due to his retiring disposition, but one thing he did in perfection: his stuffed birds were marvellously painstaking and truthful copies of nature. He was brimful of facts, but these had always to be drawn out of him by persistent questioning. He was by far the best naturalist it was ever my lot to meet. Dr. Bell made public in the Zoologist, I think, some of his observations on the hybernation of caterpillars, especially on that of the White Admiral Butterfly. $\mathrm{He}$ was also very successful in his treatment of birds in captivity, and appeared to have no difficulty in keeping healthily in confinement some of the most troublesome of the warblers; his knowledge of their habits and his patience enabling him to succeed where others failed.

"Although he never published anything, he was always pleased to. assist anyone requiring help, and many a young naturalist had to thank him for having first led him into correct habits of observation. He was an excellent botanist and an enthusiastic horticulturist and florist. His experiments in the propagation of fruits and vegetables were of great public importance, inasmuch as he raised varieties of peas, which have enabled us to have Marrow-fat peas over a month sooner than it was possible before he began his experiments. The same may be said of the varieties of rhubarb he raised. The very earliest and best kind grown, his Early Red, is still unsurpassed for flavour and early fitness for the table. As a florist also, he was most successful. Lovers of the pelargonium have to thank him for many valuable varieties, he having raised the first white one known. In short, there was nothing he touched which he did not excel in, and it was a matter of general regret amongst his friends that he could not be induced to put to paper anything out of his great accumulation of facts and observations." *

He was evidently an adept at netting birds, and in his letters to Heysham (I6) more than once speaks of his "spider nets." In one, he says :-

* For the foregoing notice of Dr. Maclean, I am indebted to the kindness of Dr. Laver. 
"The extraordinary success I have had with my spider nets will afford ycu much amusement. I have taken all the Warblers except the Wood Wren, the Grasshopper Warbler, and the Dartford Warbler ; also Kingfishers, Rock Larks, and an endless number of other birds, and I have not the least doubt but I could take any birds except those which are constantly at the tops of high trees."

The net seems to have been made of the finest knitting silk, with a mesh small enough to take the Warblers. This size seems to have been strong enough to take Blackbirds, though the Doctor evidently had a larger net for the purpose, for he mentions having accidentally taken three Sparrow-hawks when after Blackbirds. Mr. Hoy and Mr. Savill have, he says, each taken one. He also enters at considerable length upon his method of bird-stuffing and says: "I stuff my birds upon plans which I have myself invented." An obituary notice of Dr. MacLean appeared in the Entomolocist (vol. iv, p. 357).

PARSONS, Christopher, ${ }^{*}$ the only child of Christopher and Lucy Parsons, of The Lawn, Southchurch, was born in 1807 . He was brought up to farming, and in 1835 he, took Bowater's Farm, East 'Tilbury, but removed in $\mathrm{I} 842$ to North Shoebury Hall Farm, where he resided until within a few years of his death. He then again removed to The Lawn, Southchurch, where he died in $188_{3}$. He must very early have become interested in Natural History and sport, for his Game-book commences in I822, when he was only 15 . In the following year, when he was at school at Poplar House Academy, kept by a Mr. Stock, he was in correspondence about works on Natural History with one Robert Castle, a naturalist, as shown by a letter which still exists. His interest in science was deep and to some advantage, for he afterwards became extremely proficient as an ornithologist, botanist, entomologist, and meteorologist. In 1828 he spent some months in London learning to stuff birds, \&c., after which he remained at home, assisting in the work of the farm and "following his bent." His home-life about this time seems to have been varied by sporting trips and by visits to France, Scotland, the Fen-district and the North of England, as well

* Christopher Parsons, the subject of this notice, was at least the sixth and the last member of his family who bore that name. His father, Christopher, who died in 1869 , was son of a Christopher Parsons, who died April 21, 1805, aged 67, and who was the son of another Christopher Parsons, who died in 1787 , aged 88, and who was the grandson of yet another Christopher Parsons, who died on March 22, I713. He was overseer of Southchurch in 1682 , and churchwarden in 1689 . There was a Christopher Parsons, junior, who held Samuels in 1690 , and Palgraves in. 694. His last signature was at Southchurch in 1700 . The Parsons family long resided at Thorp Hall, Southchurch, and the Shore House, Shoebury. For the following information I am indebted to Mr. E. A. Fitch. 
as by frequent visits to London, and return visits from $\mathrm{Mr}$. Curtis and other well-known London naturalists of the day. When in town, he seems frequently to have called on Sowerby, Yarrell, Gould, and other leading naturalists. Many interesting letters belonging to this period still exist in the possession of Mr. S. W. Squier, J.P., of Horndon-on-the-Hill, who acted as his widow's executor, and to whom I am indebted for much of the information here given. These show that he was in correspondence with the following, amongst others :- John Curtis (1827-42), Edward Blunt (1825-26), Messrs. J. and J. F. Ward (I828-34), T. C. Heysham, of Carlisle (1838-39), Thomas Pain, of Great Yarmoutn (1839-40), and G. S. Gibson, of Saffron Walden $(185 x-65)$ with reference to the Flora of Essex. In 1839 he was elected a Fellow of the Linnean Society. His first published notes on Natural History seem to have appeared in 1833 in the Field Naturalist, a short-lived magazine edited by James Rennie. The first was a brief article "On the Black-headed Gull" (I3. i. 533), to which the editor added, "Other communications from our intelligent correspondent will be acceptable." He afterwards contributed to the same publication articles on the "Migration of the Tree Sparrow" (r3. ii. I 53), "The Method of forming a Rookery" (13. ii. I53), "The Dunlin" (13. ii. I54), and "Hints on collecting Water Birds" (13. ii. 197). The latter especially shows him to have been a thoroughly practical, working ornithologist, and especially familiar with shore birds. In I 844 he contributed some remarks on the nude space around the Rook's bill to the Zoologist (23.937). Beyond these notes he seems to have published little or nothing.

In $1827 \mathrm{Mr}$. Parsons and his father, who thoroughly shared the son's tastes, killed the following (8) at New England on May I I, and sent them to "Mr. Ward" on the following day:-I Ring Dottrell (? breeding), 2 Pewit Gulls, I Sandwich Tern, I Common Tern, I Large Grey Gull, I Whimbrel, and I Grey Owl. On Jan. 21, r 829, Mr. Parsons and his father had "a famous day's sport" on New England, killing 2 Golden Eyes, 6 Brent Geese, 4 IVigeon, I Pochard, sc. (8). From a ticked MS. list of British birds, in his handwriting, and dated $\mathrm{x}_{33}$, it appears that he then possessed specimens of $\mathrm{I} 66$ species, and of the eggs of 93 species; but some of these he had evidently not obtained at or near Southchurch. In all that he did he was exceedingly painstaking and methodic. In 1840 , whilst residing at East Tilbury, he married Miss Anne Jane Silversides, but, after her death, he was again married, in 1850 , whilst he was living at North Shoebury, to Miss Mary Benton, sister of 
Mr. Philip Benton, the historian of the Rochford Hundred, who survived him a short while. After his second marriage he seems, unfortunately, to have given up his Natural History work. Had he not done so, there can be no doubt he would have become one of the best working naturalists of his day. He is described as being of an exceedingly retiring nature. In or about $\mathrm{I} 8_{40}$ it appears that he contemplated undertaking a History of British Birds, or at least of some classes of them--perhaps the IVaders--on a pretentious scale, as there are among his MSS. papers now preserved at the Southend Institute, which seem intended to form the beginning of such a work (2I), though the only species completed are the Cream-coloured Courser, the Stone Curlew, the Ringed Plover, the Kentish Plover, the Little Ringed Plover, the Dotterel, the Golden Plover, the Grey Plover, and the Lapwing--nine in all. These are very elaborately described, the generic characters, synonymy, plumages, habits, \&c., ic., being treated at great length, though, it must be confessed, without much originality, the whole appearing to be little more than a compilation. The paper of the MS. is water-marked I840. It is clear from remarks inserted that he was then friendly with Heysham.

Another series of papers, preserved in a separate portfolio, appears to be connected with the foregoing. They seem to be the rough notes from which revised Natural Histories of other wading birds were to have been prepared for his contemplated work, and they are pieced together, erased, and interlined in both red and black ink, to an extraordinary extent. Evidently Mr. Parsons was a very laboured, though careful, writer. The birds treated of are the Turnstone, Oyster Catcher, Black-winged Stilt, Avocet, Curlew, Whimbrel, Sanderling, Dunlin, Ruff, Knot, Green Sandpiper, Bar-tailed Godwit, and Vood Sandpiper. Each species is enclosed in a piece of newspaper, having outside the name of the species and a date-apparently that on which the drawing up of the remarks was completed. These dates range from February I6, I 843, to February 26, I 845 . With the remarks on each species is a paper of Parsons' own observations, chiefly relating to the dates of arrival and departure on the coast, and evidently entered as each observation was made. On the back is a table of the length, breadth, and weight of all the specimens of each species he had shot, evidently also entered at the time.

He died on September 23, I882, aged 75 years. On the 20 th of the following March his household furniture, plate, books, and other effects were sold by auction by Mr. T. W. Offin at The Lawn by order of his executors. Fifty-two lots, comprising 203 , birds, stuffed 
and set up, 4 cases of birds, 8 cases of insects, 8 boxes of eggs, some stuffed mammals, spiders, \&c., and 2 10 bird skins, sold for $£ 39$. Many of the lots were purchased by relatives, and presented to the Southend Institute. This now contains his herbarium, consisting of two large portfolios of plants and one of grasses, all well preserved and carefully labelled; two volumes of meteorological observations, extending from 1834 to May, I869, and containing daily entries relating to the wind, thermometer, rainfall, barometer, \&c., \&c., from January, I84I, to the date named; the MS. already alluded to; and a fine collection of stuffed birds and skins, presented by his executor. He has also left an interesting journal of his natural history observations, which is now in the possession of his brother-in-law, Mr. Philip Benton, of Great Wakering, for whom he prepared a flora of Rochford Hundred, which will probably be printed at the end of his History of Rochford Hundred. (35). Part of his collection of butterflies and beetles is now in the possession of Mr. Philip Benton, but the greater portion is with his other specimens at the Suuthend Institute. Numerous references to his birds, now at Southend, will be found scattered throughout this work.

RUSSELL, Col. Champion (I $820-1887$ ), of Stubbers, North Ockendon, was eldest son of the late Champion E. Branfill, of Upminster Hall, but assumed the name of Russell on succeeding to the estates of the late Joseph Russell. He married in 1855 , Emily Augusta, eldest daughter of the late Rev. C. Way. On March 3rd, I $85^{2}$, he qualified as a Justice of the Peace for the county, and among the county committees of which he was a member at the time of his death were the Highways and Bridges, the Constabulary, and the South Essex Licensing Committees. He was also a D.L. for Essex, and was High Sheriff in $\mathbf{1} 858$. Colonel Russell was for many years connected with the Militia and Volunteer forces. He joined the IVest Essex Militia, now the Fourth Battalion Essex Regiment, as a captain in 1852 . He was promoted to the rank of major in 1855 , to hon. lieutenant-colonel in $\mathrm{I} 8 \mathrm{So}$, and retired from the service in March, 1882, with the rank of lieutenant-colonel. From 1860 to 1873 he was also captain of the Romford company of Rifle Volunteers. He showed the vigour of his character at Cambridge by winning the Wingfield Sculls, becoming amateur champion sculler of the Thames in 1846 . He was, however, above all things, a keen observer of nature, an enthusiastic wild-fowl sportsman, and a strong friend of fishermen gunners. Few faces were better known 
on the Blackwater, where for many years he kept his yacht. He had one of the biggest punt guns used in the district, with a special arrangement of his own for loading, and was recognised by common consent as one of the best punt-gunners on the coast. To the poor homeless vagabonds, he was generous almost to a fault; but he was kind, just, and generous to all, and he has left his stainless and honourable life as an example to his children and to all who knew him. Colonel Russell's letters to the Times, Field, Essex Chronicle and other papers, in reference to wild-fowl and to the real character of the Sparrow, as compared with that of the Martin, will be well remembered. He also wrote, "Notes on Common Birds in my Garden," in the Field (29. June and Aug., 1878.). He took a prominent part in getting the close-time for wild-fowl altered, and was chairman of the committee on this subject appointed by the Court of Quarter Session. He advocated a close-time for all animals that required protection. At Quarter Sessions, where at one time he attended pretty regularly, he was very popular, and was always listened to with respect on the subjects he had made his own, especially that of a close-time for wild-fowl.

The following notice appeared in the Essex Naturalist (50. i. I40) :-

"Colonel Russell was a very good chemist, and was most inventive and neat. fingered, always ready with contrivances for effecting any purpose in hand. In I859, he patented an invention for the improvement of marine engines, chiefly with a view to the economy of fuel; and among other scientific work he studied photography with considerable success, being awarded a gold medal at the Paris Exhibition, and a bronze one at Dublin, for his discovery of the tannin process in dry plate photography.* The open-air study of nature, as a sportsman and wildfowler, was his greatest delight, and aroused all the enthusiasm of his character; his knowledge of birds, their habits and feeding-grounds, was most extensive and accurate, far more so than his written notes ever expressed.

"The company of congenial listeners called forth from the stores of Colonel Russell's memory a remarkable flow of capitally-expressed narrative and anecdote, and he has been known to talk continuously for four hours without in the least repeating himself! A well-known Essex wild-fowler once said, ' $\mathrm{He}$ was a marvellous man ; I believe he remembered distinctly every shot he had ever fired, and they were thousands.' Even in the study, his ruling passion was manifest, his favourite literature being books of travel and sport. He collected birds in America and South Africa. The Kafirs had a great respect for 'the Whitebeard's' skill as a shot, and it is related that he astonished them once by patiently skinning a Black Eagle that had become so 'high' that even they were repulsed. He was a great advocate for protecting birds and animals, and gave important evidence before the Wild Bird Commission, taking a prominent part in the alteration of the close-time, and was the chairman of the committee on this subject appointed by

* On Nov. 24, 1888, Professor Meldola, F.R.S., read before the Essex Field Club a paper on Col. Russell's contributions to photography, which were of considerable importance. 
the Court of Quarter Sessions. The House-Sparrows found in him a persevering and relentless foe, his argument being that the Martins and Swallows about our village and homesteads were being rapidly exterminated by this dominant and ubiquitous species. He boasted that at Stubbers he had, by killing off the Sparrows, increased the number of Martins' nests from two to nigh one hundred and fifty [44. iii. xx.].*** He was a frequent contributor to the Natural History and public journals on this question, and was one of the writers, in conjunction with Mr. Gurney and Dr. Elliott Coues, of a volume on the Sparrow-question, which appeared in 1886. He constantly advocated the claims of his feathered friends for outdoor-assistance in hard winters, and in his garden could be seen contrivances in aid of tiny housekeepings, and nets full of scraps of fat and biscuits, \&c. temptingly displayed and fitting for the season or the whims and fancies of his little pensioners. The place was indeed a veritable paradise for all that dwell in nests or have the ' $g$ ift of song.'

"Col. Russell was one of the keenest sportsmen of his time, and few faces were better known, or will be more missed, in the Blackwater estuary and on the 'Main.' It is now forty-five years since he first came regularly to the river, punting and wild-fowling, and it is stated that from that time to the present he only lost one season, when in America. His first yacht was the 'Greyhound.' (sixteen tons), built for him at Heybridge Basin, which he sailed for fifteen years. Next came the 'Sheldrake' (twenty tons), built at Harvey's, at Wivenhoe, which he used for thirty-two years (he had this and the 'Greyhound ' together for about two years). Next the 'Champion' (twenty-eight tons) built at Mr. J. Howard's, Maldon, launched in September, I886, without a name, but speedily christened by the Maldon Hythe duck-hunters, the 'Black Goose,' and the name still survives. She is a first-class boat, and Col. Russell took great interest in her while building, superintending much of the work himself. The year previous (I88j) he had built at Mr. Howard's yard a light punt, he and his skipper working at it themselves during the whole summer, nothing to be touched except when he was present. He was equally careful with his lifeboat built in I884. Both boats were designed by himself, and were very successful ; the punt is an especially interesting craft. The Colonel was always much interested in shipbuilding, and was constantly inventing varnishes, and glues, and other appliances for his favourite work. So skilful and much at home was he in the yard, that strangers have taken him for one of the regular workmen.

"He was a remarkably good shot at wild-fowl, having one of the biggest guns used in the district, and was known to the Maldon gunners as a most fair-dealing shooter; however small the gun or bad the chance of one shooting with him, the ' kill' was always equally divided by the Colonel, always to his own disadvantage. He was most patient and persevering in his pursuit of the Black Goose, and as Gabriel Clark (who was with him all the forty-five years, and who still lives at Maldon) tells, it was wonderful how many hours he would wait and work for them, and whenever he did get near the birds it was 'all up' with them : their doom was certain. His knowledge of the Blackwater Estuary and the Main outside was far and allowedly superior to that of any of the natives, and he was an authority to the Marsh-bailiffs and oyster dredgermen on many points of river lore.

Col. Russell's health failed in the beginning of $\mathrm{xSS}_{7}$. In February, he went for a trip on his yacht to Holland, but the change did not benefit him. When he returned early in March he was seriously ill, 
and he was never able to leave his room again. He died at Stubbers, on May 16 th, in his sixty-seventh year.

It is exceedingly to be regretted that he seems to have left absolutely no notes or papers whatever of ornithological interest. I have been kindly permitted to examine such of his papers as seemed likely to yield matters of interest, but they appear to contain nothing beyond the first rough draft.s of the papers which he contributed at various times to the Field and other publications. We can only feel deep regret that a man of such wide experience and one who had undoubtedly met with many rare and interesting Essex birds from time to time, should have left so few permanent records of his observations. His son, Mr. Champion B. Russell, informs me that Col. Russell never systematically collected, though he was a very fair amateur stuffer, and occasionally set up specimens to illustrate some particularly remarkable stage of plumage or other interesting fact, while he also occasionally had rare birds stuffed.

SHEPPARD, Rev. Revett (—?-I $\delta_{3} \circ$ ?), of Wrabness, seems to have been a good ornithologist, conchologist and entomologist, but the information I have been able to collect about him is extremely meagre. He was for some time at the beginning of this century rector of Vrabness, where he made many observations. He was joint-author with the Rev. Wm. Whitear of the "Catalogue of Norfolk and Suffolk Birds" (9.-Trans. Linn. Soc. xv. p. I), and also author of a List of the Land and Fresh-water Shells of the Locality (loc. cit). Some letters, written by one of his sons ( 17 ), and containing, amongst other things, a list of his father's observations on the arrival of the summer migrants at Wrabness, similar to that given in his paper above cited, have been lent me by the Rev. H. A. Macpherson, who, in a letter dated March 22nd, I88S, says: "Mrs. Sheppard, the relict of the Rev. R. Sheppard, states that, for two or three years before her husband's death, he was prevented by ill-health from carrying on his observations." He apparently died early in I 83 .

SMOOTHY, Charles, of Old Riffhams, Danbury, is a good naturalist and an excellent taxidermist, as shown by his fine collection of British Birds (most of them, however, not being Essex specimens), at present deposited in the Chelmsford Museum. He has assisted with many notes of his observations, including a list of the birds observed round his house.

SPALDING, Frederick, of Colchester, where he is curator of the Museum, is a good observer, and has supplied useful informa- 
tion. His father, Mr. T. M. Spalding, of Broome, near Bungay, contributed the List of Suffolk Birds to Suckling's History of Suffolk (pp. xxiv.-xxxix.)

WALFORD, Cornelius ( $180^{--1} 88_{3}$ ), of Witham, came of a good Essex family, but sustained losses in early life, and being very fond of the study of Natural History, he took to preserving animals as a means of livelihood. He was evidently a good naturalist, but he seems to have published almost nothing, and the personal information relating to him now obtainable is very limited. His father, when a lad, had removed from Essex to East London in connection with the then flourishing, but now extinct, Essex baize trade, and the son, who had no liking for a commercial life, spent much of his time in his early days in the forests of Epping and Hainault. Some twenty years before his death, in 1883 , at the age of eighty, he returned to London, where he continued to carry on his trade as a naturalist. The Essex Literary Journal, in I839 (I9. 27) speaks of Mr. C. Walford, of Witham, "whose collection of birds and insects is well worthy the inspection of those who feel interested in the study of those beautiful departments of nature's handiwork." 


\section{NOTICES OF THE CHIEF ESSEX BIRD COLLECTIONS.}

The Audley End Collection (Lord Braybrooke's) is very fine for a private collection, both British and foreign species being well represented. All the specimens are stuffed, most of them being admirably done, and all are equally well cased. The majority of the cases, which are large and contain many birds each, occupy the sides of one of the rooms in the mansion, but a few are ranged down the sides of the I ong Gallery. The specimens they contain are in an excellent state of preservation. Most were collected about forty years ago by the late Lord Braybrooke, but others have been more recently added. Each specimen bears a number referring to the catalogue, which is in manuscript, but there are comparatively few instances in which the locality and date are given, and still fewer in which those data show the specimens to have been obtained in Essex.

The Baxter Collection, the property of Mr. G. H. Baxter, of Hutton, is comparatively small, but is admirably preserved and is of interest as it consists mainly of specimens shot by Mr. Baxter himself in the county. It is especially strong in sea- and water-birds, and is preserved in cases which occupy the walls of the billiard-room.

The Bree Collection. A considerable portion of the ornithological collections of the late Dr. C. R. Bree of Colchester (see p. Io) is, fortunately, still preserved. The unmounted skins, \&c., are in the possession of Mr. IV. H. Harwood of that place, who purchased them from Dr. Bree's representatives shortly after his death. 'The series, which is in good preservation and well taken care of, consists of several hundred skins, an interesting collection of birds' nests (among which are that of the Swallow taken at Walton in December, I866, and a reputed Fieldfare's taken at Alresford); also a considerable series of the sterna and furcula of birds, among which are the bones of the Egyptian Vulture shot at Peldon. The great majority of the skins, many of which are foreign, have no special connection with Essex, but are of great interest as being undoubtedly the type specimens used by Dr. Bree when compiling his History of the Birds of Europe. Among others there is a large number of valuable skins collected in Sweden and Lapland by the late Mr. Wheelwright. The 
skins which are of special interest in connection with the county, comprise, among others, the three Parrot Crossbills shot at Lexden in I862, a Scaup and many other ducks shot in the neighbourhood of Colchester, as mentioned hereafter under the various species. Among the bones are those of the Peldon Vulture, Essex specimens of the White-fronted and Pink-footed Geese, \&c. \&c. Mr. Harwood informs me that a great number of Dr. Bree's stuffed specimens were sold shortly before his death, when he also disposed of his very fine collection of eggrs, which realised no less than £200. Mrs. Bree herself, however, still retains a considerable number of Dr. Bree's specimens, including some from Essex, at her house at Colchester. They are well preserved and well cased. Among them are four Sand Grouse shot in the county in 1863. Other of Dr. Bree's specimens are in the possession of Mr. Elwes of East Hill, Colchester; Mr. H. Cameron of Woodchurch, Ashford, Kent ; the Rev. E. Bree of Moulton, Spalding; and Captain Henniker.

The Colchester Museum Collection is not of great pretensions, and is not very extensive, either as regards the number of specimens or the number of species represented. It is accommodated in a small though not unsuitable room in the Borough Museum in the Castle, where it is under the efficient care of Mr. F. Spalding, and it is mainly, if not wholly, the property of the Colchester Natural History Society. A majority of the specimens are very well stuffed and separately cased, and these are in good condition, though of considerable age, but the rest are in a bad state. The former are, in all probability, the work of the late Dr. Maclean, as they were formerly in his possession. The most valuable specimen in the collection is the Nutcracker from Horkesley, but there are several other interesting specimens which were probably shot in the neighbourhood. As, however, the cases bear no inscriptions beside the bare names of the species, it is difficult to be certain of their history. In the Harsnett Library, which is also preserved in the Castle, is a small collection of birds, shot in the neighbourhood, belonging to Mr. J. Round, M.P.

The Hope Collection, the property of Mr. G. P. Hope, of Upminster Hall, near Romford, is of considerable extent and contains many interesting specimens, as will be found noticed in the following pages. A large proportion of the birds are of Mr. Hope's own shooting and stuffing, and were mostly obtained in Essex and Suffolk.

The Hoy Collection, now the property of Mr. J. F. Lescher, of Boyle's Court, Brentwood, is still preserved at that place, and is without question the most valuable in the county, though there 
are but few specimens in it that can with certainty be set down as having been obtained in Essex. It was very fully described by Dr. Bree in the Field in 1867 . Further information may be found under the notice of Hoy (p. 23).

The King Collection, though not now preserved within the county, is of local interest, having been collected round Sudbury by the late Mr. W. D. King, under the foregoing notice of whom (p. 23) further information about it will be found. It is now the property of his nephew, Mr. John Grubb, of Birmingham.

The Saffron Walden Museum Collection, which is by far the finest in the county, so far as number of specimens goes, is in an admirable state of preservation and in good hands. It has been systematically overhauled and re-arranged within the last few years, and a considerable number of specimens, purchased at the sale of the late Mr. Henry Stevenson, of Norwich, were added to it in I888. The collection dates from the year i $\delta_{32}$, when the museum was founded. Among those who laboured most strenuously to get together this fine series of British birds were Messrs. Joseph Clarke, Jabez Gibson, Stephen Salmon, and Henry Doubleday. The firstnamed especially contributed many specimens, which were chiefly shot in Norfolk. At the present time the collection of British birdsalone comprises some I Ioo specimens representing about 3 Io species (almost all of which are stuffed), of which perhaps one-quarter were obtained within the county, though there are few strikingly rare specimens from Essex. The birds are not separately cased, but are admirably displayed in wall-cases ranged around, or upright cases extending across, the great hall. As regards the museum in which this magnificent collection is preserved together with many other valuable collections, it is certainly not too much to say that it is unquestionably in all respects the best and most complete which any town of equal size in the United Kingdom can boast. It was opened on May 12 th, 18.35 . The abridged Catalogue, pullished in 1845 , contains the names of 305 British and 231 foreign birds, as being contained in the Museum and most worthy of attention. This Catalogue, which is illustrated, is exceedingly well printed, and is admirably got up for the period when it appeared-indeed, it is said to have been the best of its kind in existence at that day.*

* It may be interesting to mention that the fine specimen of the African Elephant now in the Museum was the first ever brought to this country. It was stuffed and mounted by Mrr. Joseph Clarke, who has often told me how he "built" it, as he expressed it. He and his assistants worked two whole days and a night continuously upon it, constantly pouring cans of water over it to prevent the skin from becoming hard before it was properly stretched over its 
In the year ${ }_{1} \delta_{3} 8$ there appeared in the Essex Literary Journal (19.3) an account of a visit to the museum, together with the report of a lecture on geology, three hours long, by Professor Sedgwick on the occasion of the re-opening for a new session. An admirable history and description of the museum also appeared in Life-Lore for November, 1888. The Rev. C. G. Green states (Recollections of Sport and Natural History, p.5) that his earliest reminiscences of Natural History are associated with this Museum.*

The Salter Collection, the property of Dr. J. H. Salter, of D'Arcy House, Tolleshunt D'Arcy, is, I believe, of interest, containing many specimens (especially of the Falconidae) shot by Dr. Salter himself on the adjoining marshes; but I have not yet seen it.

The Smoothy Collection, the property of Mr. Charles Smoothy, of Danbury, is at present deposited in the Chelmsford Museum, but, though a good series, it does not contain many Essex specimens of special interest.

The Sudbury Museum Collection was dispersed by sale in 1872 , some of the specimens being purchased for the Walden Museum, the rest being lost sight of. Of the museum, Mr. T. B. Hall of Coggeshall gave in I843 a brief account (23.34I) in the Zoologist, from which it appears that it had been opened in the beginning of the previous year, a building having been erected on purpose for it in Friar's Street. At that time it contained 3 ro specimens of British birds (nearly I 70 species) and the eggs of 160 species, beside numerous other collections, including the following specimens : an Otter (near Sudbury), a black Hare (Henny), pair of Curlews (Sudbury), pair of Arctic Terns (Friar's Meadow, Sudbury), \&c. \&c. Canon Babington says (46.7): "The collections of all sorts are now dispersed. The sale catalogue (June 4 th, I872), of which I possess a copy, enumerates their contents, but not in a very satisfactory manner." Elsewhere (46.6) he says that the localities of the specimens of birds were not recorded and adds "after many inquiries, I have only been able to make out that, though a great part of them were obtained about Sudbury, the stations of a very few only of the specimens are known, some of which [presumably the birds] are now in my possession."

\footnotetext{
wooden framework. The stuffing ot so large an animal was, in those days, a great accomplishment. The elephant was exhibited in the Great Exhibition of 1851 , where it excited considerable interest, and was caricatured by Leech in the pages of Punch.

* It may here be stated that the Museum is very deeply indebted to the late Mr. George Stacey Gibson, who, shortly before his death in $188_{3}$, devoted a large amount both of time and of money to its reorganisation.
} 


\section{TABLES OF OBSERVATIONS}

ON THE

\section{ARRIVAL OF THE SUMMER MIGRANTS}

\section{AT EPPING (1828-1845),}

BY HENRY DOUBLEDAY.

\section{AND AT WRABNESS (1818-1830),}

BY THE REV. REVETT SHEPPARD.

The two following tables seem to be worth reprinting, though the greater part of the information contained therein has already been published-Doubleday's observations in the Zoologist, and Sheppard's in the Transactions of the Limnean Society. In both cases, however, I have, curiously enough, come across copies of the original MS. records, both containing additional information, which I have inserted. Doubleday's observations are given in his letters to Heysham (ro) and Sheppard's in his son's letters to the same gentleman (I 7). 
Arrival of the Sumier Migrants at Epping, as observed by Henry DOUBLEDAY, I $828-\mathbf{I} 845^{*}$ *

\begin{tabular}{|c|c|c|c|c|c|c|c|c|c|c|c|c|}
\hline \multicolumn{4}{|c|}{ Species. } & 1828. & 1829. & 1830. & 1831. & 1832. & I833. & I834. & 1835. & 1836 \\
\hline Swallow & - & - & - & Apr. 7 & Apr. II & $\operatorname{Mar} .30$ & $\left.\begin{array}{c}\text { Apr. } \\
5_{3}^{*} \\
13\end{array}\right\}$ & Apr. 8 & Apr. II & Apr. 7 & Apr. 8 & Apr. I3 \\
\hline Martin & - & - & . &, 27 & , 23 & Apr. I7 & $", 9$ & , 16 & " 24 & ", 25 & 91 & $\Rightarrow \quad 24$ \\
\hline Swift . & - & - & - & May 6 & May 8 & , 29 & $\left.\begin{array}{c}\text { May I* } \\
, 6\end{array}\right\}$ & May $5^{a}$ & $\left\{\begin{array}{c}\text { May } 2^{*} \\
, 5\end{array}\right.$ & $\begin{array}{rr}29 * \\
" 30\end{array}$ & \} May 9 & May 13 \\
\hline Nightjar & - & - & - & - & ," 6 & May 4 & , 8* & $\left\{\begin{array}{l}, 3 \\
, y\end{array}\right.$ & May $\left.10^{*}\right\}$ & May 8 &, 15 & ", \\
\hline Red-backe & d St & rike & . & - &, 28 & , 3 & Apr. 30 & , 8 & $\left\{\begin{array}{c}\text { May } 3^{*} \\
\Rightarrow 9\end{array}\right.$ & $\begin{array}{ll}\prime & 2^{*} \\
" & 7\end{array}$ & $\{\quad 9$ &, 9 \\
\hline Spotted Fl & ycat & cher & - & May to & , I2 & Apr. 30 & May 4 & Apr. 30 & $\begin{cases}\prime \prime & 1 \\
" & 4\end{cases}$ & $\begin{array}{ll}\Rightarrow & 2^{*} \\
, & I\end{array}$ & \}, 15 & $\begin{cases}\because, & 9 \\
,, & \text { II }\end{cases}$ \\
\hline Wheatear & - & - & . & - & Apr. 7 & , I & Mar, $30^{\prime \prime}$ & Mar.29 & Apr. 5 & Mar. 28 & $\left\{\begin{array}{l}\text { Apr } x^{*} \\
\text { Mar3I }\end{array}\right\}$ & Mar, $x 6 e$ \\
\hline Whinchat & - & - & • & - & May 2 & , 15 & Apr. 22 & Apr. 22 & $" 23$ & Apr. I9 & Apr. I6 & , 18 \\
\hline Redstart & - & • & - & Apr. I5 & Apr. 4 & , 5 & $\left.\begin{array}{ll}\Rightarrow & 5^{\prime \prime} \\
, & 6\end{array}\right\}$ & ", I2 & $" 2^{*}$ &, $7 b$ & ", & Apr. I2 \\
\hline Sedge Wa & rbler & . & . & - & May 8 & "I4 &, 2 II & , 16 &, $\mathbf{I}^{*}$ & , 16 & , & May 4 \\
\hline Nightinga & & - & . & Apr. I4 & Apr. $I_{7}$ & Apr. 9 & $" 9$ & "I5 &,, 20 & , I9 & $\Rightarrow \quad 2 \mathrm{I}$ & Apr. ${ }^{17}$ \\
\hline Garden IV & $\mathrm{arbl}$ & & . & - & May 6 & May 8 & May I \{ & $\begin{array}{ll}" 29 \\
" 130\end{array}$ & May $\left.2^{*}\right\}$ & , 30 & May ro & May" I2 \\
\hline Wood Wr & & . & . & Apr. 29 & , Io & Apr. I9 & Apr. 23 & " 24 & $\left\{\begin{array}{c}\mathrm{Apr} \cdot 26^{\circ} \\
-\end{array}\right.$ & "2I & $"$ & $\begin{cases}, & 9^{*} \\
, & \text { II }\end{cases}$ \\
\hline Common & Vhit & thro: & & "I5 & Apr. 18 & " $\mathrm{I}_{3}$ & , 12 &, $2 \mathrm{I}$ & Apr. 23 & "I9 & Apr. I5 & Apr. IS \\
\hline Lesser Wh & itet & roat & - & , 27 &,$\quad \mathbf{1} 8$ & , $25^{\circ}$ & , 16 &, 18 &, $20^{*}$ & $\begin{cases}, & 25 d \\
, & 18^{*}\end{cases}$ & $\left.\begin{array}{r}\text { May } 2 \\
\text { Apr. } 29^{*}\end{array}\right\}$ & , $2 I$ \\
\hline Willow WV & ren & . & . & " I0 & $\because \quad$ II & " 3 & $\left.\Rightarrow \begin{array}{l}5 * \\
, 6\end{array}\right\}$ & " 4 & $\Rightarrow I$ & 37 & $"$ & " 10 \\
\hline Chiffchaff & - & . & . & Mar. 31 & Mar. 28 & Mar. 25 & Mar. 27 & $\Rightarrow 2$ & , 2 & Mar. II & $"$ "I & Mar. I9 \\
\hline Yellow W & agta & 1. & - & - & Apr. 24 & Apr. 13 & Apr. 14 & $\Rightarrow 19$ & "1, 22 & Apr. Ig & 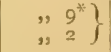 & Apr. Io \\
\hline Tree Pipit & - & - & - & - & - & , $\mathrm{I}_{3}$ & , I0 & $\Rightarrow \quad 18$ & , II & "II & , 9 & 18 \\
\hline Wryneck & - & - & . & Apr. I4 & Apr. I2 & Mar. $3^{\circ}$ & 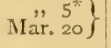 & " 4 &, 115 & ", & $"$ & ", \\
\hline Cuckoo & . & - & - & , 17 & , 16 & Apr. Ig & Apr. 2I & ", 20 & $\Rightarrow 2 \mathrm{I}$ & $\Rightarrow \quad I_{5}$ & $" 2 x$ & 14 \\
\hline Blackcap & - & - & - & ," 8 & , 18 & , 9 & Mar. 29 &, I4 &,$\quad x^{*}$ & ", & ," 9 & "15 \\
\hline Turtle Do & & . & & - & - & - & May I* \{ & $\begin{array}{c}\text { May I } \\
, \quad 7\end{array}$ & $\left.\begin{array}{c}\text { May } 2^{*} \\
, 9\end{array}\right\}$ & , 30 & 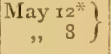 & ", 2 \\
\hline Sand Mar & & - & - & - & - & - & Mar. $27^{*}$ & Mar 29 & Mar. 28* & , 8 & Apr. 18 & "19 \\
\hline Grasshopp & er $V$ & arble & & - & - & - & - & May I & Apr. 26 & , 22 & May 7 & May 3 \\
\hline
\end{tabular}

* The following series of observations (probably the most complete of its kind ever compiled by one observer), upon the arrivals of twenty-five of our commonest summer migrants at Epping, for eighteen consecutive years, is taken from Henry Doubleday's Letters to Heysham (ro) and from his published tables in the Zoologist (23.12, 222, 65 $\mathrm{x}$ and 1066). The years 1828.30 are wholly from the Letters. The years $1831-36,1839-40,1841$ (partly) and I844 appear in both the Letters and the Zoologist; while the years $1837-38$, I34I (chiefly), I $3_{42}-43$ and 1845 are from the Zooloyist alone. When two different dates are given for the same year, the one marked with an asterisk is the published one. I am quite unable to account for so many differences between the two sources of information.

a "These arrived as usual all at once."

b "Arrived in great plenty on the gth of April. I saw more than a dozen males in sight at the same time,

c "Young birds flew on the roth of May."

d "Fewer have visited us this summer than in any preceding year that I can remember."

e "Earlier than I ever before met with one." 
Arrival of the Summer Migrants at Epping-Contimued.

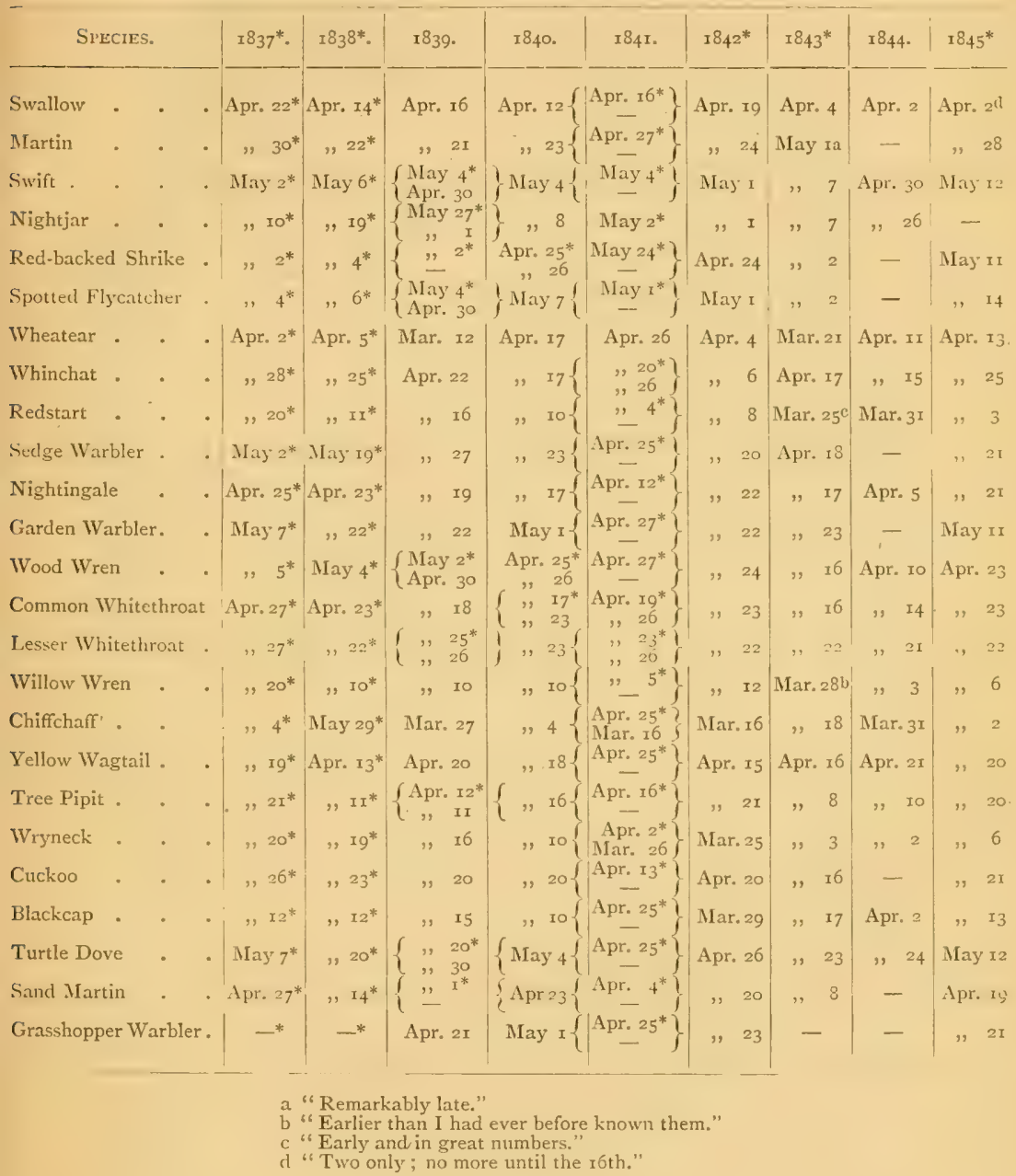




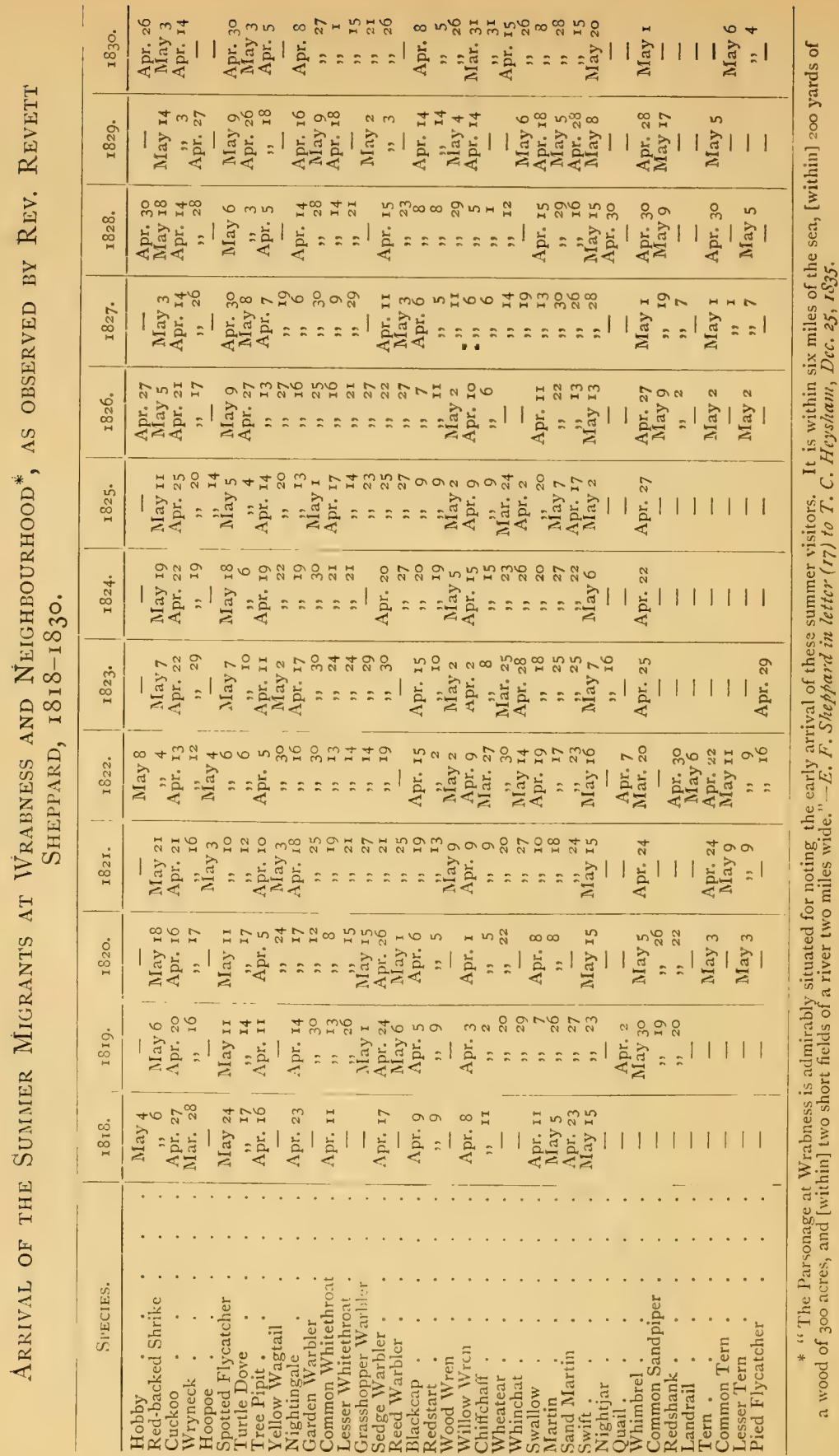




\section{OF HAWKS AND HAWKING IN ESSEX IN THE OLDEN TIME**}

By J. E. HARTING, F.L.S., F.Z.S. (Menber of the British Ornithologists' Union).

$\mathrm{M}$

ANY lands in Essex, as in other parts of England, were held of old by the serjeanty of keeping hawks or finding hounds for the king, when he should come that way upon a hunting tour, or for the use of the lord of the manor, as the case might be.

At Tey Magna, the tenants of the manor were formerly bound to maintain a number of hawks for the lord's use till they were a year old, a service which was afterwards commuted into an annual payment of thirty shillings, which in 1782 was paid to, and received by, Thomas Astle, Esq.

At Saling, in Edward the First's time, Ralph Picot held land by the serjeanty of keeping a Sparhawk (Sperverium) for the king, and mewing it at his own proper cost.

At Ardeley, Baldwin Tillot held certain land in the town by a similar tenure, per serjant. servandi nisum.

At Hallingbury, Walter de Hauville held land by the serjeanty of falconry, which he had of the grant of King Richard I.

In $\mathrm{I}_{304}$, Cicely, the widow of Humfrey de Hastings, held the manor of White Roding by the service of keeping two lanner falcons for heron-hawking, and a greyhound trained to make a heron rise, from Michaelmas to the Purification, for the king's use (Morant's Essex, vol. ii. p. 469).

At White Withings, Thomas de Longville and Beatrice, his wife (daughter and heir of Philip de Hastings), kept two of the king's lanners for the same period of the year, that is, from September to February (Blount's Ancient Tenures, 4th Ed., I8I 5, p. 277).

When James I, who was a great sportsman, journeyed from London to hunt and hawk at Newmarket, he used to go by way of Waltham Cross and Royston, and the Exchequer accounts show the great expenses which were incurred in these journeys. In 1624 , for

* These remarks are extracted, by permission, from an interesting paper by Mr. Harting read before a meeting of the Essex Field Club, held by invitation of Mr. Philip Colley, at Writtle Park, Chelmsford, on May xith, 1889, and since printed in the Essex Naturalist (50. iii.) 
example, the king went to Newmarket against the advice of his physicians to see some hawks flown.

A French falconer had arrived in London with a present of hawks, horses, and setting-dogs from Louis XIII. Chamberlain, writing to Sir D. Carleton on January $\mathrm{I} 7$ th, from Londor says :- " $\mathrm{HC}$ made a splendid entry with his train by torchlight, and will stay till he has instructed some of our people in this kind of falconry, though he costs his Majesty $£_{25}$ to $£_{30}$ a day." Accordingly we find entries of the following payments :-

"Expensis of the diet of Mons. Bonavons, a falconer at Royston and Newmarket, in the months of Jan. and Feb. viz, at Waltham Cross, $£ 34$ I7s. 8d. ; Royston, £4I 7s. 7d.; Newmarket [where a prolonged stay was made] £2I5 IIs. 6d. Then on the return journey, Royston, fo43 Ios. 2d. Waltham Cross $f_{049}$ 8s. 9d, ; and London $£ 354$ IIs. 9 d., thirty-five days in the said months amounting altogether to the sum of $£ 73975$. 4 d." (Exchequer L.T.R. Wardrobe Accounts, Cofferer. Ser. iii, box E. Rot. 45, P.R.O.)

It is to be regretted that no record has been found of the nature of the instruction imparted by the French falconer in return for all this outlay.

It is not surprising that Essex was a favourite hunting-ground with many of our kings and queens, seeing the great extent of woods which once covered the greater portion of the county, and long harboured plenty of deer* and the open heaths and marshes which afforded excellent and varied sport for the falconer.

One such place was the common at Stock, which even in Morant's day (I 768) was "pretty large, and almost joined with Gallows Common on the north, and Ramsden on the south-west." It was here, in $x 665$, that the Lord Petre of that day, who kept hawks at Thorndon, lost a valuable falcon, for the recovery of which a reward was offered in The Nerves of November 9th, 1665. The advertisement ran as follows :-

"Lost on the 28 th October last, betwixt Stock and Billerica, in Essex, a white Goshawk, $†$ having upon its varvels $\ddagger$ the name of the Right Hon. WVilliam Lord Petre. Whoever shall deliver the said hawk safe into the house of the said Lord Petre, at Thorndon, in Essex, or to Mr. Andrews, at the "White Horse " in Drury Lane, shall beside his charges defraied, have 40 . for a rewarde."

It is not unlikely that this hawk had been flown at a Kite, for at that date Kites were not uncommon on the open heaths, wastes, and

* See Fisher, The Forest of Essex, chapter iv ; and J. E. Harting on the "Deer of Epping Forest," Essex Naturalist, vol, i. pp. 46--62.

† By this term was meant a Jerfalcon. See Sir A. Weldon's Court and Character of King Janes, p. I04.

¥ The small flat rings, generally of silver, attached to the hawk's jesses, and having the owner' name engraved thereon. 
warrens on which they got their living, and showed excellent sport when flown at with a cast of falcons; sometimes, as Sir Anthony Weldon relates, mounting to such a height, that both hawk and quarry disappeared from view. King James lost a valuable hawk in this way once, while kite-hawking at Royston.

It would be interesting to know whether any record has been preserved of the sport obtained with the hawks at Thorndon, and up to what date they were maintained there. Having the honour to know the present (as well as the late) Lord Petre, I ventured to inquire for information on this subject, but without success, although his lordship is under the impression that some account of hawking at Thorndon was pullished in one of the earlier volumes of the Gentleman's Magasine. A recent search, however, through several volumes has not brought it to light.

It may be worth mention here that a notable book on hawking has been written and published by an Essex man. It is entitled, An Approved Treatise of Hazeks and Hawking, 1619, by Edmund Bert, gentleman, who resided at Collier Row, near Romford, and was very successful in training the Goshawk. In his prefatory remarks to the friendly reader he says :- "In truth I have not kept any hawke above three yeares, but I have put them off for much money, besides many thanks and much love. I had for a Goshawk and a Tarsell a hundred marks, both solde to one man within sixteen months." 


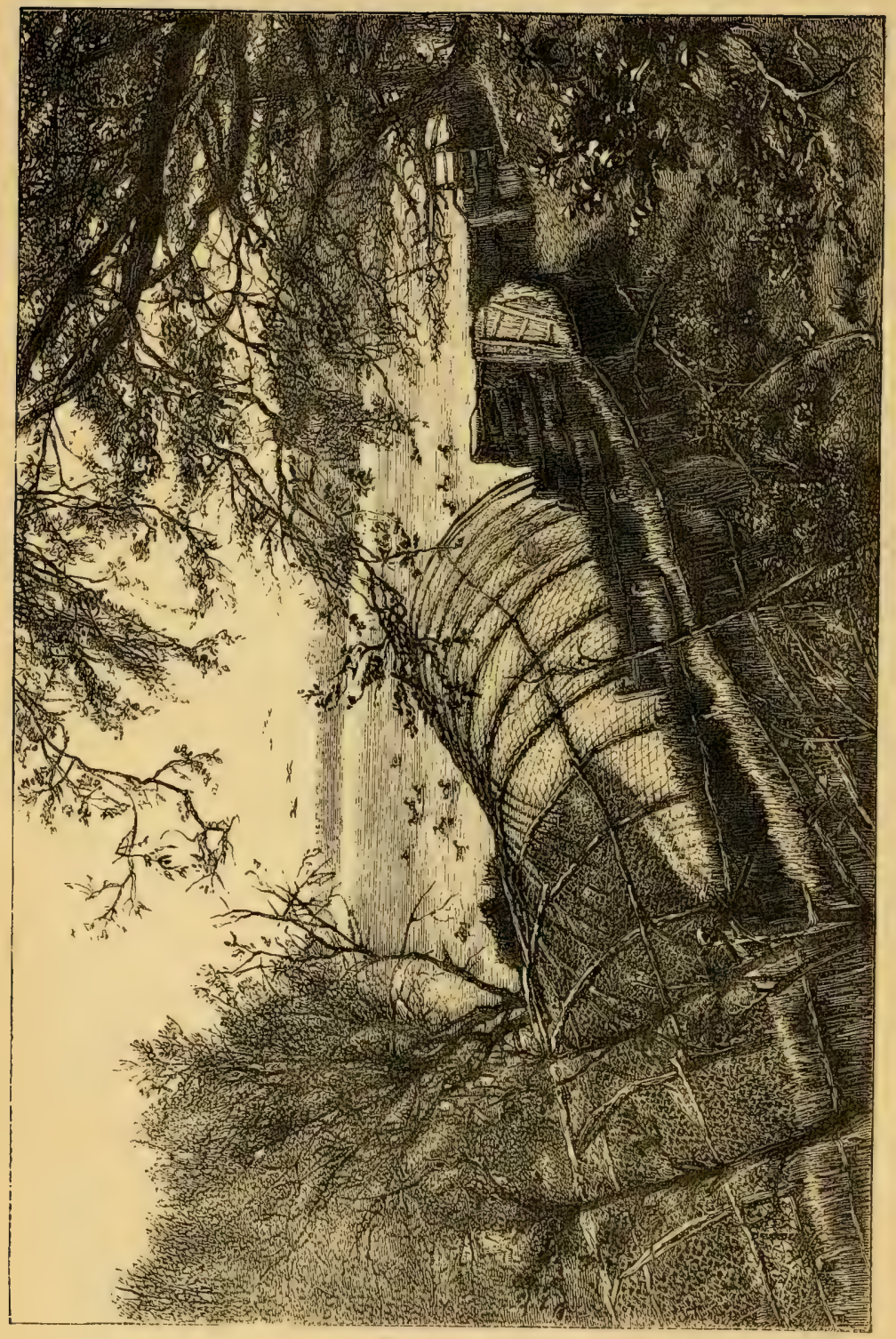

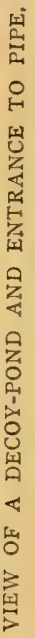




\section{WILD-FOWL DECOYS AND WILD- FOWLING IN ESSEX.}

T $\mathrm{N}$ the days when decoys for taking Wild-fowl were in common use, those of Essex were of great importance. Next to Lincolnshire, indeed, Essex may fairly claim to have been the foremost county in England, so far as the number of its decoys is concerned.

Tl are are several early references to these decoys. Thus, the Rev. T. Cox in his Magna Britannia (1720) says of Essex (vol. i. p. 722), "By the sea-side there are divers decoys, which bring in great profit to the owners in the winter season."

Daniel Defoe, too, in his Tour Through the Whole Island of Great Britain (1724) says (vol. i. p. II) :-

"Here is Osey or Osyth Island, commonly called Oosy Island, so well known by our London Men of Pleasure, for the infinite Number of Wild-Fowl, that is to say, Duck, Mallard, Teal, and Widgeon, of which there are such vast flights, that they tell us the island, namely the Creek, seems covered with them at certain times of the year, and they go from London on Purpose for the pleasure of Shooting; and, indeed, often come Home very well loaden with Game. But it must be remembered, too, that those Gentlemen who are such lovers of the Sport, and go so far for it, often return with an Essex Ague on their Backs, which they find a heavier Load than the Fowls they have shot."

Morant also says (vol. i. p. xxv.) :- "At Goldhangre, Kirby, and other parts along the coast are many decoys, which yield plenty of Wild-fowl of all kinds."

It appears from Daniel's Rural Sports (6. ii. 482) that in I8oo "the several proprietors and occupiers of decoys, on and in the neighbourhood of the river Blackwater" formed an association for the purpose of prosecuting all such gunners and puntmen "as shall hereafter by fowling, or in any other manner, disturb the wild fowl in or near such decoys, or hinder or prevent their resort thereto." An advertisement, dated "Maldon, September I Ith, I800," and signed by " $\mathrm{Wm}$. Lawrence, Solicitor to the Association," was inserted in the papers, offering a reward of five guineas for information leading to a conviction.

Considering the nature of our Essex coast, it is nothing more than might have been expected that both decoys and wild-fowl 
should have formerly abounded. On this subject Mr. Harting writes (50. ii. I 59) :- -

"We have only to look at the map of Europe to see how favourably the county of Essex is situated to afford refuge to the vast flocks of wild-fowl which migrating southward at the approach of winter, come to us from Scandinavia and countries further north, as well as from the opposite shores of Holland.

"Looking more particularly at a map of the county, we cannot fail to be struck at the number of important rivers (no less than six) which empty themselves into the sea along its coast, forming wide estuaries and tidal harbours, some of them studded with islands and bordered in some places for many miles with extensive marshes and mud-flats, which afford attractive feeding ground to many species of Wild Duck, as well as to large flocks of Brent Geese. * * *

"Viewing the country in its present condition, intersected by railways, with thousands of acres of marsh-land reclaimed, drained, and cultivated, we can form but a faint notion of what a paradise for wild-fowl the Essex coast must have been before an increased population and extended civilisation narrowed the limits of their domain. It is difficult to realise the state of things which existed before the introduction of shot-guns in the r6th century, when wild-fowl were killed with the cross-bow, with trained hawks, or with such kinds of snares and nets as the ingenuity of man at that period could devise; and we have no better proof of their former abundance than the number of decoys which once existed for their capture."

Daniel says (6. ii. 478 ) that, by dropping down with the tide in his punt, a man has been known to bring home

" from four score to a hundred wild-fowl of various kinds in one night's excursion, and this will not seem an exaggerated account when the multitudes which in hard, frosty weather, with the wind at East or North-east, haunt the Blackwater River, are known. The numbers that are seen in their day flights, and the noises of the various kinds of a night are almost beyond belief. To the compiler, prepared as he was to behold amazing quantities, they exhibited far beyond what he was led to expect; and to others who have seen their throngs, the astonishment has been perhaps still greater. A punt-shooter of the name of Bowles has been known to clear upwards of a hundred pounds in a season by his gun. The wild-fowl were sold to the higglers, \&c., at two shillings a couple, one with the other. Allowing his expenses to be only thirty pounds, here were 2600 birds brought home-an immense destruction when the whole period allotted to it does not much exceed five months. Forty-two Wigeons have been killed at a single shot in the daytime, and the difficulty of approaching the great flocks of fowl in the light is tenfold. A man, in whose punt the compiler was, got eighteen Wigeons at one shot, and many that were crippled escaped. If in the day or at night the punters get a shot at the fowl at feed upon the ooze, they tie on their 'plashes' [which are] similar to the mud-pattens used in Hampshire, and collect the spoil. *** In the day, shooting upon the river below Goldhanger in Essex, at half-ebb, very extensive oozes are dry, where grows a long grass upon which the wild-fowl feed. The nicety required is so to place the punt in some of the creeks which intersect these oozes as to intercept the birds, either in coming to their feed when the tide recedes, or when it makes so as to cover the feeding ground, and drive them from the spot. It is then the shooter has full employment an hour and a half or two hours, after which the fowl either get settled upon 
their feed beyond the reach of interruption, or if driven from it by the tide, they hasten to the various decoy-ponds upon that river to repose themselves."

Daniel also says (6. ii. 47 I) :-

"A decoy in some seasons is astonishingly lucrative. In I795, the Tillingham Decoy in Essex, at that time in the occupation of $\mathrm{Mr}$. Mascall, netted, after every expense, upwards of eight hundred pound, and the only birds taken were Duck and Mallard. In I799, ten thousand head of Wigeon, Teal, and Wild Ducks were caught in a decoy by the Rev. Bate Dudley in Essex."

Writing in 1802 , he says (6. ii. 475):-

"At the pond of Mr. Buxton, at Goldhanger in Essex, as many Pochards have been taken at one drop as filled a waggon, so as to require four stout horses to carry them away; and the lower birds in the pens have been known to be killed and pressed entirely flat, from the numbers of their companions heaped up above them."

In more recent times, the Rev. J. C. Atkinson writes (36. I 43) :-

"Within my own recollection many decoys on the Essex coast were wrought constantly and successfully, which for many years now have been dismantled and unused. I well remember, when I was a lad of ten or twelve, being at a house in Tolleshunt D'Arcy, on a farm belonging to which was an active decoy, and seeing the birds which had been taken in the course of one morning. The numbers were so great that many of the undermost ducks, where the great accumulation had taken place at the end of the 'pipe,' had died of pressure and suffucation, and some even were sensibly flattened by the superincumbent weight of their fellows."

Mr. Thos. Kemble, of Runwell Hall, speaking of Bradwell in his Sporting Reminiscences of an Old Squire, says :-

"I am now going to relate what possibly sportsmen who go down there at the present day for wilc-fowl shooting will not believe. I have seen the sky darkened with Wild-geese covering a space of half a mile by a quarter of a mile, as thick as manure spread upon the ground, and making a noise which I could only compare with fifty packs of hounds in full cry. I have also seen seven acres at low water covered with Wigeon, Curlew and Ducks, making such a noise that I could not hear my brother talking to me a few yards off. Colonel Russell was off the coast in his yacht. He told me that he had sent off from Maldon to London upwards of two tons of Geese."

\section{A recent writer on this subject in a popular paper says :-}

"The Essex coast has always been considered one of the best wild-fowling grounds in the country, and that bit between Dovercourt and Clacton-on-Sea, and such places as the backwaters of the Wash, with Landermere, Pewit Island, and Horsey Island in the neighbourhood, often afford capital sport. Of course, like other places within easy distance of large cities, the birds are not so plentiful as they used to be, but for those who are strong and have the nerve to brave the cold and difficulties which half-frozen ditches and a continual pelting of storms of hail and snow present, much good wild-fowling may still be had. Years ago wild-fowling was principally practised by the hardy race who employ their time in fishing during the summer, but in the winter pursue the feathered tribes for the support of themselves and families, and from their exertions the markets were partly supplied. However, the quest is now followed by amateurs as a recreatiun, 
and probably nowhere has wild-fowling been brought to greater perfection than on the oozes, creeks, and flats along this coast, where they have some of the best gunning-punts to be met with in the kingdom."

\section{On this subject Folkard says (The Wildfowter, 3rd Ed.,} p. 125$)$ :-

"The gunning-punts of the eastern coast are of considerable reputation, particularly those in the neighbourhood of Maldon, in Essex, the form of which is much in favour with those who resort to the pursuit of punting in winter as $a$ means of subsistence. The form of the Maldon gunning-punt is very similar to that of a coffin : simply fat-bottomed, with nearly upright sides, formed of two broad strakes. The usual length is $I \in \frac{1}{2}$ to $I 7$ feet, and the breadth 2 feet 8 inches to 2 feet Io inches. They are very handy for "setting" to birds, because of the narrowness of their form, enabling the punter to use his arms freely, and (by means of the paddles) with considerable effect ; but they are easily up:et and require very great care on the part of the occupant in all his movements. They have strong gunwales and a cross-piece, and are the least costly of any gunning-punt that can be built. When intended for an extra large gun, they are built in proportion-longer and wider as may be required In loading the gun (if a muzzle-loader) whilst afloat in one of these punts, it is usual to row ashore or lash the punt alongside a larger vessel."

Several accounts of extraordinary "bags" of wild-fowl will be found in the following pages, chiefly in the notices of the Brent Goose.

With reference to the Essex Decoys, Sir R. Payne Gallwey says (49. I0) :-

"It is pretty certain that decoys for catching ducks were first used in Lincolnshire and Essex, and that the neighbouring counties of Northampton, Cambridge, Norfolk, Suffolk, and Yorkshire, followed suit." ***

"Though Lincolnshire had great returns, other counties did wonderfully well, particularly Essex, with its immerse estuaries and their feeding-grounds to attract the fowl."

"The Essex decoys were individually famous ones, and rivalled in number those of Lincolnshire and Norfolk."

It appears from the list given (49.59) that, in respect of the number of decoys, Lincolnshire stands first with thirty-nine, but that Essex comes next with thirty-two, no other county having more than seven, except Yorkshire (14), Suffolk (12), and Somerset (12). Essex, therefore, formerly had twice as many decoys as any other county, except Lincolnshire.

Speaking of Essex Decoys, Sir Ralph says (49.75) that, as might be expected, they

"were chiefly placed near the banks of the great estuary of the River Black. water. This sheet of water is some dozen miles in length and two miles in width, with its shores and outside its mouth flanked for miles with fine feeding. grounds, in the shape of beds of ooze, to attract and support wild-fowl. Round the estuary of the Blackwater, at least fourteen or more flourishing decoys existed. To the north of the Blackwater, the Hamford Water estuary, with its multitudinous creeks, small islands, and channels, had, as might be expected, attendant decoys. St further north, on the border of the county, and dividing 
it from Suffolk, is the estuary of the Stour, with also some decoys on its banksa sheet of water but one-third less in size than that of the Blackwater. In the southern part of Essex, betiveen the Blackwater and the mouth of the Thames, the estuary of the River Crouch, with its many arms and backwaters, affurded protection and food to the wild-fowl $* * *$ : The fowl taken in the Essex decoys were -and, indeed, are-chiefly Wigeon, as they are lured to their capture from the sea-cuast, whereon these birds always predominate among the duck tribe. For this reason, there are no decoys in Essex distant from the sea, as is the case in several of our other Eastern counties, wherein large meres and fens existed *** and in which Duck, Mallard, and Teal were abundant, and therefore usually taken in the decoys."

Sir Ralph quotes a case, known as "Carrington v. Taylor, I I East 57 1. 2 Camp. 258," in which, in 1810 , a wild-fowl shooter was summoned by the owner of the decoy at Beaumont-cum. Moze for shooting ducks on a creek near the decoy, although he did not come within 200 yards of it. The Court held that the decoy was protected by law, and the verdict was for the plaintiff.

For general information as to the construction and mode of working a decoy, the reader must refer to Mr. E. C. Walcott's Guide to the Coasts. of Essex, Suffolk and Norfolk (p. 68), to Pennant's British Zoology (vol. ii, p. 595), to Sir Ralph Payne Gallwey's entertaining Book of Duck D.coy's (49) and to Mr. Harting's paper on "Wild-Fowl Decoys in Essex" in the Essex Naturalist for I 888 (50. ii. 159). Such information scarcely falls within the scope of a local work like the present; but apology is hardly necessary for reprinting from the pages of the Field (29. Feb. I5, 1868) the following interesting article, which gives a detailed and graphic description of one of our chief Essex decoys-that at Marsh House, Tillingham, described hereafter-as well as of the mode of working it and decoys in general. $\uparrow$ The accompanying cuts, too, will give the uninitiated a very good idea of the general appearance of a decoy.

DECOY PonIs, - The following particulars *** are derived more especially from a well-known pond near Tillingham, on the cuast of Essex, which the writer has lately, through the kindness of the owners, had the good fortune of visiting, and where he witnessed during several days, at the most favourable time of the year, the operations of catching carried on with great success. To those gentlemen, and to their skilful and obliging decoyman-one of that Skelton family mentioned in almost every treatise or description that has been written on decoys, and who have been hereditary decoymen from father to son, in Lincolnshire, Norfolk, and Essex, for many generations past-he has to tender his best thanks

* Daniel (6. Suppt. 43I) also cites a case in which a decoy-owner sued a gunner for shooting within 100 yards of his decoy, and thus frightening the birds, and he won the day.

+Mr. Fitch has ascertained that this article, which is simply signed "P." was written by Mr. Jacob L. Pattisson, private secretary to the Rt. Hon. W. H S Smith. Some of his statements were attacked in the following numbers of the Field (pp. 183, 235, and 245) by Admiral Hickley writing under the nom-de-plume of "Decoy Duck," but he was able successfully to hold his own 


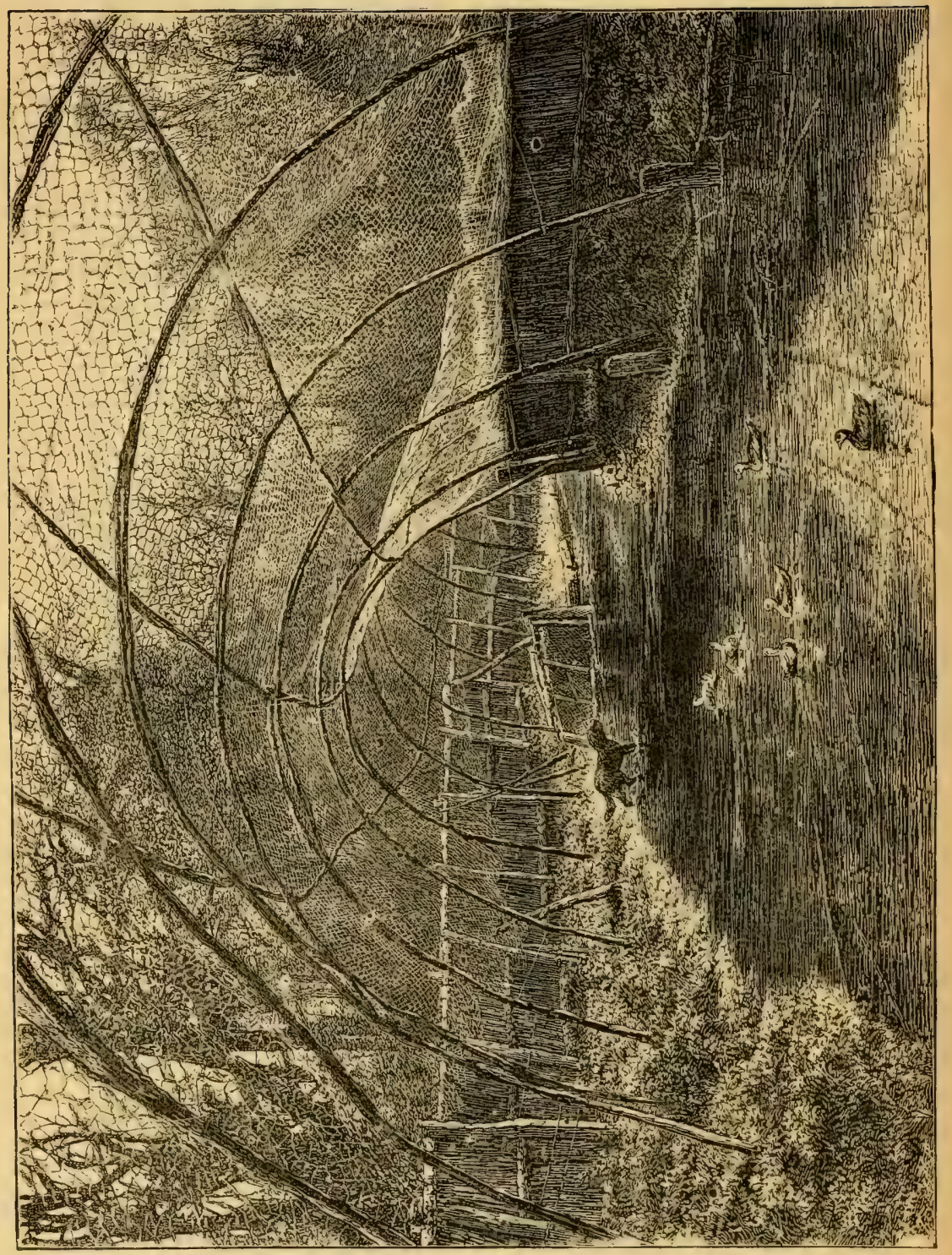

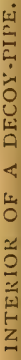


for many interesting particulars of the habits of the wild-fowl, and for their permission to visit so freely the pond itself; a permission the more valued from the fact that decoys are usually jealously guarded, and strictly closed to all visitors. The reasons for this will be apparent in the following description; but it may be mentioned that so seldom in former days was anyone but the owner and decoyman-often one and the same person-allowed to see a pond in working order, that several of the accounts that have been published in the works of eminent naturalists, and still quoted at the present day, are absurdly incorrect: one of them, for instance, stating that the birds are taken at night, the very time when the pond is empty, or when it would be impossible to take them, if in; and another that the dog drives the birds up the net from behind, the whole secret of the success in using a dog being that he should always be ahead of the birds. As exceptions to these, however, should be mentioned the very minute and accurate account of decoys given by Mr. Folkard in his entertaining book, the IVild Fozvler, and that of the Rev. Richard Lubbock in his Fauna of Norfolk. ***

Decoy ponds formerly were of great size, those in Norfolk being as much as a hundred acres in extent, the largest nearly a thousand; but experience proved that, though many thousand birds would come to them, fewer were caught than in those of smaller size, and that actually the most successful of all were not more than two acres in extent. The pond at Tillingham covers about an acre and a quarter. . It stands in the marshes, about half a mile from the sea-wall, on the other side of which, at low water, is a vast expanse of mud extending nearly two miles, and where in severe weather thousands and tens of thousands of Wild Geese, Duck, Widgeon, \&c., will congregate, while still more numerous flocks of Plover, Dunlins (Oxbirds), Curlew, \&c, skim up and down among them. It is surrounded by large beds of tall-growing rushes and plantations of willow and other trees, which serve at the same time to shelter the wild-fowl, and to hide from them the approach of human beings and other things likely to alarm them. Standing also as they do in a clump on the otherwise bare marshes, the trees are visible a long distance out at sea, and act as a mark to attract and guide the birds to the pond. Wild-fowl are easily alarmed by noise, and a decoy must be away from high roads and houses, or fields where horses are likely to be ploughing. In the precincts of the pond itself silence is necessary, and conversation must hardly be carried on, even in a whisper. Shooting within a considerable radius is, of course, strictly prohibited; and several actions at law are recorded where damages have been recovered from punters and others who have caused the birds to "rise" (the technical name for taking flight in alarm) from decoys, by firing off guns in their neighbourhood. In wild-fowl, again, the sense of smell is strongly developed, and they easily scent and take alarm at anyone approaching on the windward side. It is said that some coastguardsmen, cooking a mutton chop in the wind several hundred yards away, once caused the birds to rise from this pond; and extra precautions have to be taken in the kitchen of the nearest tarmhouse, though quite a quarter of a mile distant, when the wind blows from it to the pond. The sight of the birds is also remarkably quick, and the decoyman not only must keep himself hid, but must take care that his shadow even does not fall across the water. The necessity for taking these precautions is the excuse for the usual rule of "no admittance to visitors," the effluvia from an engineer's oily jacket, or a "swell's" sealskin coat, being enough to alarm the birds in some moods ; and when once frightened out of a pond, they are shy about returning to it again.

The water in the pond is supplied from a brook running near, and is kept fresh and clear, and at a consistent level, the depth being from three to four feet in the centre, but gradually lessening towards the sides. Several landing-places on the banks, and in the mouths of the pipes, are neatly turfed, and on these the fowl delight to sit and bask-banking, as it is called-the IVidgeon also being especially fond of eating the short grass. The pond itself is in the form of a star-fish, with six (sometimes more or less) arms or ditches extending from it in semicircular shape to different points of the compass. These arms-technically called pipes - are about 70 yards in length by 8 in breadth where they leave the pond, gradually narrowing to half a yard at the other extremity. Ovtr their whole length, and inclosing on both sides a small strip of the bank, is 
stretched a tarred net upon wooden hoops, closely fastened down to the ground, except for a small distance on one side of the pipe, near the pond, which is left open for the evolutions of the dog, to be mentioned presently. At the pond end the net is about 12 feet from the water, but the hoops gradually taper away to a lreight of only half a yard. At the small end is fixed a circular tunnel net, about $12 \mathrm{ft}$. by $2 \mathrm{ft}$., which can be easily detached and clused, and in which, erentually, the ill-fated birds are secured; the whole effect of the pipe resembling at a little distance the tail of a huge serpent, whose body is hid in the rushes and trees around the pond. From the mouth of each pipe is fixed, along the outer side, a series of screens to hide the decoyman and his operations from the birds in the pond. These screens, twelve or fourteen in number, are made of reeds in fixed wooden frames. Eich screen is about $12 \mathrm{ft}$. long by $6 \frac{1}{2} \mathrm{ft}$. high, and they are arranged to overlap one another like the folds of a perpendicular Venetian blind, with spaces between each at which the decoyman may show himself to the birds in the pipe when the time comes to drive them into the tunnel net. These openings are closed towards the ground by a smaller screen of $2 \mathrm{ft}$. in height, for the purpose of hiding the decoyman's dog, and over which he is taught to jump in and out at a given sign. By means of these screens, and the reeds which grow thickly round the pond in the intermediate spaces between the pipes, the decoyman is able to approach the water from any quarter unseen. Small wooden wedges are purpusely left in the screens, and by moving these from right to left a sufficient peep-hole is made to enable him to watch the move. ments of the birds, and to command from different points a complete view of the whole pond.

Most interesting and instructive is the view from this peep-hole when the pond is fairly full of birds, not only to the anxious decoyman or the inquiring naturalist, but the least curious visitor can hardly fail to be struck by the sight of a thousand or fifteen hundred birds, many of them of surpassing beauty of plumage, dotted over the surface of the water, swimming, sleeping, playing, and feeding, unconscious of danger, and in their most natural manner, within a few feet of him. Many of them will be asleep on the water with their heads tucked under their wings, and on a stormy day he may see them, while in this position, blown about, and turned round and round, by each gust of wind. On another and sunnier day he may watch a hen Widgeon receiving with perfect equanimity the attentions of five or six cock birds who swim about her, bowing and showing off, each striving in the most unmistakable manner tu eclipse his rivals and prove himelf the most eligible farti of the flock; and when the lady indicates lyy some sign her preference for one particular suitor, he may oberve the favoured individual proudly take his place at her side, driving away the others as if by right, and jealoucly swimming round to interpose himself if one of them approaches on the other side to whisper a parting compliment in her ear. He will notice on one side rows of birds asleep or basking on the banks, and on another the Widgeon eagerly cropping the short grass. He will hardly tire of gazing on the beauty of the Mallard, and he will laugh over the pert little Ttal and the pugnacious Tuke, or at the Dunbird diving for its food, which the impudent Widgeon close by seizes from its bill, and makes off with the moment its head apfears above water again. He will notice the golden crests of the cock Widgeon as they glance backwards and forwards in the sun, and he will marvel at the wonderful arrangement of nature by which their light and downy plumage is rendered impervious to the water they are floating in for hours at a time. The longer he looks the more will he find to admire, till at last he almost envies the decoyman his solitary life, with such beauties of nature constantly to study and wonder at.

Wild Duck, Widgeon, and Teal are the chief frequenters of decoys, but the pond is scldom full without a few couple of P'intail or Dunbirds being in it, while occasionally a pair of the rarer Gadwall or Tufted Duck are seen among the other birds. Tukes also collect in it and take possession of the landings, and a few Coot are regular inhabitants. The latter are very watchful birds, and the wild-fowl, which sleep a great part of the day, are supposed to feel more confidence in a pond where they are present. The Duck and Mallard begin to congregate in the pond soon after midsummer; but these are the birds bred in the neighbourhood. The earliest foreign fowl to arrive are the Teal, which come in the first week in Sep- 
tember. Widgeon make their appearance at the end of September; but it is not till severe weather sets in that the wild-fowl arrive in any numbers. The decoy season is from Octuber to Ma ch, when most of these birds take their departure for the north again. Wild Duck were formerly abundant in Essex, but are becoming scarcer and scarcer every year, as the marshes get more and more drained, and a higher system of cultivation is brought into use on the adjacent farms. Widgeon apparently are as plentiful as ever, finding a favourite and abundant food on the Maplin and other sands off this coast.

Duck and their congeners invariably spend the night away from where they have passed the day. The Wild Duck and Teal feed at night, but the Widgeon chiefly during the day, though also at night. The birds that come to the decoy poid arrive about daybreak, and, if not frightened, or disturbed by an approaching storm, remain there quietly till sunset, when, rising in parties in quick succession, they all leave the pond, and fly out to sea, or to marshes and ditches further inland. Those that go to the mud on the seashore will often return to the pond during the night when disturbed by the rising tide, but remain only till the ebb uncovers the mud again. The tide in the daytime does not affect the birds, few wild-fowl either entering or leaving the pond during daylight. But the pond is found generally to be fullest, and the birds more settled, when high water occurs between six and eigh: o'clock. With certain winds larger numbers may be expected than at other times; but the quantity in the pond one day is no criterion of what may be there the next. A large increase, or the contrary, usually denotes that a change of weather is about to take place. After the first severe weather has brought the wild-fowl off the coast, the decoyman wishes for but little frost, on account of the difficulty in keeping his pond open. When the water does get frozen, he uses his best endeavours, with the assistance of several labourers, to keep some of the pipes clear of ice during the night-the only time when such an operation is possible, or when any repairs to the pipe can be performed. Very often in this manner large catches are made at the beginning of a frost, the wild-fowl being glad to find an open space of water when other places are fruzen up, and their food not procurable; but when a hard frost has regularly set in, little can be done in the decoy, the birds knowing that, in addition to other dangers, foxes can get at them on the ice-an advantage which Reynard always is ready to make the most of.

The first birds that arrive in the pond, attracted by seeing the tame ones swimming in it as they fly overhead, are generally young and hungry and could be easily caught, feeding up the pipe with avidity; but these are usually spared to take back to their compations the news of such good quarters, and to tempt others to return with them next day. The "lead," as it is called, gra lually increases in this way, till at last several hundred birds have found their way to the pund. Occusionally as many as 2,000 wild-fuwl of different kinds are seen at one time in the pond; but the number usually varies trom 100 to 1,000 , of which by far the greater proportion are Widgeon. The most favourable weather for catching is a dull cloudy day, with a moderate wind bluwing, the decoyman then being able to work without casting a shadow, a d the noise of the waving rushes preventing his footsteps from being heard. In making his captures his only assistants are his dog and tise time ducks.

His dog, denominated "the piper,' is a small sandy-red terrier, of no particular breed, with a mind equally indifferent to game and to vermin. He has to be carefully trained in the summer-time to go in and out of the pipes, jumping over the small screen, at the opening which his master indicates by throwing a small piece of bread or cheese to the spot, and running along the bank, coming out again at the next opening higher up the pipe. He has to learn silence on all oc. casions, and must nut even bark at the approach of a stranger; and, above all, he must never attempt to seize, or in fact to notice, the wild-fowl. The decoy ducks also have to undergo a training. Of the common small tame breed, resembling in colour the Wild Duck, they are taken in the summer to the pond and taught to come at the whistle of their master, whom they do not see, to the opening of the pipe, where he is waiting to reward them with food. They are fed regularly, and always at the mouths of the different pipes, so that they may not be over hungry at any time, and show too great eagerness to answer the whistle; neither are they 
allowed to gorge, so as to be indifferent to food when offered. Answering the signal with a chorus of quacks, they learn to swim steadily through the other foul, guessing by the ear which pipe they are to come to ; and, lastly, they are familiarised with the sight of the decoyman, so as to take no alarm when he shorvs himself suddenly between the screens.

All wild-fowl in tiking flight from the water rise head to wind-partly, it is supposed, because of the mass of down and light feathers with which they are covered being so easily ruffled, if the wind catches them the reverse way; and partly from instinct that they thus may more readily scent and detect approaching danger. Whatever the cause, the rule is so invariable, that the decoyman can make no captures except in those pipes from which the wind blows into the pond ; and hence the reason of having pipes extending in different directions to suit every wind. But having to approarh the birds from the windward obliges him to hold before his mouth a piece of lighted turf to keep them from scenting him. Armed with this turf, accompanied by his dog, and with a basket of food (refuse corn and grass-seeds) upon his arm he cautiously approaches the proper pipe, and first satisfying himself that no birds are accidentally already in the pipe, he makes his way to the end nearest the pond. Then whistling to his tame ducks, he throws two or three handfuls of food over the screen so that it falls into the mouth of the pipe, and is partly drifted by the wind into the open water. His tame ducks hearing the call, swim into the pipe, and begin eagerly to devour the food. The wild-fowl about the mouth of the pipe tasting a few grains that have been blown within their reach, and seeing the tame birds securely feeding, are tempted also to join them under the net; the decoyman, watching every movement through the peep-holes, goes back a screen or two, and throws another handful of food into the pipe higher up, and the birds, gradually gairing confidence, follow after it. It is not necessary that they should advance far up the pipe, as once under the net their fate is sealed; but the decoyman waits till the party feeding are detached from the main flock in the pond whose curiosity does not appear to be aroused, and then running briskly back to the screen nearest the pond, but where he is still hid from the birds in the open water, suddenly shows himself behind those in the pipe, and waving his hat frightens them into flight. Misled by the bend, which seems to promise an escape, they fly headlong up the pipe, some of them striking the top of the net in their course and falling back into the water, but immediately rising again, till all scramble and flutter into the tunnel-net, where the decoyman who has been following them with gestureshe dare not make a noise-detaches the net and secures the whole flock. At one time, after the birds had been enticed into the pipe a net used to be let fall, in the manner of a portcullis, to cut off their retreat; but experience soon proved that no bird hut a very old stager, who by his frequent visits had learnt the secrets of the pond, would break the custom of rising head to wind-i.e., in the direction of the tunnel net-and that it required nothing but the presence of the decoyman to frighten them into the fatal trap. The tame birds do not rise, but taking nn notice either of the decoyman or the sudden disappearance of their companions, swim leisurely back to the remainder in the pond. The captured birds are too frightened to make a noise, and the other wild-fowl seeing none return, conclude that they have left the pond in a natural manner, and swim and play about as before. The whole operation, from the time the decoyman signals his tame ducks till he gives the detaching twist to the tunnel net, hardly occupies three minutes. Finally, he takes the birds out of the net, and in a skilful and expeditious manner puts them to death by dislocating the neck.

Hitherto the dog has taken no share in the proceedings, but has sat quietly watching his master, understanding every movement, and well satisfied to wait till his services are required. The decoyman, replacing the tunnel net, now returns to the pipe, and, knowing that he has caught all the birds who for the present are likely to be tempted by food. gives a signal to his dog, throwing at the same time a small piece of bread or cheese at the foot of the opening between the screens nearest the pond. The dog picks it up in his mouth, and jumping over the screen, suddenly displays himself to the astonished wild-fowl, who give a flutter of surprise, but are not sufficiently alarmed to attempt to fly away. While they are speculating what intruder has had the boldness to 


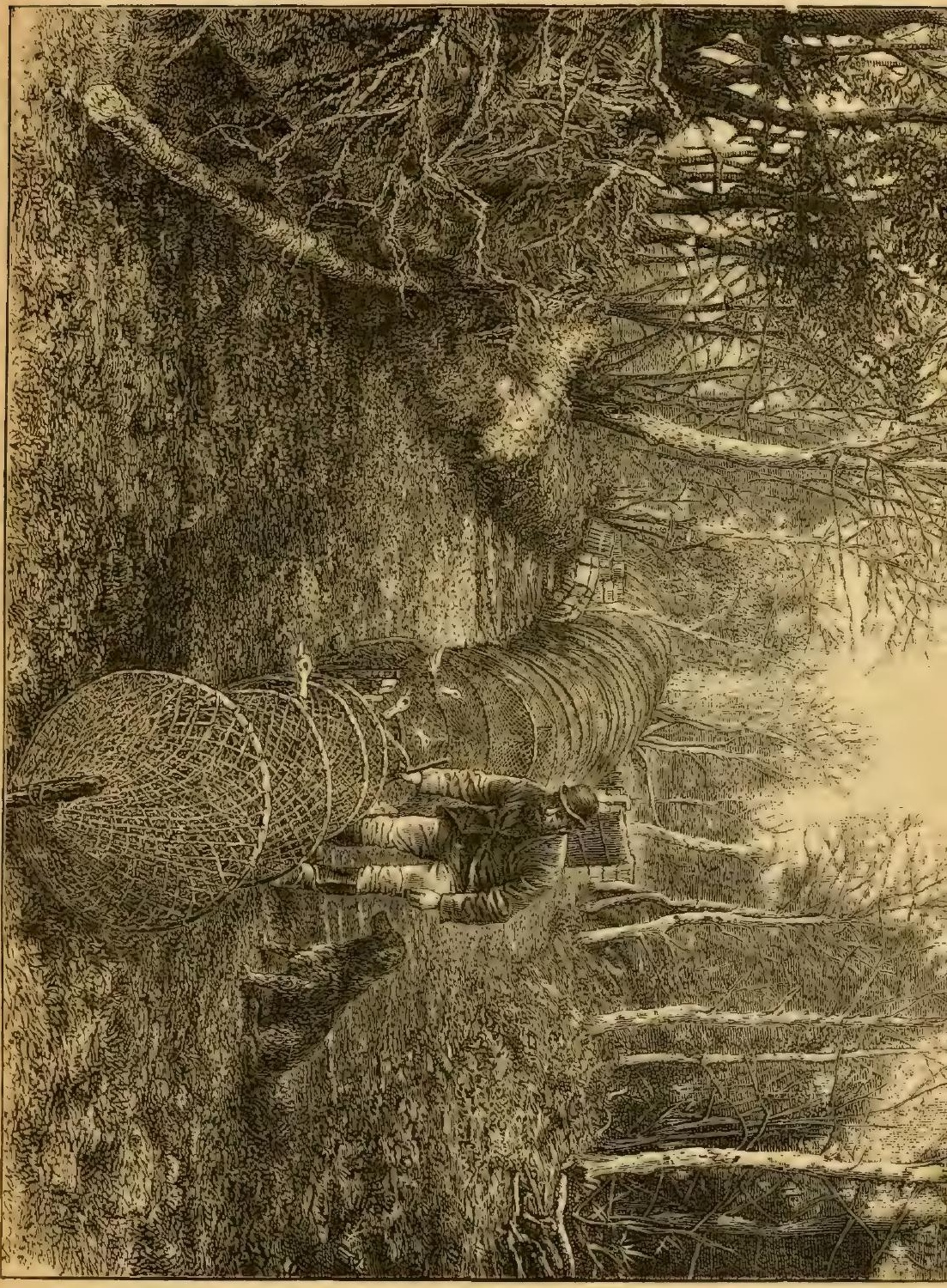


invade their retreat, he disappears at the next opening, but in another second is seen a few yards higher up the pipe. Prompted by curiosity, and taking courage from numbers, they advance towards the dog, exactly in the same manner as a flock of sheep will do in a field when disturbed by the same visitor; but again he has vanished, and they stop, wondering. He appears again still a little higher up the pipe, and they follow more confidently, perhaps believing that they are driving him away; but at last he vanishes altogether, and while they are looking for bis reappearance they are startled by the figure of the decoyman between them and the pond, waving his hat as in the previous case. Completely frightened, they follow their instincts, fly up the pipe, and are all soon secured in the tunnel net. Should the dog by any accident mistake the screen at which he has to show, and appear behind the birds in the pipe, they will at once become alarmed, and swim back into the pond.

The number of birds caught at each attempt varies according to the numbers in the pond and the state of the birds themselves, the younger birds being, of course, the most easily enticed into the pipe. In favourable seasons from one to two hundred are sometimes caught in a day, while on other days few are taken at all. The number in each drive is usually between ten and fifty, but occasionally considerably exceeds the latter number. After making catches in a pipe by both feeding and the dog, the decoyman has to leave the remainder alone till a later period in the day, when the birds having altered their position in the pond some are again near the mouth of the pipe. There is usually only one pipe at which they can be caught by feeding, but the dog may often be successful at another, perhaps two others, if the wind lies between them. On some days the birds are much more sluggish than at others, and will hardly take any notice of either the dog or food. At such times the decoyman will send his dog suddenly into the midst of those "banking," and they scramble frightened into the pond; but before they have recovered their senses the dog has disappeared, and they only see him again presently in the mouth of the pipe. The numbers taken by means of the dog are mure than those by feeding, but it is a curious fact that the hen birds are the most ready to follow the dng, and the males to be caught by the food-so much so, that the birds in one catch are nearly all of the same sex.

Wild Duck, Widgeon, and Teal rise when alarmed, but there is one variety of the Duck-tribe-the Pochard or Dunbird-which is by habit a diver, and in a pond of this description escapes the fate of the others by swimming back under water from the pipe into the open. In places where their numbers render it worth while, a particular arrangement of the pond is made, and they are taken by an ingenious net, which is suddenly placed in their line of flight as they leave the pond at dusk. The net, which is very large. is stretched between two poles, laid horizontally near the side of the ponds, but fixed on pivots, and so weighted that by severing a rope the decoyman can cause thcm to spring up suddenly into the perpendicular. This he does the moment the birds rise to leave the pond (there being several nets to suit the different winds, as in the case of the pipes), and the flock, striking the net, fall into baskets or pens placed underneath, from which they are unable to rise before the decoyman has time to secure them. Great numbers have been caught in this manner. but the plan is only adopted for Dunbirds; and at ponds where other kinds of wildfowl are more numerous there is a difficulty in using the nets without frightening away more than are caught. The best known pond of this description is in the island of Mersea, at the mouth of the Blackwater.

Day by day the spoil of the pond is sent up to Leadenhall Market. The prices, of course, vary much during the season, and depend upon the sererity of the weather, as in a hard winter vast quantities of wild-fowl are sent from abroad.

The following information regarding Essex Decoys, past and present, is mainly condensed from Sir R. P. Gallwey's remarks (49. 76--92), but I am also greatly indebted to Mr. E. A. Fitch, who has been indefatigable in hunting up scraps of half-forgotten information relating to our ancient decoyss. 
"The Birds of Essex." PL. 1.

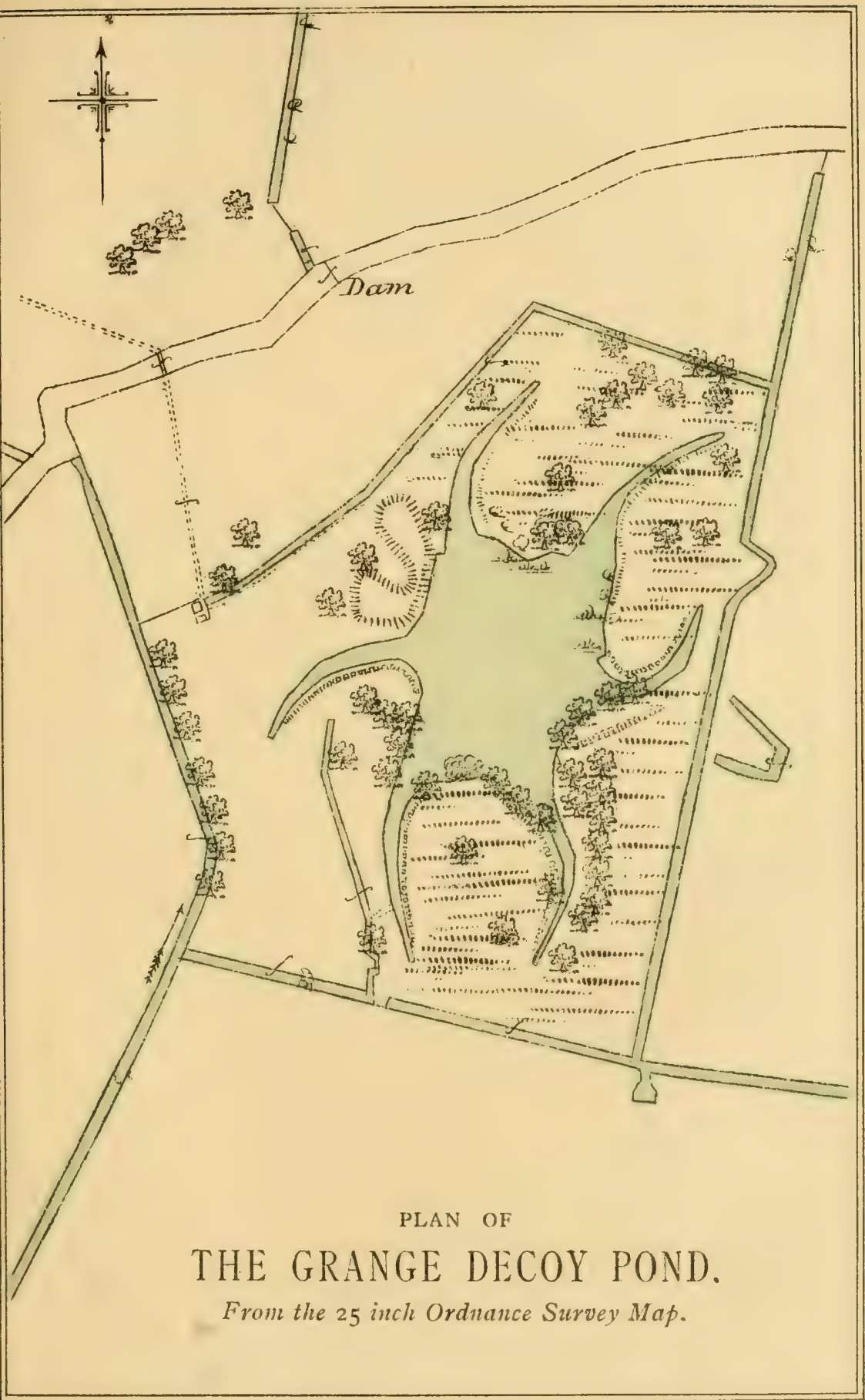



The Essex decoys still in use are now only three in number. They are:--The Marsh House Decoy, Tillingham; the Grange Decoy, Tillingham; and the Old Hall Decoy, Tollesbury (only occasionally used), each of which will be fully noticed hereafter.

The positions of all our Essex Decoys are clearly shown on the accompanying map, together with the numbers assigned to them in the following list.

It does not appear that there are any decoys about Canvey Island or along the Thames banks. Commencing with the most southerly Essex decoy and proceeding northwards along our coast-line, we meet with the following :-

(I.) South Hall Decoy is in Paglesham parish, about half a mile from South Hall, and a mile S.IV. from Paglesham, on the north bank of the Roach river, an arm of the Crouch. It is one acre in extent, and has the remains of six pipes. It has been disused for Ioo years, but there is some chance of its being re-worked by its present tenant, Mr. James Wiseman.

Those decoys on the south side of the Blackwater estuary (ten in number) are as follows :

(2.) The Grange Decoy is in Tillingham Marsh, two miles S.E. from Tillingham, and three-quarters of a mile from the coast. The pool is rather more than an acre in extent, and has six pipes. The average yearly take is from I,500 to 2,000 fowl, chiefly Wigeon, although more than once over 10,000 birds have been taken in a year, even recently. In some years, the Wigeon almost entirely desert this pool for the one next mentioned, and vice versa. The present tenant, Mr. Chas. Page, of Dengie Hall, is cousin to Mr. Robert Page, of Down Hall, Bradwell, tenant of No. 3.

(3.) The Marsh House Decoy, Tillingham, is the property of the Dean and Chapter of St. Paul's, and is in the occupation of Mr. Robert Page. The pool is rather more than an acre in extent, and has six pipes. A precise description of its construction and methods of working it has already been given above (pp. $5^{\mathrm{I}-5^{S}}$ ) ; while ground-plans of both this and the last-named decoy, taken from the 25-inch ordnance survey maps, are given herewith. Many Wigeon are often taken here, though in some years they are scarce. Pochards used to be taken, but they caused trouble by diving back when in the pipe, and Mr. Page took steps to destroy them. From I859-60 to $1864-65$, the average yearly catch was about 3,500 ; since then it has been about 2,500 a year; but of late years it has fallen to about 
2,000 , and the decoy does not now do more than cover expenses. About I822, a Mr. Hudson, the then-tenant, cleared over $\mathcal{E}_{400}$ in one year, which would represent at least 10,000 fowl taken. In I795, however, according to Daniel (p. 49) this pond cleared $£ 800$, after paying all expenses. It is also to this decoy that he refers (6. iii. 266) where he says "that in I799, I0,000 head of Wigeon, Teal, and Wild Duck were caught in a decoy by the Rev: Bate Dudley, in Essex." The decoy (says Sir R. P. Gallwey) is one of the oldest in Essex, having doubtless been constructed when the land on which it stands was reclaimed from the sea, about 200 years ago. Mr. Fitch, however, writes:-

"This Decoy was made quite at the end of last century. In Arthur Young's Agricullural Survey of Essex (vol. ii, pp. I29-130) we read:- "The great exertion that was made at Tillingham by the Rev. H. B. Dudley ten years ago, I heard on every hand commended as one of the most considerable that Essex ever saw : 300 acres of saltings were taken in by a wall so complete that the expression used was "it was executed famously!" He took down hills and banks, filled up rills, and reduced the whole to a level. The cartage was all done by bullocks. He formed also a decoy. It is rented under the Dean and Chapter of St. Paul's ; was $£ 800$ a year for 800 acres, 140 of which were arable. This Michaelmas ( 1805 ) he has relet the 1,100 acres for the remainder of his lease at 61,750 per annum; and in the estimation of the country, his prcfit (so great was the expenditure) cannot be much more than repaying an expense in which the public good has been promoted in an extraordinary manner."

An old rate-book in the vestry at Tillingham gives the names of former tenants as follows :-I 795, Mr. Mascall; I 797, the Rev. Sir Henry Bate Dudley; I805, Mr. Alston; i 8 I I, Mr. Kebbell ; and I8I5, Mr. R. Willes.* Mr. Page has most Wigeon in the decoy in January, the next most productive months being February, December, November, October, March, and September, in the order named. In one year, four Wigeon were taken in August, but in other years none until October. In ordinary years the adjoining Grange Decoy is said to be more profitable than this, but a great deal depends on which gets what is called the "lead" of the birds. An interesting collection of birds which have been taken at one time or other in this decoy--some of them evidently by accident -is preserved at Marsh House, Tillingham (Mr. Rolt. Page's). It comprises specimens of the following:- Hooded Crow, Kingfisher, Brown Owl, Kestrel, Sparrow-hawk, Peewit, Wild Duck, Scaup, Garganey, Shoveller, Pintail, Wigeon, Gadwall, Scoter, Ferruginous Duck, Tufted Duck, Smew, Coot, Redshank, Spotted Redshank,

* This record has been erroneously supposed (49.) to refer to the Glebeland Decoy (No. 4), but a comparison with Arthur Young's remarks, quoted above, clearly shows that it relates to this decoy, as the date of Sir H. B. Dudley having let Marsh House agrees exactly, and No. 4 is moreover, in Bradwell, not Tillingham parish. 
"The BIRds of EsSEX." PL. II.

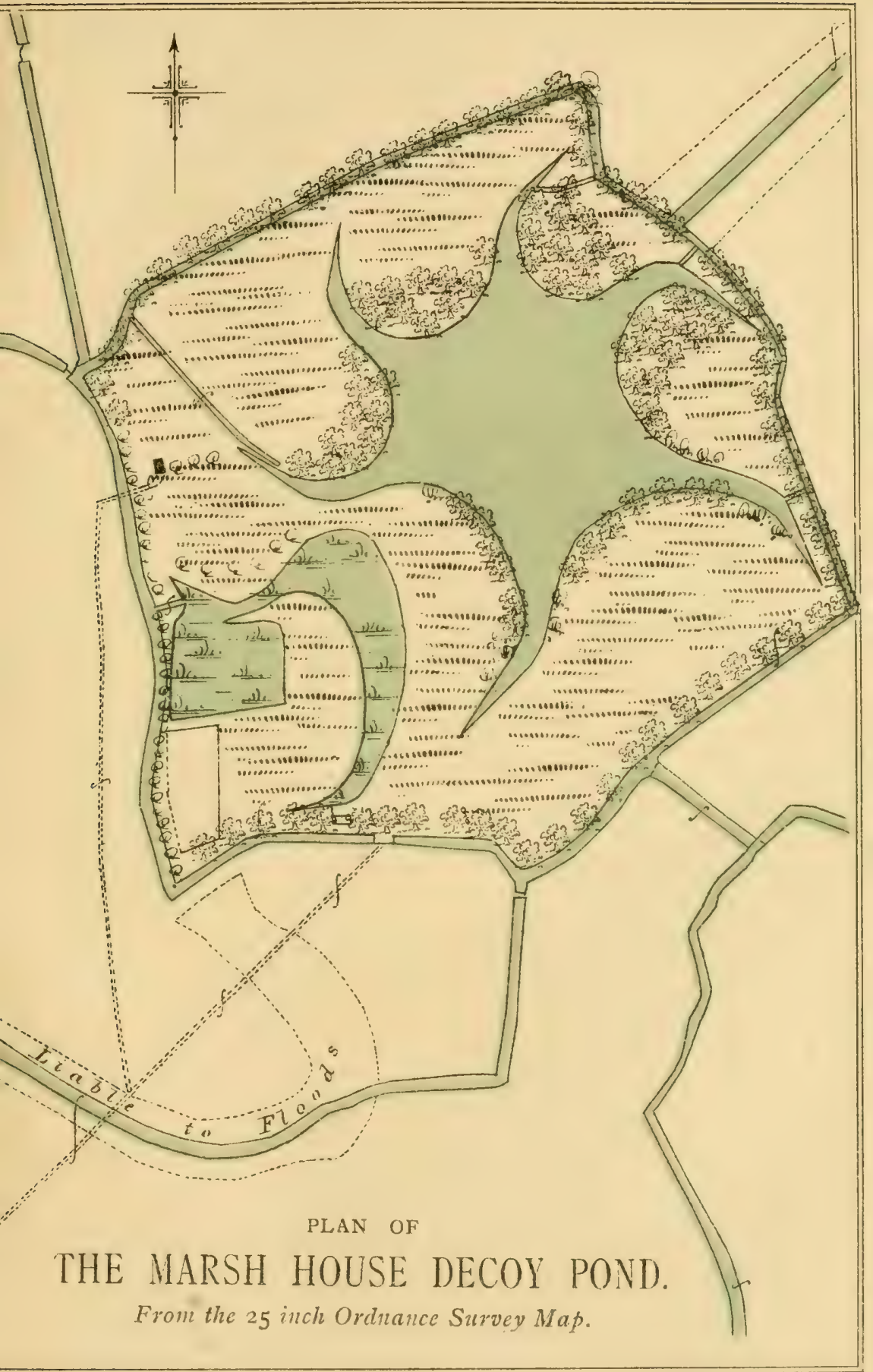



Green-shank, Oxbird, Common Sandpiper, Little Grebe, Common Gull and Storm Petrel.

(4.) The Glebeland Decoy lies one mile and a quarter S.S.E. from Bradwell-juxta-Mare, north of the brook that runs to Sandbeach Outfall, and three-quarters of a mile from the sea-wall.

(5.) East Hall and (6.) West Wick Decoys are both in Bradwell parish, the former one mile and a half N.E. from the village, and the latter the same distance $W$. Both are now disused, but have been worked within living memory. Their sites are still discernible. East Hall Decoy is about midway between Sales Point and Bradwell Chapel.

(7.) Ramsey Island Decoy. On an old map of Essex, published in 1772 , an "Old Decoy," of which traces are still discoverable, is shown close to Stansgate Wick, on the E. side of the Channel, separating it from Ramsey Island (49.79).*

(8.) Steeple Decoy was in Canney Marsh, on the E. bank of Steeple Creek, and midway between Steeple Church and the Blackwater. It is on Steeple Hall Farm. Further information relating to this decoy is given hereatter.

(9.) Mayland Decoy is situated in the corner of Sheep-pound Marsh, in the extreme N.E. corner of the parish of Mayland, and on the point west of Steeple Creek. It is on Nipsell's Farm (called Old Nipkin's in some maps), the present tenant of which is Mr. John Bunting. This decoy, which is still known as "the Old I)ecoy," is not alluded to by Sir R. P. Gallwey or Mr. Harting, and its ciiscovery is due to Mr. Fitch.

(ı.) Latchingdon Decoy. On Bowen's Map of Essex ( I 760 ) a decoy is indicated on the IV. side of Latchingdon Creek, two miles IV. from Steeple, and one E. from Mundon.

(I I.) Northey Island Decoy. The site of a decoy, unnoticed either by Sir R. P. Gallwey or by Mr. Harting, exists on the eastern side of Northey Island, Maldon, now held by Mr. E. A. Fitch. It is still known as "the Decoy Piece." It has been disused certainly during this century, and although the pond and ditches are probably but little altered, it is now impossible to say how many pipes there were. From an advertisement appearing in Mercurius Publicus for 6 th

* The only map on which this decoy seems to be marked is Chapman and André's, which was published in I777. Probsbly, therefore, the date given by Sir R. P. Gallwey (I772) is wrong. 
August, 1663 , it does not appear to have then existed. For information as to this decoy, I am indebted to Mr. Fitch.

The above are all on the S. of the Blackwater, except the last-named. Those on the $\mathrm{N}$. bank (also ten in number), passing from $W$. to E., are :-

(I2.) Goldhanger Decoy (No. I), which was one mile S.IV. from Goldhanger, two and a half miles E. from Maldon, and 150 paces from the shore. It had five pipes. Traces of it, situate on Cobb's Farm, may still be seen. It was worked until about 1870 .* Mr. Fitch writes :--

"This was used as a flight-pond until about twenty years ago, and has altered little in appearance since then. A man named Cooper, who is now dea l, used to take large numbers of Pochards in some seasons. His spring nets were attached to long stout poles, which being weighted at one end were, by the removal of a peg, made to fly up and extend the net at a height of about ten to twenty-five feet. This was done when the gun was discharged. The birds, rising against the wind, the flight of poles in that direction being sprung, struck the net and fell down into the pens or pockets at th: bottom, from which they were unable to rise, and were then secured." $\dagger$

(I3.) Goldhanger Decoy (No. 2), was a very fine one, with eight pipes. It lay one and a quarter miles $\mathrm{E}$. of the former, on a point of land on the $\mathrm{N}$. side of Goldhanger Creek, and half a mile S.E. from Goldhanger village. It has been worked within living memory.

(ㄱ․) Goldhanger Decoy (No. 3), presumably once existed on "Decoy Marsh," which consists of about eight acres of grassland, lying next to the sea-wall, immediately in front of the farmhouse, on Bound's or Bartlett's Farm, Goldhanger, now held by Mr. Abram Francis. It is called "Brand's Farm" on the six-inch ordnance survey map, probably in error. No trace now exists of either the decoy-pond or its pipes. This is another of Mr. Fitch's discoveries.

(I4.) Joyce's Decoy, also known as the "Wigeon Pond," is half a mile E. from the last named, one mile S.S.E. from Goldhanger, and beside the creek running up to Joyce's Farm. It is in

* Arthur Young was probably alluding to this decoy where he says (General View of the Agriculture of the County of Essex, $18 \mathrm{c7}$, vol. ii. p. 362), "Mr. Lee has a decoy at Goldhanger, in which he took at one haul one waggonload and two cartloads of dunbirds; but the disturbance made frightened such as escaped so much that he took no more that season.'

$\dagger$ This decoy probably existed in $\mathbf{1 7 3 5}$, for, as Mr. Fitch points out, Salmon, in his History of Essex (p. 426), alluding to the inundation in February, 1735, says that "Mr. John Cooper, a great Decoyman at Goldhanger, and four others, perished." Probably the decoyman of the same name mentioned above was a descendant of this one. 
Tolleshunt Major, or Beckingham, parish. The pool is a large one, with eight pipes. It has, not been used for about twenty-five years.*

(15.) Gore Decoy is on Harvey's Farm, in Goldhanger parish (detached portion), half a mile $\mathrm{E}$. from the last-named and close to the sea and the $W$ : end of Gore Saltings. It has not been worked for many years, but has been within living memory.

(I6.) Skinner's Wick Decoy is within one hundred paces of the shore, and opposite the last-named, across a creek. It is in Tolleshunt D'Arcy parish and takes its name from the farm on which it is situated. $\dagger$ It had eight pipes, and was formerly worked with great success, but was given up about thirty years ago.

(I7.) Bohun's Hall Decoy, so called from an adjoining residence of that name, is on the $\mathrm{N}$. side of Old Mill Creek, a quarter of a mile WV. from Mill Point, and rather over one mile and a half S. from Tollesbury. It is situated on "Decoy Farm," and is the one named "Left Decoy" on the one-inch and other Ordnance Maps. It was large, with eight pipes, and formerly possessed a set of poles and nets for taking Pochard, but has been out of use for many years.

(18.) Old Hall Decoy (No. I), which is still used, is in Tollesbury parish, close to Pennyhole Fleet on the Old Hall Marshes, and in the centre of the peninsula of land between Salcot Creek and Tollesbury Fleet North Channel. Sir Ralph P. Gallwey says the pool covers about fourteen acres, and has eight pipes, but these are errors, though eight pipes are shown on both the six-inch and twenty-five-inch Ordnance Maps. The decoy, which covers only about two acres, was visited by Mr. E. A. Fitch and myself in June, I888, when we learned that it has now but six pipes, instead of seven as formerly, the two south-easterly ones having been disused and a new one dug in place of them. The decoy is very ancient, but the date of construction is unknown. Dr. J. H. Salter is the present tenant. The numbers of fowl formerly taken are reported to have been almost fabulous; but although the decoy is one of the largest and best in the county, no account is now kept, the adjoining marshes being largely used for grazing, and consequently much

* Sir R. P. Gallwey calls this "Solley's Decoy," but Mr. Fitch has ascertained that (although Mr. Richard Solly held Bohun's Hall Decoy, No. 17) he never held this. It is better, therefore, to style it Joyce's Decoy, after the name of the farm on which it is.

+ Sir R. P. Gallwey speaks of it as "Skinner's Wick, or White House Decoy," but as Mr. Fitch has ascertained that no portion is situated on White-house Farm, it seems unnecessary to retain the name. 
disturbed. Dr. Salter, therefore, usually prefers to shoot the fowl in the surrounding marshes, though in hard winters a few hundreds are sometimes taken. These are chiefly Duck and Teal, but Pintails, Shovellers, Tufted Ducks, Long-tailed Ducks, Pochards, Golden Eye, Mergansers, and Divers of various kinds, are sometimes obtained. Very few Wigeon are taken, as these, for some reason, prefer to resort to the decoys nearer the coast.

(19.) Old Hall Decoy (No. 2), or Teal Pond, lying one mile E. from the Old Hall Decoy already described, has been long disused. It is a small square pond with four pipes, and was formerly ust d for taking Teal. It was visited by Mr. E. A. Fitch and myself in June, $\mathbf{1} 888$.

(20.) Mersea Island, or West Mersea Decoy, is on Waldegraves Farm, one mile and a half $\mathrm{E}$. from West Mersea village, and was discontinued nearly twenty years ago on account of its disturbance by shore-shooters. It had five pipes and was originally a Pochard pond. Arthur Young, in his General Vieze of the Agriculture of the County of Essex (1807, vol. ii., p. 361) says it was one of the best decoys in the county in his time. He visited it in company with the owner, and was much interested. The expenses of working he found considerable, two attendants receiving $£$ roo a year, while repairs, nets, rent; \&c., amounted to about $£ 300$. Ducks, he says, sometimes sell as low as I4s. a dozen. Dunbirds resorted to the decoy in lärge numbers, and were taken in nets, which were lowered when not in use.*

With reference to this decoy, Mr. Fitch has interviewed Charles Hipsey, formerly the captain of Col. Russell's yacht, who still lives at Maldon though he has reached a great age.t $\mathrm{He}$ says that it was last used thirty or forty years ago, and that it was formerly a great place for taking Dunbirds. After a strong south wind immense numbers were taken, the position of the decoy, of course, favouring their arrival with that wind. Flight poles, he says, were used here before they were introduced at Goldhanger. They were like the masts and topmasts of ships: as soon as the gun was fired, a trigger was pulled; up went the poles ; and the birds, striking the nets, fell down into bags or pockets at the bottom. On one of

* White's Gazetteer of Essex, published in 1848 , says $\left(26.3^{6}\right)$ : "There are many decoys in the creeks by the coast for taking wild-fowl. One of the best is on Mersey Island, and is attended by two men whose wages, with rent, repairs of nets and other expenses, amount to $£_{3} 00$ a year. Wild Ducks, \&c., are caught in great numbers; and in a decoy at Goldhanger the fowls called Dunbirds are exceedingly numerous.". This is copied almost word for word from Wright (Hist. of Essex, i. 25.-1836), who, in his turn, seems merely to have quoted Young.

† Mr. Hipsey died on Sept. 3oth, 1889, aged 84. 
the last occasions when they were used, a waggon-load of birds was taken. Bean was the name of the farmer who then held the decoy, and Samuel Mussett, of West Mersea, fired the gun. Arthur Young, who seems to have been much struck by this arrangement, is corroborated by Capt. Hipsey's statement. He says (lec. cit. ii., p. 362):-

"The contrivance for taking Dunbirds was new to me. At the decoy for them near Ipswich, there are a series of very high poles, to which the nets are attached, for taking them in their flight; and these poles are permanent. At this Mersea Decoy, to which this bird resorts in large quantities, as well as ducks, the net poles are suspended when not at work."

Speaking of this subject, Folkard (The IVildfowter, 3rd Ed. p. 95) says :-

"To give some idea of the immense flights of Dunbirds which used to be taken in the flight-nets at Mersea and Goldhanger, in Essex, the body of birds has there been known to be so great that when their flight has been attempted to be intercepted they have actually been heavier in a body than the ponderous boxes of weights placed at the lower ends of the poles, and the consequence has been that the birds have borne down the net and partly spoilt the fowler's drop ; but such is a rare occurrence, and cannot happen if the balance-boxes are judiciously weighted. ***

At these same decoys, the capture of Dunbirds on one or two occasions within present memory, has been so great at a drop that a waggon and four horses were required to remove them from the yard; and they have fallen in such heaps on striking the net that many of those at the bottom of the pen were taken up dead-apparently crushed or stifled by the pressure of those above.

To give a further illustration of the countless numbers of Dunbirds which sometimes used to assemble on the Essex flight-ponds, it is a fact that the birds have been known to resort in flights so numerous as to cover, apparently, almost every available space of water on the pond."

Teal also seem to have been sometimes taken here. Folkard says (The IVildfowler, 3rd Ed., p. 75) :- "The Essex decoys are still famous for their supplies of Teal. A few years ago, a 'spring' of 400 visited a small pond at Mersea, in Essex, the greater number of which were taken in a few hours."

We now leave the estuary of the Blackwater and enter that of the Colne, in which the two following are situated:-

(2 I.) Villa Farm Decoy lay beside the River Colne, two miles and a half S.S.IV. from Elmstead, and one mile E. from Wyvenhoe. The pool still remains, but is almost overgrown with reeds and willows.

(22.) Lion Point, or Wick, Decoy is on Cockett Wick Farm in the WVick Marshes, two miles S.S.E. from St. Osyth. It was made in 1860 , but never worked. 
Proceeding now northward along the coast, we next encounter the four following decoys lying round the inlet known as Hamford Water.

(23.) Old Moze Hall Decoy was in Beaumont-cum-Moze parish near the N.IV. extremity of Hamford Water. The pond was nearly circular, I oo yards across, and had six pipes (now obliterated). It was last worked in I84I. The case of Carrington v. Taylor, already mentioned, had reference to this decoy.

(24.) Great Oakley Hall Decoy lay at the head of Oakley Creek, in Great Oakley parish, about 300 yards N. from the last-named. The pool was rectangular, and about one acre in extent. There were six pipes. It has now been disused many years, but James Smith, who acted as the last decoyman some fifty years ago, still lives (or lately did so) at Harwich, though over eighty years old. Sir Ralph Payne Gallwey describes him as the last of the old race of Essex decoymen, and he prints an interesting interview which Col. Leathes had with him. Smith describes the enormous takes of fowl made by himself and his father (whose father before him had also acted as decoyman at this decoy) many years ago. He began work at the age of fourteen. The largest take he ever remembers in one season was 700 dozen whole fowl-an enormous take for the size of the pond. Supposing 300 dozen to have been half-fowl (i.e., Teal, Wigeon, Divers, \&c.), we have the following as the result of one season's catch on a single acre of water :-

400 dozen whole fowl 600 dozen half-fowl .

- 4,800 Ducks.

- 7,200 Teal, Wigeon, \&cc.

Total . I 2,000 birds.

Mr. Smith never remembers more than 18 dozen ducks (i.e., 2 I 2 birds) being taken in one drive. The rivalry between the Smiths and the decoyman at Old Moze Hall was so keen that both decoys eventually had to be given up.

(25.) Horsey Island Decoy, of which the pool and six pipes may still be seen, is in the S.E. of Horsey Island, between the Wade and Stand Creek, close to Walton Creek. It is in Kirby-leSoken parish and was worked by a man named Abraham Annis up to about fifty years ago, when it was discontinued, owing to the difficulty of supplying it with fresh water. On the 25 -inch ordnance map it is called "New Decoy Pond." 
(26.) Dovercourt Decoy, one mile E. of Ramsey, on a marsh adjoining South Hall, has not been worked for sixty years.

The four following decoys lie along the S. side of the estuary of the River Stour, within three miles E. of Bradfield. All have been worked within living memory, but no particulars are now obtainable.

(27.) Roydon Hall Decoy lies near Roydon Hall, S. of Stour Wood, one mile IV. of Ramsey and four miles E. of Bradfield.

(28.) The Old Decoy, or Jacques Hall Old Decoy, lay half a mile E. of Jacques Hall, and one mile N.E. from Bradfield. It is now dry.

(29.) Jacques Hall Decoy lay three-quarters of a mile S. of the last-named, and one mile S.E. from Bradfield. Slight traces only of it now remain.

(30.) Pond Hall Decoy lay half a mile E. of the last-named, and, like it, is in the parish of Wix. Both are about a mile S. of the River Stour. Mr. Fitch sends me the following interesting advertisement (dated I754) relating to this decoy:

"A Sober Man, either single or married, who can come well recommended, and understands managing a DECOY POND, by enquiring at Pond-Hall in Wicks, near Manningtree, in Essex, may hear of a Place. He will have Husbandry Work found him after the Catching Season is over, and a House to live in, if married."

"Whereas the WILD-Fowl coming and going to and from my DECOY-Ponds have several Times last Season been affrighted by People shooting and making Paths through my Fields, out of the ancient Church or Foot-Paths : I give this publick Notice, to prevent such unwarrantable Practices, that I will bring an Action at Law against any Person who shall presume to do any Detriment to my said Ponds for the future : And as an Encouragement to my Decoy-Man, or any other Person who will make Discovery of any one doing me Damage in the a bove Manner, or breaking my Hedges ; I do offer upon the Conviction of any one Person, or Persons, a Reward of Two Guineas, to be paid by me.

"Tho. Hickeringill."

(3r.) Wormingford Decoy, on the S. bank of the river, three miles W.S.IV. from Nayland, is further removed from the sea than any other Essex decoy. The pool is nine acres in extent, and is still much visited by Wild-fowl. It is skirted by reeds and bulrushes, and surrounded by willows and alders.*

* It is by no means improbable that other Essex decoys, now forgotten, may yet be brought to light. For instance, Mr. Fitch has been informed of the former existence of decoys on Osey Island and at Mundon, but can find no trace of them; while the "Old Pool" and the "New Pool" appear on the Ordnance Maps in a detached portion of Great Stambridge parish, due S.S.E. from Burnham.

It may be useful to point out that, as near as can be made out, the above-named decoys are marked on the following old county maps :-

Maps in Morant's Essex (I768): 6, 8, Brick House, Mundon, I2, I8, 30.

Chapman and André's (I777): 2 (marked but not named), 5, 7 (an old decoy), I2, I7 (2), 20, $24,25,27$. 
The following interesting additional information relating to Steeple Decoy (No. 8) is extracted from an article by Mr. J. E. Harting, entitled "An Ancient Essex Decoy," which appeared in the Field of July 5, 1879. (vol. 54, p. 38.) Mr. Harting says :-

"Tradition only points to the place where 160 years ago a profitable business was carried on in the capture of Wild-fowl, chiefly Wigeon, for the London markets. Fortunately, however, for those who at the present day take an interest in such matters, the Essex yeoman who constructed this decoy, being a business-like man, took the trouble to write down the cost of its construction, and for thirteen years kept a strict account of the numbers of Wild-fowl captured by him, and of the prices they realised. This curious MS., which is contained in a small folio volume, bound in vellum, was written between the years $\mathrm{I}_{7} \mathrm{I}_{3}$ and $\mathrm{I} 727$, and by the favour of the present owner, Mr. Robert Smith, of Maldon, is now before me.* The decoy in question was situated in Canney Marsh, just behind Steeple Church, and rather more than half-way between Maldon and Tillingham. It was originally constructed in $\mathrm{I}_{7} \mathrm{I} 3$, but in $\mathrm{I} 72 \mathrm{I}$, the owner, evidently finding it to be a source of considerable profit, went to some expense in enlarging it; and it would appear that when the pond was dug out it was first filled by pumping from Steeple Creek, but was subsequently supplied from a well which was sunk at what now appears an insignificant outlay, $£$ IO, but which probably represents about $t_{5} 50$ of our money. As affording a good illustration of the prices paid for material and labour in the days of Queen Anne, the first page of this MS. is not without interest, and we here transcribe it verbatim et literatim."

\section{An Acct. of the Charge of MAKeing the Duckoy Pond uppon}

Canney Marsh, by me John CoOch, iziz.

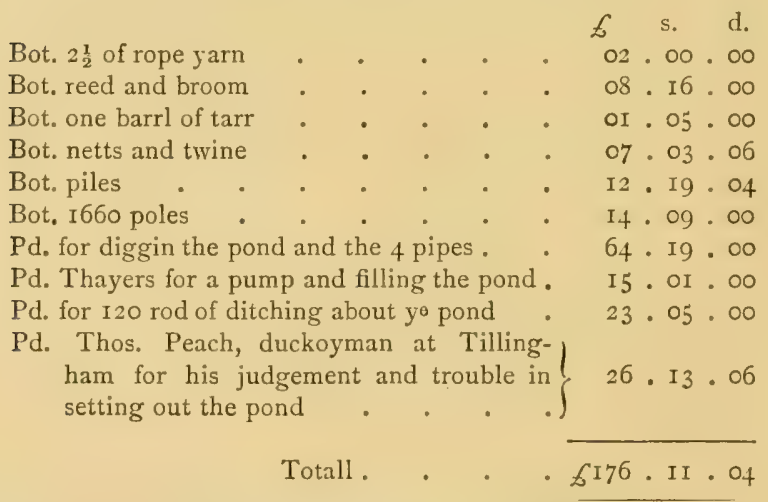

Emanuel Bowen's (about 1778) : 6, Brick House, Mundon, 12, 30.

John Cary's (1801) : 12, 20, 25.

Greenwood's (1824) : 3, 4, 5, I2, I3, I6, I7, I9 (marked but not named) 20, 24, 25 (marked but not named).

An Early Proof Ordnance (early in century) : 3, 4, 5, I2, I3, I4, I6, 20, 24; 3, I4 and 24 (marked but not named).

* Mr. E. A. Fitch, to whom the discovery of this interesting MS, was originally due, inform me that it has now been lost sight of and is probably destroyed. 


\section{An ACct. of the Charge of makeing the Duckoy Pond uppon CANNey Marsh LARger, BY ME JohN COOCH, I 72 I.}

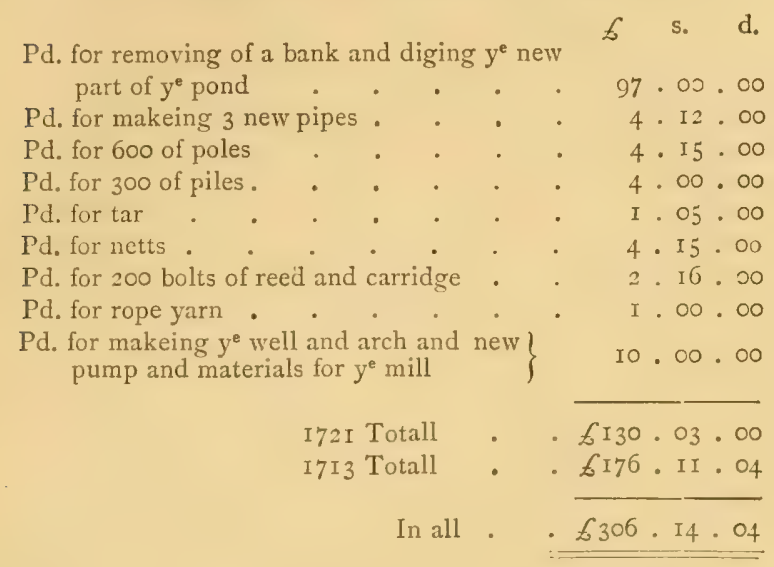

"The decoy was completed and ready for use by September, I7I4; and on the 3 rd of that month the result of the first day's take by 'Jos. Woodward, Duckoyman " is set down as Duck 8, Teal 4, and 'Wiggin' 54-in all 66 birds. The decoy season for the first year lasted from September to January inclusive during which period there were captured 675 Ducks, 347 Teal, 46 'Pyntail,' and 6296 'Wiggin'; in all 7364 birds, in the following proportions :-

$\begin{array}{lcrrr} & \text { Ducks } & \text { Teal } & \text { Pintail } & \text { Wiggin } \\ \text { Sept. } & 39 & 8 \mathrm{I} & 9 & 3,907 \\ \text { Oct. } & 26 & \text { I9 } & \mathrm{I} & \mathrm{I}, 899 \\ \text { Nov. } & 185 & 92 & 3 & 244 \\ \text { Dec. } & 219 & 103 & \mathrm{I} 3 & \mathrm{I} 53 \\ \text { Jan. } & 206 & 52 & 20 & 93 \\ & - & -- & - & - \\ & 675 & 347 & 46 & 6,296\end{array}$

"Then follows the entry, 'Sold to Mr. Neptune this year's whild-fowll at 95. 6d. per doz. $£$ I50.'*** Had the owner sold all the birds taken at 95. $6 \mathrm{~d}$. per dozen, he might have paid the cost of constructing the decoy out of the first year's proceeds and had a balance in hand of $\&_{115}$. This shows what a profitable source of income in those days a decoy was when properly managed."

"In glancing at the table last given, several points of interest are suggested. In the first place it appears that by far the larger number of fowl taken in Essex at that date were Wigeon. In the next place it seems that the greater body of these birds arrived in autumn, before the cold weather had set in, and that after November comparatively few were taken. The Ducks and Teal, on the other hand, did not appear in force till mid-winter, while 'Pyntails' were always scarce and irregular in their appearance. These conclusions are not based merely on the returns of the first year, I7I4, but are borne out by the returns of subsequent years. In I7I6, the price paid for wild-fowl thus captured rose to IOs. and in the following year to IOs. $6 \mathrm{~d}$. per dozen, the purchaser being 'Jno. Deal.' In I7I8, 'Joseph 
Woodward ' ceased to be 'Duckoyman,' and in his stead one 'Ben Carter' was. employed; but either he was not so skilful as his predecessor, or wild-fowl were never afterwards so plentiful. He never succeeded in taking more than 4,500 . Wigeon in a season (this was in I722), while Woodward never took less than 5,200 of these birds, and once captured 6,296 in five months. The months of December, I7I8, and January, I719, were, so to say, singularly unproduc( $k$ ) tive. During the former month, the decoy was worked only on two days, the 22 nd and the 30 th, when only 40 birds, all Ducks, were taken. In January four days' work only produced 53 Ducks and I2 Wigeon. *** In I 72 I the price of wild-fowl rose to I2S. per dozen. *** The following year, Deal gave I2S. per dozen to Michaelmas, and 145 . per dozen from that date to the end of the season."

"In I723, the price from Mr. Wm. Foster was I6s. per dozen, and in I725-6 Messrs. Darnoll and Basset paid the same price. With the close of this season the MS. ends, and we are left in ignorance as to whether the decoy was then given up, or whether the owner died and it changed hands, or what its fate was. It would be interesting to know when and why it was finally abandoned. $* * *$ To judge by the following summary, which we copy from the last page of the MS. (which is all in the same handwriting) it would appear as if one reason for giving up the decoy was the gradual falling off in numbers of the fowl observable during the last three years in which it was worked, or at least the last three years in which an account has been preserved, and the consequent falling off in profits, which dwindled from $£ 8 \mathrm{I}$ to $£ 69$, and eventually to $£ 33$ only, but no reasons for this decrease are given."

\section{An Account of Wild Fowl ketcht att Steeple Duckoy.}

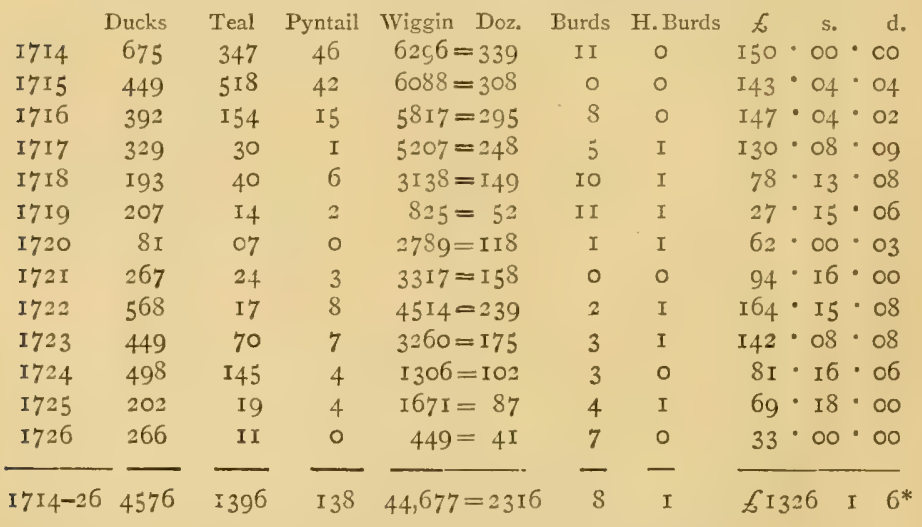

* From this it appears that the reckoning was kept in "dozens, birds and "half-birds," just as. it might be in pounds, shillings and pence. Thus in the thirteen years in question no less than 50,787 birds were taken, or an average of about 3,907 a year. But of these only 4,7 x 4 (the Ducks and Pintails) were "whole birds," giving 393 dozen and 1o birds over. The remaining 46,073 birds (the Teal and Wigeon) were only "half birds," giving $x, 9$ rg dozen and 8 birds and I "half bird" over, or a total of 2,312 dozen, 6 birds and I half bird, as shown above, allowing for a slight error in calculation somewhere. In the Ashby Decoy, South Lincolnshire, from $1833^{--4}$ to I867--8 were captured : Wild Duck, 48,664 ; Teal, 44,568; Wigeon, 2,or9 ; Shoveller, 285 ; Pintail, 278; Gadwall, 22. Total 95, 836, an average of 2,74I birds per annum for the thirty-five years (see Field vol. xxxii. p. 73). Thomas Pennant records $3 \mathrm{r}, 200$ Ducks having been sent to London in one season from ten decoys, near Wainfleet, Lincolnshire (Britis/ Zoology, vol. ii. p. 595). 
"From this table it appears that the amount realised by the sale of wild fowl during thirteen years was $£ 1,326$ Is. $6 \mathrm{~d}$. or an average of $£_{102}$ per annum. "Half Burds" such as Golden Eyes and Tufted Ducks have, it will be observed, a column to themselves. They were regarded as only half the size of ordinary Wild Ducks, reckoned at half the value, and were not counted in the dozen. It would seem that nearly all the Ducks and Teal taken in this decoy were foreigners, and not home-bred birds; for it is remarkable that during the months of August and September, before the large migrating flocks had arrived, comparatively few were captured, which would scarcely have been the case had these birds nested in any numbers in the surrounding marshes.

Mr. John Cordeaux gives the following additional particulars from this old MS. book, in the Field for April 6th, I878 :-

"In one year (I7I5), taking commenced as early as August 25th, and from this time to the end of the month 8 Duck, 96 Teal, I Pintail, and 544 Wigeon were taken. I7I6 also appears to have been an early season for IVigeon, the decoy commencing work on August 24, and before the end of the month 7 Duck 9 Teal, 5 Pintail, and 538 Wigeon were captured. The best year of the thirteen was I7I4. The best months were Sept., I7I4-39 Duck, 8 I Teal, 9 Pintail, 3,907 Wigeon. Also Sept., I7I7-I2 Durk, 8 Teal, I Pintail, and 3,440 Wigeon.

"Some of the best days were as follows: September, 20th, I7I4-I Duck, 20 Teal, 785 Wigeon. September 23rd, I7r5-7 Teal, I Pintail, 478 Wigeon. October 7th, I7I5-6 Teal, 4 Pintail, 5 I2 Wigeon. Uctober I4th-2 Teal, I Duck, 490 Wigeon. October 18 th-r Teal, I Duck, I Pintail, 537 Wigeon. August 23, I7I6-3 Teal, 548 Wigeon. September I6, I7I7-702 Wigeon and 384 on previous day. The immense number of 44,677 Wigeon, taken in this decoy during thirteen years, are divided between the months in the following proportion : I7I4 to I726-August, I,085 ; September, I5,897; October, I8,67I ; November, 7,655; December, I,085 ; January, 275 ; February, 9. These figures are very curious, as they show at a glance that the great captures of Wigeon were made in September and October. This is exactly the opposite to the case in the present day. The best months for Wigeon on our Eastern coast now are January, February and also Narch, a period during a greater part of which the old decoys were closed altogether. $* * *$

"A correspondent, the owner of a decoy in one of the Eastern counties [this was Mr. Robert Page, of Down Hall, Bradwell], writes: 'Of every hundred Wigeon taken in our decoy [Marsh House, Tillingham], 30 are killed in January, 20 in December, I9 in February, I9 in November, 7 in October, 4 in March, and I in September. This is the average of fair seasons. During the same time we have had the greatest number in the decoy in January, and the months follow in the following order: Fehruary, December, November, October, March, September. In one year we had four Wigeon in the decoy in August. In some seasons none have arrived until October; and in one year we had the greatest number on February 26th."

Many more interesting facts relating to this now-almost-defunct Essex industry, in addition to those given above, would doubtless reward a little painstaking research, and the subject is well worthy of further attention. 


\section{A CATALOgue}

\section{of \\ THE BIRDS OF ESSEX.}

\section{Order PASSERES. Family TURDID王.}

Mistle Thrush: Turdus viscivorus. Locally, "Mavis" (Orsett).

A common resident in all districts.

Round Orsett, it is always known as the "Mavis" (Sackett), a name which in other parts of Essex and elsewhere, is usually reserved for the Song Thrush.

Song Thrush : Turdus musicus. Locally, "Mavis."

An abundant resident.

Ray, writing to Dr. Lister, on April 4th, I676, says (Phalosophical Letters, p. I37),

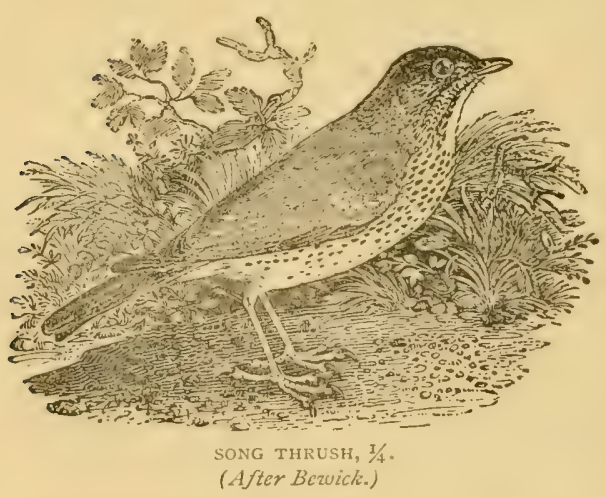
thrushes were then called "Mevisses" in Essex, and he believes elsewhere. From this it would appear that the name, which is now seldom heard except in the north of England, was then more general. In the Epping district it is "abundant in the autumn, but almost absent in mid-ivinter" (Buxton-47. 85). In the Audley End Collection (24) is a white variety which lived for some time in the aviary there and died in 1847 . On May Ioth, I878, Mr. R. W.

Christy found a nest containing two eggs at Boynton Hall, built in the drivingwheel of a corn mill which had heen used only five days before. Among the many strange sites for birds' nests which have been recorded the following, taken from the Chelmisford Chronicle of May 23rd, I879, deserves mention :-

"At the Mistley Railway Station, a break-van is kept for the purpose of 
breaking trucks down the incline on to the quay, a distance of half-a-mile. This van, when not in use, is kept at the top of the incline, but it is left on the quay daily for several hours, during which time it is shunted about various sidings. On the beam underneath the floor of the van, a pair of Thrushes have built their nest and laid three eggs. About two years since a Blackbird and his mate built their nest in the same place and hatched their young " (see p. 74).

\section{Redwing : Turdus iliacus.}

A common winter visitor, especially abundant in severe winters.

Mr. Buxton says (47.85) :-

"Large numbers roost in the denser thickets [in Epping Forest] during hard winters, especially when there is a good supply of holly and other berries. At sunset they come trooping in from all quarters, and sweep round the trees in graceful flight before settling down for the night in the lower brushwood."

Henry Doubleday, writing to Mr. Heysham in Nov., I831, says (10): "I have now alive a Redwing I got last January, and in August it moulted; but instead of the usual colours, it has become a perfect black."

Fieldfare: Turdus pilaris. Locally, "Felf," "Felfer," "Jackbird," "Pigeon-felt" (E.A.F.) and "Felty-fare" (E.A.F.)

A common winter visitor, especially during severe seasons, sometimes remaining until the beginning or middle of May. It usually arrives about the middle of September, but the Rev. G. H. Raynor records seeing a flock of twenty-five at Woodham Mortimer on September 6th, I880, a date so unusually early as to suggest the idea that the birds seen were Mistle Thrushes (29. Oct. 2.).

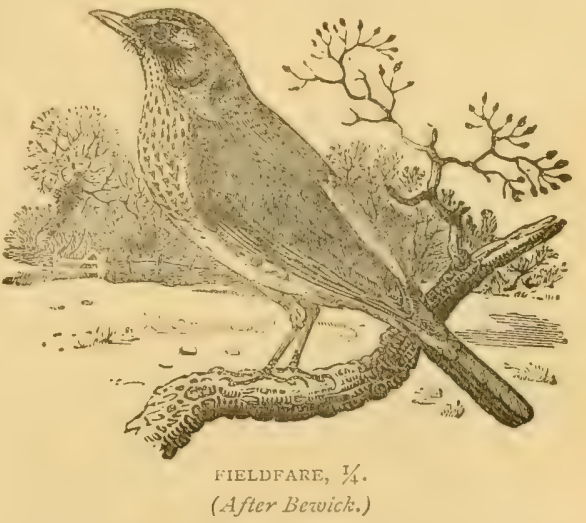

Writing from Epping in July, I834, Henry Doubleday says (10): "The Fieldfare stopped here very late. I saw vast flocks on the Ioth and I Ith of May." The following spring was very late and cold, and they seem to have again stayed late, as Doubleday writes that they "remained in vast flocks until the third week in May." On April I5th, I888, I saw a flock of twenty at Good Easter. Mr. Grubb says (39) that it "continues with us [at Sudbury] very late in the spring, and is sometimes seen in the middle of May." In 1843 , it remained at Layer Marney until almost the end of May (Rev. John Atkinson-23. 355). Mr. Joseph Clarke, writing (2.4) of the neighbourhood of Saffron Walden about I845, says that it is "more or less common most seasons." He also notes the - occurrence of a specimen in very dark plumage at Debden on April 28th, I839. There is also in the Museum at Saffron Walden a curious rariety of this species, shot at that place many years ago. The whole of the head and the upper part of 
the back are white, with a few coloured feathers intermixed; lower part of back much lighter than usual; upper tail-coverts nearly white; tail feathers as usual,. except that two on each side and one near the middle, are white; under parts white, except for a few coloured feathers on the throat and the usual darklymarked feathers on the sides of the breast ; wing-coverts and secondaries mostly white, also a few of the primaries; legs and bill lighter than usual.

There is no really-reliable evidence that the Fieldfare has ever yet bred in this country, though not a few more or less unsatisfactory instances have been from time to time recorded. For instance, Dr. Bree has recorded (29. June I2 and I8, I869, \& 34. I864), what he regards as a "well-attested and proved case" of the Fieldfare nesting and rearing young in the grounds of the rectory at Alresford in $\mathbf{1 8 6 9}$. The nest was built in the lower fork of the boughs of a medlar-tree on the lawn. The gardener was certain that the birds using the nest were not Mistle Thrushes, but further corroborative evidence is wanting. It was afterwards sent to Dr. Bree, and I have seen it in his collection, now in Mr. Harwood's possession. It is constructed externally of birch and fir twigs, also of moss, coarse bents, and a few roots, lined with fine grass "and moss, which are the usual components of the nest of the Mistle Thrush.

\section{Blackbird: Turdus merula.}

An abundant resident. There are good reasons for believing

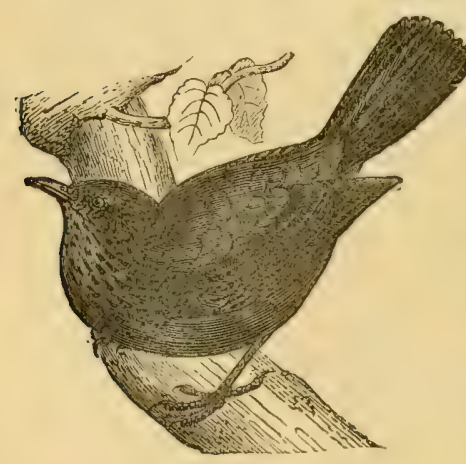
that this species occasionally interbreeds with the Song Thrush in a state of nature. It varies greatly in number from time to. time. Mr. Parsons records (35) an invasion of Blackbirds on New England Island, in October, I 836 , almost every hedge being full of them for a week or two. White or pied varieties are rather frequent.

BLACKBIRD, femrale, $1 / 4$.

The following curious circumstance is recorded in the Essex County Chronicle for June Ioth, I887:-

"While two local constables [at Bradwell-on-Sea] were consulting for a few minutes the other morning, a blackbird settled on the helmet of one of them, where it remained some little time. It then flew on to a gate only a couple of yards off and sang splendidly for ten minutes without showing the slightest sign of fear."

The following also appears in the same paper for May Ist, I877:-

"There is a break-van at Mistley Station, which is used for the purpose of ' breaking down' trucks to the quay, a distance of half-a-mile. This is used two. or three times a day, and is frequently left on the quay two hours before being brought back to the siding in the yard. On the framework underneath the van, a Blackbird and his mate have built their nest, and the latter is now sitting upon four eggs, regardless of the frequent journeys to and fro."

On April 24th, 1878, Mr. F. G. Marriage found a nest containing four fresh eggs at Springfield, built in the centre of a thousand-head cabbage. 
In the middle of January, I85I, a nest containing one egg was found near Southend (28. ii. 84); and on July 3Ist, I88I, I found a very late brood still in the nest near here.

Albin figures an adult male, very much pied on the head, neck, breast, and wing-coverts, which he says (3. i. 35 \& ii. 34) was sent him "by Sir Robert Abdy out of Essex." In the Saffron Walden Museum is a variety shot at Wenden by Mr. Salmon. It has the throat striped much like a Thrush, the breast much lighter than usual and a good deal marked with arrow-headshaped spots. Another specimen, a mature male, killed at Saffron Walden, has a white spot behind each eye, la white throat, and a patch of white joining that on the throat and half encircling?, the neck. In general appearance, this bird is strikingly like a Ring Ouzel. Another mature male from Bard field has part of the crown white; while a young male (?) from Chrishall is entirely white, except for a few scattered feathers on the breast and back and most of the primaries and inner tail-feathers, which are normal. On December 26 th, I875, I saw one with a white wing at Chignal St. James, and, curiously enough, on December 26th, I876, exactly a year later, another at Broomfield with part of its right wing white. About a week before, my father saw, beside the high road at High Easter, a pure white bird, which he had no doubt was a variety of this species. A white specimen was taken from a nest near Leigh in May 1877, and another was hatched, with several normally-coloured ones, in a nest at Shelley, in I888 (Essex Chron., June I5th.).

\section{Ring Ouze1 : Turdus torquatus.}

A rather uncommon passing migrant in spring and autumn, when on its way to and from its breeding grounds on the moors of the north and west of England. A few are recorded in most seasons, usually during April or October. On one occasion it has been known to breed in the county, but its doing so is quite exceptional.

Henry Doubleday, writing to Heysham in I83I, says (I0) that at

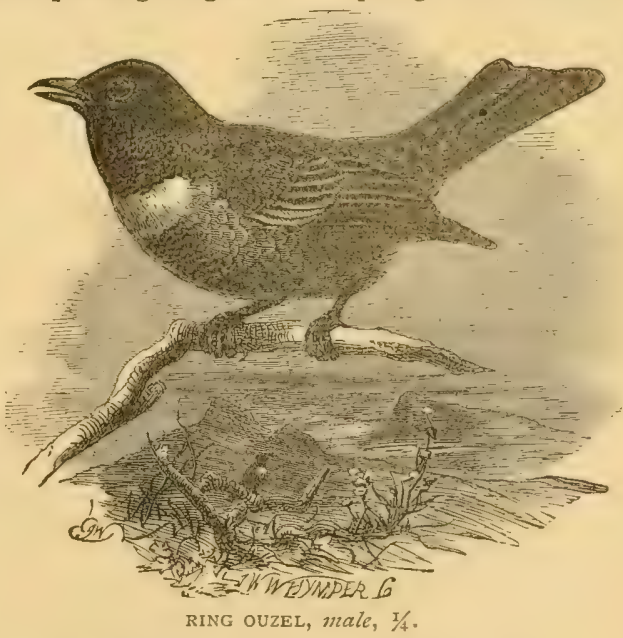
Epping it "is only now and then seen in spring and autumn." He afterwards mentions (IO) killing a young male with a very indistinct ring, at Epping, in Oct., I832. He also says (I0) on Oct. 2 Ist, I836, "As I was riding to Chelmsford yesterday, I saw a Ring Ouzel feeding on a haw-bush." Later still he writes (10), "About the middle of April [I8+2], I killed a fine Ring Ouzel on an oaktree in the forest." On May 3 rd, I840, he writes (10) :- 
"Last week several Ring Ouzels were seen here, and one or two killed, but I was not able to get one myself. My brother Edward saw a pair on a warren about four miles from us, about a week since. I went to look after them by daylight next morning, hoping to be able to shoot them, but I could not find them."

A few days later he notes killing "a remarkably fine female, at some gravelpits in the forest, about a mile off" $(23,13)$. One also frequented Doubleday's garden, at Epping, during the first week of Nov. I87I (34.2942). At Epping, Edward Doubleday wrote in 1835 (I5), that they were "seen only at the time of their equatorial and polar migrations." "One was seen in the spring of 1884 by the River Roding" :(Buxton-47. 85). There is in the Saffron Walden Museum a young bird shot at Littlebury on April 27th, 1836. Mr. Clarke (24) mentions two others shot at Audley End, on Aug. Ioth, I836 and April 28th, I839, respectively. He adds the remark, "One, sometimes two, taken most seasons." Round Harwich it is "occasionally seen during the spring and autumn migrations." Two were seen (40. v. 26) on Oct. 10, 1880 (Kerry). Four were shot by Mr. Catchpool, of Feering Bury, in I857 (C. E. Smith-3I. 53). One was seen "by a keeper close to this house about the middle of April, I877. Mr. Hope says it is not uncommon, during migration, at Marshall's Park, Romford. Mr. Lister (40.442) saw a fine male in a garden near Wanstead Park, on Sept. 5 th, 1877 , and another cock about ten years previously at West Ham. One was seen at Hylands, Widford, on April I4th, I878. In I883, Mr. Stacey, of Dunmow, showed me one shot shortly before near Stanstead. Mr. Parsons (35) records one shot near Southchurch in 1850 , and in his collection are specimens from near Shoebury. Mr. Joseph Clarke tells me that a female, weighing $4 \frac{1}{4} \mathrm{oz}$, with a bare breast, was shot at the Roos, in Oct.I878.

The only reliable record of its having bred in the county is the following, though Yarrell says (I4. i. 207) that "from the circumstance of a specimen having been shot early in the month of August, 1836, near Saffron Walden [see above] it was conjectured the bird had been bred in that neighbourhood":-Mr. C. E. Bishop, of Wickham, found a nest with four eggs, built almost upon the ground, about a foot from the edge of a ditch, and a few yards from the edge of the Blackwater, in that parish, on May Ioth, 1879. The hen only was seen, and she was sitting (40. iii, 267).

\section{Wheatear : Saxicola ananthe.}

Best known in Essex as a passing migrant in spring and autumn

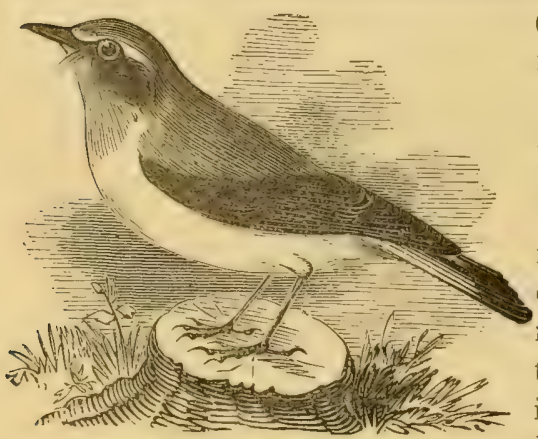

WHEATEAR, Male, $1 / 3$. (especially the former), though it breeds commonly along our sea-coast at Maldon, Burnham, Brightlingsea, Walton, Shoebury and elsewhere. I have never known it breed in the inland parts of the county, except occasionally near Saffron Walden, where the hilly and chalky country is exactly suited to its habits. It often arrives early in March. 
and remains till September. In IS88, Mr. Walter Crouch observed one at Barking-Side as early as March Irth (50. ii. 53).

Mr. Joseph Clarke, writing of the Saffron Walden district in I845, says (24) it then bred there occasionally, though not commonly. He notes the occurrence of a very beautiful white specimen at Newport in May, 1843 ; it was then in the possession of one Watson, a tailor, there. I saw a pair, probably breeding, at Saffron Walden, in the beginning of May, I830. W. D. King describes it (20) as " not very uncommon" around Sudbury. Lindsey, writing from Harwich in I85I, says (27. App. 57), it "arrives in great numbers here in spring." Mr. Kerry says it is now scarce there during the breeding season, but is very common when on migration. Ed. Doubleday says (I5) he had met with it at Epping, meaning probably when on migration, for his brother wrote on May igth, I84I (I0), "The Wheatear never breeds about us," and Mr. Buxton speaks of it (47.9I) as only "a passing visitor [to Epping Forest] in spring and autumn." Round Orsett, it never breeds, but is common on migration about the end of March and end of August (Sackett). In the Paglesham district, Mr. J. F. T. Wiseman informs me that it is common. Lieut. Legge, writing in $\mathbf{1} 865$, from South Shoebury, says (23.9837) :-

"This handsome bird is very plentiful [here], frequenting the flat wastes and uncultivated lands. They build here in the holes between dry sods or in deserted rabbit burrows. The young birds of the year are very plentiful on the marshes in August, and may be seen in all directions, perched on some stone or clod, bowing and cocking their tails."

Mr. Hope has noticed young birds on the coast on June I 7 th. On Aug. I8th, I88 I, Mr. Kerry shot, at Ramsey, a curious variety, having about it a good deal of white. Mr. J. H. Gurney, junr., who has seen the specimen, pronounces it to be of this species.

\section{Whinchat: Pratincola rubetra. Locally, "Furzechat."}

A regular, though rather local, summer visitor, coming to us about the middle of April, and leaving again early in October. It is most commonly seen at the times of its migration, but is fairly abundant during summer on some of our furze-covered commons, and nests, not very rarely, in meadows and cultivated fields throughout the county.

Henry Doubleday, writing to Heysham in Nov., I83I, says (I0) that it was then numerous in Epping Forest, but in Sept., 1839, he writes (10), it "has been so remarkably scarce here this

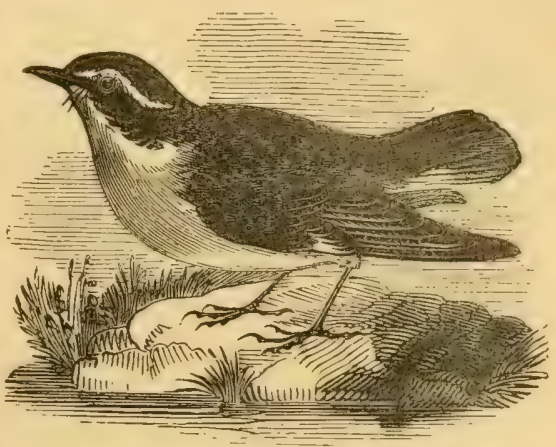

WHINCHAT, male, $1 / 3$. year that I do not think I have seen half a dozen all round this neighbourhood." Again, in May, 1843, he wrote (23. 222), "Although in former years one of our most abundant visitors, for the last two or three seasons [it] has been very scarce. I have not seen more than one or two pairs anywhere in the neighbourhood this spring." In the Forest, Mr. Buxton now speaks of it (47.9I) 
as "a summer visitor breeding in the furze-bushes." Around Saffron Walden, Mr. Clarke wrote (24), about I845, that it bred occasionally. King says (20) it is common at Sudbury. Round Harwich it is scarce, though it breeds there (Kerry) At Orsett, it is uncommon (Sackett). Henry Doubleday says (10) that in 1832, he saw, in a collection at Colchester, "a snow-white specimen which had been obtained near there."

Stonechat: Pratincola nibicola. Locally, "Furzechat," and "Blackcap."

Chiefly a summer visitor, though partially resident, as some

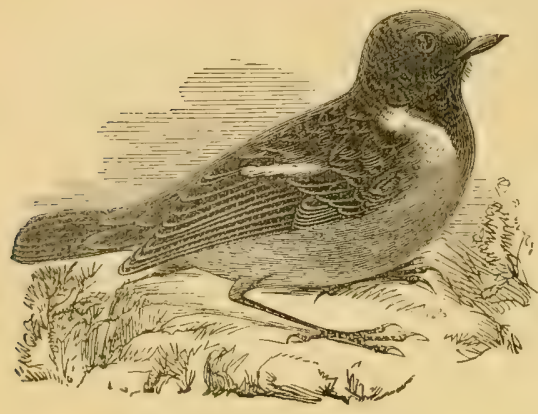

STONECHAT, male in summer, $1 / 2$. remain throughout the winter. It breeds commonly on Lingwood, Danbury, Mill Green, Fryerning, and other furzecovered commons through out the county.

Henry Doubleday, writing in Nov., I8 3 I, to T. C. Heysham, says (IO) it "used to abound on the furze bushes by the sides of the forest, but, what is very singular, it thas within the last three years totally disappeared." In a later letter (AprilıI5th, I833), he says (I0): "I forget if I ever mentioned to you the total disappearance of the Stonechat from us. About six years since it was very common, but for the last three years I have not seen one; and have only a bad specimen of the male." The same thing has been observed elsewhere. Round Epping it is now "much more abundant than the Whinchat; breeds on the open forest; a few remain throughout the year" (Buxton-47. 91). Round Saffron Walden it bred occasionally (about 1845 ), like its cousin the Whinchat, but was not common (Clarke-24). King says (20) it is common at Sudbury. At Orsett, it is "far more abundant than the Whinchat, especially in furze-covered districts, such as Mucking Heath and Orsett Heath, where it resides (Sackett). Round Harwich it is common and breeds (Kerry). During a spell of cold weather about the middle of March, I883, Mr. Travis received one (a female or young bird) shot near Walden. 'On Dec, 4th, I879, I saw a female between here and Chelmsford, but comparatively few remain with us through the winter.

\section{Redstart : Ruticilla phenicurus. Locally, "Firetail."}

A regular summer visitor, though rather uncommon, at least in the inland parts of the county. Its arrival may usually be looked for about the middle of April, when for a short time the birds are much more numerous than during summer. It breeds sparingly in all parts of the county, I believe, and used to do so, if it does not now, abundantly near Shoebury. 
Writing from Epping in 1832 , Henry Doubleday "says (I0) : "The Redstart has arrived this year in immense numbers. I never saw half so many before." A little latter helldescribes it (IO) as "more abundant than I ever knew it before. The forest literally swarms with them. Some females |[were] sitting on the last day of April." Mr. Buxton says $(47.90)$ it is now "frequent in summer and a great ornament to our Forest." Mr. Clarke describes it (24) as "common in summer" round Saffron WaIden. King says (20) it was "common" at Sudbury in his

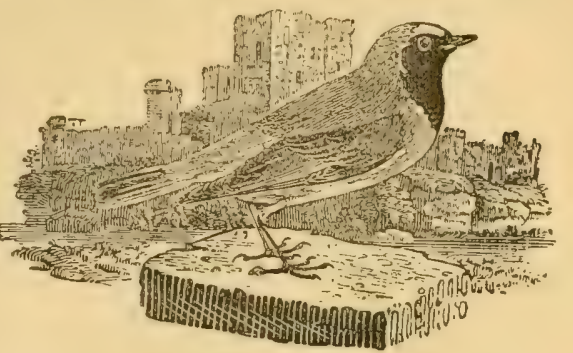

REDSTART; male, $1 / 3=$ (After Bervick.) time $(1840)$, and Mr. Grubb includes it (39) in his list of Sudbury birds. Round Harwich, Mr. Kerry says a few breed; he adds that they were very common during the autumn migration in 1888. After the excavations in 1878 , at the site of the supposed Saxon cemetery in the grounds of the late Mr. George Stacey Gibson, at Saffron Walden, when nearly two hundred skeletons were discovered, a Redstart made its nest and reared four young in one of the skulls during the time it remained exposed. Access to the interior was obtained through the eye orbit. The skull and nest, which $\mathrm{I}$ have seen, are still in the possession of Mrs. Gibson (34. 5042 \& 5II6). Lieut. Vincent Legge, R.A., writing from South Shoebury in IS65, says $\left(23.9 S_{3} 6\right)$ : "This bird is very plentiful about here, frequenting particularly those parts where the pollard willows most abound. ** $*$ I never saw them so plentiful in any part of England, and most probably it is on account of the numbers of these trees, which line the ditches in the marshy districts that are so common here," and for which he says they have a special predilection. In 1865 their eggs were laid "for the most part by the last week in April."

\section{Black Redstart: Ruticilla titys.}

A regular, though uncommon, winter visitor to the extreme southwest of England but rare and occasional elsewhere. I only know of its having occurred twice or thrice in Essex. A recorded instance of its having bred in the county is, I am satisfied, wholly erroneous.

Mr. Kerry records one (40. iii. 306) shot at Ramsey on April I4th, 1879, and he informs me of another seen at Dovercourt in December, I887. The Rev, H.

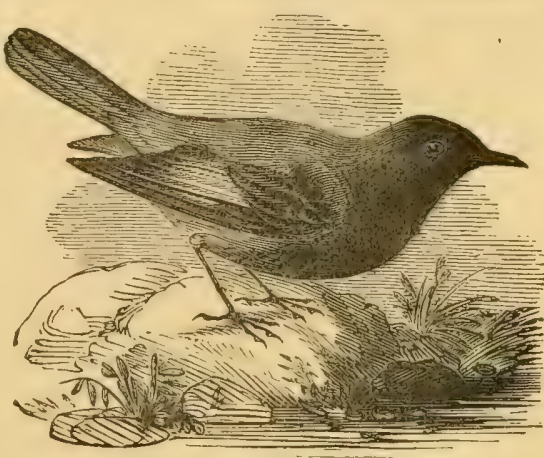

BLACK REDSTART, male, $1 / 3$.

* Mr. W. R. Ogilvie Grant has recorded (40. 390 \& 50 . ii. 192 \& 256) this more than doubtful 
A. Macpherson remembers seeing at Burton's in Vardour Street, some years ago, a very good specimen killed in Essex. On March 3Ist, 1889, whilst walking in company with several other gentlemen, on the top of the cliffs, a little to the north of Walton-on-the-Naze, I several times obtained a view of an undoubted specimen (29. April 6). Mr. Ambrose has preserved specimens from Brightlingsea and Harwich.

\section{Red-spotted Blue-throat : Cyanecula suecica.}

A rare spring and autumn straggler to Britain, of which I

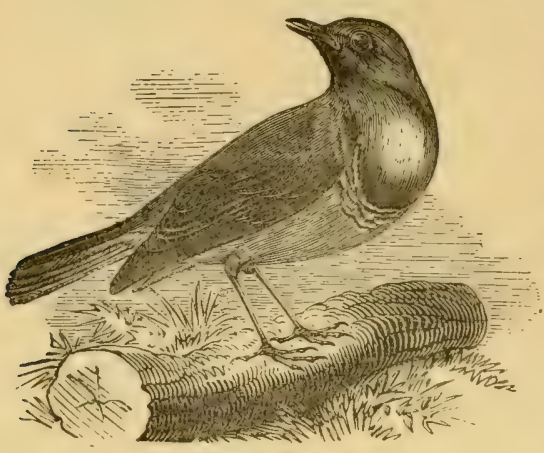

BI,UE-THROAT, male, $1 / 3$.

have only a single record in Essex. There are two, if not three, forms of this species - the one here mentioned (which alone has been proved to visit Britain), and a White-spo:ted race or subspecies.*

Mr. Hope informs me that his keeper at Felixstowe has seen it near Harwich and has described it unmistakably to him. It is not unlikely to have occurred in the county on previous occasions.

\section{Robin or Red-breast: Erithacus rubecula.}

\section{An abundant and very familiar resident.}

W. D. King states (20) that a Robin in his brother's garden at Sudbury " caught the scream of the Starling, which it imitated at times so exactly as to

instance of its breeding in Essex. The nest in question was built in May, 1888 , in a hole, four or five feet from the ground, in an ivy-covered oak-tree standing a few yards from the door of the dairy at Danbury Palace. It was first discovered by some village boys, who ultimately caused the bird to forsake. Before this, however, it was watched by the Hon. Mrs. Ronald Campbell, who twice saw the bird fly off- "a dark-coloured bird with a red tail." That lady subsequently presented the nest and two of the four eggs which it originally contained to the Natural History Museum, South Kensington, where they are still preserved. I have inspected both the nest and eggs, and in my opinion they are undoubtedly those of a Robin. The white variety of the eggs of this bird may almost be called common, and I have repeatedly either taken or heard of such in this district. The nest is composed externally of dead hazel and oak leaves, the interior being constructed of bents, fine roots, and skeletonized leaves, lined with fine grass and a very little hair. I consider it a typical Robin's nest in all respects, except that it contains no moss, while the site, which I have seen, is also exactly what one might expect a Robin to select. The two eggs which have been preserved differ much in size. The larger, and normal, one measures 8 by - 6 of an inch, almost exactly, these being the average dimensions of Robins' eggs. The other egg is very much smaller, and is evidently an abnormal egg, such as might be expected from a weak or injured Robin, laying colourless unspotted eggs. I feel confident that the nest is that of a Robin, and that the "dark-coloured bird with a red tail," which Mrs. Campbell thought she saw leave the nest, was a Redstart, with a nest somewhere in the immediate vicinity. The breeding of the Black Redstart in England has been several times recorded on very doubtful grounds, but never yet satisfactorily established.

* The accompanying cut represents the White-spolted form of this bird, which is known as C. wolf, and prevails in Central and Southern Europe. 
frequently deceive me. There is every year a nest of Starlings close by." Mr. W. Pamplin, of Whip's Cross Nursery, records (29) having found a Robin's nest containing five eggs, in the bottom of a haystack there on Nov, I2th, I884. "S. E. W." writing from Blackmore on April 22nd, I867, says (Essex Chron.):-

"The Robin Redbreasts have again this year put in an appearance in Blackmore Church. At the present time the happy little'couple

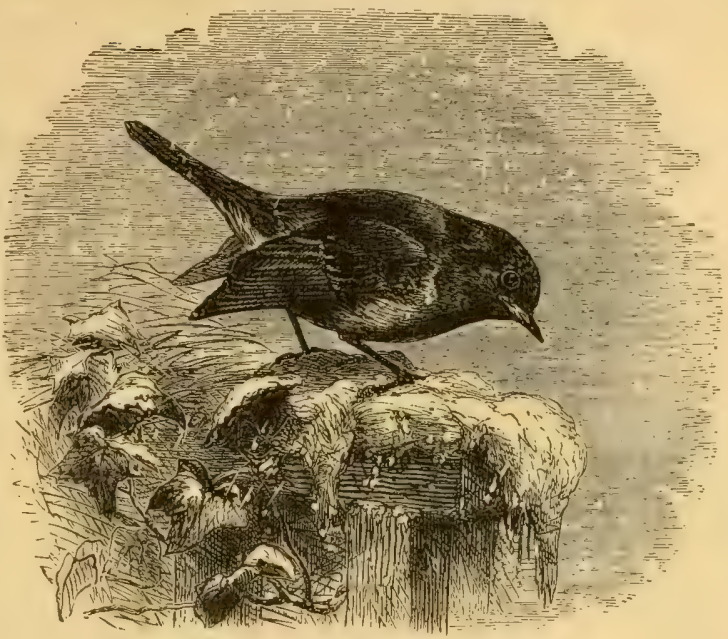

ROBIN, T/3. have built their nest and deposited six eggs therein, in the reading-desk, underneath the Bible, notwithstanding the repeated attempts to prevent them from doing so, the sexton's wife having pulled the nest to pieces several times. Some few years ago, no doubt, you will remember a similar occurrence. The eggs were then hatched, which will probably be the case again."

Pure white eggs are by no means uncommon, especially late in the summer. In 1876 , two nests containing such eggs were taken about the premises here, and on June 22nd, I877, I took a nest with two pure white and two very slightly spotted eggs on a bank about half a mile away. On July i2th following I found two more white eggs in a nest not far from the first. One nest containing white eggs was recently recorded as that of a Black Redstart (q.v.). In I876, a nest was constructed on

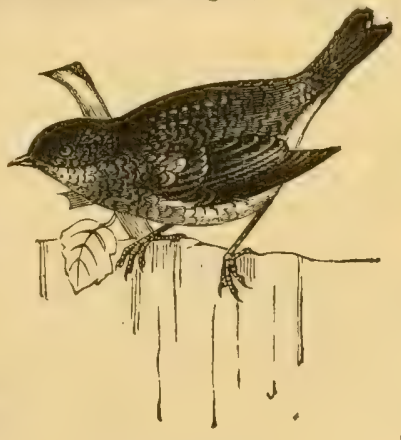

ROBIN, young, $1 / 4$. the top of a clock in the parlour of a dwelling-house at Stanford Rivers, access being obtained by the door and window. The nest was unfortunately destroyed (34). Mr. Sackett writes: "During the winter, a year or two back, a Robin became very tame. Ile entered my bedroom every day by the open window and fought himself in the looking-glass." Swainson, alluding to the common belief that it is unlucky to destroy a Robin's nest, quotes the following as an Essex saying (48. 16) :-

"The Robin and the Redbreast, The Robin and the Wren, If ye take out of their nest, Ye'll never thrive again. 
The Robin and the Redbreast,

The Martin and the Swallow,

If ye touch one of their eggs,

Bad luck will surely follow."

Nightingale: Daulias Luscinia.

A common summer visitor, especially abundant, I think, in the

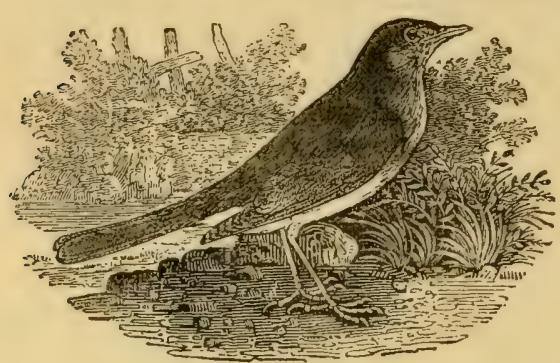

NIGHTINGALE, $1 / 3$.

(After Bewick.) Epping Forest and Saffron Walden districts. It is generally first heard about April 15 th, though in 1878 , it is said (but almost certainly erroneously) to have been heard at Bridge Hall, Stisted, on February roth (Chelmsford Chron., Feb. 15). In 1879, Mr. Harwood heard it at West Bergholt on April 7 th, the earliest date he had ever heard it (29. Apr. I 2), while Dr. Bree records one (34. 454) heard singing near Colchester as late as August 9th, 1866. The males arrive several days before the females.

Mr. Grubb writes (39), "We have a nest almost every year in our garden [at Sudbury], and generally see the young birds after they leave the nest. They are foolishly tame, sometimes coming into the wash-house, and suffering themselves to be caught." Mr. Buxton says (47.89) it is "well distributed over our district. *** In the spring of 1858 , an old Leytonstone bird-catcher caught thirty-four about the avenues."

Morant says (Hist. of Essex, i. p. 59) that Havering was

" as ancient retiring-place of some of our Saxon kings, particularly of that simple saint, Edward the Confessor, who took great delight in it as being woody and solitary, fit for his private devotions. The legend says it abounded with warbling nightingales; that they disturbed him at his prayers; and he earnestly desired of God their absence. Since which time, as the credulous neighbouring swains believe, never nightingale was heard to sing in the park, but [as] many without the pales as in other places."

\section{Lesser Whitethroat: Sylvia currica.}

A fairly common summer visitor, arriving about the middle of April and leaving again about the beginning of September. It is most often seen at the time of the spring migration, but breeds with us in fair numbers, though it is at all times less abundant than the Common Whitethroat.

Hy. Doubleday, writing 1 to Heysham in I83I, says (IO) that at Epping it is "equally common with the larger one, and much more destructive to fruit in gardens. Its song is very different from any other bird's." W. D. King describes it (20) as common around Sudbury. 
Whitethroat: Sylvia cinerea. Locally, "Haychat"or "Hayjack."

A very common summer visitor, arriving early in April and staying till September.

I have, on one occasion, known it occur in Essex in mid-winter, a fresh specimen having been found dead by the gardener on a heap of coals in an outhouse at the residence of my friend Mr. H. Corder, at Great Baddow, on or about Dec. 22nd, I886, after a heavy snowstorm. This is a most remarkable occurrence.

I find the following among Dr. Bree's notes (32a):- - " 877 I -A nest with four eggs in quick-hedge in garden; began to

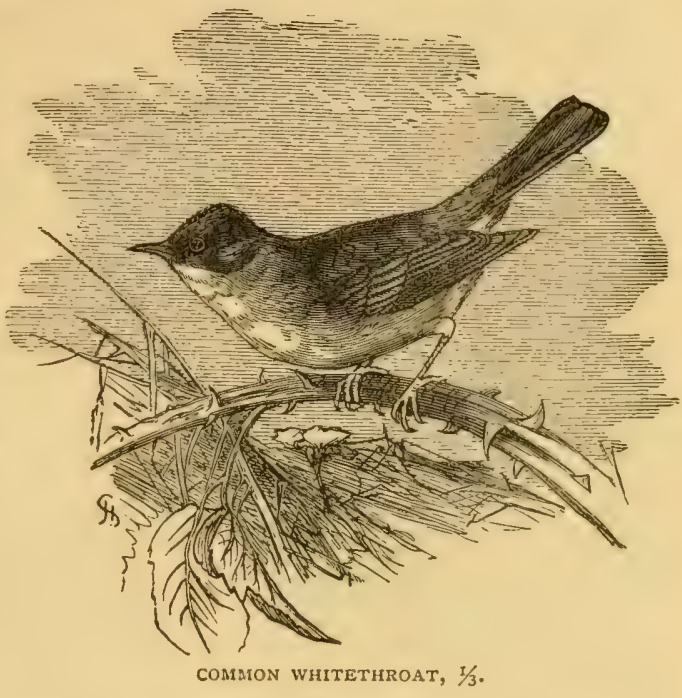
sit May 23 rd ; young hatched June 3rd ; skedaddled on the I4th."

Mr. Stacey, of Dunmow, has a remarkable variety which has the feathers of the bastard-wing white on both sides.

Blackcap : Sylvia atricapilla.

A fairlycommon summer migrant, occurring, I b e 1 i e ve, throughout the county. It arrives about the middle of April and departs in September.

Mr. Buxton says $(47.90)$ it is "common in the Forest and in gardens, but especially in Wan-

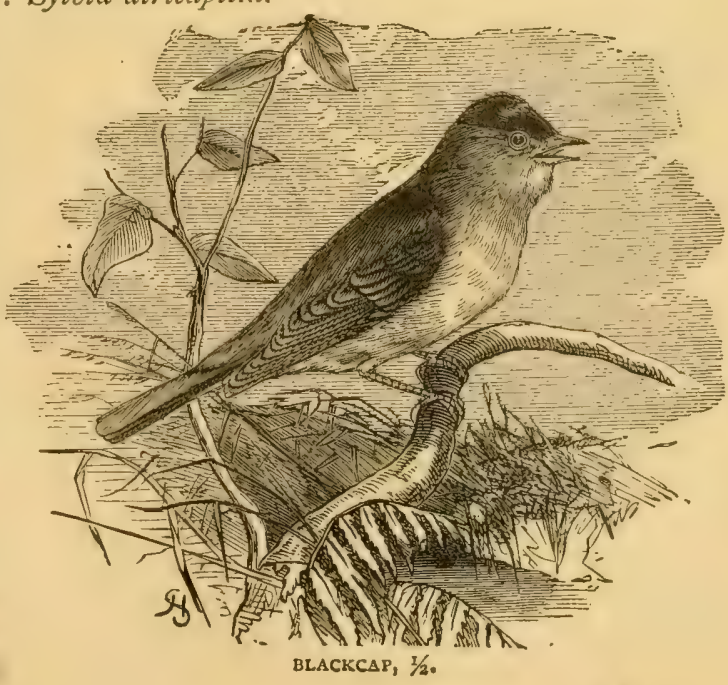

G 2 
stead Park, where the wood echoes in early summer with its fine song." Round Orsett it is uncommon (Sackett). At Harwich it is "scarce," though it breeds (Kerry).

\section{Garden Warbler: Sylvia hortensis.}

A fairly-common summer visitor, coming to us about the beginning of May and leaving again late in September. It breeds throughout the county, though rather sparingly.

It is not infrequent in the Forest and in Wanstead Park, where "it used to be common about the avenues " (Buxton-47.90). At Harwich it is "scarce," though it breeds (Kerry).

\section{Dartford Warbler: Melizophilus undatus.}

A resident, but uncommon and very local, though it breeds in most of the southern counties, and even occasionally as far

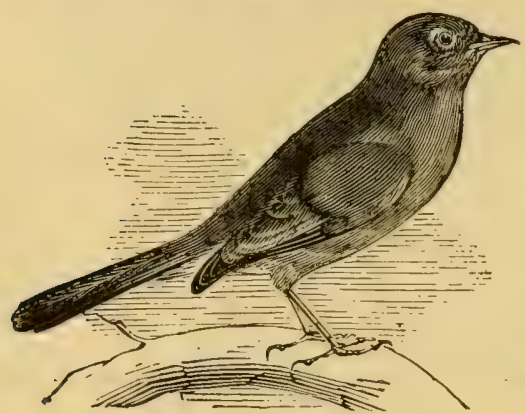

DARTFORD WARBLER, $1 / 2$.

north as Sheffield. I am only aware of three occurrences in Essex, though careful search on some of our furze-covered commons might reveal the bird, as it is exceedingly shy and retiring in its habits.

The Parsons Collection contains a male, shot on South Shoebury Common in Nov. 1837. Mr. Travis, in June, 1880 , received for preservation a specimen shot near Saffron Walden. Mr. Charles Smoothy shot a specimen, which is now in his collection, at Great Chesterford, on the Cambridgeshire border, on Dec. 5th, 1870. Mr. Harting (38. I7) gives no Essex localities.

Gold-crest : Regulus cristatus.

A resident throughout the county, though not common. Its numbers are often greatly increased in autumn by the arrival

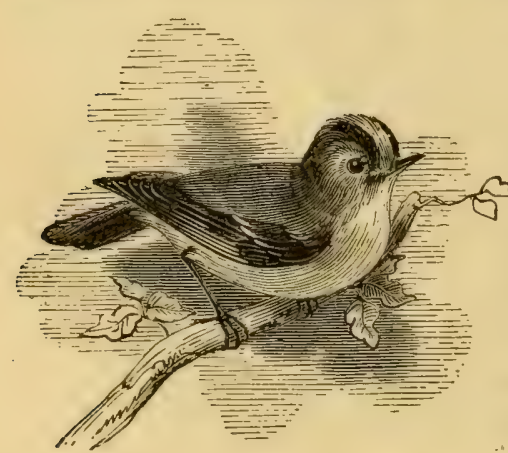

GOLU-CREST, $1 / 2$. of flocks from elsewhere.

Dr. Derham informed Albin (3. i. 98) that it built its nest " every year in fir-trees growing before his house at Upminster, in Essex, and that with great art, hanging them. [sic] under the branches in some thick obscure part thereof." Mr. Clarke says (24), it used to be "rather common round Walden," and on Oct. 9th, I880, I saw many in gardens there, probably new arrivals. At Sudbury, Mr. Grubb says (39), it is "constantly with us." Mr. Buxton describes it (47.9I) as "common" [in Epping Forest] "throughout 
the year, especially in the Wanstead Park Woods." It breeds not uncommonly in both the Colchester and Paglesham districts (Laver). At Harwich it is scarce during the breeding season, though often numerous during migration (Kerry). Mr. Hope writes: Migratory individuals arrive "on the Essex coast in vast flocks and singly about the Ioth of October; I have had them fly aboard when off the Sunk lightship, so tame that they would hop all over one, apparently looking for water to drink ; it breeds at Havering."

Fire-crest : Regulus ignicapillus.

A rare and accidental visitor.

A specimen "taken by a birdcatcher, at Epping, 26th November, 1878 , is preserved $* * *$ in the British Museum" (Buxton-47.9I). Mr. J. H. Gurney, jun., records (40. 225) I888, the occurrence of five specimens (three of which are in the possession of a Mr. Thos. Sorrell) in the month of November, some years ago, among about seventy Goldcrests taken on the Galloper L.V. Mr. E. R. Green, of Ilford, informs me that he shot specimens "in a small wood close to Barking Side," but,

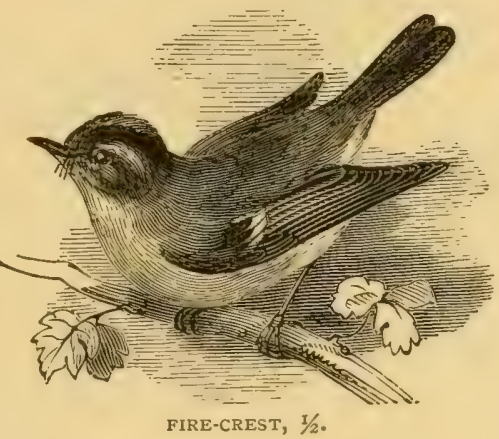
though preserved, they were accidentally destroyed.

\section{Chiffchaff : Phylloscopus rufus. Locally, "Oven-builder."}

A regular summer visitant, though by no means common and decidedly local in Essex. Its name is derived from its familiar note. Of all our spring migrants, it is the earliest to arrive, being sometimes heard before the middle of March. In I878, Dr. Bree both saw and heard it in his garden at Colchester, as early as March $5^{\text {th }}(29$. Mar. 9). In I88I, I heard the first on April 4th, near Audley End. In $188_{3}$, I did not hear the first here until April 7 th.

At Sudbury, it is only a very occasional visitor (Grubb-39). Round Paglesham it is common (Wiseman). Round Harwich it is also "common," and may be heard every spring in the Wrabness woods (Kerry). It is common in both the Colchester and Paglesham districts (Laver). In the extensive woods about Danbury and in the Writtle and Blackmore Highwoods, it is fairly abundant, but I have never once heard its note round my own home, at Chignal St. James, for several years past. Mr. Sackett has taken undoubted eggs at Orsett.

\section{Willow-Warbler: Phylloscopus trochilus.}

A very common summer visitor, arriving usually about the first week in April, and remaining until the middle of September. It breeds, I believe, abundantly throughout the county. It is very 
difficult to distinguish it from the Chiffchaff, but its note, nest, and eggs are entirely different.

Mr. Grubb says (39), it is "usually the first of our summer migrants heard" at Sudbury : elsewhere, however, the Chiffchaff usually precedes it.

\section{Wood-Warbler: Phylloscopus sibilatrix.}

A summer visitor, though very local, and not common. In Essex I only know of its occurrence at Epping and Saffron

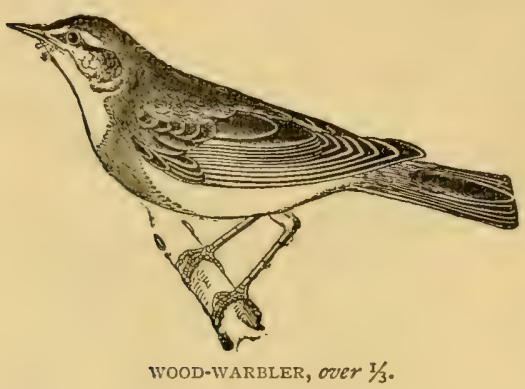
Walden. It seldom arrives before the middle of April and departs in September.

In the Saffron Walden Museum are specimens from Epping and Walden, the former presented by Hy. Doubleday. One was shot in Whitley Wood, Birdbrook, in 1830 (19.9). Mr. Clarke, writing about 1845 , described it (24) as "not uncommon in summer" round Saffron

Walden, and Mr. Travis assures me that many years ago he took a nest near the aviary at Audley End. Henry Doubleday writes (23.356) :-

"The three species *** are all common [at Epping], and I have had abundant opportunities of observing their habits. The Wood Wren arrives the latest-generally in the third week in April-and always frequents woods, generally where there are tall trees, but is only locally distributed, as there are many parts of our woods and forests where they are never seen. They seem particularly attached to certain spots, and seldom move far away, and are very rarely seen in the open country."

Mr. Buxton says (47.90) that in Epping Forest it is still "local, rather than rare, generally frequenting tall trees." $\mathrm{He}$ adds that it usually arrives in the Forest about April I5th, and that it breeds there. Yarrell says (I4, i. 3co) it is "not uncommon in the metropolitan counties."

Reed Warbler: Acrocephalus streperus. Locally, "Reedchat" (Orsett).

A regular summer visitor, though rather uncommon except on our coast, and decidedly local. It inhabits the reed-beds beside the Stour at Sudbury, and in the marshes near the coast, but I have never $m$ et with it in the central parts of our county.

In the summer of I83I, Mr. Grubb procured some specimens of this bird and its nest at Sudbury, where, he says (I2. v. 3IO) "it abounds in the reeds on the banks of the Stour, and in the ditches communicating with the river." He adds that he discovered two nests. Dr. Maclean, writing to T. C. Heysham, about 1838 , speaks (I6) as though it were then not uncommon round Sudbury. W. D. King, also writing at Sudbury in 1838 , says (20): "This interesting bird abounds on the reedy banks of our river. Its simple nest is elegantly and ingeniously suspended between three reeds or rather interworen round their stalks. The figure of this bird and its nest given in Loudon's Magazine of Natural, 
History (12. v. 310) were copied from specimens taken in this neighbourhood." Henry Doubleday, writing in I83I, says (20) "I never till this summer saw the Reed Wren living, but in July I saw it in plenty by the side of a brook at Sudbury, in Suffolk, and got a good pair. A friend of mine $[\mathrm{Mr}$. Grubb]*** found two nests, beautifully placed over the water, between three or four reeds." $\mathrm{He}$ also records (23. I3) that a single specimen "was shot at a pond close by the town [of Epping] in 1835 , which is the only individual I have seen here." Of the Epping district, Edward Doubleday wrote (I5) in I835:- "I am not aware of its being found near any of the rivers around us. It is common at Sudbury." It occurs in both the Colchester and Paglesham districts (Laver). Round Orsett, where it is called the "Reedchat," it is "fairly plentiful in the reed-beds and "fleets"" (Sackett). Round Harwich, it is common, and breeds abundantly in the large reed-beds beside the stream locally known as the Dock River, and also in the Little Oakley Marshes (Kerry). Mr. Fitch has found several nests at Maldon. Lieut. Legge writing from South Shoebury in I865, says (23.9838):-

"Great numbers of this lively little bird frequent the reeds, which grow in great profusion in the dykes intersecting the marshes in the vicinity of this coast. They are very plentiful in Canvey Island, and thread their way amung the reed-beds, hopping from one stalk to another with great rapidity. About May I $5^{\text {th, they }}$ begin to build." He adds a careful description of the nest, of which he says, "I have found half-a-dozen in a space of a few hundred yards."

[Marsh Warbler: Acrocephalus palustris.

A regular, though uncommon, summer visitor to the southern counties of England, especially to Somersetshire. It may be commoner than is generally supposed, as it is very closely allied to the Reed Warbler, from which it has only recently been distinguished in this country. The only actual record I have of its occurrence in the county is not a very satisfactory one. Mr. Joseph Clarke informs me that there is in the Saffron Walden Museum a bird which was shot and stuffed, about thirty years ago, by the late Mr. Stephen Salmon of Wendens Ambo, probably near the rivulet there. It was labelled "Reed Warbler," but Mr. Clarke considers it to be of this species. Mr. James Backhouse, junr., who has compared it with a genuine specimen of the Reed Warbler in his collection, says that although there are slight differences, he should hesitate before accepting it as a genuine Marsh Warbler, especially as the specimen is old and much faded, and therefore very difficult to distinguish from the very nearly-allied Reed Warbler. The bird is, however, likely to be met with in Essex.]

\section{[Great Reed Warbler: Acrocephalus turdoïdes.}

A rare and accidental visitor to Britain, which is recorded once to have been met with in Essex in the breeding season, though on such very doubtful authority that it seems in every way best to reject the record. Mr. J. Green, Naturalist, I, East Road, City Road, writes (? to Ed. Newman-23. 40I4): "The specimen of the Thrush Warbler, which you saw in the flesh, was caught at Dagenham, in Essex, on June I6th, I853." Newton considers (37. i. 365) that, although Green was wellknown to be a dealer, as the specimen was "shown when in the flesh to competent judges," there is no reason to doubt its authenticity, though he admits that Gould's warning (Birds of Great Britain) should not be neglected. However, as Green was known to deal largely in birds from Holland and elsewhere on the continent, where the bird is common, it seems best to reject the record.]

Sedge Warbler: Acrocephalus phragmitis. Locally, "Nightwarbler" (Maldon-E. A. F.).

A very common summer visitor, frequenting the sides of ponds, 
lakes and streams in all parts of the county. It arrives late in April and remains till late in September.

Lieut. Legge says (23.9837) that round Shoebury it is

"one of the commonest of our Warblers, frequenting the reedy ditches of the lowlands and situations where there are bushes, brambles, and sedge in the vicinity of water. They resort particularly to dykes which are lined with the wild sloe, which grows in great abundance in Canvey Island and other flat lands in the vicinity. They build in the sloe in preference to any other bush." He adds that "out of about two dozen nests, found in the course of a few days, seven were built in almost the same manner and position as those of the Reed Warbler."

\section{Grasshopper Warbler: Locustella navia.}

A summer visitor to all parts of the county, I believe, but decidedly uncommon, and always far more often heard than

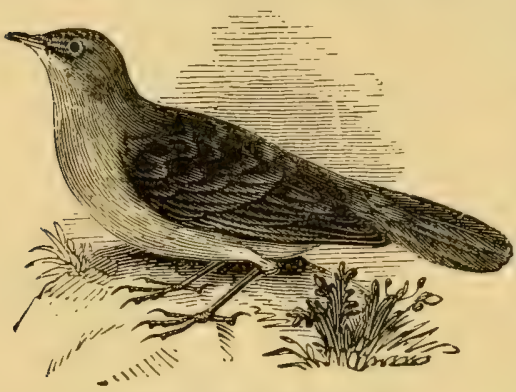

GRASSHOPPER WARBLER, $1 / 2$. seen. It is usually first heard about the end of April, and leaves us in September.

Mr. Clarke mentions one shot at Audley End on May 20th, 1836, and two shot at Widdington on April 3oth, 1839 (24). King, writing at Sudbury in 1838 , says (20): "I have only once seen this bird in our neighbourhood. Probably from its retired habits it often passes unnoticed, and may not be so rare as we suppose." Henry Doubleday, writing from Epping in 1832, says (10), "only a single pair appear in the vicinity-in a thick, damp wood;" but Mr. Buxton describes it (47.90) as "common throughout the [Epping Forest] district." It breeds round Harwich (Kerry). I have eggs taken at Chignal, where the bird is not uncommon among the standing corn, and Mr. Fitch has known it nest at Maldon.

Savi's Warbler: Locustella luscinioïdes.

A very rare summer visitor to the eastern counties, now probably extinct, as no British specimen has been recorded since

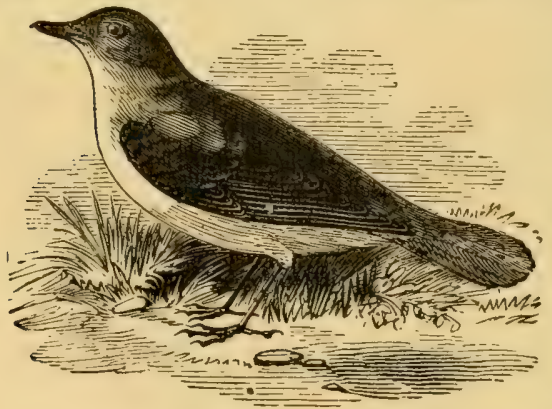

SAVI'S WARBLER, $1 / 2$. I856. It is very probable that it used to nest in Essex when the marshes were entirely undrained, but the only actual record of its having done so is the following very doubtful one :-

J. Green, of Whitecross Place, Wilson Street, Finsbury, writes (23. 2849) :-"I took a nest of Savi's Warbler at Dagenham on 
the I4th of May [I850]. The nest was built solely of reeds, and exactly resembled that represented in the Zoologist (p. 1307). It contained five eggs uniformly freckled all over with minute dark brown spots."

More (33. 23) regards this record with doubt, and it is hard to do otherwise, though it is quite possible that it is genuine. Green was a dealer in skins and a bird-stuffer.

\section{Alpine Accentor: Accentor collaris.}

A rare and accidental straggler to Britain, where it has occurred about a dozen times. The first British example met with was obtained in Essex.

Mr. James Pamplin of Whip's Cross Nursery, Walthamstow, says (12. v. 288):

"A few years since I shot a small bird in a garden on the borders of Epping Forest, which I did not know, nor could anyone tell me what it was, till within a fortnight a gentleman requested me to allow him to take it to London. He accordingly went to $\mathrm{Mr}$. Gould, Naturalist, 20, Broad Street,

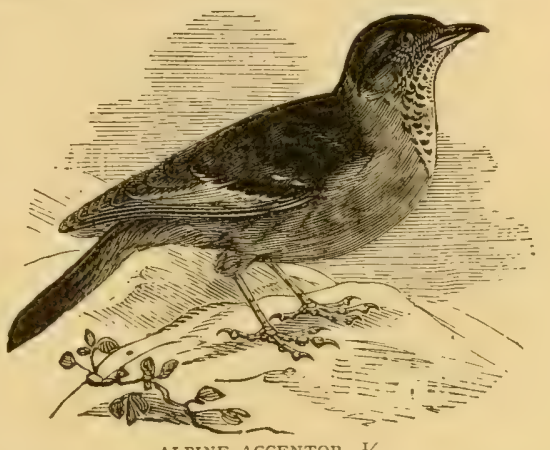

AI.PINE ACCENTOR, $1 / 3$. Golden Square, who sends me an account of its being the Accentor alpinus, or Alpine Warbler, the only one known to have been killed in England with the exception of one in Dr. Thackeray's garden at Cambridge."

Mr. J. H. Gurney, jun., who has carefully investigated the history of this specimen, has ascertained that it was shot in August, I8I7, in the garden of Forest House, close to Mr. Gurney Barclay's fields, from among a number of Chaffinches which flew up from one of the beds, and that it is still in Mr. Pamplin's possession (37. i. 279).

Hedge Sparrow: Accentor modularis. Locally "Hedgebet," "Hedge-betty," or "Hedge-moke."

An abundant resident everywhere. It is sometimes styled the "Hedge Accentor," which name is scientifically correct, as it is not nearly related to our mischievous enemy the House Sparrow.

Mr, Walter Crouch has told me of a white variety seen several times at Carswell, Barking-Side.

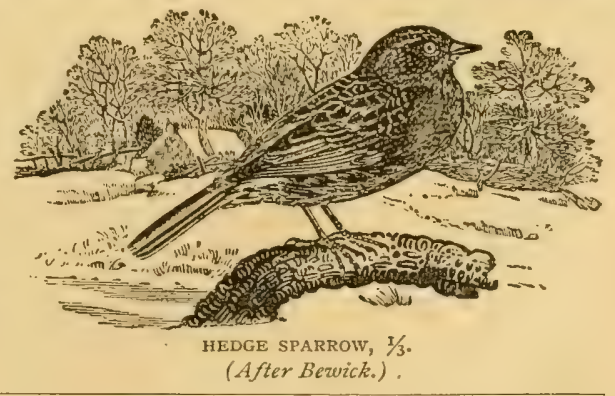

* It is interesting to note that the specimen figured by Xarrell is one of several (23.79 \& $\mathrm{I}_{4} \mathrm{i}$. 268) obtained at Duxford, in Cambridgeshire, just beyond the Essex boundary, about the year 1825 , by Mr. Joseph Clarke, as I am informed by that gentleman himself. One or more of them are now in the Saffron Walden Museum. 


\section{Family CINCLIDÆ.}

\section{Dipper : Cinchus aquaticus.}

A common resident among mountain-streams, but only a very rare and accidental visitor to Essex, and the east and south of England generally, although an instance of its breeding in Middlesex has been recorded (40. vi. I09).

Mr. Clarke speaks (24) of one killed at Audley End in I830, and formerly in the Walden Museum, and in the Museum Catalogue prepared by him in I845, this bird is marked as having occurred near the town. Yarrell, doubtless referring to the above occurrence, says (14. i. I76) it " has been seen in Essex." $\mathrm{Mr}$ J. D. Hoy records (I8. i。 II 7) that "one [was] shot early in the autumn of 1835 , on the borders of a large fish-pond [at] St. Osyth." He adds, "The occurrence of the Dipper in this part of the island is extremely rare." Dr. A. Maclean of Colchester, writing to T. C. Heysham about I835, says (I6), "I have lately mounted a fine specimen of the Water Ouzel, shot within sixteen miles of Colchester." Another was obtained near Colchester in the winter of I880-8I, and preserved by Ambrose (29. Apr. 23). Possibly the former of these is one of two specimens (one of which is of the black-bellied sub-species) still preserved in a case in the Colchester Museum. Mr. Hope informs me that he has heard of specimens being shor on the Stour; and one was "seen in a stream of running water at Wrabness in 1887" (Kerry). The Rev. J. C. Atkinson informs me that he never met with it in the county, and Mr. J. F. T. Wiseman has never met with it in the Paglesham district. Mr. Baxter tells me that about the beginning of September, I889, one was killed in Leigh Ray, but was unfortunately eaten by a cat. Canon Babington mentions $(46.49)$ "a pair of the chestnut-breasted form from the Stour above Sudbury, formerly in Mr. King's collection." He adds: "Mr. Hills bought them at the sale of the Sudbury Museum, and gave them to me."

\section{BlaCk-Bellied Dipper: Cinclus aquaticus-melanogaster.}

This is the Scandinavian and North European form of the Common Dipper. It occasionally appears in this country during winter, chiefly in the eastern counties; but I only know of one actual occurrence in Essex, though an examination of the various specimens mentioned above would very likely show them to belong to this form.

In the Walden Museum there is a specimen shot near the town many years ago, and presented by Mr. Jabez Gibson. Probably it is the Audley End specimen mentioned above. 


\section{Family PANURID无.}

\section{Bearded Tit : Panurus biarmicus. Locally, "Reed Pheasant."}

A scarce and local resident in Britain, and rapidly becoming rarer on account of the draining of its haunts. It once bred commonly in Essex, and a nest was found near Sudbury as lately as $\mathbf{r} 868$. It may even do so yet, though this has not been established.

Albin says (3. i. 46): "I have been informed by Sir Robert Abdy that they are found in the salt marshes in Essex," and Donovan quotes (5. i. 6) Albin's words. "A Lover of Nature," writing from Woolwich in

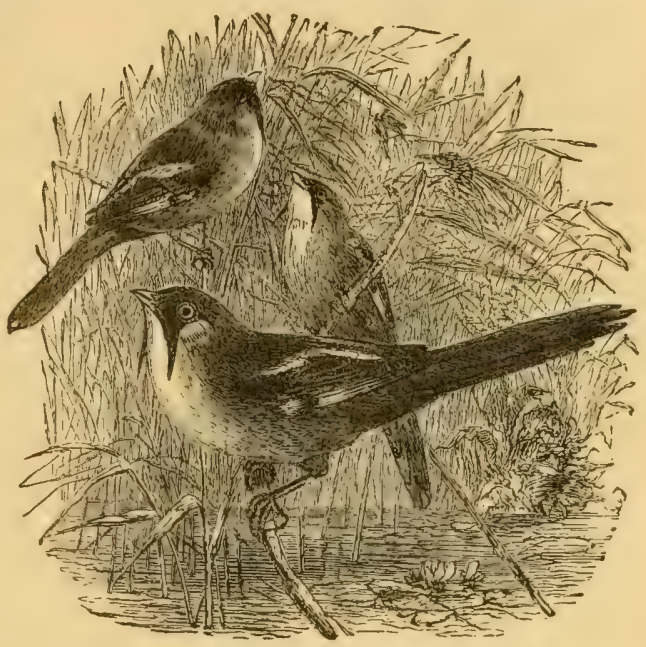

BEARDED TITS, $1 / 3$.

I829, says (I2. ii. 222): "Bearded Titmice inhabit the marshes bordering on the Thames, both in Kent and Essex. I was told in December last that some had lately been seen in a large piece of reeds below Barking Creek.*** The Bearded Titmouse is known in these parts by the name of the Reed Pheasant." He next details his observations upon eight or ten of these birds which he saw at the spot named, and one of which he contrived to shoot. "O," writing in 1832 , says (12. v. 544) that at that time it might be seen about the months of November and December feeding on the seeds of the reed, which then grew in great luxuriance on the banks of the lake at Dagenham. Yarrell, in I843, says (14. i. 353) it "inhabits the various reed-beds on the banks of the Thames."

More, writing in I865, says (23. I2I) that it "still breeds in Surrey (Rev. J. C. Atkinson), and probably in Essex (where the bird has been noticed)." This surmise seems to have been correct, for Mr. Grubb informed Canon Babington (46.65) that he believed he saw a pair in a bed of reeds in the Stour near Brundon Hall, Sudbury, in or about I868. Mr. J. F. Hills informed the same gentleman $(46.65)$ that he also had seen them on the Stour at Sudbury, and that they bred there in April, I868, when he took three young birds out of a nest of five, and brought them up by hand. They were exhibited at the Crystal Palace the following February when nearly ten months old. Mr. Hills tells me that this nest was on the Essex side of the river. In reply to my enquiry as to whether it used formerly to breed in the Essex marshes, the Rev. J.C. Atkinson writes: "Yes ; I never saw the nest myself, but $I$ heard of it. There were many acres of reeds in various places in my boyish days." Dr. Laver also remembers seeing specimens 
among the reeds at Tollesbury in September, I858. Mr. Ambrose tells me that Dr. Maclean once shot three among the reeds beside the river Colne, near Marriage's Mill at Colchester. These are probably the three specimens still in the Museum, as Dr. Laver recollects Dr. Maclean telling him that he shot them himself in the neighbourhood, and that they were formerly not uncommon. They are very nicely preserved, probably by Dr. Maclean himself.

It is not improbable that the Bearded Tit may still be reckoned as a resident in Essex, though undoubtedly a very scarce one; for on July I2th, I888, Mr. Edward Taylor, of Bishop's Stortford, saw a male in a large reed patch on the Herts side of the River Stort, near that town. He had a close view of the bird, as it rested on the top of a bulrush, and was able clearly to distinguish the long tail and black moustache. Mr. Taylor writes me : "I could not possibly be mistaken, as I was not more than a dozen yards from it. I went to the spot once or twice afterwards, but never saw it again. It might, however, have been near me at the time, as the bed of osiers was a large one, and the reeds thick." Mr. Hope, too, has a male shot on Dec. 24 th, I885, no further off than the King's Fleet, an arm of the River Deben, near Felixstowe, in Suffolk, not more than about two miles from the Essex border. A female was seen at the same spot in Feb., I886. The fact of the Bearded Tit actually breeding in Essex at this day still, however, remains to be demonstrated.

\section{Family PARIDÆ.}

Long-tailed Tit: Acredula caudata-rosea. Locally, "Bottletit," "Oven-builder," "Oven-tit," and "Pudding-poke," also "Bottletom," and "Long-tom-capon-bones" (E. A. F.).

A common resident. The British form of this species differs from the White-headed form (A. caudata), which is usual on the Continent, but is only sub-specifically distinct. The latter has

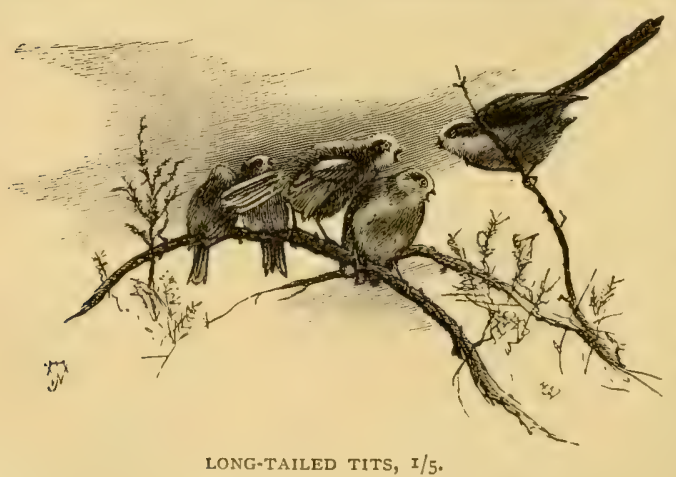
probably occurred in the county, as it occasionally straggles to Britain, but I am not aware that it has been actually observed.*

Mr. Joseph Clarke, writing in 1854 , noted (24) that it had been "very rare of late," round Saffron Walden. Round Orsett, where it is known as the "Bottle Tit" or "Oven-builder," it is uncommon (Sackett).

* There is, however, in the Colchester Museum Collection a specimen of this form which was probably killed in the neighbourhood, though nothing definite is known about it. Very likely it was stuffed and presented by Dr. Maclean. It appears to be intermediate between the true A. caudata and the British form, as the head is not wholly white. 
Great Tit: Parus major. Locally; "Saw-sharpener," "Post-builder" (E. A. F.).

A common resident.

Round Orsett, Mr. Sackett describes it as "apparently less common in summer than in winter," a remark which I think applies to the whole of the rounty.

Marsh Tit: Parus palustris-dresseri. Locally, "Blackcap."

A very common resident in most parts of the county, I believe, though Mr. E. R. Green tells me he does not meet with it. In

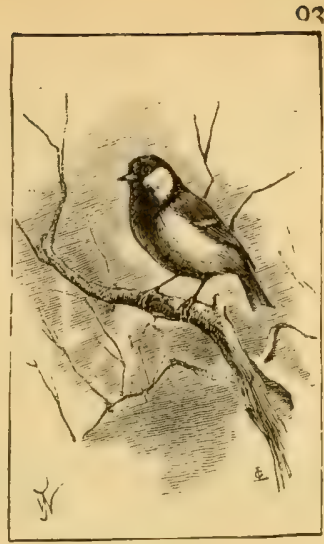

GREAT TIT, I/7.

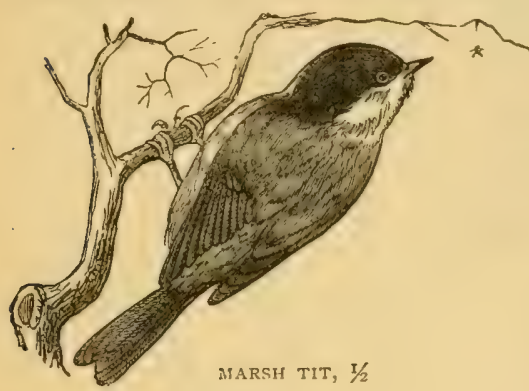

this species, again, we find a form differing somewhat from the true form ( $P$. palustris) usually met with on the continent of Europe.

Round Chignal, it is very common at all seasons, to the almost total exclusion of the Coal Tit. Round Harwich it is common and breeds (Kerry).

Coal Tit: Parus ater-britannicus.

A resident, though somewhat local and uncommon. This, the normal British form of the species, can only be regarded as a sub-species. The Continental form ( $P$. ater), with the upper part of the back slate-grey, instead of brown, may have occurred with us, as it sometimes visits Britain, but has never been identified, I believe.

In the Colchester district, and near London, Dr. Laver believes it to be commoner than the Marsh Tit, although round Chignal I have seldom seen a specimen of late years. Mr. Smoothy, however, tells me it is common at Danbury. Round Orsett it is "not com-

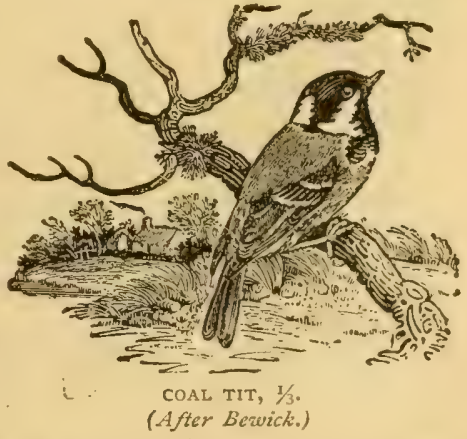
mon" (Sackett). Round Ilford, Mr. E. R Green tells me it is common. Mr. Hope says it is common round Upminster. Mr. Kerry mentions "one seen in the Wrabness woods." In the Paglesham district it is "pretty common." (Wiseman). 
Blue Tit: Parus caruleus. Locally "Pick-cheese" and "Blue-cap" (E. A. F.).

A very abundant resident.

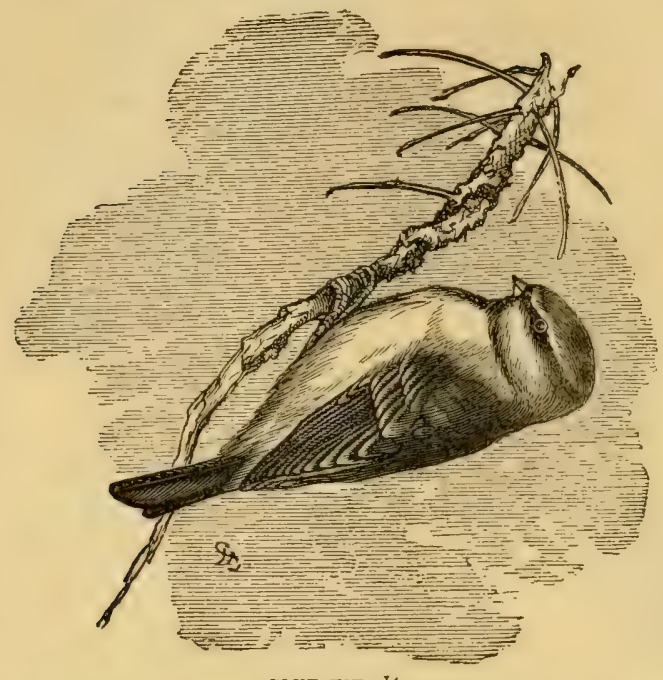

BLUE TIT, $1 / 2$.

The following is taken from the Chelms. ford Chronicle of June 6th, 1884 :

"In a hole one inch in diameter in one of the buffers of railway carriage No. 79, the property of the Great Eastern Railway Company, which makes daily excursions between Thorpe andClacton-on-Sea [five miles], a Tomtit has made its nest, laid its eggs, and is at the present sitting upon them.***The buffer $* *$ is often in violent concussion with other carriages. Notwithstanding this fact, the bird is always to be found on its nest. At the end of the day's work. the carriage is shunted at Thorpe for the night, and at that period the male bird invariably pays a visit to its mate."

\section{Crested Tit: Parus cristatus.}

A scarce and local resident in certain parts of Scotland, but

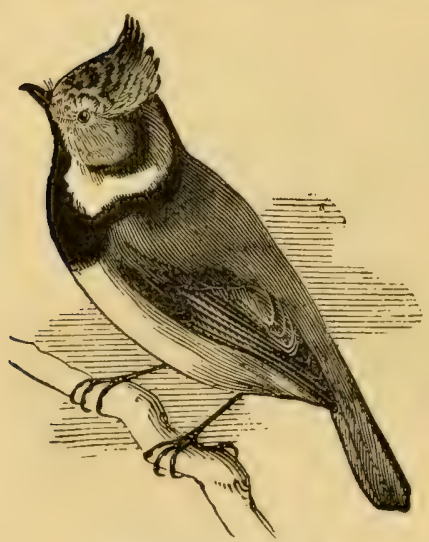

CRESTED TIT, male, $1 / 2$. only a very rare and accidental straggler to England, though two or three individuals are said to have been either seen or killed at or near Saffron Walden at different times in the first half of the century. It is now all but impossible to substantiate these unsatisfactory records, which must, therefore, pass for what they are worth.

Mr. Joseph Clarke relates (24) that two were killed at Ashdon in 1829 , one of which was in the possession of Joseph Stager (?), a bird-stuffer. The late Mr. Chater of Saffron Walden also informed Mr. Clarke that one was killed in his Nursery in I844. Mr. Travis informs me that he saw one whilst walking in Audley End Park many years ago. 


\section{Family SITTID无.}

\section{Nuthatch : Sitta cesia.}

A fairly-common resident throughout the county, especially in Skreens, Audley End, Thorndon, Hylands, Danbury and other parks, where the numerous ancient trees afford suitable nesting sites.

Mr. Grubb and Mr. King both give it a place on their lists of Sudbury birds (39 \& 20). English includes it in his list of Epping Forest Birds (43. i. 24), and Mr. Buxton says (47.86): "Frequent in the neighbourhood of Buckhurst Hill. A neighbour of mine supplies them with nuts, which they carry off every morning, invariably leaving the unsound ones." It is frequent at Stanway (Laver). At Harwich it is scarce, but breeds (Kerry).

In I880, I exhibited before the Essex Field Club (43. i. 69) a strange mass of dry mud which had been deposited by a Nuthatch in an old Thrush's nest, built in a large yew tree in the park at Audley End a year or two previously. The lump of mud, which has been presented by Mr. Travis to the Club museum, was very hard and completely filled the Thrush's nest, except that a hole had been left down the centre, exactly as if the Nuthatch had been plastering up the entrance to its nesting hole. It almost seems as if the Nuthatches had committed this strange freak "for practice."

\section{Family TROGLODYTID $Æ$.}

Wren: Troglodytes parvulus. Locally, "Diddy Wren," "Jenny Wren," and "Tiddy Wren."

An abundant resident.

Swainson says (48. 35) that the Essex name of "Tiddy" or "Tidley Wren" is in allusion to its diminutive size. Mr. Grubb says (39), "Three or four years ago a nest of young Wrens hatched in our garden [at Sudbury] were of a very light cream-colour. * * They very soon disappeared and were seen no more." About the year I886 a keeper at Lexden shot a Hooded Crow and hung it up to a tree by a piece of wire to swing in the wind as a warning to its fellows. In the spring of 1888 , a pair of Wrens built their nest of oak leaves within its hollow carcase, and therein safely reared their brood (50. ii. 205 \& iii. 23). The accompanying cut shows the nest in question. *

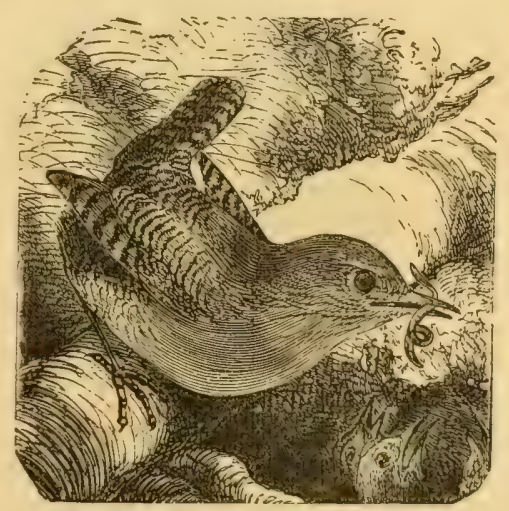

WREN, $1 / 2$.

* Curiously enough, my friend, Mr. Arthur Midgley, of Saffron Walden, bas an almost exactly similar case. A pair of Great Tits built their nest under exactly similar circumstances, 


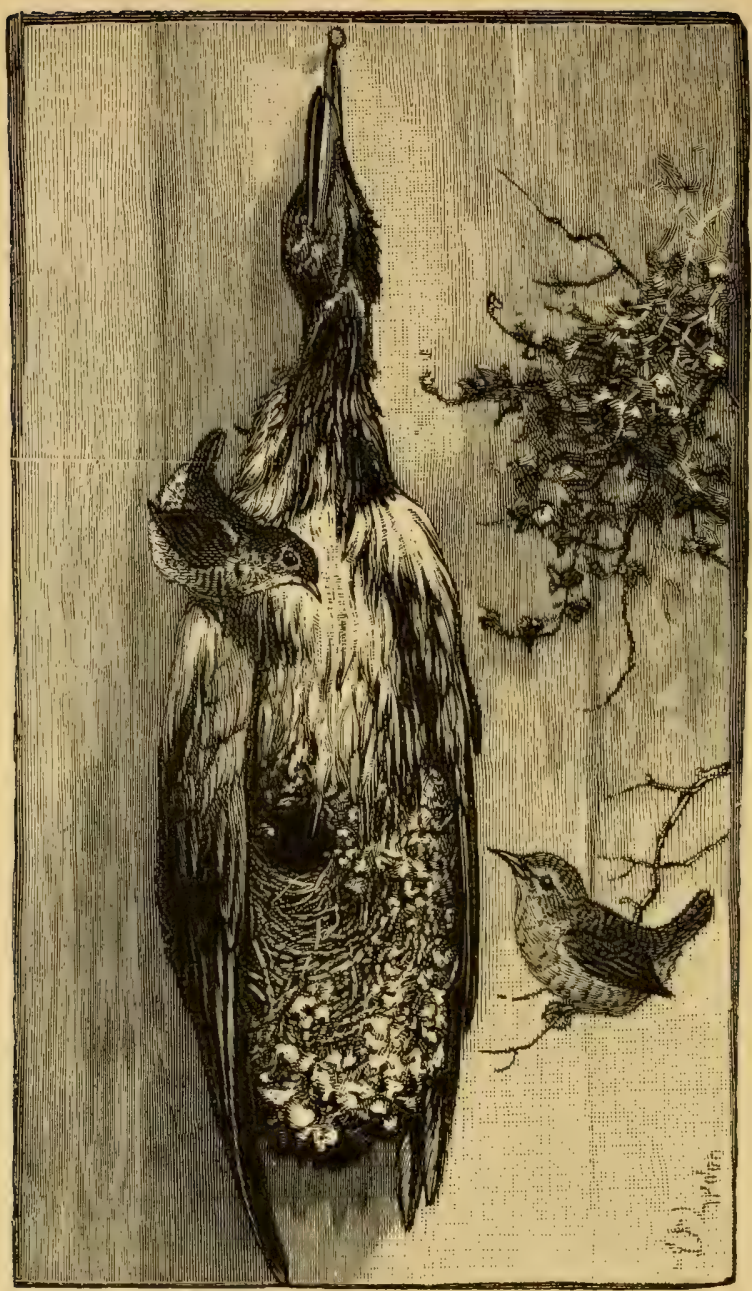

WREN'S NEST IN CARCASE OF HOODED CROW.

\section{Family MOTACILLID $Æ$.}

\section{White Wagtail : Motacilla alba.}

A rare straggler, chiefly in spring or summer, to the southern parts of Britain. It occurs, without doubt, occasionally in Essex,

at Rougham Hall, Suffolk, in 1885 , and are now shown with their nest in the dead body of another "Hoody" in a glass case. If Tits were substituted for Wrens in the accompanying cut, it would exactly represent this second case. 
though I have never personally identified it with certainty, and the only actual record of its appearance here I have been able to meet with is the following:

Mr. Joseph Clarke, writing at Saffron Walden about 1845 , says (24) of the "Pale Wagtail, Mot. allar, Tem.," that it "breeds here occasionally. A whole brood of five, with the old one feeding them, seen at Wenden, $18_{3} 6$, hy S. Salmon and self." It has also been known to breed in several other southern counties.

Canon Babington says $(46.248$ ) that two specimens, one in winter, the other in summer plumage, which "were in all probability obtained in the neighbourhood of Sudbury," are in the King Collection, passing as Pied Wagtails.

Pied Wagtail: Motacilla lugubris. Locally, "Nanny Wagtail," and "Dish-washer."

A common resident, though partially migratory, most of our birds going south during winter.

Mr. Buxton says (47. 89) that in Epping Forest it is "a common resident." He adds: "The greater number go south, to return about the end of February, dressed in their summer plumage. Those that remain with us, retain their

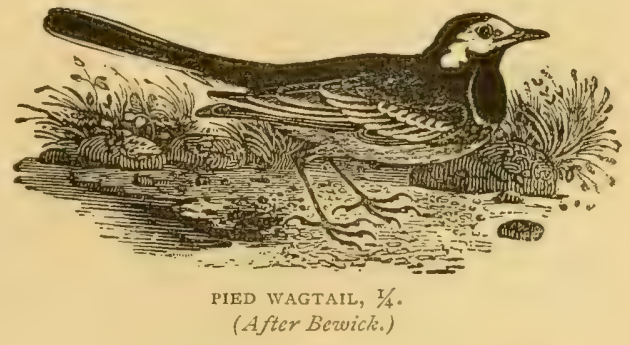
winter garb until the spring is farther advanced." Many certainly do leave us in winter, but not all, as I saw one here on December 8th, 1879, the day after the very severe frost. Mr. E. Gottwaltz records (29. Feb. 5, I876) that for three winters one amused itself almost daily by tapping on a window of a house at Great Baddow, a strange proceeding which has before been recorded of this and other species.

\section{Grey Wagtail: Motacilla melanope.}

An uncommon autumn and winter visitor. I have no knowledge of its having ever bred with us.

Mr. Seebohm says (45, ii, p. 204):

"I first became acquainted with these charming birds in the neighbourhood of Saffron Walden. Between this town and Audley End lies Lord Braybrooke's Park. A winding brook runs through it, by the margin of which you might stroll any winter's morning with the certainty of seeing one or two pairs of Grey Wagtails. They were regular winter migrants, appearing about the beginning of October and disappearing as regularly towards the end of March."

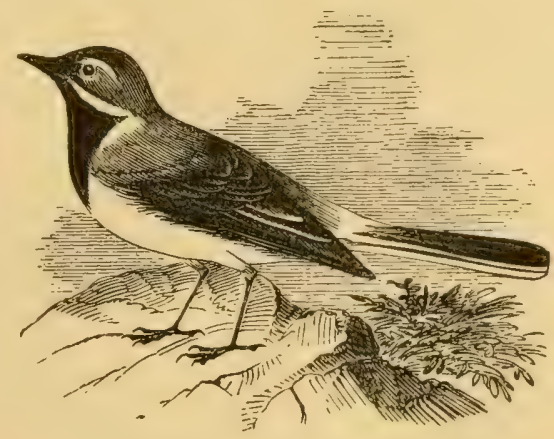

GREY WAGTAIL, male in summer, $1 / 3$. 
At Epping and at Sudbury Edward Doubleday and W. D. King respectively record it (I5 \& 20) as "a winter visitant." Henry Doubleday writes to T. C. Heysham in $18_{3}$ I (10), "The Grey Wagtail is very rare here, and I never could get one in summer plumage." Mr. Buxton says $(47.89)$ it is "not uncommon along the Roding in winter." Round Orsett, it is uncommon, being only occasionally seen, and never breeding (Sackett). It occurs in both the Colchester and Paglesham districts (Laver). Mr. Joseph Clarke tells me of one shot on Oct. 2nd, 1878, at The Roos, where it is rare. At Dedham, on Oct. 29th, I887, Mr. Stanley Edwards shot a young bird which he had observed for several weeks feeding on the lawn in front of his house. Mr. Fitch has seen it at Maldon.

\section{Blue-headed Yellow Wagtail: Motacilla flava.}

A rare straggler to Britain from the Continent. It has been most often met with in the eastern, southern, and south-western counties.

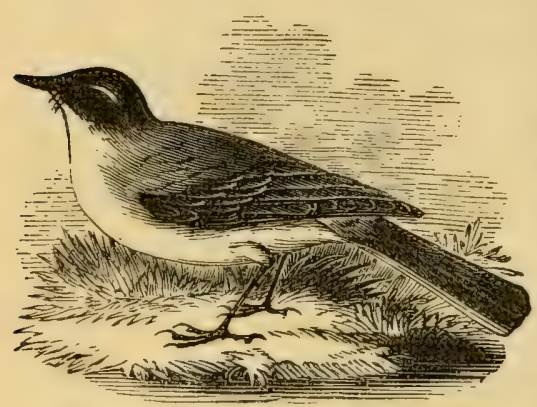

BLUE-HEADED WAGTAIL, I/3.

The first specimen recognised in Britain was shot by Henry Doubleday at Walton-on-theNaze on Oct. 3rd, I834, while the third (?) British specimen was met with about two years later on the border of Essex. It certainly occurs oftener than is commonly supposed, but is overlooked on account of its general resemblance to the commoner species.

Henry Doubleday, writing to Heysham on Dec. 29th, I834, says (I0):

"On the 3 rd of October, walking with two friends on the top of the cliffs at Walton-on-the-Naze, I had the pleasure of seeing two individuals of the Greyheaded Yellow Wagtail (Motacilla neglecta of Gould), one of which (a male) I fortunately shot, thus proving that this bird occasionally at least, visits this country. Although, being in its autumnal plumage, the marks are not so well defined as in spring, yet there can be no doubt of the species. The whole underparts are pure yellow, except the chin; this and the eye-streak are pure white. The head and back of the neck are light bluish-grey, tinged with brown at the tips of the feathers. *** The back, clear olive-green. When I came to London 1 took it to Bruton Street [where the museum of the Zoological Society then was] and there I met with Bennett, Gould, and Yarrell, all of whom at once pronounced it neglecta."

Doubleday briefly recorded his specimen in Loudon's Magazine of Natural History (I2. viii, 6I7). At his sale in $187 \mathrm{I}$, with five other birds, it fetched 345. (? purchaser), Mr. J. D. Hoy records (I2. ix. 352) that on May 2nd, I8 36 , he shot a specimen following a plough in company with several of the pied species in the parish of Stoke Nayland, which, though lying actually in Suffolk, adjoins Essex. Mr. Pettitt has preserved for Dr. Laver a very fine pair netted in company with several of the common yellow species at Fingringhoe in May, I889. The specimen figured by Yarrell was taken near Finsbury in April, I ${ }_{37}$, and was lent for the purpose by Mr. Joseph Clarke. 


\section{Yellow Wagtail: Motacilla raii.}

A regular and common summer migrant, arriving early in April and departing in September. I have never seen it, except occasionally during the times of its migration in autumn and spring, or known it to nest (though it seems formerly to have done so in Epping Forest) in the inland parts of the county; but it breeds very commonly on the marshes and lowlands along the whole of our coastline, placing its nests in the sides of the mud walls. Mr. Buxton says (47. 89) that in the neighbourhood of Epping Forest it "used to be frequent in summer, but [is] now scarce."

Round Orsett, it is a common summer migrant, breeding on the marshes, where the sea walls are a very favourite resort. When migrating, they may be seen at short distances inland, but after having settled down to breed they are only seen near the salt marshes (Sackett). At Harwich, it is very common and breeds (Kerry). Dr. Laver says it occurs on the marshes near the sea in both the Colchester and Paglesham districts, but he never knew it breed inland. It is common at Maldon and is especially brilliant on its arrival. It nests in the footmarks left by cattle at the sides of the marsh-ditches (Fitch).

Lieut. Legge, writing from South Shoebury in I 865 , says $(23.9836)$ that " great numbers $* * *$ frequent the low cultivated and marsh lands of this coast and that they nest in the sod-banks of the watercourses, and, on the approach of an intruder, circle round his head, uttering their note incessantly, endeavouring to their utmost to draw his attention away. The nest $* * *$ is consequently rather difficult to find."

\section{Tree Pipit: Anthus trivialis.}

A fairly-common summer visitant, arriving early in April and leaving us again during September.

Mr. Buxton says (47. 89) that in Epping Forest it is "frequent about the borders of the woods." Almost every year, Mr. Fitch finds a nest or two in the woods near Maldon, but it is not common there.

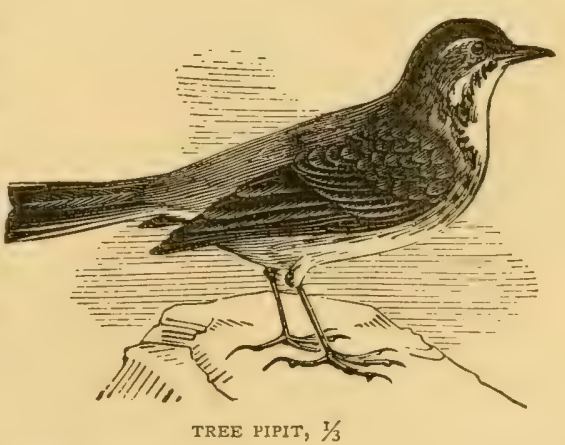

[Richard's Pipit: Anthus richardi.

Mr. Clarke writes me, "Some years ago, there was a long-legged lark which followed the plough and ran upon the land here. It wagged its tail. The ploughman was a very observant man, and I have always believed this to have been Richard's Pipit."]

\section{Meadow Pipit: Anthus pratensis. Locally, "Titlark."}

A common resident in some parts of the county, though not in others; especially abundant on the marshes and saltings near the 
coast; rarer inland, where it is seldom met with except during winter.

At Harwich it is very common and breeds (Kerry). Mr. Clarke describes it (24) as "not uncommon in meadows" round Saffron Walden. King describes it (20) as being "common " at Sudbury, where he says it breeds in the meadows. Lieut. Legge says (23.9839) that round Shoebury they are "very plentiful, particularly near the shore." In Epping Forest, Mr. Buxton speaks of it (47.89) as "only a winter visitant." Round Orsett, it is not common, though it breeds (Sackett). I do not remember to have met with its nest near Chelmsford. Mr. Hope says it is very common on the coast at all times of the year, but fresh arrivals take place in October.

Mr. Pettitt has a light sandy-coloured variety, sent to him anonymously from the Chelmsford district, about the year I896, and au albino has been obtained near Stratford (29. Oct. 19, 1889).

\section{Rock Pipit : Anthus obscurıs. Locally "Mudlark."}

A common bird on the marshes and saltings on and near our coast from autumn to spring; but, notwithstanding the following state-

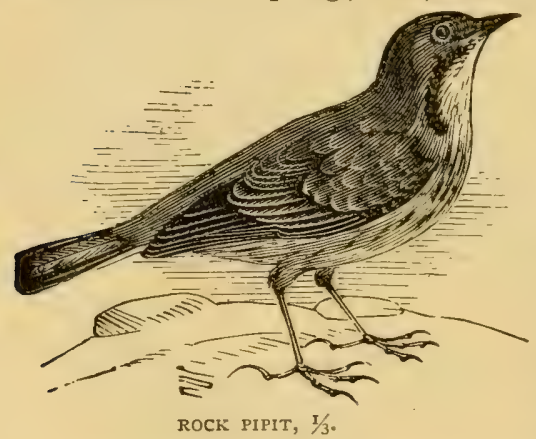
ments by Dr. Bree, I know of no authentic instance of its breeding in the county. It seems probable that the birds seen on the banks of the Colne during winter were true Rock Pipits, but that the birds breeding on the cliff, which Dr. Bree mistook for that species, were really Meadow Pipits, a species which I know is now abundant at the spot.

I found it very common on the mudbanks and saltings of the Maldon Estuary at Christmas, I888. Round Harwich, however, Mr. Kerry describes it as scarce, He adds that two in his possession, which were shot on the sea-shore in the autumn, are the only specimens he has seen there. The Rev. M. C. H. Bird, saw specimens on Canvey Island, in 1889 , as exrly as September 27 th. Mr. Sackett writes me that when on the Orsett marshes on December 25th, I888, he shot one "which being winged and falling into a marsh-pool, he was surprised to see swim readily and easily." Dr. Maclean, writing from Colchester to T. C. Heysham, about I835, says (I6):

"The Rocklarks, which are still upon the mud in this part of the world, are covered with stumps about the head and neck, and several specimens had scarcely any feathers upon them. One which had nearly perfected its plumage had a very rich breast and very different to the autumn plumage. I shall watch their departure and should much like to know the time of their arrival in their breeding places and the statc of their plumage immediately on their arrival."

Dr. Bree writes (34. 792): "When I first came to Colchester in 1859 , Dr. Maclean, who is a well-known naturalist, put me it possession of the whole "little history,' which is very interesting. All through tne winter, the banks of the Colne between Colchester and the sea are occupied by the Rock Pipit, and Dr. Maclean es- 
pecially pointed out to me that whenever they were flushed they invariably alighted on the muddy portions of the shore-never on the grass. One of them was shot and stuffed by Dr. Maclean, so there could be no mistake about the species, with which, in fact, he had been many years acquainted. In the spring all the birds leave the shores of the river, and will be found breeding among the grassy cliffs of the coast, returning to the banks of the river again in the autumn." He adds that they breed annually on the Felixstowe and Walton Cliffs.

Dr. Bree elsewhere writes (29. May 22, I875) that in winter it is "found along the banks of the River Colne, between Walton and Colchester. In the spring they go down to the coast and breed there. I have known this many years. When the Ruck Pipit is disturbed in winter, it always alights again on one of the muddy patches found by the side of the river-a fact pointed out to me by the late Dr. Maclean. Hence its name of Mudlark.'

In his notes, he again says (32a.) that it is "found throughout the winter on the banks of the Colne, and breeds on the cliffs along the coast from Walton to the Blackwater," but in this the Doctor was certainly mistaken.

\section{Family ORIOLID $Æ$.}

\section{Golden Oriole: Oriolus galbula.}

A rare and accidental summer visitor, though a good many specimens have been shot in the county. It seems very probable that it would on more than one occasion have bred with us had it not been molested, as several of our recorded specimens were met with in May and June. It has been known to do so in Kent, Surrey, Suffolk, Norfolk and other counties.

Hoy records (12. iii. 436) that " a brilliant specimen was shot on May Ioth, I 830 , by a gamekeeper at Lawford Hall, Manningtree. It had in its stomach the remains of a cockchafer and several small green caterpillars.' Mr. H. Barclay of Leyton writes (23, 285I):

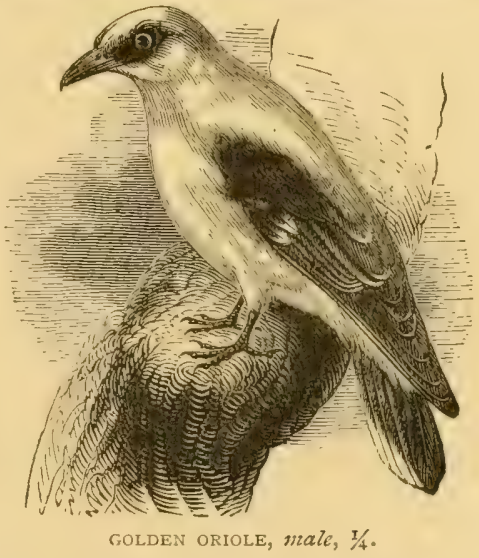

"On Saturday, the 25 th of May [1850], the gardener of John Masterman, Esq., of Leyton, shot one of a pair of strange birds that he had seen about the garden for some days. The bird proved to be a female Golden Oriole. It was sent to Mr. W. Morris, bird-stuffer, of this place, for preservation, and on dissection was found to contain two eggs, but with unformed shells. This seems to warrant the supposition that the birds had a nest, but it has not yet been found."

A specimen shot about 1850 at Birch Holt, is now in the possession of Mrs. Ingle, of Alexandra Road, Colchester. Dr. Bree records (23. 8032) that "a fine male specimen... in fresh breeding plumage" was shot at Tiptree about the second week in May, 1862. He adds: "There is no doubt, I think, that the bird was after breeding." E. L. M. of Leyton records (29. May I3) that he both heard and shot a fine adult male there on May 6th, I865. Mr. Hastings Warren, of 
Bourchiers, Little Dunmow, has one, shot there on May 7th, IS67. At the sale of the late Mr.Troughton, of Coventry, in I869, Mr. J. H. Gurney, jun., purchased and still has a young male labelled, "shot in Essex by Mr. Maclaren." Dr. Bree records a fine male shot at Copford on April 29th, I870 (29. May 7, and 32a), adding, "Colonel Hawkins has just informed me that he saw one in the woods at Alresford a few days ago." On June I6th, I874, a fine pair, which were doubtless about to breed, were shot in the rectory garden at Bradwell-juxta-Mare (29. June 27). One was shot at Dudbrook about 1882 (Scruby). On May 22nd, I883, our foreman at Lindsell Hall shot a female on a tall ash-tree in the orchard there, after it had been about for several days. Its loud sonorous whistling note had disturbed the congregation in the adjoining church on the previous Sunday. Its mate was not seen or heard (40. vii. 335).

Mr. Fitch writes (50, i. II 3 ) on June 9 th, I887:

"I was pleased this morning to see a male Oriole fly out of a tall hedge by the roadside, almost opposite my Mosklyns farm-house [Purleigh]. I was on horseback and followed it, gently flushing it twice along the road towards Hazeleigh. It eventually took refuge in my little Box-iron Grove, where I trust, if it has a mate, it may continue. One midsummer holidays, about eighteen years ago, I saw an Oriole twice or thrice at Wixoe in Suffolk and at Baythorne End, Essex. I well remember seeing it on both sides of the river."

Mr. Fitch informs me that he saw the male again, but never its mate, always near the same spot, for a week or two after the date named. There can, therefore, be very little doubt that there was a nest. A fine adult male was shot by Mr. A. S. Pearson in the parish of Belchamp Walter, on May 2nd, 1888. No other was seen about, either at the time or afterwards, and it bore no evidence of having ever been caged. It was preserved by Mr. Rose of Sudbury, and now belongs to the Rev. Mr. Leaky of Acton, Suffolk (50.ii.72). Mr. Capel Hanbury records that he observed one feeding on the haws of a large white-thorn bush in company with some blackbirds and thrushes on November $20 t h, 1888$ (29. Dec. 8 th), but the date suggests that the bird seen belonged to some other species. Mr. Travis preserved a fine male caught at Elmdon by some labourers under a hedge where it was driven by a high wind, in June, I888. Mr. Smoothy informs me that a gentleman saw one several times in his garden at Sandon early in May, 1889. Yarrell says (30. i. 24I) several "have been taken in Kent and Essex."

There is no thoroughly satisfactory record of its having bred in Essex, but Mr. Hope informs me that the late Mrs. Lescher, of Boyle's Court, Brentwood, who resided many years ago at Warley Place, could recollect more than one instance of their breeding there; and the Rev. G. C. Green, of Modbury, Devon, in his Collections and Recollections of Natural History and Sport (London, 1884), says :

"There are, I fancy, very few recorded instances of the Golden Oriole breeding in England, and few people have ever seen this bird upon its nest. My wife, however, can count herself among those privileged few. When she was quite a little girl, she was living at Tiptofts, near Saffron Walden, in Essex, the house of her uncle, T. W. Gayton, Esq. It was a very old house, surrounded by a moat, and was in the midst of its own grounds, entirely away from all other habitations. $* * *$ It was rather a celebrated place, having formerly [it is said] been attacked in vain for fourteen nights by Dick Turpin's gang. Near to the moat grew a clump of fir trees, and in one of these, in the year I84I, a pair of Golden Orioles built their nest. One of my wife's uncles was well acquainted with the names and habits of birds, and he soon discovered the presence of the illustrious strangers, and told his niece what they were, and the gardener used frequently to lift up the 'little girl' to see the beautiful bird upon its nest. They were zealously guarded and I have every reason to suppose that they brought off their young safely; but I was but a 
small boy myself at the time, and did not hear of the occurrence till many years afterwards. But it was well known to all my wife's family at the time, and I have heard it constantly spoken of by them ever since. They never appeared to have returned in later years. This rare occurrence has never been recorded in any work on Natural History, so I think it is well worthy of insertion in these notes."

\section{Family LANIID $Æ$.}

\section{Great Grey Shrike : Lanius excubitor.}

An occasional visitor met with in Essex in most years from autumn to spring, and very exceptionally during summer. Records given below, to which Yarrell, More, Hoy and other good observers apparently give credence, speak of its having been seen in Essex during summer, and a specimen was seen by a trustworthy observer near Kelvedon in May last, but it is not known with certainty to have nested in Britain.

Henry Doubleday, writing in $183 \mathrm{r}$, says that he had never seen more than one in Epping Forest, but he afterwards heard of a female, shot about six miles from the town, early in March, I845 (10). He also writes (23.40):

"An individual of this species which I had in confinement for a long time, invariably hung its food round the cage. If half-a-dozen birds were put in, it hung them all up by forcing their heads between the wires of the cage, and pieces of meat were also fastened up. I never saw the Red-backed Shrike impale insects, nor do I recollect ever to have found any impaled here, although the bird is not at all uncommon."

Edward Doubleday, in 1835 , mentions (I5) its having been killed at Harlow. Mr. Parsons says (II) it was "rarely seen" in Rochford Hundred in his day. Hoy records (I8. i. II7) one "caught in a common trap-cage set for small birds in a garden on the outskirts of Colchester in February, $18{ }_{3} 6 . "$ Mr. Clarke says (24) in his notes, that round Saffron Walden "generally two or three are killed every season, during the winter." From this it appears to have been of more frequent occurrence then than now. Mr. Clarke specially mentions one shot by Mr. Salmon at Wendon in 1827 , a female shot by a Mr. Master in Burton Wood Saffron Walden, in Nov., I843, a female shot at Thaxted on Dec. I5th, I844, a male (now in the Audley End Collection) shot at Saffron Walden on Mar. 3rd I854, and a female shot at Shortgrove Park on Apr. 5th, I854. A male was killed at Loughton on Apr. I2th, I858 (23.6096), and another (23. 8325) on Oct 28 th, I\$62, in a garden adjacent to Leyton Marsh. Mr. Kerry records (34.4827) a male in full plumage shot at Ramsey on Nov. 9th, 1875, and he himself shot one near Harwich on Dec. 6th, 1879 (40. iv. p. 70). A female was shot at Clavering on Nov, I2th, IS80, by Mr. H. Rolfe (44. i. lxiii). A female was shot at IVillingale on Nov. Ist, I88I (Chelmsford Chronicle, Nov.4). Mr. Scruby informs me of one shot at Forest Hall, Ongar, and another at Beauchamp Roding about thirty years ago. Mr. Pettitt, of Colchester, preserved one picked up dead close to his shop, on Dec. $3 \mathrm{rd}, 1888$, it having been killed by flying against the telegraph wires. In I\$82, one was shot near Thaxted about April Ioth. Mr. J.A. Cooper of Leytonstone records one (29. Ort. 25) captured on Oct. Sth, I8S4, near Epping, by a bird-catcher netting small birds. One was shot near Elmdon by Mr. Nottage, cf Jan. 7 th, I885, and another at Thaxted on Nov. Ioth, I8S6. Mr. John Smith of 
Brentwood has one shot at Brook Street in Oct., I887. It is killed most winters in the Colchester district (Laver). Mr. Main of Walton killed one there about the middle of Oct., I859. Mr. Stacey of Dunmow has one caught in a bush there several years ago. Mr. Kerry records a male shot at Harwich on Dec. 7th, I889, which had an entire Sky-lark's foot in its stomach (40. xiv. 20), and he informs me that another was seen there on the I6th. Mr. Pettitt received a female, shot at Halstead two days later.

J. D. Hoy says (I2. iv. p. 34I) : "Seldom a season passes without my observing the bird in this neighbourhood. A friend of mine assures me he has seen it in Essex, near Colchester, in the month of June, that he had a good view of the bird, and could not be mistaken, but I consider it merely an accidental occurrence."

W. D. King writes (20):

"Last summer (1837), whilst walking near Chilton Hall, my brother's attention was attracted by the clamour of a group of small birds. Cautiously approaching the spot, he soon discovered the cause of the uproar in one of these Shrikes, upon whose character the surrounding group appeared to be earnestly and angrily descanting. At the same time he observed a pair of Red-backed Shrikes sitting upon a neighbouring hedge."

Chilton Hall lies only a few miles beyond the Essex boundary. Yarrell says (I4. i. 150), "On two occasions it has been seen in Essex during summer by observers who know this bird well." More says (33. I7), "Yarrell mentions its occurrence during summer in Essex and Northumberland." Mr. Hope also writes: "Not uncommon in Essex; have seen it about breeding time, but have never found the nest."

A more recent instance of its occurrence in Essex during the summer is mentioned in a letter to me from Mr. Spalding of Colchester, who writes :-

"On Sunday, May I2th, I889, when walking from Kelvedon Station towards Prested Hall, Feering, on the Colchester high-road, we saw a Greater Shrike sitting on the telegraph wire. We got quite close, but it flew along a hedge in an adjoining field, and though we looked closely, we failed to get a second sight of it."

Mr. Clarke writes me that he believes it bred near Audley End on one occasion many years ago. The son of a baker, named Bush, took a nest belonging to "a great slate-coloured bird," and brought the eggs to the Walden Museum for comparison. They were, in Mr. Clarke's opinion, undoubtedly those of this species, but he could not persuade the boy to part with them.

\section{Greater Grey Shrike: Lanius excubitor-major.}

Probably not much less common during winter than the form mentioned above, but from which it is not often distinguished. It is the Eastern and Siberian form of the common Great Grey Shrike, and can only be regarded as sub-specifically distinct from that bird, though some writers have raised it to full specific rank. In Scandinavia, both species meet and freely interbreed, producing intermediate forms. Typical specimens may be chiefly distinguished by their wing-spots, the true $L$. excubitor having two : the sub-species, only one. I have myself only identified two Essex examples of the latter form ; but no doubt an examination would show that nany of the specimens mentioned above belong to this form; while possibly some might be found to belong to an allied, but much rarer, 
species, the Lesser Grey Shrike ( $L$. minor), which has on several occasions been detected in Britain.

Mr. C. H. B. Croxon, of Reddings, Tillingham, has an example, shot at the Glebe Decoy, Bradwell, a few years back, and Mr. Robert Page, of Down Hall, Bradwell, has another which was observed to fall from one of the bushes round his decoy at Tillingham as though in a fit, early in January of the present year.

[Southern Grey Shrike: Lanius meridionalis.

Dr. Bree (34. 472 I \& 29. Nov. I3) records a male, shot within a few miles of Colchester during the first week of November, I875. It had a shrew in its stomach. This, he says, was the first British specimen. He describes it fully, stating that it was $10 \frac{1}{4} \mathrm{in}$. in length, and had the four central tail-feathers black, though one is slightly tipped with white. It appears from Dr Bree's notes (32a) that it was "shot at Dedham the last week in Oct., I 875." It is strange that Dr. Bree should not have entered further particulars, as this species has never otherwise been observed in Britain, either before or since, and the specimen would therefore have been of great interest. As Dr. Bree (so far as I know) never afterwards alluded to it in print, it seems probable that he subsequently discovered his identification of the specimen to be erroneous, though I am not aware that he ever corrected his record of it. I have enquired carefully of Mrs. Bree and others without being able to ascertain that the specimen still exists. It is impossible, therefore, to accept the record as authentic.]

\section{bird."}

Redbacked Shrike: Lanius collurio. Locally, "Butcher-

A common summer visitor, usually arriving about the first week in May, and departing again late in August. It varies considerably in number in different years, and it appears to be decreasing with us.

Mr. Joseph Clarke says, in 1845 , that this species was "formerly not common [round Saffron Walden] but latterly more so" (24). Henry Doubleday, in I83I, says (IO) that it was then very common in Epping Forest, though, in the spring of 1834 , he notes it (10) as "less abundant than usual." Mr. Buxton says (47.83) that "they breed in the neighbourhood [of Epping Forest] frequently, if not every year." King describes it (20) as "common" round Sudbury. In the Birdbrook district it is common, but at Maldon somewhat rarer (Fitch). Mr. Hope writes:

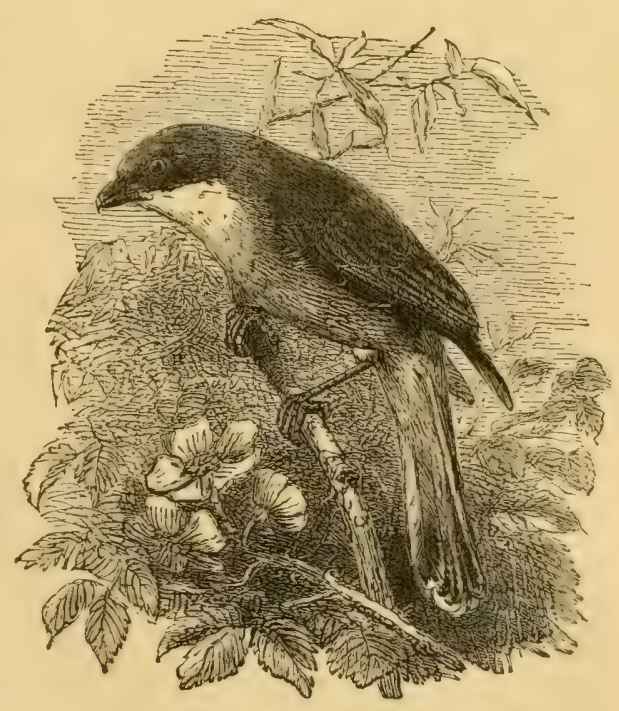

RED-BACKED SHRIKE, male, $1 / 3$. 
"It is very common in Essex. I have reared young birds, and have copious notes. I have seen the old birds kill as many as five field-mice in one day. They lift the mouse up on their beaks and hitch it on to a thorn and then pull it downwards with all their weight and strength. I think they are put on thorns for the convenience of eating at the time, as they seldom finish any animal. They can kill another bird, or one another, by one stroke of the bill."

\section{Woodchat Shrike: Lanius pomeranus.}

A rare and irregular summer visitor to England. I only know of a single instance on record of its having been actually obtained in Essex.

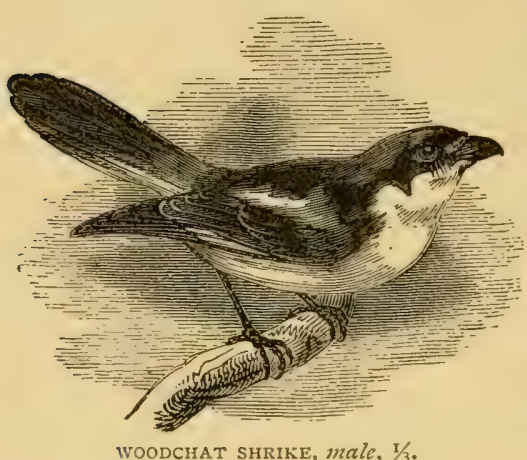

WOODCHAT SHRIKE, male, $1 / 3$.

Mr. Ambrose tells me that seven teen or eighteen years ago he saw an undoubted specimen one Sunday afternoon in the Colchester Highwoods, but he had no gun at the time.

Mr. Travis records (44, i. lxiii.) that on August 27th, I880, he received for preservation "a pair of Woodchat Shrikes shot by a man named Jeffrey, between Elmdon and Arkesden. A boy driving sheep into Walden was accosted by Jeffrey, who had a gun. He gave the birds to the boy, remarking that they were 'a pretty pair, and perhaps the birdstuffer might give

something for them." Mr. Travis adds, "I received them within two hours of their death, quite fresh and hardly stiff. These are the first specimens of this very rare bird I have heard of as occurring in Essex." I have personally inspected these specimens, which are undoubtedly a fine pair, male and female.

Mr. Pettitt informs me that, some years ago, on a farm near Mark's Tey, held by his uncle, Mr. Bickmore, the late Dr. E. G. Varenne saw a pair of birds which he pronounced to be male and female of this species. Dr. Varenne is now dead, but as he was a good naturalist, the record is worthy of some credence.

\section{Family AMPELID E.}

\section{Waxwing : Ampelis garrulus.}

A rare and irregular winter visitor, though it sometimes appears in considerable numbers, as in the years $1835, \mathbf{1} 849-50, \mathbf{1} 866$, Ic.

Mr. Clarke mentions (24) two specimens from Saffron Walden (both now in the museum there?), a male shot in August, I835, the other about 1838 . Yarrell says one (30, i. 4I ) was killed by Mr. Clarke out of a flock. Mr. C. Walford records (I9. 57) that several were shot at Braxted, one at Terling, and another at Kelvedon in or about 1838 . King describes it (20) as "a very rare visitant" to Sudbury. Newman records (23.2767) specimens from Chelmsford, Rainham, and many other localities round London in the third 
week of January, I $\$ 50$, and Mr. H. Barclay others at Walthamstow. Mr Chas. E. Smith of Coggeshall records one (3I. 52) near that place "shot from among a flock of Starlings, I85I." Mr. English includes it as a "casual visitor" in his Epping List (43. i. 23). One was shot at Willingale about 1858 , and another more recently (Scruby). Ed. Newman records one (34. 560) near Ongar on November 28th, 1866, and another two days later at Loughton. Dr. Laver remembers seeing some that were shot at Abberton about I878. One was seen alone in a garden at Dovercourt on December I3th, I882 (Kerry, 40. vii. I20). Mr. Travis records (44, iv. xii.) a male shot at Chrishall on January I7th, I883, and a female shot about the same time at Sampford. "E. C." records (29. Jan. 20) that while walking round Wanstead Park on January I4th, I 883 , he watched three for several minutes. He adds, "It is fourteen years since a pair of these birds were killed near Chigwell." About the same time, two males and a female, all shot in Essex, were sent to Mr. Travis of Walden for preservation. One is recorded (Chelmsford Chronicle, Mar. 30) as having been shot at Dedham by Mr. B. Watson, jun,, about the third week in March, ISS ${ }_{3}$, another being seen about at the same time. The Rev. P. A. Leaky of Sudbury possesses a fine specimen shot in Essex. Mr. T. W. Offin shot one at Rayleigh about ten years ago. Mr. Charles Smoothy observed one on several occasions at Danbury in January of the present year.

\section{Family MUSCICAPID $Æ$.}

\section{Pied Flycatcher: Muscicapa atricapilla.}

An uncommon passing migrant in spring and autumn, when on its way to and from its breeding localities in the North of England and in Scotland. Its usual dates of appearance in the county seem to be early in May and early in September. It has once been known to breed in the county, and it has done so exceptionally in several other southern counties.

The Rev. R. Sheppard observed it occasionally at Wrab. ness, as he notes its arrival there (17) $i$ on May 16 th and April

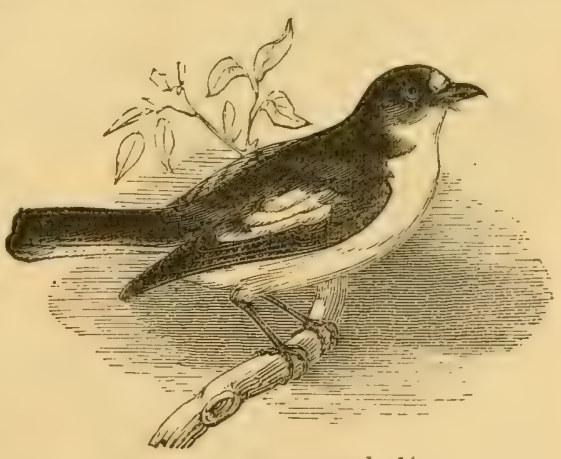

PIED FLYCATCHER, male, $1 / 2$ 29 th, in I822 and I823 respectively. Mr. Joseph Clarke notes (24) the occurrence of a male at Audley End in or about I826. At Stoke Nayland, in Suffolk, just beyond the Essex border, J. D. Hoy records (I2, iii, 436) that several were seen on May Ist, I830. He also records (I2. vi. I5I) that one was shot at Stoke Nayland on the 7th of September, 1832 . "It was in company with several of the spotted species. I know several instances of its having been met with in the same vicinity, both spring and autumn, but never heard of its remaining to breed."

Henry Doubleday says (10) one was seen at Epping in August, IS35, and in 
July, 1836 , he says (I0) "For the first time, I this spring lobtained a male Pied Flycatcher here. It was sitting on some rails by a pond in the town." Edward Doubleday records this (I5. iv. 233) as killed in May, 1836. English calls it (43. i. 23) an "occasional visitor" to Epping Forest. One was shot in the grounds of Chestnut Tree House, Leytonstone, about the middle of April, I87 I (29. April 22). "A female *** was taken in the Forest by a bird-catcher on the I $3_{\text {th }}$ of September, I877.*** It was kept alive for some days on chopped egg and meal-worms. Two examples were shot in Theydon Grove, and are in the Doubleday Collection" (Buxton-47.89). Mr. Smoothy has one shot near Thaxted about 1878. On May Ist, I88 I, Mr. Travis watched one near the Bull Lodge, at Audley End, About fifteen years before he shot another near the same spot. Mr. Stacey of Dunmow preserved a pair shot there by himself in I882. Mr. Scruby informs me of one shot at Dudbrook about I883. The Rev. M. C. H. Bird found a dead, but fresh, immature specimen washed up among some débris on the shore at Canvey Island, on September 27th, I889.

Mr. Harting ("Our Summer Migrants," p. I63) says he has known it nest in Essex, but he cannot now recollect where. I know of no other instance.

Spotted Flycatcher: Muscicapa grisola. Locally, "Wallbird" (Orsett).

A common summer visitor, usually arriving about May ist, on which date, in $I 88_{3}$, I saw the first bird of that year near

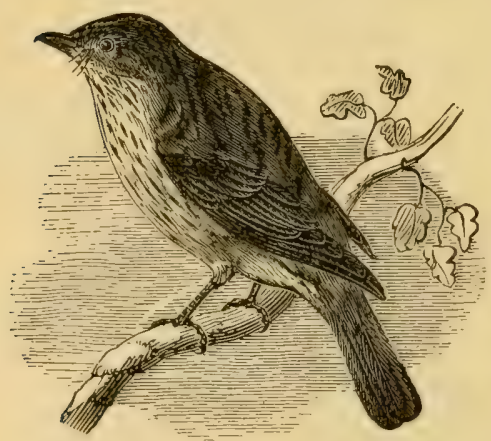

SPOTTED FLYCATCHER, $1 / 2$. Wethersfield. In I888, it was unusually scarce round Chelmsford.

In July, I876, I found here a nest of this bird, containing eggs, which was built in a portion of the mud lining of an old Thrush's nest, suspended loosely in a bush overhanging the brook. More than one similar instance has, I believe, been recorded.

\section{Family HIRUNDINID $Æ$.}

\section{Swallow: Hinundo mustica.}

An abundant summer visitor, usually arriving early in April and departing again about the end of September, though specimens may not unfrequently be observed and even nests found in October or November and later. Cream-coloured or white varieties are not very rare.

In I880, I saw the first at Walden on April I 5 th, and the last on November I 7 th, and I saw one at High Beech, on October 30 th, I88I. One was spen at 
Chipping Hill, Witham, on November I3th, IS7S (29. Nov. 30), and Colonel Marsden observed one over a pond at Great Oakley, on Nov. 26th, I8s9 (29. Dec. I).

Mr. Buxton writes (47.92):

"In the late summer these birds gather in thousands to roost in the reed-bed in the pond in Cook's Folly. [near Walthamstow]. This seems to be the general rendezvous for the district, and at sunset they may be seen flying in small companies from every direction towards this point. The confused noise, as they swarm like bees to gain a foot-hold among the reeds, is most remark. able."

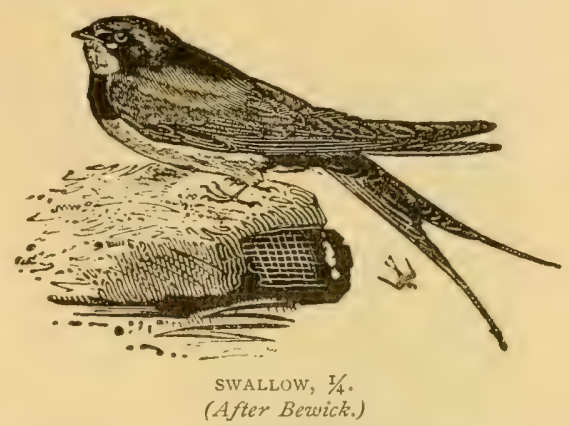

Round Shoebury, Lieut. Legge says (34.92) it breeds largely "under the bridges over the watercourses in the marshes." In 1865 , he saw the last on November 5 th. In 1887 , they were observed at Maldon after cold weather as late as Nov. $4^{\text {th }}$ (29. Dec. 10).

Mr. Hope informs me that he knew of a swallow living all one winter in Epping Church. Dr. Bree states (29. Nov, 20, 1875) that he had "a nest and eggs taken while the old bird was sitting on them in the middle of December [IS66] at Walton-on-the-Naze." The nest in question is still in Dr. Bree's Collection in Mr. Harwood's possession.

Mr. Clarke, writing about 1845 , says (24) that two perfectly white specimens had been taken at Saffron Walden. One of these, a young bird, is still in the Museum there. Henry Doubleday records (23.487I) having seen a pure white specimen flying over his garden at Epping on the evening of August I9th, I855. A young fawn-coloured specimen was shot near Little Baddow, on November 2nd, I880 (29. Nov. 13).

\section{Martin : Chelidon urbica.}

An abundant summer visitor, arriving usually early in April and departing again about the middle of October, though individuals are sometimes observed much later. They would be very much commoner than they are with us were it not for the Sparrows taking possession of their nests. I consider that the late Col. Russell was more than justified in all that he wrote upon this subject.

His interesting paper, entitled "Martins and Sparrows," published in the Journal of Proceedings of the Essex Field Chub (vol. iii., p. 20), should be read by every one. In this paper he clearly shows how the useful and ornamental Martins are being steadily exterminated by the injurious and obnoxious Sparrows, which take possession of their nests. For many years Col. Russell carried on an incessant war against the Sparrows at Stubbers, shooting every one that appeared, until at last they became scarce birds. The 
resulting increase in the number of Martins was quite extraordinary. Commencing with the year 1870 , he had in successive years the following number of nests on his house :-7, 20, 45, $5 \mathrm{I}, 68,8 \mathrm{I}, 100$

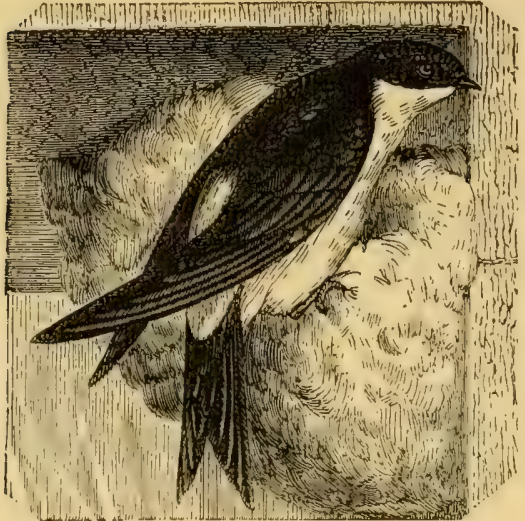

MARTIN, $1 / 3$. and I Io. After this the number remained stationary at about $\mathbf{1} 30$, that being, apparently, the greatest number that could obtain subsistence. Col. Russell's evidence as to the injurious nature of Sparrows, is not less interesting, but is out of place here.

Henry Doubleday saw thirty or forty flying together at Fpping on October I 5 th, I866 (34. 523). Mr. Laver records (29. Nov. II) having observed a party of ten hawking over Colchester on the 5 th of November,

I882. They eventually disappeared to the westward. On Nov. 22nd, I888, two were observed for fully an hour at Woodham Walter (50. ii. 270). Mr. Philip Papillon saw a specimen at Colchester on Dec, 23rd, 1869 (29. Jan. 3rd, 1870). At Harwich, Mr. Kerry says "it decreases in numbers every year." I am incline 1 to think that the same remark applies to the entire county.

\section{Sand-Martin : Cotile riparia.}

A common summer visitor wherever there are sandy river- or pit-banks suited to its nesting habits. It usually appears about the end of March and disappears again during September, although in I865, Lieut. Legge saw a pair near Shoebury on November I8th (34. 92), and Mr. Hope mentions having observed them in Essex in Christmas week-a very remarkable date. Its nesting-colonies are found throughout the county wherever there are suitable sandy banks.

Edward Doubleday says (I5) it occurs at Epping, but does not breed there. The Rev. J. C. Atkinson says (36, IOI): "A ballast-pit at Fingringhoe, in Essex, is occupied by the most numerous colony I am acquainted with." They have occasionally been known to nest in walls. Dr. Laver, for instance, saw several pairs carrying nesting-materials into holes in the stone walls of Colchester Castle, on May 25 th, I 878 (29. June I). Probably the scarcity of sandy banks throughout the district led them to this.

[Purple Martin : Progne purpurea.

An American species, which has been admitted into the British List, chiefly on the strength of a specimen said to have been shot near Kingstown about 1840 , but there are not sufficient grounds for allowing its 
name to remain. There are records of two reputed occurrences of it in Essex. Dr. Bree says (29. Oct. 5) Captain Dugmore, formerly of Colchester, told him that about Sept. $26 \mathrm{th}, 1878$, he saw " a specimen of the Purple Martin (Hirundo purpurea) on the barrack exercising ground here. Having lived in Canada, where the bird is plentiful, and being within ten yards of the Swallow as it sailed past him, he had no doubt whatever about the bird being the one indicated. *** The strong prevalence of westerly winds for the last month may be expected to have blown over many birds. Colchester may now boast of being the locality where three very rare specimens of the Hirundinidae and Cypselidae have been procured [?]." This record seems very unsatisfactory, but if so good a naturalist as Dr. Bree gave credence to it, it is perhaps as well to follow him. Mr. Fitch also writes me that he remembers seeing $\mathrm{Mr}$. John Squire, formerly of Wixoe Park, shoot one on the Stour about twenty years ago, but he does not know the present whereabouts of the specimen.]

\section{Family CERTHIID $Æ$.}

Tree Creeper: Certhia familiaris. Locally, "Barkrunner" (E. A. F.).

A common resident throughout the county, especially in well-wooded districts.

Yarrell gives (14. ii, 159) as a vignette a wood-cut of a nest of this bird which he says was taken at Bower House, Havering. Round Orsett, it seems to be uncommon, as Mr. Sackett has only twice seen it.

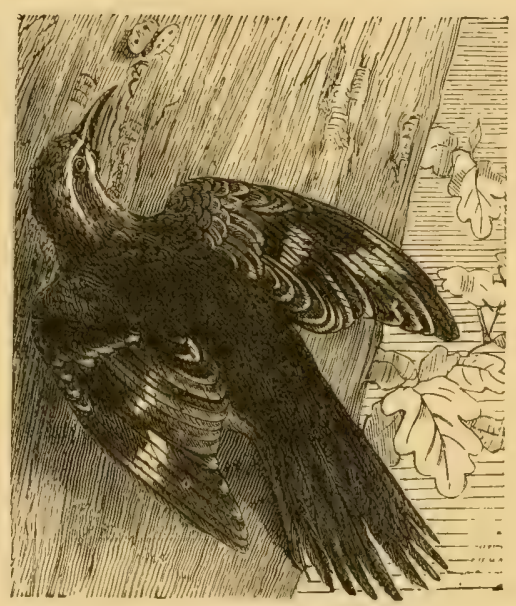

CREEPER, $1 / 2$.

\section{Family FRINGILLID $Æ$.} once).

Goldfinch: Carduelis elegans. Locally "Redcap" (E.A. F.--

A resident in Essex, though local, not abundant, and to some extent migratory. It is to be feared that its numbers in the county are decreasing.

King says (20) it was "common" around Sudbury in his time. Mr. Buxton says (47. S8) it "used often to be caught by bird-catchers on Wanstead Flats; 
common about the lanes of Loughton." The Rev. H. A. Macpherson says (29. Dec. I7, I887 \& 4 I. ii. 20) that in I 876 a few pairs nested in private grounds round Chingford, and that the late Mr. Cartwright, bird-stuffer, used to take a good many on a common in the vicinity [? Nazing Common] but of late his takes became more scanty. Mr. W. Crouch says it occurs at Barkingside, but is "not common now." At Harwich it is fairly common when migrating, and a few breed (Kerry). Round Orsett, it is uncommon (Sackett). Dr. Laver says it is "frequent in the Colchester and Paglesham districts, but less so than formerly." There are usually a few small flocks about here in winter, especially if the weather be sharp, but I believe they nearly all go elsewhere to breed, as I have very seldom seen a nest here. In the winters of 1876-79 they were rather unusually numerous, Mr. Hope observes that "about Oct. Ioth it arrives on the Suffolk and Essex coasts in flocks of from ten to fifty. They feed awhile on the thistles on the sea-wall and then coast along southward."

\section{Siskin: Chrysomitris spinus. Locally, "Barley Bird."*}

A winter visitor only to Essex, and much commoner some years than others. Further north it has been known to breed sparingly,

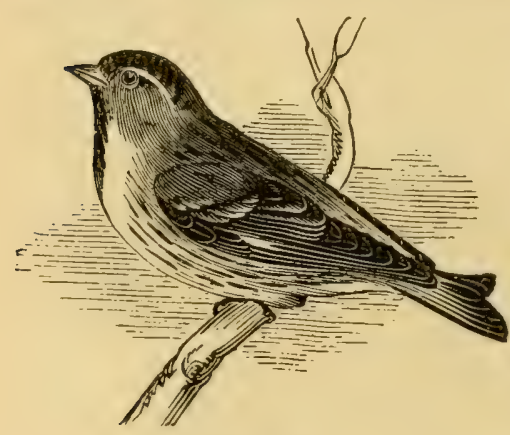

SISKIN, $1 / 2$. and in the north of Scotland freely, but with us never.

Chas. E. Smith says (3I. 53), "a dozen were shot this spring $\left[185^{8}\right]$ near Halstead." King described it (20) as "a very rare winter visitor" to the Sudbury district. Round Walden, Mr. Clarke says it is seen in "small flocks in winter" (24), and I have myself occasionally seen small flocks there, but Mr. Travis says they used to be much commoner than now. He remembers seeing flocks of over one hundred in the Park. Mr. Buxton says $(47.88)$ it is an "occasional winter visitor to Wanstead Park. I saw one about the alders last spring (1883) ; three were seen in February, 1884." Mr. Grubb says (12. vii. I8) it abounded on the alders round Lexden Springs in 1833. Round Harwich it is common during migration (Kerry). It is fairly common round Danbury (Smoothy).

STRANGE Finch. -Mr. Travis of Saffron Walden has at the present time in confinement a strange finch which was captured close to the town in some fields on the Debden Road about September or October, I888. I have inspected the bird, but am not able to make any suggestion as to its species. The following is a brief description of it: Bill, remarkably conical; general colours, greenish-brown and dark brown; tail-coverts and lower part of back, dirty greenish-yellow; breast and under-parts, greyish-brown, tinged with buff, and striped down the middle of each feather with dark brown; secondaries 
blackish-brown, edged with dirty white; over each eye there is a light stripe, and the sides of the neck are light; bill and legs horn-colour. Mr. J. H. Gurney, jun., who has also inspected the bird, is inclined to think it may be a female Cape Canary. He writes: "It resembles a very large hen Serin, with a darker crown, and darkish 'whiskers.' There is no yellow anywhere, except on the rump, and very little there." Mr. Backhouse, who has also seen the specimen, thinks it may be a hybrid Serin of some kind. About this specimen Mr. G. E. Lodge writes (40. xiii. 29) :-

"A short time ago, hearing of some 'English Wild Canaries' at a birdstuffer's at Saffron Walden, I went to see what they might be, and here give a description of them. One, which was living in a cage with some Redpolls and a Twite, looked almost exactly like a hen Siskin, except that it had a very short and stout beak almost like that of a Bullfinch. A light yellow stripe over the eye was very conspicuous. This bird was caught near Saffron Walden. The others, (there were two more) were stuffed, and the owner told me that one of them was caught near London, and had been living in the Zoo. This was a much more gaily-coloured bird than the living one. The forehead, throat, sides of neck just behind the auriculars, and breast being bright greenish-yellow, with a few dark streaks on the flanks. The back was much greyer than a cock Siskin's, with dark streak down centre of each feather, getting yellowish-green lower down, and tail-coverts the same colour as the back; top of head plain greyish-green. I suppose they were cock and hen Serin Finch; but as I have never before seen a specimen of this bird I am not certain about them."

\section{Greenfinch : Ligurinus chloris. Locally, "Green Linnet."}

An abundant resident.

The Rev. J. C. Atkinson writes $(36.78)$ that in a thick thorn hedge "bordering an orchard in Essex, of perhaps seventy or eighty yards long, 1 found one day a dozen or more of Greenfinches' nests, almost all with eggs in."

Mr. J. H. Hills, of Prested Hall, Feering, has a specimen of a mixed white, creamy, and bright yellow colour, shot there by himself in December, I874.

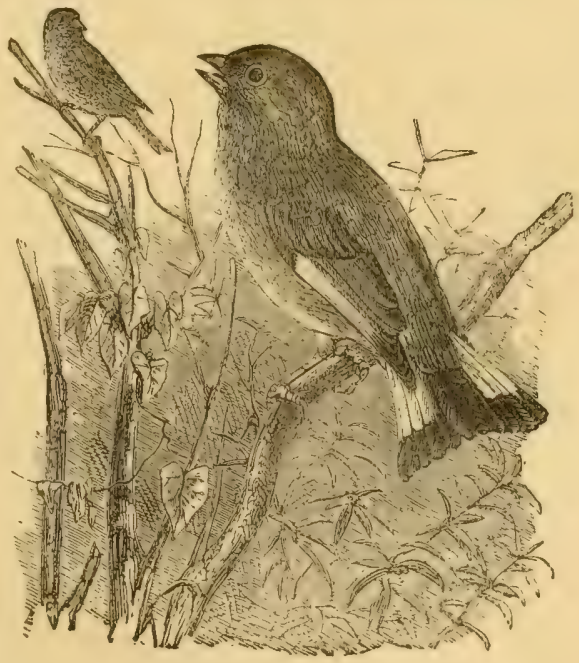

GREENFINCH, male, $1 / 3$.

Hawfinch: Coccothraustes vulgaris.

A resident, and a much commoner one than is usually sup- 
posed, as its shy nature leads to its being comparatively little

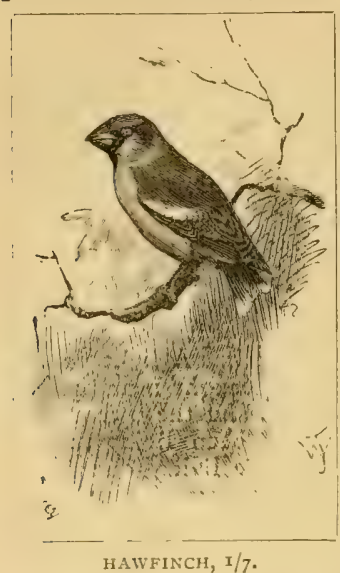
observed. There is good cause also for believing that it has increased considerably in number during the last half-century, and in some winters it may now almost be described as abundant with us. Epping Forest seems to be a stronghold of the species - indeed, it was Henry Doubleday's observations in the Forest about fifty years ago which first drew attention to the fact that this bird was by no means so scarce as had hitherto been supposed. The account of the species in the first edition of Yarrell is largely composed of contributions from Doubleday (14. i. 483). Many more of his observations, which have never yet been published, are to be found in his letters to Heysham, whence I have culled many extracts.

Mr. J. Gurney Barclay has given (23. 569) an interesting account of their habits in the neighbourhood of Walthamstow. He says :

"This species came first under my notice about the winter of $I \& 25$, when a fine cock bird fell dead on the gravel walk before the gardener-from what cause was not ascertained; but it was not until 1837 that I was aware of their being resident and rather numerous in the neighbourhood. * * In the winter season, and especially during severe weather, these birds are frequently seen in the neighbourhood of the forest in large flosks of from fifty to a hundred or more, feeding on the seeds of the hornbeam, to which they appear to be particularly partial ; and as spring advances they disperse into retired spots to breed. I am inclined to think that their shy habits, together with their being a very local species, has led to their having remained so long comparatively unobserved."

Mr. Clarke notes (24) that one was killed in the churchyard at Saffron Walden many years ago; seven (two of which are still in Walden Museum) at Audley End in 1832 ; another in the garden at Audley End on Feb. 7th, I837, and one at Walden in $\mathrm{I} 844$.

Hy. Doubleday, in Aug., I831, says (10):

"The Grosbeak, I believe, breeds in our extensive forest every year, and I doubt not I can procure thee specimens in November, as at that time it draws near gardens and plantations to feed on the stones of the plum, cherry, laurel, \&c. It is an extremely shy bird and difficult to shoot, as it darts with great rapidity through the laurels, firs, \&c., and seldom shows itself till cut of reach of shot."

On June I 2 th, I832, he writes (I0):

"I am happy in being able to send one rarity, viz., two eggs of the Hawfinch, which till this spring I never saw. The nest is built in the most careless manner, and consists of a few coarse sticks, then a layer of that coarse lichen which grows on the stems of oaks, and [is] lined with a few roots. It is also extremely shallow. They seem to build in any situation. The nest I took was in a whitethorn, about four feet high, and I saw one on the top of a tall spruce fir. * * I have now a full-grown young. Hawfinch in confinement, which was caught in our forest about a fortnight ago."

On Mar. 22nd, I8 36 , he writes (10), "Many Hawfinches may be daily seen in 
the forest, feeding on the hornbeam seeds, but they are extremely shy and difficult to procure." In July following he writes, "I have brought up some young ones this summer, and have just sent three to our friend Thomas Allis" (of York). In the next letter (August 24th) he adds :

"I have no doubt I can get some more Hawfinches for thee. Mine is still alive and well. The nest is so loose that it can hardly be moved without falling to pieces-in fact it is the clumsiest nest I am acquainted with. It has been found in Kent, but rarely, as Mr. Yarrell had not a British specimen of its egg until I gave him one about a month ago."

On Dec. 2 nd, $1 \varepsilon_{37}$, he writes ( 10 ): "I do not know what will become of the Hawfinches this winter, as there is an entire failure of their favourite fosd, the seed of the hornbeam. I do not think there is a seed all through the forest, and last winter every tree was loaded. It may quite drive them away." In June, 1839 , he observes (10) that the bird "seems to have diminished in our neighbourhood," and again on Jan. I5th, I840, he writes (I0): "We have very few Hawfinches, which I think is owing to the entire absence of seed on the hornbeams, the cold spring having, I suppose, cut off the blossoms, and they certainly live principally on the seed of this tree." Else. where $(23.40)$, about the same time he wrote as follows:-

"In the winter of 1835 and spring of 1836 , they were extremely common in the forest, associating in large flocks, and feeding upon the seeds of the hornbeam, which were very abundant. In the spring of I 837 I saw fewer birds, and the seed was not abundant-I mean the crop of 1836 . The springs of $1837-38-39-40$ were cold and frosty when the hornbeam was in flower, and I believe not a seed was to be seen through the whole forest. During this time I scarcely saw any Hawfinches-only a single bird now and then in gardens, \&c. The spring of $184 \mathrm{r}$ was fine and warm, and there was an immense quantity of seed upon the hornbeams in the summer. As I expected, during the autumn of that year, and the spring of $\mathrm{I} 842$, hundreds of Hawfinches were to be seen wherever there was seed, and I saw many nests in the summer. Now, again, there is little or no seed and not a Hawfinch is to be met with in the forest, and I have seen only one or two solitary individuals during the winter. What becomes of them all? Do they disperse over the country, or do they leave us altogether? They will feed on the kernels of haws, yew-berries, laurel, and plum-stones, \&c., but decidedly prefer the seed of the hornbeam to anything else. In the summer they are very destructive to green peas. They become very tame in confinement, though extremely wild in a state of nature."

In 1856 , he writes $(23.5 \mathrm{cg} 8)$ that "it used to breed in great numbers in our forest, but has become comparatively rare within the last three or four years." Doubleday believed (34. II33) that in some years their numbers in Epping Forest were increased by arrivals from the continent, as in the winter of 1865 66 , when there was much seed on the hornbeams, and large flocks were scattered all over the forest. Writing from Epping in I835, Edward Doubleday says ( 15 ):

"This interesting bird is very common here, though rarely to be seen, save by a practised ornithologist, from its shyness. In the winter it visits our gardens to feed on the fallen stones of plums, bullaces, or laurel, which it dexterously cracks with its powerful bill. Sometimes it may be found in small companies of ten or fifteen, feeding on the fallen seeds of the hornbeams. It generally builds in a tall whitethorn or holly. The nest is sometimes as loose as a Ringdove's, but at other [times the bird] bestows rather more pains upon it. It lays from five to six eggs. When the young are fledged they visit the gardens near the forest in search of green peas. I have been told that last year nearly, if not quite, thirty were killed in the garden of Colonel Conyers, of Copt Hall, whose park I believe to be a favourite breeding-place of this bird."

Mr. English stated (44. ii. iv.) in I88 I that in Epping Forest "he had seen 
flocks of 200 to 300 at a time. They fed principally upon the seeds of the hornbeam (Carpinus), and in winters like the present, when hornbeam seeds were scarce and the weather very severe, they spread over the country to villages and gardens in search of food." Dr. Bree, in a letter to the Standard (Jan. 28, I88I), after stating that the bird had been more numerous that winter round Colchester than he had ever known it before, says :

"I have known it as a breeder in this neighbourhood for the last ten years. Ambrose, the local bird-stuffer here, tells me he has had upwards of thirty this year. There are more than twenty now in his shop. He says they come from all parts of the neighbourhood. One boy caught seven in a garden near the river."

At the same time they were much more common than usual round Saffron Walden, many being sent in to Mr. Travis from the surrounding villages, especially during the hard weather in January. A pair were also shot in our garden at Lindsell Hall. On Mar. Igth, I878. Mr. H. Corder saw a flock of about twenty in a small wood near Writtle. Mr. F. Spalding informs me that his sister caught one by hand in her bedroom at Shenfield, it having entered by an open window. At Harwich it is "scarce," though some are seen most winters (Kerry). "T. F. R." mentions (I2. ii. 404) an egg, evidently of this species, found in July, I829, in a nest in an elm-hedge in Essex. Mr. C. E. Smith notes $(3 \mathrm{I}, 53)$ that "A inest and eggs of this bird [was] taken near Felix Hall, by Mr. William Deal, keeper to T. B. Western, Esq., M.P., during the summer of $1857 . "$ Mr. Hope says that it breeds at Havering, where it is commoner than it used to be. Dr. Laver says it breeds not unfrequently in the Colchester district. The Tuck Collection contains specimens taken from nests at Audley End in June, 1858. In May, I877, a friend found a nest with eggs in a large old hawthorn in Danbury Park, and in the previous year I found an old nest in the woods adjoining, where the bird nests pretty freely, I believe. At Dedham, Mr. Rowland ' $\mathrm{T}$. Cobbold informs' me that it is becoming increasingly common, being a constant visitor during winter to his bullace-trees, easily splitting open the stones to get at the kernels, and in summer to his rows of peas. The same might be said of many other parts of the county.

\section{Tree Sparrow : Passer montanis.}

A resident, breeding more or less sparingly in several parts of the oounty, I believe, though I never found a nest. In winter its num-

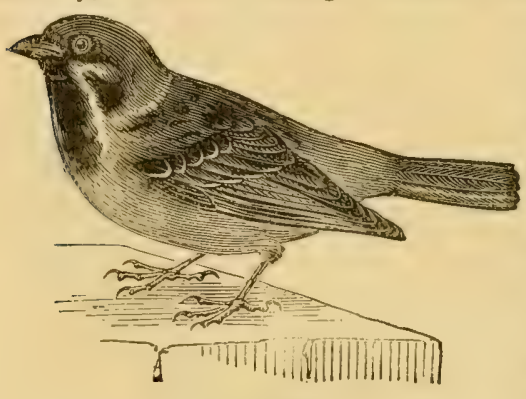

TREE SPARROW, $1 / 3$. bers are largely increased by the arrival of flocks from elsewhere, and it is then fairly common in all, or most, parts of the county.

Mr. C. Parsons, writing from Southchurch in 1834 , says ( I $_{3}$ ) :

"This bird is a constant winter visitor here. I have shot them repeatedly in severe weather in January, intermixed with the common Sparrows in the farm-yards, and also with Greenfinches, Chaffinches and other small birds in the fields. About a fortnight ago, I caught one at night in a folding-net in a corn-stack, when in quest of common Sparrows. I never saw one here in the summer months." 
At Southminster, about I834, Mr. W. H. Hill described it (12. viii. 573) as "occasionally abundant." Mr. Grubb says (I2, vii. 5 I8) it was repeatedly shot at Lexden in the winter of $\mathrm{I}_{3} \mathbf{3 3}_{3}-4$. Henry Doubleday, speaking of a visit he paid to Colchester early in March, I840, says (I0) : "I saw scarcely any Tree Sparrows, which are generally so common near Colchester." In March, I8.4 , he says (I0), "I saw many Tṛee Sparrows near Mersea Island." Mr. Clarke notes it (24) as "not uncommon" round Saffron Walden at the time he wrote (about I845). There are two specimens from Saffron Walden in the Museum at that town. Mr. Grubb includes it (39) in his list of Sudbury birds, and King says (20) it is "not uncommon" there. Mr. Buxton says (47.87) that it is "common about the pollard willows near the River Roding," but does not indicate at what time of year. Mr. Hope describes it as "not uncommon in the county." During winter, and especially during hard weather, they are by no means uncommon here, and I have shot them out of flocks of common Sparrows. I have also frequently taken them with the sparrow-nets at night. They never roost with the common Sparrows in cornstacks or in holes in thatch, but always, so far as my observation goes, singly and in hay-stacks. Considerable flocks have sometimes been observed off the coast on their way hither. Yarrell (37. ii. 85) quotes cases in which, in October, I833, flocks numbering 100 settled on a ship bound for the Thames, as she passed the coast of Norfolk, Suffolk and Essex; and in November, I860, thousands boarded a vessel between the Dogger Bank and the Galloper lightship. Dr. Laver has shot them during the winter in both the Colchester and Paglesham districts, but never knew them breed in either. In the Iatter district, however, Mr. Wiseman informs me that it breeds in considerable numbers, and his son has frequently taken their eggrs. Round Harwich, it is "fairly common; breeds in holes in trees, also in trees covered with ivy at Ramsey" (Kerry). Mr. A. J. Crosfield of Reigate informs me that he saw one close to Dagenham Gulf on May 23rd, 1879, when it must have been breeding. Several specimens labelled "Frating Abbey, April, I875," are in the collection of the late Dr. Bree. Round Danbury, though not common, Mr. Smoothy says it certainly breeds, as he has seen the old birds there during summer, as well as young birds just out of the nest.

\section{House Sparrow: Passer domesticus.}

An all-too-abundant resident everywhere. It is unquestionably a very injurious bird to the farmer, consuming a large amount of young green wheat when in the ear, and much fewer insects than some sentimentalists would have us believe. It also drives away Martins, by taking possession of their nests. I consider the late Col. Russell was more than justified in his onslaught upon the sparrow and that he fully made good his case. Varieties, generally white or pied, frequently occur.

Lieut. Legge records (34.32) a nest, built during the first week in November,

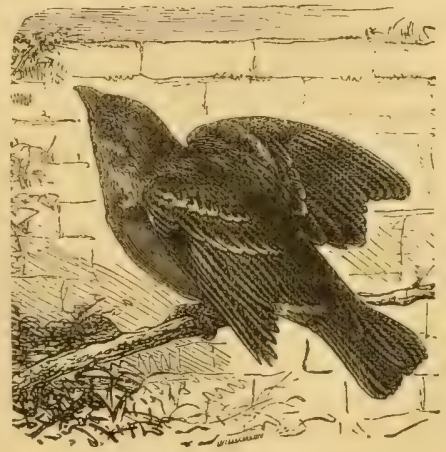

HOUSE SPARRnW, male, $1 / 3$. 
I865, in the tackling of a heavy pair of sheers erected at Shoebury for the purpose of dismounting a large gun. Early in July, I88I, a nest containing ten eggs (doubtless the produce of two birds) was found here by one of my brothers.

Mr. C. E. Smith states (3I. 52) that on August 26th, I 858 , he noticed a white specimen in a flock, and another with tail and wings of a dull cream-colour on the I 8 th of the following month. In September, I880, Mr. Travis received from Clavering a young and pure white specimen. I saw one here with the primaries of one wing almost entirely white, on January 9th, 1877. A dark cream-coloured variety, presented by Mr. C. Balon, and a lighter cream-coloured variety, presented by Mr. S. Salmon, both killed at Saffron Walden, are in the Museum at that town, as is also an almost white individual from Wenden, presented by Mr. Salmon. Round Orsett, Mr. Sackett knows of several stuffed albino specimens. A variety with a more or less brilliant chocolate throat, instead of black, is rather common. I captured one on January 4th, I877, and another with it very brilliant on February 26th, I878.

Those who agree with the late Col. Russell on the Sparrow question would have been gratified by a sight which was to be seen here in the early part of June last (29. June I5). Upon the south-east corner of our house, in a position which has been regularly occupied for many years past, was a half-finished Martin's nest. A short time previously this nest had been burglariously entered by a pair of Sparrows, who took possession of it, undeterred by the fact that many others of their kind in previous years had paid the penalty for this offence of being shot by me. This year, however, one of the intruders met with a different fate. For several days the hen was to be seen hanging by her neck from the nest, swayed by the breeze, and suspended by a thread of horsehair some eight inches or nine inches in length, which had somehow got twisted round it,- -a warning to all evil-doers of her kind. This occurrence singularly resembles a similar one depicted by a woodcut in Yarrell (37. ii. 93), which represents the sad fate that befel a Sparrow which had built its nest in the ornamental frieze of the Rotunda, in Dublin. Amongst the materials used for that purpose there chanced to be a woollen thread, with a loop at one end. By some accident, the bird got its neck into the noose, and, all its efforts to escape being in vain, was miserably hung below its own home. In the instance now recorded, however, the bird was hung, not below its own home, but below the home of a much more worthy bird which it had "evicted," and had caught its neck, not in a noose at one end of a piece of twine, but in a loop formed by a knot in the middle of a long piece of horsehair. Similar occurrences are, I believe, not very rare.

\section{Chaffinch : Fringilla calebs.}

\section{An abundant resident. White or pied varieties sometimes occur.}

Albin figures (3. ii. 50) a curious variety having the head and neck, wings and most of the tail-feathers white or nearly so. He saw it in the possession of a Mr. Noble, who told him that "it frequented his brother's garden at Havering Bower in Essex, where he used to feed it a long time before he could take it," which he at last did on April 2oth, 1732.

In the Museum at Saffron Walden is a variety from Wenden, many years since presented by Mr. S. Salmon. It has the whole of the under-parts, the tail and the quill-feathers of the wing, pure white; the crown and nape, faint grey; the back white, tinged with canary yellow, strongest over the tail and on the shoulders; wing-coverts pale brown. There is also an adult male, shot at Wal- 
den in 1842 , which has a white crown, and a narrow white ring almost en. circling the neck. A specimen "of a light yellow colour, with the exception of the white bars on the wings" has been obtained near Stratford.

Brambling: Fringilla montifringilla. Locally, "Bramblefinch."

A somewhat irregular and usually rather uncommon winter visitant, though sometimes appearing in considerable numbers, especially during severe weather.

Henry Doubleday mentions (IO) a flock he saw at Epping about October Ist, I840, and says that a large flock passed over on January I4th, I844. In the same district, his brother Edward speaks of it (I5) as " an occasional visitant at the time of their spring and autumn migrations." Mr. Buxton says (47.87) that in Epping Forest it is "more frequent in the winter than is usually supposed. A few years since there were large flocks feeding upon the beech-nuts." Mr. Joseph Clarke says (24) that small flocks appear round Saffron Walden in winter, and during a spell of cold weather in March, $\mathrm{I}_{8} 8_{3}$, many were shot round the town. I also saw

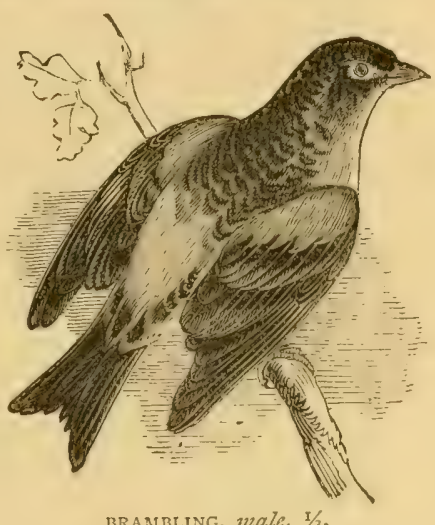

BRAMBLING, male, $1 / 3$.

some fine birds about. King describes it $(20)$ as " an occasional winter visitant to Sudbury." It is common, in some seasons, in both the Colchester and Paglesham. districts (Laver), and Mr. Kerry says it is common most winters round Harwich. Mr. Fitch has frequently noticed it at Maldon. Mr. Stacey of Dunmow has a remarkable variety with the head, neck and throat entirely black. Mr. J. H. Gurney, jun., has a very similar specimen.

\section{Linnet: Linota cannatina. Locally, "Red Linnet" (male).}

An abundant resident, especially in the vicinity of commons and uncultivated grounds, the more so if near the coast.

Lieut. Legge says (23.9839):

"Next to the Lark there is hardly any bird so common on this coast [Shoe. bury]. They frequent the sandy ground near the shore feeding on the seeds of the rank herbage which grows on the saltings. They nest here in great numbers, and build sometimes within half a dozen yards of the shore, in the brambles growing on the sea-walls."

W. H. Hill of Southminster speaks of it (12. vi. 452) as occurring "in immense flocks on the sea-shore" about I832, and in 1880 , "immense numbers " arrived on the Essex and Kentish coasts between October Ist and 26th-none, or very few, were observed further north $(44.47)$. Mr. Buxton says (47.88) "large numbers were taken by bird-catchers on Wanstead Flats a few years ago."

Mr. T. E. Gunn exhibited a variety shot on Canvey Island, on February 23 th, I882, before the Linnean Society on the Igth of June, I883. It was pure white, with the exception of the quill-feathers of the wings and tail. 


\section{Lesser Redpoll: Linota rufescens.}

A resident in the north of England and Scotland, but best known as a winter visitor to Essex, though individuals certainly sometimes

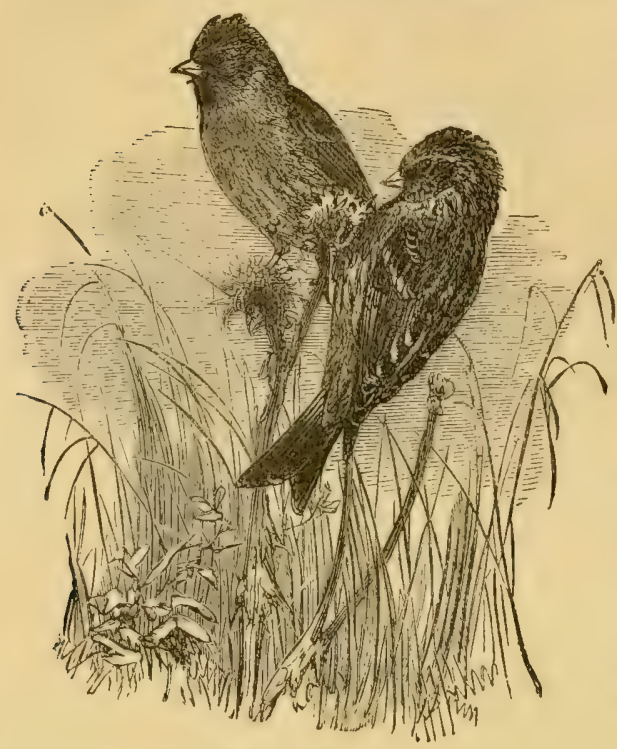

LESSER REDPOLLS, I/2. remain and breed with us. It appears not to be so common in Essex as formerly, for my late father could recollect that many years ago he often used to take them in the nets with Sparrows when roosting in stacks of corn during winter.

Mr. Clarke says (24) that about forty years ago it was "seen occasionally in winter" round Saffron Walden. King says (20) it was then "common" around Sudbury -meaning presumably in the winter-time. Henry Doubleday, on September 24th, I840, says (IO):

"I do not know whether we are likely to have a sharp winter or not, but I see some birds from the north are arriving. I have seen flocks of Redpolls for three weeks past. We do not often see them so early here."

Edward Doubleday includes it (I5) in his Epping list, and Mr. Buxton gives "Loughton Forest and Wanstead Flats" (47. 89). At Harwich, it is "common during migration" (Kerry). Dr. Laver describes it as "common in winter in both the Colchester and Paglesham districts," but he never knew it breed in either. Mr. Hope says they are "caught near Upminster in large quantities in the autumn and fetch 2d. each in London." He has also shot them in the spring.

As regards its breeding in the county, Mr. Travis records (44. i. lxiii.) that on June 27 th, I879, a boy named Rushforth took a nest out of some fir-trees by the roadside close to Shortgrove Park, near Saffron Walden. It contained young birds, which were brought to Mr. Travis, in whose possession one of them lived for some time, and I often saw it at his house. Mr. Brewis of Chesterford Park has known it breed on the Common there. I have specimens of its eggs which I believe were taken near Chelmsford about the year 1869. Mr. Fitch finds the nest, he tells me, almost yearly among the shrubby sea-blite on the east side of Osey Island. Mr. Sackett informs me that on June 7th, I887, he saw one at Reeve's Shaw, a copse in Orsett parish. He has not the least doubt as to the species, as he has kept this bird in captivity and knows its note well. It is common there in the autumn.

In October, I872, Mr. Stacey of Dunmow preserved a white variety shot at Hatfield. 
Mealy Redpoll : Linota linaria. Locally, "Stone Redpoll.' An irregular and uncommon winter visitor.

Henry Doubleday mentions (IO) a pair sent to him from Colchester in I 836. He adds:

"I have never yet met with one in this vicinity [Epping], but about three weeks since I had the pleasure of seeing it wild, feeding on the alder, in company with a number of Siskins, near Colchester. I shot one and immediately after a specimen with a fine rose-coloured breast alighted on the alder close to me, but flew ere I could load my gun. I cannot find that any of the bird-catchers have ever taken the Stone Redpoll here."

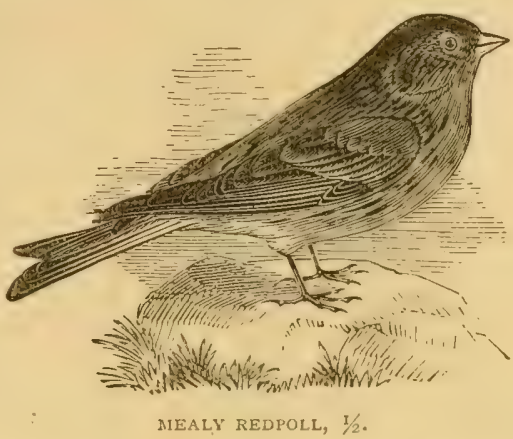

Doubleday also supplied Yarrell with some notes of his observations upon this bird at Colchester on this occasion (14. i. 510).

Mr. Buxton says (47.89) that in Epping Forest it "only appears at long intervals, and, like the Crossbills, in considerable numbers, probably in quest of food." Mr. English adds that some years ago many were trapped by Henry Doubleday and himself. Yarrell says (37. ii. I 36) that, although seldom noticed in spring, the Museum at Saffron Walden contained one killed near there in May, $1 S_{3} 6$, and it is marked as having occurred near the town in the catalogue issued in 1845. The Rev. M. C. H. Bird saw some in company with Siskins on Canvey Island on December 8th, I88I. A specimen from Colchester in the spring of 1862 is preserved in the Bree Collection. Round Danbury, Mr. Smoothy has seen a few among the crowds of Lesser Redpolls in winter.

\section{Twite : Linota flavirostris.}

A more or less common resident from the midland counties northward, but known in Essex only as a common winter visitor to the sea-coast. It often abounds on the saltings round Maldon and elsewhere, going in small flocks.

Messrs. Sheppard and Whitear write $(9.27)$ :

"We have found them plentiful in the month of Uctober on Pewit Island, and on the main-land of Essex near it, in flocks of ten and twenty together, and towards evening we noticed flocks of about a hundred, so that it seems not improbable that the flocks may collect together to pass the night. No

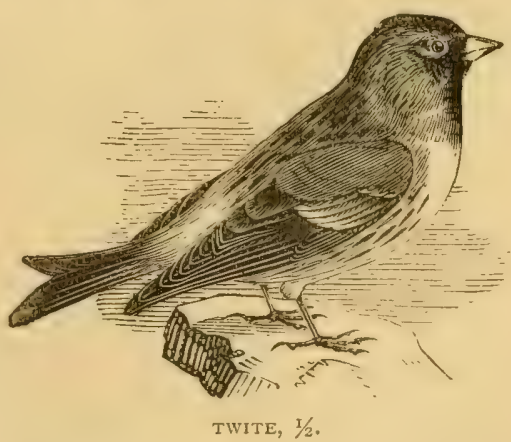
other birds were feeding on the seeds of the marsh samphire and sea starwort. * * * At half-past five o'clock on the morning of March 20th, 1820, a very extraordinary migration of small birds was witnessed at Little Oakley in Essex. The attention of the observer was arrested by an uncommon chattering of birds, 
and looking up he beheld an incredible number of small birds flying abreast, in a line, as far as the eye could distinguish them and three or four yards deep. Their direction was towards the south-east, the wind favouring them: their height only a few yards from the ground. The flock was supposed to consist principally of Chaffinches, Linnets, Twites and Bramblings. None of the two latter species were seen in the neighbourhood after that time, and there is on these shores in the winter season an immense quantity of Linnets-more than can be bred in the neighbourhood."

Round Harwich, it is "very common in winter" (Kerry). Mr. Smee says (34. 2605) that, although in "some winters they rise from the saltings in tens of thousands," they were "scarce" in the winter of I870-7I. Edward Doubleday includes it (15) in his list of birds which have occurred in the vicinity of Epping, and English calls it (43. i. 24) an "occasional visitor," while King says (20) that it "frequently appears in small flocks in the winter" in the neighbourhood of Sulbury, but it is not frequent in the inland parts of the county, though Mr. Travis has two alive, caught close to the town, in Oct., I888. At Danbury, Mr. Smoothy says it is common in the winter, and is taken by bird-catchers with Linnets.

\section{Bullfinch : Pyrrluta eurofae.}

A fairly-common resident throughout the county, though most often seen during winter, when it is often very destructive to the buds

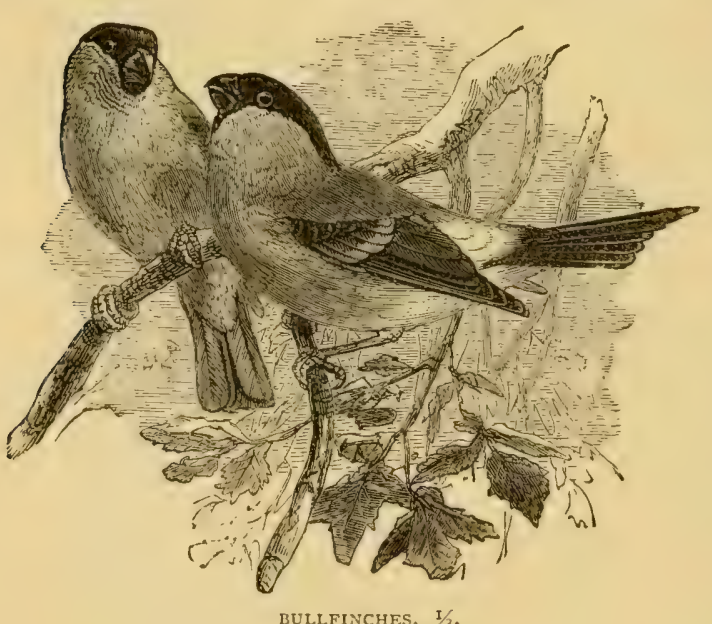

BULLFINCHES, $1 / 3$. of fruit-trees. I believe it has become commoner of late years.

Mr. Clarke describes it (24) as "very common" round Saffron Walden. He mentions "a very singular one-half one, and half the other, sex." It is "frequent " in and around Epping Forest(Buxton-47. 83). King speaks of it (20) as "common" at Sudbury, and Mr. Grubb says (39) that to his garden there it "comes in numbers in early spring, to the destruction of the gooseberry buds." At Harwich, it is very common, and breeds (Kerry). Mr. J. H. Hills of Feering has a pure white specimen shot by himself at Little Tey in October, I874. Mr. Alfred Fitch of Sible Hedingham has a male stuffed which became quite black in confinement through being fed on hemp seed. Many similar cases have been reported.

\section{Crossbill : Loxia curvirostra.}

An irregular and uncertain visitor, chiefly between midsummer 
and the end of winter, though it has bred in Essex on more than one occasion. In some years it appears in considerable abundance. Thus, in $1835^{-}$ 36 , it was abundant round Saffron Walden, and in $1838-39$ it abounded at Epping, but only limited numbers have been since observed. It certainly bred at Epping at the time named, if not at Saffron Walden, but Doubleday's record, though noticed by More (33. I 31), Harting (38.29), and Newman (Montagu's Dictionary, p. 37), has been overlooked by Yarrell, Seebohm and other writers. Of late years, the bird has been singularly rare, though a few have been observed

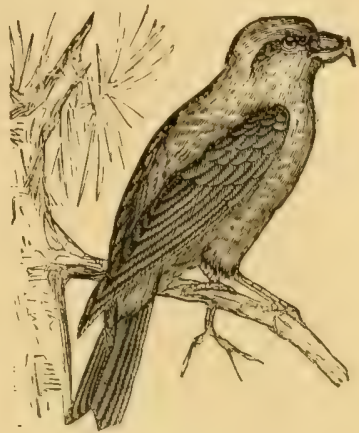

COMMON CROSSBILL, $1 / 3$.

from time to time. Yarrell's account of this species (14. ii. 15) was largely compiled from information supplied by Messrs. Clarke and Doubleday, and his figure was drawn from specimens shot at Saffron Walden by Mr. Clarke and still in his possession there, where he has often shown them to me. Doubleday also lent Yarrell about a dozen specimens for the same purpose (I4. ii. 26).

Mr. Hoy, writing at Stoke Nayland, which, though actually in Suffolk, adjoins Essex, says (I8. i. I17) :

"The Common Crossbill was rather numerous in some localities in this district during the last year LI8 36 ]. I first observed them about the 20 th of July, I 835 , and in the month of August we had a large flock in some fir-plantations in this neighbourhood.*** They remained with us through the autumn and winter months. I did not observe any after March, but in the beginning of the month of June following a flock of fifteen or twenty were noticed in the same plantations."

Mr. Joseph Clarke writes (I8, i. I64):

"During the latter end of the month of June, 1835, a flight of these singular birds was observed in and about the plantations at Saffron Walden and the adjoining villages, several of which were procured during that and the following months in their different stages of plumage."

After a discourse upon the varying colours of their plumage Mr. Clarke continues :

"The mandibles of these birds are indiscriminately crossed, though in by far the greater proportion of those that came into my hands the upper crossed the lower one to the right. Only three out of twenty-seven that I examired were crossed to the left. These busy strangers with their incessant twittering were continually seen flying from tree to tree, curiously examining every fir apple and with one of their strong feet grasping the twig and the other the fruit of the fir, sometimes in a horizontal, sometimes in a vertical position, turning up and down with as much facility as if on a pivot, swaying their bodies to and fro in almost every possible attitude, breaking with their strong crossed and admirably adapted bills the scaly case and extracting the seed from every cone. *** They seemed totally unused to the busy haunts of men, and had not yet learned to fear the approach of an enemy. So tame were they, as to be but little alarmed at the re- 
port of a gun, even when near them. *** At no time could they be said to be wild or shy. $* * *$

"What seemed most puzzling to me was that up to March they were gregarious, but after that they evidently went in pairs for about a month, during which time they were in their brightest colours; afterwards they were again seen in flocks, and began evidently to assume a less bright plumage, as may plainly be seen from specimens shot at different intervals. Several were procured up to January, I836, of which I made no notes; two or three were taken in January, a few in February, several in March, two on April 7th, five on April Igth,

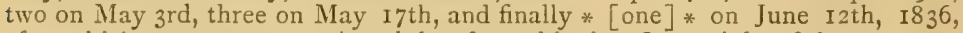
after which they were once heard, but from this time I lost sight of them.

"I was naturally very curious to know whether they would breed in this country and requested several persons near whose neighbourhood they were occasionally seen to keep a sharp look out for me; but, though they were here somewhat more [? rather less] than twelve calendar months (from the latter end of June, I835, till the I 2 th of June, I83E.*** ) I could never learn they made any attempt to build. Some eight or ten years ago, early in March, a pair made a nest at the Audley End aviary near this town, in which the female deposited five eggs. * * * They, however, deserted them without ever attempting at incubation, although I believe they were perfectly undisturbed. About the same time a pair also built their nest in a garden in this town, on an apple-tree, but they were shot before they had completed it."

Mr. Clarke then proceeds to recount how a young male, caught early in August, 1835 , and kept in a cage, soon became very tame, but died in about three months. Mr. Clarke elsewhere describes it (24) as "an uncertain visitant" to Saffron Walden. He details the occurrence of the following specimens :-Many (of which four males and three females are now in the Museum) killed from a large flock frequenting some pine-trees near "The Roos" in October, 1835 ; three at Audley End on the 26th of the following Feb. ; other specimens killed on Mar. I6th, Apr.7th (two), April Igth (five), May 3rd (two), May Igth (three) and June I2th (a male in dusky plumage). It is perfectly clear from these dates that some at least must have bred at Walden. A flock of about sixteen was again seen near "The Roos" on June 2 Ist, I837. Mr. Clarke has often told me that in what he calls "the great Crossbill year" they were very numerous on the firtrees near "The Roos," where he observed the young being fed by the old birds. He also says he saw a nest in a garden at Bridge End, but he believes no eggs were laid in it. Another observer (I9.8I) says: "The Crossbill is still to be met with in this county, several specimens having been killed during the last month, a pair on the 24th ult." Earthy of Halstead wrote (I9. 90) that he had received "an unusual number on Saturday, 22nd of December, three males and two females, besides three other specimens in the two preceding months." He adds "These birds are considered rare with us." Another correspondent writes (Ig. 90), "A great many of these birds have been for several months past in the woods and grounds around Havering, four of which (out of a flock of about twenty) were shot on the 3rd inst. in Major Anderson's shubbery at the Grange." "Three Cross" bills have also been recently shot in Mr. Bartlett's garden at Chelmsford." Mr. C. Walford says $(19.27):-$

"On the 2Ist of July, I received two specimens of the Crossbill to be preserved. One was a fine male, its general colour being a bright red, and the quill-feathers and tail pale brown. It was found in a garden at Coggeshall. The other was a female, the colour mostly a dingy green, inclining to a bright yellow on the rump. This was shot at Great Braxted; and, as I saw a specimen of this curious bird sitting on a tree at Cressing, in the early part of June, I am inclined to suppose they may have bred in this part of the county."

- Henry Doubleday mentions (IO) having shot an adult male in "coppery- 
green " plumage at Epping on March 9th, 1833. He adls: "It is the only one I ever saw here, and was evidently a very old bird from the toughness of the fibres, \&c. Later, he says, (10) "A small number of Crossbills came here about the midule of August [1835], but remained only a few days. I shot three or four, and have one alive." Writing on Nov. 7 th, $18{ }_{3} 8$, he says (10) :

"About the middle of July we were visited by hundreds of Crossbills, but at that time the plumage was so bad they were not worth preserving. Many of them were nestlings. Some yet remain, and I killed four very fine ones in our garden a few days since. I have taken infinite pains to ascertain the changes of plumage and have sent a long history to Yarrell. One thing is certain: that some young males at least become yellow at the first autumnal moult. Two males I killed a few days since, one is bright clear yellow, the other fine light red. A bird I have alive has just moulted. He was very red: now he is quite yellow. They are very puzzling."

In June, I839, he writes (I0):

"I have shot several very fine Crossbills this spring, and obtained a nest and six eggs from a tall fir-tree in Lord Frankfort's plantations close to our town. The nest very closely resembles the Greenfinch's, but has twigs of larch interwoven with the outer rim. The eggs also strikingly resemble those of the Greenfinch, but are rather larger. Hewitson's figure is very bad. I should hardly think it was a Crossbill's egg from which it was taken."

On Sept. 20th, he says " a few Crossbills occasionally pass over here. I shot three in our garden a day or two since." On Jan. I5th, 1840, he writes (10): "The Crossbills seem to have quite left." Again in the foilowing March he says (10) :

" 1 believe the Crossbills have entirely quitted England. They remained here just a year. I saw the first in June, I8 38 , and they were numerous till May, I839, and a few remained through June, since which time I have not heard or seen one at liberty, nor can I hear of any one who has. I have a pair alive, and always in fine weather hang one out in the garden, and, did any pass over, he would be sure to call them. Last autumn [?] they were daily in the garden, and I shot many very fine ones. *** lt is very singular they should arrive in such multitudes and all at once disappear. It cannot be want of food, as that is plentiful enough."

However, on May 3 rd, I840, he says (Io):

"On Tuesday last, as I was walking in our garden, I was surprised to hear the call of the Crossbill, not having heard or seen one for nearly a year. I soon saw five of them flying over, and wanting a pair of them for a friend, I shot at them and killed a male and a female. I regretted afterwards that $I$ did so, as the female was evidently sitting, from the state of her breast."

Again, on Mar. 25th, I84I, Doubleday says: "I shot a single female Crossbill last Saturday. I have not seen one before for months."

King, writing about 1840 , of the district around Sudbury, describes it (20) as "Rare : an occasional visitant." A male, entirely of a "dark brick-red," was shot in Feb., I862, near Walton-on-the-Naze (Bree-23. 8033). At Harwich, it is occasionally seen during, severe winters (Kerry). Mr. Stacey of Dunmow preserved a pair shot near there about the year I88 I, and Mr. Offin shot several at Rayleigh the same year. Mr. Fitch has once seen it at Maldon, Mr. Buxton says (47.87) a pair " nested in some firs at the Bower, close by Epping Railway Station." He refers to Doubleday's nest, mentioned above. Mr. Scruby preserved a specimen (the only one he ever received), shot a few years back by a keeper in Ongar Park Wood. "IV" of Romford, states that (I9.9) "several arrive annually in the plantatiuns at Whitley, in the parish of Birdbrook," from which it seems likely that they bred there in 1838 . 


\section{Parrot Crossbill : Loxia curvirostra-pityopsittacus.}

Of this very rare Scandinavian and North European form of the Common Crossbill, no less than nine specimens have been obtained in Essex-more, I believe, than have been met with in any other county, except Devonshire. Although formerly separated from the Common Crossbill, from which it differs in its varying size and larger bill, the best authorities are now agreed in regarding it as a local race or sub-species merely.

Mr. Joseph Clarke relates (24) that a pair formerly in the Museum at Saffron Walden, were shot in a garden in that town about the year 1823. They were stuffed by Travis-so he informs me. Yarrell says (25. ii. 25), "Mr. Blyth has recorded one instance of its being shot in Surrey and a second instance of its being obtained in the autumn of 1835 , in Epping Forest."*

Doubleday says $(23.7759)$ :

"Three specimens of the Parrot Crossbill were killed yesterday [September 20th, I86x ], at one shot, by a boy at Lambourne, about four miles from Epping -a male in fine red plumage, another male in yellow plumage, and a female. This is the first occurrence of this species in this neighbourhood, so far as I am aware. $\dagger$ The Common and White-winged Crossbill I have shot here."

At his sale in I871, two of these Parrot Crossbills, with a couple of Quails were sold for 33s. to Mr. Smee. Dr. Bree writes (23. 8032) :

"Three specimens were brought to me in the flesh on the 2Ist of February last [1862]. They were one male and two females, and were killed on the Lexden or London Road, just south of this town.*** Their crops contained the seeds of what I believed to be the Scotch fir. *** I have heard of one other specimen having been shot, which, from its size, I should infer was this species. *** My specimens are rather larger than those from Sweden."

These three specimens, two in greenish-brown, and one in red plumage, are still in the Bree Collection in Mr. Harwood's possession.

\section{Two-barred Crossbill : Loxia bifasciata.}

An exceedingly rare British bird, of which a couple of specimens only are known to have been met with in Essex.

Yarrell says (I4. suppt. ii. 20) that Henry Doubleday had favoured him with the loan of a young bird, "shot by himself in his own garden at Epping." This must have been between I843, when the 2nd vol. of Yarrell's Ist. ed. was issued, without mention of this specirnen, and I 856 , when the and supplement appeared. In his subsequent edition he says (30, ii. 3I) Doubleday lent him three specimens; "one shot by himself in his garden at Epping-a young bird." Harting (38. II6) and others seem to accept this record without question, but Professor Newton appears to doubt it, for he says (37. ii. 213), "Somewhere about the same time [1846], it is believed Doubleday shot a young bird in his own garden at Epping." There does not seem to be any real ground for doubting this record, for, as may be seen above, Doubleday himself, in recording the occurrence of the Parrot Crossbill at Epping (23.7759), says, "The Common and Whate-winged Crossbill I have shot here." No reference to this interesting specimen occurs (so far as Mr. Mlacpherson and myself have been able to discover) in Doubleday's letters to Heysham (I0), which cover the above date. The specimen, however, was sold at Doubleday's sale in $187 \mathrm{I}$ (? to whom), with seven Common Crassbills, for $36 \mathrm{~s}$.

* I have been unable to find Blyth's record here referred to.

+ Doubleday evidently had overlooked, or was not aware of, Yarrell's reference to Blyth's record above mentioned. 
As regards the second Essex specimen, Mr. Rowland T. Cobbold, of Dedham, writes me as follows :-

In July, I866, I observed six or eight small birds feeding among the tops of some spruce firs growing on my place here at Dedham. Having my gun with me, I tried for some time to get two or three in a line, but being pressed for time, as I had to catch a train, I had to take a quick shot, killing one only. That it was a Crossbill was evident, but some white bars on its wings puzzled me, so I sent it off to my friend Capt. Haward, formerly of Bramford, but now of Little Blakenham, who is a good taxidermist, and who set it up. $\mathrm{He}$ informed me that it was a specimen of Loxia leucoptera, and asked for another if I could obtain one. I afterwards learned that they had been seen in some,fir-plantations across the river in Suffolk, where they made a great litter below the trees, by pulling off the cone in order to eat the insects contained in the galls [? Adelgethes abietis] on their stalks.'

Unfortunately this specimen (which probably belonged to $L$. bifasciata, not to $L$. leucoptera) is not now in existence. Capt. Haward states that the moth so injured it that it was impossible to restore it, and it was destroyed. He describes it as "a male in immature plumage. The lower bars on the wings were much more distinct than the upper ones, which consisted of only a few white feathers. The rest of the plumage resembled that of the young of the common species."

Corn Bunting: Emberiza miliaria. Locally, "Common Bunting," and "Bunting-lark."

Occurs, I believe, throughout the county, though local and not abundant. Round Chelmsford I fancy it breeds less often than it used to do, and Mr. Clarke described it (24) as "not uncommon" round Saffron Walden about forty years ago, while King says (20) it was "common" around Sudbury in $1 S_{3} \delta$. English, too, say's (43. 88) : Around Epping it "used to be more frequent than now. I have often had nests with eggs brought to me by the mowers."

About Orsett, it is "fairly abundant, and b:eed commonly" (Sackett). Round Harwich, it is fairly common and breeds (Kerry). In IS87, Mr. Stacey preserved a white variety shot at Great Waltham.

\section{Yellow-hammer : Emberiza citrinella.}

An abundant resident.

At Harwich, Mr. Kerry says it was "very scarce," through some unaccountable cause, during 1887 and 1888 , though previously common. Now, however, it is again increasing in number. On July I8th, I877, I found a nest containing young in an exposed position on the bank beside the footpath and road leading from the railway arch in New Street, Chelmsford, to Bishop's Hall Mill. Many scores of people daily

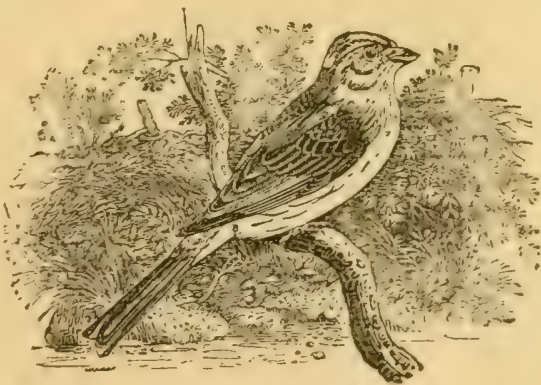

YELLOWHAMMER, $\pi \alpha l e, I / 3$. (After-Berrick).

must have passed within four feet, and within full view, of the nest. 
Dr. Bree had a yellow variety taken from the nest by Mr. Docwra of Foxburrows, Kelvedon, in the spring of 1880 . The other young birds and their parents were all of the normal colour (32a).

\section{Cirl Bunting: Emberiza cirlus.}

Though locally resident in most of the southern counties, this bird seems to be very rare in Essex. There are but two or three records of its occurrence in the county.

IV. D. King, writing at Sudbury in 1838 , says (20):

"I cannot speak quite confidently as to the occurrence of this bird ; but about four years ago, by the side of the chalk pits on the road to Middleton [in Essex] I saw a bird on a low tree which I believed to be a Cirl Bunting. I had a stuffed specimen in my possession at the time."

Chas. E. Smith records one (3I. 53) shot at Latchingdon in I854. Mr. Arthur Lister, who is perfectly familiar with the note of this bird, informs me that several years ago he heard one at Saffron Walden, but had unfortunately no time to verify the observation further. There is, however, no reason to doubt it, for Mr. Travis has a very nice specimen taken near Thaxted about 1885 , and sent to him in the flesh.

Reed Bunting : Emberiza schaniclus. Locally, "Black-headed Bunting," or "Reed Sparrow."

A fairly-common resident throughout the county, especially in those parts which are more or less marshy. It is, however, to

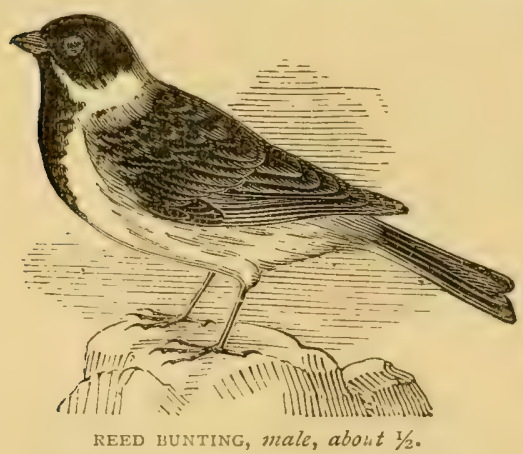
some extent migratory.

It breeds very commonly round the source of the Stour, in the Bumpstead and Birdbrook districts, but is rare at Maldon (Fitch).

\section{Snow Bunting: Pleclrophanes nivalis.}

A scarce resident in the Scotch Highlands, but a winter visitant only to Essex and the rest of England. It usually occurs on the coast during severe winters in greater or less numbers, but indi viduals have occasionally been shot as far inland as Bardfield, Dunmow, Halstead, and Epping.

Mr. Parsons shot one (8) at New England, on Nov. 29th, 1830, and another on Oct. 25 th, 1836 . A male was shot at Bardfield in 1836 (Clarke-24). One was shot near Halstead in the severe winter of $1837-38$ (I9. 34). Mr. Buxton 
says (47.88) one was "killed by a boy with a stone on Epping Plain. Another was killed in I840." English includes it (43. i. 24) in his Epping List. In 1858 Hy. Doubleday wrote (23. 6093) "I have seen inumbers of these birds on the coast of Essex." Lieut. Legge says (34. 90) that in the second week of November, 1865, several occurred near Shoebury during mild weather. Mr. Kerry says (40, iii. I82) that in October and November, 1878, large flocks frequented the shore at Walton and Dovercourt, and many were shot, while it is more or less common most winters round Harwich. Four were shot near Walton-onthe-Naze early in November, 1879

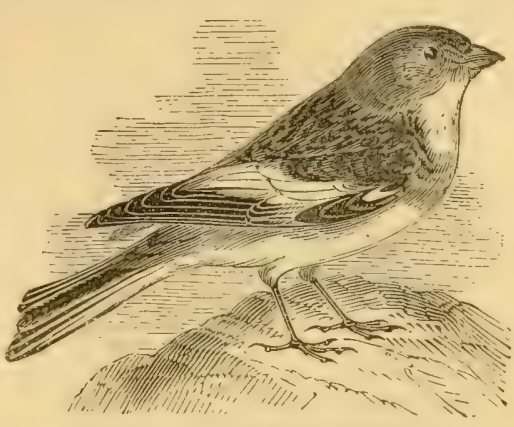

SNOW BUNTING, male in autumn, $1 / 3$. (29. Nov, 8). Mr, R. H. Eve of Maldon has several which he shot on the seawall there.

Mr. Hope writes: "I saw the first, which was very tame, this year (I888) on Sept. 24th, just before a gale, but they generally arrive in flocks of hundreds about a month or six weeks later. When they first land they will often let one walk within a yard of them." Mr. Stacey of Dunmow preserved some shot near there in or about the winter of $1879-80$.

\section{Family STURNIDÆ.}

\section{Starling: Sturmus vulgaris.}

An abundant resident. It has become of late years very much commoner than formerly. Cream-coloured, pied, or white varieties are not very rare.

Mr. Grubb says (39), "This bird almost darkens the air on our meadows [at Sudbury] in winter." Mr. Buxton says $(47.85)$ that it is "perhaps the most abundant bird in the [Epping Forest] district after the sparrow." W. H. Hill speaks of it (12. vi. 452) as occurring "in immense clouds on the marshes "near Southminster about I832. Yarrell says (I4. ii. 46) that in summer and autumn they "roost by thousands among reeds in the fenny parts of Essex, Cambridge, and other counties."

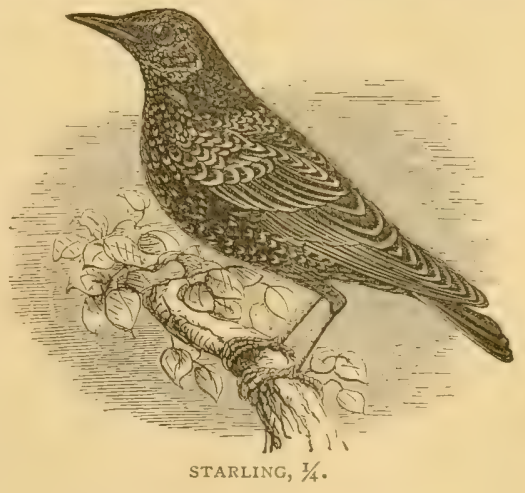

The Tuck Collection in the Saffron Walden Museum contains several white specimens taken from a nest at Quendon in May, 1858. Lieut. Legge records 
(34. 32) "a perfectly white variety," probably a female, on July 3 Ist, I 864. On February I5th, I880, I saw a cream-coloured specimen in a flock here. Mr. Hope informs me that he saw a white variety last year. At Orsett there is a stuffed specimen with a white tail (Sackett). Mr. Stacey has a similar specimen shot at Dunmow. Mr. Scruby informs me of a beautiful white specimen shot at Stondon Place several years ago. The same gentleman has a "grey and white" specimen shot by Mr. Thurgood at Toothill on Feb. 27th, I887. Mr. J. F. T. Wiseman of The Chase, Paglesham, has two pied specimens, shot there within the last year or two. Mr. R. Cross' shepherd shot a pure white specimen at St. Osyth on June 2nd, I873 (29. June 14).

Rose-coloured Pastor: Pastor rosens.

A rare and occasional visitant to Britain. I have only heard of one or two specimens in Essex.

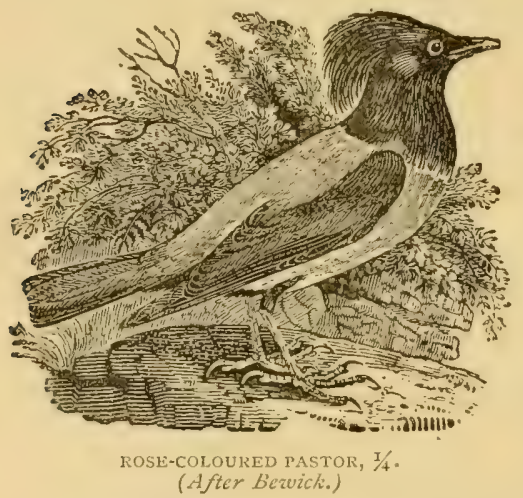

Mr. E. J. Tuck records (23.5319) that "a very fine specimen, with a good crest, and the beautiful rosecolour on the back, \&c., very pure," was shot at Strethall about the middle of September, I856. In August, I887, one was killed at Kelvedon by Mr. Frank Osborn of that place. It was first seen early in the morning, and in the afternoon it was observed again feeding in company with some Starlings on mulberries, when it was shot. It was preserved by Mr. Rose of Coggeshall for Mr. Osborn who still has it (Spalding). Mr. Hope writes "Col. Russell had one shot at Maldon by Gabriel Clarke. One was reported to have been seen at Havering." Mr. Fitch informs me that on Sunday and Monday, Dec. 29 and 30, I889, a bird having a crest and in every way answering to the description of this species, was observed to frequent the lawn of Mr. Belsham's garden at Heybridge, in company with Starlings. As it was seen by several different observers there seems no reason to doubt the correctness of the identifi. cation. Mr. Fitch adds: "Some twenty years ago, a similar bird was shot in the adjoining garden, then the late Mr. Stephen Cross's. My uncle, the late Mr. Thos. Pannell, also shot one some twenty-five to thirty years ago, near Sturmer Mere. It is now in the possession of another uncle of mine, Mr. A. G. Fitch, of Wixoe Mill."

\section{Family CORVIDÆ.}

\section{Chough: Phyrrhocorax graculus.}

A scarce, very local, and fast-decreasing resident in Britain. It is now chiefly confined to the high sea-cliffs on the west and southwest coast of England. It breeds nowhere in this part of England, so that any individuals which occur in our county can only be re- 
garded as rare and accidental stragglers. The first of the two following records of its occurrence in Essex may, from the description given, be accepted, but the second is very doubtful.

Mr. John Cordeaux, a member of the British Association Migration Committee, writes as follows (40. 185): "In a migration schedule received this morning from Mr. Owen Boyle, of the Landguard Light-house, is the following entry:'April 2nd, I888 : Two Crows put in an appenrance, $7.30 \mathrm{a.m}$. ; larger than Jackdaws; they had red beaks. and legs, and went north-west." "

In Stifford and Its Neighbourhood, by the Rev. W. Palin, occurs the following

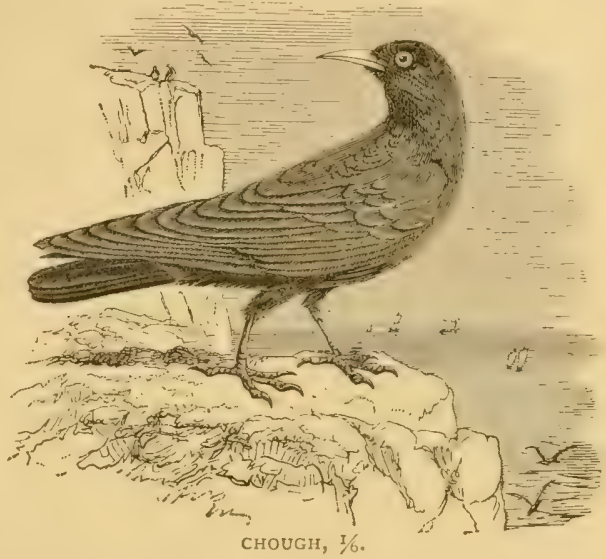
under West Tilbury :- "There were at that time [1840] 'the Chough' and of course the Crow and Herons. All (except the Crow) are happily being frightened away by the plough." There is probably some mistake here. West Tilbury is not a place at all likely ever to have been frequented by Choughs. Mr. Palin, however, again alludes to the subject in Mlore About Stifford (p. 45), saying that the Chough was "common enough here only thirty years ago."

\section{Nutcracker: Nucifraga caryocatactes.}

A rare and irregular straggler to Britain during autumn. The only records I have of its occurrence in Essex are the following :

Dr. Bree writes (29. May 7, I870), "I have lately heard of three unrecorded cases of the capture of Nutcrackers in this neighbourhood in the month of September, ten or twelve years ago. They were all shot in the same locality and about the same time. I saw one of them a few weeks ago." One of the specimens thus recorded is now in the Colchester Museum, to which it was presented by the late Dr. Maclean, as I understand on the authority of Dr. Laver. The following interesting note from Mr. C. Nicholls of Bovill's Hall, Ardleigh, who has another of the specimens, gives all the details of the occurrence which seem to have been preserved:-

"The Nutcracker in my possession was shot by myself one day when I was out Partridge shooting in the month of September, in Horkesley parish, considerably more than thirty years ago. There was only one bird seen when I shot this; but within a short time, two more were seen in the neighbourhood, and one shot by Mr. Osborne's keeper in Ardleigh parish. The other was shot in the neighbourhood, but I am uncertain where. For a long time no one knew what bird it was, but on showing it to the late Dr. Bree he told me it was a Nutcracker. I had it stuffed in Colchester, and I think by Mr. Ambrose."

Mr. Ambrose himself has informed me that this was the case, and that he also preserved the specimen shot in Ardleigh parish, which was killed by a man 
named Tillett. It passed into the possession of Mr. Errington, banker, of Colchester, who sent it to Dr. Maclean, after whose death it went to the Museum: It is still in fair condition. The foregoing statements are confirmed by the following memorandum among Dr. Bree's notes (32a) :-

"Dec. 30, I869.-A specimen of this bird was sent to me for identification, shot twelve or fourteen years ago at Horkesley by Mr. Nicholls, the brewer, who informs me that two others were shot at the same time. One of them was obtained at Boxted by Mr. Osborne, and I can trace the other to Dr. Maclean, I think, it having been shot at Ardleigh,-C. R. B."

Of another Essex specimen, I have received information from Dr. R. Z. Pitts of Chelmsford, who owns a fine specimen shot at Tollesbury in Sept., 1872, by Mr. Wm. Seabrook of Brent Hall, Boreham. This makes four occurrences in Essex of this rare species. Beside these, Mr. W. H. Bott of Cardfield's, Boreham, has an old cased specimen which not improbably was shot in the neighbourhood, but there is no record to show.

\section{Jay : Garrulus glandarius. Locally "Jay-bird."}

A common resident, especially in thickly-wooded districts, in spite of incessant persecution.

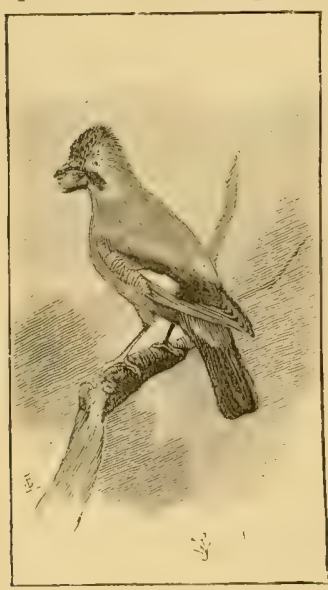

$\mathrm{JAY}, \mathrm{I} / \mathrm{ro}$.

I understand that in one month of the year 1878 no less than ninety-five were killed in the woods around Writtle Park. Mr. Smoothy trapped fortysix in his woods at Little Baddow with eggs during I887, and twenty-eight during 1889. Mr. Buxton says $(47.84)$ that "the character of the thicket has greatly encouraged this bird" in Epping Forest. An outcry has been raised in some quarters against the edict ordering the destruction of the Jay in the Forest, recently issued from the Guildhall, but I consider the action of the forest authorities perfectly justifiable. No bird is a more inveterate destroyer of other birds than this. Eggs are to it an irresistible temptation.

In I886, a remarkable instance occurred at Great Tey of a Jay building in a high Portugal laurel overhanging the high-road, and on being disturbed it built a second nest among the ivy on a house, closeto a bedroom window (29. Aug. 7).

\section{Magpie: Pica rustica.}

A scarce resident, except in a few localities, though formerly quite common. Its decrease is due chiefly to persecution by gamekeepers. In Dengie Hundred, I believe, it is commoner than in any other part of Essex. In January last, whilst driving through Tillingnam and the adjoining parishes, Mr. Fitch and myself were often able to see several old nests at once, built in the trees around us.

In May, I883, I saw them quite common in the woods round Danbury. Mr. Clarke, about 1845 , described it (24) as "not uncommon " round Saffron Walden, and I knew of a nest near there in April, I88 r. King describes it (20) as having 
been "not uncommon" around Sudbury in I838. Mr. Buxton says of Epping Forest (47.84):

"This predatory foe to other birds is happily not common hereabouts. There are several about Loughton, and they breed regularly in the Rectory garden. A pair used always to breed at Knighton, but I have not observed them for two or three years."

The Rev. J. C. Atkinson writes (36. 90):

"I used to be assured as a school-boy that there were two sorts or varieties of Magpies, distinguished hy the comparative length of their tails and the site of their nests :-the alleged short-tailed one was called the Bush Magpie; the other the Tree Magpie. It is almost idle to say no such variety or distinction really exists."

Mr. Sackett informs me of one shot near Grays "having a deformed beak, the upper mandible being curved to the right like that of the Crossbill." Round Harwich, it is fairly common and breeds (Kerry). On December 26th, I875, I saw several at Chignal St. James, and on January Ist following one at Roxwell. About the same time the keeper here trapped another. On June I6th following, I saw another at Broomfield. In 1877 , a nest of eggs was hatched in the Boyton Hall Springs. In the Paglesham district, fifty years ago, Dr. Laver says (50. iii. 33):

"Magpies' nests might be frequently seen, the highest tree being a favourite position. Sometimes they chose most unlikely spots only a few feet from the ground: at other times they nested in fruit-trees in a garden close to the house. I am sorry to say this bird is now rarely seen in my district."

\section{Jackdaw : Corvus monedula.}

An abundant resident, breeding chiefly in holes in large old trees in parks. Pied or albino examples occasionally occur.

At 3.30 a.m. on July IIth, I88 r, I saw a small flock down in the Market Square, Saffron Walden - a very unusual locality for them, surely! In the summer of $\mathrm{I} 883$, a nest containing two pure white and two normally-coloured young birds was taken near Harlow Mill. The white birds were tamed and kept in the vicinity for some time. Early in January I879, the keeper at Mark Hall, Latton, shot a pure white specimen which had been seen about the park for some months (Chelmsford Chronicle, Jan. I6). "T. S. H.," also records that a white specimen was shot in Essex in Oct. I857 (29. July 3, I858).

\section{Carrion Crow : Corvus corone.}

A resident in various parts of the county, though local and nowhere abundant. It is rapidly becoming scarcer through persecution. As long ago as 1845 , Mr. Clarke noted (24), that they were "not so frequent as they used to be" round Saffron Walden, though King, in 1838 , described it $(20)$ as still "common" around Sudbury.

Lieut. Legge, writing from Shoebury in 1866 , says $(34.600$ ) it " is very

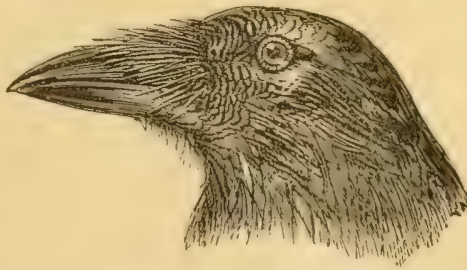

CARrion crow, (heal of), $1 / 4$. plentiful here, breeding both in the tall trees in the lowlands and in the extensive woods near Hadleigh. They do not nest as early in the season as they are said 
to do." Round Orsett and Grays, Mr. Sackett says it is very common, breeding plentifully. During I886, he took no less than fifty of its eggs. Mr. Hope says it is "very plentiful round Upminster." They still breed not uncommonly in the extensive woods round Thorndon Park, Brentwood and Warley; and Mr. M. Vaughan says that (40. iii. 459) "it is fairly common round Finchingfield, and that for some miles round Felstead there is scarcely a wood where the nest may not be found." Mr. Fitch states (4I. i. I42) that in 1887 there were two nests on Northey Island. In the Epping Forest district, Edward Doubleday says (I5) that it was "very rarely seen" in his time (1835), but this was probably an error, for a Londoner describes (28. i. 43) meeting with a nest with four eggs in Hainault Forest in April, I85I, and Mr. Buxton says (47.84) that, even now, in the Forest "a few are always about. * * * They nest in several places in the neighbourhood," while in Ongar Park Wood, in 1877, the keeper showed me a couple of old birds and two young ones taken from a nest there that year. Round Harwich, it is common, and destroys many egga of the Wild-duck and sea birds (Kerry). Writing of the Paglesham district fifty years ago, Dr. Laver says (50. iii. 33) they were then "very general, and their nests, like those of their near relative the Raven, were occupied year after year, probably by the same pair of birds."

Mr. Fitch records (40, vii. $47 \mathrm{I}$ ) that on October 2 nd, I 883 , he disturbed from a meadow near Maldon, a Crow which rose with some object in its claws. On being shouted at, the Crow dropped its burden, which proved to be a Lark, partially eaten.

Hooded Crow : Corvus cornix. Locally, "Dun Crow," "Grey Crow," "Hoody" and "Grey-back."

A winter visitor, common enourh on and near the coast, but rather rare as a rule inland. Near Chelmsford, I do not often observe them. It breeds in most parts of Scotland and Ireland, but very rarely in England, except in the Isle of Man. Cases of hybridism with the Carrion Crow are not unfrequent in the north, and common in Central Siberia. It seems that formerly it bred in some numbers on our coast, but it certainly never does so now, and its. doing so formerly was quite exceptional in this part of England.

Mr. Joseph Clarke, writing of the Saffron Valden neighbourhood about the year 1845 , describes it (24) as "common in winter." In a later note he adds "a great many here in I854." I have sometimes seen single specimens or small parties there in winter. Edward Doubleday (I5), English (43. i, 24), and Mr. Buxton (47. 84) all describe it as an occasional winter visitor to Epping Forest, and I saw two in a keeper's "larder" in Ongar Park Wood in I877. Both Mr. Grubb and Mr. King describe it (20 and 39) as "an occasional winter visitant " to Sudbury. Lieut Legge says $(34.90)$ that in I 865 he saw the first at Shoebury on October 28th. They afterwards became plentiful on the saltings. On October 17 th, 1879, I saw one feeding in a stubble field here, and on the following day two near Lindsell. Mr. Hope says: "It arrives about Sept. 3oth, and all through October, in small parties. The fowlers do not look for fowl until their arrival. In winter they will seize wounded Plover and other birds before one's eyes." Mr. Fitch also tells me that the punt-gunners on the Blackwater find them most daring and voracious in hard weather. Round Harwich, it is "common in winter, generally arriving during the first week in October" (Kerry). 
More, writing in 1865 , says (33. 1 33 ) :

"Mr. Laver of Colchester has informed Dr. C. R. Bree that the 'Dun Crow" occurs in great numbers near the Blackwater River in Essex, and [that] some remain and breed there every year. Mr. Laver has frequently seen and taken the nest on Osey Island, in the parish of Steeple, on Ramsey Island and at Paglesham. His cousin, Mr. Robert Laver, has shot the old bird from the nest which is generally that of the Carrion Crow." *** "Dr. Bree has since written to say that the trees in which the Hooded Crow used to breed have been cut down in one of the localities whence he kind!y endeavoured to obtain specimens."

Prof. Newton, commenting on their reported breeding in this locality, says ( 37 . ii. 279): "it would seem that this is not so now," which is certainly the case. In reply to my enquiry, Dr. Laver writes: "There can be no mistake about their breeding, as stated in the Ihis. They bred on a haulm-wall in Foulness, but I have not heard of a nest for years, as I now never visit that district." The Rev. J. C. Atkinson never knew of a nest in Essex, and in reply to an enquiry, Mr. J. F. T. Wiseman of Paglesham informs me that he never knew of its breeding in that district.

\section{Rook: Corvus frugilegus.}

A very abundant resident. Instances of its nesting in the autumn and winter are by no means rare, and varieties of various kinds, chiefly white or pied, are rather common. A very large proportion of young Rooks have a white spot between the branches of the lower mandible (40. x. 339 \& 40. xii.).

It is stated (Chelmsford Chronicle, June I 4 th, I878) that during a thunderstorm a few days before,

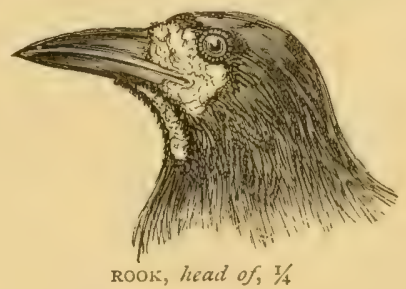

"On a field on Chapple Farm, Goldhanger, five Rooks were struck and killed while on the ground, and four horses which had just been ploughing over the spot may thus be said to have had a narrow escape. A tree hard-by was untouched."

During winter, the trees at Birch, in which the Herons build, are occupied by Rooks, many thousands roosting there every night. During a visit paid to the Heronry on April I6th, I888, by Mr. E. A. Fitch and myself, we were surprised to see the ground below the trees completely strewn with small fragments of white and red brick, disgorged by the Rooks in their pellets. Old india-rubber bands, gathered by the birds from the Colchester and London manure, are not uncommon. In $188_{3}$, there was a nest in one of the trees immediately adjoining the Museum at Saffron Walden.

For some unexplained reason, all the Rooks in our Rookery at Lindsell Hall, near Dunmow, suddenly left on March Ioth, I880, when in the middle of their building operations, and did not return that year, though they had nested there regularly and in large numbers for many years. The same occurred at Fingrith Hall, Blackmore, the same spring, all the Rooks taking their departure after a good deal of nest building had been accomplished, except one pair which reared their young successfully. In the following year they returned to their nests at both places.

I have been told that about forty or fifty years since a number perished through 
being frozen to the branches on which they had perched for the night in Sheepcote's Wood, Great Waltham. A writer on the "Superstitions of Essex," in I 839 (19. 86), says,

"In Essex the issue of a journey is often unravelled to the traveller by the number of Crows which cross his path, as the foliowing couplet showeth, and which we well recollect our good old nurse took especial care to teach us as an indispensable part of education :-

\section{"One Crow, bad luck; two Crows, speed; Three Crows, good luck ; four, good luck indeed."}

Another form is,
One's unlucky,
Two's lucky,
Three is health,
Four is wealth,
Five is sickness,
And six is death.

On the morning of Christmas Day, I876, several pairs were observed building in a Rookery at Ilford, and on the 23rd of January following I observed them building in the trees forming the avenue in front of Torrell's Hall, Willingale. In I88I, several pairs began to build a little before Christmas time in a Rookery at Saffron Walden, and a week later (Jan. 2) I saw others similarly engaged at another Rookery adjoining.

In February, I881, Mr. Travis received a young bird with the mandibles considerably twisted and crossed at the tips.

A "very curiously marked specimen of the Rook, beautifully mottled," was shot at Mark's Hall, in December, I838 (I9. 90). This bird was doubtless similar to the variety figured by Hancock. Mr. Chas. E. Smith, writing at Coggeshall in I858, says (3I. 53), "Two of these birds, of a uniform drab-colour, have been shot in the neighbouring Rookeries and preserved by a bird-stuffer of this town." I have the skin of a cream-coloured specimen with pink eyes hatched here in the spring of I880. Mr. Hope has a white specimen shot at Nelmes, Hornchurch, in June, I888. A "dun-coloured" specimen was shot at East Tilbury, on May I5th, I884 (29. May 24). Mr. A. C. Stephenson records that a cream-coloured specimen was shot at Chigwell on May I2th, I872 (29. May I8).

\section{Raven : Corvus corax.}

Still a resident in Essex, though a very rare one-indeed, it is probable, if not certain, that ours is the only county in the east, south-east, or midland counties of England in which the Raven still breeds regularly. It is much to be feared, however, that unless the few pairs still nesting with us receive in the future more consideration than that they have had during the last few years they will soon cease to remain with us. The Raven was once a common bird, breeding frequently in Essex, and there are still many trees known as "Raven Trees," from the fact of their having once been regularly occupied by a pair of birds for many years ; but it is now almost extinct, though I saw and heard one at Great IVarley on Feb. I 2 th, I88o. The species lingered on the coast some time after becoming rare inland. It is most earnestly to be hoped that naturalists, collectors and others will abstain from molesting our few remaining Essex Ravens. The fact of 
the Raven nesting in Essex at the present day, within between forty and fifty miles of the metropolis, is a matter of the highest interest to ornithologists and very remarkable. In Suffolk, the last known nest was in I869, and in Norfolk the last was in or about I872, while in most other adjoining counties the Raven probably ceased to breed still earlier. In Essex, the species is already on the verge of extinction, and it can hardly be expected that under any circumstances it can exist with us very many years longer ; but the disappearance of so interesting a feature in our avifauna would be a thing to regret deeply, and it is much to be hoped that the day of the Raven's final extermination in Essex will be delayed as long as possible.

Messrs. Sheppard and Whitear state (9. Ic) that

"The sons of Mr. Lord of Ramsey, Essex, took four young Ravens from a nest and put them into a waggon in a cart-shed. About the same time, they destroyed the young of a Magpie, which had its nest near the cart-shed, and the old Magpies, hearing the young Ravens crying for food, carried them some, and constantly fed them till they were disposed of by the boys."

Mr. W. H. Hill (I2. vi. 452) met with it round Southminster about I832. Mr. Parsons shot one (8) weighing 3 lbs. on the shore at Shoebury, on Nor. 28th, I834. King, in 1838 , described it (20) as being then "not uncommon" in the Sudbury district. Mr. Clarke states (24) that round WValden it used, forty years ago, to be "not uncommon." He adds that it "builds annually at Audley End and Debden Hall," but that in "I8 39 and I854 it was seldom seen." Both Edward Doubleday (15) and English ( +3. i. 24 ) include it in their list of Epping birds.

Mr. J.H. Gurney writes to Mr. E. N. Buxton (47.83) :

"A pair of Ravens used to nest in the Wanstead Heronry. Your grandfather, Samuel Gurney, took me there one spring-I think about I833 or 1834and we then saw two young Ravens which the keeper had taken out of the nest a few hours previously. Your grandfather brought them and turned them loose in the stable-yard at Ham House, but as he would not have their wings cut, in a few weeks' time they flew away."

Professor Newton informs me that he has six eggs, taken from a nest at Copt Hall in 1846 . They were sent by Mr. Conyers' gamekeeper to a dealer in London, from whom Mr. WVolley obtained them. Mr. Edward Corder of Writtle tells me that he knew of their breeding regularly on a tall elm at Warden's Hall, Willingale, up to about $\mathrm{I} 865$, and also in a very large oak-tree that used to stand beside the Chelmer, near Broomfield Mills.

Lieut. Legge, writing from Shoebury in I866, says (34.599):

"I was surprised to find three pairs nesting within a distance of six miles of this station. They seemed to have preferred the lowlands, probably on account of the large trees growing in the hedge-rows, as all three nests were built in tall elms so situated. I have not yet met with any Ravens in the uplands of this part of the county, but down here they both breed in the season and remain during the winter. The first nest found was on the I6th of March, and was built high up in the fork of a large elm."

Fifty years ago, Ravens were so common on the Essex coast that Dr. Laver says (50. iii. 33$)$ :

"A sheep 'cast' (as it is called), or in any other trouble, would, if neglected by the shepherd, almost certainly be attacked by some of the numerous Ravens, when maiming or a miserable death would be the result. It is astonishing for how 
long a number of years the same Raven's nest was tenanted. The birds appeared to build the new nest on the top of the old one, until the bulk of the whole would almost equal that of the body of a large cart."

The Rev. J. C. Atkinson writes (36.86) :

"The chosen tree soon comes to be called the 'Raven-tree.' One such accumulation of nests I knew, as a boy, in Essex, and after a stiff climb succeeded in reaching it. I did it in jeopardy, however, for the Ravens were very bold, and every moment I expected they would assail me, in spite of the short bludgeon I had suspended to my wrist. The appearance below the nest of the farmer in whose fields the Raven-tree grew, decided the question--perhaps he frightened the Ravens as well as threatened me; perhaps they knew he came as their protector-anyhow I did not get my egg, although I had actually had it in my hand."

Mr. Atkinson informs me that this "Raven-tree " stood in Great Wigborough parish, about three-quarters of a mile N.E. from the church. Mr. J. H. Hills of Prested Hall, Feering, informs me that a large elm there, known as "the Raventree "was occupied up to about I840. He occasionally saw Ravens about for some twenty-five years later, but not building. Mr. Hope has occasionally heard its croak in the summer months, and has seen fresh birds on the coast about the middle of September. Mr. Kerry says it is very rare round Harwich, though he has seen two at Dovercourt.

The following graphic account of the storming of a Raven's nest, near Earl's Colne, was communicated to Mr. Seebohm by Mr. Edmund Capper (45. i. 536) :

"It was a splendid day in March, warm for the time of year, as we wandered through the preserves, crossed some fields, and entered the copse in which we understood the Ravens had built their nest. It was just such a spot as one could have fancied a Raven might have selected for its home-a large, well-preserved copse, with densely thick undergrowth, together with little patches of open glade in which were a few tall elms and other trees. On the afternoon of our visit, it was intensely silent; the sun was bright in the heavens and only the cooing of the Ring Doves and the whirring of the Pheasants and other game, served to give evidence of animal life in the wood. We silently entered, creeping along the glen up to its centre; but, so little did we see of the objects of our search, that we began to fear that we had missed the right plantation; when, all at once, we came to a little clearing in the middle of the copse, and there, straight before us, on the top of an immense elm, was the Raven's nest. The hen slipped off the moment we emerged from the undergrowth, and we did not see heragain; but the cock instantly flew down towards us, with a menacing bark, to give us battle. We were well acquainted with his complacent pruk, pruk, as he used to sail over the valley [of the Colne] in his daily rambles; but this was an angry hoarse growl. The nest had been frequently robbed, and he had grown bold from experience.

"We were soon at the foot of the tree, and, throwing a line over the lowest available bough, were soon in a position whence we could ascend further, aided by our hands and feet. The nest was at an immense height. As we drew nearer to it, the Raven became bolder, and we had to stop occasionally to menace him. At times he must have been within a few yards of us, sailing from one tree to another, and darting at us as he passed. At last we reached the nest-a large structure of twigs of many years' accumulation, very compact and very difficult to reach round. it was built almost at the top of the tree, in a fork at the end of a bough, and in a position not very safe to hold on by. With care, cap between our teeth to keep our friend off, we got one hand over the nest and could just balance ourself sufficiently to look over its edge. There, to our delight, on the lining of sheep's wool and fine fitre, rather deep down, lay three fresh eggs, just like the ones in the second figure of Hewitson's third edition. By great care and by keeping the bird at bay with our handkerchief, we succeeded in getting them safely down. We slowly retired as we came, the cock bird tearing off the twigs and driving us before him, with ruffled feathers, savage barks, and short menacing sallies; and it was not until we were at some little distance from his nesting-place that we really felt 
out of danger. At this lapse of time, we confess our robbery seems rather cruel; but never shall we forget our visit to the 'Raven's-tree.'"

A much more recent instance of the Raven breeding in Essex, is that reported to me by Mr. Stanley Edwards, who writes that a pair

"used to build for some years in three Scotch fir-trees," in the park of Lawford Hall, near Manningtree, the property of F. M. Nicholls, Esq. These trees stand quite alone on a mount, supposed to be the grave of some Roman chief, and are very conspicuous all up the valley of the Stour. The birds used to nest there every year, and were protected from the superstition of the villagers, which was much increased by a mortality that occurred among the cows of the place at the same time the Ravens first made their appearance, and which, of course, was laid to their charge. I am speaking from memory, but should say they were there from 1870 to 1880 , and then suddenly disappeared-why, or how, I have never been able to learn. They did not seem to mind any one looking at their nest, beyond just flapping slowly off to a neighbouring tree, from where they could watch the intruder. The Nichollses several times took a young one from the nest to bring up as a pet."

Mr. Walter B. Nicholls, who has sent me corroborative information, adds :

"The Ravens came to us from Sutton, just orer the river [Stour], in the winter of $1870-71$, I think, and stopped some six or seven years. On their arrival they did some damage among weakly lambs, but never afterwards, so far as I observed, preyed on anything so near home. They always had two nests in adjoining trees in a clump of firs growing on a barrow here. The cock bird was magnificent in appearance, as he rushed barking from the trees at the first sight of anybody approaching : the hen permitted a much nearer approach."

Quite a number of other "Raven-trees" have been reported to me from time to time in various parts of the county.

As regards the breeding of the Raven in Essex at the present day, it may be said, I believe, that we still have several nests annually, all of them in the lowland parts near the sea, but it is not wise to reveal their exact whereabouts to rapacious collectors. For most of my information relating to them, I am indebted to Mr. E. A. Fitch, who has carefully collected all the available facts. That gen. tleman tells me that from "time immemorial," a pair built on the "Raven-tree" - a large elm-on his farm on. Northey Island, but they deserted it in I887. The principal nest I know of is built in a tall elm, being one of many similar trees standing in a hedgerow on an island off the coast which is fortunately rather difficult of access. It has been built in the same spot regularly for many years past, notwithstanding the fact that, for several years at least, not one young one has been allowed to fly. In 1886 , four young birds were taken from it, of which one is still alive, the rest having been stung to death by bees. In July, I887, the same gentleman took three more, and again in 1888 the entire brood. In September of that year I visited the spot, when I found the nest, which was chiefly of sticks, rags, wool and matting, lying on the ground below the tree, having been poked down by a farm-lad because Hawks had laid eggs in it after the Raven's nest. In April following, I again visited the spot, but the tree was not then occupied. However, the Ravens had been seen about shortly before and were doubtless nesting in the vicinity, though several likely-looking nests we found seemed to be unoccupied. In the southern part of the county I have been informed of several nests-two of them within a quarter of a mile of one another - which were occupied very recently and probably are now, but I have not been able to visit the spot. In I888, too, there was a nest on Brick House Farm, Mundon, but it was unoccupied the following year. Probably other nests might be found. Two Ravens, which surely must have been breeding 
in the neighbourhood, were observed (42) at Languard Point on June 22nd, I 884 .

Mr. Fitch, who has taken great interest in our Essex Ravens, writes to me:-

"Mr. Gurney's plea for the Essex Ravens [50. i. I82] is sadly needed. I wish we could enforce its protective influence. This year Mr. Harting, Mr. Belfrage and myself saw the Ravens (a pair) on Osey shore on February 25th; and on Northey, on May 22nd, for the whole day, a pair were fighting with the Kestrels and Crows that were nesting on the island. But, although seen on both islands, they nested on neither. On April I5th, Mr. Miller Christy, Messrs. Freeman and myself went to visit, as we hoped, the Osey nest. We found the old nest lying in the ditch, where it had been seen by $\mathrm{Mr}$. Christy the year before, and Jordan (the resident on the island) told us the Ravens were still there almost every day and had commenced a nest at the east end, which we saw, far removed from their old quarters. This, however, they had abandoned and he told us they must be nesting this year over the water; he bedieved it was on my island (Northey). I found this nest, as I thought, on Brick House, Mundon, - the same nest from which Newman had a young one, taken last year. On my second visit, I found the tree (an elm) cut down, purposely to destroy the young Ravens, but it was found their nest had not been used this year, so no harm was done, except that done to the tree! This same day I found the nest with the old bird on in a hedgerow elm between Iltney and White House farms, Mundon. Upon enquiry, I found the tenant of Iltney (Mr. Isaac Granger) knew of it, but wouldn't disturb the nest for the world. So here even superstition had its bright side. The tenant of White House (Mr. Daniel Mead) knew nothing of it. I then hoped it was safe and this proved to be correct, but it is the only nest I can hear of as having escaped destruction this year.

"To return to the Osey nests-now a thing of the past l fear. The following is the tale of the young birds that have been taken from it by the same persons, generally on Easter Monday:-In I882, one (the rest had flown); I883, four; 1884 , none (the visit was too late : the young ones had gone) ; 1885 , three ; I886, four; 1887 , four and three of a second brood [50. i. 142]; I888, four. In this year there was a second brood, which was not only taken by strangers, but the nest was destroyed and thrown into the ditch beneath the tree. Thus twentythree young birds have been taken in seven years, and it is fair to suppose that very few have been got off by their parents, although the second brood had only lately been found out. This certainly was attempting to rear a family under serious difficulties and speaks well for the indomitable perseverance of the Raven as a breeder. It shows, also, its strong attachment to locality. These young ones were not taken for sale purposes, although some of them made, and all could have been disposed of at, more than Mr. Abel Chapman states.

"He says (Brrd-Life of the Borders, pp. I9-20) :- 'there are now only a few spots remaining along the Borders where these fine birds are allowed to nest. With young Ravens at half-a-guinea a-piece, and the insatiable-ay, insane-greed of "collectors" for British-kulled specimens, it is wiser to omit names. If " naturalists" must all have Collections, why cannot they be satisfied with the beautiful specimens which are so easily procurable from northern or eastern Europe, instead of hastening the extirpation of this, and other scarce indigenous birds, by placing a high premium on their heads?' Very good indeed, but humanum est crrare! I had a young Osey bird which was allowed its liberty and became very tame. It was passionately attached to me, and frequently flew over more than one field to accompany me home. When I was indoors, it hardly ever left the window-sill of the room I was in. It was a deep grief to me to lose him on the night of the flood (August Ist and 2nd), but not so to some other members of the household.

"The Fambridge Ravens were probably nesting somewhere on the Crouch, but they had a rough time of it, and I cannot hear that the nest was found. In I 888, Mr. William Laver had at least $£$ Io worth of damage done to his ewes and lambs by Ravens on Blue House farm, and when IValter King (the shepherd) found them about again this spring (probably the same birds, as their presence was announced by a sheep being found dead with its eyes picked out), he dressed him. self in the sheep's skin and laid up against some strawed hurdles on the marsh. 
On two mornings he had a shot at the Raven, and, as he supposed, wounded it severely the second time. It, or another, however, returned after some days and' was seen to take three poisoned eggs and next morning was looking for more! Quite a number of poisoned eggs were consumed on the other side of the river -at Norpitts and Raypitts, Canewdon - as the neighbourhood was well aroused by this Raven visitation. Whether the eggs destroyed the young birds I know not : they evidently didn't the old one! I never heard of any damage from Ravens near either Osey or Northey. These destructive and bloodthirsty habits were probably developed from the fact of one or two dead horses being left on Bridge Marsh.

"I used to know (for three years, I872-4) of two nests within a quarter of a mile: of one another near the Devil's Steps, Thundersley, in some tall hedgerow-elms. The Ravens probably nested there long previously, and they continued to do so. at least up to I880. In I879, I nearly had the young ones sent me from one nest, by my brother-in-law, Mr. John Wallis, of Jarvis Hall, instead of a brood of Carrion Crows, which I wanted for Mr. Henry Laver. My wife thought the youngCrows ate quite enough, during the few days we kept them! This locality is now deserted. Mr. James Farrow, bailiff at Kent's Hill, South Benfleet, in answer to. enquiries, replied as below, under date April 9th, I889 :-

" "I have been waiting to see if I could hear anything about where the Ravens. are building, but cannot. They have cut the branches what they used to build on off, and I should think that is the reason they have left the trees.'

"One of these pairs had probably removed to the Hole or Pinesnest farm, between South Benfleet brick-field (now disused) and Hadleigh Castle. We saw this year's eggs from this nest exhibited by Mr. Foster, at the Southend meeting of the club. Within the last twenty years $\mathbf{I}$ have heard of nests in this neighbourhood, at Nipsells and Clarke's farm, Mayland; Stansgate Grove; Brick House, Mundon Hall and White House, Mundon; Iltney, Mundon (in upper fence, stubbed five years ago) ; and Goldhanger Decoy (once). I have two "Raven-trees" myself, one on Northey Island, the other at the bottom of Jingle Hills, between Jenkyns and Hazeleigh Hall. I should be only too pleased to welcome back the old tenants or their descendants.

"Mr. Gurney says quite truly the Raven is already trembling on the very verge of extinction in Essex, and this note will show something of what is happening to them in the last days of their persecution."

"P.S.-The Ravens were seen on Osey Island last month [Jan. I890]."

\section{Family ALAUDID屃.}

\section{Sky Lark: Alauda arvensis.}

An abundant and well - known resident, though partially migratory. Its song may sometimes be heard during every consecutive month of the year.

Lieut. Legge writes (23. 9839) :

"The stubble lands and low-lying fields [round Shoebury] literally swarm with Larks at this season of the year [October], and they are

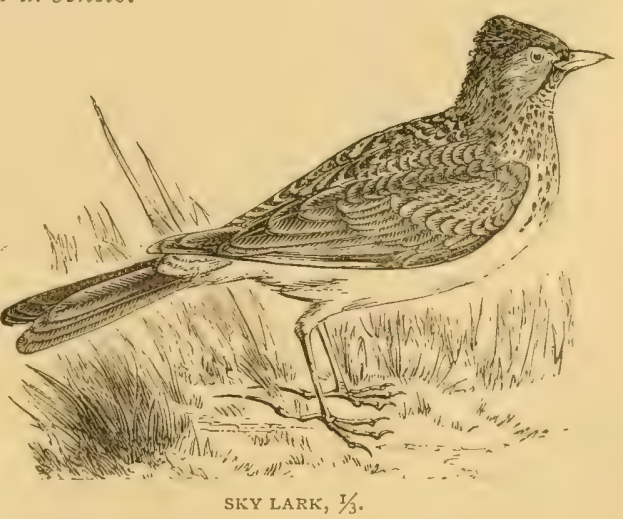


just as plentiful in spring time. They resort very much to the saltings, $* * *$ roosting there at nights. They may also constantly be seen at some distance from the shore, picking up sandworms on the fore-shore after the tide has left it. I have never seen Alauda arvensis resort so much to the sea-coast as it does here.',

On May I3th, I88I, I witnessed a very extraordinary occurrence near Saffron Walden. I was walking with a friend across a ploughed field when a Sky Lark suddenly flew up from beneath his feet. Looking down, we saw its nest containing young. On the edge of the nest lay the feathers of the bird's tail, upon which my friend had unconsciously trodden, and she, sprirging up, had left them behind. I have them yet. Mr. Sackett writes that round Orsett "great numbers were drowned by the extensive flood on August 2 nd, I888. When shooting on the $4^{\text {th }}$ of that month, he noticed many floating on the submerged marshes." The Rev. M. C. H. Bird informs me that, on April 24th, I882, he found three abnormal white eggs in a nest on Canvey Island.

About the middle of January, I88I, a cream-coloured variety was shot close to Saffron Walden, and in the Museum is a specimen in unusually light plumage shot there and presented many years since by Mr. G. Bullock. Mr. Hastings Warren, of Little Dunmow, informs me that, for several years in succession, he observed a remarkably light-coloured specimen in the fields round his house. " WW. H. P." records a white specimen, all except a few pied feathers on the top of the head and the wings, shot by him at Chesterford Park on Sept. Ist, I870 (29. Sept. I0).

\section{Wood Lark: Alanda arborea.}

Formerly a rare and local resident in the Epping Forest and Saffron Walden districts, but it seems of late years to have, for some

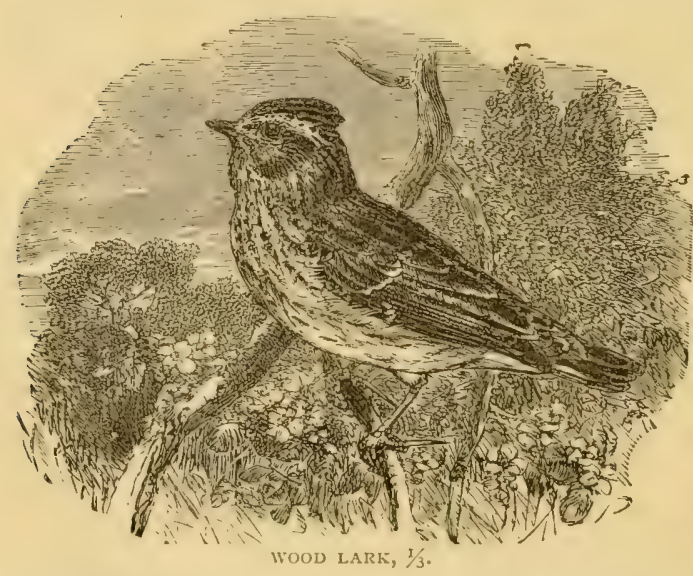

unknown reason, disappeared from those localities, and I have not heard of the occurrence of more than a single specimen in the county for years.

Henry, Doubleday writes (10) in 1832 : "The IVood Lark seems to have become very rare. I never saw it alive wild, and never could procure a specimen." However, in June, 1839, he wrote (10), "The Wood Lark is rapidly increasing. They sing most delightfully of an evening:" In March, I840, he says (I0), "We have a number of Wood Larks about this spring, but I fear the London bird-catchers will thin them." Again, a month later, he wrote "We have a great many Wood Larks." Its name occurs without comment in Edward Doubleday's list of Epping birds ( $\left.\mathbf{I}_{5}\right)$, and in I8So English includedit as 
a resident in Epping Forest (43. i. 24), but Mr. Buxton (47) does not mention it. Mr. Joseph Clarke speaks of it $(24)$ as "rarely seen" round Saffron Walden about 1845 . In the Museum there are a pair obtained at Epping on November 6 th, 1839, and presented by Henry Doubleday. Formerly there was a specimen obtained near Saffron Walden. I have been personally assured by Mr. Clarke that many years ago they used to be fairly common round Walden, and this statement is corroborated by Mr. Travis, but I believe they never occur there now.

Mr. W. H. Hill mentions (I2, vi. 452) having met with it near Southminster, about I832, but the Rev. J. C. Atkinson expressly says (36.7I) he never met with it in Essex. Mr. Charles Smoothy has kindly presented me with a skin shot by himself in a ploughed field near his residence, Old Riffhams, Danbury, whilst partridge shooting during a very high wind on Jan. 2 Ist, I889. It is the only specimen he ever met with in Essex, and his attention was first attracted by its unfamiliar note.

More, writing in 1865 , says (33. I24) it "nests only occasionally in Essex," probably alluding to Doubleday's observations in Epping Forest. Certainly it does not do so now.

\section{Shore Lark: Otocory's alpestris.}

A rare and irregular straggler to our coast during winter.

Dr. Bree states (29) that in the winter of I880-8 I one was "captured close to the cavalry barracks, Colchester." $\mathrm{He}$ adds, "It is a very rare bird in this locality." Mr. Kerry says (40. vii. I20, \& 46.73): about the end of November, I882, "a large flight of Shore-Larks arrived on this part of the coast [Harwich] and frequented the salt marshes. No less than thirty-five were shot." Mr. Hope writes he has met with them "occasionally off Harwich about Christmas time:" but does not remember to have seen them in summer plumage. Mr. Gurney (40. 225) has received one from the Galloper L.V. Mr. Ambrose tells me that in years gone by he has preserved specimens from Mersea, and also one shot beside a wheat-stack at Shrub End, Colchester. Specimens are recorded from Maldon (29. Nov. 29, I862), and Mr. Kerry informs me that at Harwich, on Dec. 12th, 1889, five were shot out of a small party of seven. Other occurrences have probably passed unrecurded. 


\section{Order PICARIAE.}

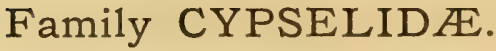

Swift: Cypselus apus. Locally, "Shriek Owl," "Screek Owl," "Deviling" (E.A.F.), and "Tommy Devil."

A common summer visitor in all parts of the county, breeding wherever there are suitable nesting holes in either ancient or modern

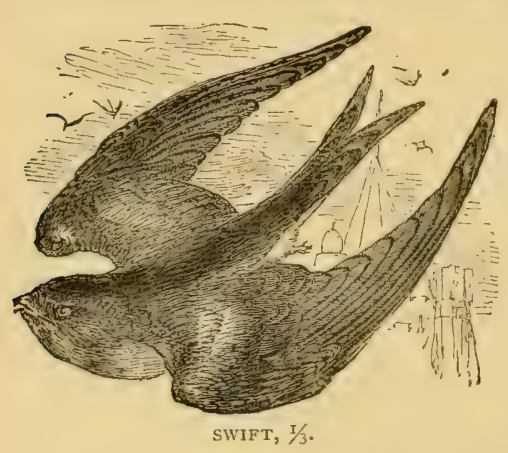
buildings. It usually arrives. about the end of April and leaves: during August, though individuals may sometimes be seen in September, and occasionally even in October. Mr. Sackett notes the first in 1884 on May Ioth, in 1887 on May I 2 th, and in 1888 on May 6th. He also observed a very late specimen on September I2th, I887. In that year a pair were observed near Harwich on September 16 th, and another pair at Stony Point, near Walton-on-the-Naze, on the I ith (29. Oct. I). I saw a pair at Audley End on August 25th, I880, and one at Maldon on September 4th, r888. T. S. Tiller shot one at Great Chesterford on October 27 th, $\operatorname{I} 877$ (29. Nov. 3), an extremely late date. Another was seen at Colchester on September $23 \mathrm{rd}$, I 878 (29. Oct. 5).

At Harwich it breeds commonly and seems to be increasing (Kerry). Around Broomfield, where they are often called "Skreek Owls," they are decidedly common, and considerable flocks of them may often in the late summer be seen wheeling and dashing about overhead, screeching loudly. Their abundance is due, partly at least, to the fact that a number of different houses and cottages built by the late Mr. Thomas Christy, about forty years ago, were all roofed in a manner which left open eaves, affording them excellent nesting sites.

Mr. Thomas Catchpool records (23. I499) that at the end of June, I835, on a cold. wet day, he and some friends found numbers of Swifts, stupefied by the cold, clinging to ledges of the cliffs at Walton-on-the-Naze. "In some places [says Mr. Catchpool] they were settled one upon another, four or five deep, and we literally took them up in handfuls, five or six together. So numerous were they, we could probably have caught some hundreds." Edward Jesse relates a very similar occurrence. He says (Scenes and Tales of Country Life, p. I69) that 
in $I \delta_{35}$, just after their first appearance, there occurred so remarkably cold a day that they clustered together in masses like swarming bees. "A large cluster [was] seen hanging to the water-spout of Harwich Church. Some boys were able, with poles, to knock them down, and many were caught." Mr. Hope observes that "When they are seen flying over the mouth of Harwich Harbour the approach of heary weather is looked for."

\section{White-bellied Swift: Cypselus melba.}

A rare and accidental straggler to Britain which has once, or perhaps twice, been met with in Essex.

Yarrell says (I4. ii. 240) that the fourth British specimen he knew of (really the sixth) "was picked up dead near Saffron Walden, in Essex, in July, I8 38 , as communicated to me by Joseph Clarke, Esq." (also Macgillivray, Hist. British Birds, iii. p. $6 \mathrm{r}_{3}$ \& 38. I26). In the last edition, Prof. Newton states on Mr. Clarke's authority (37. ii. 373) that it was picked up dead near Hinxton, which is in Cambridgeshire, just beyond the Essex boundary. Another Essex record is by Dr. Bree, who says that on June Sth, I87I, Col. Delmé Radcliffe thrice saw this bird on the wing near Colchester (29. June 17), but the specimen was not obtained (38. 126). Frederick Holme, writing to Mr. E. H. Rodd (probably in I833) says (23. 5034) :-

"The great White-bellied Swift (Cypselus alpinzs) has been shot three or four times in Ireland within a ferv years, and once in England, at Attleborough, in Norfolk, in September, I83I; I think, but am not sure, that a second instance has occurred near Romford, in Essex."

\section{Needle-tailed Swift: Acanthyllis caudacuta.}

An exceedingly rare and accidental stragster, which has only been met with twice in Britain, but which has nevertheless a perfectly good claim to be considered a British bird, notwithstancling its rejection by Prof. Newton (37.ii. 37I), and the fact that it has not been met with elsewhere in Europe. It would be almost impossible to import such a bird alive.

The first British specimen was shot near Colchester. It was recorded (23. 1492) by Ed. Newman in the Zoologist, after having been examined and identified by Messrs. Yarrell, Ed. Doubleday, W. R. Fisher, and himself. Newman quotes the following information, supplied to him by the late Mr. Thos. Catchpool of Colchester, to whom the specimen belonged :

"It was shot about 9 p.m. on the 8 th of this month [July, I846] by a farmer's son, named Peter Coveney, in the parish of Great Horkesley, about four miles from Colchester. He saw it first on the evening of the 6th. He tells me it occasionally flew to a crreat height, [and] was principally engaged in hawking for thies over a small wood and neighbouring trees. Being only wounded, it cried very much as it fell, and when he tóok it up, clung so tightly to some clover-it was in a clover-lay -as to draw some stalks from the ground."

The specimen is now in the possession of Mr. Catchpool's son, Mr. Thos. K. Catchpool, of Leicester.*

* The second occurrence of this bird in Britain was in 1879 , when Mr. G. B. Corbin (40, iv. 8 I) obtained one near Ringwood, Hants, on July 26 th or 27 th, after having for several days seen it flying over the Avon in company with another. Dr. Bree refers to another possible British 


\title{
Family CAPRIMULGIDE.
}

\author{
Nightjar: Caprimulgus europaus. Locally, "Night Hawk" \\ (Orsett).
}

A regular summer visitor, but very sparingly distributed, except in a few spots which are peculiarly suited to its habits, as Epping

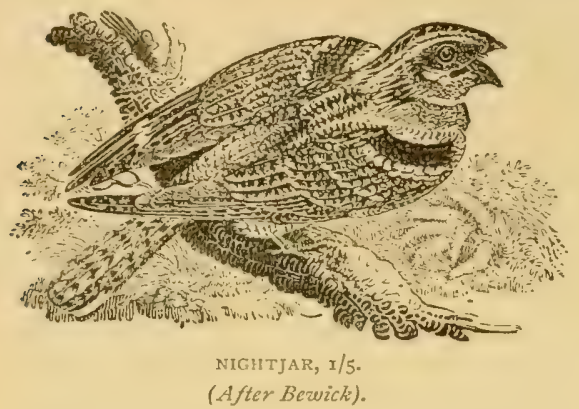

Forest, Ongar Park Wood, and the woods and commons round Danbury, Tiptree, Warley, and elsewhere In most parts of the county it is seen occasionally when on migration. It usually arrives about the middle of May, and departs in September.

Albin says (3. i. I0), "I have seen them on Epping Forest and divers other places." Mr. Buxton says (47. 93) they are "frequently seen during summer in the Forest, where they breed." "J. H." records (29. Jan. I3, 1883) that in $188_{3}$ he found a couple of nests in the Forest, and I found a nest near Ambresbury Banks in I870. I also saw a nest-or rather eggs-in Ongar Park Wood in 1877 . Mr. C. Walford wrote in 1838 : This bird "appears to have been unusually numerous in this county during the last season, several having been sent to me to be preserved." (I9.74). According to King (20) it is "rather rare" round Sudbury. At Harwich it is fairly common and breeds (Kerry). Round Orsett, where there is very little woodland, it is "not common" (Sackett), but Dr. Laver speaks of it as "common in both the Colchester and Paglesham districts." Mr. Clarke states (24) that one or two were killed in most years round Walden, where in 1880 I knew of two nests, although I know the bird to be decidedly uncommon there, except round Chesterford, where Mr. Brewis tells me it breeds commonly. Mr. W. C. Emson of Littlebury also informs me that they breed there every year. It abounds among the woods and commons round Danbury and Little Baddow, and on Tiptree Heath. My cousin, Mr. R. IV. Christy, saw a specimen in Nightingale's Wood, Roxwell, on several different days during frosty weather in the winter of I881-82. This is a very remarkable occurrence, though it has on other occasions been known to remain till November. Mr. Fitch has once found the eggs in Hazeleigh Hall Wood.

specimen (29. Nov. $23 \& 30,1878$ ) which is said to have been preserved by Morris, a bird-stuffer, of Low Leyton, Essex, but nothing further is known about it. Ambrose of Colchester, through whose hands the specimen passed, did not believe it had been set up from a skin. 


\section{Family PICIDA.}

\section{Lesser Spotted Woodpecker: Dindrocopus minor.}

A rare resident, though it occurs from time to time, and is occasionally found breeding in most parts of the county, and is even common round Danbury.

Mr. Clarke mentions specimens, which occurred respectively one in the churchyard and another in a garden, at Saffron Walden, on March 2nd, 1830, one in Audley End Park in 1847 , and another on a walnut tree at the Roos, in February, I852. On June I4th, I88I, I saw a nest containing both eggs and young in an old rotten damson tree in a garden on the outskirts of the town. Mr. C. Walford records (I9) several killed at Braxted about 1838 . My uncle, Mr. David Christy, has a specimen shot at Stanford Rivers about I873. One was seen here several times about the middle of December, 1877 , and another at the end of November, IS79. Dr. Bree

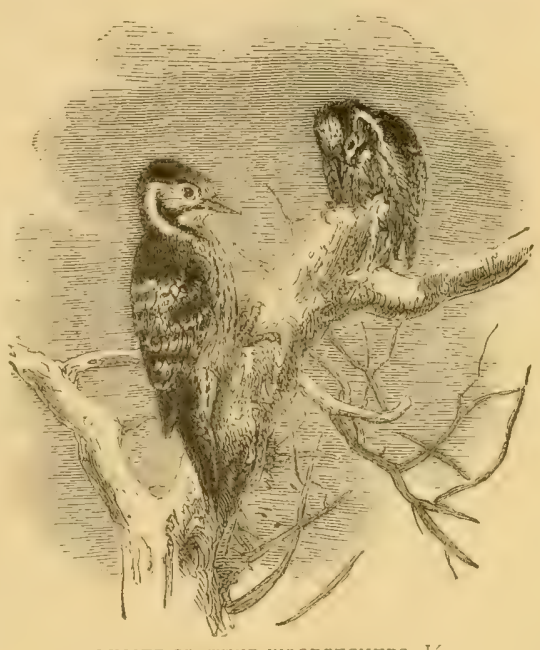

LESSER SPUTTED WOODPECKERS, I/3.

mentions one at Tiptree in April, 1870 (29. May 7). Henry Doubleday, in I\$32, says (IO), "I have seen it here [Epping] once or twice." Again, in $\mathrm{I} 840$, he wrote (IO), " $\mathrm{jt}$ is, as far as my observation goes, very rare [round London]. ***A solitary, straggling individual or two, is all I ever heard of anywhere round us." In the Forest, nowadays, however, Mr. Buxton says (47. 86) that it is " not very uncommon." Mr. Lister adds, "Three times seen in my garden at Leytonstone." English includes it (43.i.24) in his Epping list, as also does Edward Doubleday (15). A female was killed at Wix in February, 1888 (Spalding). Mr. Kerry records one (40. iii. I82) on February 2nd, I879, at Ramsey, where he says it is "very rare." Mr. Chas. Ed. Smith says (31. 53) that it is "occasionally shot in the woods of Mr. Honeywood, Marks Hall." Mr. Hope says it is common at Upminster, and observes that it "generally descends a bush or small tree tail first." It occurs in the Colchester district (Laver). The only part of the county where it is at all common seems to be that round Danbury, where Mr. Smoothy tells me he meets with it fairly often in the extensive woods. Mr. Fitch has known three or four taken in nets used to protect young peas in a garden at IVixoe, on the Stour, and has also seen it five or six times round $\mathrm{Ma}^{\prime} \mathrm{don}$,

\section{[Great Black Woodpecker: Picus martius.}

A doubtful British bird, which has often been erroneously recorded as occurring in the United Kingdom (on one occasion in Essex), but there is not sufficient evidence to justify its being regarded as a British species.] 
Great Spotted Woodpecker: Dendrocopus major. Locally, "French Magpie" (Saffron Walden).

A resident, though very sparsely distributed over the county. I have very seldom seen the bird.

Mr. Clarke describes it (24) as "not unfrequent in woods" near Walden. King says (20) it is "rare" round Sudbury, and Mr. Grubb writes (39), a specimen was "seen last winter (1875) by my children to fly across our river and settle among some trees on the other side." In the Parsons Collection is a specimen shot at Little Wakering in I848. In April, I883, I observed one here. It "occurs in Loughton Manor" (Buxton 47. 86). Henry Doubleday, writing from Epping in 1832, says (IO), "I have procured two eggs of the Pied Woodpecker this year. The bird is scarce here, and I never saw the nest before." However, both Edward Doubleday $\left(\mathrm{r}_{5}\right)$ and English $(43 . \mathrm{i}, 24)$ include it in their lists of Epping birds. Mr. Arthur Lister observed one in July, I888, in Wanstead Park, where he had formerly supposed it only a winter visitor. Mr. Hope says that it is "common" at Upminster, and Dr. Laver informs me that it occurs in both the Colchester and Paglesham districts. One was killed with a stick in Lexden Park in I882 (Spalding). At Harwich it is scarce, though it breeds (Kerry). Mr. Travis says that in the vicinity of Saffron Walden, where it is rare, it is known as the "French Magpie."

Green Woodpecker: Gecimus viridis. Locally, "Whetile," and "Yaffle", "Rain-bird" (E. A. F.) and "Heigh-ho" (E. A. F).

A fairly-common resident, especially in parks and thickly-timbered districts, as round Danbury, Epping, Maldon, \&c.

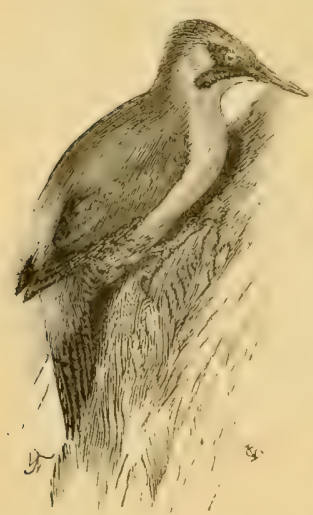

GREEN WOODPECKER, I/7.

According to King (20), it was "not uncommon" around Sudbury in 1838 . Mr. Buxton say's that it (47.86) " may be constantly heard tapping, and occasionally seen, in the northern part of the Forest ; very frequent about Cook's Folly, near Walthamstow." It is getting "more cummon than formerly in the Colchester district, but is decreasing in number round Rochford "(Laver). At Harwich it is scarce, though it breeds there (Kerry). Round Orsett, where there is very little woodland, Mr. Sackett says it is "not common," but adds that it is "fairly plentiful on and around the Laindon Hills." In the summer of $1883, \mathrm{Mr}$. Chas. Smoothy met with a nest containing young in a hole, which I have seen, in an elm-tree at Little Baddow, not more than two feet from the ground. (29. Sept. 15). Mr. Fitch found twelve new nests at Hazeleigh in 1888. The Rev. C. Swainson (48) gives "Whetile" as its name in Essex and Herts, which he says is derived from the Anglo-Saxon thwitan, to cut, whence also comes the Yankee verb "to whittle," according to Yarrell (14. ii. I37).

Wryneck: Ij'mx torquilla. Locally, "Snake-bird" and "Cuckoo's Mate."

A fairly-common summer migrant, usually first heard about the 
beginning of April and departing in September. In some years it is very scarce. In $\mathrm{I} 888$, I did not hear one near Chelmsford.

Round Orsett, Mr. Sackett describes it as a common spring visitor, but adds: "I do not think that all we hear in the early spring stay to breed, as I have only taken two clutches." King says (20) in 1838 , "This bird does not appear plentiful in our neighbourhood" (Sudbury), but Mr. Grubb says (39) it "never fails to give tidings of its arrival [there] about the middle of April." WVriting from Epping in 1832 , Henry Doubleday says (10), "This bird, which used to be heard a few years since in all directions, is now so

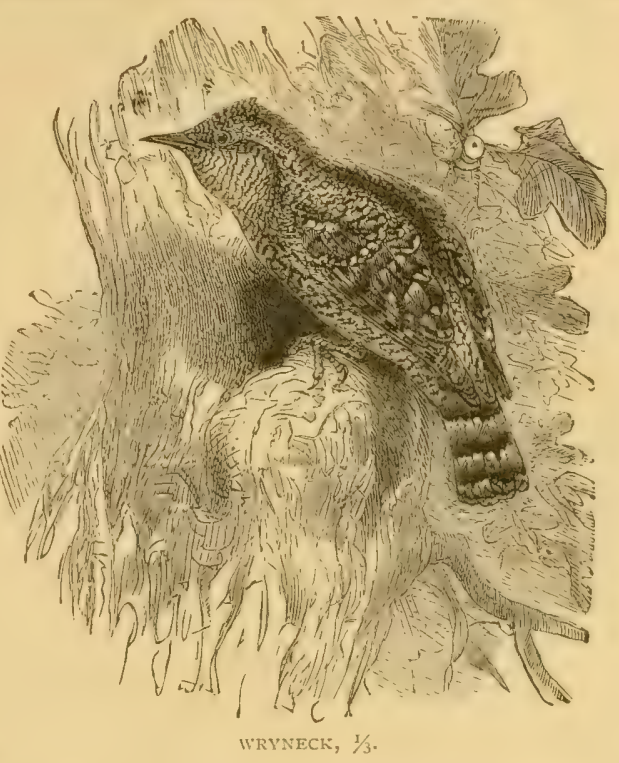
scarce that I have not heard more than three or four in the neighbourhood." In the following year he says, "This bird appears to decrease in number every year in the neighbourhood." Mr. Fitch has found nests several times in the Birdbrook District, twice at Maldon, and twice at Rayleigh.

\section{Family ALCEDINID $Æ$.}

\section{Kingfisher: Alcedo ispida.}

$A$ resident throughout the county, I beliere, though nowhere common. On the saltings round our coast, MIr. Fitch says it becomes much more common during winter than it is in summer.

Around Sudbury, King says (20) that it was "not uncommon," in I838. The Rev, J. C. Atkinson says (36. 98): "In my fishing and other excursions in Suffolk, Essex, Norfolk, and Herefordshire, I used to see many pairs; each, however, domiciled at some distance from its nearest neighbours. Mr. Buxton says ( 47.87$)$ it is "not unfrequently seen by the ponds and streams in the Forest. The

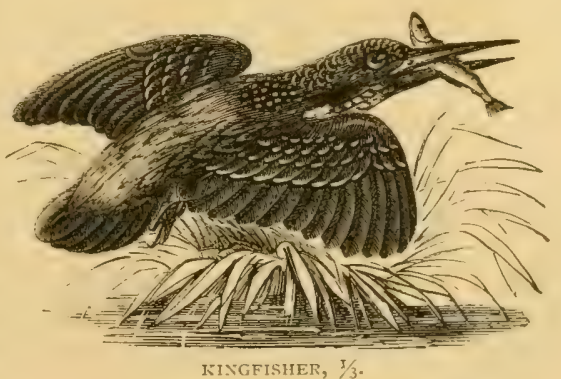


last I saw was a few weeks ago, when one flashed out like a streak of blue light ning from a ditch close to the Forest Hotel at Chingford."

In May, I880, a nest of young ones was reared in a hole in the bank of the brook Slade in the park at Audley End, in a position exposed to the view of every one passing along the public footpath running through the park. The nest itself was perfectly clean, but the hole was full of filth, which even streamed down the bank from the entrance.

They certainly breed here in the banks of the brook Cann, as 1 see them about every summer. On July 2 Ist, I876, a party of three flew very close to me as I was bathing. I believe it is not common to see more than one, or at most a pair, at once. Mr. Hope, who has reared young from the nest, has met with it breeding all over Essex, but says fresh arrivals take place on the coast about September. At Harwich "it is fairly common in the autumn" (Kerry). In the Orsett district it is a winter visitor only, frequenting the fens and saltings (Sackett). It nests every year in the floodgate hole at Baythorne Mill, Birdbrook (Fitch).

\section{Roller: Coracias garmla.}

A rare straggler to Britain, of which only a single specimen, so far as I know, has occurred in Essex.

In the Museum at Saffron Walden is a specimen shot at Great Chesterford Park in 1865 , and presented by Geo. Sanders, Esq. Presumably the specimen mentioned by Yarrell (37. ii. 429) is identical with this. One, caught at " Rainham " in I889 (40. xiii. 33), was taken at the village of that name in Kent, not in Essex.

\section{Bee-eater: Merops apiaster.}

This rare straggler to Britain during summer has been met with at least twice in Essex.

Mr. Thomas Catchpool records one (23. 4478) "shot in the garden of a mill close by the river's side in the parish of Feering * * * [not "Feeting" as stated by Yarrell (37. ii. 36)] about Midsummer Day [1854]" which came into his possession (3I. 53). Mr. Buxton mentions one (47.89) "observed at Wanstead by: H. I."

\section{Family UPUPID $\mathbb{E}$.}

\section{Hoopoe : Upupa epops.}

An uncommon, though, it may almost be said, a regular, passing migrant in both spring and autumn. Its appearance in Essex in the spring seems usually to take place between April I $5^{\text {th }}$ and May 7 th: in autumn, during September, though instances are recorded of its appearance in autumn as early as August 7 th, and as late as October 9th. The occurrence in Essex of at least one specimen is. 
reported in most years. There is little or no doubt that it would breed with us occasionally, were it not for the fact that its very striking exterior causes it to be shot immediately on its first appearance. It has been known to breed in Dorset, Hants, Sussex, Surrey, and elsewhere, but not yet in Essex, so far as I am aware, though the pair shot by Mr. Par-
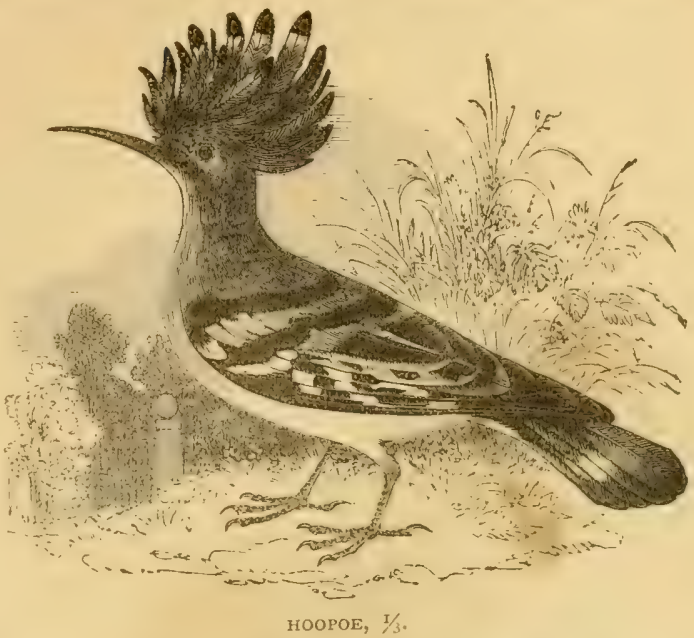
sons in $1 S_{39}$ would, in all probability, have bred had he not killed them.

Merrett says (I. I73) "in the New Forrest in Hampshire, and in Essexia, sed raro invenitur." Albin figures (3. ii. 39) a hen which he says "was shot in the garden of Mr. Starkey Mayos at Woodford, on Fpping liorest, where they had observed it for some time, and used all the means to take it they could; but it was so shy that it aroided all their traps which were laid for it, which the gentleman observing, ordered it to be shot." Buffon alludes to the occurrence of this specimen. The Rev. R. Sheppard seems to have met with it occasionally at Wrabness, as he notes its arrival there (see p. 42) on May 3 rd in I82I, on May

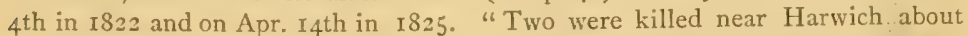
the middle of September [I832]" (Hoy-I2. vi. I50). Edward Doubleday, in 1835 , records ( 15 ) one "killed a few years since about a mile from the town," and English includes it as an "occasional visitor" in his list of Epping:Birds (43. i. 24). Mr. C. Walford (19. 47) records that one was shot at Wickham Bishops and another at Braxted about 1838 . Mr. Scruby of Ongar informs me that about fifty years ago, a specimen, now in the possession of Mr. Muggleston of Grays Farm, Ongar, was shot near that place and sent in a box, apparently dead, to Mr. Leadbeater of Golden Square to be preserved. On his opening the box, however, it flew round the room and was caught with difficulty. Since then Mr. Scruby has preserved two, one shot at Little Laver, the other at Villingale. Mr. Kerry has one shot at Harwich many years ago. On April 6th, 1839, Mr. C. Parsons shot a male at North Shoebury, and on the roth a female. Although he several times disturbed them they returned almost directly to the same spot, and, as there was a hollow tree near, he thought it not unlikely they would have bred (35). Henry Doubleday mentions (IO) one shot by Sir Edward Smijth's keeper in a wood near Epping about May 6th, 1840. In Kidd's Own Fournal (May 22,1852, p. 335) it is recorded that Mr. C. Walford had recently shot a 
female at Little Braxted, and that about two years previously he had seen one in Braxted Park (3I). Mr. T. Bramley, of 9, Winchester Street, Bethnal Green, writes (23.4895) that "a person employed on Tyler's Farm, near Low Leyton, being engaged in catching sparrows, had the good fortune to capture a young Hoopoe on the 7th of August last [1855]." It is quite possible that this may have been a home-bred bird. One was shot at Ashdon about the end of Sept., I856 (23.5319). Mr. P. Matthews, of Little Laver, still has a female which he shot there about 1858 (Essex Chron., Ap. 27th). Dr. Bree records one (23. 8034) shot in the rectory garden at Erwarton, in Suffolk, on the Stour, in the beginning of May, I862. Mr. W. Jesse records one (23.9627) seen by a gamekeeper at Woodbarns Farm, near Ingatestone, on and for several days after April 20th, 1865. Mr. Clarke records (24) that one, shot at Strethall in I840, was in the possession of the late Mr. Nicholas Parry of Strethall Hall, and that another was shot in Peverell's Wood, Wimbish, in I\$65. Dr. Bree records a male shot at Mersea about the middle of Apr., I87I (29. Apr. 22 \& 32a). Mr. H. A. Barclay records $(34.4035)$ that one was seen feeding for several hours on his lawn at Knott's Green, Leyton, in company with Starlings, Blackbirds and Thrushes, on May 3 rd, I874. It was very wild. Mr. Travis tells me that in 1876 he received five for preservation. In the spring of that year, two men picking twitch beside a wood at Ashdon, were followed all one day by a pair which ate the insects, \&c., they turned up. The Rev. M. C. H. Bird informs me of his having seen a pair at a farmhouse at Basildon, where they were shot about the year I878. About the end of Oct., I879 (Chelnisford Chronicle, Nov. 14) one was killed by some men at work on the railway near Felstead. One was seen for several hours to frequent a lawn at Great Bentley on April 24th, I880 (29. May 8) and (strange to relate!) was not molested. The Rev. J. Whitaker Maitland has informed me of one killed some years ago at Walthamstow. Mr. Buxton says (47.87), "One bird frequented a garden at Knott's Green for several days," about I881. One shot on September 2oth, I880, by Mr Elgie of the Oak Inn, Woodham Mortimer, on the confines of that parish and Danbury, it having been observed in the neighbourhood for several days (29. Oct. 2 \& 42.52). Mr. Travis records (44. iv. xii.) a young male shot at Wimbish on Sept. 30th, I882, and a female on October 9th following at Horseheath, Cambs, on the Essex border. I saw one beside a wood at Saddler's Farm, near Saffron Walden, on April 22nd, I $88_{3}$-probably the same shot shortly after near Royston. Lieut.-Col. Marsden has informed me of one shot near Walton-on-the-Naze about the year I885. Mr. Wm. C. Emson of Littlebury informs me that his brother has a specimen shot at Wimbish about the year I886. A male was shot at Little Walden on April 7th, 1886, and preserved by Mr. Travis (Chelmasford Chronicle, April I6). Mr. Reginald W. Christy of Boynton Hall, Roxwell, has one which he shot there as it rose from a damp ditch in which it was feeding, on May 3, r886. Mr. Hope has one, shot in mistake for a Jay at Forest Hall, Ongar, in May, 1886. He knew of three, all females, shot in Essexin that year. Mr. W. R. Sackett records one shot at Grays early in Apr. I888 (29. May 5th). One was shot at Langford Park during the first week of Sept., I 886 (4I. ii. 33 \& 29. Sept. I I). A male was shot at Willingale on Apr, 2oth, I 888 (Essex Chron. Apr.127th). Mr. Hastings Warren, of Little Dunmow, has one shot in that parish several years ago, when it was observed in company with another. 


\section{Family CUCULID $Æ$.}

\section{Cuckoo: Cuculus canorus.}

A common and very familiar summer visitant, arriving about the middle of April, or a little earlier, and leaves again late in August, though young birds often remain until much later. For instance, about the middle of Octolver, $\mathbf{1} 877$, a young bird was sent to Mr. Scruby of Ongar for preservation, and another was killed at the Swin Middle Lightship on Nov. 26th, I 885 (42).

Mr. John Smith, of Brentwood, possesses a specimen, killed at Upminster Common in June, I885, which he describes as being an adult female in brown plumage, the colour and markings on the upper parts being exactly similar to those on the hen Kestrel, while the under-parts resemble those

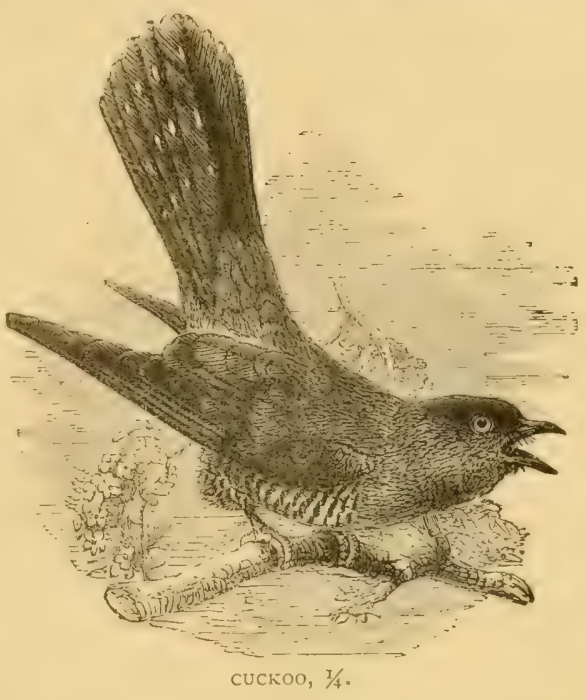
of a young Cuckoo. In the Museum at Saffron Walden is a specimen which Mr. Gurney describes as "the most beautiful specimen of a young Cuckoo he ever saw." Mr. Smoothy has one shot by himself in Mann Wood, Ashdon, in May, 1850 , which has the reddish back and tail of the young bird, while the breast is barred like that of the adult. It is a female, as an egg fell from it when shot. 


\section{Order STRIGES.}

\section{Family STRIGIDÆE.}

Barn Ow1: Strix flammea. Locally, "White Owl," "Grey Owl," "Billy Owl," and "Willy."

A fairly-common resident, breeding in old hollow trees, church towers, dove-cotes, $\mathbb{i}$ c. I often hear them after dark near Chelmsford.

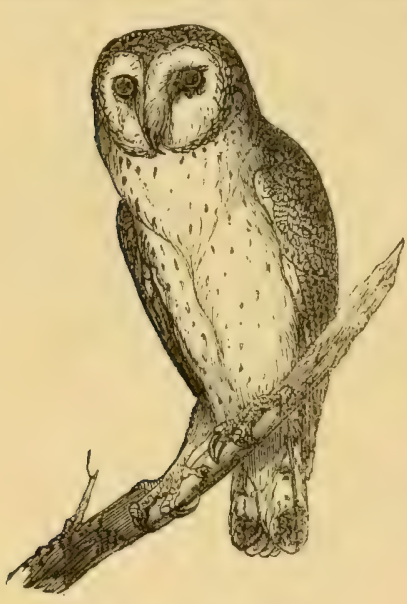

BARN OWL, $I / 6$.

No bird more richly deserves protection than this. It feeds almost entirely upon mice, shrews, and young rats, and rarely touches birds of any kind -a fact for which I can vouch, having paid much attention to the point.

Albin says (3. ii. II) that the specimen he figures was met with "in a field near Waltham Abbey, in the dusk of the evening, flying up and down, and now and then catching at the grass." He adds: "I desired my son, who was with me, to shoot him, and when we dissected him I found in his stomach several of the White Grass-moths and other insects." Mr. Buxton says $(47.83)$ : "I used to hear this bird nightly twenty years ago in Lord's Bushes, the old hollow trees of which it frequented. I am sorry to say it has disappeared from that locality." Mr. Grubb speaks of it (39) as "an almost constant resident " at Sudbury. They have for some years nested in the large disused railway sheds at Dagenham. The Rev. J. C. Atkinson writes (36.43):-

"My most familiar boy-acquaintance, however, was with the nesting-place and habits of a pair which nested for many consecutive years in a slight hollow in the crown of a large pollard elm tree in my father's churchyard [at Layer Marney] in Essex. There were usually three or four young ones year by year, often with perceptible differences of growth among them. * * * Quainter, graver, odder, stranger, more irresistibly comic creatures than these young Owls I never saw; and the hissing and snoring, and peering looks at the spectator, and strange anticcontortions I heard and saw, baffle all attempts at description. The entertainment, for such it was most truly, usually began some little time before sunset, about which time the old birds might be seen commencing their labours of purveying food for Masters and Misses Howlet. At intervals of from seven to ten minutes one or other of them came to the nest with a prey, and I could always tell by the sounds and gestures of the young Owls when the old one was approaching. How they knew I could not tell; it was not by sight, and I could hear no. 
sound myself; but know they did, most certainly. Mice, slugs, sometimes a large insect apparently, or a small bird, very rarely a mole or rat of no large dimensions, were brought in continuous succession, and in the claw, not with the bill. When the animal was of small dimensions, the old Owl flitted off again with scarcely any pause at the nest. If a large one, it seemed by the time which elapsed, and the sounds which became audible-most vehement snorings and hissingsthat partition had to be made, and that the said partition was a matter of the greatest interest to the parties concerned."

This is the same nest described by Mr. Atkinson's father in the first volume of the Zoologist (23. i. 384).

Fifty years ago, before scientific farming came in, and before a cheap, abundant supply of coal was obtainable in Essex, numerous large old pollarded trees stood in the hedge-rows in all parts of the county, and afforded logs for the winter fires.

"These were, I think," says Dr. Laver [50. iii. 33 ] "invaluable to the farmers, as they formed the retiring and nesting-places of numerous Owls. Most of these pollards are now gone, and with them have disappeared the Owls to a great extent. Formerly, rats were rarely found in the fields; but now, from the destruction of Owls and other so-called vermin, they abound, and may be found in almost every hedge. I think, could a balance be struck, it would be found that the Owl-tenanted pollard did not occasion anything like the loss to the farmer now caused by the numervus rat; and mice. * * The destruction, therefore, of pollards has, in my upinion, resulted in great injury to the county generally."

Henry Doubleday, on March 23rd, I843, says (10), "A short time since a person here [Epping] shot a common Barn Owl with the whole of the under parts, legs, \&c., of a deep ochre-yellow, with a few black spots. The face alone was white." He also records $(34.522)$ that in December, 1864, a similar variety was killed near Epping, having "the whole under-parts tawny yellow, spotted with black. The upper-parts were more mottled with grey than usual. It was a large bird and a female." These specimens, in all probability, belonged to the "very darkly coloured" Danish form of this bird, mentioned by Prof. Newton (37. i. I98) and Mr. J. H. Gurney, jun. (Birds of Norfolk, p. 22).

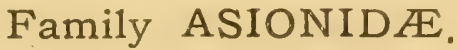

\section{Long-eared Ow1: Asio otus.}

A resident in many parts of England, but in Essex I think we can only regard it as a rather uncommon winter visitor. I never actually heard of its breeding in the county, except at Harwich, though it has probably done so elsewhere. It seems once to have been much more common than it now is.

Mr. Clarke says (24) that "one or two are killed every season round Saffron Walden." He mentions specimens killed at Newport in I829, at Siward's End on August 3 Ist, I $8_{3} 1$, at Wenden in $18_{33}$, and at Audley End (two) in $18_{34}$. Mr. Travis says they are now quite uncommon there. He received one shot near Ashdon on November Ist, IS8I. In I83 I it was "not uncommon in the wooded districts of Hadleigh and Hockley, and [was] occasionally met with in the more open parts and small groves at Southchurch, the Wakerings, and Shoeburyness" (Parsons). W. H. Hill (12. viii. 573) met with two at Southminster about 1834. According to King (20), it was "rare" round Sudbury in 1838 . One was shot at Stondon Massey on 
November I6th, 1876 (Chelmsford Chronicle, Nov. 23), and in 1880, English exhibited one shot at Magdalen Laver (44. i. xi). According to Mr. Benton (35.294), the screams of one of these birds caused the country people to regard as haunted a certain wood at Hockley. In Epping Forest it "has been obtained several times, and it would multiply rapidly if it were not so frequently destroyed by gamekeepers " (Buxton-47.83), while both English (43. 1.24) and E. Doubleday (I5) include it in their list of Epping Birds. It is common, and breeds round Harwich (Kerry). In the woods round Danbury, it is not rare (Smoothy). Mr. Fitch has one shot in the Maldon district. Dr. Bree writing on the "packing" of the Short-eared Owl (29. Jan. Io, I880), says :-

"Col. Hawkins informs me that at Alresford there are about fifteen of them, which take refuge in a fir tree, from which, when tapped, they noiselessly fly away, but return again when all is quiet. Fancy a covey of Owls! I have seen several similar instances recorded in the journals, especially the account given by Mr. Gurney, jun., who flushed a covey of, I think, thirty of these pretty birds!"

Later Dr. Bree again writes (29. Jan. 24, 1880): "Col. Hawkins has kindly sent me one out of the covey of Owls at Alresford. It is the Long-eared Owl, and not the Short-eared Owl, as stated in my former Ietter.'

Short-eared Ow1: Asio brachyotus. Locally, "Horn Owl," "Woodcock Owl," "Turnip Owl," and "Cabbage Owl."

A winter visitant, common in some years, but rare in others. I have one conclusive record of its having bred in the county, and it

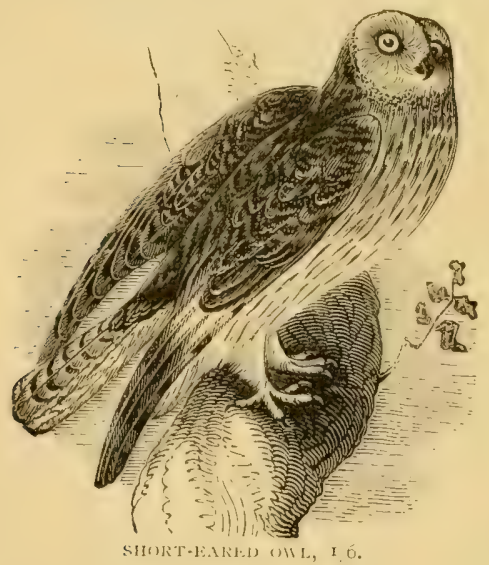
probably once did so abundantly. There are good reasons for believing that it also bred on the Walton Marshes in $\mathrm{IS}_{4}$ and again in $\mathbf{r} 889$. I believe that this species has never before been recorded as breeding so far to the southward in Britain. It is occasionally met with in all parts of the county, but most often near the coast, and it frequently gathers into small flocks.

Dale, who calls it the "Horn Owl," says (2. 396), "I have seen these caught in this county toward the sea, some of which may not unlikely [have]

be[en taken] here [Harwich]. These are that sort of Owl which Childrey *** mentions." King says (20) it was "not uncommon " round Sudbury in I838meaning, presumably, in the winter. Edward Doubleday met with it (15) in the Epping district, and Mr. Buxton says it is an autumn and winter visitor (47. 83). About I832, Mr. Parsons wrote (II) "that it was not uncommon on the marshes [of Rochford hundred] in the autumn, arriving in October, though by no means a regular visitant, and in some seasons scarcely one seen." Mr. T. S. Tiller notes that when shooting at Great Chesterford, on November 27th, 1879 , he sprung thirteen from some rough grass, eleven being on the wing at once (29. Dec, 13). 
Mr. Clarke's notes show that it used to be fairly common at Saffron Walden. He notes "several in 1854 " (24). They are now not uncommon there in winter, one or two reaching Mr. Travis annually. In the winter of $1880-81$, from the end of November to the beginning of March, they were very common, several sometimes being sent to Mr. Travis in the course of a single day. Just after the tremendous snow-storm of January I8th, a flock of twelve was seen at Littlebury and another of seven at Rickling. In the following winter they were again unusually abundant from November Ist onwards. On December 3oth, I88 I, I watched one for fully ten minutes beating systematically over the magnificent lawn between Audley End House and the River Cam. Twice while I watched it, it caught and ate something. At Orsett, a few are generally shot during the autumn (Sackett). Round Harwich, according to Mr. Kerry, it is common during the autumn migration. It was especially numerous there during the week ending Nov. 4th, I876, when a great many were shot (40. i.52). Mr. Kerry adds: "Whilst shooting on the Bentlings near Walton-on-the-Naze, on Aug. 4th, 1884, I saw three of these birds, two of which were shot. No doubt they were bred there." It is difficult to avoid the conclusion that they were really bred on the spot, as Mr. Kerry surmises, especially as Mr. Kerry informs me that a pair undoubtedly bred there in I8Sg. He writes:-

"They made their nest in the rough grass on an island, near Little Oakley, and some of the young $\mathrm{O}_{\mathrm{wl}}$ were caught before they were able to fly. I saw an old bird hawking over the bentlings in the sunshine on the afternoon of July 3 Ist" (40. xiii. 453 ).

In I884, one was observed at Languard Point as early as Aug. 20th (42).

Hollinshed, in his Cluronicles (1587. vol. iii.p. 1315), says :-

"About Hallontide last past [ 1580$]$, in the marishes of Danesey Hundred, in a place called Southminster, in the countie of Essex, a strange thing hapned: there sodainlie appeared an infinite multitude of mice, which, overwhelming the whole earth in the said marishes, did sheare and knaw the grasse by the rootes, spoyling and tainting the same with their venimous teeth, in such sort that the cattell which grazed thereon were smitten with a murreine, and died thereof; which vermine by policie of man could not be destroyed, till at the last it came to passe that there flocked together all about the same marishes such a number of Owles as all the shire was not able to yeeld: whereby the marsh-holders were shortly deliuered from the vexation of the said mice."

Stow, in his Annales of England (I605. p. II66), makes the same statement in almost identical words. In his second edition ( 16 I5), he again repeats the story, adding, "The like of this was also in Kent." Speed also mentions the circumstance. Joshua Childrey, too, in his Britania Baconica, or the Natural Rarities of England, Scotland and Wales (1660. p. I00), gives a similar account, adding "It is reported that in 1648 there happened the like again in Essex." Elsewhere he informs us that 1580 was " an extream dripping warm year, and a mild and moist winter." Lilly, in his Aferlinus Anglicus Funior, published about 1664 , also alludes to an invasion of mice at Southminster in I660. Childrey's account of the occurrence is often quoted, but curiously the earlier accounts seem to have been overlooked. All the different accounts of the invasion above referred to are obviously copied from Hollinshed, to whom credit should accordingly be given. It is clear, however, that the remarks by Fuller in his Worthies of England (1662. p. 348) are quite original and are not copied from Hollinshed or any other chronicler. He says:-

"I wish the sad casualties may never return which Iately have happened in this County [of Essex] : the one [in] $158 \mathrm{I}$, in the Hundred of Dengy (Stow : Chron. Anno Citat); the other [in] 1648, in the Hundred of Rochford and Ile of 
Foulness (rented in part by two of my credible parishioners, who attested it, having paid dear for the truth thereof), when an army of Mice, nesting in Ant-hills, as Conies in Burroughs, shaved off the grass at the bare roots, which, withering to dung, was infectious to Cattle. In March following, numberless flocks of Owls from all parts flew thither and destroyed them, which otherwise had ruined the country if continuing another year."

Not a few modern instances of the abnormal increase of this species (evidently the Short-tailed Field Vole-Arricola agrestzs), causing great damage, have been recorded, notably one in the Forest of Dean in $\mathrm{ISI}_{3}-\mathrm{I}_{4}$ mentioned by Jesse in his Gleanings. Other similar cases are referred to by Mr. Fitch in an interesting paper published in the Essex Naturalist (50, iii. I78).

\section{Tawny Ow1: Symium aluco. Locally, "Brown Owl."}

A resident in the county, but locally distributed. It is becoming rarer with us, and is now nowhere common. I have not heard of its

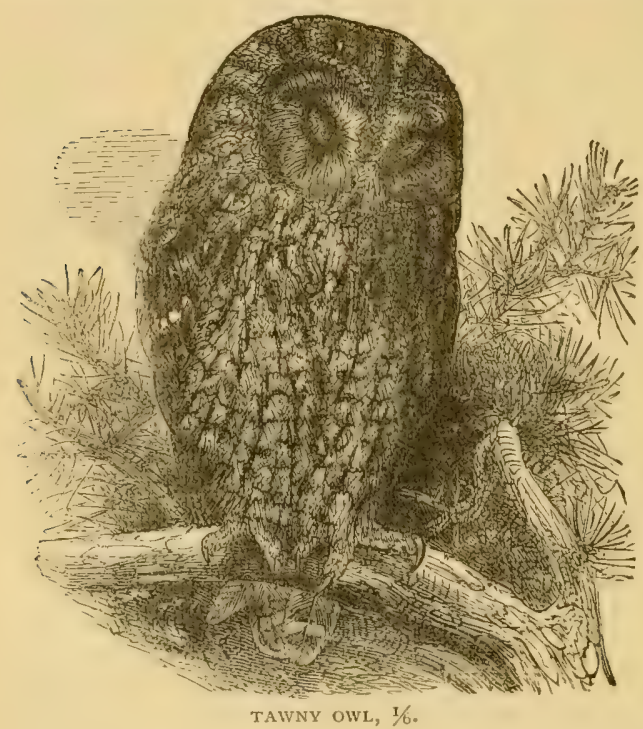

breeding anywhere, except at Birch, Danbury, Birdbrook, and Epping.

In I832, Mr. Parsons described it (II), as " common" in Rochford Hundred, and W. H. Hill (I2. vi. 452) met with it round Southminster about the same time. Mr. Grubb speaks of (I2. vii. I9) hearing it about ${ }^{1833}$ round Lexden. IV. D. King, in 1838 , described it (20) as "common," round Sudbury, but Mr. Grubb says (39) that it is "now very seldom heard" there. Mr. Clarke notes (24) the occurrence at Saffron Wal-

den about 1834 of two specimens, one of which is still in the Museum. They are now very scarce there, but occur occasionally. Mr. Travis received one early in October, 1880 . Both English and E. Doubleday include it in their lists of Epping Birds (43. i. 24, \& $\mathrm{I}_{5}$ ), and Mr. Buxton says $\left(47.8_{3}\right)$ that in Epping Forest they are "not uncommon; may be heard in the evening at almost any season; Monk Wood," implying that they breed. The Rev. J. W. Maitland also informs me that there is usually a pair in Monk Wood. At Boynton Hall, Roxwell, is a pair shot there about I850. Mr. Hy. Stephenson, head keeper at Birch Hall, informs me that they are still fairly common in the woods there, and that they breed regularly. Mr. Smoothy meets with it not uncommonly in the woods round Danbury and has known it breed there, also in Boreham Park, and at 'Toft's. They sometimes perch and hoot loudly on the chimneys of his house, Old Riffhams. Mr. Kerry says that round Harwich it is "fairly common," though he has never found the nest. It is common in the Colchester and Paglesham dis- 
iricts (Laver). Mr. Sackett says it is uccasionally shot in the Orsett district, but he has never known it to breed there. Mr. Fitch has its eggs which he took at Birdbrook.

\section{Snowy Owl: Nyctea scandiaca.}

There is no record of this large and conspicuous bird having actually been obtained in the county. It is a rare winter straggler to Britain, and is likely to have visited Essex, as it has been met with in Suffolk, and at least nine times in Norfolk. 'The following observations, however, must pass for what they are worth :-

Mr. John Pettitt, of Colchester, informs me that one was seen near Paglesham about $188_{3}-84$, while Mr. Hope informs me that he has "seen it on the borders of Essex at Christmas time." "Mr. Owen Boyle, of the Languard L.H., under date of February gth, Wind E., reports this species as shot by a visitur near the lighthouse. Subsequently, Mr. Boyle writes in reply to my letter, that he is sure the bird was a Snowy Owl." (B. A. Migration Report for 1885

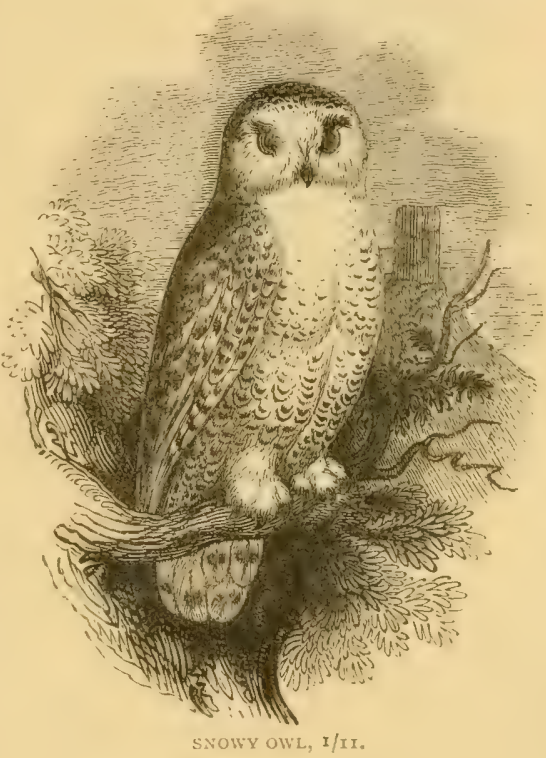
(42) p. 39). Further information from the person who shot it, or the present possessor, would be very desirable.

\section{Tengmalm's Ow1 : Nyctala tengmalmi.}

A very rare and accidental visitor, which has only once been met with in Essex.

Mr. Edward Bidwell relates (40. i. I77) that about the end of January, I877, some boys noticed a bird in a tree near the iron bridge in the Barking Road, Poplar, which on being disturbed was soon killed and taken to him, when he ascertained that it belonged to this species. The sex was not ascertained.

Scops Owl: Scops giu.

A rare and occasional visitant only to Britain, though it has several times been recorded in Essex.

Mr. Clarke notes (24) that two were taken at the Aviary, Audley End, about the year I82I. One, being only slightly wounded, was kept alive for sume time by Travis the keeper (I2. iii. I00; I4. i. II4 and 38.93). The approximate date of the occurrence of these specimens has not, I believe, before been 
recorded. Dr. Laver informs me that "for several weeks in 1854 a bird of this species rested in a privet hedge at Paglesham." Mr. Wm. C. Emson of Littlebury shot a male on June IIth, I888, near a large wood in Littlebury

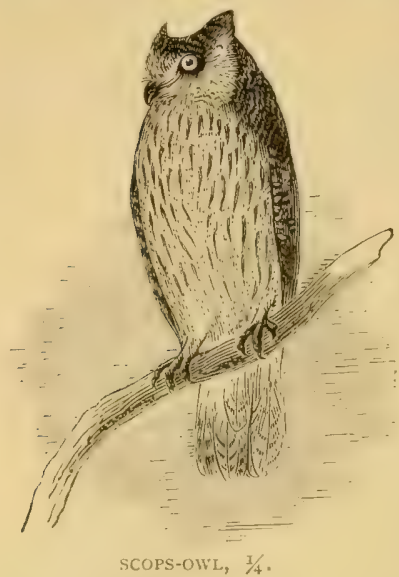
parish, known as Howe Wood, in which it had for some time taken up its abode (40. xiii. 30). Mr. Emson informs me that he believed there were at first two, as he shot at one about a week before and it appeared to fall among some clover, whither some boys ran to pick it up, but could not find it. Two are also said to have been heard previously. The bird used to commence its plaintive cry about halfpast eight every evening, usually when perched on some high elms about half a mile from Howe Wood. The cry is described by Mr. Emson as somewhat resembling the loud croaking of a frog, and the village boys tried to imitate it by crying "chalk, chalk." Its dismal cry was kept up the greater part of the night, and could be heard more than hall-a-mile off. The country people got quite superstitious about the bird and regarded it as an evil spirit, especially as it was shot at several times before it was secured, and several of them even asked Mr. Emson whether he thought shot would penetrate it. That gentleman says that the Owl did not appear to mind his approaching it below the tree, but concealed itself against a branch, all the while keeping up its curious cry, which appeared to come from a place quite different from that at which the bird really was. MIr. Emson got a boy to climb the tree and shot it as it flew out. In a letter, he adds:- "a neighbouring farmer says they have nested two years in succession in a rabbit's hole, about four miles from here, on the borders of Cambridgeshire, but have disappeared this year."

As this species has on several occasions been met with in Britain in summer, and on no less than four occasions since 1805 in pairs (38.93), and as it has once been recorded (though erroneously) as having bred here, I thought it well to make further inquiry into this statement. The supposed breeding took place, it seems, in I886 and I887, in Heydon Hill plantation, in the occupation of $\mathrm{Mr}$. Wm. Jonas, of Heydon Bury, who informs me that he several times heard strange Owls in the plantation, making " a peculiar noise-something like a child crying." It was, however, his gamekeeper, J. Ward, who first detected the birds in I886, and consulted Mr. Joseph P. Nunn of Royston as to what species they were. From Ward's description of their size and colour, that gentleman came to the conclusion that they must be Scops Owls, in which he was confirmed when Ward, on being shown the cuts in Yarrell, selected that bird. Mr. Nunn offered Ward a handsome present if he could find their nest, but this he was unable to do until the following year, when he found two young birds, from six to eight inches high, on the ground in the plantation. At the time, Ward had with him Mr. T. H. Wrycroft of Heydon, who has independently informed me that he saw the birds, which were small, dark brown, and on the ground, though he could find no nest. They seemed to have a hood of down. No one disturbed them. Mr. Nunn believes all Ward's statements in the matter are reliable. It is very 
remarkable, that in March, I889, Mr. G. IV. Brewis, of Chesterford Park, about a mile distant, noticed two singular Owls which remained for some weeks in a larch plantation close to his house. Though not seen, there is some probability that they were Scops Owls, for their note, which was described to me on the spot by both Mr. Brewis and his keeper, and which was heard every evening for half-an-hour, was not a hoot, being a metallic call, somewhat resembling the " toot" of a horn, pronounced regularly every half or quarter of a minute. The keeper (Harrington) is sure they were "Foreigners." The evidence is not altogether unsatisfactory, as the reports more or less corroborate one another, and the birds were seen in four successive years, while one was shot in the third. Still none of those who saw the birds were really competent to identify them, and it is probable they were only young Long-eared Owls.*

\section{Eagle Owl: Bubo ignavus.}

I have no record of this large, rare and showy species having ever been obtained in Essex, but Mr. Hope has "seen it on the borders of Essex in May and October."

\section{Little Ow1: Athene noctua.}

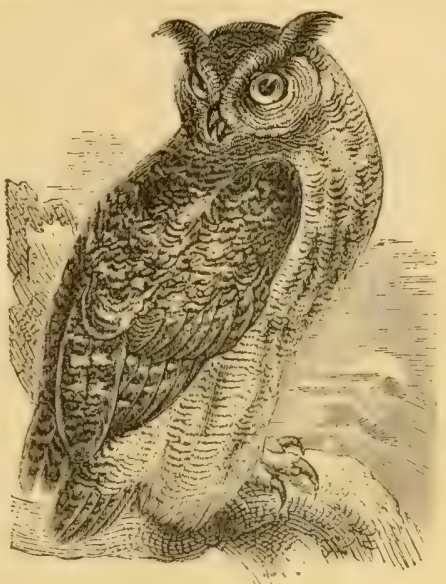

E AGLE-OWL, I/IO.

A rare and occasional visitant only to England. Its occurrence in Essex has only once, or perhaps twice, been recorded.

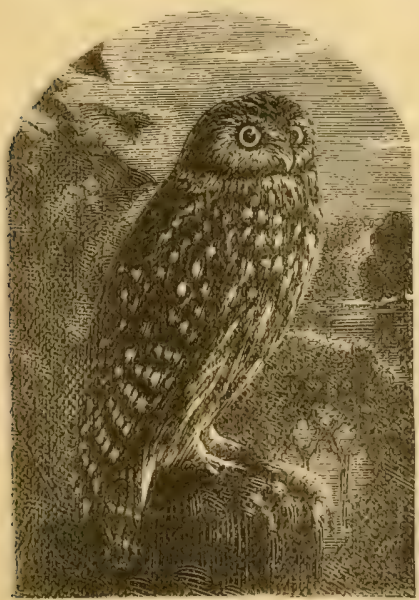

LITTLE OWL, I/4.

s. Mr. Edwin Ward records that on January 2 nd, IS65, whilst out shooting, Dr. Sewell found an adult female in perfect plumage and quite fresh, lying dead beneath a tree in a small fir-plantation at Chigwell. It had apparently killed itself by flying against a tree, as the skull and atlas-bone were fractured and th.ere was extravasated blood in the throat (29. Jan. I4, and 38.92$)$. It is now in the collection of Mr. Hope, of Upminster Hall.

Edward Blyth writes (12. ix. 624):-

"I was told this morning [October I8. I836], that about two months ago a person offered to the son of my informant ' a curious little Owl, no bigger than a Starling,' which had been just knocked down in the county of Essex. The youth not caring to have it, it was offered to another person for 2s., who refusing, however, to give Is, 6d. for the specimen, did not obtain it. What finally became of it I could not hear, but most probably it was thrown away."

* A specimen recorded (29. Oct. 25 th, 1879 ) to have been shot off Southend, on Sept, 25th 1879, proves to be an abnormal Short-eared Owl. 


\section{Order ACCIPITRES.}

\section{Family VULTURID $Æ$.}

\section{Egyptian Vulture: Neophron percnopterics.}

An accidental straggler to England, where it has only twice been met with-on the second occasion, however, in Essex.

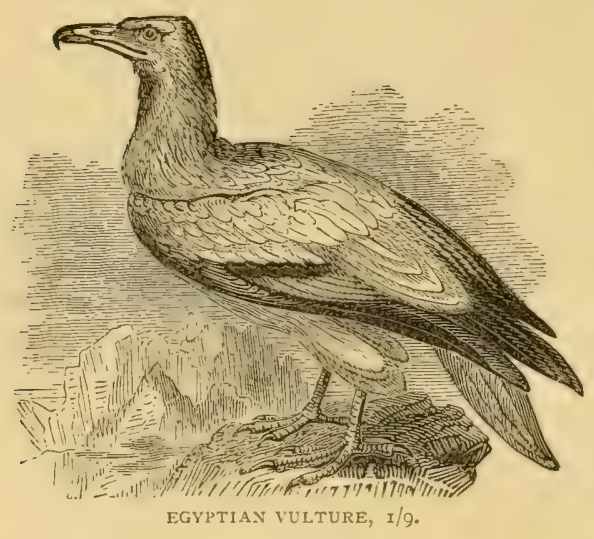

Dr. Bree says (34. I456 and 29. Oct. IO, IS68) :-

"On the 28th of September last the labourer who had charge of an off-hand farm of Mr. Woodward [not Woollard] of Stanway Hall, situated at Peldon, Essex, had been killing his Micnaelmas Geese. On going some time after in the yard where the said Geese had been slaughtered, he saw a strange bird feeding upon the blood. The bird flew away, and the man loaded his gun. Presently the bird came and hovered over the spot in hopes of another spell at the blood; but his fate was sealed, and he fell dead to the labourer's shot. I saw the bird next day at the house of Mr. Ambrose [birdstuffer'] of this place, to whom it had been sent for preservation. Mr. Woodward has since kindly furnished me with the above information $* * *$ Mr. Laver of this town informs me that many years ago his father, who lived near Burnham, further up the Essex coast than Peldon, had a flock of Vultures for several days among the large trees on his farm. They were known by their bare heads, and were most probably the Egyptian Vulture."

Dr. Bree further states that it was immature, and adds a detailed description. He lent the specimen to Mr. Gould, who figured it in his magnificent Birds of Great Britain. Its bones are now in Mr. Harwood's possession.

\section{Family FALCONID $Æ$.}

Marsh Harrier: Circus anuginosus. Locally, "Bald Buzzard," or "Puddock."

A rare visitor, though once breeding commonly in the county. It still breeds in some of the more remote corners of the British Isles, but will probably never do so again in Essex.

In I $832, \mathrm{Mr}$. Parsons wrote (II) :-

"Frequent in all the marshy districts [of Rochford Hundred], and formerly very common, remaining to breed in the corn or long grass on the marshes at Barling, Foulness, \&c., \&c. Now rarely seen but in the winter months." 
Mr. Edwards, of Ingrave, has a fine female shot by himself. King, writing in 1838 of the district around Sudbury, says (20), "This is, perhaps, the least uncommon of our larger Hawks." Mr. Clarke notes (24) the occurrence of one at Littlebury, on August Ist, I823; of one at Wenden in I828, obtained by Mr. Salmon; and of two at Saffron Valden in 1835 , one of which is now in the Juseum there. The Rev. M. C. H. Bird mentions one seen on Canvey Island, on Feb. 28th, I882. Specimens, generally birds of the year, are killed occasionally at Tollesbury (Laver). Mr. Hope says it is "not uncommon on the north-east borders of Essex near the sea." The Rev. J. C. Atkinson says (36.37) he used to hear it called "Bald Buzzard " in Essex, and he writes me that in his boyhood, some sixty years ago, it "bred in an old decoy at Tolleshunt D'Arcy." Fifty years ago, too, in the Paglesham district, Dr. Laver says (50. iii. 33):

"At the sides of those pieces of water locally known as 'fleets,' the Marsh Harrier would sometimes be found nesting amongst the sedges. *** I fancy few of these nests escaped destruction : all those I ever heard of were rifled."

\section{Hen Harrier: Circus cyaneus.}

Now a rare visitor, though there can be no question that it once bred commonly in Essex, as it still does occasionally in some of the wilder and more remote parts of Great Britain.

Graves says (7. iii.) that in his time (I82I) it was "not uncommon about the marshes of Kent and Essex, bordering on London," while as lately as the year 1832, Mr. Parsons described it (II) as "frequent on the marshes and along the sea-shore from Shoebury eastward." Albin figures a fine cock which he says (3. iii. 3) "was sent me by my honoured friend Sir Robert Abdy out of Essex." Mr. Clarke, writing

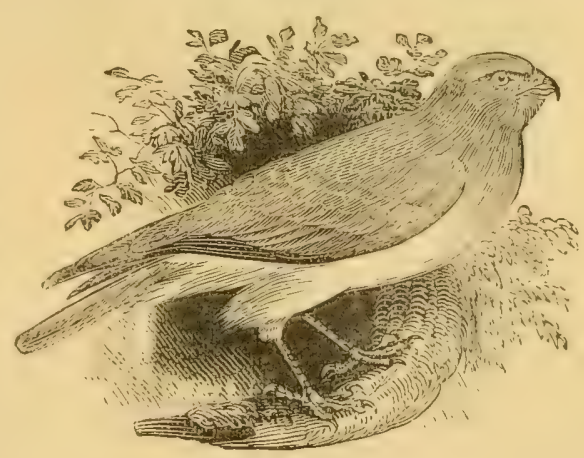

HEN HARRIER, adult male, I/IO. (After Bervick.) of the Saffron Walden district about I845, notes it (24) as having been "frequently taken "there then. He mentions a fine adult male, obtained at Ashdon, and there are several local specimens in the Walden Museum. W. D. King says (20) :-

"Driving one day with a friend on the Hedingham Road [out of Sudbury], we saw a large Hawk fly to the top of the tree by the side of the road near a wood. As we approached, it flew off, and (what appeared singular) it advanced towards us till within perhaps twenty yards, when it turned aside and skimmed over some fields to the left, thus affording us an excellent view of it. It was evidently a female of this species,"

Mr. Kerry says (40. iv. 69) that four were seen and one shot near Harwich, on December 5th, I879. The one that was shot had just struck down and killed a Gull that was teasing it. It did not attempt to follow the Gull, which was picked up by a man who then shot the Harrier. On or about Nov. Ioth, I888, one was killed at Tolleshunt D'Arcy (Laver). An adult female, with the remains of a Thrush in its crop, was shot at Walton-on-the-Naze oḅ Dec. 
2oth, I888 (Gunn-40. xiii. I 44). Mr. Harold Raeburn observed an old male on the wing at Bulphan Fen as early as Aug. 4 th, I889, and Mr. Pettitt received one shot at Boxted in Oct. following. Mr. Brewis, of Chesterford Park, has a young male taken there on Nov. 3rd, 1887. Specimens shot recently at Paglesham, Harwich, and Tollesbury have been preserved by Mr. Pettitt.

\section{Montagu's Harrier: Circus cineraceus.}

A rare and accidental visitor, though once fairly common in fenny districts. It has been known to nest several times in England

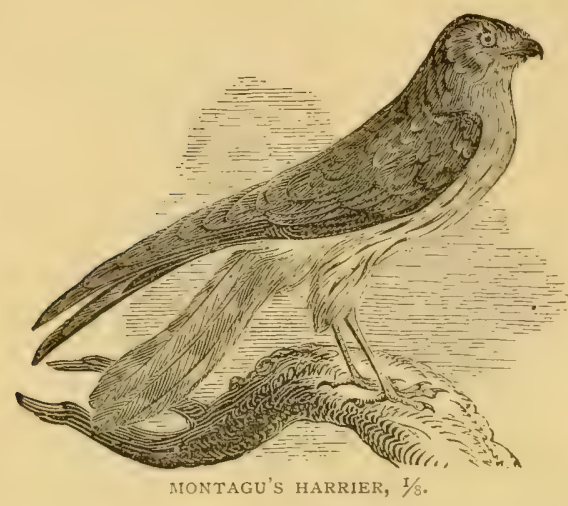
during the last few years, but not in Essex.

Henry Doubleday mentions (IO) having seen in I832 a specimen obtained near Colchester in a Collection there. Dr. Bree records "a fine specimen, in the rich dark red plumage of the young bird," shot at Bright. lingsea in Sept., 1867 ( $32 \mathrm{a} \& 29$. Sept. 28) ; also one shot about April 30th, IS7O, at Great Holland (32a. and 29. May 7). The former is still in Mrs. Bree's possession. Mr. E. A. Fitch informs me of one shot by Mr. Llewellyn Owen at Bradwell-on-Sea, about 1875. During the third week in November, I887, a specimen was trapped at Paslow Hall, and preserved by Mr. Scruby. In I879, Mr. 'Travis received one shot near IValden. On July 3oth, I889, Mr. Harold Raeburn observed a bird at Hornchurch, which he believes to have been of the species. On the IIth of the following month, and again on the 23rd, he observed a pair at the samespot, whichısuggests the idea that they may have bred in the neighbourhood.

\section{Buzzard : Buteo vulgaris. Locally, "Puttock."}

Once a common resident in Essex, as throughout the British Isles. It now breeds nowhere in the eastern or midland counties of England. From the following statements it may be gathered that although this bird bred not uncommonly in Essex among the woods in Rochford Hundred, and elsewhere near the coast, up to about the years I $8_{30-35}$, it had even then ceased to do so round Epping and Sudbury, and in other inland districts.

Mr. James Round, M.P., tells me that they not unfrequently visit his Park at Birch, where he has a tame one at the present time. Round Harwich a few are seen nearly every year (Kerry). Mr. Hope says it is

"often seen at Stubbers, near Romford. One was seen by the late Col. Russell eating a hare. On Sept. 29 th, ISSI, about noon, I saw three circling round slowly, off Woodbridge Haven, in Suffolk. When they attained a great height, they struck 
off in a S.W. direction, and were seen by Col. Russell the same afternoon passing over Stubbers."

In Rochford Hundred, about I832, Mr. Parsons described it (II) as occurring "chiefly in the woods at Hadleigh and Hockley, but not uncommon."

On an old map of this parish (Chignal St. James), dated I8Io, a field, now thrown into another, is called "Puttock's Leys," or "Puttock's Leaz, "which, being translated, means "Buzzard's.Mead, or Leys."

Mr. Clarke notes (24) that a young female was trapped at Saffron Walden in November, 1834 (now in the Museum); that another occurred shortly afterwards at Painter's farm; that another (also in the Mu-

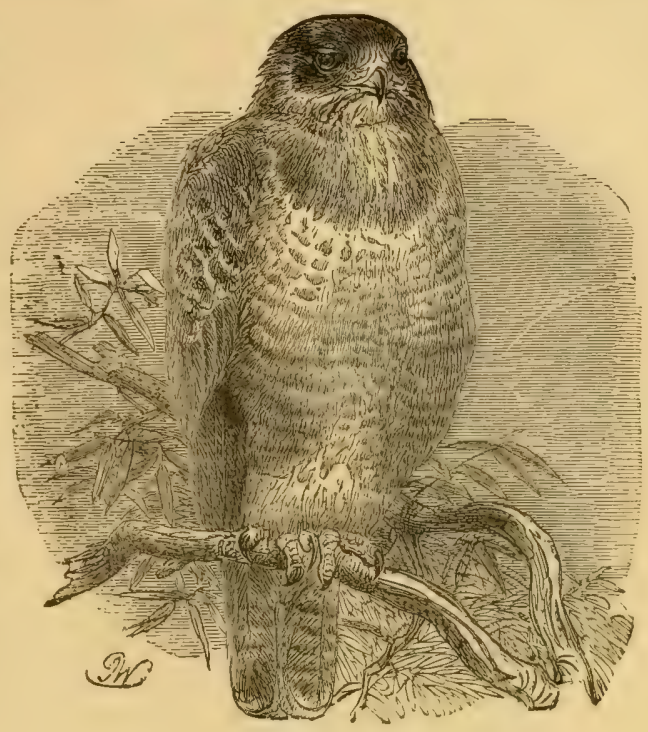

COMMON BUZZARD, I/7.

seum) occurred at Quendon in 1836 ; another near Saffron Walden on December I5th, I845; and that another (female) was trapped at the same place on January 25 th, 1853. King describes it (20), rather curiously, as "rare" in the district around Sudbury in his time. He adds, "I only know of one well-authenticated instance of its occurrence here." Writing of the neighbourhood of Epping in I835, Edward Doubleday says (15),

"The Buzzard and Kite are now extinct [here] (thanks to the gamekeepers) ; but the former $I$ have seen within four or five years. Previous to that time, I have very often watched them, soaring high in the air, over the Park Hall and Hill Hall Woods. They feed chiefly on small quadrupeds, toals, frogs and insects; but a toad is their most favourite dish."

Henry Doubleday; writing from Epping, says (IO) :

"This morning [September 8th, I840] one of the forest keepers shot a rather singular Common Buzzard. It is lighter coloured than any specimen of the Rough-legged Buzzard I have seen. The head, neck, thighs, and all the underparts are creamy-white, with a few oblong brown spots. I expect it is a male, as it is small, but I have not yet skinned it. It is the only Common Buzzard I ever had in a recent state."

English includes it as an occasional visitor (43. i. 24), while Mr. Buxton says, (47.8I) it "has been seen several times during the last few years." Major Ed. Taylor of Bishop's Stortford has one shot there about I850, and Mr. Gripper of Chelmsford another killed at Layer Breton about 1870 . A handsomely-marked male was shot in Short Grove Park by one of the keepers about October 6th, I88I. In its crop and stomach were the remains of a rat and two field-mice (44. ii. Ixxiii). Mr. Wm. C. Emson of Littlebury has one caught there in a baited 
trap in I887. Mr. F. Spalding informs me that a fine female in his possession was killed at St. Osyth in'188I. Mr. T. Aldham, of Ulting, has one shot there by himself about ten years ago. Mr. E. Curtis, jun. writes (29. 29, I88I) : On January 2oth, two Buzzards were seen hawking over the large reed-beds near "the Gulf," between Barking and Rainham. A man named Sutton shot another on the previous day.

The Rev. J. C. Atkinson writes (36. 35):

"I well remember as a schoolboy [at Kelvedon] in Essex, some thirty odd years ago [about 1830 ], that the nests of the 'Puttock,' as the Buzzard was invariably called in that district, were more frequently found by us than those of any other wood-building Hawk; and many a hatch of young 'Puttocks' it fell to my lot to see brought withiri the old school-gates."

\section{Rough-legged Buzzard: Archibuteo lagopus.}

A somewhat rare and irregular visitant chiefly during autumn and winter.

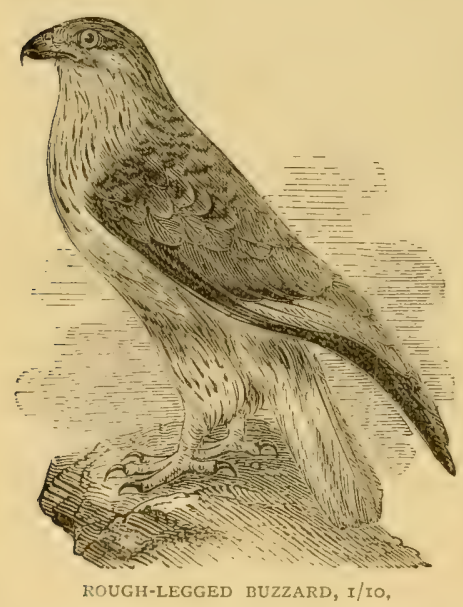

Mr. Hope writes it is

"common on the coast, first arriving at the end of September, but coming in flocks in very cold weather. I once saw twenty-five hawking rabbits over a tract of sand-hills within three miles of Harwich, and obtained three of them. In early autumn they seem to come from the east, but in winter from the north."

A pair killed many years ago at Epping were presented by Henry Doubleday to the British Museum, where they are still preserved (Buxton-47. 8I). Mr. Clarke notes (24) the trapping of a fine specimen (presumably the one now in the Museum, presented by S. Salmon) in High Baulk's Wood, Saffron Walden, on Mar. Ist, I8 36 , and the occurrence of another near IValden in Nov., I843. There is also a female from Epping presented many years ago by Henry Doubleday. Mr. Clarke also mentions the death of one at Shortgrove on Nov. 3rd, 1839. Mr. T. Brunton records one (23. 7844) shot by a keeper in Hatfield Forest, on Nov. I8th, I86r. Dr. Bree records that during the winter of I862-63, three were killed at Oakley, two of them being a pair (29. Mar. 7, I863). One was shot at Tillingham in or about Oct., I876. Mr. F. Kerry records (40. i. 258) a fine dark-coloured specimen shot at Harwich in Nov., I876. A fine female was shot by my uncle, Mr. David Christy, of Patching Hall, on Dec. I9th, 1879, after it had for about a fortnight frequented the meadows beside the Chelmer at Broomfield, where I myself made an unsuccessful attempt to obtain it. It was exceedingly fat (43. i. 63). About the middle of Oct., I882, one was shot near Berechurch by Samuel Palmer, a gamekeeper (Cholmsford Chronicle, Oct. 29th). One of a pair was shot near Manningtree on Dec. Ist, I879 (29. Jan. 3) astit was flying over with a full-grown rat in its claws. It is "frequent in autumn," in the Colchester and Paglesham districts (Laver). Mr. J.F. $T$. Wiseman informs me that one was shot at the latter place about the middle of Nov., ISSS. One was shot by Mr. Arthur Fitch at Whitley, Birdbrook, about Nov. 
I 3 th, I88S (29. Dec. 8). When shot it was flying close to the ground, mobbed by Rooks. Mr. Harry Garon of High Street, Southend, shot one near there on Oct. 28th, 1888, after it had been observed about for several days (Essex Chromcle, Nov, 16 and 29. Dec. 22).

\section{Golden Eagle: Aquila chrysaëtus.}

An occasional visitor only to England, and in fast-decreasing numbers, though known once to have been resident. It is frequently recorded as being killed in different parts of England, but in almost every case these records are found on investigation to relate to the White-tailed Eagle, from which it may be at once known by its feathered tarsus.

Mr. Hope says it is "seen passing up the coast and off the main." On March Ioth, 1877, a bird, supposed to be of this species, was seen flying over Easton Park. Being mobbed by Rooks and Jackdaws, it sailed away towards the S. W. (29. Mar, 24). A gentleman who saw it, and who claimed to be well acquainted with this species, was satisfied that it was not a young White-tailed Eagle, as he ha I a very good view of it, and was sure it had no white about it. A young specimen, which is still ipreserved at Nazing Park, was shot at Claverham Bury Farm, on Nov. I5th, I858, by Fredk. Carr, jun. Its weight was 9lbs.; length from beak to tail $3 \mathrm{ft}$. 4 in.; and expanse of wing $8 \mathrm{ft}$. $\frac{1}{2} \mathrm{in}$. (Mr. Villiers Palmer).

Mr. G. W. Johnson, in his History of Grat Totham (p. 8), which is dated September, I $8_{31}$, says: "An Eagle was seen a few months since in one of the adjacent woods, which is not a solitary instance, since it is upon record (Ray's Philosophical Letters, p. 269) that in Mr. Wilde's woods in this parish one was killed in I684, whose wings were nine feet in expanse."

\section{White-tailed Eagle: Haliaëtus albicilla.}

Now an occasional winter visitor only to England, though once a more or less common resident, and still much commoner than the Golden Eagle, under which name it is usually recorded when killed, but from which it may at once be distinguished by its bare and unfeathered tarsus. It usually occurs on the coast, and generally during severe weather. Adults are very seldom met with.

Hoy records (12. iii. 436) that during the cold weather in the winter of $1829-30$ one was shot in Stour Wood, near Harwich, while three other birds (apparently of the same species) for some time frequented the rivers Stour and Orwell.

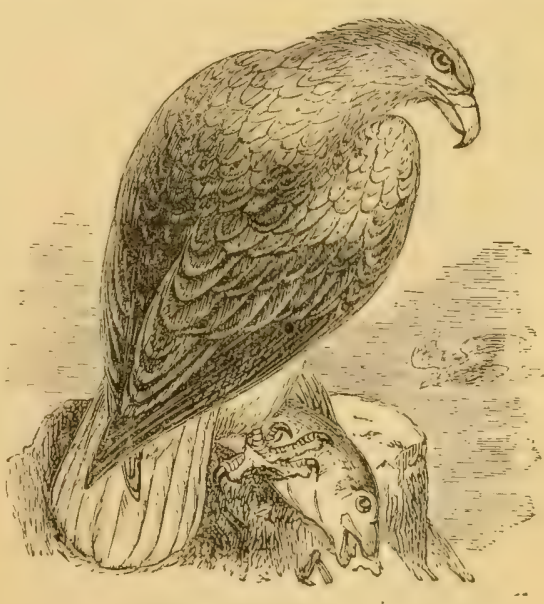

WHITE-TAILED EAGLE, I/I2. 
In Feb., I839, "A rery fine Eagle shot at Forest Hall," Ongar, was presented to the Chelmsford Museum (I9. IOI). Mr. Hope says it is "often seen passing up the coast; and is not uncommon off the main." In Rochford Hundred in I 832 , Mr. Parsons says (II) it used to be seen "on the shore, but very rarely; one killed at South Shoebury"-probably ithe fine adult shot there on Aug. Ist, 1835, and still in the Parsons Collection. Mr. E. F. Sheppard, son of the Rev Revett Sheppard, formerly rector of Wrabness, writing to T. C. Heysham of Carlisle on Jan. I9th, I8 36 , says (I 7) :

"Almost every winter we saw Eagles at Wrabness. Once, walking with my father on the banks of the river Stour, we saw four together. They there principally prey upon the Coots. It is a curious sight to see the Eagle drive up a flock of many thousands of Coots-perhaps, previous to the Eagle's visit, extending over more than a mile-into a thick knot, and to see them with fluttering wings scrambling over each other, some under vater, some above. The Eagle then, very deliberately, picks one up, and flies to the ooze; or, if in very serere weather, perhaps to some floating ice, where he devours his victim. If the silly birds would fly, they would be safe enough, for I am quite sure the Eagle cannot catch a bird on the wing. The Great Black-backed Gull assails the Coots in precisely the same way as the Eagle. A gunner once told me that he fired into a flock of Coots, when a Great Gull was hovering over them, and bagged sixtythree. I used to try all manner of schemes to shoot an Eagle, but 1 never succeeded. I was once within ten yards of one when I had not got a gun. They were sometimes shot by the fowlers on the river and the gamekeepers in the woods."

During Dec., 1879, "one was seen on several occasions on the marshes opposite Manningtree." It was repeatedly shot at, but escaped (Chelmisfor Chronicle, Dec. I9). A bird, presumably of this species, was seen in Takeley Forest about I 880 , by Mr. John Sheldrake, who still lives there. It was not obtained. Mr. Smoothy informs me that there is one at Hylands, shot there some years ago, and that one winter, about I883, one frequented his meadows at Danbury for nearly six months. During Nov, and Dec., 1887, one was frequently seen round Wyvenhoe, but the many attempts to shoot it were unsuccessful. In Dec., IS68, one was frequently seen and shot at round Wyvenhoe and Alresford (50. ii. 20 \& Chelmsford Chronicle, Dec. 30, '87). It was subsequently trapped at Thornham, Suffolk (29. Jan. 2, I869 \& 34. 1558.) Yarrell says (I4.i. I6) it has been shot in Epping Forest.

\section{Goshawk: Astur palumbarius.}

\section{A rare straggler to Britain.}

Mr. Clarke notes (24) the occurrence of a female at the Aviary, Audley End, in 1822 ; but, as it had a jess on one leg, it was certainly an escaped individual. It is still in the Audley End Collection. Hoy records (I2. viii. 53 \& 29. Oct; ' I2, I867) an adult male trapped by a gamekeeper upon the esta:e of Sir Joshua Rowley, Bart., of Stoke Nayland, which is just across the Stour, on March.I6th, 1833. This specimen is probably one of those still in his Collection. Mr. Hope informs me of one "shot by Mr. Lescher's keeper whilst hunting a French Partridge." Mr. Lescher does not know the present owner of this specimen.

\section{Sparrowhawk : Accipiter nisus.}

A fairly-common resident, but decreasing through incessant persecution.

Edward Doubleday records it ( $\left.\mathrm{I}_{5}\right)$ as "common" at Epping, in $18_{35}$. In 
March, IS78, one chased a sparrow into a stable at Priors, Broomfield, when the door being shut it was quickly killed, and on August 23 rd following, a young one killed itself by flying against a window, at Melbourne, about a mile distant from Priors. In Orsett district, Mr. Sackett says it breeds commonly, especially in the Old Ford Woods and Mucking Heronry. One nest he discovered in June, I885, was in the fork of a tree, only about six feet from the ground, so that he was able to reach it without climbing; and a clutch he took on the I 7 th of the same month was deposited in a portion of the nest of a Carrion Crow that had been pulled from its original position, but had lodged on some branches.

Kite : Milvus ictinus. Locally, "Crotchet-tailed (or Crutch-tailed) Puttock."

Now practically extinct, though formerly abundant. It has been known to breed once or twice in Britain during the last few years, but will probably not do so for long. In Essex, no specimen

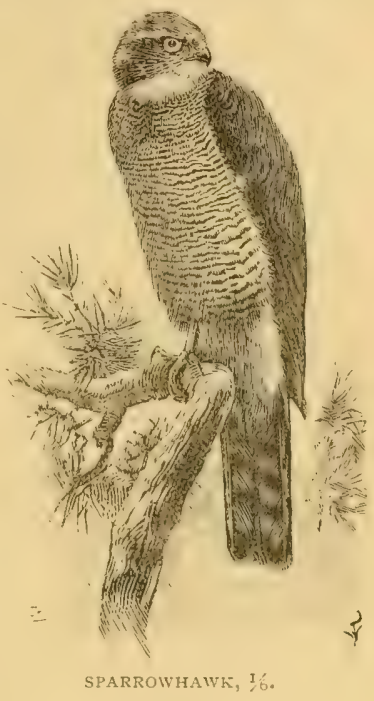
has been recorded for many years, and records show that it

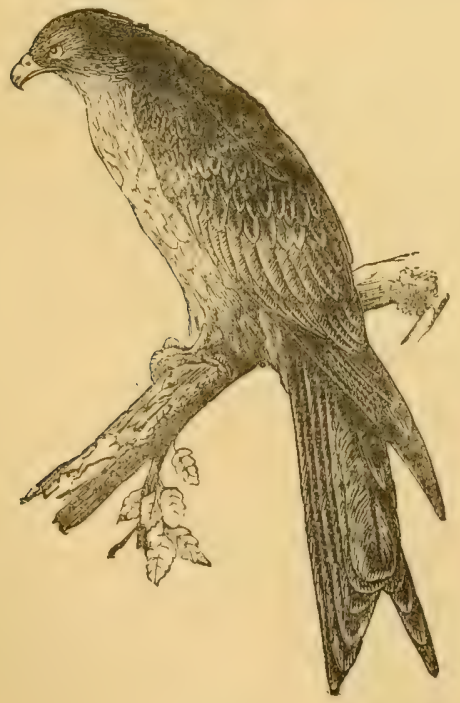

KITE, I/8. had become scarce by the end of the first quarter of the present century, though a nest, mentioned below, is said to have been built at Mersea as late as I 845 .

Mr. Clarke notes (24) the occurrence of one, obtained by Mr. Stephen Salmon, at Newport, in I\$29; of a male (now in Walden Museum) obtained at Ashdon about $\mathrm{I}_{3} \mathrm{O}$; and of another at Debden on June 22nd, I837. Probably the last-named is the male from Debden, now in Walden Mluseum, presented by the Hon. Lindsay Burrell. The date of its death indicates that it must have been breeding. Mr. Clarke writes me: "The-last I saw was about ten or twelve years ago.. It sailed orer so low that it was within gunshot." "J. C.," of Witham, writing in March, 1834, says (I2. vii. 5 II):

"We have a few about us. It is provincially called the "Crotchet-tailed Put'tock.' One flew over the garden a few days ago, mobbed by several Rooks. 
The gardener, on seeing this bird, remarked, "What fierce things they are when. they have got nests. I was along with a boy once who got up to one, and the old one piciked a hole smack through his hat, and scratched his hand properly before he could make her go off the nest. There used to be a good many of them about here once, but there are not many of them now.' This last remark is perfectly correct."

In the Epping district, notwithstanding the extent of the Forest, they had, "thanks to the gamekeepers," become extinct as long ago as 1835 , according to Edward Doubleday (I5). King, in I838, says (20):

"About ten years ago, whilst walking across Friar's Meadow [Sudbury], a gentleman pointed out to me one of these birds, wheeling in the air at a considerable height above us. Its forked tail at once distinguishes it from every other British Hawk. It has become scarce in this district."

Canon Babington (46.32) speaks of one "mentioned to Mr. Hills as having been lately (I880) seen flying over Sudbury," and adds that "two specimens in. the Hoy Collection are considered [by Mrs. Lescher] to be from the neighbourhood " of Stoke-by-Nayland. Dr. Laver informs me that in 1854 he approached near to an unmistakable individual at Paglesham, but refrained from shooting. it, although he carried a gun, and had a good opportunity of doing so.

Mr. Edward Corder, of Writtle, says he can remember their breeding in the HighIVoods. Mr. Hy. Stephenson, head-keeper at Birch, tells me that he has heard of a "Crotch-tailed Puttock's" nest which was built in Stroodland Grove, Mersea, about the year I845. In I8SI, Mr. Travis showed me a fine old male said to have been shot at Sampford, about I872, " in the middle of summer." The Rev. J. C. Atkinson writes me: "As to the Kite, all I know was that some of my school-fellows knew of a nest not far from Kelvedon." This must have been about sixty years ago.

\section{Honey Buzzard: Pernis apivonis.}

Formerly a not uncommon summer visitor, but now rare. It still breeds occasionally in England: but, so far as I have been able

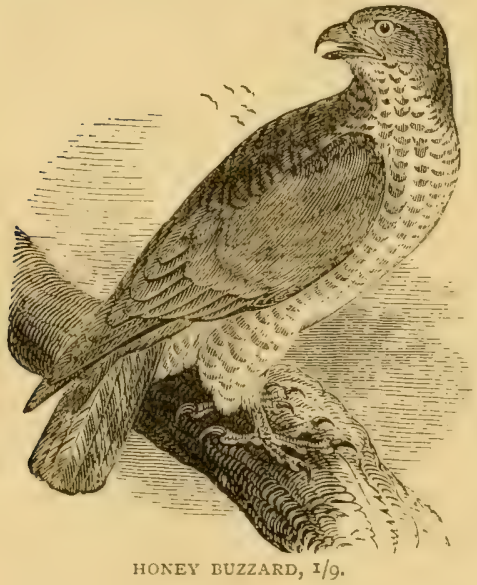
to discover, there is no actual record of its having done so in Essex, where, however, it still now and then occurs as a passing migrant, usually in the autumn, though very rarely in the spring. In September, I88I, several occurred in Essex, and in other parts of the comntry.

Mr, J. D. Hoy records (I2, v, 280) that a male was shot on October I2th, I8 3 , in Tendring Hall Park, which is in Suffolk, just beyond the Essex boundary. It was very fat, and had remains of wasps and beetles in its crop and stomach. Mr. Clarke notes (24) that a very handsome bird was shot in I 837 by Harrington, the keeper at Debden Hall, and was lately in the posses- 
sion of one Watson, a tailor, at Newport; that another was obtained at Sandon in 1840 ; and that another very fine specimen, said to be a male, was shot at Audley End on June Ist, I838. It was very tame, and "had assumed the ashcolour on the head." Dr. Bree (32a) mentions "a female in breeding plumage" shot at Wyvenhoe Park in $\mathcal{F u n e}$ 1867, and preserved by Cater for Mr. Hector G. Rebow. Mr. Travis remembers (44. ii. Ixxiv.) that a specimen was shot at Newport about fifty years ago, and about forty years ago in September he himself shot one, which is now in Lord Braybrooke's Collection, at Audley End. A few days later another was shot almost at the same spot. He also records (44. ii. Ixxiii.) one shot near Strethall in September, about the year I876, as it was ransacking a wasps' nest. It was an old male, and is now in the possession of Mr. Edmund Emson. Mr. Travis very seldom receives them now. Mr. Wm. White records one (44. ii. lxxiv.) caught on a hedge at Aveley on September

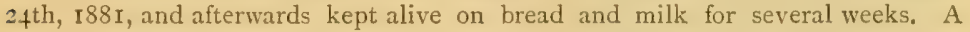
wasps' nest was discovered within a few feet of the spot. Another bird of the same species was seen about on the same day and for a month afterwards. On one occasion it was mobbed by Wood-pigeons.

Sir T. Fowell Buxton records (44. ii. Ixxii. \& 29. Oct. I) that he saw a specimen near the same spot on Woodredon Hill, in Epping Forest, on three consecutive days, 23rd to 25th September, 188I. Sir Fowell says that on the first occasion,

"it rose from a bush of beech close to my feet, and flew with rather a heavy flight to an oak about twenty yards off, where it remained for a few seconds. On examining the bush I found it swarming with ivasps, which began to ily out on my touching the bushes. I then found pieces of wasps' comb lying on the ground outside the bush, and the dead leaves scattered around.'

The following day,

"on approaching the spot, we again saw the bird flying over the trees away from us. Much more of the wasps' comb was lying about, and a large cavity could be seen under the branches, where the nest had evidently been scratched up and the contents strewn around."

On Sept. 26th, I88 I, a young male (?) was shot (44. ii. lxxiii. \& 29. Oct. I) in the rectory garden at Great Chesterford and sent to Mr. Travis for preservation. When shot it rose from near a large wasps' nest, but Mr. Travis and myself found in its stomach what appeared to be the remains of grasshoppers, small beetles, and other insects. The bird was very fat. About the same time another example was shot by one of Lord Braybrooke's keepers, near the Aviary at Audley End. It is now in the Collection there. Mr. Charles Smoothy shot a very fine female at Little Baddow on May I8th, I888 (29. June 2). Its stomach contained the remains of beetles and caterpillars, together with the shells and yolks of eggs. He has one shot at Elmdon some years ago. Mr. Hope says it passes over regularly every year, and mentions one shot at Upminster early in Oct., I888.

\section{Greenland Falcon: Hierofulco candicans, or It is impos-} Iceland Falcon: Hierofalco islandus. J sible to decide to which of these two species the specimens recorded below réally belong, as they have, until recently, been lumped together as "Gyrfalcons." Both are rare winter visitors to Britain.

C. E. Smith, of Coggeshall, records one (3I. 52) "shot close to the town by Mr. William Gardiner, I 855." Of its present whereabouts, I know nothing. 
Mr. J. Pettitt, of Colchester, informs me that, in Feb., I888, one visited

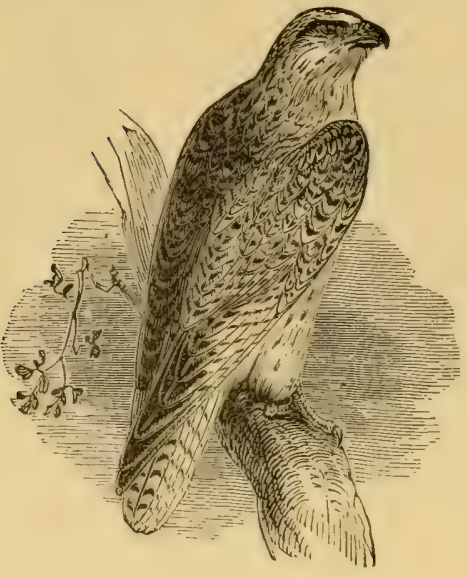
Paglesham, where his uncle, Mr. R. Pettitt, made various unsuccessful attempts to obtain it; one day, when he had no gun, he was able to get near enough to see distinctly what it was. Mr. J. F. T. Wiseman informs me that one was shot there about the middle of Nov., I888.

GREENLAND FALCON, I/IO.

\section{Peregrine Falcon: Falco peregrinus.}

Now only an uncommon and irregular winter visitor to Essex, though it still breeds not very rarely on high rocky cliffs in other

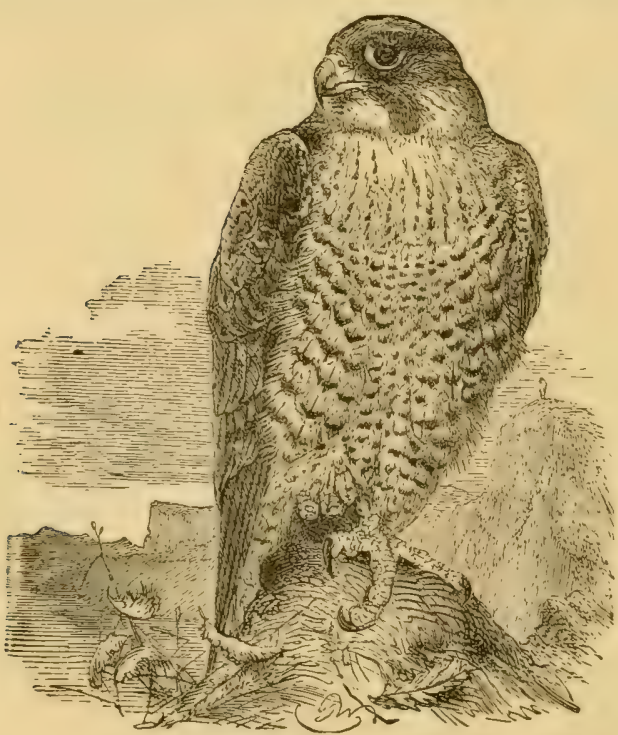

PEREGRINE FALCON, $1 / 6$. parts of England. It certainly does not now breed in any part of Essex, and Mr. Clarke's record of its having bred - presumably in a tree, which is unusualat Sampford as lately as 1843 , is very interesting. Most of the specimens met with are immature birds of the year.

IV. D. King says (20) that in the district around Sudbury it was rare in his time. He adds :-

"In the winter of I835-6, a splendid female was shot in a meadow close to our town by a gentleman who kindly presented it to me. The following winter, I received a fine adult male specimen shot at Borley." 
Both these specimens are now at Birmingham. Mr. Parsons says (II) that in Rochford Hundred in his time it used not unfrequently to be seen on the wing, though very rarely killed. His father shot a female on New England on Jan. 28th, I832 (8). Mr. C. E. Smith of Coggeshall records one (3I. 52) "shot by the keeper of - Hawkins, Esq., I857," and another shot near Colchester in 1858. In 1859, "G. S." sent to the Field office a young one shot at St, Osyth, on Oct. Igth, "in the act of eating a Wild Duck, which it was seen to strike down (29. Oct. I5). Mr. John Porter of Saffron Walden has a young male (?) which he shot about 1860 in a wood close to the town as it was devouring a Kestrel, now stuffed with it and placed in its claws. Dr. Bree records (32a) a female shot at St. Osyth [about I865], "a very fine old tiercel" killed after it had struck down a Drake at Tollesbury on Apr. 8th, I868, and a male shot on Pewit Island on Oct. 20th, I868, as it was killing a shrieking Golden Plover. Early in Dec. 1873, one was shot at Southminster (29. Dec.6, and 34. 3830). About the middle of Dec., 1879, one was observed at Bradwell "in pursuit of a flock of Wigeon; singling out one of them he struck it down, and was in the act of devouring it, when he was shot by a man named Linnett" (Chelmasford Chronicle, Dec. 26). During .I880, Mr. Travis of Saffron Walden received for preservation (44. i. Ixiii.) no less than four specimens killed in that neighbourhood:-One at Loft's Hall by a gamekeeper ; another trapped in Nov, by one of Lord Braybrooke's keepers at a Moorhen on which it had been feeding. On Sept. 27 th, I880, I saw a pair flying over high up near Thaxted, and on Jan. I Ith following I saw near. Audley End a single bird which I have no doubt was of this species. Mr. C. H. Hills of Feering has a fine young female (?) shot by himself at Messing on Oct. I th, ISS 5 , whilst it was pursuing some Ringdoves. Another,with it at the time, escaped. Mr. Benton says (35.198) that on Foulness "The Peregrine, locally known as the Puttock [?], is a frequent visitor," but this is probably an exaggeration. Mr. Hope writes that it is "common on the Blackwater and Thames. One pair on the Blackwater used to wait for the Gulls flying out of the mouth of the river and took a pair each time." Mr. Stanley Edwards shot a remarkably large female, measuring twentyone inches in length and weighing thirty-six ounces, at Langham on Dec. I2th, I884. Mr. Kerry says "some are seen every year round Harwich." He records (40. i. 258) two females on the Stour, one shot in the act of stooping at some Sea-gulls, the other after it had killed and commenced to eat a IWood-pigeon. They are not unfrequently met with at Paglesham (Pettitt). Mr. Buxton says (47.8I) a pair "were killed some years ago on the Copped Hall Estate." Mr. Stacey preserved a specimen shot at Dunmow in the month of July, I887. In Jan., ISS9, a wounded specimen was picked up on the marshes near Stratford (40, I06). During March, 1889, one was trapped by a keeper at Forest Hall, Ongar, and preserved by Mr. Scruby ; and I understand that several were killed by keepers at Hylands, Widford, in the following autumn. Mr. Pettitt preserved a fine female, weighing two and a half pounds, shot by Dr. Salter on his marshes at Tollesbury on Nov, 16 th. gives

As regards its breeding in the county, Graves says (7. i.) that the figure he

"was coloured from a very fine specimen communicated by Mr. Bullock, who received it from a gentleman resident near Harwich [? Rev. R. Sheppard], who is particularly conversant with the hawk-tribe. He took this, with several others, from the nest and has kept them several years. Our bird is in the last state previous to its arriving at the adult plumage."

The Rev. J. C. Atkinson writes me that he never heard of a nest in Essex, even in his boyhood, but Mr. Clarke notes (24) that a pair bred at Sampford in 
the summer of I843. The male and female (both being fully adult), and three young (which are now in Saffron Walden Museum) were all taken in the month of July. In a private letter, Mr. Clarke informs me that he still recollects the occurrence. He also states that a specimen was trapped at the Aviary, Audley End, in 1823 ; that a fine male (now in Saffron Walden Museum) was killed at Ashdon on Dec. 2 Ist, I835; and that another specimen in moult was killed at Saffron Walden in 1844 .

\section{Hobby : Falco subbuteo.}

A summer visitor, which used to breed commonly in the county, but is now scarce, though instances of its having nested here within

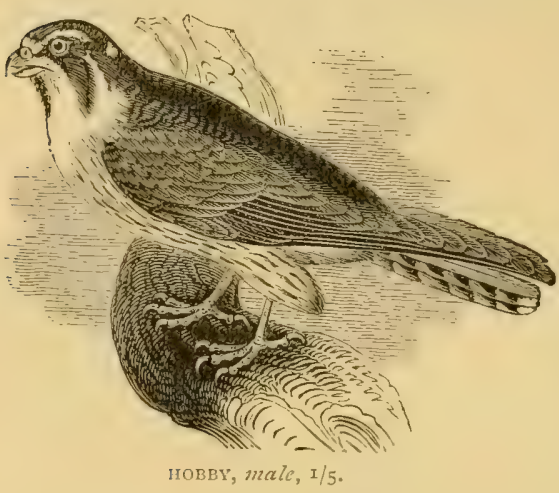
the last year or two are not unknown.

Mr. Clarke notes (24) that a pair, both of which were shot, nested at Debden in 1829 , and that another pair nested there in I835. These were also shot and their eggs taken. One or other of these pairs is now (or was recently) in the Walden Museum. Another pair, with their young, were taken at Walden in 1843 . In the Walden Museum are the following specimens:-An adult male from Debden, a young male, and iwo adults, all from Saffron Walden; the two latter in 1844 and the spring of I858 respectively. Henry Doubleday, writing at Epping on September 2oth, I 839 , says (IO) a remarkably fine one was shot there a few days earlier. He also mentions (10) killing a male at Lexden in 1832. About Epping, it was already "very rare" in I835, according to E. Doubleday (I5), though English (43.i.24) styles it an "occasional visitor." Henry Doubleday says (23. I3) it "occasionally visits us in the spring, but its appearance is very uncertain." Yarrell says (30. i. 54), "Mr. Doubleday has obtained two specimens in the vicinity of Epping, and I have one that was shot near Bishop's Stortford." Mr. Parsons describes it (II) as having been "rare" in Rochford Hundred in I832, but W. H. Hill wrote (I2, vi. 452) in 1833 that it was "very destructive to Larks" round Southminster, as though then fairly common there. IV. D. King says (20) that it was rare in the district around Sudbury in his time. He says :

"Returning one evening last summer from a little excursion down our river, a Lark passed over our heads hotly pursued by a pair of Hawks-I believe of this species. We watched the pursuit with intense interest, and were glad to believe that the poor little Lark at length escaped them. This, at first, we thought almost impossible, as the Hawks darted at it alternately, giving it no respite : but, as the chase led across the meadows in the direction of the town, perhaps the pursuers felt a little intimidated, as they appeared to lose their quarry among some trees, afterwards pursuing a straightforward course till they were lost in the distance. 1 once witnessed a similar chase along the shore at Walton, in Essex. Whilst writing this, I received a letter from an ornithological friend in Essex, who writes 'Last night a boy brought me the finest adult Hobby I ever saw. I asked him where he got it. The boy said, "It was eating our peas (!!!) and father shot it." " 
Mr. J. H. Hills of Feering has a fine old female shot by himself in Prested Hall IVood (now stubbed) about! I859. Writing at Coggeshall in I860, Mr. C. E. Smith describes it (3I. 52) as being "frequently shot in this neighbourhood." In Sept., I870, Mr. Scruby set up one shot by Mr. Cox at Margaret Roothing (29. Sept. 24). A female was shot in the grounds of Coval Hall, Chelmsford, by my cousin, Mr. Jacob Marriage, early in April, 1877, and early in September, I878, a male was shot in Nightingale's Wood, Roxwell, by my uncle's keeper, who was of opinion that a nest had been reared that summer in the wood, and that there were other birds about at the time ( 5 ग. ii. 37). On Nov. 27 th, I 879 , I saw here what I have little doubt was one. Mr. Hope, who has one shot at Shalford in the autumn of I875, says it is "not uncommon at Havering." One was caught alive as it was feeding on a Swift which it had captured at Mistley on May I 5 th, I888 (29. June 2).

Mr. Saunders says (Mamual, p. 337) that " at one time [it bred] with tolerable regularity in Essex." Dr. Laver informs me that he took a nest in Hockley-Bull Wood when at school in I842. Mr. Buxton says (47.8I) a pair "nested [in Epping Forest] for two years-I $8+6-47$. After being disturbed, they nested on the Hill Hall Estate, and brought off their young." They have probably bred there since, for Mr. Harting writes me :-

"In June, I869, a male Hobby was seen for some days about the Forest at Chingford and was eventually taken by a bird-catcher on the Ioth of that month. I saw it a few days later in the possession of a friend who had secured it and had it stuffed."

Mr. M. Vaughan of Finchingfield records (40. iii. 459) that in 1877 his brother found a nest with four young at Felstead. Lord Clifton states (40. iv. 259) that he "ascertained beyond doubt" that a pair bred near Belhus Park in I879. His lordship saw a splendid male which had been shot from the nest. Mr. Hy. Stephenson, head-keeper at Birch, informs me that a pair bred in Layer Wood in I885. The female was shot and the eggs were afterwards taken by some boys, while Mr. James Round, M.P., has informed me that the dead bird was brought to him. Mr. Stacey has a specimen shot during the summer of $188_{5}$, or ISS6, at Great WValiham.

\section{Merlin : Falco cesalon.}

An uncommon winter visitor. It breeds in moorland districts further north, but certainly does not now breed in Essex, though it is stated to have formerly done so in the marshes of Rochford Hundred.

In Rochford Hundred, Mr. Parsons says (II) it was "rare" in his day (I830). Mr. Clarke notes (24) that Mr. S. Salmon shot a male at Ashdon in 1829 ; that two males were killed at Saffron Walden in Nov., I843; that Mr. J. Wilkes shot an adult male at Elmdon on Dec, 28 th, 1844 ; that a male (said to be in the Audley End Collection) was shot at Grimsditch Wood, Saffron VValden, on Jan. 20th, I837; that a female was shot at Clavering in I829; that Mr. Salmon killed one at Wenden in 1830 ; that two specimens were killed on Jan Ist, I830; that a female was killed at Audley End on Jan. 4 th, I837 " The finest I ever saw : weight 9 oz., J. C."); that another female was taken at Westley Farm, Feb. 7, I 837 (weight $8 \frac{3}{4}$ oz.) ; and that another female occurred at Andley End on Oct. I8th, I853. In the Museum at Saffron Walden are an adult male from Saffron Walden, presented by E. J. Tuck, and an adult female from Saffron Walden in Feb., 1837, presented by Mr. S. Salmon, probably the specimen from Westley Farm mentioned above. In 1835 , Edward Doubleday wrote (15) "The 
Merlin is merely a visitant [to Epping] in the autumn months, and that very rarely. I only know of one having been killed here, and that a young female." King says (20) that he only once met with it in the neighbourhood of Sudbury. Mr Travis states (44. i. Ixiii.) that in I880 two were killed at. Newport, and he received one shot near Littlebury early in Dec., I88I. In Nov., I887, one was shot by a gamekeeper at Langford Park (4r. ii. 33). Mr. Hope, who has two shot at Stubbers, Romford, in I887, says it is, "not uncommon at Havering in the autumn." It is "frequent" in autumn in the Colchester and Paglesham districts (Laver). Mr. Kerry has one shot at Dovercourt by himself.

More, writing in I865, says (33. I0): "From Essex, Dr. C. R. Bree writes that the Merlin breeds in the marshes of the Rochford Hundred. Mr. Laver, his informant, has brought up young birds from the nest" (37.i. 75). In reply to my inquiry, Dr. Laver writes: "There can be no mistake about their breeding, as stated in the Ibis. They bred on the Paglesham Marshes, as well as on Foulness, in the rank grass beside the marsh ditches, but I have not heard of a nest for years, as I now never visit that district." As to its breeding in that district, Mr. J. F. T. Wiseman of Paglesham writes: "I do not doubt it, but I cannot say that it does so from personal observation." The Rev. J. C. Atkinson writes: "I knowit used to breed a long while ago, but not commonly:"

\section{Osprey: Pandion halieietus.}

A rare winter visitor or passing migrant in spring and autumn, It still breeds in a few localities in the Highlands.

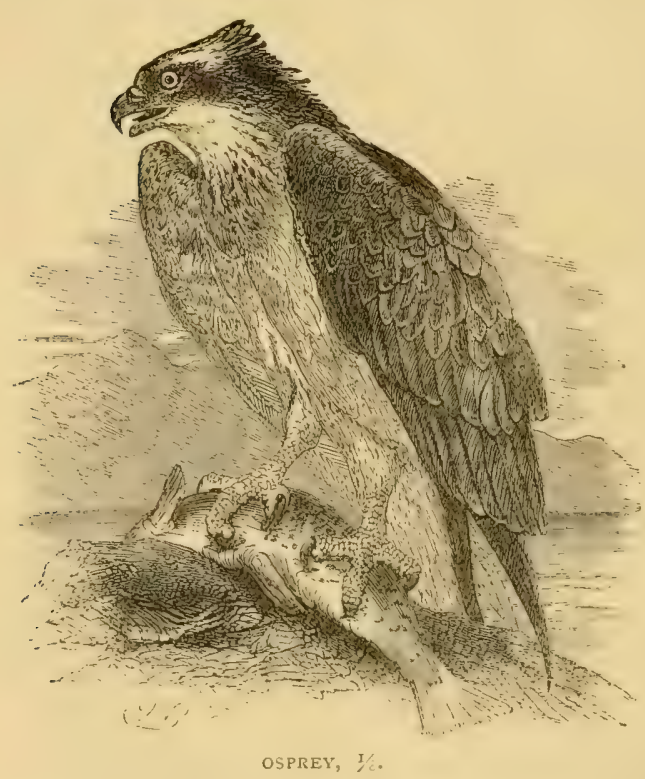

Dale says $(2.396)$ :

"Whether this bird is at any time to be seen here [Harwich] I know not; but, this being a bird that frequents the sea-coast, and haviny seen the cases of two of them which have been shot in this county, the first at Maldon, in the house of one Mr. Robjent, killed near that place, and the other at the Horn [Inn] in Braintree, but killed at St. Osith, in Tendring Hundred, I do not doubt but sometimes they frequent this place."

Mr. Joseph Clarke notes (24) an Osprey killed on the lake in Debden Park, about the year $18 \mathrm{I} 7$, by William Harrington, a gamekeeper. It had a carp weighing three pounds in its talons. Hoy re-

cords (12. v. 28I) that a young individual in its first plumage was shot on Aug. I7th, I83I, in Stoke Nayland parish, which is in Suffolk, just beyond the Essex border; and in his Collection at Boyle's Court there are two shot by him at Stoke-. 
by-Nayland in I835 (29. Sept. 28. I867). In Rochford Hundred, about I832, Mr. Parsons say's (II) it was seen "On the coast and marshes very rarely." Henry Doubleday mentions ( 10 ) having seen in $I_{32} 2$ a specimen in a Collection at Colchester, obtained in that neightourhood. Newman records one (23. 2764) shot near Colchester about the middle of Jan., I850. About Oct. Ist, I880, one (now in Mr. Hope's Collection) was shot at "The Basin," at Maldon by a young man named Arthur Clarke, who killed it whilst sitting upon a post (Chelmsford Chronicle, Oct. 8). At Cooper's, the bird stuffer's, in $188 \mathrm{I}, \mathrm{Mr}$. Harting saw one that had been shot, flying over the Lea in Hackney Marshes during the autumn (29. Oct. 8). Mr. E. A. Fitch writes on January 7th, I887 (50. i. 45) :-

"During the last fortnight a large Eagle has several times been seen haunting the Upper Island (Northey) in the Blackwater. ***About [half] a dozen years ago Clark shot an Osprey in this same locality, and two or three gunners who saw that and our present visitor suppose them to be the same species."

It may, however, have been a Rough-legged Buzzard. Mr. Hance of Maldon has a fine pair (50. ii, 2+2), which I have seen, shot on the river by Mr. R. Bygrave some years ago. Others, Mr. Fitch tells me, have also been met with there. One was taken on the Tollesbury Marshes during April, 1889, and was preserved by Pettitt for Dr. Salter (Laver-50. iii. 8S).

Red-footed Falcon: Tinmunculus vespertinus.

A rare and occasional visitor to England. It has only once been met with in Essex, so far as I know.

Dr. Bree records (29. June $7 ; \& 34.3615$ \& $368 S$ ) that a female was shot at Alresford, by one Gilders, head-keeper to Col. Hawkins, on May 3Ist, I873, after severe gales, and was added to his Collection. Gilders believed that he had shot another the previous year, but he was so close to it, and injured it so badly, that it was not preserved.

Kestrel : Tinmunculus alaudarius. Locally, "Hoverer."

A fairly common resident, though partially migratory, and rippidly decreasing on account of the senseless persecution it has to undergo. 


\section{Order STEGANOPODES.}

\section{Family PELECANIDAE.}

\section{Cormorant: Phalacrocorax carbo.}

A common visitor to our coasts and estuaries from autumn to spring, but never net with inland in Essex, except occasionally,

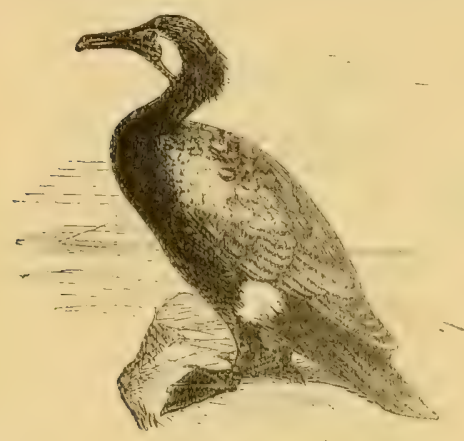

CORAIORANT, I/IA,

when blown there by severe storms: for instance, Edward Doubleday, in 1835 , mentions (I5) its having been killed at Harlow.

They are not uncommon off Leigh (Sackett). At Harwich a few are seen every year (Kerry). Two were seen on Canvey Island on Sept. I5th, I882 (Bird). Mrr. Hope writes that they "come south in August and September; very common on the Main; a large number can always be scen on the Buxey Beacon,"

Shag: Phalacrocorax graculus.

An uncommon winter visitor to the const.

Sheppard and Whitear mention one (9. 59) which they saw "at a distance, swimming prodigiously fast" on the River Stour on September 30th, I820.

Gannet: Sula bassana. Locally, "Solan Goose."

A fairly-common bird on the coast from autumn to spring, but it has no breeding-station in Esses. After severe storms in winter, it

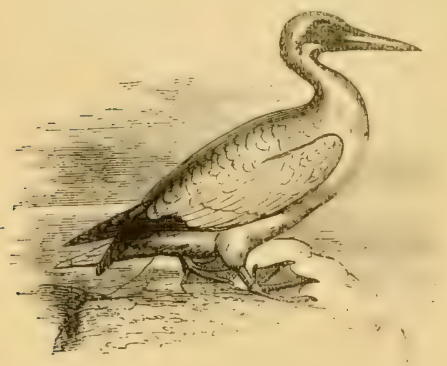

GANNET, I/:6 is sometimes found in an exhausted state far inland.

Mr. C. Walford says (19.5S) that about 1830 one was "picked up in the. snow at Terling, from which it appeared that it could not rise." Mr. Clarke mentions (24) the occurrence of immature specimens at Ashdon in 1832, and at Saffron Walden in 1844 respectively. Both are (or were) in the Walden Museum, while in the Audley End Collection is a specimen obtained at 
Arkesden. Dr. Bree mentions (32a) a specimen taken alive at Wyvenhoe in Oct., I863, and another shot at West Mersea in Dec., I874. He also notes a fine male found in a dying state in one of the woods at Alresford early in May, I868 (29. May I6). One was caught alive at Willingale on Dec. I2th, I88I. It was very savage, and bit a piece out of the hand of its captori(Chelmsford Chronicle, Dec. I6). Mr. Hope has seen them off the Outer Gabbard, and in Oct., 1888, he found a dead bird near Harwich, where, Mr. Kerry says, "A few are seen every year." Mr. Fitch has heard of one at Maldon, but cannot give particulars. 


\section{Order HERODIONES.}

\section{Family ARDEIDA.}

Heron : Ardea cinerea. Locally, "Frank," "Frank Hern," and "Hernshaw."

A common resident; met with singly or in small parties in most parts of the county from autumn to early spring, especially among

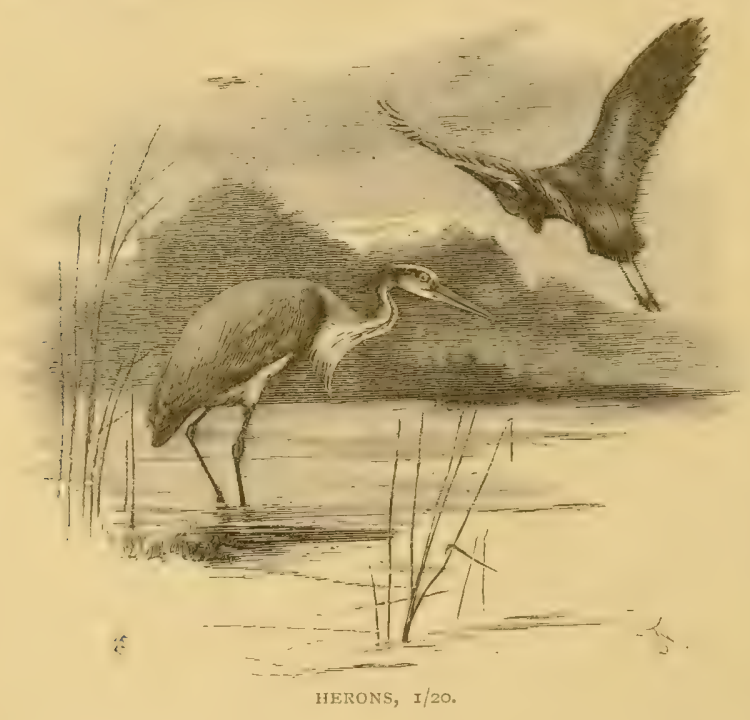

the marshes along the 'Thames,and on our east coast. 'There are four Heronries now existing in the county, two of which are of considerable size, namely at Birch, where there are about 170 nests, and IV anstead Park;

where there are about forty. At St. Osyth there are about five nests, and at Borcham about nine. For fuller cletails, the reader is referred to Mr. E. A. Fitch's most interesting article on Essex Heronries (50. ii. I 7 I ), from which I have gleaned much information.

These birds are occasionally seen during summer at a considerable distance from any Heronry. On July Ioth, I877, I put one up from the brook at Chignal St. James, and on July I 7 th following 1 saw another at Roxwell. On July 2oth, I876, I saw one near Dunmow, and on June I 3th, I880, another at Great Chesterford. On June 4th, I882, I saw another here. About the first week in December, I875, one was killed in the brook Cann at Chignal St. James, Dy a dog, which jumped on its back from the bank of the stream. It severely bit the hand of the man who assisted. At Orsett, Mr Sackett says they are fairly plentiful on the marshes durng spring, summer, and autumn, but he has never observed 


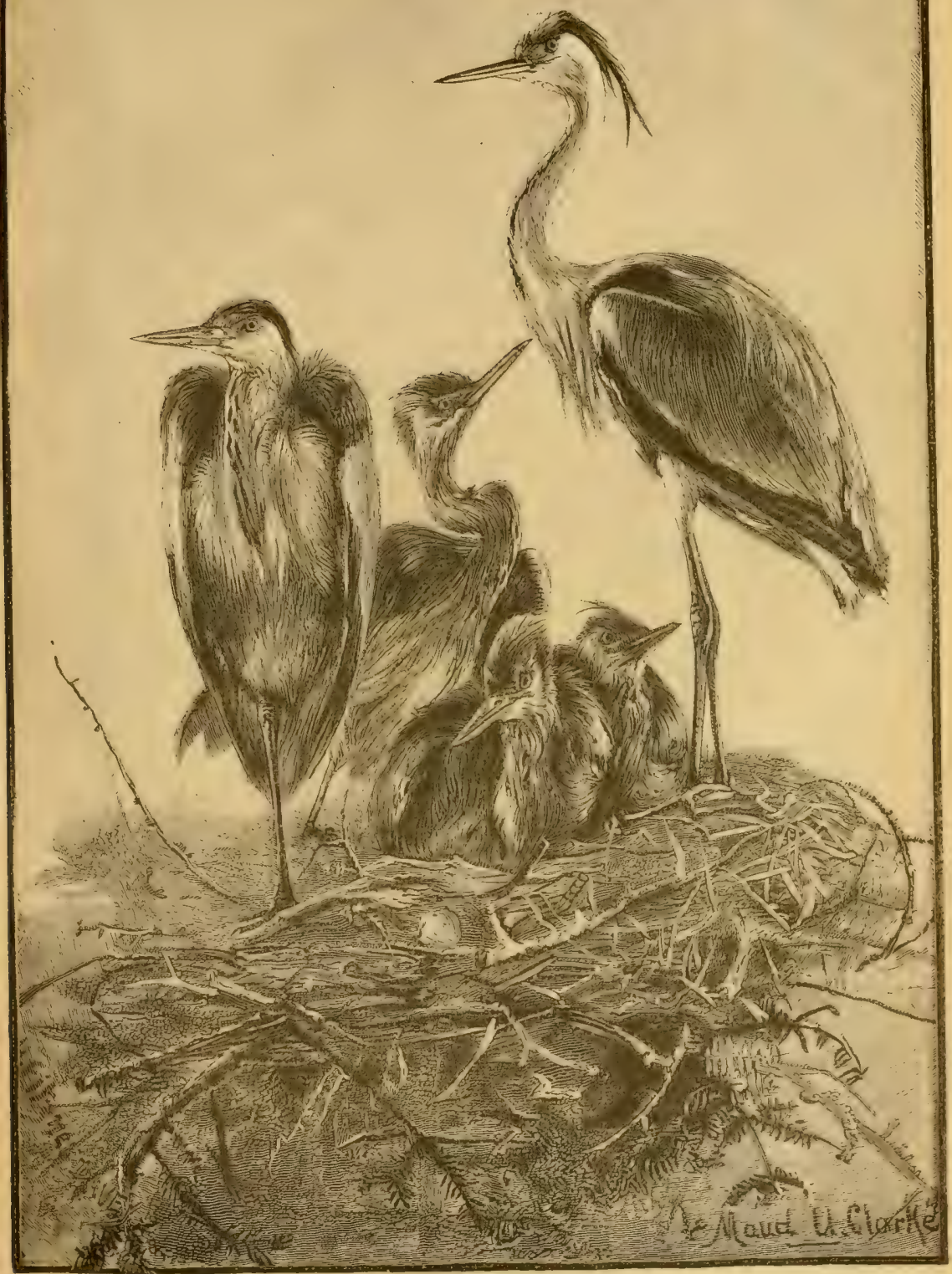

- HERONS AND NEST.

1.. (Drazn frem a case in the British Musenm.) 
them there in the winter. They probably come across the Thames from the Heronry in Earl Darnley's Park at Cobham.

The Dictionary of the Thames says: "About Barking or Rainham these birds may be met with at all times of the day in the marshes adjoining the river, as well as in the creeks and on the mud-flats around Canvey Island."

By far the largest and most important Heronry in the county is that at Birch, the property of Mr. James Round, M.P., who informs me that he believes it was originally started by a pair that came from Brightlingsea when the Magens estate was sold, some twenty-five years ago. I visited it on April I6th, I888, a charming, summer-like day, in company with Mr. E. A. Fitch, from whose description of our visit (50, ii. I7I) I cull the following passages :-

"The Birch Heronry is in the middle of an oak wood of about eighteen acres, known as Calve's Pasture. There was little or nothing to indicate the presence of the Herons until we got well under the trees they occupied; ther we saw them sitting upon their nests, and on the tops of the trees, or flying leisurely around in all directions. The birds appeared to be particularly tame, and were in no wise disconcerted at our presence; several were still building, and there were certainly no young, nor, possibly, any sitting birds. We counted I25 nests, and Mr. Henry Stephenson, the head-keeper, told us that he expected at least forty more would be built; he had seen over 300 birds about this year. All the nests were on oaks, and the largest number on one tree was eight. The usual flat platform of small branches and twigs was here lined with nettle-s.raw, not dock, as at Boreham. It was quite astonishing to see what comparatively large branches the Herons had broken off for building purposes. Mr. Stephenson was able to give us a complete history of this now-extensive Heronry, as it was he who found the first nest in Chest Wood, Layer-de-la-Haye, in 186I, on one of the tallest oaks, said to be nearly thirty feet to the first branch. The next year (1862) there were three nests, and they increased in numbers steadily every year, until 1877 , when there were about 100 nests in their first-chosen spot, Chest Wood. In February, 1878 , the Herons came as usual to roost there, preparatory to nesting; but, shortly afterwards, a pair of Peregrine Falcons appeared, and caused great alarm among the Herons. One day, when on his rounds, Stephenson watched a Heron high overhead apparently trying to outsoar a Peregrine, until both were lost to sight, but shortly afterwards Heron and Peregrine fell to the ground almost at his feet. The Peregrines were not shot, but the effect of their presence was that the Herons entirely forsook Chest Wood for nesting purposes, and came to their present abode in Calve's Pasture. That same year (1878), they built about Ioo nests in the latter wood, and the colony has now increased to nearly 200. No nest has been seen in Chest Wood since 1877 , until last year, when a solitary one was observed. The birds are strictly preserved in every way and iespecially from the Rooks, which are prevented from roosting in the wood as far as possible, being looked upon by the keeper as very destructive to Heron's eggs, and he especiaily complained of their depredations among the early nests of this present year, during the severe weather of March."

Next on our list of Essex Heronries, in size and importance, stands that at Wanstead, which of the $3 \mathrm{co}$ or more now existing in Great Britain, is, I believe, the nearest of all to London, being only about seven miles distant from St. Paul's. As long ago as 1834 , it was described (13. ii. 195) as "of long establishment and very populous "-a character which it still maintains, and is likely long to maintain, as Wanstead Park now forms part of Epping Forest, and is under the control of the Corporation of London, acting as Conservators of the Forest. Mr. Fitch says (50. ii. 178):

"Formerly the birds built on an island in the upper pond in the park, which consequently acquired the name of Heron Pond [by which it is still known]; but they now frequent Lincoln Island, and during the nesting season special precautions are taken by the Conservators to prevent their being disturbed." 
At present they occupy some tall elms growing upon an island in the largest sheet of water in the Park. In I869 there were about thirty pairs; in 1883, about twenty-five ; in March, I88 4 , forty-three nests were counted (47.94); and in April, 1887, about thirty-eight. There have since been a few more added. Mr. Fitch says (50. ii. 179): "It 1s satisfactory to learn that the free admission of visitors to the Park, except that the path by the lake is closed in May and June during nidification, has not apparently resulted in any injury to the Heronry."

An interesting account of a visit to this Heronry, was given by Mr. Harting in Science Gossip for April, 1869, and also in his Skotches of Bird Life (ISs 3, p. 266); while a small sketch of it (here reproduced) appears in Mr. Buxton's Epping Forest $(47.9 \mathrm{t})$; and a larger one by C. Whymper in Seebohm's British Birds (ii. p. 472). Through the kindness of Mr. E. A. Fitch, I am enabled to introduce as the frontispiece of this work, a lithographic reproduction of another drawing of this Heronry, made by Mr. C. Whymper in 1885 . The original is in Mr. Harting's possession.

The next Essex He-

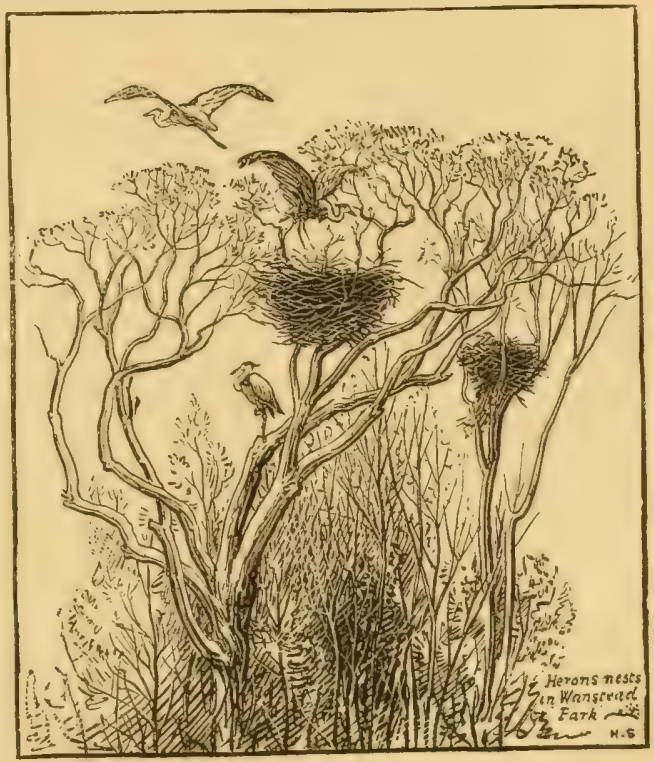

HERONRY IN WANSTEAD PARK, ESSEX. ronry deserving notice is that in the park surrounding Boreham House, the residence of Lieut. J. L. Tufnell-Tyrell. Mr. Fitch writes (50, ii. I74) :-

"This Heronry is not now in its old position. The birds used to build where the Rooks do now, immediately behind Boreham House; but about seven years ago this colony became reduced to a single nest, and the old bird was shot whilst sitting. In 1884 , the Herons first nested in West Mead Grove, a small grove planted as an apple orchard in $18+2$, and subsequently with oak, spruce firs, and a few miscellaneous trees, including some Scotch pines. The grove being only about 400 yards from the river, and on about the same level, the soil is very wet, like all the grass-land of the Chelmer Valley, and consequently the apple trees soon cankered and died out, although one or two still remain, and the growth of the firs has been very slow. In company with the Rooks, the Herons have taken possession of these last-named trees. In 1886 , there were nine nests, but thirty young Herons were destroyed in one day, and several more on other occasions. In 1857 the position was about the same, and although the persecution was continued, there appears to be the same number of nests this present year." In I889, there were six nests, from which tẻn eggs were taken.

Of the Brightlingsea (St. Osyth). Heronry, Mr. Fitch says:-

"In Yarrell's British Birds and other works, mention is made of a Heronry at St. Osyth, but this appears to have been a mistake. The only Heronry in the 
neighbourhood was one just over the arn! of the Colne Estuary at Brightlingsea. * * * It is a most secluded spot, on the Wyvenhoe side of the Twenty-seven Acre Grove, on Mr. Bateman's estate, known as Heronry Wood, a little more than a quarter of a mile west of Brightlingsea Church. Mark Gooch, the old keeper, told us that formerly the Heronry certainly contained over roo nests, but that forty-three or forty-four vears ago the largest trees were felled, and this seriously diminished the number of Herons."

Then the Rooks came and robbed the eggs, while more trees were felled, and an unruly tenant used to shoot the birds on their nests (much to the annoyance of Mr. Bateman), till "in 1870 , there were about thirty nests $* * *$; in I87I, there were only fifteen or eighteen; and the"Herons finally deserted the spot in I872," the majority probably going to Birch, though a few established themselves at St. Osyth. Since $1872, \mathrm{Mr}$. Bateman has done all in his power to encourage the Herons to return, but has so far been frustrated by the Rooks. The few which migrated to St. Osyth established themselves in Nunn's Wood, where they still flourish under the protection of Sir John H. Johnson, who writes to Mr. Fitch as follows: "Five or six years ago, a solitary pair came and built on a tree on an island in one of my ponds. Then one or two more pairs came and built on another tree, and two years ago a pair built on a low tree in my little wood closely adjoining." In 1877 , there were five nests, and Mr. Fitch tells me there are now two smali colonies at St. Osyth.

There can be no doubt that there have formerly been various other Heronries, now extinct, in our county. Thus, quaint old Norden speaks of "Towleshunt Darcye : nere $w_{c h}$ is a fayre Heronry." Morant, in his History of Essex (I76s i. p. 78), says of Belhus, Areley :-

"Here was formerly a Heronry, which being a thing not commonly to be met with, was esteemed a circumstance of no small consequence, while the diversion of Hawking was in fashion; but of late years not thought to balance the inconveniences attending it, and the Herons therefore are not suffered to build longer."

Morant (i. p. 208) also says: "The Manor of Heron or Herne [whence HeronGate], East Horndon, seems originally to have taken its name from a Heronry here." Mr. J.'F. T. Wiseman, of Paglesham, informs me that, about the year I 8S2, there was a nest in his wood at Barton Hall. Mr. A. Smee says (My Garden, p. 530), "I have seen a nest at Chigwell in Essex"-- doubtless an offshoot from the Heronry at Wanstead. Mr. Fitch says (50. i. I42):-

There is a disused Heronry at Walton's Hall, Mucking. ***It stands on the edge of the marshes south of the railway leading from Stanford-le-Hope to Tilbury, about half a mile from the Thames. The trees are oak and ash, with a few elms. Mr. William Clark, jun., who has been tenant of Walton's Hall for some years, tells me he never knew a nest there, although six to eight Herons are constantly to be found on his marshes. It is the same here [at Maldon]. I see half a dozen Herons almost every day throughout the spring, and have often wondered where they can breed. About seven years ago, there was one nest in Mundon Furze, two and a-half miles south from here, which was destroyed by shooting through the nest and killing the parent bird. Still this same nest was repaired and occupied next year, and two other nests were built not far off.

Mr. Fitch also mentions (50. ii. I74) haring either seen or heard of solitary Heron's nests at Stony Piece, Lawling Hall, Latchingdon; the Nursery, Bradwell Glebe ; the Old Farm (Dunmow Wick), Burnham ; Steeple; Scot's Grove, opposite Guisnes Court gate, Tollesbury; and the Great IVood, Tolleshunt Major. There used also to be a Heronry, consisting usually of from twelve to fifteen nests, in Bower Hall Grove, on Mersea Island, until it was stubbed about forty years ago. I 'have "been told that there were formerly nests!"at "Tofts," Little Baddow, but have failed to obtain any confirmation.', 


\section{Purple Heron: Ardea purpurea.}

A rare and accidental straggler to Britain, of which only one specimen is recorded as having been certainly met with in Essex.

Mr. C. Walford records (I9. I26) a fine specimen shot during the second week in April, I839, in a wood near Maldon. He adds: "It was very low in flesh when killed, not weighing more than two pounds six ounces." A specimen which Selby says (British Ornithology, ii. I5, note) was killed "near London," is very likely to have been obtained in Essex, but no locality is given.

\section{Great White Heron: Ardea alba.}

A rare and accidental straggler to Great Britain. The only record of its appearance in Essex is the following :

Messrs. Sheppard and Whitear write $(9.4 \mathrm{C})$ :-

"On the 3 rd of October last [? 1823], in a walk on the banks of the River Stour, we observed a large White Heron cross over from the Suffolk to the Essex side of the river. It appeared to be pure white, and to stand up rather taller than some common Herons which were feeding not far off. A similar bird was observed in the spring on the Oakley shores; and, subsequently to our observation, one was seen on the banks of the River Orwell."

\section{Little Bittern: Ardetta minuta.}

A somerwhat rare visitant to Britain, which has occurred at least half-a-dozen times in Essex, chiefly during the autumn or early winter.

C. E. Smith, of Coggeshall, in 1860 , mentions one (31. 52) "shot by Mr. Sach of the Abbey Farm." Dr. Bree records (29; 32a; and 34. 517), "a male, in good plumage," shot on Aug. I3th, I866, just above North Bridge, Colchester. He adds: "I never heard of one being captured here before," and says further that it was added to his Collection. Mrs. Bree still has it. Henry Doubleday has recorded (34. 4199) that a young specimen, probably a male, having just completed its first autumnal moult, was shot at Passingford Bridge on Sept. I5th, 1874, after having been seen about for ser-

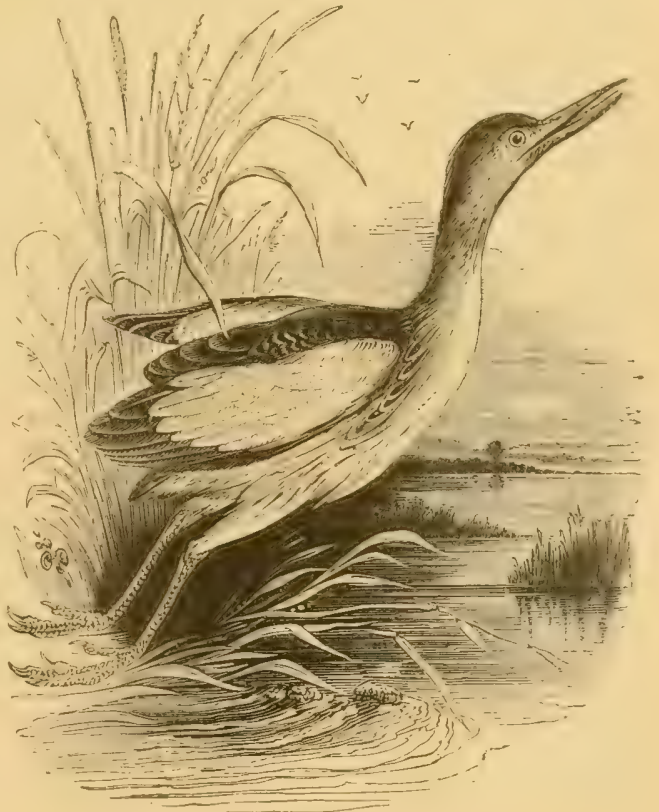

LIT PLE DITTERN, male, I/5. 
eral days. It is now in the possession of Sir Chas. C. Smith, of Suttons. English describes it as an occasional visitor to Epping Forest (43. i. 24), probably on the strength of the foregoing record. In the winter of $1879-80, \mathrm{Mr}$. Travis received for preservation one shot at Ashdon. Mr. Laver records one (40. viii. 342), killed near Colchester by flying against the telegraph wires late in the autumn of 1884 , and says another had occurred there a few years before (? Dr. Bree's). Dr. Salter has the former. Mr. Hart received two specimens from Essex on June 15th, I867 - a very strange date, but he does not state their exact locality (34. I5II). It is not easy to believe they were breeding, though Mr. Bond says (23. 1969) he received "a young bird of the year, which I believe has been bred in the neighbourhood, as there are some remains of the nestling-down, and it is not fully fledged." This individual was shot by a barge-man on the River Lea, near Enfield, on Sept. I8th, I847.

Night Heron: Nycticorax griseus.

A rare straggler to Britain, chiefly in spring or autumn. I am not aware of its having been met with more than once in Essex.

An immature female in spotted plumage and weighing 27 ounces, was shot at Dovercourt on Nov. 29th, 1880 (Kerry-40. v. 68). It was preserved by Ambrose, of Colchester.*

\section{Bittern : Botaumus stellaris.}

Once a common resident, before the draining of the extensive swamps it used to frequent, but yearly becoming rarer, and now only a winter visitor. A considerable number have, however, been obtained in Essex during the last half-century. It probably bred commonly in the county many years ago, but the Rev. J. C. Atkinson never heard of its doing so, even in his early days. It is by no means improbable that some of the following specimens would, on careful examination, prove to belong to a distinct species, the American Bittern ( $B$. lentiginosus), which, though a rare straggler in Britain, has occurred at least a score of times. It is a very common American bird and closely allied to our species, but is distinguishable chiefly by its uniform dull leaden-brown primaries.

Mr. J. Cunnington, of Braintree, in 1838 , endeavoured to prove (I9) that Springfield was the original of Goldsmith's "Deserted Village." In support of his argument he advances the fact that,

"the Bittern, although a scarce bird in Essex, is by no means unknown, for a pair only a few years ago were frequently seen near, and known to frequent, a piece of low sedgy ground at Halstead, and I lately saw three which had been shot near Maldon and sent to Mr. Walford at Witham to be stuffed. During the last severe winter, a wounded Bittern was caught alive in Baddow Mead, which is within a mile and a half of Springfield village. It is now in a fine collection of stuffed birds belonging to a gentleman at Chelmsford."

Mr. Clarke notes the occurrence (24) of the following specimens:-One at

* A specimen recorded by Dr. Bree to have been killed near Colchester in the winter of $1880-81$ and preserved by Ambrose (29. Apr. 23; and 32a) is, presumably, the same bird. According io Pennant, the first British specimen was shot in 1782 "near London"-perhaps in Essex. 
Wenden in I826, one shot by Lord Braybrooke at Audley End in I83 I, and a female (now in the Audley End Collection) shot by Mr. G. Webb at Wenden on Jan. roth, I849. Henry Doubleday, writing from Epping on Jan. I9th, I832, says (I0) "a fine Bittern was shot here yesterday - a singular place for such a bird." Edward Doubleday, writing.in 1835 , says (15) it "has occurred here but once." "J. C.", of IVitham, records (12. vii. p. 5II) one shot at Maldon about Feb. 6th, 1834. He adds, "Bitterns are not unfrequently met with upon the marshes by the side of the river which runs to that town." Yarrell says (25. ii. $54^{1}$ ), "specimens are not unfrequently shot from some of the numerous beds of reeds growing by the sides of the "Thames on the shores of Kent and Essex," Mr. H. Barclay records one (23.277I) shot at Walthamstow in Jan., 1850. It rose first from among some cabbages in a garden. Major Edward Taylor, of Bishop's Stortford has one shot there about I850. Mr. David Christy, of Patching Hall, has one shot by himself beside the Chelmer at Broomfield about the winter of I860. C. E. Smith, of Coggeshall, says (31.52) that it was "heard booming in the plantations that skirt the river [Blackwater] during the winter of I856." Mr. Scruby informs me of one shot at Stanford Rivers about 1860. Mr. Geo. Withers records a fine male killed out of a sedgy pond in the neighbourhood of Wanstead Flats in Feb., I864 (29. Feb. 20). One was shot at The Spieney on the Chelmer, Dec. 23rd, I879 (Chelnusford Chronicle, Jan. 9). One was shot on the Stour about Dec. I5th, I879, during a spell of hard weather, by a puntsman named Chas. Porter, of Manningtree (Chelmsford Chronicle, Dec. 19). One is recorded to have been killed near lillingham in January, I879 (Chelmsford Chronicle, Jan. 3I). Dr. Bree records three killed in Essex in the winter of I879-SO, one near the Musketry Station, Colchester (29. Jan. 10), now in Mr. J. Round's Collection. Mr.lG. A. Thompson, of Fobbing, shot one on the marshes below Tilbury, opposite Thames Haven, on Nov. 22nd, I879 (29. Nov, 29). One was shot near Maldon in March, I883. Mr. Hope has a specimen shot by a miller at Ilford in the snow at Christmas, 1872 , and another shot at Harwich in Jan., I886. Mr. Buxton mentions one (47.96), "killed a few years ago by the stream adjoining Wanstead Park." The Rev. J. W. Maitland, of Loughton, has a fine male which he believes to be the last specimen killed in Epping Forest. It was purchased at Doubleday's sale for $75 \mathrm{~s}$. and was shot at Coopersale by the Rev. C. B. Abdy. Mr. Leonard Saunders, of Maldon, shot a male in a wood at Woodham Ferris on Jan. 3 Ist, I886 (Chelmsford Chronicle, Feb. 6). Mr. E. A. Fitch informs me that his grandfather, Mr. Daniel Pannell, shot three on Sturmer Mere, and his uncle, Mr. Thos. Pannell, another at the same place, all about the year I850. About I882, Mr. Wm. Sewell shot one, which he still has, on the Marsh Farm, Tillingham, and about 1886, another was caught alive near the adjacent Decoy and was forwarded to the Zoological Gardens, where I believe it still is. Mr. IValter B. Nicholls, of Lawford Hall, has one shot some years ago on the Stour, and on Dec. 7th, I889, Mr. Dale, of St. Osyth, shot a fine male in good condition there (Pettitt). Mr. Thomas Aldham, of Ulting, has one shoi there, and Mr. Hance, of Maldon, a very fine one shot near that town by Mr. R. Bygrave (Fitch). 


\section{Family CICONIID E.}

\section{White Stork: Ciconia alba.}

An occasional straggler to Hritain, which has once or twice lecen killed in Essex.

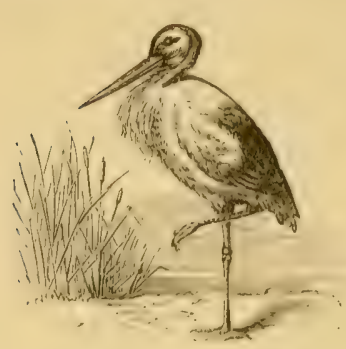

WHTE STORK, I/3O.

Yarrell says (25. ii. 556) "one was shot ncar Yarmouth in May, 1842, and Thomas Thornhill, Esq., favoured me with a notice of one killed in Essex during the same month." * In the last edition of his work, it is stated (37, iv. 220) that "several examples have also been obtained or observed in Suffolk and Essex." Two are reported to have been captured near Tillingham, in Jan. I879 (Cholms. ford Chronicle, Jan. 31).

\section{Black Stork: Ciconia nigra.}

Another rare and occasional straggler to Britain, which has occurred once in Essex.

Dr. Bree records (29. Apr. 23) that a fine female was killed on or about April I2th, I88I, on the Stour at Stoke-by-Nayland. It was shot by Mr. WV. Frost Mortimer of that parish and was preserved by Ambrose of Colchester. This specimen was seen in I888 in the possession of Mr. Mortimer, at Hastings, by Mr. J. II. Gurney, jur., who describes it as " a splendid bird and well stuffed." Mr. Mortimer informed Mr. Gurney that he shot it in the month of May, and that it was very tame. Strictly speaking, this is a Suffolk specimen. Canon Babington says (46.24I) it was shot by Mr. Frost Mortimer, in a meadow on the Suffolk side of the Stour in May, I88 I, after having been observed flying down the river valley, towards the sea, by Col. Rowley. Its crop was full of gudgeon.t Mr. Fitch has kindly obtained the following additional particulars from Mr. Mortimer, who still resides at Hastings, but does not now possess the bird, haying sold it about two years ago for $\&$ to to Sir Vauncey H. Crewe, of Calke Abbey, Derbyshire. Mr. Mortimer says that he saw the bird, the day before it was shot, in his fields at Boxford. IIc put it up, and its mode of flying with its neck out, as it flew down the river, showed him ationce that it was not a Heron. On the following morning it was reported to one of Col. Rowley's keepers as having been seen in one of the ponds on the estate, but in the afternoon, which was wet, it was reported by one of Mr. Murtimer's men to be then sitting perched on some rails in one of his fields. On his approach it flew into the back-river, where he got within five

* In the $3 \mathrm{rd} \mathrm{Ed}$. (30. ii. 558) the datc differs and the passage reads: one "was shot at Brey" don, "near Yarmouth, in $\times 85_{52}$, and Thomas 'Thornhill Esq., favoured me with a notice of one killed in lissex during the same year."

t'The specimen said (37. iv. 227) to have heen "killed between July and 8 th of September, r883, near Kainham, in Essex.". (40. viii. 429) is not an Essex specimen at all, having been killed at Rainham in lint. 
yards of it, as it was feeding with its head under water. He called to it to make it rise, and shot it when thirty or forty yards distant. A second shot from a barrel loaded, like the first, with No. 2 shot was necessary, and even then it flew on to within fifty yards of the river, where it dropped dead with its wings stretched out on the ground. This was in the parish of Stoke Nayland. Although Col. Rowley wanted the bird Mr. Mortimer kept it and had it very nicely mounted by Ambrose, of Colchester. Mr. Mortimer says he shot it in the month of May, but this is clearly an error of memory. He also says another specimen was reported as having been seen about the same time, but he does not believe in it (Fitch).

\section{Family PLATALEIDÆ.}

\section{Spoonbill: Platalea leucorodia.}

Once a resident, loreeding in various counties, including Norfolk, Sussex, Middlesex, but now for a long time only a rare straggler chiefly when on migration in spring and autumn. That it formerly bred also in Essex is more than probable, although there is, I believe, no actual record of its so doing.

Sheppard an 1 Whitear say $(9++2)$ "it has been shot on the River Stour." Mr, Kerry says (40. i. 52) one was shot on Oct. 20th, 1876, on the mud-flats of the Stour by a wild-fowler named Porter, who consigned it to the spit (Chellnufford Chronicle, Nov. 2). Mr. Hope writes: "I have seen them fly by. Two which did so were eventually shot in the month of May, near Bawdsey in Suffolk; they were found to contain eggs and were bought by Mir. Robert Hillen of WVoodbridge." This is an interesting fact, as it indicates a still-surviving inclination to breed in this country. One was shot at Mersea in I863 by Mr. Geo. Mason ('Pettitt). A sternum and furculum in the collection of the late Dr. Bree, now in the possession of Mr. Harwood, bear the following label: "Shot at Harwich, June, I877. Two were shot out of a flock of nine." They were preserved by Ambrose (32a). One was seen in Aug., ISSS, on the mud-flats between Harwich and Walton-on-theNaze (Kerry). At the end of Dec., I889, three were shot out of a flock of seven, by one of Mr. Patmore's dredger-men at Burnham (Fitch). I saw one of these at Maldon on Jan. 4 th last.

\section{Glossy Ibis: Plegudis falcinellus.}

A rare straggler to the British Isles. The only one recorded to have been met with in Essex was shot by Mr. J. F. T. Wiseman when snipe-shooting on Oct. $15^{\text {th }}, 1872$, and is now in his possession. It rose from the old decoy pond on one of Mr. Wiseman's farms on the South Hall Marshes, Paglesham, and was preserved by Travis $(35.440)$. It is an immature bird.

\section{[Flamingo: Phonicopterus roseus.}

The grounds on which some writers have admitted this bird to the British List seem to me, on the whole, too slight. There is one Essex record. Yarrell mentions one seen on our coast in I873 (37. iv. 245) and afterwards shot in the Isle of Sheppey, on Aug. I6th. It seems in every way probable that this was a specimen known to have escaped from the Zoological Gardens on July I6th in the same year.] 


\section{Order ANSERES.}

\section{Family ANATIDÆ.}

\section{Grey Lag Goose: Anser cinereus. Locally "Grey Goose."}

A winter visitor, most often seen during severe weather.

Mr. Parsons says ( 8 ) "The winter of $1822-23$ was very severe. There were a great many Geese orer and some Swans, but very few IVigeon. Eight Grey Geese stopped in the Great Mead at the Hall [Shoebury], and my father shot one of them." Edward Doubleday wrote in 1835 (I5) that it had been killed at Harlow. Mr. Clarke says (24) it is "occasionally [met with] in hard winters" round Saffron Walden, In I880, an authority on the Essex coast wrote :-

"The Grey Geese were seen on Saturday, Feb. 2 Ist; from 600 to I,000 flying in a triangular form in a N.E. direction. I have repeatedly seen them sometimes passing for whole days and have alwavs noticed that we never had any winter to speak of afterwards. They fly generally about a mile high. IVe rery seldom see them going south-I suppose because the days are shorter, or possibly some may go another way; but they generally go north about this time of the year. I used to try to shoot them with a rifle to see what sort of Geese they were" (42.30).

Mr. Hope observes that it passes over in the autumn and spring in vast flocks, going south-west and north-east. When the Geese fly north in the spring, there is seldom any more cold weather. Round Harwich, "some are seen every winter" (Kerry).

This species-the only one that is resident and breeds in Britain-is commonly supposed to be the chief source from which our domestic goose has sprung, and the following may; therefore, be appropriately inserted here. Daniel says (6. ii. 4 66):

"Vast numbers of Geese are driven annually to London from distant counties to supply the markets, among them all the superannuated Geese and Ganders (called Cagmags), which by a long course of plucking prove uncommonly tough and dry. In I 783 , one drove of above 9,000 passed through Chelmsford. Droves of two or three thousand are common."

In connection with this subject, Daniel elsewhere relates an amusing anecdote of a race between a flock of Geese and another of Turkeys, both of which must have passed through Chelmsford. He says (6. ii. p. 409) :

"Lord Orford, in 1740 , made a considerable bet with the present Duke of Queensberry that a drove of Geese would beat an equal number of Turkies in a race from Norwich to London. The event proved the justness of his lordship's expectations; for the Geese kept on the road with a steady pace ; but the Turkies, as every evening approached, flew to roost in the trees adjoining the road, from which the drivers found it very difficult to dislodge them. In consequence of [their not] stopping to sleep, the Geese beat their competitors hollow, arriving at their destination two days before the Turkies." 


\section{Pink-footed Goose: Anser brachyrhynchus.}

\section{A winter visitor.}

There is in the Saffron Walden Museum a specimen shot there in I84I; and the bones of one killed at Brightlingsea, on Dec. 3Ist, I874 (32a) are among Dr. Bree's specimens, while Mr. Elwes of Colchester has the bird. My uncle, Mr. Joseph Smith, has one, shot some years ago at Pattiswick Hall, near Braintree, by his son, Mr. Joseph Smith jun., who saw another with it, which escaped.

White-fronted Goose: Anser allifirons. Locally, "I Laughing Goose."

A not uncommon winter visitor.

Mr. Clarke speaks of it (24) as occasionally met with round Walden in hard winters. Meyer (British Birds) mentions one shot on the Thames, near London, in Feb. I846. On Dec. $37 \mathrm{~d}$, I 879 , three were seen near Harwich, and an old Gander and a young bird were shot (Kerry -40. iv. 69). An old male was shot at Tollesbury early in Jan., I870 (29. Jan. I 5 ).

It is shot occasionally on the coast in both the Paglesham and Colchester districts (Laver). The sternum and

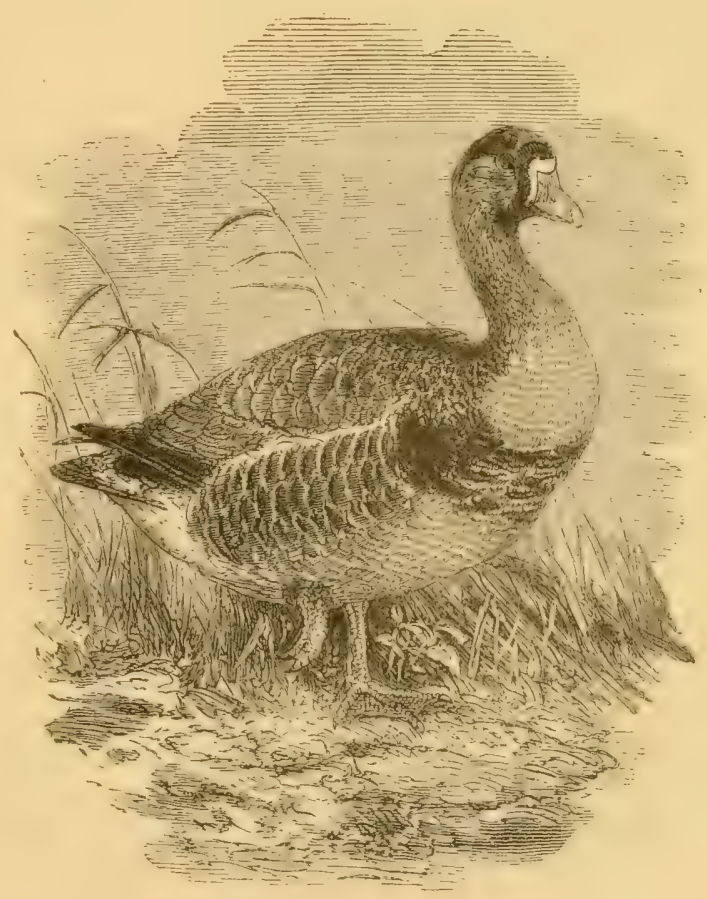

WHITE-FRONTED GOOSE, I/IO. furculum of a specimen shot at Brightlingsea in Jan., I87I (32a ; and 29. Feb. 25), are in the Bree Collection.

On Feb, $23 \mathrm{rd}$, I889, a specimen was observed and was afterwards fairly decoyed by means of a dog, together with several Ducks and IVigeon, exactly in the way Ducks are taken, in Mr. Robert Page's Marsh House Decoy at Tillingham. It is still preserved at Marsh House, where, through Mr. Page's kindness, I have seen it. The taking of any species of Goose in a Decoy is highly remarkable, and probably quite unique, though Mr. Page has another specimen, caught in an ordinary rat-trap in the same Decoy eight or nine years ago. Once 
in Mr. Page's experience, he has killed in his decoy-pond a Brent Goose-probably a "pensioner," or wounded bird.

Bean Goose : Anser segetum. Locally, "Grey Goose" (E.A.F.)

An uncommon winter visitor, most often seen during severe weather.

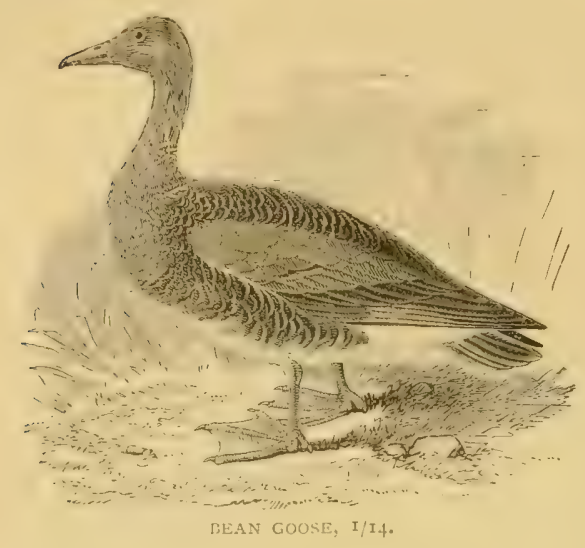

Around Sudbury, King described it (20) as "not uncommon " in I8 38 , meaning, of course, in winter. Around Saffron Walden (24), it used occasionally to be seen in hard winters (Clarke). Dr. Laver describes it as killed occasionally on the coast in both the Colchester and Paglesham districts. Dr Bree records two (one of which weighed 7 lbs.) shot on the coast in Dec., I87I (29. Dec. 23). Mr. Hope observes that it passes over in the autumn and spring, going S.W. and N.E.

\section{Brent Goose : Bernicla brenta. Locally, "Black Goose."}

The commonest and smallest species of Wild Goose frequenting our coast, where it may be found, especially during hard weather,

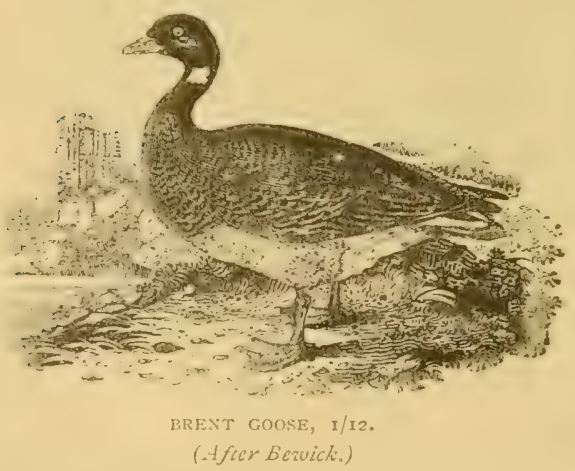
from autumn to spring. Although essentially a marine species, individuals are sometimes met with inland. There appear to be two forms of this species-a darkbreasted one, which is the commoner, from the N.E., and a much rarer light-bellied form from the N.WV.

Dale, who calls it the "Rat" or "Rond Goose," writing of Harwich in I730, says (2. 403): "These, no doubt, are in winter to be found here, having divers times seen them in Braintree Market, being caught on the Essex coast." Lindsey, writing from Harwich in I85 I, speaks of it (27. App. 59) as the "most numerous" of all the species of Geese visiting that place. He adds, "It is a regular visitor to our shore, and remains with us throughout the winter." It is still common there in hard winters. (Kerry). King says (20) it was in 1838 "not uncommon "round Sudbury-of 
course in the winter time, if he is correct in what he says, which is doubtful. The Rev. J. C. Atkinson writes (36. I39) that it is

"by far the most numerous of all the Geese which visit our shores in winter, as it is also the least. I have seen it in inconceivable numbers on the Essex coast in hard winters, and the numbers reported to have been killed at one discharge of a heavy punt-gun seem simply incredible. In the very hard and long-continued winter of $1837-8$, I saw the ice which, in broken fragments of four or five feet square by three or four inches thick, covered the whole estuary of the Blackwater at Tollesbury (a space of very considerable width), black with them during high water. The expression made use of by one of the sea-faring men of the neighbourhood was, 'There ire acres of 'em.'

The late Col. Russell also informed Mr. Fitch that he had at times seen them on the Essex coast in "numbers sufficiently large to completely cover a ten-acre field." Mr. Fitch himself has frequently seen them at the mouth of the Blackwater in clouds, consisting of immense numbers. Their short hoarse cough is very remarkable, and has already been alluded to (p.49.)

In $187 \mathrm{I}$, according to Mr. Smee $(34.2605)$, the first were seen at the mouth of the. Thames in the second week of October. Large flocks, some of which numbered over 200 birds, afterwards frequented the mud-flats about the Blacktail and Nore Sands. Such flocks had not been seen there for ten years and the gunners made a good living out of them. On March 24, a large flock, evidently migrating, passed over high up and in a N.E. direction, none having then been seen for three weeks. During Jan., I87I, Brent Geese were also seen in extraordinary numbers on the Main, and it is recorded (29. Feb.4) that "sixteen punters went together after a flock, and fired at it simultaneously at a given signal from their leader. Fourteen guns went off, two having missed fire, and $47 \mathrm{I}$ birds were bagged."

Many other enormous "bags" of these birds have been from time to time made on the Essex coast, and some of the reports as to the numbers shot at one time, which are current among the gunners, marshmen, punters, and others dwelling on our shores, are almost beyond belief. The largest bag I ever heard of on reliable authority, as being made at one time, was on Dengie Flats, one very sharp winter about thirty years ago (? I860). Mr. John Basham, jun., of Maldon, my informant, says that his father, the late Col. Russell, and thirty other gunners - thirty-two in all, under a recognised leader, as is the custom on these occasions - approached a very large flock of Geese, and, all firing together, at a given signal from their leader, bagged and shared equally between them (as is custonary) no less than an average of twenty-two Geese apiece, or 704 altogether, beside a great number more which were not obtained or were concealed dishonestly by some of the shooters. The largest "shoot," however, in which Mr. Basham ever personally took part was, he tells me, some twenty years or so ago, when eighteen punt $:$ r, including himself, under the leadership of a gunner nanied James Chaney, fired simultaneously at an enormous congregation of Geese collected together, one bright moonlight night, on the muds of the St. Peter's Flats, off Bradwell Chapel, obtaining as share twenty birds apiece, or 360 in all. One gun missed fire, but, as usual, all shared alike. On this occasion the punts were allowed to drift onwards with the tide. The biggest bag, made at a single shot, John Basham ever heard of was, he tells me, made about twentyfive years ago by a gunner (now deceased), known as "Old Stubbins," of Maldon, who killed no less than fifty Geese at the mouth of Thurslett Creek, in Tollesbury Parish, by a single discharge of his large punt gun, which weapon nas familiarly 
known in the neighbourhood as "Old Jubilee." It afterwards belonged to Mr. James Spitty of Bradwell, but has since been lost overboard.

Another extraordinary bag is recorded by Sir Ralph Payne-Gallwey in Shooting (Badminton Library), p. 307. He writes:-

"A heavy shot at fowl is becoming a rare chance now on our shores, and is only achieved in very severe weather. Some ten years ago, off the mouth of the Blackwater, in Essex, a wonderful shot was made at Brent Geese. A vast herd of these birds had collected on the ooze to feed. All the local punt-gunners, to the number of a dozen, were attracted by the sight; and setting together to the Geese, just as they were densely packed on the last bit of feeding-ground left by the rising tide, aimed and fired by signal. The result was that the gunners picked up close on 300 fowl. This incident was recorded in various sporting papers at the time, and was related to us by a gentleman who had actually seen the occurrence."

Possibly this is only another version of one of the occurrences described above, but such is certainly not the case with the following :-Col. Russell, writing to Mr. Hope in Aug., I884, says: "One of the Mussetts of West Mersea was in the Goose-shooting in the fog about Christmas last; the lot got some I60 Geese altogether; only one young one. I thought there were no young ones by their behaviour in Holland and on the Main." I have heard of even larger "bags" than the foregoing, but probably they are apocryphal. Other references to the great abundance of this species on our coast have been already given (p. 49).

In I 879, a number (the first seen thatiseason) were observed making for the Stour on January 2 Ist (Chelmsford Chronicle, Jan. 24). In I880, the first were observed on the Essex coast on October 6th. On the 20 th, a hundred or more, were seen on the Buxey Sands (42). Mr. Hope writes: "They arrive about the I2th October. I have never seen them inland except when lost in a fog. They leave about the middle of May." Mr. Kerry, however, says (40. iii. 306), that in 1879 many were Istill to be seen round Harwich on May I5th, when most of them had paired. He fancied they might be breeding, but this is altogether unlikely. Many were still about our coasts on May 25th (29. June 7). In I882, the Rev. M. C. H. Bird saw two off Canvey Island as late as May 2nd. Dr. Laver describes it as "excessively numerous in some years" round Paglesham, and Mr. Benton, writing of the South Hall Marshes at Paglesham, says (35.440) "formerly great quantities of Geese, locally called 'Scotch Brants,' which are something less than Grey Geese, used to make choice of the surrounding swamps for feeding grounds, but they have not been seen for some years."

As a rule they keep to "the Main " or the open sea, but Mr. Atkinson writes: "I have occasionally seen a 'Black Goose' in the larger arteries of the saltings at Tollesbury." One was seen about the brook here during a spell of hard weather in December, 1878 , and a pair were seen to fly out of the brook near this house on Jan. Ioth following, while the weather was still severe. On October Ifth, I879, my brother Cuthbert shot the male of a pair feeding in the brook Cann close to this house. I have the bird still. From theircomparative tameness, I can only think that they had escaped from some preserved water.

Mr. Cordeaux, writing in I887, says (40, xi. 152): "Some years since Col. Russell sent me a fine White-bellied Brent, shot by himself on the Essex coast, ascompanied by some interesting and exhaustive notes as to the two races and their comparative abundance and scarcity in various years." Essex specimens of both the white- and dark-bellied varieties are among the birds collected by the late Col. Russell, while some very interesting remarks upon the two races are 
containe 1 in some letters by the Colonel, published in the Zoologist (40. xiv. 59). He says :-

"On Feb. 4th, 1879, a large number of White-bellied Geese came [to the Blackwater], probably from the south, as just before coming to us they appeared at Leigh, on the north side of the mouth of the Thames. There is little or no feed for them there, and only Geese which do not know the country call there, but of course do not stay long. Their ignorance was also shown by their foolishness when they came on our coast; a great many were shot for five days, but these were very thin. Most likely they had been southward, but had failed to find good feeding ground. I was not on the coast till about Feb. 2oth; by that time the White-bellied Geese were fat and almost unapproachable; they were then mixed with the Black [-bellied] sort. They stayed, to my knowledge, till March $1_{5}$ th, -I believe much longer. As usual, the White-bellied [Geese] had no more young with them than the Black [-bellied] If, as I suppose, the two varieties are bred in different parts of the world, the cause of failure of breed must be widespread. I wonder whether those who have been at their breeding-places have noticed which variety they saw. *** We have not only the two well-marked varieties, but every intermediate shade -perhaps from intermediate places. *** In the winter of $1880-8 \mathrm{I}, * * *$ we had not many White-bellied Geese; I had some difficulty in getting a good specimen for you, and another for Capt. Fielden. There were very few young among them, but I think a larger proportion than among the black sort. Last winter [I88I-82], we had hardly any White-bellied ones at all. I heard of one being shot among some black ones quite early in October-the only one I heard of being got. My man saw one among a flock of black soon after : and I saw only one White-bellied (a single bird) early in November or late in October,-I forget which. One gunner-always on the coast-said he had seen only one little lot of the White-bellied sort, about a dozen, all the winter."

Upon the general subject of the Brent Goose on the Essex coast, and upon the varying proportion of young birds to old in different years, Col. Russell says :-

"The Brent Geese seem to come to the Essex coast pretty regularly about the beginning of the second week in October. Sometimes the first I hear of are not seen at all. With a fair wind they may be heard miles off at sea, far out of sight. In 1880 , my informant (a very experience 1 gunner) told me he was afraid that there were no young ones, and he was right. Throughout the season from the time of their first arrival, there was not one young one to a hundred old ones. Last October, my informant about their arrival was another gunner, who lives close to high water mark in the part most frequented by the Geese : he told me that there were young ones among them. *** To repeat the proportions ***:-Young [were] very numerous almost every season for about twelve years up to 1878 .

"I878-79, about one young Goose to twelve old ones.

"I879-80, great numbers of young all the season.

"I I80-8I, about (or less than) one young Goose to a hundred old ones.

"I881-82, nearly as many young as oll.

"I do not think that of these birds the young and old migrate separately. * * The mildness or coldness of the winter has nothing whatever to do with the presence or absence of young Brent Giese. *** We had a good many Brent Geese this last winter [I8SI-S2] considering the mildness of the weather. Quite early, there were about 300 , and more came from time to time, till there were 1000 or more between the Blackwater and Crouch Rivers. ***. Our coast is more disturbed than ever. People have taken to hunting the fowl in steamlaunches. *** Every bird that swims is driven away-even such rubish as Scoters-except the Brent Geese, which keep well out of the boat's way, but will not, however, leave the country. I think they will soon cease to visit us, the disturbance getting worse and worse, and the feed failing more and more. The Zostera marina is gradually disappearing everywhere on the Essex coast an 1 in 
all the rivers. ***. The Geese have less and less feeding ground every year. There is hardly a place where they can sit at low water and feed far enough from the edge not to be liable to be disturbed; yet the Geese of late years come more regularly than thirty or forty years ago. Then, in mild winters, we often saw none, or next to none, through whole seasons. I know not why this is-perhaps because, on account of a run of good breeding years, there are more of the birds, or perhaps, as there is much less of the weed they eat, there may be less of it adrift at sea-for the Geese used sometimes to remain all the winter without coming within sight of land. *** I will make one more remark about them : They never go to sleep. Look at them when you will with a telescope, all day they are wide awake, and all night they seem equally busy, whether you find them near the land or go off to sea after them on a calm night. When far off at sea, you may hear their noise the whole night, shifting its bearing with the tide. I never saw, or heard of anyone seeing, a Brent Goose with its head on its back, as if asleep [though] Ducks and Wigeon may' often be seen in this position.'

\section{Barnacle Goose : Bernicla leucopsis.}

A rather uncommon winter visitor, very much less abundant than the Brent Goose.

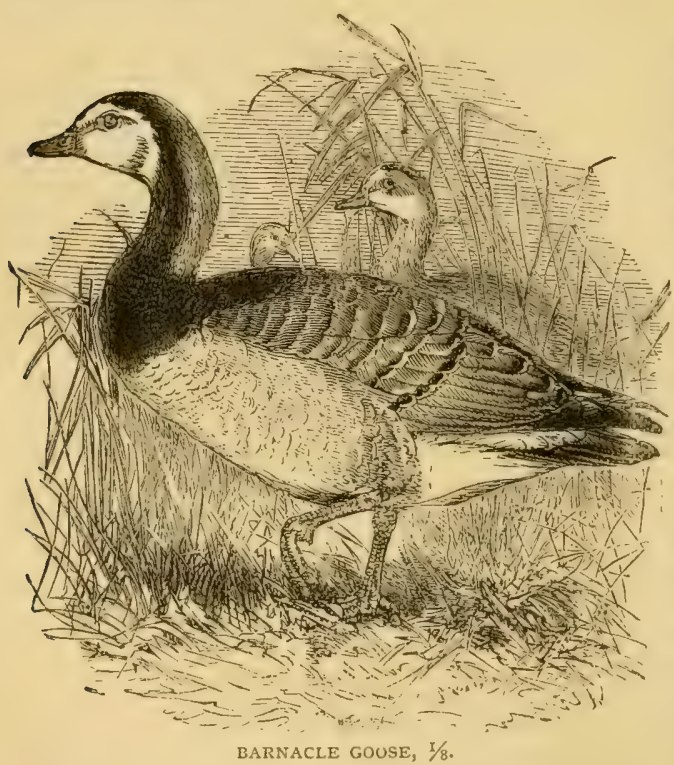

being shot out of one his ponds at Brick House, Maldon.
Lindsey, writing from Harwich in $185 \mathrm{I}$, speaks of it (27. App. 59) as "a winter visitor here, appearing in considerable flocks, particularly when the weather is severe." The Parsons Collection contains one shot by Mr. Parsons on New England Island, on Dec. IIth, I830. In the winter of I870-7 I a few were seen in the Thames estuary, in company with Brent Geese (Smee-34. 2605). Mr. F. Spalding has two, shot at Tollesbury in January, r887. Mr. Hope, who has specimens shot at Maldon in March, 1886 , says it is "not uncommon in small lots." Mr. Fitch remembers four Dr. Laver describes it as rare in both the Colchester and the Paglesham districts. Mr. Pettitt has a couple
shot recently with two others at Dovercourt, and Mr. Hope writes: "On June I6th [1889], four Barnacle Geese flew out of the Deben River [Suffolk], and went southward across the Cork Sand, off Harwich. I have never seen these birds at this time of the year before," Curiously enough, Mr. Fitch also tells. me that on the 26 th of the same month he saw four Geese fly over the east end of Canvey Island, on which they settled.

Canada Goose : Bernicla canadensia.

An introduced North American species, which has been admitted 
into some British lists because often found at large, especially during winter. It has no right to a place on the British list. Probably those which occur in Essex from time to time have escaped from Kimberley or Gunton in Norfolk, at both of which places Mr. Gurney informs me a good many are bred annually. "After being once shot at these go away, and no doubt some of them leave the county. Others remain at large, and are quite unapproachable." Mr. Clarke mentions (24) an example (still in the Walden Museum) killed at Radwinter on Apr. 24th, I836. Four were seen at Harwich on June 27 th, I877 (Kerry-40. i. 525). Early in December, I879, one, weighing twelve and a half pounds, was shot out of a group of six, by Mr. J. J. Hawkins, near Middle Wycke, Burnham (Chelnusford Chronicle, Dec. I2); and about the middle of the same month, during a spell of severe weather, a flock passed over the Maldon district (Chelnisford Chronicle, Dec. 26). Dr. Bree records one (29), shot on the seashore at Wix, where it was feeding alone, on the long-to-be-remembered I8th of Jan., I88I. He adds that "it cost the shooter a severe frost-bite of the ends of his ten fingers," and that it had probably escaped from some ornamental water. At Harwich, "some are seen nearly every year" (Kerry).]

\section{Red-breasted Goose : Bernicla muficollis.}

A very mare straggler to Great Britain, of which a single specimen happens to have been killed in our county.

Mr. Harting has recorded (34.25I3: \& 29. Jan. 21, \& Feb. 4), that a speci. men was shot out of a flock of Brent Geese at Maldon, on Jan. 6th, I87r, and added to his Collection. The sex was not ascertained. This is the twelfth and last recorded British specimen, and the first met with since $1845^{*} \mathrm{Mr}$. E. A. Fitch, who has taken some trouble to investigate the history of this specimen, writes (50. iii. 35 ) :-

"It was on Jan. 6th, I87I, that Henry Handley, with his brother John, Josiah Pitt, John Basham, and seven others, were gunning on the Ray Sands, popularly called the 'Main,' when amongst a quantity of Black (Brent) Geese they shot one of the rare Red-breasted species (Bernicla ruficollis). It was shot off the south part of the Bachelor Spit-in the bight of the Bachelur-and was picked up, winged, by Josiah Pitt. The birds were brought home and given to Henry Handley to hawk round the town of Maldon, as was his wont, at two shillings each, but nobody would have the 'foreigner,' so Handley had resort to Robert Blanks, a local bird-stuffer, now deceased, and, after abating sixpence off his two shillings, sold it to him. Blanks set up the bird and took it to Mr. Richard Poole, who identified it by Yarrell as the Red-breasted Goose, and wrote to the Editor of the Field, asking what it was worth. Mr. Harting replied that he would willingly give five pounds for the bird, should it prove to belong to the species represented. Blanks, of course, was willing to sell at this (to him) enormous price, and the specimen became Mr. Harting's property. When this gentleman parted with all his birds that were stuffed and set up, limiting his Collection to skins only, the specimen was knocked down at Stevens' Rooms on the '6th of June, I872, for $£ 3$ I IOs, to John Marshall, Esq., of Belmont, Taunton, in whose possession it still remains [37. iv. 282].

\section{Mute Swan: Cygmus olor: Locally, "Tame Swan."}

Common in a more or less domesticated state on ornamental waters. It has been admitted to the British list for many years, but

* It is worth mention that Montagu (p. 127) says :- "One, Dr. Latham informs us [Syn., vi., p. 455], was shot near London [very likely in Essex] in the severe frost of $I_{7} 66$." Harting says (38. 156) that "according to Fox (Synop. Netuc. Mits.), this date should be ${ }^{7} 77^{5}$." 
as it was probably introduced into England, though many centuries ago, it has not a very good claim to this distinction.

\section{[Black Swan.}

An introduced Australian species, which has no claim whatever to a place on the British list, though individuals are not unfrequently shot, apparently quite wild and undomesticated. For instance, one was shot at the Lordship Farm, Writtle, in the winter of $1875-6$, and another here in July, 1878 , while Dr. Bree records (34.3492) one, shot out of a pair at Bradwell, on July 9th, I873, after having been seen at Walton-on-theNaze, Frinton, \&c. Col. Russell, writing to Mr. Hope on August I7th, I884, says: "One of the Mussetts from West Mersea shot a Black. Swan on the Ist Aug. One, probably the same, was there on Aug. Ist,. three or four years ago." Dr. Bree records an adult male shot at Mersea on June Ioth, I864 (29. June 25). This had probably escaped from Abbots Ripton Hall, Hunts (29. July 9th, 1864). On July 9th, I87r, two were seen about ten yards above the sea and fifty from the shore passing Walton-on-Naze, going from Harwich towards Clacton. They were fired at but missed at Frinton. A. Mussett subsequently shot a male, having an entirely empty stomach, at Bradwell. The other escaped (29. July 29, I87I).

\section{Whooper Swan: Cygmus musicus. Locally, "Vild Swan."}

A not uncommon visitor to our coast during severe winters, when. it is also sometimes met with inland.

Dale, writing of Harwich, says (2.403): "This in winter time is often shot upon this coast," and Lindsey, writing at that place in IS 5 I, says (27. Ap. 58) they "visit us in the winter, arriving in flocks, sometimes as late as Christmas, and are generally more numerous as the weather becomes more severe." Mr. Kerry says (40. iv. 69) that a good many were seen about Harwich during the severe weather in December, 1879 , and that one was shot on the 8th. Mr. Parsons writes (8):-

"The winter of 1829-30 was very severe. There were a good many birds before Christmas, but in January the weather was so severe and the shore so bunged up with ice, that there was no shooting. In February, we had a few days good sport. There were a good many Swans about, and an Eagle [was] shot on Foulness. From Dec. 9th to Jan. I6th, it snowed every day, with only one or two exceptions."

Mr. Clarke notes one (24) killed many years since out of a flock of four, and long in the Audley End Collection; also two killed at Audley End on Jan. 3 Ist, 'and two more on Feb. 4th, I838. Mr. Blyth says (I2. iii. 4I4) that in the winter of $1837-38^{\prime \prime}$ many appeared in this country and large numbers were shot. In one place on the Thames I have information of a flock settling among a num. ber of tame Swans, and readily coming to feed on bread, \&c., that was thrown to them. It was consequently hoped that they would have been induced to remain in the locality, but at the breaking up of the frost they all disappeared, after a sojourn of some weeks. At Manningtree, in Essex, however, a number appear to have taken up their abode, and it is expected will breed there." King also says (I 5 ) that "during the last severe winter [I837-38], this country was visited by immense flocks of these birds. Several were shot in this neighbourhood [Sudbury]." Edward Doubleday includes it in his list of Epping birds (15). One, weighing $22 \frac{1}{2} \mathrm{lbs}$, was shot at Southend early in $186 \mathrm{I}$ (29. Feb. 9). Mr. A. H. Smee says (34.2525) that during the severe weather in the beginning of $187 \mathrm{I}$, some were seen round the mouth of the Thames. One weighing twenty- 
three pounds was shot in the third week of January, and Mr. Smee says he approached within 120 yards of one in Hadleigh Ray, just after daybreak on the morning of Feb. I5th. It is recorded (Chelmsford Chronicle, Jan, 3I) that on the 28 th of Jan., I879, "A group of these birds, twenty-three in number, were about the river, and after having been fired at took their departure. Several have since been seen close in-shore." On the 20th, one was "captured alive after being slightly wounded। in the wing, and was afterwards sold to Dr. J. H. Salter." Mr. Fitch says that, in the same year, "twelve lit close by the high-road at South House, Maldon, and I believe four were bagged. I heard the shots fired."

\section{Bewick's Swan: Cygnus bervicki. Locally, "Little Swan."}

A not uncommon winter visitor to our coast, especially during long spells of severe weather, and occasionally met with inland.

In the Collection at Audley End is a specimen killed there in $18+1$. King, writing in 1838 , at Sudbury, says (20) :-

"Last winter one was shot on the Stour about three miles east of the town. It was a beautiful specimen and the first I had ever seen; but I was unsuccessful in my endeavours to obtain it. *** I subsequently obtained another specimen of this bird, also shot on the river."

Dr. Bree records one (29) shot at Alresford Creek in the winter of I850-8 I, and now in the collection of Mr. Jas. Round, M.P. Mr. A. H. Smee says (34. $255^{2}$ ) that during the severe weather in Jan. and Feb., I87I, several flocks of Swans were seen round the mouth of the Thames. "Twenty-six were seen in one flock by the Nore Light-ship. Another flock of ten was seen on the mud-flats opposite Leigh. The fishermen called them 'Little Swans,' evidently meaning Bewick's." Two which were shot off Leigh on Jan. $24^{\text {th }}$ and Feb. I $3_{\text {th }}$ respectively, both weighed thirteen pounds. Mr. Hope remarks that both this species and the Whooper are "not uncommon in winter." He adds: "I have seen them going south in November and north again about April 7th. Dr. Laver describes it as rare in the Colchester and Paglesham districts, but more frequent in both than the Whooper.

\section{Sheldrake: Tadorna cornuta. Locally, "Bargander," or} "Bar-goose."

A resident on our coast, though not common, and certainly decreasing. Without doubt it used to breed much more commonly than at present.

Merrett say's (I. I79): "Chenalopex vulpanser, a Bergander, nusquam alias vidi nisi in Thamisi fluvio aiunt tamen Esse frequentem in insula Tenia (Thanet) vocata et illic in scrobibus cuniculorum nidulari." Albin says (3. I90): "They are found about several lakes and rivers near the sea-coast of England and Wales, but chiefly in Lancashire and Essex." Donovan also, apparently quoting Albin, says (5. iii. Pl. lxxi): "It is found in vast quantities on several of our sea-coasts, and particularly about the rivers and lakes in Lancashire and Essex, where it finds an abundance of small fish, marine insects, \&c." Dale, in 1730 , says (2. 405): "This I have seen at Braintree, brought from these parts [Harwich], it being very frequent on the east side of England." Mr. Kerry says it is now "very common" round Harwich in some winters. He adds that a pair bred near Walton-on-the-Naze in 1888 , and again in 1889 . Mr. W. H. Hill, in 1835 , says (12. viii. 574) it "is common, either in pairs or in flocks of about a dozen, in the creeks and inlets of the River Crouch." In 1838 , it was "not common" ri)und 
Sudbury (King). The Rev. M. C. H. Bird informs me of a pair seen on Canvey Island on Jan. 20 th and 25 th, I8SI ; another on Jan. 2Ist, I882 ; another pair on April I8th and $23 \mathrm{rd}$, I885; and also of two pairs seen on March gth and again on April gth, I882, all on Canvey Island, where, he adds, he still knows of their breeding.* He says (40. xi. I95) it is known as "Bargoose" on the Essex coast. He never heard the term Bargander applied to the male. "It appears to be a late breeder. One, killed off Canvey Island a few years ago on May gth, had no down off the breast, although the feathers there were dirty, as if she had been burrowing, and the most fully developed egg in the ovary was not so large as a pea."

As regards its breeding in the county, Mr. Fitch writes (4I. i. I96): "A nest of this handsome duck was found on Osey Island this year [1887] in a rabbit hole on the cliffs. The old bird was caught, but again liberated, and the seven eggs taken by Jordan and put under a hen. These all hatched in three days time." One young one was speedily killed, but the rest were kept alive by Mr. E. H. Bentall. Mr. Fitch also knew of a nest on the Crouch at Fambridge in 1839. The Rev. J. C. Atkinson writes me that he knew of its breeding at West Mersea some sixty years ago. He adds: "One of my friends, the son of the then Rector of East Mersea and Curate of West, got a 'clutch' of eggs out of one of the sand-hills, near where he and I used to bathe, and hatched them at East Mersea Rectory, I forget whether under a hen or a duck." Dr. Laver describes it as "common on the coast, where it still breeds in some spots." Mr. Hope who has specimens shot at Harwich in December, I867, says it "still breeds on the coast in rabbit holes." On June 12 th, I888, Mr. Fitch and myself were $\mathbf{i}_{\text {nformed }}$ by the keepers of the Old Hall Marshes, Tollesbury, that a pair were then breeding near at hand, but we did not actually see them. Mr. Benton says (35. I98) : "The Bargoose occasionally rears its young in haulm-walls, \&c.," on the coast.

\section{Ruddy Sheldrake: Tadorna casarca.}

Of this rare visitant to the British Isles, I have only a single record in Essex, and that a rather unsatisfactory one, inasmuch as the whereabouts of the specimen said to have been obtained is not now known.

Mr. Hope writes me :-

"I quite remember the fact of a Ruddy Sheldrake being shot in the Black. water one time when I was fowling with Col. Russell on the Mlain; and I remember at the time hearing who shot it, and how he only got a trifle for it, and how the next man sold it for a large sum; but I never saw it, and cannot remember the exact date."

\section{Wigeon: Mareca penelope.}

A very common winter visitor to the coast and sometimes killed inland. It used to be taken in the Decoys in prodigious numbers, as already mentioned (p. 70). It seldom arrives before the end of September. Any seen earlier have probalsly been bred in Britain, as a few undoubtedly breed in Scotland and Ireland, but it has never yet been known to do so in England.

* On the latest Ordnance maps, a sand-bank at the east end of Canvey Island is still marked as the "Bargander Sands." 
Dale, in 1730 , says $(2.404)$ : "These in winter time are brought to [Harwich] Market from the decoys." Mr. Bond met with "one specimen only" at Southend during the last week in August, I 842 (23.40). Mr. Clarke, about I845, speaks of it (24) as "not infrequent" then round Saffron Walden. According to King (20) it was formerly "not uncommon" around Sudbury. Mr: Buxton says (47. 97) that in Epping Forest it "may be seen occasionally in winter," and English includes it (43. i. 24) in his Epping List. Round Harwich, Mr. Kerry calls it common, and it is said locally to breed there occasionally, but this is almost certainly an error, though Mr. Hope informs me that he has seen birds of the year near Harwich early in July, and that they remained in the neighbourhood for two months. Six young birds were also observed on the Essex coast on August 7 th, I8So (42), while four young birds were taken some years ago in the Marsh House Decoy, Tillingham, during the month of August.

It is a highly remarkable fact, too (as has already been observed-p. 7I) that, whereas at present the vast majority of the birds taken in our Decoys near the coast are caught during December, January and February, a century and a half ago, by far the greatest numbers were taken during September and October, while even the month of August was then more productive than the months mentioned above now are. The inference seems to be that a very large number of the birds formerly taken were home-bred, or, at least, that their chief breeding-grounds then lay nearer to us than they now do. Now-a-days, the Wigeon is only known to breed in Britain on the rarest occasions.

\section{[American Wigeon : Mareca americana.}

A very rare straggler to Britain from America, only six or seven specimens having been obtained here. An Essex record by Mr. Samuel Howell Carter of Marsh Lane, Tottenham (29. Feb. I3, I86 ; and 23. 8962 ) is very vague and unsatisfactory, though accepted by Harting ( 88 . I59). He merely writes, "I shot on the Essex coast last Saturday [? Jan., r864] a beautiful female specimen of the American Wigeon." The whereabouts of the specimen is not now known, and the whole record is so utterly unsubstantiated that no reliance must be placed on it: A young male Common Widgeon in moult, shot at Maldon in Nov., I862, was erroneously recorded in the Field as an American Wigeon by "C. A. W:" (29. April 4 and II, I863).]

\section{Pintail: Dafila acuta.}

A not-uncommon winter visitor to the Essex coast. Occasionally individuals occur inland.

In the Parsons Collection is a fine old male shot on Shoebury shore at flight in Jan., 18;2. King says (20) female was shot near Sudbury in the winter of $1837-38$. It is marked in the catalogue of Walden Museum, issued in I 845 , as having occurred near that town. Lindsey, writing of Harwich in $185 \mathrm{I}$, says (27. App. 66),

"This handsome Duck is a winter visitor to our shores, and one of those species

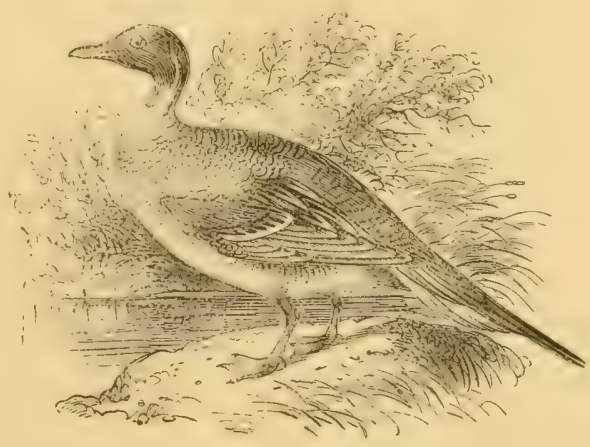

PINTAIL DUCK, adult male in sprins, I/II. 
which are taken when the Decoys begin to be worked in October. It remains here through the winter till the spring, and is obtained by. Wild-fowl shooters on the coast."

Round Harwich, it is rare (Kerry). One was shot on Canvey Island on Dec. rgth, I88I (Bird). Mr. Robert Page has a pair, taken in his Decoy at Marsh House.

\section{Wild Duck: Anas boscas.}

A resident, breeding not uncommonly among the marshes near the coast and in various private parks containing ornamental lakes,

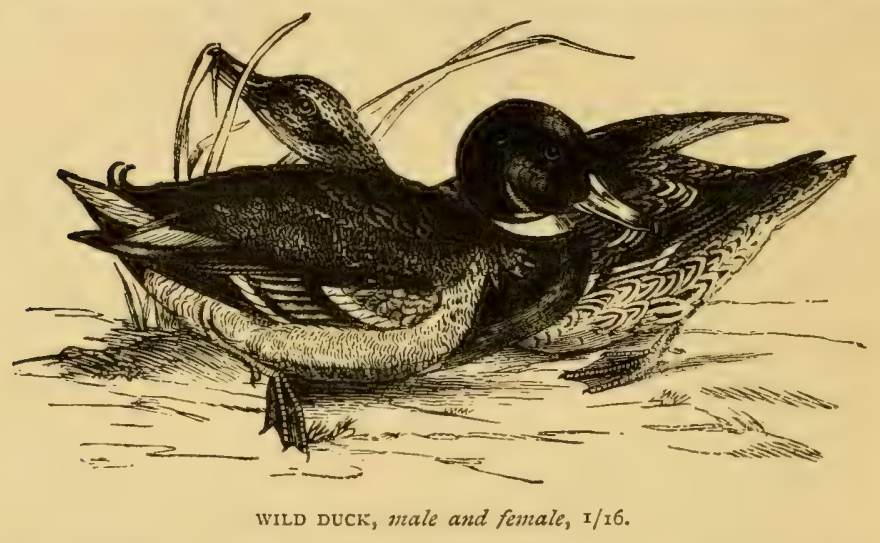

throughout the county. The resident birds are, however, enormously recruited during winter by arrivals from elsewhere. The immense numbers formerly taken in the Decoys on the coast have been already alluded to ( $\mathrm{p} .70)$.

Dale, writing of Harwich in 1730 , says (2. 404), "These are in winter time abundantly caught in decoy-ponds, from whence they are carried to supply markets." Round Saffron Walden, Mr. Clarke says (24) it used to breed freely about 1845 , and it is now by no means rare there, breeding in and around Audley End, Shortgrove and Debden Parks. I saw a nest containing nine eggs built in the crown of a huge oak growing beside the lake, in the latter, on April 27 th, I880. It "breeds annually in several parts of the forest. A small party of them frequented Connaught Water throughout the winters of $1883-84$, and being left alone, became very tame " (Buxton-47.97). In the spring of $1883, \mathrm{Mr}$. William Cole saw a Wild Duck and young on a pond near Connaught Water. In April, I877, a nest. was built in the crown of a pollard willow-tree beside the river Roding at Stanford Rivers, and a nest containing ten eggs was found in Navestock Park on May Itth, I888. As regards its breeding on the coast, Mr. Fitch writes (4I. i. I50):

"I hear that upwards of fifty 'flappers' have been seen in the ditches of South Wick, Southminster Marshes, quite lately. They breed in this neighbourhood much more rarely than formerly. In I875 a nest of eggs was hatched here on my home farm (Brick House, Maldon), but there has been no sign of one since. One nest hatched off on Northey Island this year. I have seen quite fifty young ones in a day in the Canvey 'Fleets." "

The Rev. W. Palin, in I87I, wote as follows (Stifford and its Neighbourhood, 
p. IOg) :- "A friend tells the writer that thirty years ago he and another bagged seventeen pairs of flappers (young Plovers) in a day on the Tilbury Levels." "Flappers" are, of course, young Ducks, not Plorers. On the Old Hall Marshes, Tollesbury; and all the other marshes round our coast, it is common as a breeding bird. Round Harwich, "it is common and breeds on the Bentlings, where it makes a nest without any attempt at concealment, much to the delight of the Carrion Crows" (Kerry).

In the Collection at Audley End is a black variety (? domestic) killed at that place (24), and in the winter of $1876-77$ I was informed that a white one was seen on the lake in Navestock Park. A hybrid specimen, the result of a cross between this species and the Wigeon, was among the birds collected by the late Col. Russell. It was shot on the Essex coast, but I am unable to say where. It is described as a male in full plumage, showing the markings of both parents very distinctly, and is conjectured to have been bred from a Wigeon which had been wounded, and was unable, in consequence, to migrate.

Mr. Hope observes that there are two forms of this bird, a large variety, which comes first, and a small sharp-winged form, which arrives about Christ-. mas.

\section{Gadwall : Chaulelasmus streperus. Locally "Sand Wigeon."}

A decidedly uncommon visitor to our coast from autumn to spring.

Mr. Clarke mentions (24) a male killed at Wenden in Feb., 1837, and there is at Saffron WValden a mature male shot on the lake at Shortgrove in March, I862, by a gamekeeper. King, in 1838 , says (20), "I have in my collection a female Gadwall shot about two years since on the Stour at Cornard." This bird is now at Birmingham. Lindsey, writing of Harwich in I851, describes it (27. App. 63) as "a rare species, occurring sometimes in winter, but more frequently in the spring, rather than at any other season of the year, and then only in very limited numbers." Mr. Hope says it is "often shot near Harwich." Mr. Robert Page has a pair, taken in his Decoy at Marsh House.

Garganey: Querquedula circia. Locally, "Summer Teal."

An uncommon visitor, chiefly when on migration. I know of no instance of its breeding in the county, though it has done so in Suffolk and Norfolk.

Yarrell says (I4. iii, I66) that it is rare in Essex and Kent. Lindsey, writing of Harwich in I85I, says (27. App. 62) that it

"is rather a rare species, and though specimens have been seen in October, it more frequently makes its appearance in the spring, and

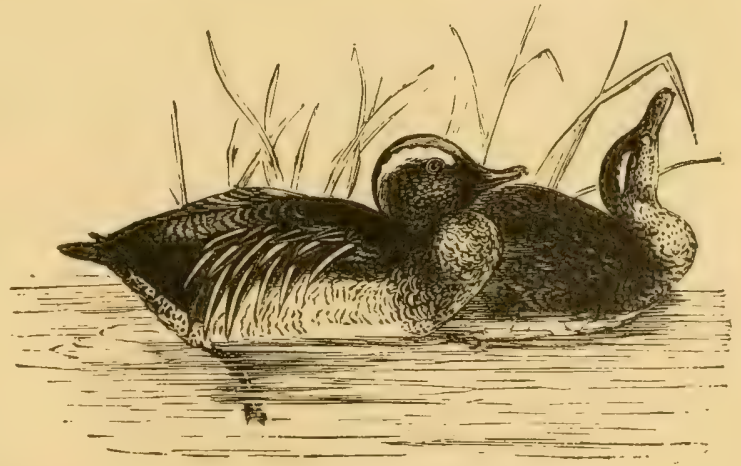

GARGANEY, male and female, $x_{1} / 8$. then only in comparatively small numbers." 
Mr. I. H. Gurney jun., has the wing of one killed on July $22 n d$, I884, at the Swin Middle L.V. Mr. Robert Page has a pair, taken in his Decoy at Marsh House, Mr. Pettitt preserved a couple of males, shot by Mr. Robert Pettitt, of Pagleshnm, on the Hyde Marshes, North Fambridge, on Mar. Ifth, I8go.

\section{Teal: Querquedula crecca.*}

Best known as a common winter visitor, especially to the marshes near the coast, but also a resident, breeding with us in small and apparently decreasing numbers. In some seasons, large numbers are taken iis the Decoys.

To Harwich, in 1851 , Lindsey described it (27. App. 62) as

" "an early and constant winter visitor, making its appearance by the end of September, sometimes sooner, and remaining till spring has made considerable progress." He adds that their numbers are "constantly recruited through the winter months by additional arrivals from the northern parts of Europe, and our markets, in consequence, obtain a regular supply from the various decoys and other modes of capture."

King, in I838, says (20) it was then "not uncommon" around Sudbury, and Mr. Clarke, about I845, described it (24) as being then "not uncommon" round Walden. Mr. Andrew Marriage has one shot by himself at Little Baddow in the winter of 1874 , when in company with two others. Mr. Buxton says (47.97) "several frequented the Wanstead Park waters in the spring of I883, and in the following spring, I saw a single bird on Connaught Water." This bird was also observed by others (44. iv. Ixxviii). Daniel says (6. ii. 472) that he turned out some which he had received from the Decoyss, upon the ponds at Little Waltham Hall, after having pinioned them, and that they bred there.

As regards its breeding at large in the county generally, the Rer. J. C. Atkinson writes (36. I45) :- "When I was a boy, I heard of nests, almost annually, on some of the [Essex] marshes I knew most familiarly." A nest of five eggs was taken on the marshes near Tollesbury in June, I883, by my brother. Round Harwich, it is common and breeds (Kerry). In the Paglesham district, too, it breeds "almost every season" (Wiseman). On our coast, however, it seems decreasing in numbers as a breeding bird. Mr. J. May, who has known the Old Hall Marshes, Tollesbury, for upwards of forty years, informs me that in his young days he remembered seeing as many as thirty pairs of Teal breeding there, but they have for some time been gradually becoming scarcer. In 1887 , he knew of two nests, but in 1888 he feels certain there was not one on the I,700 acres, or thereabouts, under his supervision. It seems to be the same on Northey Island, where Mr. Fitch states (50.ii. I9\$) that " none have bred for the last three years."

Its breeding in the inland parts of our county is very unusual, but in the summer of I886, a pair nested in the osier-ground beside the brook Cann at Writtle. My cousin, Mr. R. W. Christy, saw the old birds repeatedly during the early spring, and up to the middle of April. During the summer, the nest, which contained broken egg-shells, was found by a man named Thomas Perry.

* The Bimaculated Duck (Querqucdula bimaculata) is a spurious species, described from a cross between a Teal and a Wild Duck, which used to appear on the British Lis:. Yarrell says (Zoological Joumal, i. 585 ; and 14. iii. 166 ) that the male and female from which he took "his description" were sent up from a Decoy near Maldon in "Essex, to Leadenhall Market in the winter of $1812-130 "$. They were there observed by Mr. George Weighton, a professional naturalist, who purchased and preserved them. They afterwards passed into Yarrell's own Collection, and are now in the British Museum, labelled "? Maldon." 


\section{Shoveller: Spatula clypeata.}

Fairly common on our coast from autumn to spring, and occasionally met with inland. It breeds regularly, though in small numbers, in several parts of Britain, and a few pairs nest annually among the marshes on our coast.

Mr. Clarke notes (24) a male shot at Debden by Mr. Salmon on Mar. 28th, 1839. Mr. W. H. Hill, of Southminster, in 1835 (12. viii. 574) says, it " is rarely killed [in that district]. I have seen one pair this winter." Mr. Crouch has (44. iii. v.) a specimen shot on the Roding at Barkingside on Oct. 27th, 188I, after a week of very severe weather.

$\mathrm{Mr}$. Crosfield, of Reigate, informs me that he put a drake up from Dagenham Lake on April 29th, I879, when it seems probable that it was breeding. Mr. Hope writes that it "breeds on the marshes not far from Harwich." He shot one th. re on Aug. Ist, I.8.3 4. Mrr. Fitch and myself observed a pair on the Old Hall Marshes, Tollesbury; on June I2th, I888, which the keepers informed us had bred there that spring; and in I 3.39 , according to Dr. Salter, a considerable number bred on these marshes, where he says it is becoming commoner as a breeding bird. In a MS. letter of Col. Russell's, he says :-Several pairs "stay every summer in our place in Essex [? Stubbers], and probably breed there, but their habit is to go south soon after they can fly well.,

\section{Tufted Duck: Fuligula cristata.}

A somewhat rare and irregular winter visitor; occasionally met with on lakes or rivers in various parts of the county, but most aften near the coast. It has not yet been positively known to breed in Essex, but may do so, as it appears to be a resident and increasing in numbers in various parts of the country.

Graves says (7. iii) :-

"Some we received alive from a decoy near Mal-

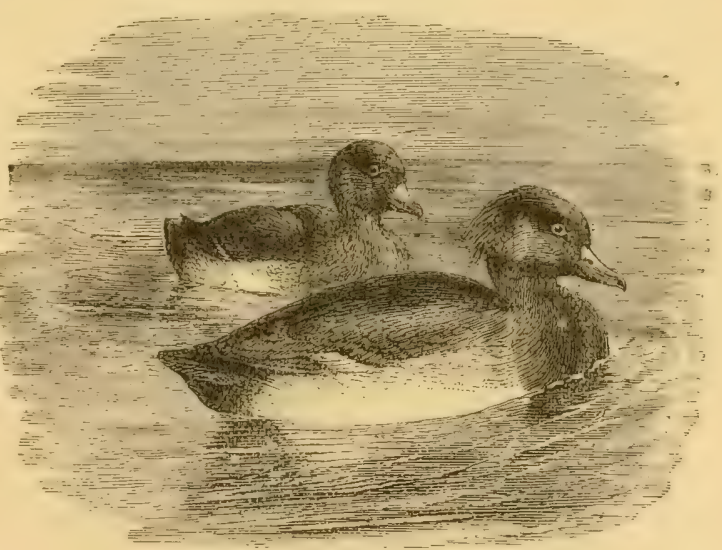

TUFTED DUCKs, male and female, I/8. don, Essex, were exceedingly wild and survived but a few days. During their confinement, on the approach of anyone, they uttered a hissing noise like the Common Goose, and were continually snapping their bills. They have many of the actions of the Teal, but are a far less elegant species."

Mr. Clarke speaks (24) of one at Littlebury on Feb. 2nd, I832, and one at Audley End in I835. Earthy, in March, 1839, records (I9. I I 4 ) the recent occurrence of one at Marks Hall. On Mar, 2oth, 1867, a flock appeared on the River 
Lea about a mile from Hoddesdon. Seven of them were shot by one gentleman (34. 709). Mr. Buxton says (47.98):-

"Early in I884, a male and three females frequented the upper pond in Wanstead Park for two months, in company with the Coots, and became almost as tame as they are. The male bird left us towards the end of February, but the females were still there on March 7th."

An adult male was shot at Ilford during the last week of 1877 (29. Jan. 5). At Harwich, a few are seen every winter (Kerry), and a pair were shot in the harbour 'on Jan. 12th, $1876(34.4827)$. Mr. Hope says that it arrives on our coasts in October. In the winter of $1887-8, \mathrm{Mr}$. Sackett says he seldom went out shoreshooting round Orsett without seeing several. On Feb. IIth, he watched five feeding on the edge of the tide; three were diving, each remaining under water for a long period, while the other two floated motionless, as if on guard. On Feb. 2nd, I 889 , he "observed a party of between twenty and thirty floating on the waves waiting for the tide to recede ; also several other smaller parties out on the river." In August, ISS8, seven young "Black Ducks" were shot on a large sheet of water, known as "The Wade," in Steeple parish, but I have been unable to satisfy myself that they were of this species, though it seems probable. Mr. Robert Page has a pair, taken in his Decoy at Marsh House.

Red-crested Pochard: Fuligula nufina.

Of this very rare winter visitor to Britain, a single example only is known to have been met with in Essex. It was killed near Colchester about January, I $8+4$, and is now in the Museum of the Cambridge Philosophical Society (37. iv. 408). The female figured in Gould's Birds of Europe was shot out of a flock of eighteen on the Thames, near Belvedere, Erith.

\section{Scaup : Fuligula marila.}

A common visitor on our coast from autumn to spring; seldom met with inland.

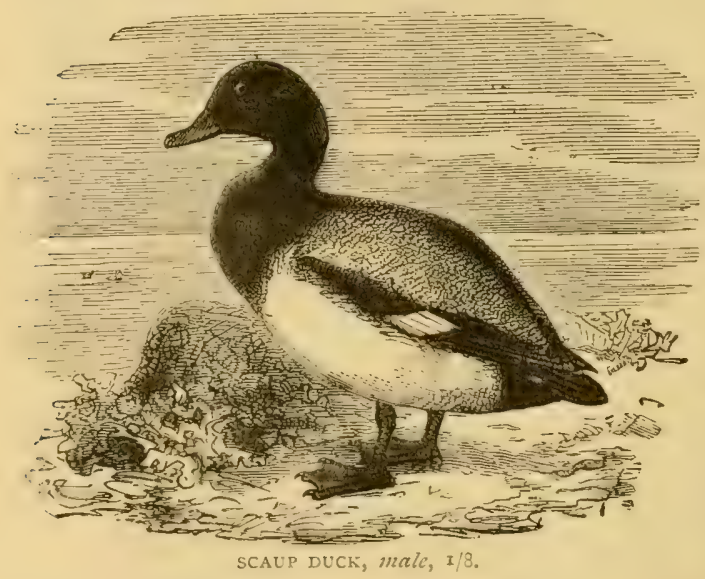

Mr. Hope says that it arrives on our coasts in October. $\mathrm{Mr}$. Clarke refers (24) to one shot at Audley End on Feb. 2nd, r830, and another (female) shot at the same place on Jan. 25 th, I 838 , which is still in the Collection there. At The Roos, Saffron Walden, a specimen shot on the pond there some years ago is preserved. Edward Doubleday wrote in I835 (I5) that it had been killed at Harlow. I. aglish records (44. iii. iv.) a young female shot on a pond at Theydon Garnon 
on Oct. I5th, I88I, it being the first he had heard of in the neighbourhood. The previous day had been very boisterous. "A flock of seven or eight remained on the Wanstead Basin for several days a few winters ago. They were very shy" (Buxton-47. 97). "A large flock of about a hundred frequented Leigh Ray during January and February [187I]. Although constantly shot at, they refused to leave the cockle-grounds" (Smee-34. 2605). "In the winter of $1887-8$, many were killed at Mersea" (Laver). At Harwich, "it is common in winter" (Kerry). Mr. Robert Page has a male, taken in his Decoy at Marsh House.

Pochard: Fuligula ferina. Locally, "Dunbird" or "Redheaded Dunbird."

A common visitor, chiefly during the winter, to our coast, where vast numbers used to be taken in some of the Decoys. During the last two or three

years a small though increasing number have become resident and have bred (for the first time, so far as is known) on the Marshes of the Blackwater Estuary.

Of Harwich, Dale, in 1730 , wrote $(2$. 409): "This is frequent in the sea and places adjoining," while Lindsey, in

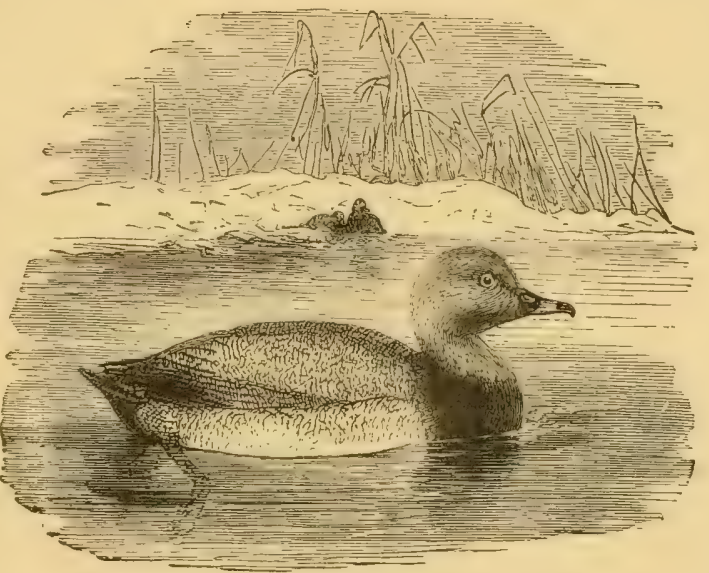

POCHARD, I/s. I85I, wrote (27. App. 60) that this species visits our coast in the wintry season. It has, however, been "very rare of late years" (Kerry). Mr. Clarke (24) mentions one killed at "The Roos," two at Audley End in Nov., 1835, and a male killed on Jan. $24^{\text {th }}, 1838$, at Audley End. Mr. W. H. Hill wrote in 1835 (12. viii, 574) that it was then rarely killed near Southminster. Mr. Buxton says that $(47.98)$ it

"has been observed at Wanstead. A single bird visited my pond last spring [1883] and remained some weeks, consorting with the tame Ducks and becoming himself very tame. A single bird came to the Wanstead Ponds early last year, and remained more than a month. At first he was very wild, but towards the end of his stay became much tamer. Last year [1884] probably the same bird returned and kept company with the Tufted Ducks, acquiring their tameness. He went away with the male Tufted Duck towards the end of February." first."

Mr. Hope observes that it arrives in October, "and is always very tame at

The Rev. J. C. Atkinson writes me that he knew of its haring bred occasionally on the Essex marshes, some sixty years ago, but that he never came across a 
nest himself. Mr. J.F. T. Wiseman, of Paglesham, informs me that he does not know of its breeding on the marshes in that district.

Along our coast, however, it seems to be increasing rapidly in numbers as a breeding bird, though I am not aware that it has been before recorded as nesting with us-at least of late years. Mr. Fitch records a nest hatched off on Northey Island in 1887, and another, containing eleven eggs, which was mown over in a field of red clover on the island in the following year (50, ii. 195). On June I2th, I888, that gentleman and myself had the pleasure of seeing quite a number of these birds, and several of their recently-used nests, on the Old Hall Marshes, Tollesbury, where we were informed by Mr. G. May, the head-keeper, that they first bred (so far as he is aware) in the year 1886, when a single pair (one of which the keepers thought had probably been wounded, and thus prevented migrating with its fellows), reared their young. However this may have been, in I887, five or six pairs-no doubt the offspring of the original pair-bred on the same marshes; while in I888, the number increased to seventeen or eighteen pairs, at least. Mr. May kindly showed us several nests, built among the reeds on the edges of the larger pools and fleets, from which broods had been hatched out only a day or two before. Some of the females seen, too, had evidently young broods among the reeds.

Golden-eye : Clangula glaucion. Locally, "White-faced Dunbird" (E.A.F.) and "Bastard Diver."

A winter visitor, chiefly to the coast, but sometimes met with inland.

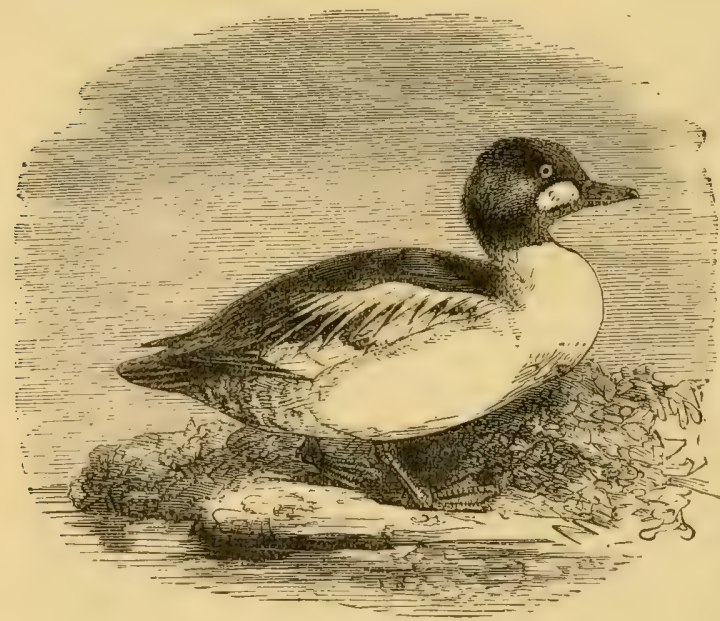

Pennant says (ii. 498) Mr. Cockfield, of Stratford, in "Es. sex favoured me with an account of two birds of this species, shot near the same time. Both agreed in colours, but one weighed $26 \mathrm{oz}$. the other only 19 oz." Mr. Clarke mentions (24) four killed at Shortgrove in Jan., I830, one at Wenden on Apr. $23 \mathrm{rd}, \mathrm{I} 836$, and a female at Wenden in $\mathrm{Feb}$. of the following year. King says (20), "Several GOLDEN-EYE, male, $1 / 8$. of these Ducks were seen in our neighbourhood [Sudbury] last season [1837]. I have a fine male in my possession [now at Birmingham], shot with another at Cornard.". Mr. Grubb says (39), "I believe almost, or quite, the last bird I shot was a female on on!r river." Mr. IV. H. Hill, of Southminster, records (12. viii. 574) that it was rare in his time $(1835)$ round that place, where it was known as the "Bastard 
Diver." Mr. Hope says it is common on our coasts, arriving rather later in the autumn than the Tufted Duck and Scaup. At Harwich it is fairly common in winter (Kerry).

\section{White-eyed Duck: Nyroca fermoinea.}

An uncommon spring and winter visitor to Britain; most often met with on the East Coast. It has, doubtless, occurred from time to time in Essex, but I have only one actual record.

A specimen (sex uncertain) taken in the Marsh House Decoy, Tillingham, about ten years ago, is preserved at the Marsh House, where, through $\mathrm{Mr}$. Page's kindness, I have inspected it. It is the only specimen known to have been taken thereabouts.

\section{Long-tailed Duck: Harelda glacialis.}

An uncommon winter visitor only to the Essex Coast.

Henry Doubleday says (IO) he saw one in 1832 in a Collection at $\mathrm{CoI}$ chester, obtained on the adjacent coast. Yarrell says (I4, iii. I66): "It is considered a rare bird, but has been killed on the coasts of Kent, Essex, Suffolk, and Norfolk." One was shot at Mersea Island, during the severe winter of $1837-3 \$$ ( 19 . 3+). Mr. Hope, who has a pair in summer plumage,

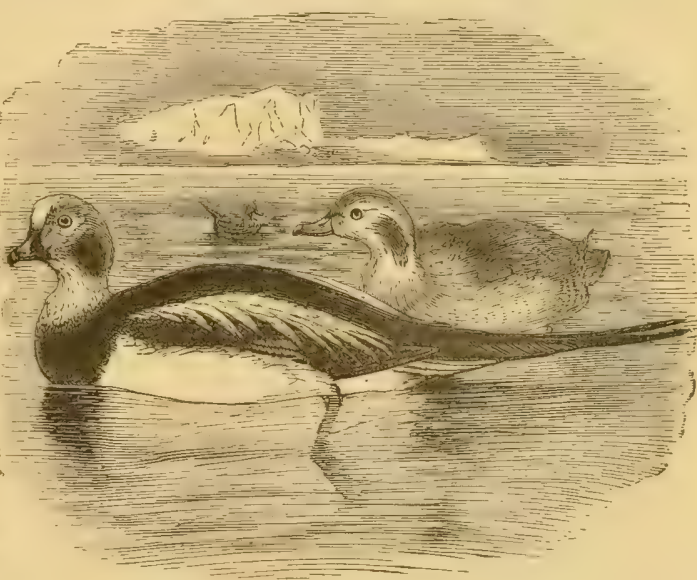

LONG-TAILED DUCKS, male and female, $1 / 8$.

killed at Maldon in Feb., I879, and a female in full plumage killed at Harwich on Nov. 9th, 1887, says: "Young birds are common every winter." At Harwich it is rare (Kerry). About the middle of Nov., I887, one was shot at Southend by Mr. J. M. Burton (29. Nov. I9; \& 4I. ii. I2). Another was shot there in the winter of I860-6I (23. 7386).

\section{Eider Duck: Somateria mollissima.}

An uncommon winter visitor only to the Essex Coast.

A couple of males shot at Maldon on Jan. 3 rd, I865, were at first supposed to be King Ducks (29. Jan. 14). Another female shot on the Blackwater, near Maldon, on Oct. $23 \mathrm{rd}$, 1875 , was also recorded as a King Duck (29. Nov. 6th, 20th, \& Dec. IIth; \& 34. 4766), a mistake afterwards corrected. Mr. A. H. Norman shot three ont of a party of four near Southend during the severe weather in Dec., I875 (29. Dec. 25). Dr. Bree records an immature male shot at Mersea on Dec. I9: I867 (29. Jan. 4). Round Harwich, it is "rare," though two have 
recently been shot on Handford Water (Kerry). On Oct. 7th, I88I, three were "seen near Levington Creek on the Orwell, two of which were shot, and the

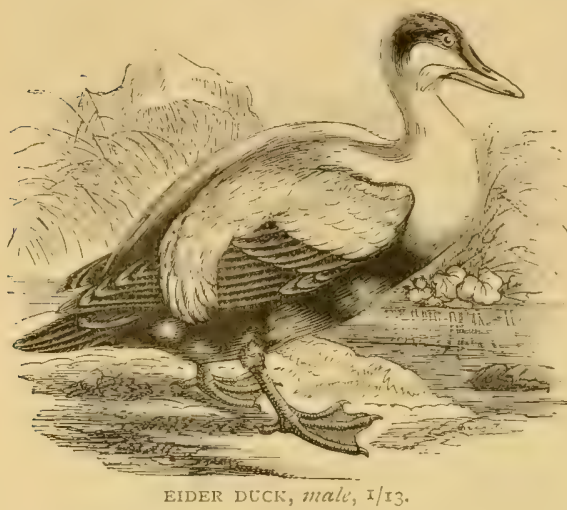
third obtuined near Harwich on the following day"' (J. H. H. Knights - 40. vi. I5I). Mr. Ambrose has preserved specimens from Mersea, Harwich, Tollesbury, \&c. Mr. Hope, who has an immature male killed on the Main on Nov. 2nd, I882, and a young female killed on Handford Water on Nov. 6th, IS88, says that on our coasts it is "common in heary weather." In the winter of $1887-88, \mathrm{Mr}$. Fitch saw several, killed in the Blackwater, and Mr. Spalding noticed others on the poulterer's stalls at Colchester. Mr.

Pettitt preserved a young male, killed at Brightlingsea on Jan. 3 rd, I \$go.

Common Scoter: Edemia Migra. Locally, "Black I)uck."

A common winter visitor to the seas off the Essex Coast; it has occurred very rarely inland. It breeds in the north of Scotland.

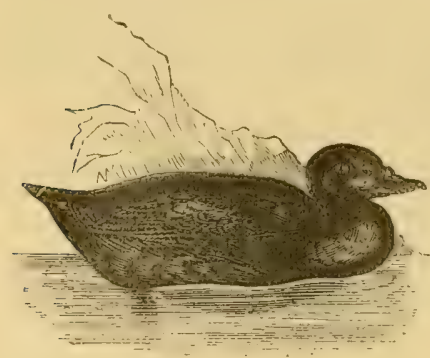

COMMON SCOTER, I/I2,

Dale, in I730, says (2. 405): "It was sent to Braintree some years past from Tendring Hundred." To Harwich, in I85I, Lindsey says (27. App. 65) it was a winter visitor only, and "during that season is to be seen in great numbers on our coast." It is now "common" there in the winter (Kerry). In the Audley End Collection is a specimen killed at Debden on Apr. 3rd, I849. Yarrell says (37. iv. p. 473): "At times the waters between the Eastern counties and Holland are black with them," and a friend saw large flocks swimming in deep water off the Maplin Sands in Oct., I888. Mr. Hope observes that it is "common on all our sands." He adds that "some birds stop all the year round." Mr. Robert Page has a female, taken in his Marsh House Decoy, at Tillingham.

Mr. Fitch writes: "Immense gatherings are to be seen all winter on the Foulness or Maplin Sands. The Black Ducks always consregate between the Crouch and the Thames, the cleaner weed-feeding Black Geese congregate between the Crouch and the Blackwater, wn the Dencic Flats and Ray Sand. The Ducks often rival the Geese in numbers, and the furmer are frequenily seen in spring and summer. On the day of the Jubilee Yacht Race (June Itth, IS87), when going down-Swin in the fog, we came on quite a large bunch of Black Duck between the Horns and the Mouse Light. Large quantities of various Ducks, chiefly Scoters, were seen near the Swin Middle L.V., in December I887; also January, ISSS. On the I2th, the vessel was surrounded with Black Ducks, as far as could be seen with a telescope" (42. ix, 54). 


\section{Velvet Scoter: Edemia fusca.}

An uncommon winter visitor to our coast.

Henry Doubleday says (10) he saw one in 1832 in a Collection at Colchester, obtained on the adjacent coast. During the winter of $1829-30, "$ About thirty were seen in the Stour near Harwich," but "they were so expert in diving that but few were shot" (Hoy-I2. iii. 436). Lindsey says (27.App. 63 ) that it is "only a winter visitor" to Harwich. $\mathrm{He}$ adds: "From its habits of diving rather than flying, when approached, it is sometimes caught in the nets of our sea-

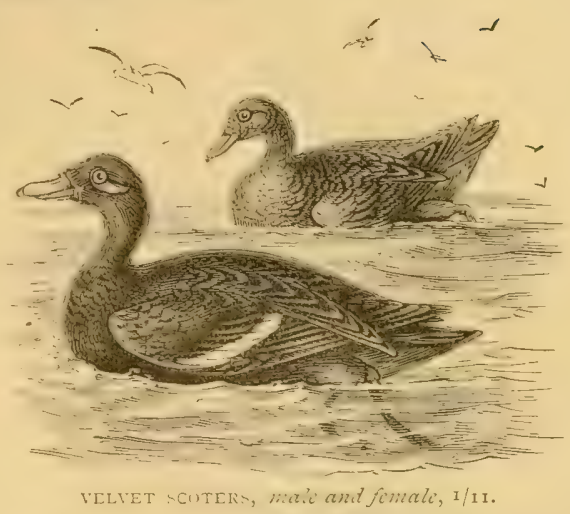
fishermen." Mr. Ambrose has received it from Merse^. A few are seen in Handford Water every winter (Kerry). It was recorded from Southend in the winter of 1860-6I (23. 7386). Mr. Hope has one shot at Maldon in Feb., I874.

\section{Goosander: Mergus merganser. Locally, "Sawbill" and} "Merganser" (E. A. F.).

An uncommon winter visitor to our coast from autumn to spring. Unlike its relative, the Merganser, it is not unfrequently met with inland.

Dale, writing of Harwich, in 1730 , says (2.402): "This is frequently to be met with here," but Mr. Kerry considers it now rare there. $\mathrm{He}$ records one ( 34 . 4827) shot in the harbour on Jan. I 7 th, I876. Mr. Clarke speaks of it (24) as occasionally met with round Walden. $\mathrm{He}$ mentions a female shot at Debden HalI on Jan. $30 t h, 1830$, one killed at Littlebury three diys later, "and two mature males at Aud-

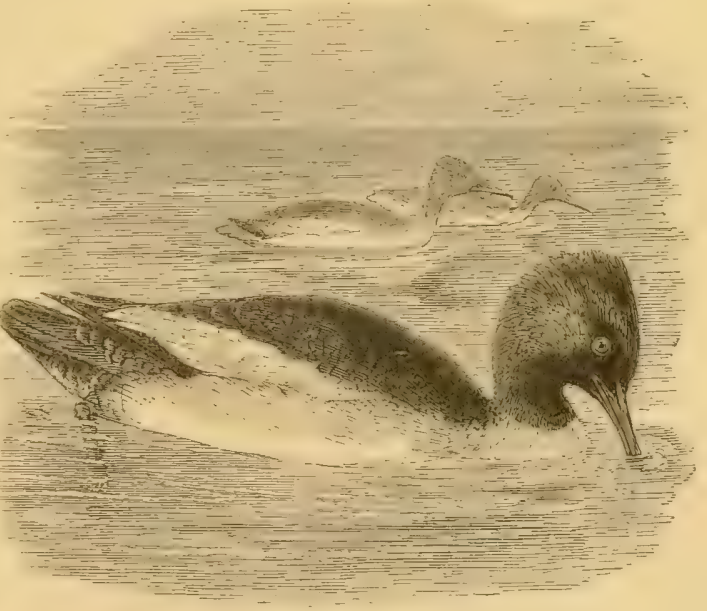

GOOSANDER, I/IO.

ley End (now in the Collection there) on Jan, 27th and 29th, I838. Dr. 
Bree records that one of a pair was shot on the Stour at Nayland in Dec., IS64. (29 Dec. 3I). He adds that it is by no means common on the Essex Coast, and that, although he had frequently met with Mergansers, this was the first he had seen in the flesh. Mr. Buxton. says (47.99): "A flock of fifteen in immature plumage remained on the Basin at Wanstead for five days during the past winter (I885)." Mr. Hope describes it as "common in the winter," Mr. C. H. B. Croxon has one shot at Tillingham.

Red-breasted Merganser : Mergus serrator. Locally, "Sawbill Diver" (E.A.F.).

A not-uncommon winter visitor to our coast, and occasionally met with inland. It breeds in Scotland and the north of Ireland,

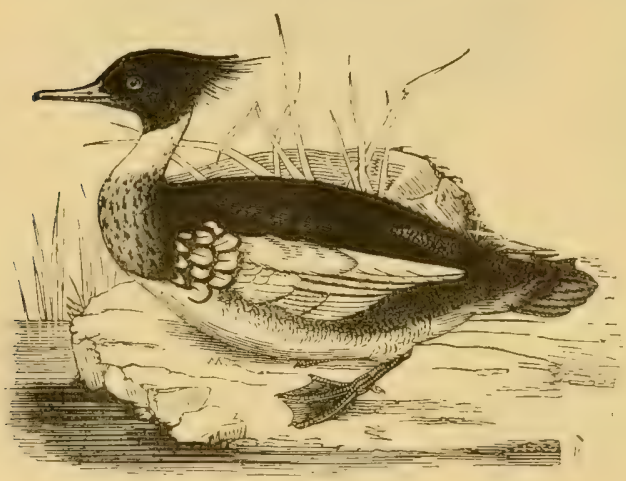

RED-DRFASTED MERGANSER, male, I/IO. but not in Essex, though Mr. Fitch informs me that a pair frequented Northey Island in the summer of 1888 .

Sheppard and Whitear state (9. 59) that' in their time it was "not uncommon on the Es. sex const." Mr. Clarke mentions (24) a specimen (formerly in the Walden Museum) shot on the lake at Debden Hall in I8 37 , and in the Collection at Audley End is another shot there by Charles, fifth Lord Braybrooke, in Jan., I850. A specimen was shot at Mersey Island in the severe winter of $1837-38$ (19. 34). A male and female were shot $(23.2775)$ on the Thames, near Barking, early in Jan., I850. At Harwich, it is very common during some winters, and in the winter of $1875^{-6}$ twelve immature females were sent from Dovercourt, one of them having killed itself by flying against the lighthouse (Kerry-34-4S27). One was shot near Maldon on Jan. I2th, I876 (29. Jan, 22), and an adult male on the beach at Walton on Jan. I6th, I889 (Gunn-40. xiii. I44). Mr. Hope describes it as "common in the winter." Mr. Fitch informs me of the remarkable fact that a pair were seen frequently round the shores of Northey Island during the summer of I8SS. They were observed constantly from the month of May until July 6th, when they were seen for the last time by Mr. Fitch's son. These dates certainly suggest that the pair in question may have bred, but it is almost impossible to believe that they did so.

\section{Smew : Mergus albellus.}

An uncommon winter visitor to our coast and occasionally met with inland. Like its congeners, it usually occurs in twos and threes.

Graves says (7. iii.) that

"in severe seasons the Smew has been taken in the nets of the fishermen in 
the Thames. Two males were taken alive in the winter of $\mathrm{i} 8 \mathrm{Ig-20}$ in Bow Creek, but although abundantly supplied with food, [they] refused all sustenance and perished. They had attained the full adult plumage, but one was without the elegant pendant crest."

Mr. Clarke mentions (24) the occurrence of two at Audley End on Feb. 3rd, I838. King says (20): "A fine male was shot last winter [1837] at Cornard." Mr. Geo. Beresford shot one near Lea Bridge on Feb. 26th, I8+5 (23. 4704). An adult male was caught at Great Holland in Jan., I86I (23.7388). An adult male was shot at Barking on Dec. 29th, I870 (29. Jan. I4). At Harwich it is rare (Kerry). Mr. Scruby informs me of one shot at Stanford Rivers about I86c. Mr. Hope describes it as "common in the winter." Mr. Robert Page has one taken in his Marsh House Decoy. 


\section{Order COLUMBÆ.}

\section{Family COLUMBIDÆ.}

\section{Ring-dove Columba palumbus. Locally "Ring-Dow."}

A far too-abundant resident, especially in well-wooded districts. They are unquestionably very injurious to the farmer. In Epping

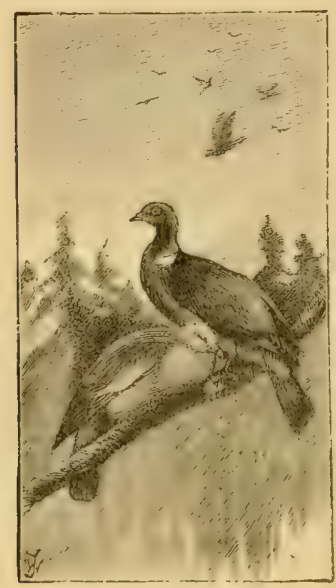

RING-DOVES, I/I3.
Forest they are especially abundant.

Round Orsett, where there is not much woodland, it is not very numerous (Sackett). The Rev. J. C. Atkinson says (23.666):

"It is a common belief in Essex that, if you touch-still more, if you breathe on-the Ringdove's eggs, she will forsake them. It is, however, totally without foundation; for I remember when a school-boy testing its truth."

About the end of July, I875, I took two rather hard-set Turtle Dove's eggs from a nest in a wood here. A few days later I was surprised by noticing that the nest had increased considerably in size, and about ten days after I was informed that it had been utilized by a Wood-pigeon as the foundation for its own nest, and that an egg of that bird had been taken from it (34. x. 4723).

In March, I88 3 , I heard of a white variety having been seen about the woods near Audley End.

Stock-dove: Columba anas. Locally "Wild Blue Rock Pigeon" (Orsett).

A common bird throughout the county, and I believe increasing. It may often be found nesting as early as February and as late as October.

Henry Doubleday writes (IO) from Epping in June, I840: "If I had known that you wanted any Stock Dove's eggs, I could have got more early in the spring. They often lay in February." King speaks of it (20) as "common " round Sudbury in $I 838$. Mr. Clarke says (24) that about I845 it bred round Saffron Walden, but was " not very common."

I have taken many nests in the county-all, with one exception, in hollow trees or in the crowns of ivy-covered pollards. The exception was a nest I took in May; I880, in a rabbit's hole in the side of a railway cutting near Saffron Walden. Mr. Benton, however, says (35. I89) that on Foulness" it sometimes breeds in rabbitholes," and a good many breed in holes in the old keep of Hedingham Castle.

[Rock-dove : Columba livia.

Mr. Kerry believes $(46,252)$ that he has received the truly wild form of this bird from Walton-on-the-Naze, but I cannot help thinking that 
all records of this species in Essex relate to either the Stock Dove or the Domestic Pigeon, which is descended from the Rock Dove.]

Turtle Dove : Turtur communis. Locally "Little Dove."

A common summer visitant, arriving about the end of April and leaving again in September. I believe it is becoming more common than formerly throughout the county.

Mr. Buxton says (47.93) it is "a constant summer visitor [to Epping Forest.] I have seen flocks of them about Walthamstow in late summer. Its plaintive note may be frequently neard in Theydon Thickets." Though usually a shy bird, I have known of nests in gardens quite in the town of Saffron Walden.

Passenger Pigeon: Ectopistes migratorius.

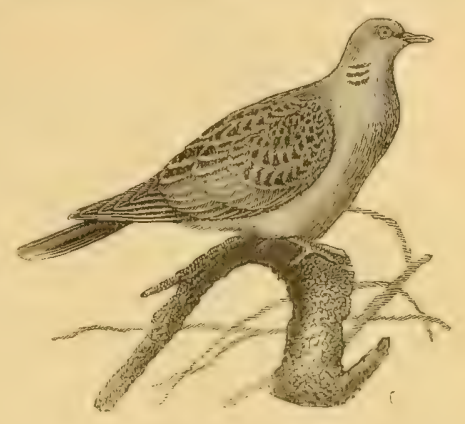

TURTLE DOVE, $: 6$

A very rare straggler to Britain from North America. A young specimen now in Walden Museum was shot between Chrishall and

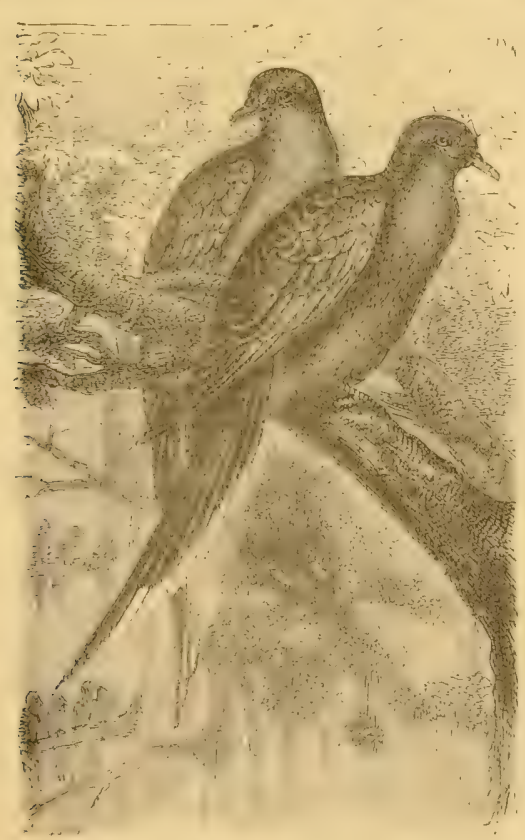

PASSENGER PIGEONS, 1'́.

Royston in July, I 844 (37. iii. $27 ; \&-38$. 128 ). Through the kindness of Mr. Joseph P.Nunn, of Royston, I am able to state that the bird was killed by the late Mrr. John Norman of Knowns Folly Farm, part of which is in Cambridgeshire and part in Essex. Mr. IV. Norman has assured Mr. Nunn that his late father had often pointed out to him the exact spot where he shot the bird, which was on some trees to the east of the farm-house. These trees stand in Melbourne parish, and are about 400 yards west of the Essex boundary; but as the bird, probably, had crossed that

boundary before being shot, and could ensily have recrossed it in less than half a minute's flight, I consider it justifial)ly included here. 


\section{Order PTEROCLETES.}

\section{Family PTEROCLIDA.}

\section{Pallas's Sand-grouse: Syrrhaptes paradoxus.}

An erratic and occasional visitor to Britain from the Steppes of Central Asia. It has several times appeared unaccountably in this country, especially on the eastern side, in small numbers, and twice in large numbers, namely, in 1863 and $\mathrm{r} 888$. An interesting account by Professor Newton of the invasion in the former year, may be found in the Ibis for 1864 (vi. pp. I85-222). On neither occasion does Essex seem to have had quite its full share of these visitors, considering the large numbers that have been seen in Norfolk and Suffolk. Bearing in mind the geographical position of the county, the numbers visiting it might reasonably have been expected to be much larger.

In I863, the following eleven specimens, at least, occurred :-Mr. J. Withers (23. 8684), shot one, which was alone and seemed very tired, in the neighbourhood of Forest Gate, in June. Dr. Bree records $(29 ; 23.8684$ and 34. 3688) a male and two females shot in a ploughed field about a quarter of a mile from the sea at Mersea, on May (?) 29th. They were alone, very tame, in good condition, and seemed to have come in from the sea, He also records $(34.3688)$ that a female (not mentioned by Prof. Newton), was shot at Peldon, and with the above two, was added to his Collection. Mr. Smoothy informs me that he saw three which had been shot near Terling. Mr. Clarke writes that a good many were shot at Siward's End, near Saffron IValden, the cottagers and others making "pigeon pies" of them all, except two which passed through Mr. Travis's hands! "On expressing my regret to Mr. Gould," adds Mr. Clarke, "at not obtaining any of them for the Museum, he said, 'Do not fear! They will breed, and there will be plenty next year.' He was surprised when I replied, 'No! There will not be one.' I was right, however, and so it will be again." The above were probably the same birds which $\mathrm{Mr}$. Travis tells me were shot in a field of tares by a boy who was scaring birds. He purchased them for 2s, and afterwards disposed of them for 65 ! Major Ed. Taylor records $(29$; and 23. 8684), that they were shot "about two miles from the town," on June 7th, and were male and female. A hitherto unrecorded specimen, which is still in existence, was shot by Mr. J. W. Stallibrass on New Marsh Farm, Foulness Island, during June. Mr. Stallibrass shot only this one out of the seven he saw, hoping they would remain and breed; but none were seen on the island after the middle of July (Fitch-50. ii. 27I). 
During the invasion of $18 \$ 8-\$ 9$, many more specimens were seen and obtained than had been the case on the previous occasion, no less than about eighty individual birds being either observed or taken. One of the earliest Essex observations in this year was that of Mr. Edward Catchpool, of Feering Bury, who observed a covey of twelve or thirteen in a field of young mangold at Ardleigh, on May 3oth (29. June 2). Mr. Fitch records (50. ii. 27I) that nine specimens were observed on Foulness Island either on May 2 Sth or June 4 th. Mr. Ernest Smith, of the Limes, Southminster, saw seven on the island, on Shelford Farm, on the 30 th of the latter month, and some were still there as late as September 8 th. On June I5th, Mr. Fitch specially visited Mersea Island in order to enquire whether any had been seen there, but without result. Mr. Crouch records (29. June 9) that on June 4th, I888, a covey of about sixteen birds was observed on St. Swithin's Farm, Barkingside. On being disturbed they went away in an easterly direction. Two of them which were subsequently shot proved to be adult males. Towards the end of May, a flock of five was seen near Harwich (40. xii. 264), and Mr. Kerry informs me that on June 23 rd he saw, near Harwich, a flock of fifteen or sixteen birds which he believes to have been of this species. Mr. A. F. Gates, of Stratford (40. xii. 264), observed about a dozen in a ploughed field near Blake Hall Station on June Ioth. Lieut.-Col. Marsden, of Colchester, saw a couple shot by a gamekeeper on Mr. Blanchard's estate, near Walton-on-the-Naze, on Oct. ISth, I888, when two others were seen but not shot. The crops of the two that were obtained were full of corn. They were preserved at Colchester for a Col. Davis, who has the shooting on the estate. Mr. Pettitt preserved one shot at Fingringhoe Hall on Feb. 4th, I889, and saw another (a male) killed at New Bridge Mill, near Colchester, by a Mr. Argent, about Nov., I8S8. During the summer Mr. Travis of Saffron Walden received for preservation no less than thirteen; but, strangely enough, not one of these was shot in Essex, though five or six of them were killed at either Whittlesford or Duxford, both of which places are in Cambridgeshire, though very close to the Essex border. Mr. Travis was, however, assured by the bailiff on one of Lord Braybrooke's farms near Audley End, that he had seen a flock of a dozen there.

Mr. Walter Crouch communicates the interesting fact that some specimens still survived in the county during the summer of 1889 . He writes :-

"On July Igth about a dozen passed over St. Swithin's Farm, Barkingside, close by the homestead, and not 100 yards from the spot where the covey of sixteen alighted on June 4 th, I88s. They were flying over a field of wheat in a southerly direction, and very low. They were seen by the tenant, Mr. Bolton, and several others, who had not only seen the live birds last year, but also the two specimens which were then shot. *** They were again seen close by the stack-yard on Aug. Ioth by Mr. Hatton and another, and I have since learned that a covey of about twelve were seen early in July about three and a half miles away, near Lawn Farm, Fairlop Plain." 


\section{Order GALLIN $\mathbb{E}$.}

\section{Family PHASIANID EE.}

\section{Pheasant: Phasianus colchicus.}

An abundant resident wherever it is sufficiently preserved. It was probably originally naturalized in England by the Romans, as the earliest known record of it is in the year ro59 (Ibis, r869, p. $35^{8}$, and 37. iii. 95). It is an interesting fact that the first record of it in Britain is in the county of Essex.

This record, according to Prof. Boyd Dawkins, is to be found in the tract, "De inventione Sancta Crucis nostrae in Monte Acuto et deductione ejusdem apud Waltham," edited from MSS. in the British Museum, by Prof. Stubbs in I86I. The bill of fare drawn up by Harold, for the canon's household of from six to seven persons, A.D. I059, and preserved in a MS. of the date of about A.D. II77, was to be :-

"Erant autem tales pitantiae unicuique canonico; a festo Sancti Michaelis usque ad caput jejunii [Ash Wednesday], aut xii. merulae, aut ii. agauscae agace : [a magpie (?) Ducange], aut ii. perdrices, aut unus phasianus reliquis temporibus aut ancae [Geese: Ducange] aut gallinae."

This passage afforc's fair presumptive evidence that the bird was introduced before the Norman Conquest, and inasmuch as the English and Danes are not known to have introduced any animals, the probability is that the Pheasant was introduced by the Romans.

Red-legged Partridge: Caccabis mafa. Locally," French Partridge," "Frenchman."

An abundant resident, though originally introduced. Round Chelmsford it is now at least as abundant as the Common Partridge.

MIr. J. Yelloly Watson writes (Tendring Hundred in the Olden Time, iii. ed., p. 234) :-

"On the Sth June, 1763 , he [IVilliam Henry de Nassau, fourth Earl of Rochford] became Ambassador Extraordinary to the Court of Spain ; and on the Ist July, Ambassador to the Court of France. When he returned, he is said to have brought with him French or Red-legged Partridges; and one of the early breed, shot at St. Osyth nearly a century ago, stuffed, and with a white Pheasant in a case, is before us as we write. Soon after this, he introduced the poplar trees from Lombardy, and two of the first planted in England are now to be seen in the Park [at St. Osyth Priory]."

Daniel, shooting near Colchester in I777 (6.ii. 410), found a covey of fourteen "Red-legs," which were flushed with difficulty, but after half an hour's exertion one was got up, and "immediately perched on the hedge, and was shot in that situation without its being known what bird it was." Two and a half brace 
more were killed from this covey within three days, but from that time until I799, Mr. Daniel did not again meet with this bird, but then he shot two and a half brace at Sudbourn, Suffolk. Referring to this record, Mr. E. A. Fitch, of Maldon, writes (50. ii. 40) :-

"It is only quite recently that the French or Red-legged Partridge has become common in the Essex Marshes and islands, and I know several sportsmen still living who well remember the first specimen they ever shot, and have heard them relate how carefully they smoothed it down and wrapped it up in their handkerchief, pocketing what they considered a rare and beautiful prize. The French Partridge is not a lover of the low-lying marsh lands, and here, at Maldon, it is much more common on the hills and broken ground than on the marshes."

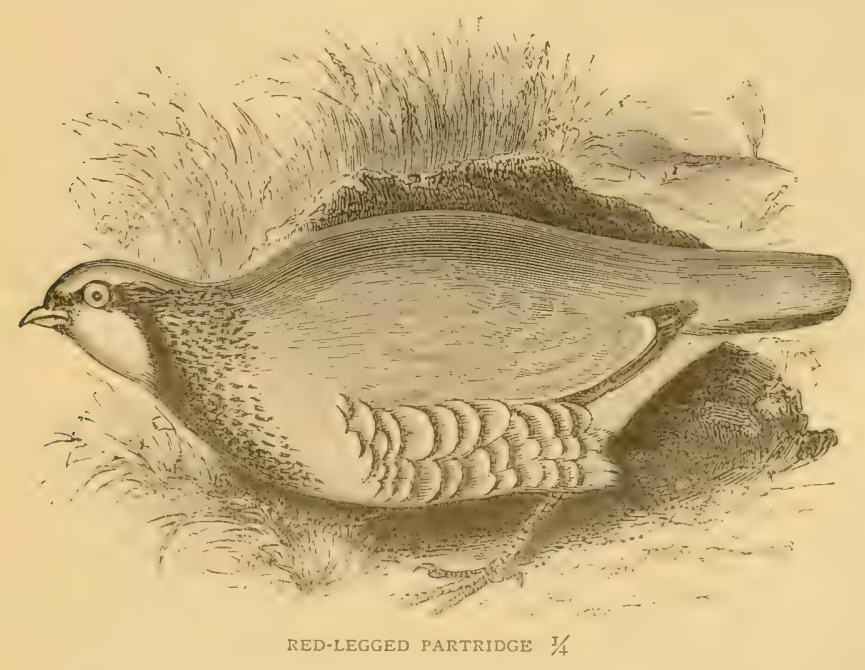

With reference to this species Mr. Thomas Kemble, J.P., of Runwell Hall, says, in a letter to Mr. Fitch :-

"I can give you another interesting tale with regard to this bird. The late Sir Henry Meux, in company with the late Lord Alfred Paget, had a very good day's shooting at it on Lord Rendlesham's property in Norfolk; he was so pleased with the French Partrilge for driving purposes (which system of shouting was little known in those days) that he determined to introduce the Red-legged Partridge into his estate at Theobalds, in Herts. At that time, I think it was I855, I had several coveys on my property in Essex (I well remember, when a young man, the first that was ever killed, or even seen, on imy property). I agreed to give him all the French eggs my keeper could find, upon his sending me English eggs in return. The contents of the first box I placed in several French nests, but the hens invariably forsook them; another box came, the eggs were placed upon a tray, and my better half painted them to resemble the French egg. The birds took to them, and hatched the greater part of them, but they proved bad mothers. The English hen broods them much more than the French. Nevertheless I had several small coveys, and my friends were rather surprised to see a French bird rise, accompanied by three or four English."

Graves says (7. iii.) that in I82I it was found in "those parts of Essex bordering on Suffolk." Around Sudbury, according to W. D. King (20), it was "not uncommon" in I $\&_{3} S$. Mr. Clarke records (24) specimens obtained 
at Saffron Walden in $\mathrm{I}_{3} \mathrm{I}-32-34-35$, and mentions a nest containing thirteen eggs built in 1848 on an oat-stack, sixteen feet from the ground. From these records one may infer that the bird was then uncommon round Walden. Both Mr. Fitch and myself have known several other instances of this bird nesting on the tops of straw-stacks. About the middle of June, I882, I put a bird-I believe of this species-out of the crown of a large old pollard oak, standing in a hedgerow near here. I could not find any nest (40. vii. 80). On June $23 \mathrm{rd}, 1877$, I found a nest in a lucerne field at Lindsell Hall, near Dunmow, containing eight eggs, all pure white except for a few reddish spots and specks on one of them. Mr. J. H. Hills, of Feering, has a specimen shot by himself, at Pattiswick, on Jan. 30, 1877, which is said to have weighed twenty-five ounces. Round Orsett, Mr. Sackett says it is as common as the English species. He adds that he has been informed (but does not personally know it to be true) that in 1877 this species interbred with the common species, on the East Tilbury Marshes. Mr. Stacey, of Dunmow, has a couple shot near there, which also appear to have been crossed with the Common Partridge, as traces of the markings of that bird may be seen upon the feathers of their backs. I shot a similar young bird at Broomfield, in September, I889. Other instances of these two species interbreeding are not unknown ( 27. iii. I I4). The Hon. C. H. Strutt records (29. Sept. 2 I), the appearance near Witham in September, I878, of a covey of nine, all of which were melanistic varieties except one. Dr. Bree records two pied specimens, shot at Alresford by Mr. Hawkins (29. Dec. 5, 1863).

\section{Partridge: Perdix cinerea.}

An abundant resident, especially where well protected. It does not appear, in Essex, to have in any way diminished since the introduction of the Red-legged Partridge, as is often supposed.

Daniel says (6. App. 397) "In I808, at Mark's Hall in Essex, Payne the gamekeeper noticed a brace of Partridges, whose nest had been destroyed, taking to a nest of Pheasants' eggs that the hen bird had been killed from by some accident, and hatching and bring up ten young ones " (37. iii. IOg). Both Yarrell (I4. ii. 334), and Colonel Hawker, in his Instructions to Young Sportsmen (I825 ed., p. 215), allude to this nest. Daniel also (6.ii. 400) mentions a nest containing sixteen eggs, found in I788 on the top of an oak pollard at Lion Hall Farm, Essex, belonging to Colonel Hawker. The bars of a stile crossing a public foot-path were fastened to the tree and many persons passed the spot, but the eggs were safely hatched and the young reached the ground by "scrambling down the short and rough boughs which grew out all around from the trunk of the tree." It is recorded (29. Oct. I5) that on Oct. 7 th, I887, a covey of nine started from West Tilbury to fly across the Thames-at this point a mile or a mile-and-a-quarter wide-and the whole of them fell into the water and were picked up by watermen. The following extraordinary circumstance is recorded in the Essex Connty Chronicle for June $3 \mathrm{rd}, \mathrm{I} 887$ :-

"On Thursday, as two boys were engaged in mowing the lawn at the Grange [Little Dunmow], a brace of Partridges suddenly started up. One bird flew directly into the face of one of the boys, striking him with such force as to draw blood and giving him a black eye, the bird itself falling dead at his feet.

The Rev. C. G. Green says (Collections and Recollections of Nat. Hist. and Sport, p. 2II):

"For a family shot, I never heard of anything to come up to one that was made by an old clergyman many years ago in the parish [IVimbish] in which stands Mr. Gayton's house, Tiptofts. *** He was such a very bad shot that he hardly 
ever killed anything during the whole season, but he was very fond of taking a stroll with his gun. One day he was passing near a grove through which a ride had been cut. A covey of seven birds rose just before him, and went straight down the ride. The old gentleman fired after them down the ride and killed all seven. This was a great boast for him, and a great joke for all his friends for the rest of his life.

"But it was in this same neighbourhood that I saw the two most remarkable shots made in one day that have ever come under my observation. I was out with $\mathrm{Mr}$. Gayton and his friend Dr. H., both very good shots. In the early part of the day, four birds rose close to a hedge in front of $\mathrm{Mr}$. H. They rose together, but flew two and two as they topped the hedge. Mr. H. killed them all four, two with his first barrel and two with his second, picking out the time of their crossing. We went on and had a good day's shooting, and towards evening were returning by the same hedge where Mr. H. had killed his four birds, when, almost at the same spot four birds rose before Mr. Gayton, going orer the hedge in exactly the same manner, and Mr. Gayton served them exactly in the same way, killing two, while crossing, with his first barrel, and two with his second. Here there was no firing 'into the brown' of a covey : only four birds rose each time, and four were killed by deliberate calculation, two and two each time."

In the Walden Museum is a variety obtained at Radwinter many years ago. It is in very light plumage, the feathers on the breast being of a creamy-white with scarcely a trace of ash-colour. A white one was shot in Essex on Oct. 2nd, I886 (29. Oct. 9), after having been seen about for several months. Mr. Scruby preserved a beautiful pied specimen shot by Mr. J. Milbank, at Leaden Roothing, on Nov. 3rd, 1869 (29. Nov. 20).

\section{Quail : Coturnix communis.}

Not a rare bird, though very sparingly distributed, never abundant, and much less so than formerly. It occurs from time to time, and has also bred, in most parts of the county, but can never be counted upon to do so regularly.

Pennant, in his Britis/2 Zoology (4th ed, I776, p. 277), says :-

"A gentleman, to whom this work lies under great obligations for his frequent assistance, has assured us that these birds migrate out of the neighbouring inland counties into the Hundreds of Essex in October, and continue there all the winter. If frost or snow drive them out of the stubble-fields and marshes, they retreat to the sea-side, shelter themselves among the weeds, and live upon what they can pick up from the algre, \&c, , between high and low water-mark. Our friend remarks that the time of their appearance in Essex coincides with that of their leaving the inland counties. The same observation has been made in Hampshire."

Daniel, alluding to these statements in I802, says (6. ii. 453), "However genuine this account is of the Quail's abode in the Hundreds of Essex formerly, there is good ground for discrediting the existence of the circumstance at present." In this he is certainly correct. Pennant must have been completely misinformed.

Mr. G. WV. Johnson, in his History of Great Totham (1831.p. 8), says: "The Quail was formerly found in this and other parts of Essex, but its occurrence now is very rare." The Rev. R. Sheppard seems to have met with it occasionally at Wrabness, as he notes its arrival there (see p. 42) on Apr. 2nd in I8I9, and on Apr. 7 th in 1822. Parsons shot one at Shoebury on Jan, Ioth, I827 (8). Mr. Hill met with it near Southminster about $I_{32}$ (I2, iv. 452). J. C., of Witham, met with a nest containing ten eggs in a clover-field on Aug. I2th, I833. He says "the bird is rather an uncommon one in this part of the county" (I2. viii. 5I7). Edward Jesse, writing in 1844 , says (Scenes and Tales of Country Life, p. 267), "In one district in Essex, numerous eggs have been found during the mowing 
season, and as many as sixty couples have been killed in the course of a few days' shooting on one manor in that county." Edward Doubleday says ( 15 ) it has occurred at Epping. King, in I838, says (20) it was then "not uncommon "around Sudbury. Mr. Clarke says (24) of Saffron Walden, that it "breeds here occasionally." One, he adds, was killed at IVenden in November, I848. Mr. C. E. Smith records (3I. 53) "two shot in the autumn of I857" near Coggeshall. In I867 a nest with eleven eggs was taken in a clover-field about five miles from Ingatestone, and in the previous year another nest was found on Sir Charles Smith's estate, near Romford (Jesse-34. 9I5). Round Orsett, in 1885, Mr. Sackett says it was "not uncommon," one nest containing eleven eggs being found at Heath Place Farm and two at Mucking. Mr. Hope, who has seen specimens shot within three miles of Harwich, says: "They appear about the first week in September, and are all gone a fortnight later." A correspondent of the Fïld (29. Aug. 4, I860), who has "met with large bevies in Rochford Hundred, near the Crouch River," expresses the opinion that the chance of killing them is lost by shooting being deferred till Sept. Ist. It is found occasionally in both the Colchester and Paglesham districts (Laver). Mr. A. Marriage has one, shot at Little Baddow. In September, I880, English preserved one shot at North Weald-the first Essex example he had ever met with (4. i. xlv.). In MIay, I88o, several were seen near Chrishall, where they had probably bred. The Rev. M. C. H. Bird informs me of one shot on Canvey Island, Sept. I3th, I88I.

[Virginian Colin: Ortyx virginianus.

This is an introduction from America, which has nerer been able to establish itself. It has been found in Essex. Dr. Bree records one met with near Birch about June 5th, I878 (29. June 22)].

[Red Grouse : Lagopus scoticus.

It is impossible to regard this as an Essex bird, though an individual in a perfectly wild state has been killed in the county. It was shot by Mr. Thomas Aldham, of Ulting Hall, in one of his fields on that farm, whilst partridge-shooting in or about the month of September, two or three years ago. No similar bird was observed at the time. The specimen was stuffed in Maldon, where Mr. Fitch and others saw it in the flesh. It is still in Mr. Aldham's possession at Ulting, where I have seen it, and believe it to be a female. It is less surprising to meet with a Grouse at Ulting than in any other part of the county, for within two miles, as the crow flies, are the extensive commons of Danbury and Little Baddow, where there is a greater expanse of heather than can be found elsewhere in Essex. The most likely supposition is that the bird had strayed from Sandringham, where fourteen brace were turned out in 1878 , of which enough remained in ISSI to propagate three broods; or it may have come from one or other of the places in Suffolk where attempts were made to introduce it about twenty years ago (46. I07)]. 


\section{Order FULICARIAE.}

\section{Family $\cdot$ RALLID $Æ$.}

\section{Water-Rail : Rallus aquaticus.}

A resident, though. local and by no means common. It evidently used to breed in the county, and may still do so, though I have no evidence of the fact. It is most often seen during hard frosts; its skulking habits making it at other times appear less common than it really is.

It evidently bred near Sudbury in $18_{3} 8$, for W. D. King says (20) :-

"Not uncommon; I had a living specimen brought me last summer, caught by hand in a cottage garden. I set it at liberty in my own garden, where it continued for some weeks, but at last made its escape. It moved about with astonishing celerity, and when seeking its food, carried its tail erect like a Moorhen, thus rendering its white under-tail-coverts very conspicuous."

In Epping Forest it is "not so rare as is sometimes supposed " (Buxton-47. 94). Round Southminster, Mr. Hill recorded it (I2. viii. 573) as "very rare" about I834. During severe frosts there are often a few in a small ditch at the end of our garden. For some days after the very severe frost of Dec. 7th, I879, when the mercury fell below zero, we had several here, and 1 shot the largest and brightest specimen I ever saw from among them. Another was shot in our garden by my brother on Dec. 20th, I878, during a spell of hard weather.

I have elsewhere commented upon the extraordinary difference observable in the sizes of different individuals of this bird (40. x. 368). The largest I ever saw is mentioned above : the smallest belongs to Mr. Stacey of Dunmow.

Mr. Fitch informs me that he has seen eggs from Goldhanger, out of a nest found in I887_by Mr. E. Page, who had also found a second nest; and the Rev. J. C. Atkinson says ( 36.135 ): "I had reason to know that it bred [sixty years ago] at Tolleshunt D'Arcy, in Essex."

\section{Spotted Crake: Porzana maruetta.}

$A$ rare and local summer or autumn visitant. It appears to be by no means common in the county, though it seems possible, from a fact mentioned below, that it may breed on our coast.

Mr. C. IValford records (19.47) one shot at Maldon about IS38. Mr. Clarke says (24), "several have been picked up dead from flying against the electric telegraph wires at Newport." It was "rare " round Sudbury in 1838 (King-20). English describes it (43, i.24) as an occasional visitor to Epping Forest, while Mr. Buxton says (47.97) it is "occasionally met with in the soft low-lying parts of the Forest, such as would be attractive to Snipe. One may be seen preserved at the house of the head-keeper, Broadstrood Lodge." A pair was shot in Hack. ney Marshes, by Mr. R. M. Presland, on the 7th Oct., I863. A third by Mr. J. 
A. Clark, in the same locality, on the 26 th, and a fourth, by the same gentleman at Leyton, on the 28th $(23.8847)$. One was obtained near Colchester in 1880 (29. Apr. 23). Mr. Kerry says (40, iii. 459) another was picked up dead on the railway-line near Harwich, having killed itself by flying against the telegraph wires, about the middle of Oct., I879. Mr. Baxter has informed me of specimens killed at Barking in Nov., I887, and on Bowers Marsh, Pitsea, on Aug. 22nd, I889, respectively. Mrs. Bree has two shot near Colchester, one of which was probably shot on the river in the third week of Aug., I866 (32a). Dr. Laver has killed it at Paglesham. Mr. John Pettitt preserved a specimen killed at Tollesbury, early in Sept, I888, which Dr. Salter now has. Mr. E. A. Fitch has a female which was shot on Northey Island. In it was a perfectly-formed egg, so that it was probably nesting. Further, Mr. Baxter has informed me that in the autumn of 18.99 , several were killed on the Pitsea Marshes, some of which were obviously young birds, probably bred in the district.

\section{Baillon's Crake : Porzana bailloni.}

A very rare and irregular summer migrant or resident. Although it has been known to breed in Norfolk and Cambridgeshire, the only record of its occurrence in Essex is the following by Mr. E. Curtis jun., of Forest Lane, E., who records (29. Oct. 10) having obtained one in a thick reedy ditch in Essex on October 3 rd, I874. It was not flushed, but was found and caught by Mr. Curtis's dog, in a ditch adjoining "Dagenham Gulf," as I am informed by that gentleman himself, who still has the bird, which he has kindly lent for my inspection. It appears to be immature, but is in good plumage.

Little Crake: Porzana parva.

A rare visitor to Britain. I only know of a single specimen having been obtained in Essex, but other occurrences have probably been overlooked.

Mr. J. F. T. Wiseman of Paglesham has a specimen shot on a marsh upon one of his farms in that parish, by Mr. Lucas of Billericay, when Snipe-shooting in the month of October four or five years ago.

\section{Corn-Crake or Land-Rail : Crex pratensis.}

Best known in Essex as a passing migrant in spring and autumn, especially the latter, when it is frequently met with in fields of clover

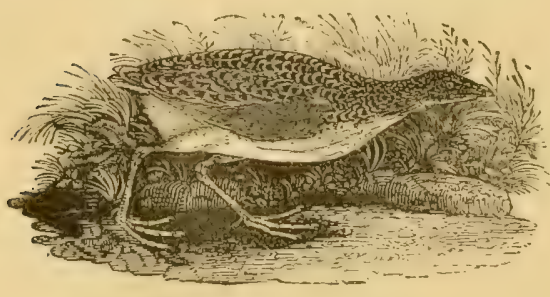

LAND-RAIL OR CORN-CRAKE, I/7.

(After Bervick). and lucerne, and killed by partridge-shooters during September and the early part of October. It is also to some extent a summer visitor, as it breeds, though sparingly, in many parts of the county, and may even almost be spoken of as a resi- 
dent, for specimens are occasionally met with in winter. In I S26, Mr. Parsons killed one (8) at Southchurch Wick as late as Nov, 7 th.

Mr. C. H. Hills informs me that, about the middle of September, I887, a partridge-shocting party killed fifteen of these birds in one day in a field near Pod's Wood, Messing. On June 29th, I88I, Mr. Travis took a nest with ten eggs close to Walden, and in May, I888, a pair nested at Feering. Mr. Clarke says (24) it "occasionally breeds" there. In Epping Forest it is "a summer visitor, nesting and remaining till the middle of September" (Buxton-47.94). According to King (20), in 1838 , it was then "not a very common bird " in the neighbourhood of Sudbury. The Rev. J. C. Atkinson says (36.133): "I do not remember ever hearing its breeding note while. I was a dweller in the district embracing what are usually called the Eastern Counties." Round Orsett,"Mr. Sackett says it is "not common." A nest, taken at Mucking in July, I887, is the only one he has met with in that district. Round Harwich, it breeds not uncommonly (Kerry). Mr. Clarke, in 1845, wrote (24) it "occasionally breeds" round Saffron Walden, but in a recent letter he says:-

"I have not heard their 'crake' for twenty years until this year. A pair have just hatched their young close at hand. The young ones are very shy but our foreman's children have caught several and let them go again. They are perfectly black."

Though by no means common during summer, I have occasionally heard its breeding note; as at Chignal St. James on June I6th, I876, May 5th and June IIth, I882, at Newport on June gth, I88I, at Stanford Rivers on June Igth, I883, \&c. I have been assured that it was once common with us. Mr. Herbert Marriage met with one near Chelmsford, on Dec. 9th, I877.

\section{Green-backed Gallinule: Porphinio smaragdenotus.}

An African bird which, though only a straggler north of the Mediterranean, has several times occurred in Norfolk and once in Essex. I quite agree with Mr. J. H. Gurney, jun. (Birds of Norfolk, p. 34), that it has as good a claim to a place on the British List as many other birds which have been admitted. A considerable correspondence upon this point took place in the Field between Nov. I6th, 1878 , and Jan. 4 th, 1879 .

An adult female, bearing no signs of having ever been in confinement, was shot by Mr. H. N. Dunnet jun,, of Jupes Hill (in whose possession it still is) at Dedham, on Oct. 30 th, I878, and shown to Dr. Bree in the flesh. There had been a fall of snow that morning. It was preserved by Ambrose (29. Nov. I6 and 30).

\section{Moorhen: Gallinula chloropus.}

An abundant resident on the banks of lakes, ponds and rivers; especially common during winter, when its numbers are greatly increased in Essex by arrivals from elsewhere.

At the time of the very severe frost of Dec. 7 th, I879, when the mercury fell below zero, they were very common here and I saw them frequently perching on trees. Lieut. Legge says (34.604) it was very numerous in the marshes on the coast in 1865 , and the Rev. J. C. Atkinson has given (23.497) an interesting account of their habits, as observed on the Essex Marshes and elsewhere. In May, I880, I saw a nest eleven feet from the ground in the fork of an ash tree 
in Audley End Park. Dr. Bree also (32a) notes a nest containing six eggs, twelve feet above the water, in a holly-tree at Alresford.

$V$ arieties do not often occur, but Mr. Travis has a pied bird, shot at Debden early in 1989 .

\section{Coot: Fulica atra. Locally, "Bald Coot."}

An abundant resident, frequenting large shects of water near the coast. It is sometimes, but not often, seen inland on the lakes in Skreens; Audley End, Wanstead and other parks, where it occasionally breeds. It is probably decreasing in numbers, through the draining of its haunts. Years ago, it is described as appearing in extraordinary numbers on the Essex coast: for instance, the Rev. J. C. Atkinson says (36. I36): "In former days I have sometimes seen them in straggling flocks of several hundreds or thousands along the tideway on the Essex Coast."

Messrs. Sheppard and Whitear write (9.49):-

"In autumn and winter, these birds make their appearance on the rivers in vast flocks, and upon an appointed day all the boats and guns are put into requisition, and a general attack is made upon them. On the bank of the Stour, the fowlers approach them, while sitting upon the ooze, by concealing themselves behind a screen made of bushes, which is placed upon a sledge and driven before them. *** On crossing the Stour in the month of January, I819, in a dead calm, we observed the Coots floating upon the water in a semi-circle. On our approach within about 200 yards, the whole body, amounting at the least calculation to several thousands, partly rose and flapped along the surface of the water, making a tremendous rushing noise. Had therc been any wind they would have risen into the air without any difficulty ; but, there being none, they could scarcely disentangle their feet. *** Foxes frequent the banks of the Stour very early in the morning to catch the wounded birds, which generally make to land, and of which there are sometimes great numbers. The larger kinds of Gulls often attack and devour Coots. We have observed the latter, on the approach of their enemy, rush together from all quarters and form a close, round, compact body, appearing like bees in the act of swarming. The Gull kept hovering over their heads, and frequently dashed within a yard or two of them. Whenever he flew to a distance, the Coots dispersed, and again at his return flocked together. This scene continued as long as we stood upon the shore, which was more than half an hour. * * * A bird of this species, having the whole plumage white, except the head and tail, was seen on the Stour last December [1825]."

Mr. Bond met with a few, probably reared in the neighbourhood, at Southend early in Sept., 1842 (23.40). Lindsey says (27. App. 55) that at Harwich it " is to be met with on the coast when the tide is down." Lieut. Legge, writing in 1866, says (34.603): "The Coot is very plentiful on the fresh water in the Essex marshes. They are especially numerous on the lagoons at Pitsea. On the 5th of May I found their nests in tolerable numbers in that locality." After heavy rains, causing floods, they will stuff fresh sedge underneath their nests thus raising them and causing them to float. Instances of this were observed by Dr. Salter at Tollesbury after the heavy rains of May IIth, I8S9. Mr. Fitch and myself found many nests in the fleets on the OId Hall Marshes, Tollesbury, in June, I888. Mr. A. J. Crosfield on May 23rd, 1879, found a nest containing seven hard-set eggs among the reeds at the head of Dagenham Gulf. King, in 1838 , says (20) it was then "rare" in the Sudbury district. Mr. Clarke mentions (24) one at The Roos in Feb., I829, one at Audley End on Feb. I6th 
1832, and another at Debden on Aug. I7th, I833. One frequented the Cam, where it flows through the lawn at Audley End, for several weeks early in $\mathbf{I} 88 \mathrm{I}$, and Mr. Travis knew of a nest at Audley End, many years ago. Here, however, it very rarely bred until the last two or three years, when several broods have been reared there annually. About Jan. Ist, I882, one was caught near Sampford and kept alive several days. In Wanstead Park, Mr. Lister says (40. ix. 64) they "bring up two broods every year, but [these] appear to leave us in late summer." Mr. Buxton also says (47.97) it "breeds in Wanstead Park, where they are numerous, and have become remarkably tame since the public have been admitted." Some idea of the size of the enormous flocks which, in years gone by, used to appoar during winter on our coasts may be gathered from the fact, asserted by Mr. John Basham, of Maldon, that about fifty years ago a gunner named Girton, of Tollesbury, bagged no less than fifty by a single discharge of a gun now owned by Mr. Basham. 


\section{Order ALECTORIDES.}

\section{Family GRUID $Æ$.}

\section{Crane: Grus communis.}

There are only two undoubted records of the occurrence in Essex of this rare straggler to Britain, although there is every probability that it was fairly common on our marshy coasts several cen turies ago. One authority considers that this bird gave its name to the parish of Cranham, near Romford-a somewhat doubtful piece of etymology.

The Rev. W. Palin (More About Stifford, p. 89) derives the name of Cranham from the Cranes, which, he says, were "common in those days in the then-undrained lowlands about Aveley." He mentions a house in the latter parish, known in 1647 by the sign of the "Three Cranes." Canon Babington mentions one (46. I57), on the authority of Mr. Hills, "said to have been seen flying over Sudbury." A modern record of its occurrence in the county is that by Mr. Henry Laver, who says (40. xiii. 34 \& 50 ii. 271) that on Friday, Nov. 9th, I888, eight large birds were observed in a field on Elmstead Hall Farm, about four miles enst from Colchester. One of these being shot proved to be an immature specimen, without the red mark on the head, and with the wing-feathers which cover the tail not fully developed. It was secured by Mr. Laver, and after being preserved by Mr. J. Pettitt, of Colchester, it was, by the former gentleman, most generously presented to the Saffron Walden Museum, where it now is. The other seven flew away. Curiously enough, rather less than a year later, the county was again honoured by a visit from one of these birds. It was first observed by $\mathrm{Mr}$. Gervase F. Mathew, R.N., of Dovercourt, who recorded it as follows in the Zoologist for November, I889 (40. xiii. 435) :-

"While shooting with a party, on Sept. 26th, in the adjoining parish of Little Oakley, I had the pleasure of seeing a fine specimen of the Common Crane. We were sitting at lunch under a hedge, when, happening to look up, I noticed-as I at first thought - a large Heron flying towards us. It was then about a mile off. Presently I looked up again, and by that time it had come much nearer, and to my astonishment I observed that the bird held its head and neck stretched out in front of it, as Herons never do, and from its immense size there was no mistaking what it was. It still came gradually towards us, and appeared to be looking for a place whereon to alight, for it flapped its great wings several times over its back until they almost appeared to touch, and then glided on with outstretched pinions. This it repeated several times, and then pitched in the next field, and well in view from where we sat. It looked a grand bird as it stood upon the grass with the bright sun shining upon it. Unfortunately it was a long way out in the field, and out of shot from theihedge. However, I thought I would try and stalk it, so crept down by the edge of the field we were in, until I reached a gap near the bottom, which I crawled through into the next field, where $I$ was well out of sight of it. I then went on until I arrived nearly opposite to where I sup- 
posed it to be standing, then looked through cautiously and had a fine view of it. It was about $I_{50}$ yards off, and appeared to be an old bird in perfect plumage. Of course it was no use firing at it at such a distance, but I thought if I went on a few yards further, and crawled through a gap, and ran in upon it, I might get within shot before it rose, or that it might fly towards me. But while I was thinking of this it took wing, and flew right away from me towards some salt marshes, where it pitched again. I followed to the bank, and, upon looking over, saw it about a mile off, standing on some bare mud. Soon after it was fired at by some one from a boat which was in a creek near at hand; and it then flew off to the westward, and I lost sight of it."

After this, I received several further reports of the bird, which was repeatedly seen on the marshes and mud-flats between Walton-on-the-Naze and Harwich for several weeks after. On Oct. I4th, Mr. Kerry reported its having been seen there in company with some Herons.

\section{Family OTIDID $\notin$.}

\section{Great Bustard: Otis tarda.}

'Ihere can be no doubt that this interesting species was once resident in Essex, as in most other parts of England, although now never seen, except as a rare and accidental straggler. It was probably never abundant in this county, which has few of those wide, open, uncultivated districts frequented by the bird. However, on the extensive downs around Heydon and Chrishall, in the extreme north-eastern corner of the county, which are exactly suited to its habits, it was 'probably once fairly common-indeed, we have actual printed evidence of the fact, for in Addison's Spectator for March 4th, I 7 I 2 (No. ccxvii.), occurs the follow-

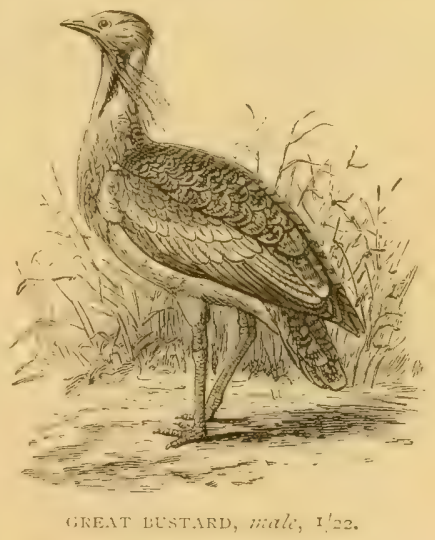
ing advertisement, to which Yarrell's attention was drawn (I 4. i. ix.) by Mr. Joseph Clarke :-

"Heyden, -in Essex, near Walden and Royston. The seat of sir Peter Soame, Bart., deceased, situate on a Gentle Hill, with a very large and pleasant Prospect, fair Gardens, Canals, Fish Ponds, Dove-Coate, and all sorts of Offices without Door, Woods of large Timber, and where is all Game in great plenty, even to the Bustard and Pheasant, is to be Let furnished or unfurnished for 16 years. Enquire at Mr. Chus, Bartly Street, Piccadilly, or at Mr. Cooper's at the Blue Boar in Holborn." 
The last individual met with in the county was killed in 1879 , under the following circumstances (40. iii. 26, I10, I44, I52, 252 \& 296) :-On the morning of Friday, Dec. 5th, soon after daybreak, Mr. Albert Pertwee of Woodham Ferris was "laid up" close to Hull Bridge in that parish, on the north side and under the wall of the River Crouch, for the purpose of shooting Wild-fowl. While so stationed, he was surprised to observe a very large bird fly leisurely across the river and over his head at a small height. Being loaded with No. 2 shot, he fired, and brought down the bird, although but slightly wounded, Mr. Pertwee had no idea of the species to which the bird belonged, but brought it with him on the day of its death to Chelmsford Market, where it was purchased by Mr. Charles Smoothy. The bird, which was a female weighing about ten pounds, was preserved by Mr. Travis, of. IValden. On the night of the day following its death, there occurred one of the sharpest frosts of the present century. It is now in the possession of Mr. R. W. Chase, of Birmingham.

About the same time, several other Bustards occurred in various parts of England. During the first few days of February, I880, one was frequently observed in a large turnip-field belonging to Mr. William Jonas, of West Wickham, Cambridgeshire, just beyond the Essex border. On the 6th, after many unsuccessful attempts, it was shot by Mr. Jonas's foreman. This bird, (also a female), was also preserved by Mr. Travis, in whose hands I saw it. It very closely resembled the Woodham Ferris bird (43. i. 59). Mr. Fitch has recorded the occurrence of a third in Essex about the same time, at Manningtree (44. i. v.). Mr. Fitch writes me that he did so "on the authority of Major Russell, who told me of it, and said he hoped to get the skin. He also told me who had it, and I believe it is quite correct, though I heard nothing more of it. He quite believed in it, but I am not sure whether he had seen it." I have no further information about this specimen.

\section{Little Bustard: Otis letrax.}

This rare winter visitant to Great Britain has occurred at least nine times in Essex.

Yarrell says (Zoological Fournal, ii. 24; \& I4. ii. 372) he possessed a female killed at Harwich in Jan., I823. Its stomach contained portions of leaves of the white turnip, lungwort, dandelion, and a few blades of grass. He adds that another was "killed at Little Clacton in the winter of 1824," and a third "very recently" near Chelmsford, of which he had been informed, he says, by Mr. G. Meggy. This latter specimen (killed on Robert.Baker's farm at Writtle, during the severe winter of $1837-38-28$. ii. 229) seems to have excited much interest at the time, as it was left by its owner at the Chronicle office, Chelmsford, for exhibition (I9. $39 \& 47$ ). It is now in the possession of Mr. R. W. Chase, of Birmingham. Dr. Bree records (23. 7352) a female (still preserved at St. Clere's Hall), shot on the St. Osyth Marshes on Dec. 17th, 1860. When first seen it rose from among rushes and flew into some young clover. It was not at all wild. Dr. Bree adds: "Dr. Maclean tells me one was shot at Berechurch a few years ago." A pair was shot by Mr. Eagle, of Walton Hall, Walton-onthe-Naze, from a field of turnips and cabbages on that estate on or about Dec. 28th. 1874. They were in full winter plumage, as were also others shot about the same time at several places on the south coast. Mr. Eagle shot one in the morning when after game, and finding it a rarity, he went back 
later in the day and shot the other. A third was said to have been afterwards seen in the neighbourhood (H. Stevenson-34. 4369). One was seen for more than a week frequenting the large fields round Ramsey and Little Oakley about Nor. 2 Ist, I882. Though often shot at, it escaped (Kerry-40 vii. IIg). A female was shot on the Marsh Farm, Tillingham, by Mr. Robert Page early in September, I885 (29. Sept. I9). It is still in his possession.

\section{[Macqueen's Bustard: Houbara macqueeni.}

At a sale held at the Argyll Street Auction Rooms, London, in 1871, Lot 689 was described as "A Macqueen's Bustard shot at Harwich in 1823 , and preserved by Hall of Finsbury Square." There is not the slightest reason to suppose that this bird was shot in England, as may be gathered from a note by Mr. J. H. Gurney jun., in the Zoologist (34. 4763). In all probability, the bird was the one described in Mar. tin Barry's catalogue as "obtained in company with the Little Bustard," namely, the one recorded by Yarrell as having been shot at the same time and place. Other gross mis-statements in the same catalogue were exposed in the Itis in I863 (p. 477).] 


\section{Order LIMICOL $Æ$.}

\section{Family CDICNEMIDA.}

\section{Stone-Curlew: Edicnemus scolopax. Locally "Norfolk Plover."}

A somewhat-uncommon summer visitor to England, breeding only locally. In Essex, although it seems formerly to have bred not uncommonly, it now only does so in one locality, so far as I know, and is best known as an infrequent passing migrant in spring and autumn, though specimens have occasionally been met with in Essex in winter.

Parsons says (2I) :- "In Essex, probably from a want of sufficient open country for it, it is only a passing and uncertain visitant." Speaking of their occurrence in England in winter, he says, "A friend and neighbour of mine residing at Shoebury in Essex shot one in a field near the coast in that parish on Jan. Ioth, 1832.* I have also known a few others killed in that part of the county late in the season-one of them in the middle of November." In a later note he adds, "In the vicinity of the Essex coast, I have known them to occur in every month from September to March, and [they are] generally seen there in severe frosts. Five about Shoebury, Dec., 1844; hard frost." Writing from Epping in 1835, Edward Doubleday says (15): "On calm, moonlight evenings in spring we frequently hear the call of this interesting bird as it passes over at a considerable height. I never knew of more than one specimen being killed in this parish." With all respect to Mr. Doubleday, I cannot help thinking that he probably mistook the curious nocturnal call of the Moorhen for the note of this species. Henry Doubleday (I0), mentions some which flew over Epping in the middle of March, 184I, and English includes it (43. i.24) as an occasional visitor. Mr. Buxton says (47.93): "I saw this bird on the 2Ist April, I883, on one of the open 'plains' in the Fairmead Thicket [Epping Forest]. When it rose it flew a few yards only and re-alighted. $* * *$ A young bird of this species was captured on the borders of the Lower Forest." More (33.430), in I 865, could find no authority for its breeding in Essex, nor, in all probability, has it ever bred in the county since that date, except in one locality. That it had previously done so, however, seems certain, for Mr. Clarke, writing of the Saffron Walden district about 1845 , says (24) it "occasionally breeds here"-meaning presumably, on the wide open downs north and west of the town, round Heydon and Chrishall. I am informed by Mr. J. P. Nunn, of Royston, that it

* This specimen, which is still in the Parsons Collection, is labelled as having been shot by Mr. H. M. Mason in a ploughed field at Shoebury. 
still breeds regularly on Mr. Jonas's land at Chrishall Grange, and that he has several clutches of the eggs taken in that neighbourhood. Several were seen there in May, r889, and two were killed by a Falcon (29. May II). Dr. Bree says (29) a young specimen was shot by Captain Ind at Birch on Sept. I9th, I878. He adds: "We rarely see this bird in the inland portion of our county." King, of Sudbury, described it (20) in 1838 as " a not uncommon summer visitant, but of extremely retired habits." One was shot in Nov., I887, by some gentlemen partridgeshooting at Bulvan. In Jan, I889, one was shot on the marshes near Stratford (40. xiii. I06). Mr. Sackett has informed me of one shot at Burstead, about Nov. 20th, I887, and of two others shot at Bulvan and Stifford respectively, but it never breeds in that neighbourhood. Mr. Kerry received one, shot at Bradfield, near Harwich, on Oct. IO, I880 (40, v. 26). The Rev. J. C. Atkinson states that he never heard of its breeding nearer to Essex than Bury St. Edmunds.

\section{Family GLAREOLIDÆ.}

\section{Collared Pratincole: Glareola pratincola.}

A rare and irregular straggler to Britain from the south of Europe. There is, I believe, only a single record of it in Essex.

Mr. Henry Shaw, of High Street, Shrewsbury, records (29. Aug. 3I, I86I) that a specimen

"was shot by Capt. the Hon. G. R. C. Hill, about a fortnight back, in Essex, whilst out Duck-shooting; it is a fine bird, and had much the appearance of having recently sat upon eggs. The stomach was full of small beetles. Its appearance on the wing was much like that of the genus Hirmalo. It is now with me for preservation, and will in due course be placed in the Collection of the Viscount Hili at Hawkstone."

Lord Hill has been good enough to inform me that the specimen, an adult female, is still in his possession, while his brother, the Hon. Geoffrey R. C. Hill, writes me that he cannot now remember the name of the parish wherein he shot the bird, but that at the time he

"was shooting 'flappers' on the Kelvedon Marshes with Mr. Philip Bennett (who was in the Blues with me at that time), and I rather fancy the marshes belonged to, or were leased by, his father, of Rougham Hall, Bury St. Edmunds. There was a decoy there in those days, and very close to that, as we were walking up the side of the ditches after Ducks, I saw a single bird coming over my head. Not knowing what it was I shot at it, and not being any the wișer after I had got it in my hand, I asked leave to keep it and sent it to Mr. H. Shaw, of 45 , High Street, Shrewsbury, for preservation for my brother's museum. I may have stated to him at that time more particulars than I am now able to give you."

From the above, it seems probable that the bird was shot close to the Decoy on the Old Hall Marshes, Tollesbury.

[Cream-coloured Courser: Cursorius gallicus.

Another rare and irregular straggler to Britain, where it is generally met with in the autumn. The bird does not seem ever to have been actually obtained in Essex, but an example has occurred on the border. Edward Newman writes (29. Oct. 30, I858; and 23.6309) :-

"I am indebted to Mr. Cooper, of No. 28, Radnor Street, St. Luke's, for sending me in the flesh a very perfect specimen of that rare bird, the Cursorius isabellinus of naturalists. It was shot in the Hackney Marshes, on the Igth of October, by Mr. George Beresford, of the White House Fishery. The bird was exceedingly tame, probably tired with a long flight." 
It is still in Mr. Beresford's possession (38. I32). Although Hack= ney Marshes are on the Middlesex side of the Lea, from the locality in which it was obtained this might fairly be considered an Essex bird.]

\section{Family CHARADRIIDÆE.}

Golden Plover: Charadrius flutialis. Locally, "Crey Plover."

A resident, breeding commonly on many high moorland wastes in the north and west of England, and in Scotland and Ireland, but only a

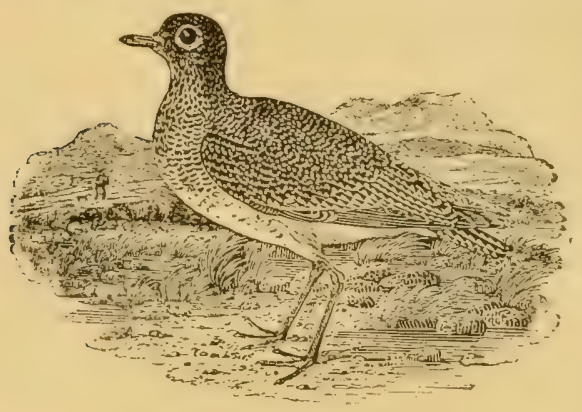

GOLDEN PLOVER, in winter, $1 / 6$.

(After Bervick). winter visitor to Essex. After severe easterly gales, and during hard weather, many large flocks appear in the inland parts of the county, frequenting arable fields, and low swampy meadows, often in company with the Lapwing. They frequently remain until quitelate. I saw a large flock here on Apr. Ist, I880. On Mar. I3th, I $88 \mathrm{I}$, many in a flock I was very close to were assuming the black breast, and two, in almost full breeding plumage, were shot near here by a gamekeeper on Apr. Ioth, 1878 .

Mr. Clarke notes (24) that "rarely a small flock" occurs at "Walden. Lindsey wrote in $185 \mathrm{I}$ that it then occurred "in great abundance during the autumn "at Harwich (27. App. 54), where it is still common in winter (Kerry). Both MIr. Grubb (39) and King (20) say that flocks occasionally frequent the large open fields around Sudbury in the winter. On and about May 9th, 1873, doubtless when on migration, many were killed by flying against the telegraph wires which cross Wanstead Flats (29. May I7).

\section{Grey Plover : Squatarola helvetica.}

A fairly-common visitor to our coast from autumn to spring, seldom occurring inland, and never in large flocks.

Mr. Hope observes that it generally arrives in Essex a little earlier than the Golden Plover, and in 1880, Major Russell (42) observed several flocks on the Essex coast on Aug. I 4 th, when all had black breasts. Mr. Bond found it (23. 39) common round Southend at the end of Aug., I842. Mr. Buxton says (47. 94) it " has been found by the Roding in late autumn. *** Its occurrence in the Forest is remarkable. One procured [at Epping] by the late Mr. Doubleday, 
of Epping, is preserved in the British Museum [32. I39]." Mr. Smee says (34. 2605) that a fair number were seen round Leigh in October, 1871. At Harwich, "it is common during migration" (Kerry).

Mr. J. Glessing, of Forest Gate, has a cream-coloured variety, obtained in that neighbourhood at the end of April, I87I (29. May 6).

\section{Kentish Plover: Esialitis cantiana.}

A rare passing migrant in spring and autumn. It breeds in Kent and Sussex, but not in Essex.

Two were seen and one shot on the beach at Dovercourt on Aug. 23 rd, I876 (Kerry-40. i. 52), and Mr. Hope "saw one near Harwich in October, I887." The Rev. M. C. H. Bird observed two, and procured one, at Canvey Island on Sept. Ioth, I88I. Several years ago Mr. Bidwell observed a pair at Clacton. At Languard Point one was observed on Aug. I2th, I884, two on June 30 th, I885, and two on Nov. 27 th, 'I885 ( 42$)$.

Ringed Plover: Esialitis hiatiula. Locally, "Stone Runner," and "Ring Dotterel."

A common resident on the coast, though its numbers are largely increased in autumn by the arrival of birds from elsewhere.

In 1865 , Lieut. Legge noticed their arrival at Shoebury at the end of September, when they were enormously fat. They seemed to spend the night on the beach, and were usually seen most about daybreak, or in the evening (34. 9I). In I888, Mr. Stacey preserved a specimen shot at Dunmow. Round Harwich, it is very common and it breeds in increasing numbers on the beach and sandy

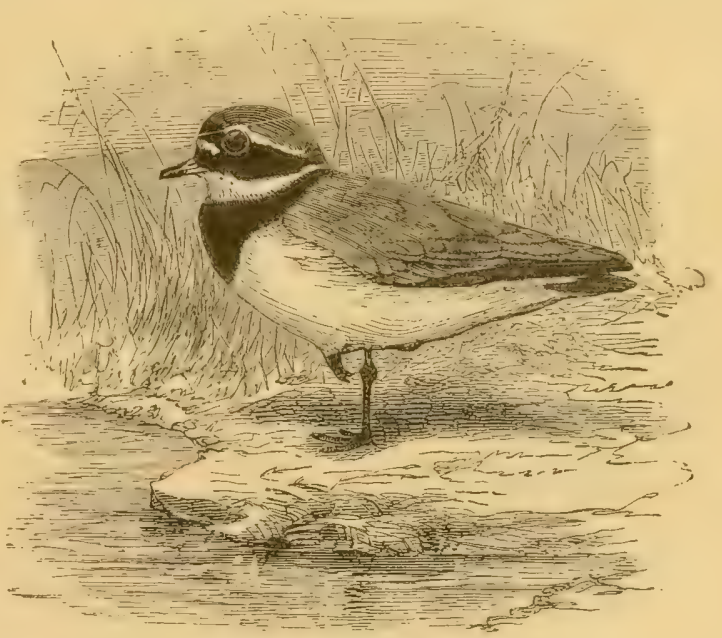

RINGED PLOVER, I/4. wastes between that place and Walton-on-the-Naze (Kerry). In the Parsons Collection is one shot by Mr. Parsons on Foulness Island on May $23 \mathrm{rd}$, I838, when he also took the nest with four eggs. Mr. Hope says: "It breeds on all our beaches."

Interdediate Ringed Plover : Egialitis hiaticula-intermedia.

The smaller and more slender race, which has been by some regarded as a distinct species, and which seems to be chiefly a south- 
ern form, occasionally appears on our coast. The Rev. M. C. H. Bird both saw and procured specimens on Canvey Island in the autumns of $188 \mathrm{I}$ and $\mathrm{I} 88_{2}$. This form, which is merely a geogra-

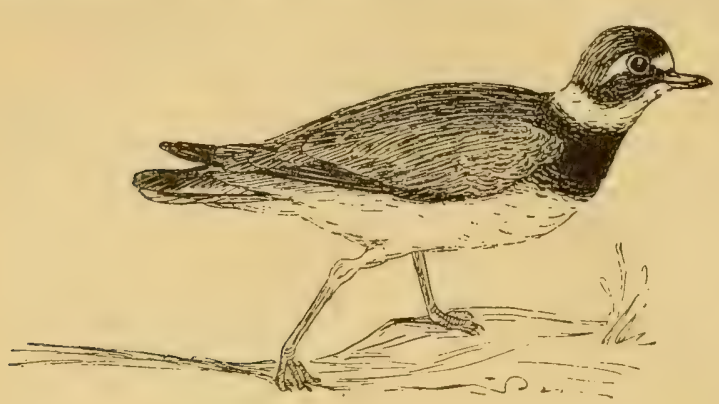

phical race, of sub - specific value only, must not be confounded with the Little Ringed Plover ( $E$. curonica) which is a totally distinct species. This latter is a LITTLE RINGED PLOVER, $2 / 5$. very rare occasional visitor, and was first observed in this country by Henry Doubleday, who obtained a specimen at Shoreham about $18+5$. The accompanying figure, for which I am indebted to Mr. Harting, is sketched from the specimen shot at Kingsbury Reservoir in August, 1864. There is no record of the species in Essex.

\section{Dottere1: Eudromias morinellus.}

A rare passing migrant in spring and autumn when on its way to or from its more northerly breeding stations among the Scotch

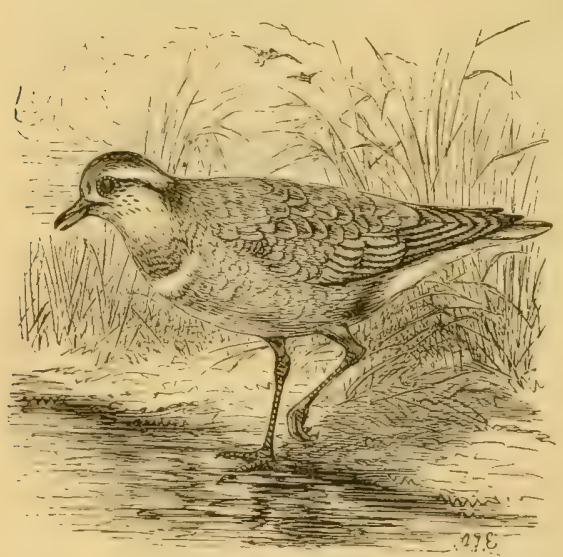

WOT TERH.1., I'5. mouncains. At these times it is occasionally met with in the inland parts of the county. The open chalk downs around Chesterford, Chrishall, Heydon and the Chishalls seem formerly to have been a rather favourite halting-place.

Mr. Clarke, writing of the Saffron Walden district about I845, says (24) it is "now and then met with; not uncommon at Ickleton [Cambs] and Chesterford." In the Museum is a mature specimen shot near the town. Mr. J. Glessing records that a flock of fourteen appeared near Forest Gate after severe gales about the end of August, I87I. They frequented a freshly-turned fallow (29. Sept. 2). Some years ago, one struck the 
telegraph wire in the neighbourhood of Colchester and lost one wing. It came into the possession of Dr. Bree, who forwarded it to the Zoological Gardens (Laver). Dr. Bree records (29) that it was brought to him alive in the third week in Aug., I876, doubtless when on its southward migration; also that in May, I880, two were shot out of a flock of seven on migration near Colchester (29. May 29). Mr. Hope writes that he generally sees them in September and May on the borders of Essex, where they are more common than they were a few years back. Mr. E. A. Fitch informs me of one "in summer plumage," shot by Mr. W. Sewell at Bradwell-on-Sea in Sept., 1875, and Dr. Salter has some killed on the shore at Mersea Island in I886. In Hone's Every'-Day Book, it is stated, under May Ioth, that

" in May and June [? June] this bird is to be found on the Gog-Magog Hills [which are in Cambridgeshire, but only just beyond the Essex border] and the moors adjacent. It is caught with nets. $* * *$ There is a tradition current here that King James I. was very fond of seeing Dotterells taken; and when he came to Newmarket used to accompany the birdcatchers to the Gog-Magog Hills and moors for that purpose." Then follows an amusing anecdote connected with the sport. Mr. Saunders says (37.iii. 255) that May Ioth " used to be known on the borders of Hertford and Cambridgeshire as "Dotterell-Day." "

Peewit or Lapwing: I inillus zulgaris. Locally, "Green Plover," "Black Plover," "Horned Pie," and "Flapper-jack" (E. A. F.-once).

A resident, breeding not uncommonly near the coast and at a few inland places, but nowhere abundantly in the county. In the winter, especially after strong easterly gales or during severe weather, enormous flocks appear in the inland parts of the county, feeding in ploughed fields and low marshy pastures. In all probability their absence from the inland parts of our

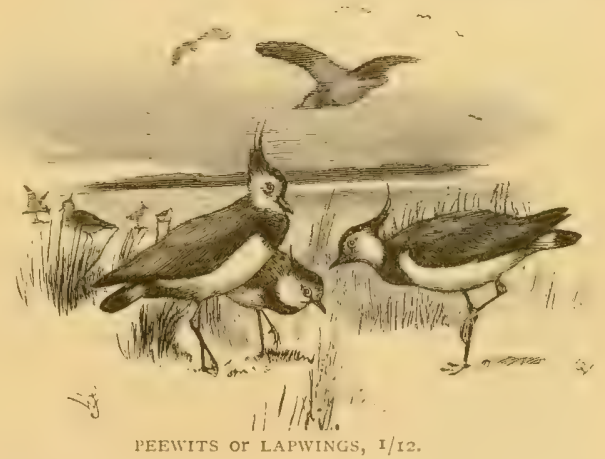
county during the breeding season may be largely accounted for by the better farming now carried on, as Mr. Clarke informs me that many years ago they were plentiful round Saffron Walden, where they do not now breed.

On July 24 th, I876, I saw a small party of seven or eight fly over here-a very unusual occurrence in the breeding season-and in 1879 I saw a flock of twenty here as early as Oct. 8th. Mr. Buxton says (47.94) that it is

"Frequently seen in flocks about the fields near Wanstead Park and elsewhere [in the Forest]. Ten years ago (I874), they used to breed on Fairmead and near the Wake Arms. I have only observed one pair this year, but there are some fields just outside the limits of the Forest to which they still resort in spring." 
On May 7th, I882, I saw several on Wanstead Flats. They were probably breeding in the vicinity. In 1877 , there was a nest at Stanford Rivers. In April, I884, I saw some, evidently nesting, in a field near Dunton. It also breeds on Osey Island, where in 1879 twenty-two nests were found in one day, while Mr. Fitch states (50. i. I50) that upwards of 300 eggs were taken on his various farms round Maldon in I887. Yarrell says (14. ii. 4I8) that in his time a large proportion of the eggs sent to the London markets came from the marshes of Essex, and other adjacent counties, but this is certainly not the case now. Walter Charleton, in his Onomasticon Zoicon (I668. p. I08), says of the "Vanellus":-

"In Essexia, est Insula quaedam haud magni circuitus, quae ab ingenti avium harum copia, eo praecisè ad diem Divo Georgio sacrum advolante, nomen suum, Foulness nempe, hoc est avium promontarium, fortita est, uti est Fullero nostro notavit supra laudatus D. Dr. Merret. Huic Vanello Congener Est."

Round Orsett, they are "common enough on the marshes and fens, in spring and summer. About the beginning of August they leave for the uplands, where they remain until the middle of March, when they return to their breeding haunts" (Sackett). Round Harwich, it "breeds commonly" (Kerry).

Oyster-catcher: Hamatopus ostralegus. Locally, "Olive" or "Olaf," and "Sea Pie."

A scarce resident on our coast, where it formerly bred not uncommonly, but now best known as a fairly-common visitor to our shore from autumn to spring.

Dale says (2.400): "This I have seen in Maldon Channel." Lindsey says (27. App. 52) it was well-known in I85I on the shore at Harwich. Mr. Kerry states that it is now fairly common there and stays all the year round, from which he infers that it breeds in the neighbourhood. This is probably the case, as in I873 I saw eggs taken on Stony Point by an old fisherman known as "Noah," who used to live on the Point in a rude hut.* Mr. J. F. T. Wiseman informs me it does not now breed near Paglesham, though it used to do so in some numbers. Mr. Bond found it (23.39) common round Southend early in Sept., I842. The Rev. J. C. Atkinson says (36. II 7 ):

"It runs well, and is even said to dive and swim with facility. I never saw this, though I have had them under my observation for hours together in former days. But I know their shrill, rattling whistle, and their short uneasy flights, and restless paddlings up and down upon the ooze, when I have been among their haunts, well-and many a nest it used to be my lot to discover on some parts of some of the Essex Saltings."

Mr. Atkinson writes me : - It bred commonly along the Tollesbury, Wigborough and Peldon Saltings in my young days. I have found many scores of its nests." King, in 1838 , says (20):

[I was] "walking one day on the banks of the Stour, at a time its waters had been drawn off to facilitate repairs. On reaching a bend of the river, one of these birds rose and flew rapidly away, following the windings of the river. It appeared to settle on the mud at a considerable distance. I was not before aware that it ever came so far inland."

In the winter of $1886-7$ one frequented the large open sheet of water in Wan-

* Mr. Kerry has since informed me that a pair undoubtedly bred on the Point in r889. 'Their first eggs were taken and brought to him for identification, but they successfully reared a second brood. 
stead Park for several days (Lister). Parsons has many notes on this species (22). In his day it occasionally bred on the coast in his neighbourhood. In I833, "a pair bred on Mr. Walton's Salterns at Shopland," and on June Ioth, I84I, he "took two eggs froma nest on Brimstone Saltings; they were sat upon." $\mathrm{He}$ also notes the following occurrences late in spring: Apr. 2Ist,1 I826, "A good many on the sands." Apr. IIth, I836, "Not yet all gone." I837, May 6th, "Saw a large flock;" 23rd, "a good many at Canvey Point ;" 24th, six on Foul. ness Ridge; June 6th, "a flock of more than a dozen about Canvey IPoint." Respecting their return in autumn he says: Aug. I5th, I833, "They have arrived in plenty." Aug. Ioth, 1835 , two on the sands; 25 th, a good many have arrived. Aug. I2th, I836, "Saw two or three lots ;" 26th, "a good many-some largish lots;" Oct. 7th, "A great many about the sands-more than I have seen for two or three years." 1837, Aug. Igth, "Several about at Canvey." I838, Aug. I5th, "They have arrived."

On June 30 th, I864, Dr. Bree had one brought to him which had been found alive, but unable to fly, in a field at Brightlingsea. He kept it in his garden for some time and made observations upon its habits (32a).

It is not improbable that the Pye Sand, off Harwich, and the Pye-fleet Channel, between Mersea Island and the mainland, take their names from this bird, which is often known as the "Sea Pie."

\section{Turnstone: Strepsilas interpres. Locally, "Stone-turner."}

A fairly common bird as a passing migrant in spring and autumn, sometimes tarrying on our coast till the beginning of June, and often returning by the middle of August, though it does not breed in the United Kingdom. It is sometimes met with in winter, and has been killed inland.

Sheppard and Whitear speak of it $(9.38)$ as "found sparingly on the seacoast." Parsons says (22):-

"During the month of May [they] are found all along the eastern coast, frequently tarrying until the latter end of the month, or even the beginning of June, at which latter time I have occasionally seen them upon the shores of Essex and [have] shot the old females with their eggs in a considerably advanced state."

He appends the following late observations on this point:-May I7th, I836, a pair on Shoebury Sands. May 23rd, 1837, shot a fine old female on. Canvey Point and saw one on foulness Shore the next day. June Ioth, 1835 , saw one on Shoebury Sands. He also gives dates of their reappearance: Aug. 27 th, I835, "a great many about the shore." Aug 29th, I836, "a good many about the cockleshell point of Canvey, with Ring Dotterel and Oxbirds." In I865, Lieut. Legge wrote from Shoebury (34. 90):

"This handsome bird is not very common, I believe, on these sands. The shore is of a muddy nature and does not suit their habits. *** Small flocks of young birds arrived on the coast during the last week in August and first days of September. They confined themselves to the shingle, and were not very shy. Several specimens were shot, all young birds. They stayed about a week, and then disappeared.'

Round Harwich, Mr. Kerry says it is "common in the autumn." He adds that three pairs in 1888 , and two pairs in 1889 , remained on the beach between there and Walton during the entire summer; but it is impossible to believe that they bred there. One was killed at Audley End on Jan. I8th, I832 (Clarke-24), and in August, 1876, Mr. Stacey preserved one shot at High Roothing. 


\section{Family SCOLOPACIDA.}

Avocet : Recurvirostra avocetta. Locally, "Crooked-bill."

Formerly a not uncommon summer visitor, but now only a rare visitant to England. The only records of its appearance in Essex I

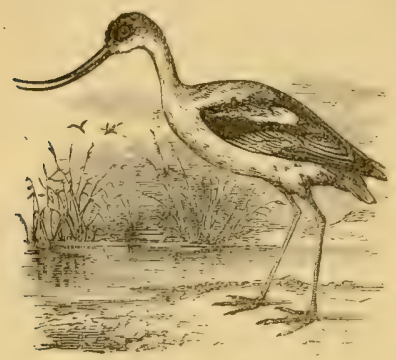

AVOCET, I/I2. have been able to discover are the following :-

Dale, mentions it (2. 402) under the name "Crooked-bill." He says it is met with " in these eastern parts [about Harwich] frequently. The first time I did see it, was on an Island below Maldon, called Northey, anno I700. In the summer time." At this time of year, it must undoubtedly have been breeding, as it used also to do in Sussex, Kent, Suffolk, Norfolk, Lincolnshire, \&c. On the north side of the Island, as Mr. E. A. Fitch has informed me, there is still a creek known, and marked on some maps, as "Awl Creek," which name is with very little doubt a relic of the time when the Avocet or "Awl-bill " bred on its banks. Such survivals are very interesting. Mr. Hope remarks that Avocets "often land in the winter time." He adds, "One gunner on the Main shot eight at one shot. The late Col. Russell bought them for $£$ I." Several are still among the birds he left, while a fine adult from Essex, now in the Norwich Museum, presented by Col. Russell, was, doubtless, one of the same lot. Mr. Hope also informs me that, on Apr. IIth, I889, about 5 p.m., four were observed to fly in from the east of the Cork Sands. They flew about I 20 yards high, and, curving round, took a northerly course up the Deben River.

\section{Black-winged Stilt : Himantopus candidus.}

A rare straggler to Britain, which is included in this list on very slight, though I think sufficient, grounds.

Mr. Clarke notes (24) that one was seen about 1820 round the pond at his residence, "The Roos," near Saffron Walden. He still remembers being hurriedly called by a man to see "a bird with legs a yard long," but was only in time to see it fly away.

\section{Red-necked Phalarope: Plalaropus liyperborens.}

A regular, though uncommon, passing migrant in spring and autumn, when on its way to and from its breeding stations on the islands in the extreme north of Scotland.

Mr. Bond met with one or two at Southend late in August, I842 (23.40). An old male, in winter plumage, was taken on the lake in Debden Park on Oct. I 5 th, I88I, after a severe storm (44. ii, Ixxx). Specimens were shot near Harwich in Aug. and Sept., 1876 (Kerry-40. i. 52). The late Mr. Bond's Collection contained a specimen, in summer plumage, which was shot in the summer of I850, whilst running between the rails near the station at Stratford (40. xiii.4I6). 


\section{Grey Phalarope : Phalaropus fulicarius.}

An uncommon and irregular visitor when on migration in late autumn or early winter.

Earthy records (I9. II4) that in Sept., IS38, he received two specimens, "one shot at Blackwater, the other found in an exhausted state in the parish of Rayne." One was killed near Woodham Mortimer in or about the same year (C. Walford-Ig. 47). Another was killed on the Blackwater, on October 6 th, I866, at which time many occurred on the south coast of England. Mr. Stacey, of Dunmow,

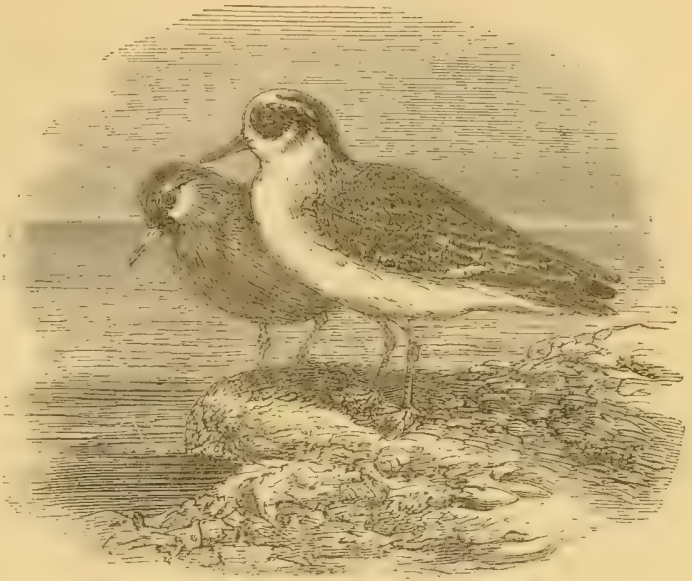

GREY PHALAROPES swmmer and winter, I/4. has a specimen shot by a pond near there about the year I870. One was shot in Wanstead Park on Oct. 5th, I875 (29. Oct. 9.) Mr. Kerry records one (34. 4827), in full winter plumage, shot at Harwich on Nov. 24th, I875, and says (40.vii. II9) that on Nov. 3 rd, I882, one was shot and another seen swimming in the Harbour. The Rev. M. C. H. Bird possesses a pair, shot on Canvey Island in I877. English includes it (43. i. 24) as only an "occasional visitor" to Epping, probably on the strength of one shot beside a brook at North IVeald (47.97). Mr. Hope says it is "common in Essex in winter and autumn after heavy north-east gales. Sometimes it is seen in summer months, generally swimming inside the mouths of estuaries." One was killed by a stone from a catapult on Wanstead Flats on Nov. 2 Ist, I888 (29. Dec. I and 8). Dr. Salter has one shot from a launch at the entrance to Salcot Creek after a heavy storm in I88r.

\section{Woodcock : Scolopax misticula.}

A fairly-common winter visitor, much sought after by sportsmen. Plentiful in some years, but scarce in others. A few remain to breed, and nests in various parts of the county have from time to time, though not very often, been reported.

Lord Braybrooke, writing to Yarrell (I.4. ii. 596), mentions one shot at Audley End about 1793, which "weighed full sixteen ounces, and was much the largestlooking bird, as well as the heaviest, I ever saw." Mr. Clarke speaks of it (24) as "frequently killed in winter" round Saffron Walden. He records nests in Peverell's Wood, Wimbish, in the years $183 \mathrm{I}-32$ and 33 . On one occasion, the nest, when found, contained eggs, and on two occasions the young birds were 
found. Dr. Maclean, about 1835 , mentions a nest taken near Colchester (I6). Daniel says (6. ii.437) : At Langleys, in Essex, the seat of "Mr. Tufnell, some

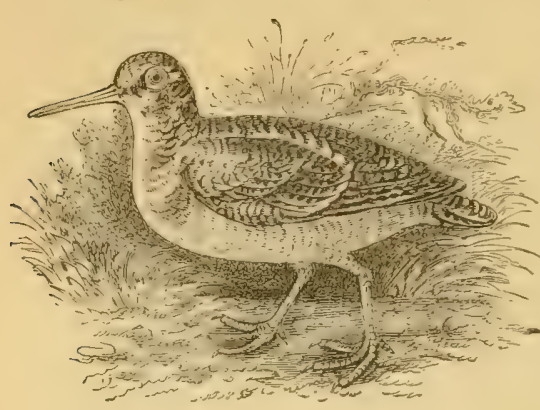

wOODCOCK, $1 / 8$. years since, a Woodcock flew through the hall window in the day timewhether pursued by a hawk, or deceived by the thorough light from the opposite windows, is unknown." He adds (6. ii. 44I), "Young Woodcocks have been found in the High Woods, near Colchester;" also that at the time of their migration they are sometimes found in great "abundance upon the Essex coast, especially in the large woods at St. Osyth." Dr. Bree (32a) notes a female containing eggs found

in a garden in Colchester on Apr. I5, I865, and also a female picked up close to the town on July 24, 1869. The late Mr. Errington, of Lexden Park, had some preserved specimens of the bird and its eggs, also taken in the Colchester High Woods (Laver). Although common in the wooded districts around Laindon. Burstead and elsewhere, it is infrequent in the more open Orsett district. On Oct. 3Ist, I887, however, during full moon, a young man who was catching blackbirds with a bat-fowling net along the hedges of a lane close to Orsett Street, captured one which sprang out of a ditch by the road-side (Sackett). Mr. John Cordeaux writes (40. xii. 62), under date of Nov. Ioth :

"A curious note comes to me from the Sivin Middle L.V.: when the lantern was lowered at sunrise a fine Woodcock was found dead on the top. Now if the bird had struck the lantern in flight, it would either have fallen on deck or into the sea; the probability therefore is that it alighted on the lantern top, and simply died from exhaustion."

Woodcocks "are not unfrequent visitors to the Forest in the winter months, but the absence of springs and the hardness of the soil are unfavourable to them, and they are never numerous where cattle have access. They do not, therefore, generally remain long, but instances have been known of their staying through the summer and breeding" (Buxton-47.95).

Henry Doubleday writes (IO) on Apr. 9th, I844: "On Sunday afternoon a lad was walking through our forest and put up a Woodcock, and on looking at the spot she rose from, found four eggs which he brought to me." The Rev. J. W. Maitland also has two nests, taken in Epping Forest, while Mr. Harting writes (4I. i. I66):-

"On the 6th April [I887]*** four Woodcocks were flushed in different parts of the Forest. $* * *$ On the 6 th of August last $* * *$ while walking at twilight in the neighbourhood of Loughton Camp, I came suddenly upon an old Woodcock and two full-fledged young ones. They all rose at my approach within a few yards of me, but the young ones not being strong on the wing, dropped again within a very short distance."

In the extensive woods around Danbury, Mr. Smoothy frequently meets with them during winter, and shoots, on an average, about seven couple every season, though in $188_{3-4}$ he killed nine couple, and in $1888-9$ ten couple. He has liept account of the weights of all he has shot during the last few years, and finds the average to be $\mathrm{I} 2 \mathrm{oz}$, though two have reached $\mathrm{I} 6 \mathrm{oz}$. It probably breeds in the woods as he has seen it late in the spring. 
Great Snipe: Gallinago major. Locally "Double Snipe."

An uncommon visitor to Britain. It has been met with fairly often in Essex as a passing migrant in the autumn, but appears to be very rarely seen in spring.

"Several were shot on the Suffolk and Essex coasts during the autumn of I 836 (Hoy-I8. i, II7). Mr. Clarke records (24) one obtained near WaIden about I825, and another at Newport in I853. Dr. Bree records one (29. Sept. 6 and 20) found dying near Lexden in Aug., I879. Mrs. Bree still has it. He also says (29):

"Mr. Ambrose, bird-stuffer of this town, has shown me two fine specimens, sent to him for preservation, and shot one on either side of the River Colne as it flows into the sea at St. Osyth and Brightlingsea, in November last [1880]. These birds weighed respectively $8 \frac{1}{2}$ and $9 \frac{1}{2}$ oz. The bird which weighed least was the finer specimen of the two.* *** With one bird in my own Collection, this makes three that have been taken in this neighbourhood during the past year."

Mr. Laver (4I. i. I8g) saw one at a game-dealer's in Colchester on Sept. 7th, I887. It was in good condition, and had been killed by flying against the telegraph wires. It was afterwards purchased by Mr. Pettitt. Mr. E. A. Fitch informs me of one in the possession of, and shot by, Mr. F. Cocks on Tiptree

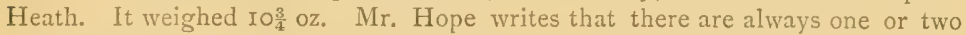
about every year. Two were shot at Brentwood in Nov., I888. Mr. Pettitt has preserved specimens shot respectively at Takeley about I884; at Paglesham alout Dec. 3cth, ISSS (weight $6 \frac{1}{2}$ oz.) ; at Langham ahout the end of August, I889; and at Tollesbury on the Old Hall Marshes by Dr. Salter on Sept. I 3 th', I889, the latter a particularly fine bird, weighing $7 \frac{3}{4}$ oz. and measuring I 2 inches in length.

Common Snipe: Gallinago culestis. Locally, "Whole Snipe" and "Full Snipe."

A common winter visitor, especially during a sharp frost or floods, when single indiriduals may be found beside small streams and running ditches in most, if not all, parts of the county. It used to be a common resident, but it is now more scarce than formerly, though it still breeds in various places on our coast, and probably in Epping Forest.

In ISSO, large numbers, which remained only a few hours, were observed to arrive on the Essex coast from Oct. 29th to Nov. Ist (42). In I88I, a pair was seen in the Osier-ground at Broomfield as late as April 7th, but they did not stay to breed. Three were also seen near here as early as Sept. Ioth. Some remarks by "a Londoner" (28. i. 43) imply that in I85I it still bred not uncommonly in Hainault Forest, and it seems not improbable that they bred in the Forest as lately as I878, for "Ranger" says (29. July I3): "For some time past we have had alout six couples of Snipe feeding on the swamps in the Forest in this neighbourhood. *** In many years' experience, I never knew them here so early." The Rev. J. C. Atkinson cannot recollect ever having found its nest in Essex, but it breeds round Harwich (Kerry), and at Paglesham Mr. J. F. T. Wiseman has known it nest occasionally. Mr. Hope also remarks that it "breeds on the marshes and passes on. Fresh birds take their place about the end of September. On the first signs of frost they go up-country to the springs." In I889, Dr. Salter says nests were found on the Tollesbury Marshes, where it is becoming commoner as a breeding bird. 
Mr: Scruby informs me that a white specimen was shot at Shelley a few years ago. He himself fired at it, but missed.

Jack Snipe : Limnocmptes gallinulı. Locally, "Half Snipe." A fairly-common winter visitor, most often seen during a frost.

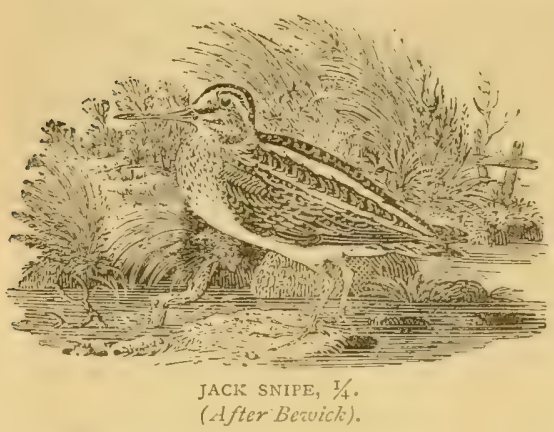

King says (20) that in 1838 it was "common" about Sudbury. It frequently occurs on Wanstead Flats in winter (Baxter). I have occasionally seen them, and once shot one, in a marshy meadow close to this house. Round Harwich, Mr. Kerry says it is common most winters. He once shot one weighing $3 \frac{1}{2}$ ounces, the usual weight being about 2 ounces.

Dunlin : Tringa alpina. Locally, "Oxbird."

The commonest Sandpiper on our coasts during autumn, winter and spring. Although it has never been known to nest in the county,

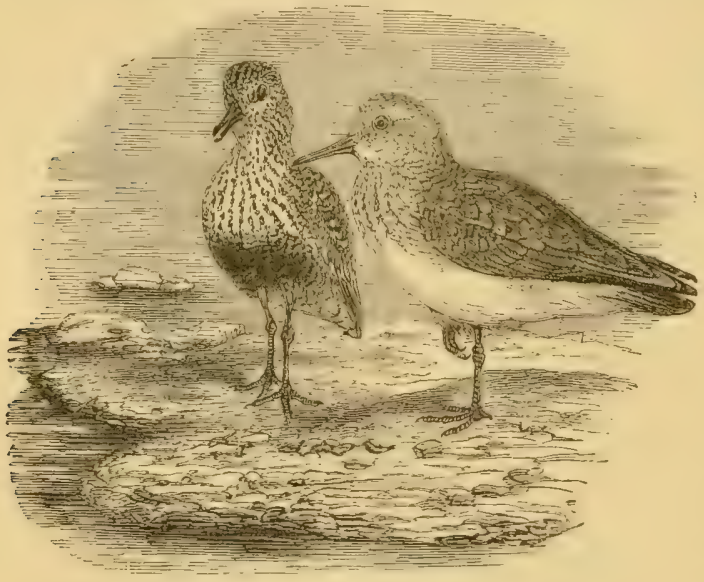

DUNLINS, summir and zuinter, $1 / 4$. specimens sometimes remain on the Coast until the end of May, and often return by the middle of July, while some even stay with us all the year round.

Parsons says (I3. ii. I 54. that at Southchurch, although noneremain tobreed, "about the middle of July the old ones arrive here, and the first of the young about the middle of

August. All that month and September [they] continue to come, and during winter may be seen in immense flocks, traversing the surface of the water, or sometimes, rising higher, they appear like a dark cloud, and rapidly turning and presenting their breasts to the spectator, they all at once appear of a snowy white." He shot seven (8) on New England on July 24th, IE24. His observations on this bird (22) are very numerous. He seems not infrequently to have observed them about until nearly the end of May : for instance, on May $23 \mathrm{rd}, 1836$, he "saw a 
pair at Tilbury ; very fine and black," and on the same date in the following year, several on Canvey Point, while the day after he notes "a few about East Point, Foulness," and he shot one in perfect summer plumage. In some years, he saw them even later: thus on June 6th, I 837 , he saw "a few about Canvey Point," and shot a female with enlarged eggs; while on June $I 5$ th he says three were shot on Yantlet. One of these which he examined was a non-breeding female in bad plumage. Such birds, he says, not unfrequently occur in most species of shore-birds. He usually noted their return in autumn about the middle of July or sometimes even a little earlier : thus, I833: July I2, "saw one ; "ISth, "saw several old ones." I835: July I sands." I838, July I4: "Twenty, or more, old birds on the sands." . As to their swimming powers he writes: when sitting at the

" edge of the flowing tide, they will frequently suffer the water to reach their bellies, and even to float them, before they move. This, I have often noticed, more particularly when they are sitting among the grass on the saltings, where they will let the tide take them off their legs and [will] paddle across the little guts that lay in their way." Again he says:

"Sept. 24th, I835.-Watching some to-day on the salterns at tide-time, to observe their habits, I saw them two or three times voluntarily take to the water and swim across the little guts that lay in their way and wading up to their bellies, bibling in the water anong the saltern grass. I have before seen them swim decently when winged, but not from choice."

Mr. Clarke mentions one in the Audley End Collection, shot there on Dec. I $5^{\text {th }}$, I844, and another, in summer plumage, shot beside the pond at "The Roos" on Apr. 22nd, I854 (24). In the Collection at Audley End, too, is a specimen in full breeding plumage, shot there on May 5th, I864. In I859, one was shot at Great Canfield (Stacey). King, in I838, says (20): "I have once or twice noticed immense flocks of these birds skimming over our low meadows [at Sudbury] during floods, most probably intermixed with other species of Tringa common on the coast, [such] as the Pigmy Curlew, Ring Dotterell and Sanderling." In I865 Lieut. Legge says (34.9I) they began to arrive on the coast near Shoebury about the end of August, and continued to increase in number until November, when, they had "attained to the vast numbers which frequent the coast always in the winter." Specimens shot on Oct. 7th were still partially in summer dress, but others killed a fortnight later had assumed the full winter plumage. They fed, he says, mostly on the mud-flats left bare at low water, often in company with the Ring Dotterell, roosting like them on the beach. At high water, they packed into vast flocks and wheeled about in the air, often at a great height. Mr. Sackett describes it as "common enough on the Mucking Flats in the winter, often flying in great clouds." He adds, "a few seem to stay all the year round." The Rev. J. C. Atkinson writes (36. I32) : "The Dunlin, always called 'Oxbird ' where my boyhood was spent, and often seen there in flocks of not simply hundreds, but thousands and many thousands, in the autumn and winter, goes to the far north to breed." In an important paper on "Reason and Instinct," Mr. Atkinson has written $(23.5465)$ :-

"How often, too, on the oozes of the Essex Coast may tens of thousands of the there-called Oxbird be seen in a flock, and with them Redshanks, a few Grey Plover, Ring Dotterel, \&c. The whole spring together, fly together, wheel together, presenting to the spectator this moment a sheet of brilliant white, and the next, as they execute one of their marvellous turns, nothing but a dusky. cloud of rapidly moving dark objects. All this would be not simply unintelligible, but impossible, except on the supposition that they have some feathered fugleman to give the word and the time, and that their 
code of signals, however expressed, is not nnly intelligihle but thoroughly understood and implicitly acted on by every bird in the flock."

Mr. Hope observes that they can be seen on our coasts all the year round, but do not breed, as far as he knows. Yarrell, too, says it has not been known (37. iii. 350 ) to breed in Essex, Norfolk or Suffolk, though its nest has heen taken in Lincolnshire, Yorkshire and Northumberland. Mr. John Basham, jun., of Maldon, informs me of an enormous bag of these birds made by his father one night abuut forty years ago, when he killed by a single discharge of his grun no less than $2 f$ dozen out of a flock settled on the ice. This was the number actually obtained, but he thinks the gulls and crows took several dozen for themselves. Josiah Pitt, of Maldon, once shot 25 dozen at a single shot. Mr. Parsons also mentions having killed 33 by one discharge of his punt gun on the New England Saltings on Nov. 25, I 836.

\section{Little Stint : Tringa minuta.}

A not-uncommon shore-lird when on migration in spring and autumn.

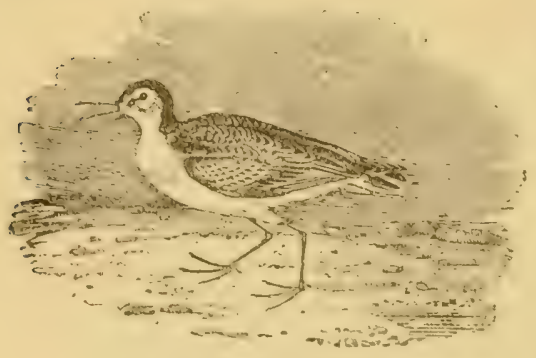

LITTLE STINT, in ruiztcr, $1 / 4$.

(After Beruick).

Sheppard and Whitear state (9. 43) that they had "killed it on Ray Island in the River Stour." In the Parsons Collection are specimens shot on New England on Aug. 27 th, I 335 , and Sept. 6th, IS36. Mr. Bond met with a few specimens at Southend late in Aug., I $8+2(23.40)$. It "has once, at least, been procured near Epping. The specimen referred to is in the British Museum" (Buxton-47. 97). Round Harwich, Mr. Kerry says it is rare, but two in his Collec-

tion were shot there, and five were shot in the autumn of r\$89. Mr. Hope observes that for a few days in April, and again in October, when on migration, they may be seen about the ditches on the saltings in small parties of five or six. Two were shot on Canvey IsIand on Sept. Ioth, I88 I (Bird). Mr. Pettitt has several killed by his. brother out of a flock at Paglesham on Aug. 29th, ISS9 Mr. A. H. Smee shot one which was flying in company with another at Leigh on Sept. I7th, IS7O (34.2383). Mr. Fitch has shot it at Maldon.

\section{Temminck's Stint: Tringa temmincki.}

An uncommon risitor to our coast when on migration in spring and autumn.

Mr. Parsons' Collection contains one which has nearly acquired its summer plumage, shot at the Lower Flect, New England Iskand, on Aug. 25th, Is35. Lindsey, writing from Harwich in IS II, says (27.App.5I) that "it is only occasionally to be seen on the oozy patches of our shore." Mr. Kerry mentions some (40, i. 52) shot on Dovercourt beach in the autumn of $I \$ 76$, but the only one he himself ever saw near LIarwich he shot, in company with a Little Stint, in rss6. Chats. F. Smith notes one ( 31.53$)$ "shot at Latchingdon, near Maldon, in the spring of IS56." Yarrell mentions one (25. iii. 72 ) killed at a pond-side in Essex by Hy. Duubleday 
in the month of May, it lling (37. iii. 395) that it has heen o:casionally met with on the Essex const.

Curlew Sandpiper: Trimse sulurmuate. Iocally, "Little Jack Curlew" (E.A.F.).

Not very uncommon on our coast as a spring and autumn migrant. It is remarkable, as the only liritish lird whose eggess still remain undiscovered.

Sheppard and Whitear met with it on Peewit Island (9. 43). Mr. Clarke (24) records one killed at Bumpstead on Feb. 2nd, 1832. Henry Doubleday says (10) that in 1832 he saw in a Collection at Colchester, a specimen obtained on the adjacent coast. He also says he shot several at Walton-on-the-Naze on Oct. 4th I833. "A specimen, procured by the late Mr. Doubleday of Epping, was presented by him to the British Museum" (Buxton

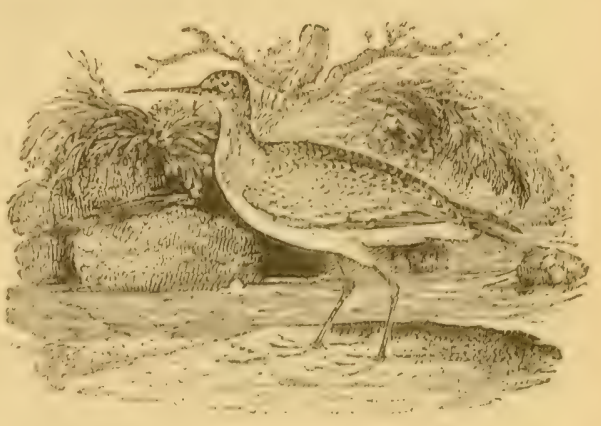

CURLEW SANDHIHER.

(Afler beruicti.)

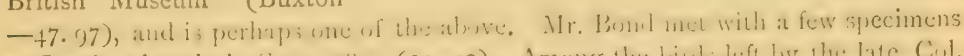

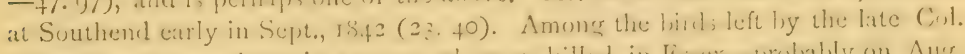

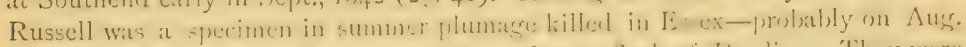

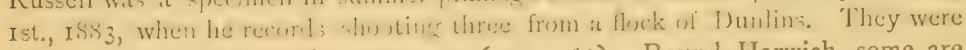
in partial moult and another was seen (40.v. 52). Round Harwich, some are seen every year, and it was "fairly common" in the autumn of 1889 (Kerry). Mr. Hope olverwes that they ate feirly phentiful amenest the "Oxlarils" on the coast in September. Mr. Pettitt has one shot by his brother at Paglesham on Aug. 2gth, I88g.

\section{Purple Sandpiper: Tringa striata.}

A rather rare winter visitor to our coast.

Sheppard and Whitear "once observed a Sandpiper, which appeared to be-

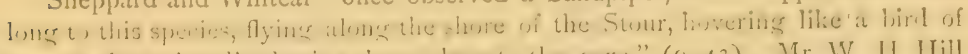

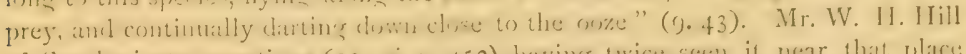
of Southminster mentions (12. vi. 1. +52 ) having twice seen it near that place

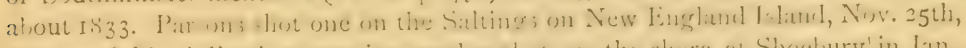

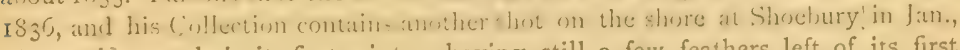
I855; also a male in its first winter, having still a few feathers left of its first

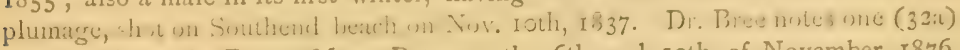
shot at Mersen in Dec., 1869. Between the 6th and Ioth of November, 1876, seven were shot on the stone breakwater at Harwich (Kerry-40. 52). One was

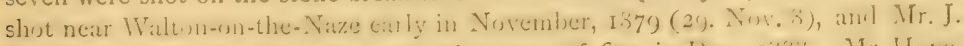

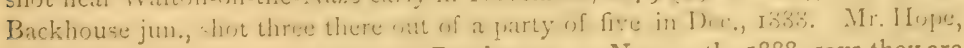
who has a male shot on Dovercourt Breakwater on Nov. I 4 th, I888, says they are becoming "less common than formerly." Mr. Baxter has one shot on Canvey 
Island. Mr. Kerry observes that round Harwich "it has been rather rare of late years. One was shot there, however, on Nov. I2th, I888; another on Dec. 9th, I889. Yarrell says (14. ii. 666) that various authorities speak of its occurrence in winter on the coast of Essex and other counties.

Knot: Tringa canutus. Locally, "Male" or "Marle" (recte Merle); "Red-Sandpiper."

A common winter visitor to our coast, often appearing in August and remaining till spring. At migration time, specimens are occasion-

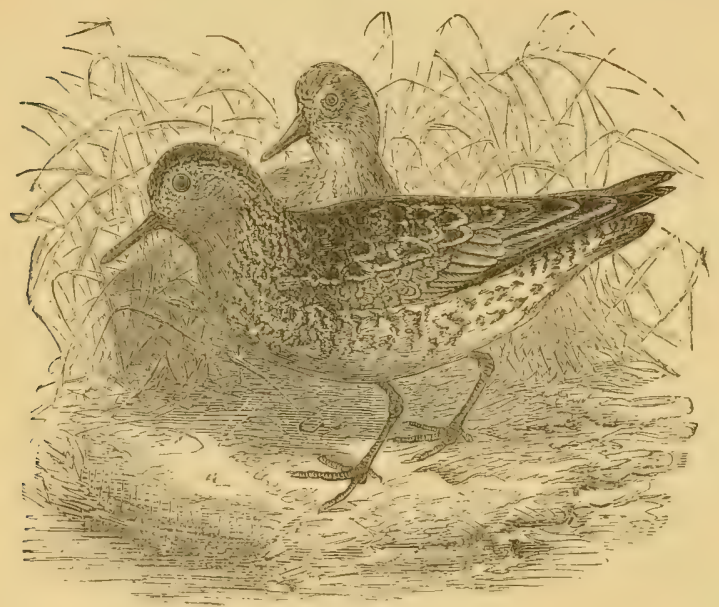

KNOTS, in summer, I/4.

ally met with inland.

Of the "Red Sandpiper," which seems to be this bird in summer plumage, Mr. Parsons makes frequent mention (22). He speaks of meeting with them on and near the shore during winter, though his notes do not give any indication of the dates of their arrival and depar. ture, except that he often met with them during August. On June 6th, I839, he saw "one in perfect winter dress, but the new stumps just appearing." $\mathrm{He}$ occasionally met with them in open fields a little way inland, sitting in a very dense flock. Pennant, who also calls it the "Red Sandpiper," says (ii. 394): "Birds of this species have appeared in great flocks on the coast of: Essex, on the estate of Col. Schutz." Mr. Bond (23.40) met with it commonly at Southend early in Sept., I842. Mr. Clarke speaks of it (24) as " now and then a straggler " to the Walden district, while around Sudbury, King described it (20) in 1838 , as "not uncommon." Round Harwich it is very common during the period of autumn migration, but is never seen there on the return journey in spring (Kerry). Mr. Hope observes that they are very common in vast flocks on our coasts during the winter, generally arriving about Sept. 2 th, and guing north in May. Newman records (23.3116) a pure white specimen shot at Maldon on Feb. I3th, I85I. It is now in the collection of Mr. F. Bond (37. iii. 4I8). The largest bag of these birds I ever heard of was made by Mr. John Basham, jun., of Maldon, who informs me that, some 20 or 30 years ago, he and another gunner fired jointly at a flock resting on the mud-flats near Bradwell Chapel, and his companion's gun missing fire, he bagged to his own gun no less than nine dozen, which they sold at 4 s. per.dozen, sharing the proceeds. 


\section{Ruff: Machetes pugnax (Female, Reeve).}

Not uncommon on our coast as a passing migrant in spring and autumn. Doubtless it once bred commonly in Essex, but I am not aware of more than one actual record of its having done so.

In the Parsons Collection are two Reeves shot out of a small party in the Lower Fleet, New England, on May I7th, I833; also a young Ruff in autumn plumage, shot on Ringwood Saltings, Foulness Island, on Sept. 27 th, $\mathrm{I}_{3} 8$. Parsons seems to have met with it commonly in summer in his time, as he writes (13. ii. r99): "The variety [of plumage] in summer is almost infinite * * The beginning of May will be found the best time for getting the males in perfection." Mr.'J. F. T. Wiseman informs me that he shot a pair by a double shot on the Little Wakering Marshes in I872. One was shot on some marshes in South Essex in Sept,. I887. Round Harwich, "a few are usually seen in the autumn." A Reeve was shot out of a flock of seven on the Ramsey Marshes on June I6th, I888,* and two were seen and one shot in I889 (Kerry). Mr. Hope has a male shot on Colne Beach in the spring of $\mathrm{IS74}$, and another shot on Rainham Marshes on Aug. I7th, 1888. A young Reeve was shot on Nov.6th, 1888, near Paglesham (Wiseman).

The Rev. J. C. Atkinson, in reply to my enquiry whether he ever in his early days heard of the breeding of this bird in Essex, writes:

"Yes, I did hear of the Ruff breeding on the Tollesbury Marshes, and not far from the land end of Shingle Hill. But I did not know it of my orrn knowledge. My reminiscence is that it had been known to breed there on divers occasions. You see I have two sets of recollections, so to speak, my own and my father's." This must have been more than sixty years ago.

Sanderling: Calidris arizaria. Locally, "Curwillet" and "Towilly."

A not uncommon spring and autumn migrant, and to some extent also a winter visitor.

Mr. Parsons has various notes on this species (22). On May 23 rd, I837, he shot one of a pair, and saw a party of six on Foulness Ridge, and on the following day another in fine summer plumage. Mr. Bond met with a few at Southend early in Sept., ' 1842 (23. 40). In I85 I, Lindsey wrote $(2 \%$. App. 53): it "is tolerably common

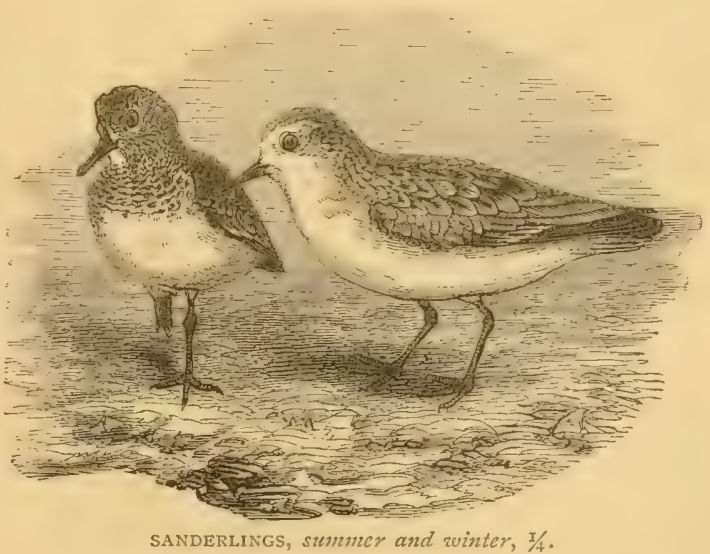

* It is difficult to account for a flock of Reeves being about at this date, but there can be no doubt about the bird, which has been submitted to Mr. J. H. Gurney, jun. 
on our sea-shore [at Harwich], where it is sometimes found at the edge of the water. *** Specimens have been obtained on our coast in the months of January, April, June, at the end of August and in October." Round Harwich, it is now common, especially during the period of spring migration (Kerry).

[Buff-breasted Sandpiper: Tringa rufescens.

A rare straggler to Britain from North America. There seems to be no actual record of it in Essex, though the species comes very near to deserving admission to our county list, as the first British specimen of this American species was shot early in September, I826, near Melbourne, Cambridgeshire, in company with some Dotterel. It was skinned by Mr. Baker, of Melbourne, from whom it was purchased by John Sims for Mr. Yarrell (Trans. Linn. Soc., xvi. p. Iog). Fifteen specimens have since occurred in Britain. As Melbourne is the adjoining parish to Heydon (Essex), this species certainly deserves mention here.]

Common Sandpiper: Tringoides hypolencus. Locally, "Summer Snipe."

Not uncommon as a passing migrant in spring and autumn, when on its way to and from its breeding-grounds further to the north and

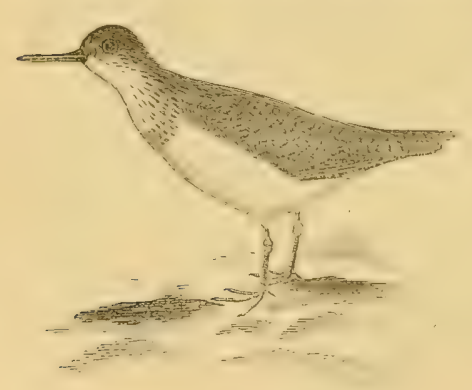

COMMON SANDPIHER, T/5.

west. I am not aware of its. having ever bred in Essex, and Yarrell says (37. iii. 447) that "along the east coast, from Essex to Lincolnshire inclusive, it is only known as a visitor on migration, and has not been known to breed," though in Yorkshire it breeds in many localities. *

Mr. Clarke says (24) that it used to be "not uncommon" round Saffron Walden. He mentions two shot at Wenden on May 3 rd, I837, when they may have been breeding. Several, he says, were killed in the previous February and two at "the Roos" in I840. Lindsey, writing of Harwich in I85I, says (27. App. 50) that it "visits us in the summer, appearing in April, and leaving us again by the end of September." He adds that it "is very generally known by the name of the Summer Snipe." At Harwich, Mr. Kerry says it is now "common in August. These are the first Waders that return to us after breeding." Chas. E. Smith records (3I. 52) shooting one "last spring"

* Of the Spotted Sandpiper (Tringoides macularius), an American species, of doubtful occur-

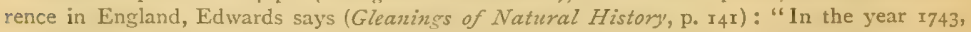
one of them was sent to me by my late worthy friend Sir Robert Abdy, Bart, who shot it near his seat of Albins in Essex. This, on inspection, I found to be a hen, and it differed in no respect from the American Tringa, but in being without spots on its under side, except on the throat, where it had a few small longish dusky spots down the shafts of the feathers. By my remarks on the drawing of the hen bird, I find that it was sent to me in the month of May, and I believe it to be a bird of passage, and very rarely seen in England." Of this specimen he gives a figure (Pl. 277). Lewin (4. vi. 20) and Harting (38. 139) both accept this record, but it seems now to be agreed ( 37 ; and Seebohm's Brit. Birds, iii. I23) that, although Edwards figured a genuine specimen from America, the specimen from Essex was of the common species. Chas. E. Smith erroneously records (3I. 53) that another was "shot by a farmer by a small stream [in] 1858," near Coggeshall. 
[1858], and another in the following year, on the Blackwater. King describes it (20) as "not uncommon" round Sudbury, and Mr. Grubb also mentions it (39) as occurring on his ground there. Mr. Buxton says (47.96) it is "occasionally seen in spring and autumn by Leytonstone Pond, [by] the waters in Wanstead Park, and by the Roding. I sav one last year [? I884] by Baldwin's Hili Pond." Round Orsett, it is uncommon (Sackett). Mr. Hope writes that it is common in all the marsh ditches on the coast during migration, but he has never known it nest there.

\section{Green Sandpiper: Helodromas ochropus. Locally, "Will} White" (E. A. F.) and "Black Snipe."

This mysterious bird has been met with in Essex in every month in the year, except perhaps January, February, and March, as the following records will show; yet its eggs are not known ever to have been taken in Britain. With us, it is most often seen in July and August, though it is not uncommon in May and September, at which times it may be regarded as a passing migrant to or from unknown breedingr-grounds further north, a supposition favoured by its comparative rarity during June and the winter months. When on migration it may often be met with inland, on the edges of ponds, \&c.

Henry Doubleday, writing from Epping on Aug. 24th, I832, says (I0):-

"I have met with no ornithological rarities, except ** a very fine specimen of the Green Sandpiper, which I shot here about two weeks since without spoiling a feather, and it has made a very nice bird. It is very rare here, and only now and then met with in the months of July, August, and September. I cannot view it in the light of a winter visitant, as I never saw or heard of one at that season. $* * *$ I should think it is a summer visitor, like the Common Sandpiper, though a much rarer one."

In Sept., I835, he says (I0): "We have had several Green Sandpipers here this autumn. I shot four at one pond." Again on Sept. 8 th, I840, he says (IO): "I shot a couple of Green Sandpipers about a week since, and saw a third, but it was very shy." On Aug. 6th, I84r, he says (IO): "I have noticed one or two Green Sandpipers at our ponds for the last two or three weeks." On Aug. I8th, I842, he says (10) :-

"There are a great many Green Sandpipers at the ponds here-far more than usual. I have noticed them for a month past. I cannot think when and where they breed, as these seem all old birds, and I never yet shot a young one here, though I daresay at different times I have killed a score. They are here in July, and remain till November, and I sometimes see them in May."

Yarrell says (25. ii. 559) Doubleday informed him that he shot one near Epping on Nov, 2nd, I840, though he had never before observed one there so late in the year. As it was only slightly wounded, he kept it alive, and it soon became very tame, running rapidly about the room and feeding readily upon small worms. Edward Doubleday, of Epping, in 1835 , says ( 15 ) it "occurs here in May, July (the first week), August, and September." Elsewhere he writes (I2. vi. I49): "Is the Green Sandpiper a resident in Britain or only a periodical visitant? With us it is only found in: July, August, September, and, I believe, October." Mr. Buxton says (47.96) that to the Epping Forest district it is an "occasional visitor in spring and autumn. One was shot in Mr. Barclay's grounds Knott's Green. Two otleers, shot near Epping, and presented by Hy. Doubleday; 
are preserved in the British Museum." Mr. Clarke mentions (24) one at Chesterford in 1833 , and two at Wenden in 1835 . Around Sudbury, King says (20) that in 1838 it was "not uncommon." Mr. W. L. Barclay, of Leyton, wrote (23. 7939) in 1862 , ?that specimens were observed there "almost every year." $M I r . W$. Jesse records (34.9I5) that on Aug. ISth, I867, one appeared round a pond on the lawn at Maisonette, Ingatestone. Dr. Bree, in recording the occurrence of a female specimen near Colchester, about the middle of April, IS74 (29. May 2) stated his belief that it bred in Essex. At Harwich " a few are seen every autumn" (Kerry). Mr. Hope generally meets with them in the marsh ditches from the middle of August until November, but seldom later. He adds: "I have known them fly aboard the dredgers at sea in August, and be knocked over by a stone. It is locally known as the "Black Snipe.'" Mr. Parsons has many notes of meeting with it on New England Island, the Tilbury Marshes, and elsewhere, sometimes singly, but more often in pairs or small parties, and in one case (July 23, I839) in a flock of ten on New England. He notes seeing a pair at Tilbury on April 2 Ist, I842, but most of the occurrences are in July and August, though there are some noted as late as November or December. They appear usually to have arrived during the first two or three days of July, though in 1838 he saw two on New England on June 27 th, and in $18+2$ one at Tilbury on June I7th (22). Writing in I834, he said (13. ii. I99) he had never seen this species except in the autumnal months. In I888, Mr. Fitch constantly observed a pair about the ditches on Northey Island, from May until the middle of July, but could obtain no evidence whatever of their having nested in the vicinity,

\section{Wood-Sandpiper : Totamus glareola.}

A rare and irregular visitor to Britain, chiefly as a passing migrant in spring and autumn. It has been known to breed in Scotland, Norfolk, and Northumberland, and two of the following records seem to suggest its having bred in Essex.

On July 24th, I837, Mr. Parsons shot a young male of the year at the Lower Fleet, on New England Island, supposing it to be a Green Sandpiper (22). From the date one cannot help surmising that it may have been bred there. Henry Doubleday, writing from Epping on May Ioth, IS,o, mentions (IO) that on the previous Monday,

"a fellow celebrated for poaching brought me a Wood Sandpiper ( $T$. glareola) which he shot at a pond on our common. It was a female, and the eggs very much enlarged. He says there were two of them, probably a pair. The one he brought is in full summer plumage."

Yarrell, who says (14. ii. 535) that it has been killed in Essex in the spring, mentions hearing of the above occurrence from Duubleday. Dr. Bree notes ( $(\hat{2} a)$ a fine specimen shot at Nayland-on-the-Stour, and sent to Ambrose to stuff in Dec., 1869. One was observed at the mouth of the Stour on Aug. I6th, I884 (42).

\section{Redshank: Totanus calidris. Locally, "Teuke," or "Pool Snipe."}

An abundant resident on our coast, where it may be seen during the winter in large flocks, increased by immigrants from elsewhere. It breeds in all suitable situations among the marshes and saltings on our coast, and as far up the Thames as Dagenham and Stan- 
ford-le-Hope (where a friend saw birds which were evidently breeding in MIay, I8S8), though I believe at no inland localities in this county.

Sheppard and Whitear state $(9.45)$ that "this species is found solitary, and also in flocks, on the ooze of the River Stour." Lindsey, who, writing from Harwich in I851, speaks of it as the "Pool Snipe," says (27. App. 50) that it "is resident with us for more than half the year." Round Harwich it is still very common and breeds in large numbers (Kerry). Mr. W. H. Hill, of Southminster, in 1835 , says ( 12. viii. 573 ): "On this coast, on the immense flat oozy banks which lie at the mouth of the Thames, this bird is to be found in flocks of from ten to thirty or forty individuals, which are there called by the name of 'teuks." " The Rev. J. C. Atkinson writes (36. I23) :-this was

" one of the most familiar of all our birds to me in my youth. Many long days have I spent amid their haunts on the Essex Saltings. * * * When the young are newly hatched the parent birds betray excessive jealousy and anxiety at the approach of either man or dog to their resort. They have sometimes come and settled on the ground within two or three paces of me and at others flown so directly towards me as to suggest the possible intention of attacking me. piping most plaintively and incessantly the while. This conduct is designated by the term 'mobbing,' on the Essex Marshes."

In I865, Lieut Legge says (34. 9I) they were very numerous round Shoebury from the beginning of September onwards, frequenting the salt-water creeks round Foulness Island, on the 'muddy banks of which they fed during low tide. $\mathrm{He}$ adds that a good many were to be seen about during the whole-summer, as they bred in a marsh on Canvey Island and elsewhere. Writing from Shoeburyness in I866, he says (16is, N. S. ii. 420): "In the low pasture grounds of the south-eastern portion of this county, frequented by Vanellus cristatus for breeding purposes, Totanus calidris is to be found nesting in about equal numbers. This year I found upwards of a score of nests in a low pasture of a few acres in extent." Mr. A. J. Crosfield informs me that when on the edge of Dagenham Lake on May 23 rd, I879, two pairs, which evidently had young, kept dashing about overhead. They leave their breeding-grounds on the marshes round Orsett and retire inland about the beginning of August, returning about the middle of March (Sackett). Mr. Hope observes that it breeds in such large numbers in the marshes along the coast that he has often found eight or ten nests in as many minutes in the grass shut up for hay. On May 2Ist, I882, Mr. C. Beckwith, landlord of The Sluice Inn on Canvey Island, who is a good observer, fuund five Redshanks' eggs in one nest (Bird). On the Old Hall Marshes, Tollesbury, on June I2th, I888, Mr. Fitch and myself found a nest containing two eggs - the beginning, doubtless, of a second brood. Within a couple of yards was a Lark's nest containing three eggs. Mr. G. W. Brewis, of Chesterford Park, has a young bird shot by himself beside the ornamental water close to his house in Oct., I887. Mr. Robert Page informs me that considerable numbers have occasionally been taken in his Marsh House Decoy.

\section{Spotted Redshank: Totanus fuscus.}

Of this passing visitor, which occurs in Britain chiefly during migration, I only know of the occurrence in Essex of five or six examples, though it is probably not very rare.

Henry Doubleday says (10) that in 1832 he saw one in a Collection at Colchester, obtained on the adjacent coast. Mr. Ambrose has received specimens 
from Brightlingsea, where Dr. Bree says (32a) one was shot on the marshes in the autumn of I863. Mr. Kerry has informed me of two which he has observed near Harwich, one in Landermere Creek, in September, I888, the other several years since on the Essex side of the River Stour. At the Marsh House, Tillingham, Mr. Robert Page has a specimen taken in his decoy there. Mr. Page tells me that others have been taken there. Dr. Bree says that the only one he ever saw in his neighbourhood was shot on the St. Osyth Marshes late in Aug., I863 (29. Sept. 5). Mr. Kerry saw three on Handford Water in I889, and shot a female in Suffolk on Sept. 4th (40. xiii. 454). About the middle of October, I889, Dr. Salter shot at Tollesbury a fine specimen which was preserved by Mr. Pettitt.

\section{Greenshank : Totanus canescens.}

A somewhat uncommon passing migrant in spring and autumn.

Albin figures a specimen which he says (3. ii, 63) "was shot by Sir Robert Abdy on the sandy bank of a river in Essex, and was not much used to the sight of men, it letting him come within ten yards of it before he fired at it." In the Saffron Walden Museum is a specimen from Epping, presented, nearly fifty years ago, by Henry Doubleday, who says (IO) that in 1832 he saw one in a Collection at Colchester, obtained on the adjacent coast, and that he observed two at Walton in the same year. The Rev. J. C. Atkinson writes ( 36. 125): "I used to meet with it occasionally in the early autumn on the Essex Saltings, and remember thinking I had got a prize the first time I shot one, and noticed its slightly upturned bill." One was "shot on the Mundon Marshes [in] I857" (Smith-31. 53). Mr. A. H. Smee shot an adult at Leigh, on Sept. I8th, I869 (34. I92I), and saw two more there on Sept. I7, I870 (34.2395). I shot a fine male (?) at Stony Point, Walton, on Sept. 7th, I888. Round Harwich " some are seen and shot every autumn. It was fairly common in the autumn of 1889 . They usually go in small parties of three to five" (Kerry). In the Shooting Times (Oct. 6th, I888) two Essex specimens are mentioned, one shot during the previous Aug., the other at Stanford-le-Hope in the following month. Mr. J. F. T. Wiseman of Paglesham writes: "They visit us nearly every year. My son shot three at one shot last season." Dr. Bree says (32a): "Two young birds were shot at-Fingringhoe, Sept. 9 th, I867, and sent to me by Mr. Symmons. They were ne stlings of the year, showing that the old ones bred most probably in the neighbouring marshes." I hardly think this probable, however.

\section{Red-breasted Snipe: Macrorhamphus griseus.}

A rare straggler to Britain from North America, where it is common. There is no absolutely conclusive evidence of its having ever occurred in Essex, but the following note seems to justify its appearance here.

Mr. Hope writes: "I saw a bird on the opposite side of Harwich Harbour on April I5th, I982, which I feel certain was a Red-breasted Snipe. I walked within five yards of it, and it then flew away. The bill looked slightly curved, which made me think it was a Curlew Sandpiper at first."

Black-tailed Godwit: Limosa regocephala.

A visitor to our coast when on migration in spring and autumn. It formerly bred with us, but has long ceased to do so. 
Mr. Bond found it common round Southend (23.39) early in Sept., I842 A fewismall flocks were seen round Leigh in Jan., I87 I. It is only seen on the mudflats there during hard weather or at the time of the autumn migration, and is never very numerous (Smee-34.2605). Mr. Ambrose says he has received it from Mersea. In the Parsons Collection are specimens shot on New England in Aug., I834, and on May 23rd, I836. On April 23rd, I868, Mr. Harting met with a party of eight on the ooze at Canvey Island and shot three in fine spring plumage after a long and difficult stalk. The Rev. M. C. H. Bird shot one on Canvey Island on Sept. gth, I880, and saw a pair there on Aug. 29th, I882. Mr. Hope remarks that it is getting very scarce now on our coast.

Bar-tailed Godwit: Limosa lifponica. Locally, "Prine," "Preen," or "Prean."

A fairly-common visitor to our coast, chiefly when on migration in spring and autumn.

The Parsons Collection contains a specimen shot on New England, in 1829 , and another shot on Shoebury shore in I836. Parsons has many notes on this species (22), which was evidently common on migration. $\mathrm{He}$ does not often refer to them in spring, but frequently in autumn. They seem to have arrived early in August: for instance, on

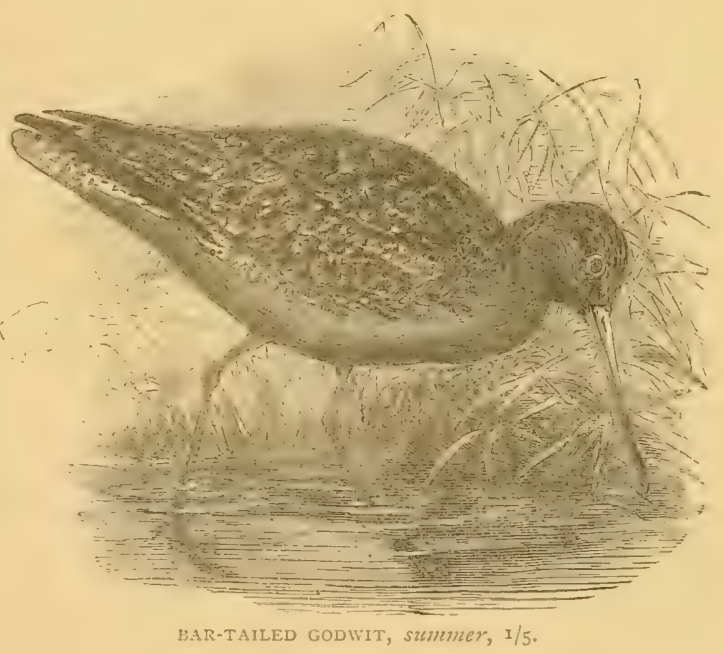
August 5 th, 1834 , he shot two, and on August I5th, IS 30 , several. On Oct. $22 n d$, I 835 , he writes :

" [I was] on the shore all tide-time to-day, and did not see one. I have before remarked that they frequent our shore a short time when they first come in the autumn, and about this time leave again, and do not return in any quantity unless we have hard weather, and then we sometimes have great quantities. A month ago, there were a good many on the shore."

Thus, in Jan., 1838 , during hard weather, he notes a great many about. At Harwich it is "very common some seasons" (Kerry). In I858, Mr. Stacey preserved one shot at Great Canfield. A specimen from Oakley in I86I is in the Bree Collection. Mr. Fitch writes: "Our Maldon gunners confirm Mr. Abel Chapman's statement (Bird-Life of the Borders, p. 245) that 'this is one of the most abundant of our winter wild-forwl.' Contrary to the opinion of many modern writers, it remains throughout the winter like the Knot." 
Curlew: Numenius arquata. Locally, "Whitterick" and "Old Harry" (E. A. F.).

A very common bird on the mud-banks and saltings on the Essex coast from about the middle of July to the end of May, but it

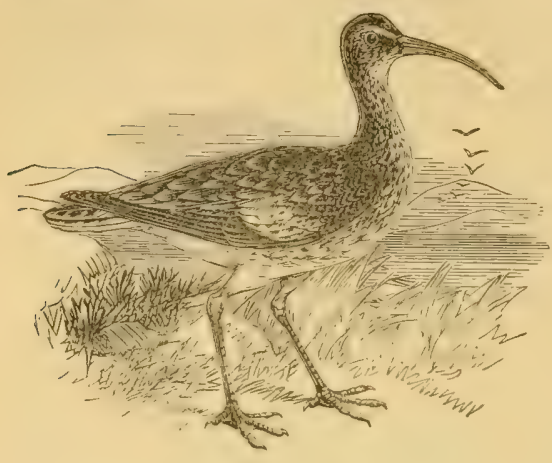

CURLEW, I/I2. does not breed anywhere in this part of England, and the only occasions when they are to be seen inland in this county are during the periods of spring and autumn migration, when small parties may sometimes be observed flying over, and their loud whistling notes may often be heard at night, especially when the birds are confused by the gas-lights of a town. Some (perhaps wounded birds) undoubtedly remain on the coast all the year round.

Sheppard and Whitear state $(9.42)$ that they are "to be met with at all times of the year between Ipswich and Harwich; but their nests have hitherto not been found in those parts." Round Orsett, too, "a few seem to stay on the flats all the year round" (Sackett). Lindsey, in I85 I, says (27. App. 49) that it is "a common bird on our coast, where it obtains a living from the middle of autumn, through the winter, until the pairing season of the following spring." Lieut. Legge, writing from Shoebury in November 1865, says (34. 92) "Great numbers of Curlews feed on the flats in company with Godwits, Dulins and Sea-gulls. *** I have never seen them so plentiful anywhere in England as they are here." As regards its occurrence inland, Mr. Grubb says (39): "We hear the distant cry of this bird" at Sudbury. Mr. Buxton says (47.97) it has been "seen several times [in the Forest] and killed at Copped Hall." Mr. R. W. Christy saw a small party here in March, 1879, and another of four about the middle of August, I888. On the evening of May I6th, I880, I saw a pair fly over here in a N.E. direction. About the middle of Jan. following, Mr. Travis received one shot at Littlebury. Their movements on the Essex coast are shown by the following observations of Mr. Parsons :- I826, Apr. 2 Ist, "a good many on the sands." I 836 , Apr. IIth, "not yet all gone ;" I6th, "a good many about Canvey Island." 1837, May 23rd, "A great many up the Ray ;" June 6th, "not one to be seen there." I840, May 30th, "a great many up the Ray." Regarding their return in the autumn he notes: 1833 , July I8, "they are arriving on the shore." I835, July 2 I, "a great many on the sands ;" July 3 Ist, " a great many on the shore now." I 836 , July I, "a flock of as many as twenty on the sands;" I 8 th, a good many about the sands" (22).

Among extraordinary shots made in Essex may be mentioned one made some thirty or forty years ago by a gunner named Frank Hope, of MaIdon, who killed 
no less than seventy-five of these very wary birds at once, as I am informed by Mr. Fitch.

Whimbrel : Numenius phacopus. Locally, "Titterel," "Maybird," or "Jack-Curlew" (Orsett).

Common on the coast as a passing migrant in spring and autumn, when on its way to or from its northern breeding-stations. They are often seen until the end of May, and re-appear soon after the middle of July. It is occasionally seen inland:

Sheppard and Whitear say (9. 42), "these birds arrive on the coasts of Essex and Suffolk early in May, and migrate again in the latter part of the autumn." In r880, Mr. Travis received a specimen found in a field near Newport with one wing off, it having flown against

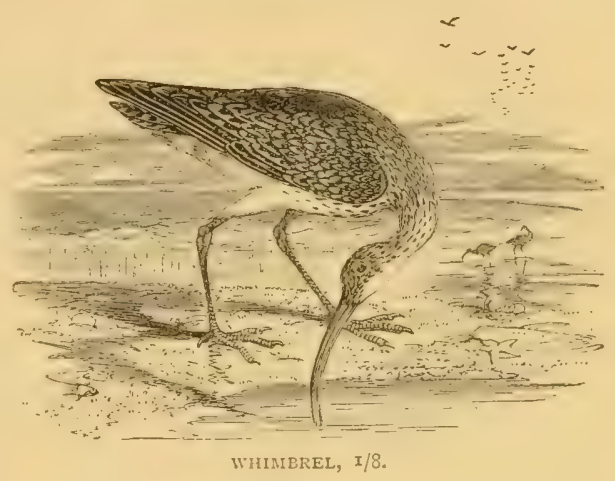
the telegraph-wires. Edward Doubleday wrote in 1835 (I5) that it had been killed at Sewardstone. The Rer. J. C. Atkinson writes (36. I22): "It is seen, in no great numbers, on many of our coasts in winter; but I have met with it on the Essex Saltings only in the early spring and previous to its retirement to the north to breed."

Parsons has many observations on their appearance in his neighbourhood on migration. In spring he has many notes of them between the end of April and the 23 rd or 24 th of May: for instance, 1836 , May 16 , "a very large flock of forty or fifty about the lower marshes, New England." I837, May 23rd, "saw some up the Ray." I838, May 23rd, "many about ; " 29th, "saw only one to-day." They seem usually to re-appear in the autumn about or soon after the middle of July, though in 1834 , he "saw some on the sands" on June 28 th. In I 843 , he says that a few had arrived on July I4th, and a great many on the $24^{\text {th }}$ (22). 


\section{Order GAVI Æ.}

\section{Family LARID $Æ$.}

Arctic Tern: Sterna macrura. Locally, "Sea Swallow." An uncommon passing migrant in spring and autumn.

Mr. Baxter has a pair shot by himself in I880, one near Tilbury, the other off the Nore Sands. Mr. Kerry shot an immature specimen at Stony Point, in Sept., 1889, and Mr. A. H. Smee shot a young male in the Lower Hope on Oct 3 rd, I867 (34. I0I7).

Common Tern: Sterna fuviatilis. Locally, "Sea Swallow."

An uncommon summer visitor, which used to breed on our coast, but does not now do so.

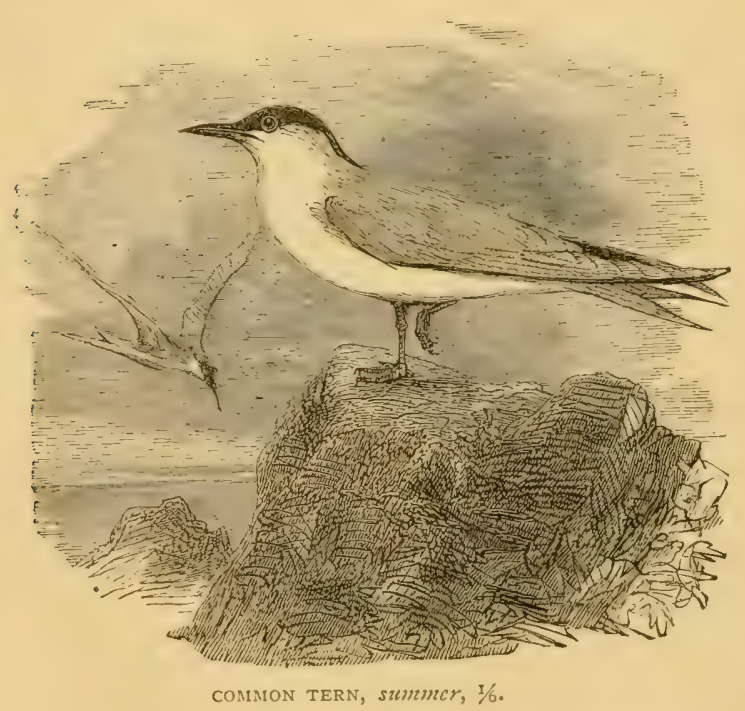

Mr. Clarke records (24) one at Haverhill in I830. Edward Doubleday, in I 835 , says (I5) that a specimen had been killed whilst "flying over some large gravel pits [near Epping] which were full of water." King, in I838, says (20): "These elegant birds are not unfrequently seen during summer, flitting over the bed of our river and following its windings." On Aug. 2 Ist, I883, a

young bird of the year was found in a very exhausted condition in a ditch at Farnham, having probably been driven inland by a gale (T. J. Mann-29. Sept., I5). At Harwich, it is "not common" (Kerry). Mr. Jonathan Grubb wrote (23. $755 \mathrm{I}):-$

"On November 5 th [1860], I saw some Terns (the species not known) flying 
over the water near Languard Fort. It would appear that these birds do not (all at least) leave this coast in the winter. I remember being the companion of Henry Doubleday when he shot some near Walton-on-the-Naze, in December, many years ago."

Dr. Laver describes it as common in the Colchester and Paglesham districts, though he never knew it to breed in either. The Rev. J.C. Atkinson writes me that in his boyhood, some sixty years ago, it nested not uncommonly on the Wigborough and Peldon Saltings. He has found its nest on Shingle Hill, and has seen it on the Goldhanger Marshes, and elsewhere, in later years, during the breeding season.

\section{Roseate Tern : Sterna dongalli.}

An uncommon summer visitor to Britain. Its breeding-distribution is very local. I only know of a single record of its occurrence in the county, though it has doubtless been overlooked on other occasions.

Mr. Owen Boyle saw one at Languard Point, at 4.45 a.m., on June Ist, I 883 (42. v.).

Little Tern : Stema minuta. Locally, "Little Sea Swallow."

A summer migrant which used to breed commonly on the Essex coast, though I only know of a single breeding colony at the present time.

One was shot at Maldon in or about 1838 . (C. Walford-I9. 47). Mr. Clarke speaks of it (24) as "common on the Essex coast" about I 845 . Mr. Bond met with it commonly at Southend early in Sept., IS+2 (23. 39). Mr. A. H. Smee (34. I92I) shot an adult and three immature birds at Leigh on Sept. I8th, I869. Mr. Kerry says (40. i. 52) that in

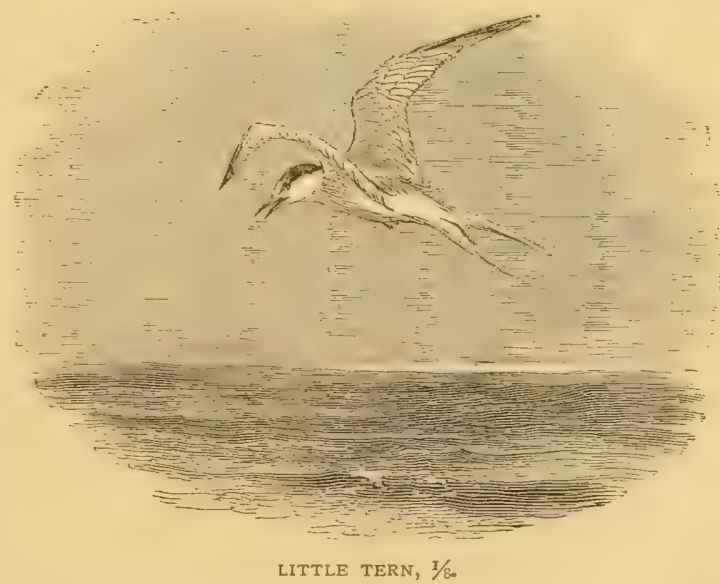
I876 a considerable number bred on Languard Fort Common, and at Harwich he describes it as "very common." He adds that

"it breeds every summer in great numbers among the shingle on the sea-shore between Harwich and Walton-on-the-Naze. They now chiefly nest on the Harwich side of the Handford Water, probably on account of the persecution to which they are subjected by the visitors from Walton, who kill a great many during the nesting season, notwithstanding the provisions of the Wild Birds Protection Act." 
Mr. Fitch has ascertained that many years ago it nested on the eastern point of Osey Island, where there is a very large shingle-bank, but the colony was destroyed by the Maldon winkle-boys who took their eggs. A specimen was, however, shot at Mundon about June Ist, I888, when it seems probable that it was breeding somewhere in the neighbourhood. Yarrell (37. iii. 559) says "it breeds on the shores of Essex, Suffolk and Norfolk," and Mr. Seebohm also (45. iii. 289) mentions scattered breeding-colonies on the Norfolk, Suffolk and Essex coasts, but these are now, for the most part, things of the past. It does not now breed in the Paglesham district (Wiseman). A specimen in summer plumage, labelled "Brightlingsea, I863," is in Dr. Bree's Collection. Mr. Smoothy observed one at Danbury on April IIth, I880. Mr. F. Ball winged one of these birds at Southend in August, 1879, and kept it through the winter till the following May. $\mathrm{He}$ writes: "It is quite tame, and comes at the call like a cat or dog" (29. May 22. I880).

\section{Sandwich Tern : Sterna cantiaca.}

A regular, though uncommon, summer visitor to Britain, breeding in a few localities. It used to breed on the Essex coast, but does so, I believe, no longer.

Sheppard and Whitear write $(9.5 \mathrm{I})$ :

"On the 5th of May, I820, we shot two of these birds at Walton, in Essex. They had made their appearance only two days previously. *** On the 24 th of April last [1823?], we saw two of these birds swimming in the Stour, one of which we shot.'

Mr. Bond met with it commonly at Southend early in Sept., I842 (23. 39). Albin, who calls it the "Great Sea Swallow," figures a specimen of which he says (3. ii. SI) : "I had [it] from my honourable and good friend Sir Robert Abdy, out of Essex." At Harwich, Mr. Kerry says it is rare, but he mentions one (40.52) shot on the Pye Sand on Sept. I2th, I876. It is not rare on the coast in either the Colchester or Paglesham districts (Laver), but it does not breed in the latter (Wiseman). Dr. Bree (32a) notes one shot at Mersea in Sept., 1870. Parsons, in I834, says (I3. ii. 20I) "I have had the pleasure of bringing home the beautiful eggs of this fine bird from some salterns at the mouth of the River Blackwater in this county, and also from the Fern Islands." It certainly does not now breed there, although both Yarrell (37. iii. 54I) and Morris (27a. vi. 89) state that it breeds "in Essex, at the mouth of the Blackwater," doubtless referring to the above record. More says (3. 452) that in 1865 it bred "in Essex, and probably also in North Kent, at the mouth of the Thames (Mr. F. Bond)," but I have no information as to the exact locality. Seebohm states (45. iii. 272 ) that it no longer breeds on the Essex coast. Mr. Hope, however, informs me that one pair or more used, until the last year or two, to breed annually on Colne Beach. I believe it does not do so now, though Mr. Hope tells me one was seen in Harwich Harbour at the end of April, I889.

\section{Sooty Tern: Sterna fuliginosa.}

An exceedingly rare straggler to Britain, only one or two specimens having been met with.

Dr. Bree records (29. Apr. 23) that, in the winter of $1880-8 \mathrm{I}$, one was killed near Colchester and preserved by Ambrose. The specimen is, however, now entirely lost sight of. 


\section{Scopoli's Sooty Tern: Sterna ancestheta.}

\section{A very rare straggler.}

The first and only specimen met with in Britain was obtained in Sept., 1875, on one of the lightships at the Nore, and may, therefore, fairly be claimed as an Essex bird. All that is known about the specimen is given by Mr. Howard Saunders, who recorded it in the Zoologist (40. i. 2I3). Although the circumstances connected with its capture are not very conclusive, Mr. Saunders says that "there does not seem to be the slightest ground for doubting that the specimen in question really was obtained somewhere at the mouth of the Thames." It seems that the bird was brought in the flesh to a naturalist named Barton, residing near the West India Docks, by one of the Trinity House men, who had just returned from duty on board the lightship, but who has since been lost sight of. The bird is adult.

\section{Black Tern : Hydrochelidon nigra.}

Now only an uncommon passing migrant in spring and autumn, though formerly a resident, breeding in the county. It appears probable from the following evidence that it bred in Essex up to about fifty years ago, but drainage and cultivation have now quite banished it, though specimens still occur quite unaccountably with us, even during the breeding season.

In the Walden Museum there used

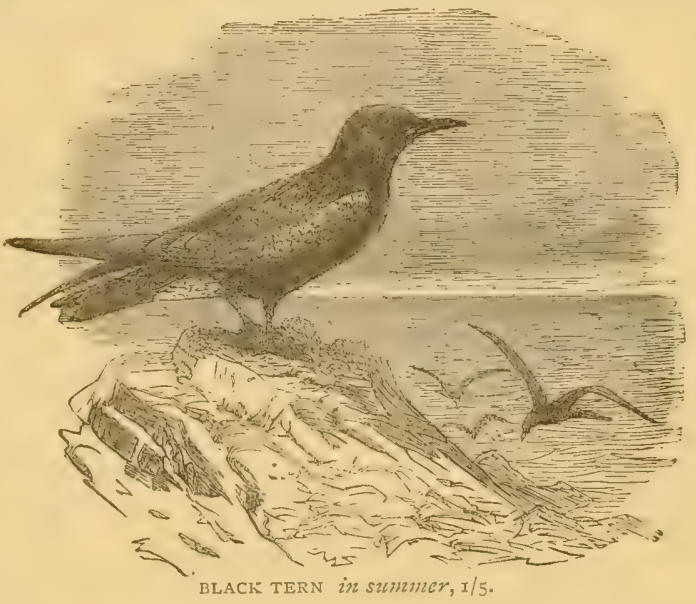
formerly to be a specimen in summer plumage, shot at Widdington on May $3 \mathrm{rd}$, I 853 (24). Mr. Clarke mentions (24) one shot at Audley End (and in the Collection there) on May 24 th, I $8_{3} 6$, when it seems likely that it was breeding near. It had a very black head and neck, with the body, wings and tail of a dark slatecolour. Another was shot at Newport about 1854. One, in black and white immature plumage, was shot on the Essex coast early in Sept., I879 (Bree 29. Sept. 20). King, in 1838 , wrote (20) of this species and the Common Tern :-

"These elegant birds are not unfrequently seen during summer, gracefully flitting over the bed of our river and following its windings. Of S, mgra I have not been able to obtain a single specimen in adult plumage, but have had several of the young birds brought me."

One, in the British Museum, was shot on the Thames. At Harwich, "some are seen every year" (Kerry). Mr. Hope informs me that in August, I888, he obtained a young bird only just able to fly, near Harwich. On August I2th, I88I, six were shot on Canvey lsland, and five more were seen there on May Igth, 
I $8 S_{2}$ (Bird). A specimen in summer plumage, labelled "Brightlingsea, I $86_{3}$," is in the Collection of the late Dr. Bree. Sir T. Fowell Buxton records (50. ii. $27 \mathrm{I}$ ) that on July I8th, I888, he watched for some time an individual which he believes to have been immature, flying over his pond at Warlies, Waltham Abbey, and that two had been seen there for two or three days previously. Mr. Smoothy has one shot at Danbury in May, I886, and Mr. Pettitt another (an immature bird) shot by his brother at Paglesham on Aug. 29th, I889.

Kittiwake : Rissa tridactyla.

A fairly-abundant winter visitor to the coast, and often driven inland by severe gales.

Edward Doubleday says ( ${ }_{5} 5$ ) it has been met with at Epping "in a very exhausted state after long stormy weather." At Harwich, "some are seen every year" (Kerry).

\section{Glaucous Gull: Larus glaucus.}

An uncommon and irregular winter visitor.

At Harwich, Mr. Kerry says it is "rare," but he shot an immature bird, probably in its second year, in the harbour on Dec. 25 th., I885 (40. xi. 466).

\section{Iceland Gull: Larus leucopterus.}

A rare and irregular winter visitor, of which I have only a single Essex record.

An immature specimen, apparently in its second or third year, was shot on the Colne, near Brightlingsea, early on the morning of Jan. Ist, I 887 (C. A. Marriott-40. xi. 466). The specimen came into the possession of Mr. Kerry, who presented it to Mr. Marriott. That gentleman still has the bird, and he informs me that it was shot by a smacksman named Thomas, who is well acquainted with the Gulls, and at once distinguished this from the rest by its white wings.

Herring Gull : Larus argentatus. Locally, "Great Cob" (mature), and "Grey Cob" (immature).

A common visitor to our coast from autumn to spring, and often

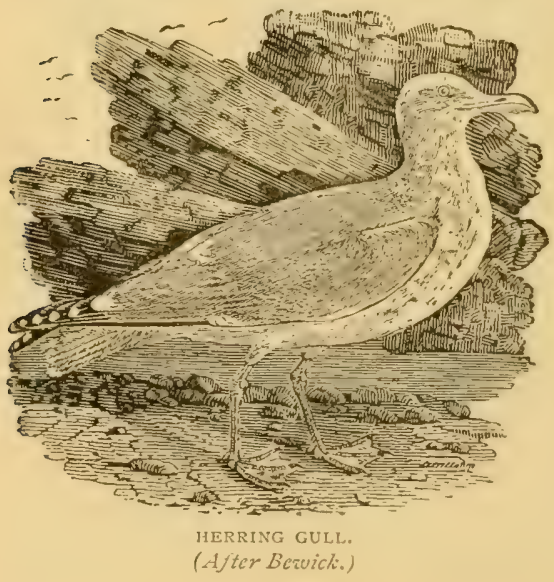

found inland after severe storms.

Dale, writing of Harwich, says (2. 402): "This is very frequent here." It is now not common there, though some are seen every autumn (Kerry) Mr. Bond met with a few at Southend early in Sept., I $\$+2$ (23.40). King, writing at Sudbury in 1838 , says it is (20) :" not an unfrequent visitor to our low meadows in rough winter weather. $* * *$ When taken young, they become comparatively tame. I had one in my possession for some time. $\mathrm{He}$ was a droll fellow, but rather a 
mischievous inmate of my garden." On Dec. 23rd and 25th, 1886, "hundreds of thousands" were seen near the Swin L.V., fishing for sprats (42. viii.) Mr. J. Gurney Barclay has given (23. II38) an interesting account of a tame pair which bred for several successive years in his garden at Walthamstow.

Lesser Black-backed Gull : Larus fuscus. Locally, "Great Cob" and "Saddleback."

A common visitor to our coast from autumn to spring, and sometimes blown inland by severe storms.

Round Sudbury, King describes it (20) as "rather uncommon." Mr. Bond met with a few at Southend early in Sept., I842 (23.40). At Harwich, it is not common, though some are seen every autumn (Kerry). On the Old Hall Marshes, Tollesbury, on June I 2 th, IsSS, Mr. Fitch and myself observed about twenty large Gulls, probably of this species. The keepers who called them "Great Cobs," to distinguish them from the more common Black-headed Gulls, which are invariably known as "Cobs," said they had been blown there by the strong south-easterly breeze, and that they would not remain. It is hard to say whence they could have come at that time of the year, as there is no recorded breeding-place on the East coast south of Northumberland. A curious specimen, shot by Mr. A. C. Marriott, on Dovercourt Beach, on Oct. 3rd, I88I (40. vi. 70), had one leg yellow, the other flesh-coloured.

\section{Common Gull : Larts canus.}

A common winter visitor, and said formerly to have been a resident, breeding on the coast; but it certainly does not do so now, and the correctness of the statement is doubtful.

Edward Doubleday says (Ij) he has met with it at Epping "in a very exhausted state after long stormy weather." Around Sudbury, King says (20) that it is "common during floods." More, in I865, says (33.455): "On the east coast of England, the Rev. J. C. Atkinson assures me that the Common Gull breeds in the Essex Marshes, where it is rare." In making this statement, Mr. More was, almost certainly, in error, though he might have been correct had he said "bred formerly," instead of "breeds;" for Mr. Atkinson writes me that in his boyhood it nested commonly on the Wigborough and Peldon Marshes, or rather Saltings, where he found dozens of nests sixty years ago. Yarrell, too, says (25. iii. 571$)$ :

"Both in Kent and Essex, where those counties bound the estuaries of the Thames, this Gull is to be seen throughout the year on the sandy flats and bars, picking up as food any refuse animal matter the tide may bring. *** Here, as well as on other parts of the coast which are flat, the Common Gull breeds in marshes, or on flat islands, while on other districts, to be hereafter named, it breeds on high rocks."

Morris also says (27a. vi. I72) they are common "in Kent and Essex by the sides of the Thames." It certainly does not now breed with us ; indeed Mr. Howard Saunders has pointed out to me the great improbability of the truth of the statement that this species has ever bred on the Essex coast, or anywhere in the south of England. At the present time, there is no known breeding-station south of the Scottish border. The above statements seem to rest mainly on the authority of the Rev. J. C. Atkinson, though Yarrell appears to assert that the species breeds on the coast from his own observation, and Morris clearly quotes him. With all respect to both Mr. Yarrell and Mr. Atkinson, I cannot help thinking 
that the "Common Gull" they have met with was the Black-headed, which is certainly the common Gull of our coast.

Great Black-backed Gull : Lams marinus. Locally, "Cob" and "Saddleback."

Common on the coast from autumn to spring, and formerly a resi-

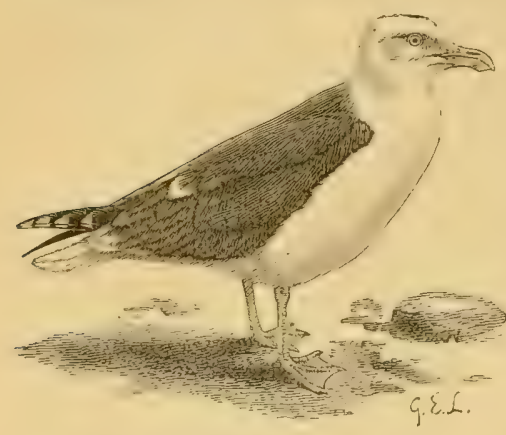
dent, but it breeds with us no longer.

Around Sudbury, King says (20) that it is "not common," $\mathrm{He}$ adds,

"A few years since, a solitary individual remained upon our meadows for a week or two, after a motley flock of Gulls, driven here by stress of weather, had retired. I frequently watched it, and it occasionally allowed me to approach pretty near."

At Harwich, Mr. Kerry says it is common. He adds, "These birds when in immature plumage, stay with us the whole year, and my impression is that they do not breed before they have attained their mature plumage."

It is "not rare round Colchester and Paglesham" (Laver). The Rev. J. C. Atkinson says (36, I65): "It breeds, in some cases, on the marsh or saltingspaces met with so abundantly on some of the southern and eastern shores." Morris says (27a. vi. I86) they are common "in Kent and Essex along the banks of the Thames." The Dictionary of the Thames says they "used formerly to breed in the marshes at the mouth of the Thames." Yarrell says (25. iii. 592), "On the flat shores of Kent and Essex at the mouth of the Thames, where this bird remains all the year, it is called a "Cob." Saunders (37), alluding to Yarrell's statements that it bred at the mouth of the Thames, correctly says "it has long ceased to do so."

\section{Adriatic Gull: Lame melanocephalus.}

This has for some years been regarded as a doubtful British bird, but may now be accepted as a very rare visitor.

Mr. Seebohm says (45. iii. p. 315) :-

"The only evidence for its admission into the British List is that of a specimen purchased for the British Museum from Mr. Whitely, of Woolwich, who stated that it was shot in January, is66, near Barking Cireek. An accidental change of label, either at the British Museum or on Mr. Whitely's part, is the probable explanation."

Its claims were also rejected by the compilers of the B.O.U. List, though Harting (38. I75) and others accepted the record as authentic. In this they were probably correct, for about the end of December, I886, Mr. G. Smith, of Yarmouth, received an adult in winter plumage which had been shot just before on the Breydon Broad, as recorded by MIr. Howard Saunders (29. Feb. 5). There seems, therefore, good reason for admitting it here as a British bird. The original Essex specimen was a hird of the yeir, according to Mr. Howard Saunders (Ibis, I872, p. 79). 
Black-headed Gull: Larus ridioundus. Locally, "Cob," and "Peewit Gull."

A resident, though local, uncommon and partially migratory. It still breeds on the coast at several spots, though in much smaller numbers than it used at one time. It is now the only Gull breeding with us. Dale speaks of it (2. 402 ) as the "Pewit or Blackcap," the former name being still sometimes used in Essex.

It does not often appear inland in the county during summer, but on June I6th I883, I saw a party of five Gulls-pre-

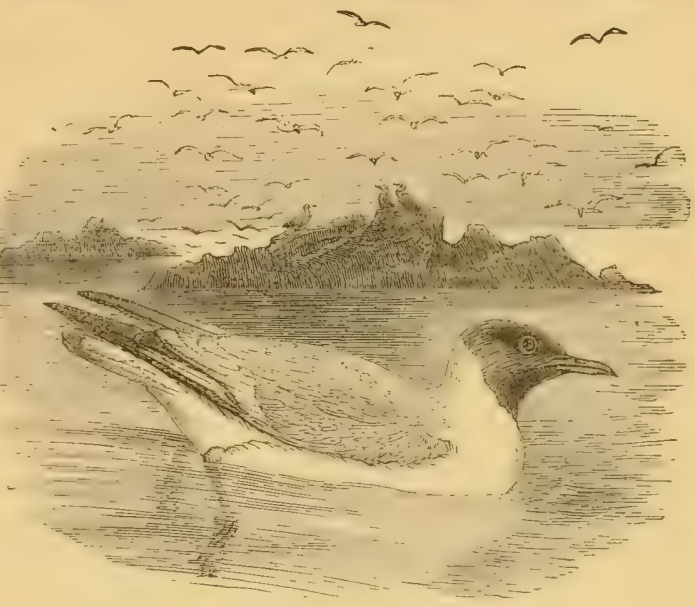

BLACK-HEADED GULL, in swmmer, $x / 6$

sumably of this species-fly over here in an easterly direction. On May Izth, I880, I saw a pair of Gulls, I believe of this species, fly over Saffron Walden, and on August zoth in the following year MIr. Travis received a young bird of the year shot near the town. Edward Doubleday states (I5) that he met with it at Epping "in a very exhausted state, after long stormy weather." Great numbers frequent the Mucking Flats during winter (Sackett).

The earliest record we have of its breeding in the county is that of Fuller, who in his Worthies of England (1662, p. 318)-says :-

"There is an island of some two hundred acres, near Harwich, in the parish of Little Okeley, in the manour of Matthew Gilly, Esquire, called the Putit Island from Puits [which are] in effect the sole inhabitants thereof. Some affirm them [to be] called in Latin upulce, whilst others maintain that the Roman Language doth not reach the name, nor [the Roman] Land afford the bird. On Saint George his day [April 23rd] precisely (so I am informed by Captain Farmer of Newgate Market, copyholder of the Island) they pitch on the Island, seldom laying fewer than four, or more than six eggs. Great [is] their love to their young ones. For though against foul weather they make to the mainland (a certain Prognostick of Tempests), yet they always weather it out on the Island when hatching their young-ones, seldom sleeping whilst they sit on their eggs (afraid, it seems, of Spring-tides) which signifieth nothing as to securing their eggs from the inun'dation, but is an argument of their great Affection. Being [i.e., when] young, they consist onely of bones, feathers, and lean flesh, which hath a raw gust [i.e., taste] of the sea. But Poulterers take them then and feed them with Gravel and Curds (that is Physick and Food), the one to scour, the other to fat them in a fortnight, and their flesh thus recruited is most delicious."

Four years later Merrett, who calls it the "Pewit," says (I82), "Insula quaedam ab iis nomen fortitur in Essexia. Haec enim migrant praecise ad diem. Divo Georgio Sacrum." Two years later, Charleton, in his Ononzasticon Zoicon 
(I668) makes a comewhat similar statement, adding, "Nomen suum Foul. ness nempe, hoc est avium fromontarium." Both these writers were probably quoting from Fuller, but Charleton was certainly in error in identifying the island in question with Foulness Island, where, however, the Gulls probably bred also. Fuller's "Puit Island" is undoubtedly the island in Handford Water, near Harwich, still known as Peewit Island. Mr. J. H. H. Knights, of Ipswich, has obtained satisfactory evidence (29. Mar. I5. I884) that, if Gulls do not now breed on Peewit Island, they at least did so annually, though in small numbers, on the adjoining island known as Horsey Island, and that people came regularly from Harwich for their eggs in $188_{3}$. On August I2th, I883, a gentleman obtained the young in down, the earlier layings having probably been taken. Morant (i. 490), in alluding to Fuller's statements, cautiously remarks that the island takes its name from the "great quantities of Pewits which come and breed in it in the spring, but whether all the wonderful circumstances related by Dr. T. Fuller are exactly true is doubtful, as (for instance) that they come on St. George's Day precisely; that they seldom sleep whilst they sit on their eggs, \&c."

Mr. Hill, of Southminster, in I833, says (12. vi. 450):-

"The Black-headed Gulls make their appearance on this coast about the third week in March. *** In the months of May and June they are very busy in the pursuit and destruction of the cockchafer. Their note is peculiar, resembling the broken caw of a young Rook. About seven miles from me, in the Blackwater River, there is a low swampy island of fifty acres [? Peewit Island, near Bradwell] where these birds resort to breed. From I0,000 to I2,000 eggs are annually taken thence and sold at $4 \mathrm{~d}$. a dozen. I last year visited the place at tre full time of their breeding, and I found the nests thickly strewed about, and the eggs laid on a little seaweed, and seldom more than three in a nest, sometimes four. *** The eggs when dressed are eaten cold. The colour of the yolk is deep orange. They are very strong, though considered a delicacy by the marsh gourmands. The fat of the bird is of the same deep hue. In the month of November they leave this coast, or at least never journey inland with the Common Gull."

Mr. C. Parsons, writing from Southchurch in 1833 , says (13):-

"The Black-headed Gull is a constant resident with us, but not until last summer have I ever been able to discover a nest in my immediate neighbourhood, although on a small island about twelve miles further on the coast, they regularly breed in abundance*. I was much pleased last. spring on finding a few eggs on a piece of Salterns, a short distance from where I reside, and on visiting the spot about a week after, I found that a large company of them had taken up their abode there."

He adds that some fishermen took many of the eggs, and although the birds were indefatigable in laying, not an egg was allowed to hatch. Mr. J. F. T. Wiseman does not know of its breeding in the Paglesham district. There is a large colony of probably one hundred nests in the vicinity of St. Osyth, according to Mr. E. Bidwell. Dr. Laver, who describes it as "common in both the Colchester and Paglesham districts," says that it "breeds in more than one locality." He has heard it spoken of as the "Pewit Gull," though rarely. Round Harwich, it is common, breeding in large numbers, according to Mr. Kerry, who writes :-

"I should think there were quite 200 in one colony breeding on the bentlings near Lower Kirby last season. Sometimes they breed in one spot, sometimes in

* Doubtless Mr. Parsons here refers to Foulness, where Mr. Dalton informs me the species still breeds abundantly. 
another; so that there are always a few pairs breeding in the old localities. I certainly think they increased in numbers this year, but the Carrion: Crows take heavy toll from the outlying nests. I saw a Gull lying dead beside its nest with a severe wound in its head, caused, no doubt, by a blow from the beak of a Crow, who had sucked the eggs of the unfortunate bird. In I889, a large number of their eggs were taken and sold as 'Plover's ' eggs."

I have seldom or never spent a "pleasanter day than June I2th, I88s, when Mr. E. A. Fitch and myself risited the breeding-haunts of this bird, on the Old Hall Marshes, Tollesbury. The first colony we reached was a small one on a large marshy pool, with reedy banks, known as Joyce's Head Fleet. Upon this we embarked in a boat with the keepers. At one end of the pool, was a large assembly of Coots, numbering considerably over 100, and among the reeds we saw several of their nests containing eggs. As we advanced we approached one of the smaller nesting-colonies of the Black-headed Gulls, which was upon a small, boggy island, some five or six yards across, and thickly overgrown with rank nightshade. Here were about a dozen Gull's nests-substantial structures, built of reed-stems outside, and lined with small tufts of grass. None were placed actually upon the ground, but all were resting on the nightshade and reeds. Several of the nests were empty, but others contained one egg each, and one held two. They were only slightly incubated. While we were at them, the old birds-locally known as "Cobs"-were very noisy overhead. Proceeding further on to the marsh we visited a second and larger colony of Gulls which were nesting in some reed-clumps about ten yards from the edge of another pool known as Pennyhole Bottom. Here were about twenty-five- nests, most of them containing either one or two eggs, though several held none, and one three. We reached them by wading, the water not being over eighteen inches deep. They did not differ in any essential respect from those already described, and the old birds, as before, were very noisy overhead while we remained at their nests. The eggs are decidedly variable, the ground-colour ranging from greenish-olive to dark russet-brown. We brought away several of the more curiously marked as specimens. Close at hand was another large pool known as Pennyhole Fleet, among the reeds on the edge of which, the keepers told us, about sixty pairs of Gulls had built their nests earlier in the year, but had suddenly and unaccountably deserted them before laying any eggs (50. iii, I88).

There can be no doubt that there were once many more nesting colonies of the Black-headed Gull on the Essex coast than there are now. The names Great Cob Island and Little Cob Island in Tollesbury Fleet, and Cob Marsh Island at the entrance to Mersea Quarters, are evidences of the ancient tenure of the Gulls in this locality. There is also a Cobb's Farm on the Goldhanger coast. In addition to the Peewit Island in Handford Water, there is another island of the same name between Mersea Creek and Parrock, and a third near Bradwell Waterside on the Blackwater, from which baskets-full of Gull's eggs used to be obtained within the memory of persons now living.

Yarrell says (25. iii. 55I): "These birds are abundant at the mouth of the Thames, both in Kent ard Essex, but the most so in the latter county, breeding by hundreds on some of the low, flat islands on the coast, and in the marshes of the interior." Morris repents the same statement, almost word for word (27a. vii. I 53). More, in 1865 , stated that $(33.454)$ there were then breeding-stations in Essex, but Mr. Howard Saunders, in the last edition of Yarrell's Birds, says (37. iii. 595) he knew of no breeding place ${ }_{4}$ in Essex, and in $1884 \mathrm{Mr}$. Harting wrote (29. Feb. I6) that he knew of none south of the Stour. Probably it still breeds in limited numbers on various other parts of the Essex coast. 


\section{Little Gull: Larus minutus.}

An irregular and uncommon winter visitor, of which about a dozen specimens, most of them in immature plumage, are recorded from Essex.

Yarrell says (25. iii. 544): "Dr. Waring gave Mr. Leadbeater a beautiful adult specimen, in winter plumage, that was shot at the mouth of a small river in Essex." In the List of Suffolk birds, by the Rev. J. Mitford, of Benhall, two are recorded from Languard Fort (Jesse's Gleanings, vol. ii., p. I89), and on Sept. 3rd, I885, two "cream-coloured Gulls" (probably of this species) were seen at Languard L.H. (42. vii.), Mr. G. B. Ashmead records an adult in winter plumage (34. I462) shot early in Oct., I868, on the Thames near Gravesend, when in company with Common Terns. Dr. Bree says (32a) he possessed a male and a female and two young birds, all in winter plumage, and shot at Brightlingsea in Feb., I870; also a bird of the year shot at West Mersea in Dec., I87. . Mr. Kerry records (40. 52) one shot on the beach at Dovercourt on Aug. 24th, I876, an immature specimen shot in Harwich Harbour on Dec. 9th, I876, and an adult on Jan. 8th following (40.259), and a second immature bird on the Dovercourt beach on Jan. Ioth, 1879 (40. iii. I82). In the Museum at Saffron VValden is a young specimen in winter plumage caught on the wharf beside the River Stort at Bishop Stortford about the year 1870 and presented by Edward Taylor, Esq. An immature specimen was shot on the Thames, between Rainham and Grays, on Sept. 20th, I875 (29. Oct. 2), when flying in company with Terns. On Oct. 3 th, 1889 , a fine example, measuring $10 \frac{3}{4}$ ins. in length, was shot at Brightlingsea and preserved by Mr. Pettitt. In the Dictionary of the Thames it is stated that "within the last twenty years we have noted the occurrence of eight or nine individuals of this species in Blackwall Reach, at Rainham, Grays, and Gravesend." Mr. Harting records (Birds of Middlesex, p. 254) one in nearly-mature spring plumage from Blackwall Reach in the early spring of $186_{3}$. A bird of the year with conspicuously-barred shoulders was shot off Mucking Light by a Mr. Cooper early on Oct. 26th, I889 (Harting-29. Oct. I9, and 40. xiv. I9). A beautiful specimen, apparently in the plumage of the second year, was shot in Harwich Harbour on Dec. $4^{\text {th, }}$ I 889 (Kerry-40. xiv. I9). Mr. Arthur Wright, of Maldon, shot one on the Blackwater in Feb., ISgo (Fitch). Mr. Hope observes that it is "not uncommon in the immature plumage."

\section{Sabine's Gull: Xema sabini.}

A scarce autumnal straggler to the British coasts from the northern regions of Asia and North America. A single specimen only has occurred in Essex.

Mr. Harting writes (Birds of Middlesex, p. 252) :-

"Early in September, I862, Mr. J. Sorrell, of Trinity House, proceeded in a boat towards the mouth of the Thames for the diversion of shooting Gulls, which, at this season of the year, appear in some numbers; and when nearly opposite Blackwall he killed the rare specimen which is now before me."

Mr. Harting adds a full description of this specimen, which was a bird of the year. As Blackwall abuts on Buw Creek this may fairly be considered an Essex bird.

Great or Common Skua: Stercortrius catarrhactes. Locally, "Turd-bird," "Dung-bird" (E. A. F.), or "Dung-eater" (E. A. F.).

A rare passing migrant, seen on the coast when migrating in 
spring and autumn. It breeds very sparingly on two of the Shetlands. In common with the other Skuas, it is known among the fishermen and others on the Essex coast by various local names, which are expressive of one of its characteristic habits, rather than polite.

One was taken at Elmdon about I 820 , by the Rev. R. Fiske (Clarke-24). At Harwich it is "rare," though one was shot just outside the harbour on Sept. I 2 th, $1876(40.52)$, and another was seen there in the autumn of I888 (Kerry). Mr. A. H. Smee saw two on the Thames on Oct. 3rd, 1867, one opposite Greenhithe, the other by the Chapman Light, at the east end of Canvey Island ( 84 . IOI7). Yarrell says (I4. iii. $48_{3}$ ) specimens have been obtained in autumn on the Essex const. I saw a Skua, which I believe to have been this species, at sea about two miles off Walton-on-the-Naze on Sept. Sth, 1888. "Wadding" records seeing one pursue, and at last seize and kill, a Black-headed Gull off Southend, on Oct. 30, 1858 , Both birds were obtained and stuffed by Ward (29. Nov. I3).

\section{Pomatorhine Skua: Stercorarius pomatorhinus.}

An occasional visitor to the coast when on migration in spring and autumn.

Yarrell mentions one (Zool. Fourn. iii. 497 ; and 30. iii.626) "shot in Hackney Marshes some years since and now in the Collection of a gentleman at Wanstead." Mr. Harting (Birds of Middlesex, p. 270), records a young one shot at the mouth of the Thames in August, IS62. Mr. G. H. Baxter has one which he shot on Oct. 7th, I879, while yachting off Southend (29. Oct. 25). A bird of the year was shot at West Mersea in Dec., I874 (32a). At Harwich, "a few are seen most autumns" (Kerry), and Mr. Hope has one shot there in Aug., I876.

Richardson's Skua : Stercorarius crefidatus. Locally "Black-toed Gull" and "Boatswain" (E.A.F.)

Fairly common on the coast as a passing migrant in spring and autumn. It breeds sparingly in the Highlands and northern isles of Scotland.

In the Walden Museum is an immature individual killed at Sampford in I 837 A specimen was shot during the severe winter of $1837-38$ at High Ongar (I9. 45 ). Mr. Harting records an immmature specimen shot in Greenwich Reach in the autumn of 1862 (Birds of Middlesex, p. 271). At Harwich it is "rare" (Kerry), but an immature bird was shot on the Dovercourt beach on Oct. I2th, I879 (40. iii. 459), and in I879 a mature and two immature birds were shot near Harwich on Nov. Ioth, I2th, and 22 nd respectively, also another mature specimen seen (40. iv. 69). Mr. Baxter has one which he shot on Oct. 7th, I879, whilst yachting off Southend. One was shot on the Blackwater Estuary in Dec., I889 (Fitch).

\section{Buffon's Skua: Stercorarius parasiticus.}

A rare and occasional visitor when on migration.

Mr. Clarke mentions one killed at Sampford on Sept. 29th, I837 (24). Mr. Bond met with a young specimen at Southend early in Sept., I842 (23. 40). On Oct. 20th, I8S I, a very emaciated specimen was picked up near Wimbish and preserved by Mr. Travis (44. ii. Lxxx.). An immature specimen was caught on Canvey Island on Sept. 27th, I882 (Bird). Mr. Baxter has one which he shot off the pier head at Southend in the month of August about the year $\mathrm{ISS}_{3}$. 


\section{Order TUBINARES.}

\section{Family PROCELLARIIDA.}

\section{Storm-Petrel : Procellaria pelagica.}

Frequents the open seas around the United Kingdom, and breeds on various islands off the west coasts of England, Scotland, Wales

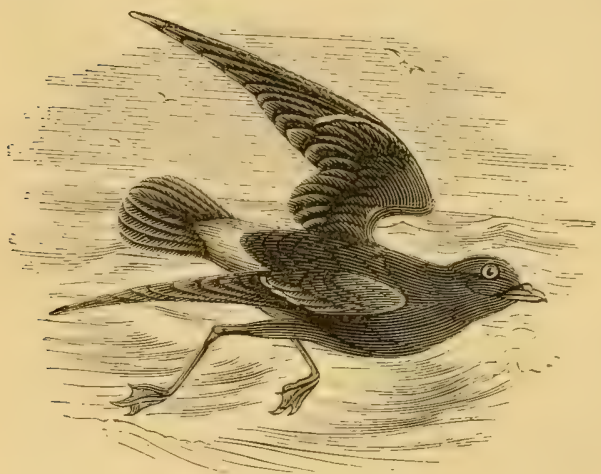

STORM PETREL, 1/3, and Ireland, but is never met with in Essex, except when blown inland by severe storms.

Lewin says (4. vii. 40): "On land it is seldom seen, though one has been shot at Walthamstow in Essex." Donovan, doubtless alluding to the same specimen, says (5. vi. Pl. cxxxix): "We possess one specimen, formerly in the Leverian Collection, which is affirmed to have been shot at Waltham. stow in Essex." Sheppard and Whitear write $(9.54)$ : "The oil issued from the nostrils of one which we killed on the Stour, May 29th, I820." Yarrell says (Zool. Fourn, ii. 24.) :- "More than a dozen Storm-Petrels were procured on the eastern coast, principally during the remarkably windy weather that occurred this month [Nov., I824]. Mr. Clarke refers (24) to a specimen in the possession of the Rev. Robert Wilkes, of Lofts Hall, which was picked up many years ago at Elmdon, and to another found at Audley End in I836. At Harwich, "some are seen every winter. On Oct. 29th, I880, several were seen in the harbour there, and one was picked up dead, probably exhausted by a recent storm " (Kerry-40. v. 26). Mr. Hope says it is seen in winter time in,Harwich Harbour and up the Orwell. On Nov. 6th, I880, a dozen were observed round the Galloper Light Vessel (42). One was observed off Languard Point on .Oct. IIth, I882, and another at the Galloper L. V., Oct. 2nd, 1884 (42, iv. and vi). One was caught at the Languard L.H. on Oct. 25, I885; several at the Kentish Knock L.V. on Nov. IIth, I885; one at the Swin Middle L.V on Nov. Ioth, 1887 ; and another on the I $4^{\text {th }}$; and another on the lantern of Languard L.H. on Dec. 24th, I 887 (42. vii. and ix.). At Marsh House, Tillingham, Mr. Robert Page has a specimen caught in his decoy there. 


\section{Leach's Fork-tailed Petrel : Procellaria leniorrhoa.}

A rare straggler to our coast during stormy weather, after which it is sometimes blown far inland. It breeds on St. Kilda and perhaps elsewhere in the United Kingdom.

One was taken alive on the Essex coast in Nor., I823, and brought into the London market, where it was purchased by Mr. Yarrell, but it died the same day (Zoological Fournal, ii. 25 and iii. 495). Hoy records one (29. Nov. 9, 1867) picked up in an exhausted state near Coggeshall in the winter of 1827-28. Yarrell mentions (I4. iii. 52I) the occurrence of "one near Saffron Walden" previous to I843. Henry Doubleday says (I0) :- " On one stormy day [about Jan. 20th, I837] a very fine specimen of Thalassidroma_leachii was picked up by a boy in our forest and brought to me." He afterwards mentions (IO) another specimen, brought to him about the middle of Nov., I840, having been "found dead in a field [near Epping] after a storm." At his sale in I87I, these two specimens (one of which Mr. Hope now has) sold for 2Is. Mr. Harting (Birds of Middlesex, p. 27I), records one shot near the Steam Mill, opposite Bow Creek, in Mareh; I864. Dr. Bree records (34. 1060 and 29. Apr. I4. 1874) that during the first week of Dec., I867, which was exceedingly rough and stormy, a boy was cleaning an engine at the Colchester Railway Station about fivero'clock in the morning, when a bird of this species flew against his lantern with great force and was stunned. Mr. Hope says it is sometimes seen in winter time in Harwich Harbour and up the Orwell.

\section{Manx Shearwater: Puffinus anglomum.}

An uncommon winter visitor to our coast, and occasionally picked up inland especially after storms. It breeds on the west coasts of England and Scotland.

Edward Doubleday, in I 835 , says (15) that a "Shearwater" [species not stated, but probably the above] had been "picked up dead in a field near the town," having no doubt been driven inland by severe weather. Henry Doubleday says (34. 526) that another was picked up dead in a garden at Epping on Sept. 21st, 1866. One was killed by flying against the telegraph wires near Colchester, in Sept., I876 (29. Sept. 23), and another was found in an ex-

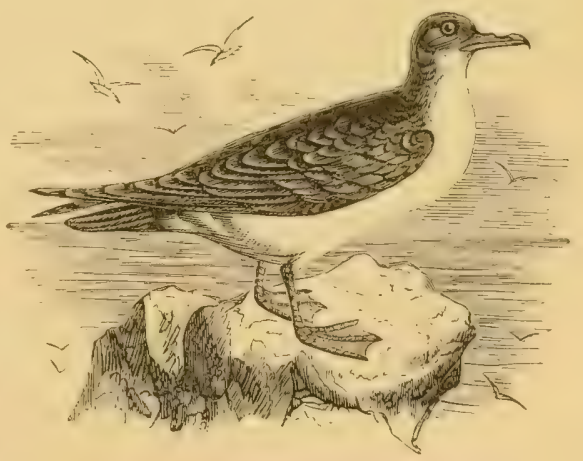

MANX SHEARWATER, I/3. hausted state at Bishop Stortford early in Sept., I883.

Mr. Travis records that (44. i. lxii.) on or about Sept. 6th, I878, after a very rough night, a Dusky Shearwater, Puffinus obscurus, was found in the early morning by the roadside at Sampford by a postman. It seemed very fatigued, but lived two days in Mr. Travis's possession, during which time it ate a few slugs and sometimes used its hooked bill to assist it in climbing about its cage. He informs 
me that another was taken on Mr. Gayton's farm at Siward's End, on Sept. I7th, 1884. These were probably Manx Shearwaters.

\section{Greater Shearwater: Puffinus major.}

An irregular autumn visitor to the British seas. It has, doubtless, occurred occasionally on the Essex coast, but I have only one record.

Mr. Clarke informs me that some twenty years or more ago one shot at Debden was purchased by Mr. F. Bond.

Fulmar : Fulmarus glacialis.

A rare winter visitor only to Essex, as to the whole of the British Isles, except when at its brecding stations on the Island of St. Kilda.

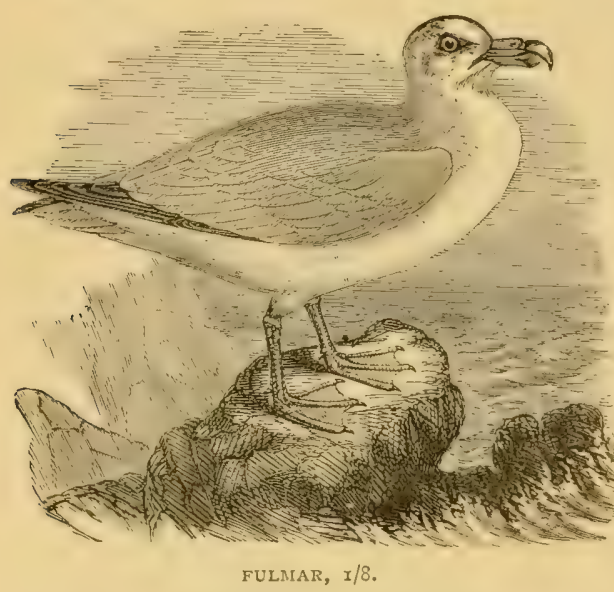

Mr. Clarke mentions (24) a fine specimen killed at Chrishall in 1834 . This is still in the Saffron Walden Museum and is doubtless the "fine example" mentioned by Yarrell (I4. iii. 50I). Mr. Travis records (44. i. lxiii) one taken on Nov. 9th, 1879, at Battle's Bridge by Mr. G. Pavitt, in whose Collection it now is. Mr. John Basham, of Maldon, shot one on St. Peter's Flats at the mouth of the Blackwater in Feb., I880 (Fitch) Mr. Saunders says (37.iv. 2) that although rare on the east coast, from Northumberland to Essex, "they are by no means uncommon at times on the fishing grounds about thirty miles out." 


\section{Order PYGOPODES.}

\section{Family COLYMBID $Æ$.}

\section{Great Northern Diver: Colymbus slaciulis. Locally, "Sprat-Loon."}

A fairly-common visitor to the Essex coast from autumn to spring.

Dr. Bree writes (23.9629): "This bird, which, in common with the other divers, is termed by the fishermen the 'Sprat-loon,' is very common on the Colne during winter." Mr. Hope observes that, although it is frequent in winter, he has never seen one in Essex in summer plumage.

\section{Black-throated Diver : Colymbus arcticus.}

A somewhat rare visitor to the Essex coast during winter, when individuals are occasionally found in an exhausted condition at places far inland, after high winds or storms.

Henry Doubleday, in March, I840, mentions (I0) a pair of adults "shot near Sudbury in nearly full nuptial plumage." Newman records one at Purfleet on Jan. 2 Ist, I850, (23.2760), and Morris one at Chesterford about the middle of the same month (27a. vi. I0). Dr. Bree says (29. Nov. 20) :

"A fine specimen $* * *$ in summer dress (with incipient signs of moulting) was shot at Oakley, the first week in November [1875].*** During the sixteen or seventeen years I have lived in this neighbourhood [Colchester], I have never before seen a specimen of this bird in summer plumage captured in the county."

Mr. A. H. Smee shot an immature male at Leigh on Jan. 26th, I870 (34. 2107). A fine male was shot on the Blackwater, near Maldon, during the last week of Dec., 1875 (29. Jan, 8, 1876). At Harwich, it is rare, but a male and female were shot in the Harbour on Dec, 20th, 1876 (Kerry-34.4827). Another, showing some black feathers.on the throat, was killed there on Dec. 9th, I889 (Id.). On the morning of Dec. $4^{\text {th }}$, I876, during a very extraordinary flooding, a man in my father's employ observed a large bird swimming on the flood in a meadow close to Pengy Mill Farm, Chignal St. James. On approaching and finding that it did not seem inclined to fly, the man set his dog upon it, and after about twenty minutes, managed to kill it. During this time it never once attempted to fly, but dived frequently. It weighed $3 \mathrm{lb}$. Io oz., and appeared to be adult (4t. iv. (xxv.). Mr. Arthur Lister believes he saw one on Wanstead Park Water in I88I (44. iv, lxxvi.). Mr. Travis records (4.. i, lxiii.) that in Nor., I8So, he received for preservation two examples shot at Southend. 


\section{Red-throated Diver: Colymbus septentrionalis. Locally, "Sprat-Loon."}

A fairly-abundant bird during winter on the Essex coast, where it is commonly known as the "Sprat-Loon." Individuals are occasionally blown far inland by severe storms.

Pennant says (Brit. Zool., I768-70. ii. p. 4I4): "On the Thames, they are called Sprat Loons, for they attend that fish during its continuance in the river." Yarrell also says (14. iii. 336) "it is common about the estuary of the Thames, both on the Kentish and Essex sides, where these birds follow the numerous shoals of sprats, and are in consequence called the Sprat-Loons. They are frequently caught in the nets." Mr. Clarke notes the occurrence of an immature individual at Saffron Walden in Feb., ${ }^{8} 88$ (2.4), and informs me that some years ago a mature specimen was shot by a gamekeeper on the lake in Debden Park. Mr. C. Walford wrote in Jan, 1839 (19. 90) that an adult bird in moult had recently been taken at Maldon. It had the red on its neck. Mr. Bond met with an adult at Southend early in Sept., I842 (23.40). Early on the morning of Dec. 2nd, 1876 , during a heavy fall of rain and a high wind which had blown all night from the S.E., a female (?) specimen alighted in the garden of a cottage at Springfield, immediately opposite the gaol, to the great surprise of the occupants of the cottage. It had no doubt been blown inland by the gale, but from the first it exhibited little or no fear of human beings, and lived contentedly for a fortnight in a pig-pen in the garden, without making any attempt to fly away. It was fond of sprats and earthworms. In the end, it was killed for stuffing (44. iv. Ixxiv.). Mr. Lister watched one-apparently a young bird-on the Basin in Wanstead Park in Jan., I877 (47.97, and 44. Ixxvi.). Dr. Bree says (29. Apr. 23), about the middle of April, I88I, "Mr. Ely sent me from Sible Hedingham a live specimen which was picked up off his land by a labourer. It could not fly, but no reason was discovered upon dissection."

An albino specimen, shot in Essex, and preserved by Ward, was among the birds left by the late Col. Russell. The whole (including the legs and bill) is pure white, except a few dark feathers on the back (29. Mar. 8, 1862; and 23.8002).

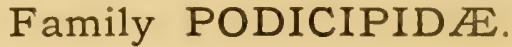

Red-necked Grebe : Podiceps griseigena.

A somewhat rare visitor, chiefly to our coast, from autumn to spring.

Mr. Clarke records (24) a fine adult specimen killed on the lake in Debden Park on Apr. 20th, I839. Morris (27a. vi. 299) says it has occurred at Saffron Walden. Yarrell says (37. iv. I25), "Examples have been obtained at irregular intervals in Essex, Kent, Sussex, "Sc. A specimen was shot at Wethersfield during the severe winter of $1837-3^{8}$ ( 19.34$)$. One was caught by a dog in a pool of water on the sea-shore at Dovercourt on Nov. 26th, I875 (Kerry-34.4827). Another was captured at Bradwell, after half an hour's exciting chase, about the end of Sept., IS76 (Chelnisford Chronicle, Oct. 6th). In the winter of I877-7S, Mr. Crick received for preservation one said to have been shot near Witham. Mr. Lister says (47.97) early "in February, I877, one of these birds remained for almost a week on the 
Basin in Wanstead Park. I watched it repeatedly with a good telescope. It was in fine plumage " (c.f. 40. i. 230). Early in Nov, I888, one was killed near Manningtree (Laver). Mr. Hope describes it as common in Essex, especially on the Blackwater. Aspecimen taken alive near the Hospital at Colchester in_I879, is preserved in the Bree Collection.

Great Crested Grebe : Podiceps cristatus. Locally, "Loon."

An uncommon visitor, chiefly to our coast, from autumn to spring. I know of only one instance of its having bred in the county.

King says (20), "A fine specimen in winter plumage was brought to me last spring, [1838] which had been shot on our river." One was shot on the river at Chelmsford in the autumn of I879. Mr. Lister observed a female "on the WVanstead Basin for several days in the spring of $\mathrm{ISS}_{3} "$ (47. 97). Mr. Hope, who has several Essex specimens, describes it as common on the Blackwater; and it is "not rare at Mersea in winter" (Laver). Mr. F. Spalding saw a fine male, recently killed, on a stall in Colchester Market on Mar. 3, I888. At Harwich,

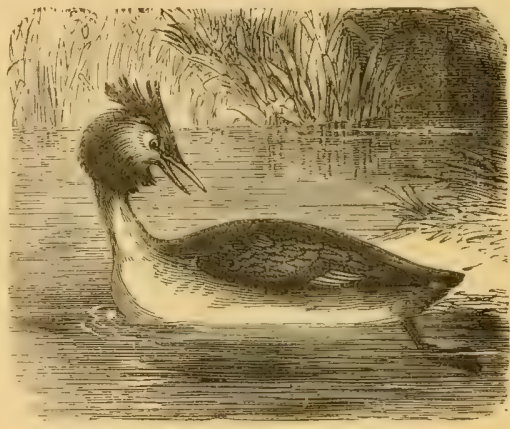

GREAT CRESTED GREBE, I/I2.

Mr. Kerry describes it as "rather rare." He adds that a pair nested near Waltonon-the-Naze during 1888 . This is the only time I ever heard of it breeding in the county, and the Rev. J. C. Atkinson informs me that he never heard of a case of its breeding on the Essex Marshes, even in his early days. Mr. J. F. T. Wiseman informs me that he never knew it breed in the Paglesham district.

\section{Sclavonian Grebe: Podiceps auritus.}

An uncommon winter visitor, chiefly to the coast, from autumn to spring.

In the Collection at Audley End is an example shot there in 1838 (24). One was shot near Maldon on Jan. I2th, I876 (29. Jan. 22). In Nov., I880, a specimen was taken at Southend (Travis-4+. i. lxiii.). Mr. Hope, who has one killed at Maldon in Feb., I874, describes it as common in Essex, especially on the Blackwater.

\section{Eared Grebe : Podiceps nigricollis.}

An uncommon winter visitor.

Graves says (7. iii.) that the figure he gives "was executed from a fine male bird, which, with the female, was shot on the coast of Essex in March." Mr. Clarke mentions one (24), shot at Audley End on Jan 26, 1838. Dr. Bree says (29. Apr. IIth, I874): "It is frequently killed in winter on the Essex coast." One was shot at Walton-on-the-Naze on Feb. 2nd, I875 (29. Feb. I3). In I875 two specimens were shot on the Stour at Harwich on Dec, $3^{\text {rd }}$ and Ioth respectively (Kerry - 34.4827). A young male in poor condition was taken on the lake in Debden Park after an hour's chase on Oct. I5th, I88I, after a very 
severe storm. Its stomach contained a mass of feathers (presumably its own) and the remains of small fish (44. ii, 1xxx.). Mr. Hope, who has one in winter plumage, killed near Harwich, describes it as common on the Blackwater. It "is not rare at Mersea in winter" (Laver). The Rev. J. C. Atkinson says (36. I5I), "I knew of one instance in Essex some thirty years ago in which one of these birds was taken from a Water Rat's hole, into which it had been seen to creep for shelter." A specimen shot at Walton on Feb. 2nd, I875, is now in the possession of Mr. Dorling of that place.

Little Grebe or Dabchick: Tachyluaptes furviatilis. (Podiceps minor, Yarrell). Locally, "Dobchick," (pl. "Dobchicken.")

Resident and widely distributed, but not common, and seldom found breeding except on or near the coast.

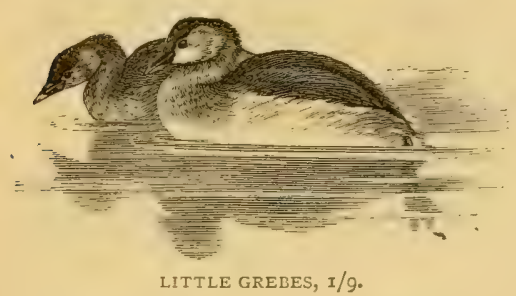

Round Sudbury in 1858 , King described it (20) as "common," and Mr. Grubb says (39) it "comes in winter" to his land there. In 1843 , Parsons wrote $(23.364)$ that it was then.

"a constant resident, either upon the small broads or fleets on the marshes of this neighbourhood, or of the creeks and arms of the sea intersecting them, keeping during the autumnal and winter months in small flocks * * * The nests are placed in the thick water-plants or reeds growing upon the sides of the marshy waters."

He adds some interesting remarks upon their habits. Lieut. Legge found two nests near Shoebury in $1865(34.603)$. A pair (probably breeding) were seen on the lake at Skreens in June, 1877 , and a pair were seen on the Chelmer at Broomfield on Dec., I879, during hard weather. In the summer of 1880 , one (doubtless breeding) was killed at Audley End, and during the laiter part of Jan, and the greater part of Feb., I88I, a party of ten remained on the Cam close to Audley End. On March I2th, I882, I saw four on the adjacent brick-ponds. I again saw one at the same place at the end of April, when it was probably breeding, but I could find no nest. To Wanstead Park, Mr. Lister says (40. ix. 64) they "come in the spring and breed, but appear to leave us in late summer." Mr. Buxton says (47. 97) it is "frequently seen in the spring in the lower and open ponds in Wanstead Park, but it is said not to remain to breed. I observed a pair on my own pond in the spring of 1884 , and I believe them to have had a nest." Round Orsett, Grays, and Corringham, Mr. Sackett says it is "not uncommon where there is enough water." He informs me of one nest built in a pool of water at the bottom of a chalk-pit at Grays, in which these birds actually bred during ISS8, although there was on the north side a lime-kiln and chalk-quarries in active working, on the east a rifle range in almost daily use, on the south a street, and on the west a high road. 


\section{Family ALCIDA.}

\section{Razorbill : Alca torda.}

Common on the seas round our coast from autumn to spring. Its nearest breeding place is on the cliffs at Flamborough.

At Harwich, "it is common during some winters" (Kerry). Mr. Hope describes it as "common on the Essex coast in winter." During the winter of $1889-90$ several were shot at Maldon, Burnham, and South. end (Fitch).

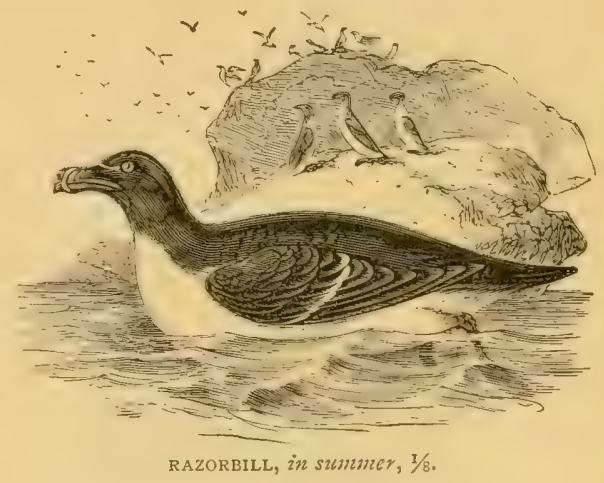

[Great Auk: Alca impennis.

There does not seem to be any record connecting this bird with the county of Essex. It is interesting, however, to note that the specimen formerly belonging to Mr. Hoy is now in the possession of that gentleman's nephew, Mr. J. F. Lescher, of Boyle's Court, Brentwood. According to Prof. Newton, this is one of the 22 specimens now existing in Britain.]

Common Guillemot : Lomvia troile. Locally, "Willock."

Common at sea from spring to autumn. It has no breeding colony in this part of England.

Mr. Hope writes that they "come south in August." $\mathrm{He}$ adds that "when they skim over the water it is considered a sign of foul weather coming." At Harwich, some are seen every year, and a fine specimen in full breeding plumage was caught on the beach at Dovercourt on June Ioth, I889 (Kerry). A specimen from Colchester in Jan,, I86I, is in Dr. Bree's Collection. Of the "Ringed Guillemot," which is now usually regarded as a form or variety of the common species, Mr. Kerry says that "some are seen every year" round Harwich, and Ambrose has also received it from there.

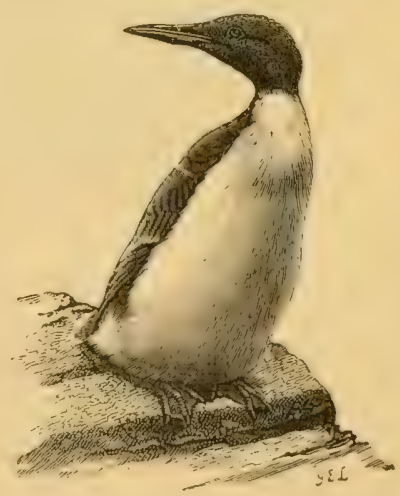

COMMON GUILlEMOT, in summer, r/ro. 


\section{[Brünnich's Guillemot: Lonvia bruennichi.}

There is not yet sufficient evidence to justify the admission of this species into the Essex list; but Canon Babington mentions (46. 246) one in his own Collection, which was "purchased at the sale of the Sudbury Museum; it formed part of a case of twelve 'British Aquatic Birds, Lot $230^{\prime}$; but although there is considerable reason for presuming that it was obtained near the mouth of the Orwell or Stour, whence so many of the aquatic birds in that Museum came, there is no direct evidence on the point."]

\section{Black Guillemot : Uria grylle.}

A rare winter visitor. I have only one record of its occurrence in Essex, but it has no doubt been overlooked.

Dr. Bree (32a) notes that a "female in winter plumage was sent to Ambrose to set up, Dec., I869 ; shot at Mersea."

Little Auk: Mergulus alle.

An irregular and accidental, though not uncommon, visitant during winter, when it is not unfrequently blown inland by severe storms as

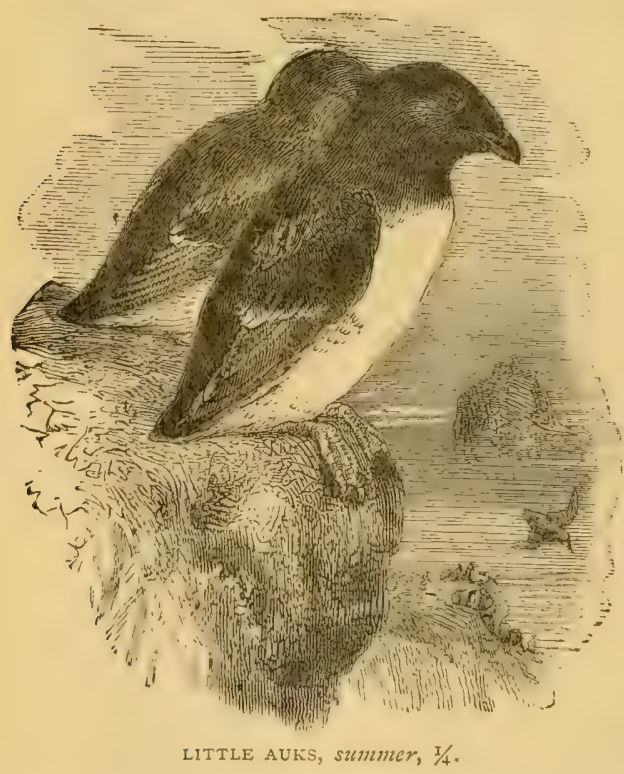

far as the midland counties.

Henry Doubleday says that in $18_{32}$ (10) he saw in a Collection at Colchester a specimen obtained near there, and in the same year he shot another at Walton-on-the-Naze, W. H. Hill met with two near Southminster about I 834 (12. viii. 573). Mr. C. Walford records (19. 58) that "about a fortnight before the severe frost of last winter $\left(\mathrm{I}_{3} 37-38\right)$ set in, two specimens of the Little Auk were found in an exhausted state-one in a gentleman's garden at Witham, and the other in Rivenhall Parish." Yarrell says (I4. iii. 359) that after a severe storm in Oct., I84 I, he heard of the occurrence One was picked up in a very rence of severe storms. It died during the day (23.7848). One was shot at Loughton (34.1867) in or about 1869. A male was picked up alive at North Weald on Nov. IIth, I870 (29. Nov. 26. '70). I have in my possession a specimen shot by our bailiff at Lindsell Hall, near Dunmow, about the year I87 I. It occurred during the winter, after a severe storm and is in winter plumage, though a few dark feathers are appearing on the chest. Another specimen is in possession of 
Mr. Philip Marriage, of Broomfield Mills, Chelmsford, who shot it there about ten or fifteen years ago, during an extensive flood. One was caught alive on the deck of one of the Great Eastern Railway Company's steamers while lying alongside the pier at Dovercourt on Dec. 3 rd, I878 (Kerry-40. iii. I82). About the middle of Dec., I879, during severe weather, one was obtained by a gentleman on the marshes at Dedham (Chelmsford Chronicle, Dec. 19), and another was shot on the River Roach on Nov. 27 th, IS\$3, by Mr. Chas. Wiseman, of Paglesham (Chelms. ford Chronicle, Dec. 1). An Essex specimen is among the birds collected by the late Col. Russell. The Rev. J. C. Atkinson writes me, "I have seen the Little Auk at sea, when shooting under sail. We had one astern of us one day within six or eight yards for many minutes." Mr. Hope has one, picked up alive in a starving and exhausted condition on the main, in Jan., I880, after a heavy gale with snow. One, which was not preserved, was killed off the Maplin Sands in Oct., I883 (Baxter). Mr. Stacey, of Dunmow, preserved one caught alive at that place on Nov. 20th, I884. During a serere N.E. gale on Nov. 9th, I873, one was taken alive among the pigeons on a farm near Walton (29. Nov, I5).

\section{Puffin : Fratercula arctica.}

To be met with on the seas round our coast during autumn, win ter and spring, but not common.

Mr. Hope describes it as common in winter in Essex. At Harwich, Mr. Kerry says some are seen every year. Mr. J.F. T. Wiseman informs me that he met with it when Wild-fowlshooting on the Tillingham Main in the winter of $1853-54$. Dr. Bree (32a) mentions young specimens shot at Mersea in Dec, IS74, and on the Stour in Nov., 1869. One was shot on

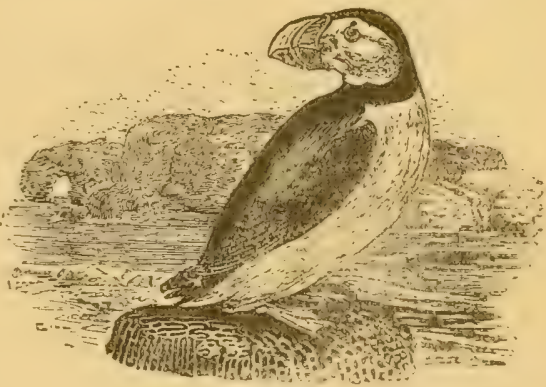
PUFFIN, I/7. (After Beruick).

the Thames between Erith and Gravesend on Fune I2th, I885 (R. Fortune-40 ix. 263). Both the time and place of capture are remarkable, but on the same page Lord Lilford records the capture of a Puffin in one of the bedrooms of Sir John Walrond's house in Brook Street, Grosvenor Square, on May I6th. 


\section{A D D E N D A.}

\section{Song Thrush (p.72).}

Mr. Kerry informs me that a very pale variety, shot near Harwich in the autumn of 1889 , was reported to him as a Golden Oriole !

\section{Redstart (p. 78).}

In illustration of the pertinacity with which the Redstart returns year by year to the same spot, and the wonderful regularity of its annual appearances, Mr. F. H. Meggy, of Chelmsford, has furnished me with the following notes of observations, taken between the years 1857 and 1874 . They refer to the first observed appearance of a pair of birds in the garden attached to Mr. Meggy's house, adjoining the River Cann. The garden is about half an acre in extent, and close to the town.

\begin{tabular}{|c|c|c|c|c|}
\hline 1859 & " & , & $"$ & at the end of April \\
\hline 1860 & $"$ & $"$ & $"$ & on April ro \\
\hline I86I & ", & , & $"$ & „April I 3 \\
\hline 1862 & $"$ & $"$ & $"$ & $\because$ April I5 \\
\hline I 864 & , & , & " & " May 3 \\
\hline I 86 & " & $"$ & $"$ & "April I6 \\
\hline I 866 & , & $"$ & ", & , April I9 \\
\hline
\end{tabular}

The nest was not often found in the garden, but about 1867 it was built in a crevice between the end of a wall and the post of a door leading from the garden to the town. The gate was not fifty yards from the house, and the passage-way running at the back of houses in Museum Terrace was constantly used; the nest was robbed. In $187 \mathrm{I}$, the male bird was killed by a cat, a few minutes after it was first noticed. In 1872 , it appeared on Apr. 27 ; in 1874, on May I2. Observations were discontinued when Mr. Meggy went to reside in London ; but as he has returned to the house where these observations were made they will no doubt be continued, if the Redstart still visits the garden.

Bearded Tit (p. 9I).

One was observed at Languard L.H., on Feb. I6th, I887, at 7.40 a.m. It was very tame, and left at noon (42, ix.20).

Rock Pipit (p. I90).

Mr. Kerry says that, in the winter of $1889-90$, he saw a good many round Harwich, where he had previously found it scarce.

Great Grey Shrike (p. I03).

Mr. Kerry informs me that one was shot near Harwich on March 4 th, ISgo. 
Greater Grey Shrike (p. I03).

The specimen obtained at Colchester on Dec. $3 \mathrm{rd}$., I $88 S$, has been kindly submitted to me by Mr. Pettitt, and proves to be a female belonging to this form. Mr. Kerry informs me that the specimen shot by him near Harwich in 1879 (p. I02), and still in his collection, belongs, he believes, to this form; but that the one shot there in 1875 (and also in his possession) is of the typical form.

Brambling (p. II9).

The wings of six were sent from the Kentish Knock L.V., on Oct. 9th, I877 (42. ix. 39).

\section{Snow Bunting (p. I29).}

One was observed in the garden adjoining the Languard L.H., at 4.20 p.m. on Nov. 9th, 1877 (42. ix. 5 I).

Starling (p. 129).

A peculiar variety was shot at Bradfield on Dec. 28th, I889 (Kerry).

Rough-Legged Buzzard (p. I66).

Mr. Wiseman informs me that the specimen shot near Paglesham in Nov., I888, and recorded as a Goshawk, proves on investigation to be of this species.

Merlin (p. I75).

Mr. Pettitt preserved a male, shot at Paglesham on Jan. Ioth, I8go.

Passenger Pigeon ( $\mathrm{p}, 215$ ).

Prof Newton (iii. 47) gives the following additional particulars concerning the specimen shot near Royston, and now in the Saffron Walden Museum (p. 2I5.):-It was obtained "by the sons of the tenant of the farm called Known's Folly, about two miles east of Royston. When the lads first saw the bird, it appeared so much exhausted that they could have knocked it down with a pole, if they had had one. They, however, fetched a gun and shot it. When examined, the crop was quite empty, but in the stomach there were some few seeds resembling cole seed, and a few small stones, but no barley or any trace of artificial food. The plumage was perfect, and neither the wings, the tail, nor the legs exhibited any sign that the bird had been in confinement."

Quail (p. 221 ).

Mr. Kerry informs me that, on the morning of Oct. 27 th, 1889 , after a gale of wind, a female was picked up dead at the foot of a lamp-post at Harwich.

[Rufous Tinamu : Rhynchotus mefescens.

An attempt has been made by Mr. John Bateman, of Brightlingsea, to introduce into Essex a new game bird, hailing from South America, where it is known to English colonists and Spanish-speaking sportsmen as the Perdiz grande. The Tinamu family to which it belongs is remarkable, with the general appearance of Partridges, but with the tail either very small, or entirely wanting. They dwell in the forests, open plains, and mountains from Patagonia and Chili to Mexico. Their colouring is very sober and protective, the sexes being indistinguishable, and they are seldom adorned with crests or plumes. The Rufous Tinamu (Rhynchotus rufescens), with which we are concerned, is found in Bolivia and South Brazil, and is common in the plains wherever long grass abounds. In April, I883, Mr. Bateman imported half-a-dozen, from which, owing to accidents, only eleven were reared. Additions were made, and eleven were turned out on the marshes; Mr. Bateman issuing at the time 


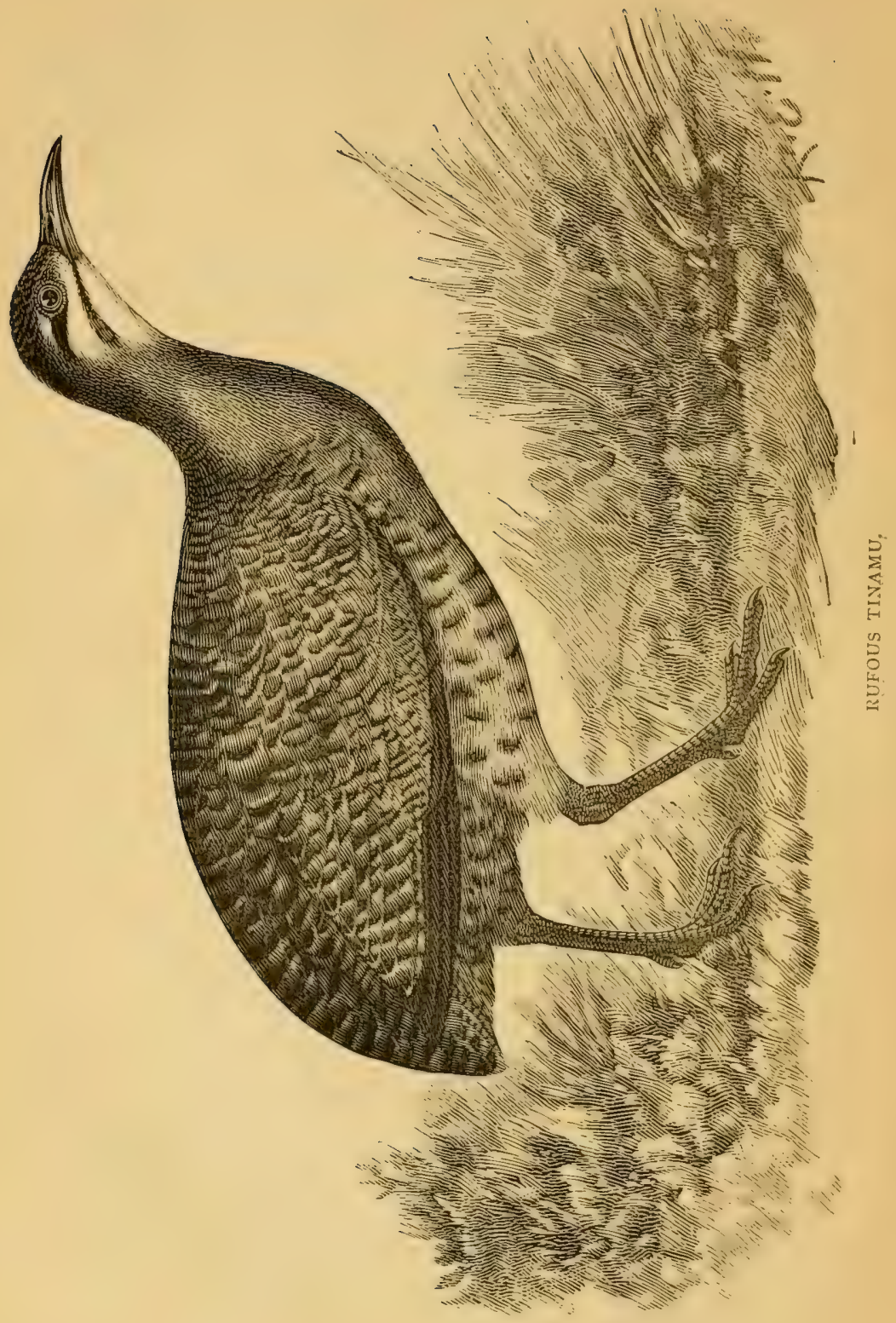


a printed notice requesting sportsmen generally to refrain from shooting them for a season or two. Their greatest enemies, however, proved to be foxes, and Mr. Bateman has had the mortification of seeing his Tinamus gradually being exterminated. A few are still left in the neighbouring parishes, and these were increased in the spring of 1888 by eleven more birds which were turned out of Mr. Bateman's aviary. The bird much resembles a hen Pheasant, with the absence of the tail ; it is capital eating and the flesh is quite white. Its food is varied ; consisting of field mice, sparrows. corn, grass-seeds, thistle-tops, and insects of all kinds. The eggs are about the size of a domestic hen's, and much resemble a purple plum with the bloom rubbed off. The nest consists merely of a few grass straws in a standing crop of barley. For further particulars, see the Essex Naturalist, ii. pp. I02 and 206, and the Field, Feb. 23, I884, Sept. I2, I885, and April I4th, I888.].

\section{Great Snipe (p. 243).}

Mr. Harting writes me: "About twenty years ago-I think in September, I869-I was shown by Mr. Hughes, of Brentwood, a good specimen which he had just shot at Stanford Rivers.

Prof. Newton has favoured me with the following memorandum by his brother, Sir Edward Newton. I am quite unable to suggest the species to which this" bird belonged.

"On the $3^{\text {rst of }} \mathrm{May}, \mathrm{I} 88_{3}$, about 3.30 p.m., when crossing the bridge near the stables at Audley End, I saw what I thought was a Turtle Dove, on a bough hanging over the water. Carl Brochner was with me and I called his attention to it. He said it had a crest,'but I did not see the crest. It flew up from the bough as if hawking a fly (there were a great many May-flies over the water), as Starlings and other birds were doing, and returned to its perch. I then saw that it was not, as I had supposed, a Turtle Dove. As it flew up, it appeared to me to have a forked tail. Brochner said it was a Jay, but it certainly was not. Had I been in America, I should have said it was one of the Tyrant Flycatchers. The bird was about the size of a Turtle Dove, and "or n uniform dirty cream-colour, without any striking marking:.

\footnotetext{
"Magdalene Coll.

"4th June, $\mathrm{IS}_{3}$."
}

"[Sd.] E. N. 


\section{A P P E N D IX A.}

\section{LIST OF SUBSCRIBERS.}

(In the following list, the names marked by an asterisk (*) are those of members of the Essex

Field Club, who are, by arrangement, entitled to obtain a single copy at a reduced price).

* Acland, Rev. C. L., M.A., Royal Grammar School, Colchester.

* Adams, Herbert J., Roseneath, London Road, Enfield, N. Ainsby, George K., St. Helen's, Tasmania.

* Allen, W., 10, Barking Road, Canning Town, E.

* Argent, W. J., Broomhill, Woodford.

Argyll, His Grace the Duke of, K.G., \&c.. Inverary Castle, N.B.

Arthy, Alfred J., Rochford, Essex.

Ashby, John, Staines.

Atkinson, Rev. Dr. J. C., Danby Parsonage, Grosmont, R.S.O., Yorks.

* Avery, John, junr., I 2, St. Thomas Road, South Hackney.

Backhouse, J., junr., F.Z.S., \&c., West Bank, York.

* Baker, James, 5, Tredegar Road, Bow, E.

Balls, J. M., Castle Hedingham, Essex.

Barclay, F. H., Knott's Green, Leyton.

Barclay, Col. Hanbury, Cross Oak, Great Berkhampstead.

Barclay, Hugh J., Colney Hall, Norwich.

* Barnes, Mrs., Oak Hall, Buckhurst Hill.

Bartlett, Rev. R. E., M.A., Rainsford Lodge, Chelmsford.

Bawtree, Ed. W., Abberton, Colchester.

Bawtree, Octavius, West Lodge, Colchester.

* Baxter, G. H., Hutton Park, Brentwood.
Ditto
ditto
ditto

Becher, H., 43, Royal Avenue, Chelsea, S.IV.

Beckett, Rev. W. H., Stebbing Manse, Chelmsford.

Bell, Mrs. Mary, The Trees, Maldon. (2 copies.)

Belt, Anthony, (Hon. Sec. Ealing Microscopic an $\$ Nat. Hist. Society), 58 , Matlock Lane, Ealing, W.

Bentall, E. H., The Towers, Heybridge, Maldon.

* Bentley, Edward J., 99, Cazenove Road, Stoke Newington, N.

Benton, Philip, Frankleigh House, Whitegate Road, Southend.

* Berry, Mrs. E., Much Hadham, Herts.

* Bewers, W., Highfield House, Barking.

* Biddell, Geo., Manor Office, Orsett.

Bidwell, E., I, Trig Lane, London, E.C.

Birley, F. H., Dorman's Land, Lingfield, Surrey.

Bliss, Rev. W. B., Wicken Rectory, Newport, Essex.

Borrer, Wm., F.L.S., Cowfold, Horsham, Sussex.

* Borrows, R., 2 I9, Evering Road, Upper Clapton. 
* Boswell, R. B., M.A., \&c., 23, Buxton Road, Chingford.

* Boulger, Professor G. S., F.L.S., F.G.S., I8, Ladbroke Grove W.

Bowles, Arthur, Temple Court, Guildford.

Braybrooke, The Lord, Audley End, Saffron Walden.

Broke, Horace, Gladwyns, Harlow.

Burrows, John, Southend.

* Buxton, T. F. V., Downton, Wilts.

* Buxton, Noel, Warlies, Waltham Abbey.

* Buxton, Sir T. Fowell, Bart., J.P., D.L., \&c., Warlies, Waltham Abbey.

* Calver, G., F.R.A.S., Hill House, Widford, Chelmsford.

* Challis, F., 9, Broomfield Road, Chelmsford.

* Chancellor, F., F.R.I.B.A., Chelmsford.

Chase, R. W., Southfield, Priory Road, Birmingham.

Chisenhale-Marsh, S., Gaynes Park, Epping. (2 copies.)

Christy, Alexander, Coombe Bank, Kingston-on-Thames. (2 copies.)

Christy, Edmund, 5, Albert Hall Mansions, Kensington Gore, S.W.

* Christy, Reginald William, Little Boyton Hall, near Chelmsford.

Church, Philip, Bishop's Stortford.

Clarke, Joseph, F.S.A., The Roos, Saffron Walden.

Claughton, The Hon. Mrs., Danbury Palace, Chelmsford.

Clifton, The Lord, Dumpton Park, Ramsgate.

* Clifton, F, 26, Great Percy Street, W.C.

* Coates, A. IV., B.A., Woodford Green.

* Cobbold, Rowland T., The Lodge, Dedham.

* Coburn, H. J., r6, Maxilla Gardens, N. Kensington.

* Cohn, Hermann, 7, Brunswick Square, W.C.

* Cole, Benjamin G., Buckhurst Hill.

* Cole, Henry A., Buckhurst Hill.

* Cole, Miss, Buckhurst Hill.

* Cole, Miss Jane E., Buckhurst Hill.

* Cole, Rev. John F., Roffey Vicarage, Horsham, Sussex.

* Cole, IVilliam, F.E.S., Buckhurst Hill. (3 Copies as Editor E.F.C.)

Cole, W. D., 1, Princess St., North St., Colchester.

Colley, Philip, Writtle Park, Chelmsford.

* Colvin, R. B., J.P., M.F.H., \&c., Felix Hall, Kelvedon.

Compton, Theodore, Winscombe, Weston-super-Mare.

* Connell, Primrose M., B.Sc., Ongar Park Hall.

* Cooper, Frederic IV., L.R.C.S., Leytonstone.

* Cooper, J. D., 4, Hill-side, Grove Hill, Woodford.

Corbet, R., (Hon. Sec, Orsett Book Club), Orsett, via Romford.

* Corcoran, Bryan, I 4 , South Park, Canonbury, N.

* Corcoran, Miss, I4, South Park, Canonbury, N.

Cordeaux, John, F.Z.S., Great Cotes, Ulceby, Lincolnshire.

* Croft, Richard B., F.L.S., F.R.M.S., Fanham's Hall, Ware, Herts.

Crosfield, J. B., The Dingle, Reigate.

* Crouch, Walter, F.Z.S., Grafton House, Wellesley Road, Wanstead.

Crowley, Philip, F.L.S., F.Z.S., \&c., Waddon House, Croydon.

* Cunnington, Augustus, Braintree.

* Cunnington, Miss M., Braintree.

* Dalton, W. H., F.G.S., S, Ducie Street, Clapham.

Daniell, Lorkin, The Armoury, West Bergholt, Colchester. 
Daniell, Thos. B., Heath House, West Bergholt, Colchester.

Day, John, Witham, Essex. (2 copies.)

* Day, George, F.R.M.S., I37, Whitechapel Road, 'E.

Deedes, Rev. Cecil, M.A., 43, Church Street, Brighton.

* Dennison, Thomas, East Ham.

Dennis, R. N., Berry View, Paignton, Devon.

* Dervick, Rev. E. S., M.A., F.G.S., 26, Oxford Square, Hyde Park, IV.

* Dixon, Joseph, Mary Villas, Birkbeck Villas, Leytonstone.

* Double, Alfred, 27, Jewin Crescent, Cripplegate, E.C.

* Douglas, James, Loxford Cottage, Ilford.

Downing, William, 74, New Street, Birmingham.

* Downes, Arthur, M.D., Chelmsford.

Dowsett, Arthur, Castle Hill House, Reading.

* Duffield, Frederick H., St. Oswald's House, Church Road, Shortlands, Kent.

* Dunning, J. IV., M.A., F.L.S., F.Z.S., I2, Old Square, Lincoln's Inn, W.C.

* Durrant, Edmund, 9o, High Street, Chelmsford.

* Durrant, Mrs., 90, High Street, Chelmsford.

* Earley, William, Aldborough Hatch, Ilford.

* Edwards, Stanley, F.E.S., Kidbrooke Lodge, Blackheath, S.E.

Elliott, Ernest A., 4I, Holland Park, London, W.

* Elliott, Frederic W., Palmerston Road, Buckhurst Hill.

Ellis, J. Bancroft, The Gynsills, Leicester.

* Evans, John, D.C.L., LL.D., Treas. R.S., Pres. S.A., F.L.S., F.G.S., Nash

Mills, Hemel Hempstead, Herts.

* Eve, R. H., Fullbridge House, Maldon.

Fanning, Walter H., California Works, Stoke-on-Trent.

* Finch, F., Carisbrooke, Gainsborough Road, Leytonstone.

* Finch, Herbert, 84, Amherst Park, Stamford Hill.

* Fisher, Lionel P., South Hill, Guildford, Surrey.

* Fitch, Edward A., F.L.S., F.E.S., President E.F.C., Brick House, Maldon.

* Fletcher, Reginald G., Ripple, Woodford.

Forster, Thomas, IOI, High Street, Colchester. (2 copies.)

Fowke, W. Villiers, Great Saling, Braintree, Essex. (2 copies.)

Fowler, W. IVarde, Lincoln College, Oxford.

Fraser, The Revi. Canon, South Weald, Brentwood.

* Fraser, Herbert, South Weald, Brentwood.

* Freeman, J. C., West Chase, Maldon.

* Furbank, A. J., 73, Duke Street, Chelmsford.

Gainsborough, The Rt. Hon. the Earl of, Exton Park, Oakham.

Gallwey, Sir Ralph Payne, Bart., Thirkleby Park, Thirsk.

Gardener, Geo., Fellside, Snaresbrook.

Gates, Arthur F., 7, Marsh Gate Lane, High Street, Stratford.

Gellatley, P., Loughton.

* George, William, I9, Church Crescent, South Hackney, N.E.

* Gepp, Rev.Edward, M.A., School-House, Felstead.

* Gibbs, Miss, 77, Beaconsfield Road, Tottenham.

Gibson, Mrs. (the late), Saffron Walden. (2 copies.)

Gibson, Theodore, Slough Mills, Slough.

Gilbey, Walter, Elsenham Hall, Bishop's Stortford.

* Gillham, A. W., Oak Lodge, Wellington Road, IVanstead.

Gingell, W. H., Kent and Essex Yard, Whitechapel, E. 
* Gough, James H., Plashet Lands, Snaresbrook.

* Gould, Chalkley, Traps-Hill House, Loughton.

* Gould, F. C., IO, Knighton Villas, Buckhurst Hill.

* Gowland, T., Altona Lodge, Tuvistock Road, Harlesden, N.W.

* Greatheed, Rev. Francis, The Rectory, Corringham.

* Greatheed, William, 67, Chancery Lane, W.C.

Green, E. R., Gants Hill, Barking Side, Ilford.

Green, Joseph E., F.R.G.S., I2a, Middleton Square, E.C.

Gimson, W. G., M.D., Witham, Essex.

Gripper, Miss Marianne, Layer Breton, Kelvedon.

Grubb, John, Alvechurch, near Redditch.

* Gurney, J. H., junr., F.Z.S., \&c., Keswick Hall, Norwich.

Gurney and Jackson, Messrs., I, Paternoster Row, E.C. (6 copies.)

* Hahnemann, Mrs., If, Highbury Crescent, $N$.

Haig'a, G. H. Caton, Grimsby Hall, Great Grimsby.

Haig, Darid, Dr., Falkirk, Scotland.

Haines, J. P. Mitten, The Lodge, Gloucester.

* Hall, Samuel, F.C.S., I9, Aberdeen Park, Highbury, N.

Hammond, IV. Oxenden, St. Alban's Court, Wingham, Kent.

Hardcastle, Henry, J.P., 38, Eaton Square, London, S.W.

* Harrison, A., Thames Sugar Refinery, Silvertown, E.

Hart, Edward, F.Z.S., Bow House, Christchurch.

* Harting, J. E., F.L.S., F.Z.S., Linnean Society, Burlington House. W.

Harvie-Brown, John A., F.Z.S., \&c., Dunipace House, Larbert. (2 copies.)

* Harwood, IV. H., Colchester.

Hempson, George F., Good Hall, Ardleigh, Colchester.

Hills, Harris, Berewyk Hall, near Halstead.

* Hilliar, John, 94, Grove Road, South Hackney, N.E.

Hills, Joseph F., Sudbury, Suffolk.

Holdsworth, Chas. J., Hill Top, Kendal.

* Holmes, T. V., F.G.S., M.A.I., 28, Croom's Hill, Greenwich Park, S.E.

* Holmes, Mrs., 28, Croom's Hill, Greenwich, S.E.

* Holmes, E. M., F.L.S., Bradbourne Dene, Sevenoaks.

* Hope, G. P., Upminster Hall, near Romford.

* Horwood, Rev. E. R., M.A., J.P., All Saints Vicarage, Maldon.

* Houblon, Archer, Mrs., Hallingbury, Bishop's Stortford.

* Howard, W. Dillworth, City Mills, Stratford.

Howard, Robt., J., Hawkhurst, Blackburn.

* Howard, David, J. P., F.C.S., Rectory Manor, Walthamstow.

* Howell, Rev. W. C., M.A., Holy Trinity Vicarage, Tottenham, N.

Hunt, Reuben, Earl's Colne, Essex.

Hurnard, S. F., Hill House, Lexden, Colchester. (2 copies.)

Hurrell, IWm. A., Southminster, Essex.

Jeffrey, Wm̃. D., (Librarian, Friends' Library) Dr. Johnson Passage, Birmingham.

* Jennings, Cecil F. J., Wolse'ey Villa, Wanstead. Johnson, The Ven. Archdeacon, The Rectory, Chelmsford.

* Jones, D. B., II3, Balfour Road, Highbury New Park.

* Jones, Gcorge T., M.D., 3, Kew Gardens Road, S.W.

* Jukes, Rev. H. N., Bradfield Rectory, Manningtree.

* Kemble, Thomas, J.P., Runwell Hall, Wickford, Essex. 
* Kenworthy, Rev. J. W., The Vicarage, Braintree.

Kerry, F., 22, Maria Street, Harwich.

King, George, High Street, Saffron Walder.

* Knightly, Miss M. E., 45, Portland Street, Commercial Road, E.

* Knobel, Edward B., F.G.S., F.R.A.S., Bocking, near Braintree.

Knubley, The Rev. E. P., M.A., Staveley Rectory, Leeds.

* Landon, Frank, Brentwood.

Langton, Herbert, M.B.O.U., I I, Marlborough Place, Brighton.

* Laver, Henry, M.R.C.S., F.L.S., F.S.A., Head Street, Colchester.

* Leach, Henry R., Hazeldean, Pinner, Middlesex.

Lescher, J. F., Boyle's Court, Brentwood.

* Lester, H. E., Leytonstone.

Lilford, The Lord, Lilford Hall, Oundle, Northants.

* Linder, Miss E. M., Oakfield, Buckhurst Hill.

* Linley, Thomas B., Homeburhs, Buckhurst Hill.

Linney, Geo. F., Friends' School, Saffron-Walden.

* Lister, Arthur, J. P., Sycamore House, Leytonstone.

* Lockyer, Alfred, Mornington Lodge, Wanstead.

* Lockyer, Mrs. A., Mornington Lodge, Wanstead.

* Lodge, R., Great Gearies, Ilford.

* Lowrey, J., 37, Cornhill, E.C., and Buckhurst Hill.

Luard, The Admiral, Witham Lodge, Essex.

Lumsden, James, Arden, Alexandria, N.B.

* Lussignea, A., Brockhill, Lansdowne Road, Wanstead. Macpherson, Rev. H. A., M.A., 20, Cecil Street, Carlisle.

* Manley, Rev. F. H., Broad Summerford Rectory, Chippenham, IVilts.

* Mann, Mrs., Hyde Hall, Sawbridgeworth, Herts.

Marriage, Mrs. Caroline, Coval Hall, Chelmsford. (2 copies.)

* Marriage, Wilson, Dilbridge Hall, Colchester.

Marriott, C. A., 83, King William Street, E.C.

Marris, Geo., J.P., I8, Harborne Road, Edgbaston, Birmingham.

* Marsden, Colonel, Grey Friars, Colchester.

* Marshall, Mrs, Whitehouse, Loughton.

* Mason, Hugh H., Abbey Lodge, Barking.

Mathew, Gervase F., R.N., F.Z.S., F.L.S., Lee House, Dovercourt, Essex.

Mathew, Rev. Murray A., Buckland Dinham, Frome.

* Meldola, Professor Raphael, F.R.S., F.C.S., 6, Brunswick Square, W.C.

* Meldola, Mrs., 6, Brunswick Square, W.C.

* Meldola, Mrs., 6, Brunswick Square, IV.C.

* Melles, William, J.P., F.L.S., Sewardstone Lodge, Sewardstone.

Midgley, Arthur, Saffron Walden.

Mildmay, Sir Henry, Bart., Dogmersfield Park, Hants.

Miller, T. F., Monk's Lodge, Great Maplestead, Halstead.

* Mills, Rev. J. IV., St. Laurence Rectory, Maldon.

Mitford, Edward L., Plas Henfaes, Dolgelly, North Wales.

Moor, E. Charles, J.P., The Rosery, Great Bealings, Woodbridge, Suffolk.

Moore, J. G., Burchall Road, Leyton.

More, A. G., 74, Leinster Road, Dublin.

* Morgan, D. J., I.P., Cecil House, Bentley Mill, Brentwood.

Morris, A. M., Beddington Park, Croydon.

* Morris, H. G., 4, Belmont Hill, Lee, S.E. 
* Newling, Benjamin, Woodleigh, Snaresbrook.

Newton, The Professor, F.R.S., \&c., Magdalene College, Cambridge.

Nicholl, Digby S. W., F.L.S., The Ham, Cowbridge, Glamorgan.

* Nicholls, Walter Buchanan, Lawford Hall, Manningtree.

Ogilvie, F. Menteith, I2, Park Lane, London, W.

* Oldham, Charles, 2, Warwick Villas, Chelmsford Road, Woodford.

Orpen, Osmond G., Hillside, West Bergholt, Colchester.

* Parker, Christopher W., J.P., Hatfield Priory, Chelmsford.

Patterson, Robert, I, Windsor Park Terrace, Lisburn Road, Belfast.

Patterson, R. Lloyd, Croft House, Hollywood, Co. Down.

* Pearl, E., M.D., Fair Oak, Sylvan Road, Norwood, S.E.

Penney, Mrs. R. H., Highcroft, Dyke Road, Brighton.

Petre, The Rt. Rev. The Lord, The Hyde, Ingatestone. (2 copies.)

Pitts, Robert Z., Springfield, Chelmsford.

Pleydell, J. C. Mansel, Whatcombe, Blandford.

* Porter, J. H., 97, Tabernacle Square, E.C.

* Porter, Mrs., 97, Tabernacle Square, E.C.

* Potter, G. W. J., Arbor Villa, Bedford Road, South Woodford.

* Poulton, E. B., M.A., F.R.S., \&c., Wykeham House, Banbury Road, Oxford. Poynting, Frank, Woodlands, Swinton Park, Manchester.

* Prance, Rev. L. Newcomen, M.A., Rectory, Stapleford Tawney, Romford.

* Pratt, B., Hurstcombe, Whitehall Road, Buckhurst Hill.

Prentis, Walter, Rainham, Kent.

* Puckridge, Alfred F., Forest House, Chigwell.

Purdy, R. J. W., Woodgate House, Aylsham.

* Raeburn, Harold, The Elms, Eastern Road, Romford.

* Ramsden, Hildebrand, M.A., F.L.S., \&c., 26, Upper Bedford Place, W.C.

Read, J. F. H., J.P., Hoe Street, Walthamstow.

* Reader, F. W., I7 I, Hemingford Road, London, N.

* Richmond, James, Burnham-on-Crouch, Essex.

* Rippen, James, 5, Hillside, Grove Hill, Woodford.

* Robarts, N. F., F.G.S., Rosebrae, Woodford.

* Rogers, John, Hill House, Burnham.

* Rose, Arthur, 5, Royal Exchange Avenue, E.C.

* Rose, Alexander, St. Helens, Woodbury Down, N.

Round, James, M.P., Colchester.

* Rowdon, Miss H. M., High School, West Ham.

* Royle, Thomas, F.C.S., Dalton House, Upton Lane, Forest Gate, E.C.

* Royle, Mrs.,

Ditto.

* Rudler, F. W.. F.G.S., The Museum, Jermyn Street, Piccadilly.

* Russell, Champion B., J.P., Stubbers, near Romford.

Sackett, Walter R., Orsett, via Romford.

Salter, J. H., M.D., J.P., D'Arcy House, Tolleshunt D'Arcy, Essex.

* Sauzé, H. A., Mount Villas, Sydenham Hill Road, S.E.

* Savage, W. H. (Surveyor, East Ham Local Board), East. Ham.

Scorer, Alfred G., Abercorn Lodge, Upper Hamilton Terrace, N.W.

Seabrooke, J., Brooksea House, Grays, Essex.

Seebohm, Henry, F.Z.S., \&c., 22, Courtfield Gardens, London, S.W.

* Shadrake, W. G., Leyton.

* Shadrake, Mrs. Do.

* Shenstone, J. C., F.R.M.S., Colchester. 
Short, Walter H., 4, North Hill, Colchester.

* Sibbald, J. G. E., Admiralty, Whitehall.

* Simons, E. A., I3, Old Broad Street, E.C.

Simpson, Thos., Coggeshall, Essex.

* Snell, E. A., M.B., \&ic., Adeane Lodge, Princes Road, Buckhurst Hill.

* Snell, H. C., ditto ditto ditto.

Smith, J. C., Sandford Mill, Springfield, Chelmsford.

* Smith, Harris, Pattiswick Hall, near Braintree.

* Smith, (Mrs.), Woolpits, Gt. Saling.

Southwell, Thomas, F.Z.S., \&c., Io, The Crescent, Norwich.

Sparrow, Mrs., Gosfield Place, Halstead.

* Spiller, John, F.C.S., 2, St. Mary's Road, Canonbury, N.

* Squier, S. W., J.P., Horndon-on-Hill, Romford.

* Stable, D. Wintringham, LL.B., Wanstead Lodge, Wanstead.

* Stable, Robert S., Cleveland Road, Wanstead.

Stanford, Alan, Honbridge Hall, Great Oakley, Harwich.

* Steele, A. Rivers, Northbrooks, near:Harlow.

* Stephens, R. Darrell S., F.L.S., F.Z.S., Kewornan, Wadebridge, Cornwall.

* Stevens, William, The Green, Woodford.

* Tabrum, Burnett, J.P., Margaretting Lodge, Leytonstone.

* Tann, Edward, Eastward Ho !, Chadwell Heath.

Tawell, James A., Greenhills, Earls Colne, Essex.

Taylor, Major Edward, Castle Cottage, Hockerill, Bishop Stortford.

Taylor, William, ro, Chad Road, Edgbaston, Birmingham.

* Taylor, Thomas, M.R.C.S., Bocking, near Braintree.

* Taylor, John, High Street, Chelmsford.

Thompson, General. C. W., Wethersfield Place, near Braintree.

Thompson, Ernest E., 86, Howard St., Toronto, Canada.

* Tiley, Thomas, 2, Scotts Road, Leyton.

* Topham, Wm. H., Fernholme, Buckhurst Hill.

* Tower, C. J. H., D.L., J.P., Weald Hall, South Weald, Brentwood. Townsend, Rev. C. G. Gretton, Berwick Place, Hatfield Peveril.

* Tozer, Alfred, Ivy Lodge, Woodford Green.

Tuck, Rev. Julian G., Tostock Rectory, Bury St. Edmunds.

Tuke, D. Hack, M.D., 63, Welbeck Street, W.

Tuke, J. H., Hitchin, Herts.

* Tuke, W. Murray, Windmill Hill, Saffron Walden.

* Twine, Thomas, Ashville Road, Grove Green Lane, Leytonstone.

Unwin, George, 7IA, Ludgate Hill, E.C.

Varenne, Mrs., Kelvedon, Essex.

* Varley, Fredk. H., F.R.A.S., M.P.S., 82, Newington Green Road, N.

* Vaughan, Howard, F.E.S., The Terrace, Woodford Green.

* Vincent, Ralph, Fernbank, Leytonstone.

* Wakelin, Joseph, Freebornes, Witham.

* Walker, Henry, F.G.S., \&c., 36, Leamington Road Villas, Westbourne Park, W Ditto ditto ditto ditto.

* Wall, Howard, Eversley, Buckhurst Hill.

* Wall, Philip W., F.G.S., 9, Duke Street, Portland Place.

* Waller, W. C., Loughton.

* Wallinger, Robert. N.A., Writtle, Chelmsford.

* Walsingham, Lord, M.A., F.R.S., \&c., Merton Hall, Thetford, Suftolk. 
Warner, Robert, F.L.S., Scravels, Broomfield, Chelmsford.

Warner, Septimus, Hoddesdon, Herts.

* Warner, Alfred, I, Firs Villas, Crescent Road, Brentwood.

* Warner, Percy, M.R.C.S., Woodford.

Wells, Mrs. H. C., Broomfield Lodge, Chelmsford.

Wesley, Messrs. W. and Son, 28, Essex St., Strand, W.C. (5 cojie.)

* Westhorp, Stirling, Oaklands, Ipswich.

* Westwood, George S., Horndon-on-Hill, Romford.

Wheldon, Mr. John, 58, Great Queen Street, IV.C. (2 copies.)

Whitaker, J., F.Z.S., M.B.O.U., \&c., Rainworth, Mansfield.

* Whitaker, Wm., B.A., F.R.S., F.G.S., \&c., 33, East Park Terrace, Southampton,

White, Chas., Holly House, Warrington, Lancashire.

White, Tyndale, Stondon Place, Brentwood.

* White, William, F.E.S., The Ruskin Museum, Sheffield.

Whitworth, J. C., Stratford, E.

Wilkinson, Johnson, Vermont, Huddersfield.

* Wilmott, (Miss) E. A., Warley Place, Great Warley.

* Wilson, J. H., Crawcrook, Endlebury Road, Chingtord.

* Wilson, Rev. W. Linton, Loughton.

Wilson, H. Lloyd, Wyddrington, Birmingham. (2 copies.)

* Winstone, Benj., M.R.C.S., F.C.S., \&c., 53, Russell Square, W.C.

* Winter, (Mrs.), Clements, Snaresbrook.

* Wire, Alfred P., I, Seaton Villas, Birkbeck Road, Leytonstone.

* Wire, Mrs., ditto.

* Wiseman, James F. T., The Chase, Paglesham.
Ditto
ditto
ditto.

* Wooll, John M., New River Office, London, E.C.

* Wright, C. A., F.L.S., F.Z.S., Kayhough, Kew.

* Yeates, Mrs., Erin Villa, Buckhurst Hill.

Young, John, F.L.S., \&c., 64, Hereford Road, Bayswater, W.

Zoological Society (F. H. Waterhouse, Librarian), 3, Hanover Square, W. 


\section{APPENDIX B.}

\section{CHRONOLOGICAL LIST}

OF

\section{PUBLISHED WORKS AND WRITTEN DOCUMENTS REFERRED TO, AND QUOTED FROM.}

[Note.--In the foregoing pages, references to passages contained in works in the following list are made by means of numbers placed within parentheses-thus: (ro), (12. vii. 5II) or (29. Jan. I0, 1834). The first number so given refers to the work similarly numbered in the following list, while the second usually refers to the number of the page in the particular work in question ; but in the case of works consisting of more than one volume, the second number (given in Roman numerals) refers to the number of the volume and the third to that of the page. Thus (40, i. 52) refers to The Zoologist, third series, vol. i., p. 52 : while (29. Jan. 20, 1872) refers to the Field of that date, and so on.]

1666.

1. Merrett (Christopher, M.D.)-Pinax Rerum naturalium Britannicarum, Svo, London.

\section{0.}

2. Taylor (Silas, otherwise Domville, Gent.) - The History and Antiquities of Harwich and Dovercourt *** first collected by S. T. *** now much enlarged in all its parts, with Notes and Observations relating to Natural History, by Samuel Dale, London.

(A second edition, identical except in title page, in 1732.)

2A, Dale (Sam1.) See Taylor's History of Harwich and Dovercourt, London.

1731-38.

3. Albin (Eleazar) -A Natural History of Birds, 3 vols., 4to, London.

1795-1801.

4. Lewin (W.)-The Birds of Great Britain, 8 vols., 4to, London.

1799-1819.

5. Donovan (E.)-The Natural History of Birds, \&c., Io vols., Svo, London.

1801-13.

6. Daniel (W. B.)-Rural Sports, 2 vols, and supplement, 4to, London.

1811-21.

7. Graves (Geo.)-British Ornithology, \&c., 2 vols. (unpuged), 8vo, London. 
$1822-1837$.

8. Parsons (Christopher).-[His Game-Book] MS. 8vo.

(A small book containing a record of everything he shot between these dates, with the dates and localities, and occasional remarks on the weather; chiefly relates to rabbits, partridges, sparrows, and vermin. Thus, during 1823 , he shot 156 sparrows ( 30 at one shot) and 78 blackbirds. In 1823 he also caught 458 sparrows by bat-fowling and other means; 98 in 1824 , and 24 I during 1825 . In $x 824$ he either caught or shot 396 rabbits; in 1825,942 ; and in 1826,489 , all at Shoebury.)

1826.

9. Sheppard (Rev. Revett) and Whitear (Rev. Wm.)-A Catalogue of Norfolk and Suffolk Birds, with Remarks, Trans. Linn. Soc. xv. pp. I-62, $4^{\text {to, }}$ London.

$1831-46$.

10. Doubleday (Henry) - [One Hundred Letters chiefly about Birds and Insects, written to the late T. C. Heysham, of Carlisle, Aug. 3oth, I8 3 I to Feb. 9th, I846.] MS.

1832.

11. Parsons (Christopher)-Birds in Rochford Hundred (MS.).

Evidently a fragment only; ends with the Rediving; perhaps the first draft of the list prepared for Benton's History of Rochford Hundred; on paper watermarked

1829-36.

12. The Magazine of Natural History, \&c. Conducted by J. C. Loudon, 8 vo, London. (2nd series, I837-40. No. I8).

1833-34.

13. [Various]-The Field Naturalist, \&c. Edited by James Rennie, 8vo, London.

1835.

14. Yarrell (Wm.)-History of British Birds, 3 vols, 8 vo, London. (2nd ed., 1845; 3rd ed., 1856 ; 4 th ed., $1871-.85$.)

1835.

15. Doubleday (Edward) - A Catalogue of Birds which have occurred in the Neighbourhood of Epping. Entomological Mag. iii. pp. 288-293, 8vo, London.

(About 125 species enumerated.)

1835.

16. Maclean (Dr. A.) - [Three Letters to T. C. Heysham, of Carlisle.] MS.

1835-36.

17. Sheppard (E. F.)-[Two Letters, dated Dec. 25 th, I 835 and Jan. 19th, I836, to T. C. Heysham.] MS.

(Son of Rev. Revett Sheppard, formerly Rector of Wrabness, whose table of the arrival of Summer Migrants at Wrabness, $1818-1830$, is given in the first letter.)

$1837-40$.

18. [Various] - The Magazine of Natural History. Second series, edited by Edward Charlesworth, 4 vols., 8 vo. 
1839.

19. [Various]-The Essex Literary Journal or Monthly Repository of Literature and the Arts and Sciences connected with the County, 4to, Chelmsford.

1838.

(12 numbers only issued.)

20. King (Wm. Doubleday) - A List of Birds found in the neighbourhood of Sudbury, 4to. Reprinted from Fulcher's Sudbury Magazine for the year I 838 (all published) p. I 26.

1840.

( 130 species enumerated.)

21. Parsons (Chr.) - [Commencement of a History of British Birds ?] MS.

(Now at the Southend Institute ; chiefly a compilation.)

1843-45.

22. Parsons (Chr.) - [Rough Notes for a Natural History of British Birds ?] MS.

1843-65.

(Now at the Southend Institute. See p. 30.)

23. [Various]-The Zoologist: a Popular Miscellany of Natural History, conducted by Edward Newman. First series, 23 vols., 8vo, London.

(See also second and third series, Nos. 34 and 40 ).

1845 (about).

24. Clarke (Joseph, F.S.A.) - Notes on Birds (MS.), chiefly made in the vicinity of Saffron Walden.

1845.

25. Yarrell (Wm.)-A History of British Birds, 2nd ed., 2 vols., 8ro, London.

1848.

26. White (Wm.)-History, Gazetteer, and Directory of the County of Essex, \&r., 8vo, London.

1851.

27. Lindsey (W. H.) - A Season at Harwich, *** to which is added Researches, Historical, Natural, and Miscellaneous.

(Contains some 23 pages of information about birds, but of such a general nature as to be almost useless for local purposes, and chiefly copied from Dale.)

1851-57.

27A, Morı is (Rev. F. O.)-A History of British Birds, 6 vols., 8vo, London.

$1851-8$. 28. [Various]--The Naturalist. Edited by B. R. Morris and others, 8 vols.,
8 vo, London.

1853.

29. [Various]-The Field, folio, London.

1856.

30. Yarrell (Wm.)-A History of British Birds, 3 rd ed., 3 vols., 8 vo, London.

1860.

31. [Various]-The Magazine of Natural History and Naturalist. Edited by Rev. F. O. Morris, 9 numbers (Jan. to Sept.) only published, 8vo, London. 
1863.

32. Gray (G. R.)-Catalogue of British Birds in the Collection of the British Museum, 8vo, London. 32. Bree (Dr. Chas. R.) - Notes and Memoranda relating to Birds [MS.],
2 vols.

(Evidently a note-book, journal, and museum catalogue in one; the notes are chiefly general, but there are a good many of interest relating to Essex; extends apparently from $186_{3}$ to about 1880 ; now in MIrs. Bree's possession).

1865.

33. More (A. G.)-On the Distribution of Birds in Great Britain during the Nesting Season. Ibis, N.S. i.pp. I, II g, and 425 , 8vo, London.

1866-76.

34. [Various]-The Zoologist, conducted by Edward Newman. Second series, II vols., Sro, London.

$1867-88$.

(See also first and third series, Nos. 23 and $4^{0}$.)

35. Benton (Philip)-The History of Rochford Hundred, 3 vols. (and in progress), 8vo, London.

1871.

36. Atkinson (Rev.J. C.) -British Birds' Eggs and Nests, 8vo, London. $1871-85$.

37. Yarrell (Wm.)-A History of British Birds, 4th ed. Edited by Professor A. Newton and Howard Saunders, 4 vols., 8vo, London.

1872.

38. Harting (J. E.)-A Handbook of British Birds, 8 ro, London.

1876.

39. Grubb (Jonathan)-Ornithological Notes. Frends' Quarterly Examiner, pp. 502-5II.

(A very entertaining article, enumerating the birds (about eighty in number) frequenting the author's "ground near Sudbury, Suffolk; which comprises seven acres of low meadow, and three or four acres of garden and upland pasture, separated from each other by the River Stour." There are many little interesting remarks and obser. vations on the habits of the birds noted.)

1877, \&c.

40. [Various]-The Zoologist. Third series. Edited by J. E. Harting, I3 vols. (to date), 8 vo, London.

(See also first and second series, Nos. 23 and 34 ).

1880.

41. Day (Geo.)-The Birds of Essex. Chelmsford Chronicle, Aug. 6th to Sept I 7 th, I880, Chelmsford.

(A series of seven newspaper articles; does not contain original matter.)

1881-88.

42. Brown (J.A. Harvie) and others-Reports on the Migration of Birds, 8vo, London.

1881-86.

43. [Various]-Transactions of the Essex Field Club, vols. i-iv., 8ro, Buckhurst Hill, Essex. 
$1881-86$.

44. [Various]-The Journal of Proceedings of the Essex Field Club, vols. i-iv., 8vo, Buckhurst Hill, Essex.

1883-85.

45. Seebohm (Henry)-A History of British Birds, with Coloured Illustrations of their Eggs, 3 vols., 8vo, London.

\section{4-86.}

46. Babington (Canon Churchill)-Catalogue of the Birds of Suffulk, with an Introduction and Remarks on their Distribution, 8vo, London.

1885 .

47. Buxton (E. N.)-Epping Forest. Cheaper edition, 8vo, London.

1886.

48. Swainson (Rev. Chas.)-The Folk Lore and Provincial Niames of British Birds, 8vo, London.

(Contains very few references to Essex or Essex bird names.) 1886.

49. Gallwey (Sir Ralph Payne)-The Book of Duck Decoys, 4to, London. $1886-8 \%$.

49A, H[arting (J. E.)] - The [Epping] Forest Birds. In Percy Lindley's Walks in Epping Forsst, pp. I22-128, oblong 8vo, London.

1887, \&c.

50. [Various]-The Essex Naturalist : the Journal of the Essex Field Club, 8vo, Buckhurst Hill, Essex.

$1888, \& \mathrm{c}$.

51. Dickens (Charles)-Dictionary of the Thames, svo, London.

1889.

52. J[ackson (Harold O.)].-A List of Birds found in Rochford Hundred. Southend Standard, Oct. Ioth, I889, Southend.

INDEX TO NAMES OF AUTHORS IN THE FOREGOING LisT.

Albin, Eleazar.

Atkinson, Rev. J. C.

Babington, Rev, C.

Benton, Philip.

Bree, Dr. C. R.

Brown, J. A. Harvie

Buxton, E. N.

Clarke, Joseph .

Dale, Saml.

Daniel, Rev。 WV. B. .

Day, Geo.

Domville, Silas

Dickens, Charles

Donovan, E.

Doubleday, Edward

Doubleday, Henry .

Gallwey, Sir R. Payne

Graves, Geo.

Gray, G. R.
NO. OF WORK

3
36
46
35
$32 a$
42
47
24
22,2
6
$4 I$
2
51
5
15
10
49
7
32

Grubb, Jonathan

Harting, J. E. .

Jackson, H. O. .

King, W. D.

Lewin, IV.

Lindsey, WV. H.

Maclean, Dr. A.

Merrett, Chr.

More, A. G.

Morris, Rev. F.O.

Parsons, Chr.

Seebchm, Henry

Sheppard, E. F.

Sheppard, Rev. R.

Swainson, Rev. Chas.

Taylor, Silas

Whitear, Rev. Wm.

White, IVm.

Yarrell, Wm.
No. OF WURK

- 39 49a, $3^{8}$

- 52

20

4

27

16

I

3.3

272

$2 I, I I, 8$

45

I 7

0

$+8$

2

26

$37,3^{\circ}, 25$, I 4 


\section{N D E X.}

Abdy, Sir Robert, 8 . Accentor, Alpine, 89 . Accentor, Hedge, 89. Adriatic Gull, 264.

Alpine Accentor, 89. Arctic Tern, 258

Arrival of Summer Migrants, 39. Atkinson, Rev. J. C., 8.

Atkinson, Rev. John, 9.

Audley End Collection, 35.

Auk, Great, 277.

Auk, Little, 278.

Authors consulted, List of, 292.

Avocet, 240.

Baillon's Crake, 224.

Barnacle Goose, I96.

Barn Owl, I54.

Bar-tailed Godwit, 255.

Baxter, G. H., IO.

Baxter Collection, 35 .

Bean Goose, I92.

Bearded Tit, 9I, 280.

Bee-eater, $\mathrm{I}_{50} \mathrm{O}$.

Bewick's Swan, I99.

Bibliography of the subject, 292.

Bird Collections, Chief Essex, 35.

Bird Lists, Previous Essex, 5.

Bittern, Little, I83.

Black-bellied Dipper, 90.

Blackbird, 74 .

Blackcap, 83 .

Black Guillemot, 278.

Black-headed Gull, 265.

Black Redstart, 79 .

Black Stork, I88.

Black-tailed Godwit, 254.

Black Tern, $26 \mathrm{I}$.

Black-throated Diver, 273.

Black-winged Stilt, 240.

Blue-headed Yellow Wagtail, 98.

Blue Tit, 94.

Bohun's Hall Decoy, 63.

Brambling, I I9, 280.

Braybrooke Collection, The, 35.

Bree, Charles R., Io.

Bree Collection, 35 .

Brent Goose, I92.

Brünnich's Guillemot, 278.

Buff-breasted Sandpiper, 250.
Buffon's Skua, 269.

Bullfinch, I22.

Bunting, Common, I27.

Bunting, Cirl, I2S.

Bunting, Corn, I 27.

Bunting, Snow, I28, 28 I.

Bunting, Yellow, I27.

Bustard, Great, 229.

Bustard, Little, 230.

Bustard, Macqueen's, $23 \mathrm{I}$.

Buzzard, $16_{4}$.

Buzzard, Honey, I70:

Buzzard, Rough-legged, 165, 281.

Carrion Crow, I33.

Cirl Bunting, I28.

Chaffinch, II8.

Chalky Uplands, 3 .

Chiffchaff, 85 .

Chough, I 30 .

Clarke, Joseph, I I.

Coal T'it, 93.

Colchester Museum Collection, 36 .

Colin, Virginian, 222.

Collared Pratincole, 233.

Collections, Chief Essex Bird, 35.

Coot, 226.

Common Bunting, I27.

Common Guillemot, 277.

Common Gull, $26_{3}$.

Common Sandpiper, 250.

Common Scoter, 2 Io.

Common Skua, 268.

Common Snipe, 243.

Common Tern, 258.

Cormorant, I78.

Corn Bunting, I27.

Corn Crake, 224.

Crake, Baillon's, 22.4.

Crake, Corn, 224.

Crake, Little, 224.

Crake, Spotted, 223.

Crane, 228.

Creeper, Tree, II I.

Crested Tit, 94.

Crossbill, I22.

Crossbill, Parrot, I26.

Crossbill, Two-barred, I 26.

Crow, Carrion, I33.

Crow, Hooded, I34. 
Cuckoo, I 53.

Curlew, 256.

Curlew Sandpiper, 247.

Curlew, Stone, 232.

Dabchick, 276.

Dale, Samuel, Ir.

Daniel, Rev. W. B., I2.

Dartford Warbler. 84.

Decoys in Essex, 47.

Dipper, 90.

Dipper, Black-bellied, 90.

Diver, Black-throated, 273.

Diver, Great Northern, 273.

Diver, Red-throated, 274.

Dix, Thomas, I2.

Dotterel, 236.

Doubleday, Edward, I3.

Doubleday, Henry, I3, 39 .

Dovercourt Decoy, 67.

Dove, Ring, 2 I 4.

Dove, Stock, 2 It.

Dove, Turtle, 2 I 5.

Duck, Eider, 209.

Duck, Long-tailed, 209.

Duck, Tufted, 205.

Duck, White-eyed, 209.

Duck, Wild, 202.

Dunlin, 244.

Eagle, Golden, I67.

Eagle, White-tailed, I67.

Eagle Owl, 16I.

Eared Grebe, 275.

East Hall Decoy, 6r.

Egyptian Vulture, I62.

Eider Duck, 209.

English, James Lake, I9.

Epping, Arrival of Summer Migrants at, 39 .

Essex Bird Collections, Chief, 35.

Essex Bird Lists, 5.

Essex Decoys, 47.

Essex, Hawks and Hawking in, 43.

Essex, Number of Species in, 6 .

Essex Ornithologists, 8.

Essex, Physical Features of, I.

Essex, Wild-Fowling in, 47 .

Falcon, Greenland, I7 I.

Falcon, Iceland, I 7 I.

Falcon, Peregrine, I 72.

Fieldfare, 73 .

Firecrest, 85 .

Fitch, Edward A., 2 I.

Flycatcher, Pied, 107.

Flycatcher, Spotted, ros.

Forests and Woodlands, 4 .

Fulmar, 272.

Gadwall, 203.
Gallinule, Green-backed, 225.

Gannet, I78.

Garden Warbler, 84.

Garganey, 203.

Gibson, Jabez, 2 I.

Glaucous Gull, 262 .

Glebeland Decoy, $6 \mathrm{I}$.

Glossy Ibis, I89.

Godwit, Bar-tailed, 255.

Godwit, Black-tailed, 254 .

Goldcrest, 84.

Golden Eagle, I67.

Golden-eye, 208.

Golden Oriole, IOI.

Golden Plover, 234.

Goldfinch, II I.

Goldhanger Decoys, 62.

Goosander, 2 I I.

Goose, Barnacle, I96.

Goose, Bean, I92.

Goose, Brent, I92.

Goose, Grey Lag, I9o.

Goose, Pink-footed, I9I.

Goose, Red-breasted, I 97.

Goose, White-fronted, IgI.

Gore Decoy, 63.

Goshawk, I68.

Grange Decoy, 59

Grasshopper Warbler, 88.

Great Auk, 277.

Great Black-backed Gull, 264.

Great Black Woodpecker, 147 .

Great Bustard, 229.

Greater Grey Shrike, I04, 28 I.

Greater Shearwater, 272.

Great Grey Shrike, I03, 28I.

Great Northern Diver, 273.

Great Oakley Hall Decoy, 66.

Great Reed Warbler, 87.

Great Skua, 268.

Great Snipe, 243, 283.

Great Spotted Woodpecker, 148.

Great Tit, 93.

Great White Heron, I83.

Grebe, Eared, 275.

Grebe, Great Crested, 27j.

Grebe, Little, 276.

Grebe, Red-necked, $27 \mathrm{~s}$

Grebe, Sclavonian, 275.

Green-backed Gallinule, 225.

Greenfinch, II 3.

Greenland Falcen, I7I.

Green Sandpiper, $25 \mathrm{I}$.

Greenshank, 254.

Green Woodpecker, 148.

Grey-Lag Goose, Igo.

Grey Phalarope, 24I.

Grey Plover, 234.

Grey Wagtail, 97.

Grouse, Red, 222.

Grubb, Jonathan, 22. 
Guillemot, 277.

Guillemot, Black, 278 .

Guillemot, Brünnich's, 278.

Gull, Adriatic, 264 .

Gull, Black-headed, 265.

Gull, Common, 263.

Gull, Glaucous, 262 .

Gull, Great Black-backed, 264.

Gull, Herring, 262.

Gull, Iceland, 262.

Gull, Lesser Black-backed, 263.

Gull, Little, 268.

Gull, Sabine's, 268.

Harrier, Hen, I63.

Harrier, Marsh, I62.

Harrier, Montagu's, I64.

Harting on Hawking in Essex, 43.

Hawfinch, II 3.

Hawking in Essex, 43.

Hawks and Hawking, 43.

Hedge Sparrow, 89 .

Hen Harrier, 163.

Heron, ISo.

Herón, Great White, I83.

Heron, Night, I86.

Heron, Purple, I83.

Herring Gull, 262.

Hill, Kev. W. H., 22.

Hobby, I74.

Honey Buzzard, I70.

Hooded Crow, I34.

Hoopoe, I5O.

Hope, G. P., 23.

Hope Collection, 36.

Horsey Island Decoy, 66.

House Sparrow, II7.

Hoy, J. D., 23.

Hoy Collection, 36.

Ibis, Glossy, I89.

Iceland Falcon, I7I.

Iceland Gull, 262.

Intermediate Ringed Plover, 235.

Introduction, I.

Jackdaw, I 33 .

Jack Snipe, 244.

Jaques Hall Decoy, 67.

Jaques Hall Old Decoy, 67 .

Jay, I32.

Joyce's Decoy, 62.

Kentish Plover, 235.

Kerry, F., 23.

Kestrel, 277.

King, Wm. Doubleday, 23.

King Collection, 37.

Kingfisher, I49.

Kite, I69.

Kittiwake, 262.
Knot, 248.

Landrail, 224.

Lapwing, 237.

Lark, Shore, I 43.

Lark, Sky, I4I.

Lark, Wood, I 42.

Latchingdon Decoy, $6 \mathrm{I}$.

Laver, Dr. Henry, 25.

Leach's Fork-tailed Petrel, 27 I.

Legge, Capt. W. V., 25.

Lesser Black-backed Gull, 263.

Lesser Redpoll, I20.

Lesser Spotted Woodpecker, I 47.

Lesser Whitethroat, 82.

Lighthouses, 5 .

Linnet, II9.

Lion Point, or Wick, Decoy, 65 .

List of Subscribers,

List of Works referred to,

Lister, Arthur, 25.

Little Auk, 278.

Little Bittern, 183.

Little Bustard, 230.

Little Crake, 224.

Little Grebe, 276.

Little Gull, 268.

Little Owl, I6I.

Little Stint, 246.

Little Tern, 259.

Long-eared Owl, 155.

Long-tailed Duck, 209.

Long-tailed Tit, 92.

Lowlands, 3.

Maclean, Dr. Allan, 25.

Macqueen's Bustard, $23 \mathrm{I}$.

Magpie, I32.

Manx Shearwater, 27 I.

Marsh Harrier, I62.

Marsh House Decoy, 59.

Marsh Tit, 93.

Marsh Warbler, 87.

Marshes, 4.

Martin, Iog.

Martin, Purple, I Io.

Martin, Sand, I Io.

Mayland Decoy, 6 I.

Meadow Pipit, 99.

Mealy Redpoll, I2 I.

Merganser, Red-breasted, 2 I 2.

Merlin, I75, 28I.

Mersea Island Decoy, 64 .

Migration Tables, 40.

Mistle Thrush, 72 .

Montagu's Harrier, I64.

Moorhen, 225.

Mute Swan, 197.

Needle-tailed Swift, I45.

Night Heron, I 86. 
Nightingale, 82 .

Nightjar, I 46.

Nomenclature, 6.

Northey Island Decoy, 6r.

Number of Species, 6.

Nutcracker, I3I.

Nuthatch, 95.

Old Hall Decoys, 63.

Old Moze Hall Decoy, 66.

Open Sea, 5.

Oriole, Golden, Ior.

Ornithologists, Principal Essex, 8.

Osprey, I 76.

Ouzel, Ring, 75.

Owl, Barn, I54.

Owl, Eagle, I6I.

Owl, Little, I6r.

Owl, Long-eared, $I_{55}$

Owl, Scops, I59.

Owl, Short-eared, 156.

Owl, Snowy, I59.

Owl, Tawny, I58.

Owl, Tengmalm's, I59.

Oyster-catcher, 238.

Pallas' Sand Grouse, 216.

Partridge, 220.

Partridge, Red-legged, 2 IS.

Parrot Crossbill, 126.

Parsons, Christopher, 27.

Passenger Pigeon, 2 I 5, $28 \mathrm{I}$.

Pastor, Rose-coloured, 132.

Peewit, 237.

Peregrine Falcon, I72.

Petrel, Fulmar, 272.

Petrel, Leach's Fork-tailed, 271.

Petrel, Storm, 270.

Phalarope, Grey, 24 I.

Phalarope, Red-necked, 240.

Pheasant, 2 I 8.

Physical Features of Essex, I.

Pied Flycatcher, 107.

Pied Wagtail, 97.

Pigeon, Passenger, 215, 281.

Pigeon, Wood, 214.

Pink-footed Goose, I9I.

Pintail, 201.

Pipit, Meadow, 99.

Pipit, Richard's, 99.

Pipit, Rock, 100, 280.

Pipit, Tree, 99.

Plover, Golden, 234.

Plover, Grey, 234.

Plover, Kentish, 235 .

Plover, Ringed, 235.

Pochard, 207.

Pochard, Red-crested, 200.

Pomatorhine Skua, 269.

Pond Hall Decoy, 67.

Pratincole, Collared, 233.
Puffin, 279.

Purple Martin, IIO.

Purple Sandpiper, 247.

Quail, 22I, 28I.

Rail, Land, 224.

Rail, IVater, 223.

Ramsey Island Decoy, 6 I.

Raven, I 36.

Razorbill, 277.

Red-backed Shrike, I05.

Redbreast, 80.

Red-breasted Goose, I97.

Red-breasted Merganser, 2 I 2.

Red-breasted Snipe, 254.

Red-crested Pochard, 200.

Red-footed Falcon, I 77 .

Red Grouse, 222.

Red-legged Partridge, 218.

Red-necked Grebe, 274 .

Red-necked Phalarope, 2.40.

Redpoll, Lesser, I20.

Redpoll, Mealy, I2 I.

Redshank, 252.

Redshank, Spotted, 253.

Red-spotted Bluethroat, 80.

Redstart, 78, 280.

Redstart, Black, 79.

Red-throated Diver, 27. .

Redwing, 73.

Reed Bunting, I28.

Reed Warbler, 86.

Richardson's Skua, 269.

Richard's Pipit, 99.

Ring Dove, 214.

Ringed Plover, 235.

Ring Ouzel, 75.

Robin, 80.

Rock Pipit, I00, 280.

Roller, I5O.

Rook, I 35 .

Roseate Tern, 259.

Rose-coloured Pastor, I 30.

Rough-legged Buzzard, I66, 28I.

Roydon Hall Decoy, 67.

Ruddy Sheldrake, 200.

Ruff, 249.

Rufous Tinamu, $28 \mathrm{I}$.

Russell, Col. Champion, 30.

Sabine's Gull, 268.

Saffron Walden Museum Collection, 37.

Salter Collection, $3 S$.

Saltings, 4.

Sanderling, 249.

Sand Grouse, Pallas', 2 I6.

Sand Martin, IIO.

Sandpiper, Buff-breasted, 250

Sandpiper, Common, 250.

Sandpiper, Curlew, $2+7$. 
Sandpiper, Green, 251.

Sandpiper, Purple, 247.

Sandpiper, IVood, 252.

Sandwich Tern, 260.

Savi's IVarbler, 88.

Scaup, 206.

Sclavonian Grebe, 275.

Scopoli's Sooty Tern, 26I.

Scops Owl, I59.

Scoter, Common, alo.

Scoter, Velvet, 2 I I.

Sedge Warbler, 87.

Shag, I78.

Shearwater, Greater, 272.

Shearwater, Manx, $27 \mathrm{I}$.

Sheldrake, 199.

Sheldrake, Ruddr, 200.

Sheppard, Rev. Revett, 33, 39.

Shore Lark, I +3 .

Short-eared Owl, I56.

Shoveller, 205.

Shrike, Great Grey, Ic3, 280.

Shrike, Greater Grey, I04, 28 I.

Shrike, Red-backed, I05.

Shrike, Southern Grey, 105.

Shrike, Woodchat, Io6.

Siskin, II 2.

Skinner's Wick Decoy, 63.

Skua, Buffon's, 269.

Skua, Common, 268.

Skua, Great, 268.

Skua, Pomatorhine, 269.

Skua, Richardson's, 269.

Skylark, I4I.

Smew, 212.

Smoothy, Charles, 33.

Smoothy Collection, 38 .

Snipe, Common, 243.

Snipe, Great, 243, 283.

Snipe, Jack, 244.

Snipe, Red-breasted, 254.

Snow Bunting, I28, 281 .

Snowy Owl, I59.

Song Thrush, 72, 280.

Sooty Tern, 260.

Southern Grey Shrike, 105.

South Hall Decoy, 59.

Spalding, Frederick, 33.

Sparrowhawk, I68.

Sparrow, House, II7.

Sparrow, Hedge, 89.

Sparrow, Tree, i I6.

Spoonbill, I89.

Spotted Crake, 223.

Spotted Flycatcher, I08.

Spotted Redshank, 253.

Starling, I29, 28 I.

Steeple Decoy, 6r.

Stilt, Blackwinged, 240.

Stint, Little, 246.

Stint, Temminck's, 246.
Stock Dove, 214.

Stonechat, 78.

Stone Curlew, 232.

Stork, Black, I88.

Stork, White, I 88.

Storm Petrel, 270.

Subscribers, List of,

Sudbury Museum Collection, 38.

Summer Migrants, Arrival of, 39.

Swallow, ros.

Swan, Bewick's, 199.

Swan, Mute, 197.

Swan, Whooper, Igs.

Swift, I 44.

Swift, Needle-tailed, I.45.

Swift, White-bellied, I 45.

Tawny Owl, 158 .

Teal, 204

Temminck's Stint, 246.

Tengmalm's Owl, I59.

'Tern, Arctic, 258.

Tern, Common, 258.

Tern, Black, 26I.

Tern, Little, 259.

Tern, Roseate, 259.

Tern, Saudwich, 260.

Tern, Scopoli's Sooty, 26r.

Tern, Sooty, 260.

Thrush, Mistle, 72.

Thrush, Song, 72, 280.

Tinamu, Rufous, $28 \mathrm{I}$.

Tit, Bearded, 9I, 280. .

Tit, Blue, 94.

Tit, Coal, 93.

Tit, Crested, 94.

Tit, Great, 93 .

Tit, Longtailed, 92.

Tit, Marsh, 93.

Tree Creeper, II I.

Tree Pipit, 99.

Tree Sparrow, I 6.

Tufted Duck, 205.

Turnstone, 239.

Turtle Dove, 215.

Twite, I2I.

Two-barred Crossbill, I26.

Uplands, Chaliny, 3.

Velvet Scoter, 2 II.

Villa Farm Decoy, 65 .

Virginian Colin, 222.

Vulture, Egyptian, I62.

Wagtail, Blue-headed Yellow, 98.

Wagtail, Grey, 97.

Wagtail, Pied, 97.

Wagtail, White, 96.

Wagtail, Yellow, 99.

Walford, Cornelius, 34. 
Warbler, Blackcap, 83 .

Warbler, Dartford, 84.

Warbler, Garden, 84.

Warbler, Grasshopper, 88.

Warbler, Great Reed, 87.

Warbler, Marsh, 87.

Warbler, Reed, 86.

Warbler, Savi's, 88.

Warbler, Sedge, 87.

Warbler, Willow, 85 .

Warbler, Wood, 86.

Water Ouzel, 90.

Water-rail, 223.

IVaxwing, I06.

West Wick Decoy, 6r.

Wheatear, 76 .

Whimbrel, 257.

Whinchat. 77.

White-bellied Swift, I 45 .

White-eyed Duck, 209.

White-fronted Goose, I9I.

White Stork, I88.

White-tailed Eagle, 167.

Whitethroat, 83 .

Whitethroat, Lesser, 82.

White Wagtail, 96.
Whooper Swan, I98.

Wigeon, 200.

Wild Duck, 202.

Wild-fowl Decoys, 47.

Wild-fowling in Essex, 47 .

Willow Warbler, 85 .

Woodchat Shrike, I06.

Woodcock, 24I.

Woodlands, 4 .

Wood Lark, I42.

Woodpecker, Great Black, I47.

Woodpecker, Great Spotted, I48.

Woodpecker, Green, I48.

Woodpecker, Leșser Spotted, I47.

Wood Pigeon, 2 I 4.

Wood Sandpiper, 252.

Wood Warbler, 86.

Works referred to, List of,

Wormingford Decoy, 67 .

Wrabness, Arrival of Summer Migrants at, 39 .

Wren, 95.

Wryneck, I46.

Yellow-hammer, I27.

Yellow WVagtail, 99. 


\title{
Demy 8vo. $\quad$ I84 pp. Price $7 s .6 d$. nett.
}

\section{The Trade Signs of Essex: \\ A POPULAR ACCOUNT}

OF THE

\section{Origin and Meanings of the Public-house and other Signs}

Now or formerly found in the County of Essex.

\section{By MILLER CHRISTY.}

FULLY ILLUSTRATED.

\section{PRESS NOTICES.}

"Mr. Miller Christy has done good service by the compilation of this book."-Saturday Review.

"Mr. ChRIsty deserves all praise for the energy which he has shown in dealing with a very large and somewhat obscure subject."- Spectator.

"Mr. CHRISTY's book is an excellent example of what can be done by local research to add to our existing information, and how much can be made of what might be thought an almost trivial subject. He has gathered together from many sources, both written and oral, testimony of facts for which the topographer of the future will have good cause to be grateful. . . . It should be added that the illustrations are appropriate and good."-Athenceum.

"Mr. CHRISTY has written an amusing book, which he has illustrated with many useful engravings. - Notes and Queries.

"Mr. MILler Christy has done good service by the compilation of this book, which ought to be followed by similar works for every county in England. . . . Let no one think that it is a contemptible branch of antiquarian research, even though it has to do chiefly with inns and country public-housts." -Siturdey Review.

"In the side walks of antiquarian study we are quite sure there are few subjects more interesting than that treated of in this book. . . . We cannot agree with all Mr. CHRISTY's explanations, but we must cordially welcome his interesting and painstaking account of a fascinating subject,"-Antiquary.

"The Essex Signs seem to be especially worth recording." - East Anglian.

"A publication of considerable local interest under this title has just been written by Mr. MILlen CHRISTY, of Chelmsford. The work is an admirably printed little volume. . . The subject is a very fascinating one. As a contribution to local archæology, Mr. CHRISTY's book is very valuable. . . The greatest care has evidently been bestowed [upon it]. We can heartily recommend the publication as one of unfailing interest."-Essex Standard.

"Mr. Miller CHRISTY is to be congratulated on the research displayed in his work on the Trade Signs of Essex. . . . If space allowed we might draw on these various chapters for much curious information of popular interest. . . . The book bears impress of having been carefully compiled; the style is pleasant; and the success of the work is not a little contributed to by the high-class illustrations."-Essex County Chronicle.

\author{
Chelmsford : \\ EDMUND DURRANT \& CO. \\ अृondon: \\ GRIFFITH， FARRAN, OKEDEN \& WEISH, \\ Newberry House, Charing Cross Road, iV.C.
}


Fcp. 8vo. 237 pp. Price 2s. 6d. nett. Post free.

\section{DURRANT'S HANDBOOK FOR ESSEX: AX GUIDE TO \\ the (principal OBjects of Jnterest itt each parish in the County, for the use of Eourists and others.}

WITH AN INTRODUCTION TREATING OF

ITS HISTORY, GEOLOGY, AREA, POPULATION, DIALECT, ANTIQUITIES, WORTHIES, NATURAL HISTORY, \&C., \&C.

\section{BY MILLER CHRISTY. \\ WITH MAPG.}

\section{PRESS NOTICES.}

"Contains an excellent introduction by that well-known lover of and writer on Essex, Mr. MILler Christy, which treats of its history, geology, population, literature, antiquities, natural history, and last, but not least, its long list of 'worthies.' Some notes on the dialect will interest the scholar, and the general information appears accurate and trustworthy."-Daily Telegraph.

"This little book might be commended as a model to writers of Guide Books. Its whole arrangement represents intelligent care and thought, and it is doubtful whether there could be found in any similar work such a mass of useful information in so singularly small a compass. Essentially business-like and practical in his directions, the author has not only given, as he proposed, 'a maximum of information in a minimum of space,' but has brought that information up to date in a way that is, unfortunately, all too rare. Sports, antiquities, and natural history, are all treated of in their place, and in every parish of the county the tourist will find in a few lines an exact list of everything worth seeing. It may be hoped that residents will be found in some of our other counties to do what Mr. Christy has accomplished so well for Essex."-Athenceum.

"Very well arranged. In alphabetical order. No Essex man should be without a copy."-Literary World.

"The quantity of valuable information comprised within its limits is marvellous, and yet, with all this, the stvle is charmingly fresh and vigorous: archxological, geological, zoological, philological, botanical, historical, and heaps of other facts being dealt with in such a crisp and pleasing way that the work is capital reading from the first page to the last."-Essex Weekly News.

"One of the very best Guide Books in existence-portable, nicely printed, and full of maps-a model handbook, in fact."-Evening News.

"No naturalist intending to visit Essex should fail to provide himself with a copy."-Naturalists' Monthly.

"A really valuable guide to the places of interest in the county, a work which was much needed and will be much appreciated."-Essex Standard.

"A handy volume for Essex wheelmen ; full of very interesting historical and general information concerning the various towns and villages."-Wheeling.

"Decidedly in advance of any similar work which has yet appeared with reference to the county."-East Anglian Notes and Queries.

\section{Criclmsford:}

EDMUND DURRANT \& CO., 90, High StREET.

\section{iconoon:}

SIMPKIN MARSHALL, HAMILTON, KENT \& CO., LTD., Stationers' Hall Court. 


\section{Messrs. EDMUUND DURRANT' \& CO.'S PUBLICATIONS.}

The Ancient Sepulchral Monuments of Essex. By Fred. Chancellor, F.R.I.B.A. Imp. 4to, cloth. $£ 33$ s. to Subscribers. After publication, $£_{4} 4$ s. nett. [Nearly ready.

Poems: by Alice E. Argent, with an Introduction by the Lord Bishop of St. Albans. Crown 8vo. $3^{s}$. $6 d$. nett. In the Press.

A History of Felsted School. With some Account of the Founder and his Descendants. By JoHs Sargeaunt, M.A. Crown 8vo, cloth, 4 s. nett.

DAILY RAYS OF LIGHT FOR SICK AND WEARY ONES. Compiled by Edith L. Welts. With a Preface by Rev. PREBENDARY HuTton. Crown 8vo, cloth, 6 s.

HOMESPUN YARNS. By EDwin COLler. Crown 8vo, cloth, 3s. 6 .

ROYAL ILLUSTRATED HISTORY OF EASTERN ENGLAND: Civil, Military, Political and Ecclesiastical, including a survey of the Eastern Counties, and Memoirs of County Families and Eminent Men of every period. By A.D. BAYNE, Esq. With many Illustrations. 2 vols., large 8vo, cloth, I $5 s$.

DOMESDAY BOOK RELATING TO ESSEX. Translated by the late T. C. Chisenhale-MARsh, Esq. 4to, cloth, 2 is. Only a few copies unsold.

JOHN NOAKES AND MARY STYLES; or, an Essex Calf's Visit to Tiptree Races. A Poem in the Essex Dialect. By the late Charles CLARK, of Totham Hall. With a Glossary and Portrait. Is.

THE HISTORY OF ROCHFORD HUNDRED, ESSEX. BY DHILIP BENTON. Vol. I, I6s. 6d.; vol, 2, I8s. nett.

SHORT NOTES ON THE BOOK OF EXODUS. By the Rer. W. J. PACKE, M.A., Vicar of Feering. Served, $7 d$. ; cloth, Is.

SERMONS BY THE LATE VEN. ARCHDEACON MILDMAY. With a Preface by the Bishop of ST. Albans. 3s. 6 .

CONFIRMATION; or, Laying on of Hands upon Those that are Baptized. Id. each; 6s. I00.

A FIRST CATECHISM OF BOTANY. By JOHA Gibis. Second Edition. $6 d$.

THE SYMMETRY OF FLOWERS. By JOHN GIBBS. $4 d$.

DURRANT'S HANDY FARM LABOUR BOOK. New Edition with Daily Diary (commt..cing either Monday or Saturday). 3s. 6 .

DURRANT'S LATEST CATALOGUE OF NEW AND SECONDhand Books, containing many works relating to Essex, sent post free to any address.

eidund durRant \& CO, 9o, High Street, Chelmiford. 


\section{THE ESSEX FIELD CLUB.}

FOUNDED JANUARY $10 \mathrm{th}, 1880$.

Jattrour:

H.R.H. THE DUKE OF CONNAUGHT AND STRATHEARN, K.G. (Ranger of Epping Forest.)

furesident:

EDWARD A. Fitch, C.C., F.L.S., F.E.S., F.R.M.S.

\section{Dire-puresidents :}

Professor G S. Boulger, F.L.S., F.G.S.

E. N. Buxton, C.A., J.P., D.L., dic.

Walter Crouch, F.Z.S.

T. V. Holmes, F.G.S., M.A.I.

HENRY LAYER, M.R.C.S., F.S.A., F.L.S.

PROFessor R. Meldola, F.R.S., F.C.S., F.R.A.S., F.E.S., \&c.

Right Hon. Lord Rayleigh, F.R.S., D.L., \&c.

ThIS Association, the only Scientific Society of like aims in Essex, was founded for the study and investigation of the Natural History, Geology, and Prehistoric Archocology of the County; the publication of the results of such investigations; the formation of a Library of local and scientific works; the formation of a Museum to illustrate the natural productions of Essex; and generaily to aid in the dissemination of practical knowledge of Natural Science and Antrguities. A further very important object of the Society is to promote a reverence for the natural features of the County, its Flora and Fauna, its numerous pre-historic remains and other monuments, and to incite a desire to protect them from wanton spoliation and injury.

The ORDINARY (SCIENTIFIC) MEETINGS are held about once a month during the autumn, winter, and early spring, and in connection with these occa. sional "WINTER MEETINGS" are held in the larger towns in Essex-the afternoons being devoted to an examination of the Museums, antiquities, and other objects of interest, while in the evenings Ordinary Meetings of the Club will be held for the reading of papers, notes, \&c., and the exhibition of specimens, especially such as may be of local interest.

F1ELD MEETINGS are arranged during the summer months, and held in various parts of the county, and elsewhere, for out-door observation under the guidance of experienced Naturalists, Geologists, and Archæologists. Other Meetings of the National Museums, Lectures, \&c., are arranged from time to time.

In organising the Essex Field Club the main desire of the Founder was to establish an Association which should be both popular and scientific, and which should represent, from the point of view of its foundation, the whole County of Essex; to form a central body to which communications and specimens relating to Essex and general Natural History, \&c., might be sent for at least careful consideration and discussion, so that the publications of the Society should in 
time comprise a body of fact and inference, useful to the local and scientific student, as well as interesting to the ordinary reader.

The Publications of the Club have gained a somewhat high position. Since the formation of the Club in $\mathrm{I} 880$, about two thousand five hunared closely printea pages of matter, relating more or less intimately to the county, and frequently of an original and important character, have been issued, illustrated with plates, maps, and mumerous other engravings. The first series, of five volumes, of "Transactions" and "Proceedings" now nearly completed, together with the "REPORT on the EAST ANGLIAN EAR'THQUAKE" (the first book of the kind ever published in England), and the volumes of the "ESSEX NATURALIST," form a record of work accomplished during the life of the Club, upon which its members may justly be congratulated, and work which has added very considerably to the advancement of natural knowledge in Essex. Une of the leading scientific periodicals ("Nature") in a notice of the "EsSEX NATURALIST," remarked as follows:"It is scarcely surprising that residents of the County of Essex should appreciate the labours of the Society, inasmuch as they are wwholly devoted to the county, and are of interest to persons who know little of Essex. In this respect-namely the thorough examination of the district lying at their doors-the members of the Essex Field Club set an example that similar societies elsewhere would do well to follow. *** There are few associations in the United Kingdom which perform so adequately and thoroughly the proper functions of a local Field Club or Naturalists' Society as the Essex Field Club."

Commencing in January, I887, the various papers read before the Club are now published as an Illustrated Periodical, entitled "THE EsSEx NATURALIST: being the JOURNAL of the EsSEx FIELD CLUB," and the fourth volume is now in progress.

Although bearing a county title, the Club offers exceptional advantages to metropolitan residents. Many parts of Essex are but little known, although of the greatest interest to the naturalist, geologist, and antiquary. The organisation of the Club in connection with the Field Meetings has enabled many to become acquainted with this portion of the Eastern Counties, which so weli repays the attention of the intelligent visitor.

The Club already possesses a good nucleus of a valuable LIBRARY, which has been obtained by donations, exchanges, and purchase. The Library is designed primarily to accumulate all books, pamphlets, maps, prints, \&c., relating to or in any way illustrating the History, Topography, Archæology, Geology, Botany, Natural History, \&c., \&c., of the COUNTY OF ESSEX ; and secondly as a collection of standard works on various branches of Natural History, Geology, Archæeology, \&c., for reference and study.

An endeavour is now being made for the establishment of a LOCAL MUSEUM in Essex, to illustrate, in the fullest and most scientific manner possible, the natural productions and antiquities of the County, and to form a home for County collections and specimens, where they may be consulted by all interested in Essex.

The SUBSCRIPTION to the Club is at present half-a-guinea per annum, payable upon election and afterwards on the Ist January in each year; and new members pay an entrance-fee of ios. 6d. upon joining. But it must be noted that the rate of subscription is now under consideration, and may be considerably altered in a short time.

All communications respecting membership, papers, and notes for the "ESSEX NATURALiST " and the general work of the Club, should be sent to Mr. W. COLE, Hon Sec., 7, Knighton Villas, Buckhurst Hill; all letters respecting subscriptions, \&c., to the Treasurer, Mr. Alfred Lockrer, Mornington Lodge, Wanstead, Essex; and all enquiries respecting the library, donations of books, \&c, to the Librarian, Mr. A. P. WIRE, at the Head-quarters, 8, Knighton Villas, Buck. hurst Hill. 
HAYMAN, CHHISTY AXD LILLY, LTD, PRINTERS,

HATTON WORKS, 113, FAREINGDON ROAD, AND 20,22 , ST. BRIDE ST, E.C. 



